\title{
Evaluated Kinetic Data for Combustion Modelling Supplement I
}

\author{
D.L. Baulch \\ School of Chemistry, University of Leeds, Leeds LS2 9JT, U.K. \\ C.J. Cobos \\ Institut für Physikalische Chemie, Universität Göttingen, D-3400 Göttingen, Germany
}

R.A. Cox

NERC, Polaris House, Swindon, SN2 IEU, U.K.

P. Frank

DLR, Institut für Physikalische Chemie der Verbrennung, D-7000 Stuttgart 80, Germany

G. Hayman

AEA Technology Consultancy Services, Harwell, Didcot OXI1 ORA, U.K.

Th. Just

DLR, Institut für Physikalische Chemie der Verbrennung, D-7000 Stuttgart 80, Germany

J.A. Kerr

EAWAG, CH-8600 Dübendorf, Switzerland

T. Murrells

AEA Technology Consultancy Services, Harwell, Didcot OX11 ORA, U.K.

M.J. Pilling

School of Chemistry, University of Leeds, Leeds LS2 9JT, U.K.

J. Troe

Institut für Physikalische Chemie, Universität Göttingen, D-3400 Göttingen, Germany

R.W. Walker

School of Chemistry, University of Hull, Hull HU6 7RX, U.K.

and

\section{J. Warnatz}

Institut für Technische Verbrennung, Universität Stuttgart, D-7000 Stuttgart 80, Germany

Received January 31, 1994; revised manuscript received August 3, 1994

This compilation updates and expands a previous evaluation of kinetic data on elementary, homogeneous, gas phase reactions of neutral species involved in combustion systems [J. Phys. Chem. Ref. Data 21, 411 (1992)]. The work has been carried out under the auspices of the European Community Energy Research and Development Program. Data slieets are presented for some 78 reactions and two tables in which preferred rate parameters are presented for reactions of ethyl, $i$-propyl, $t$-butyl, and allyl radicals are given. Each data sheet sets out relevant thermodynamic data, experimental kinetic data, references, and recommended rate parameters with their error limits. A table summarizing the recommended rate data is also given. The new reactions fall into two catagories: first, to expand the previous compilation relating largely to the combustion in air of methane, ethane and aromatic compounds; and second, provide data for some of the key radicals involved in the combustion of higher alkanes.

Key words: chemical kinetics; combustion; data evaluation; gas phase; rate constant.

(C)1995 by the U.S. Secretary of Commerce on behalf of the United States. This copyright is assigned to the American Institute of Physics and the American Chemical Society.

Reprints available from ACS; see Reprints List at back of issue. 


\section{Contents}

1. Introduction . . . . . . . . . . . . . . . 848

2. Guide to the Data Sheets............... 848

2.1. Scope and Reaction Ordering . . . . . . . . . 848

2.2. Conventions Concerning Rate Coefficients... 849

2.3. Guide to the Tables ... . . . . . . . . . . 849

2.4. Treatment of Combination and Dissociation

Reactions.................. 850

2.5. Assignment of Errors . . . . . . . . . . . . 851

2.6. Thermodynamic Data............... 851

2.7. Acknowledgements. . . . . . . . . . . 851

2.8. References................... 852

3. Errata to Ref. $1 \ldots \ldots \ldots \ldots \ldots \ldots \ldots \ldots . \ldots 52$

4. Index of Reactions and Summary Table ..... 852

4.1. Guide to the Summary Table......... 852

4.2. Summary of Preferred Rate Data........ 853

5. Data Sheets .................... 873

\section{List of Tables}

1. Bimolecular reactions. . . . . . . . . . . . . . 853

2. Decomposition reactions ............. 868

3. Combination reactions . . . . . . . . . . . . 870

\section{Introduction}

This publication is the first supplement to the set of data sheets of critically evaluated data for combustion processes published in the Journal of Chemical Reference Data 21, 411-734 (1992).

Both the previous and the present publication were prepared by the CEC Group on Evaluation of Kinetic Data for Combustion Modelling which was established as one of the projects within the European Community Energy Research and Development Program.

The original compilation was intended for use in computer modelling of the combustion of methane and ethane in air and it also dealt with a number of reactions of importance in the chemistry of exhaust gases, mainly involving $\mathrm{NO}_{\mathrm{x}}$, and in the combustion of aromatic compounds. This first supplement updates the original and extends it to cover the reactions of a number of radicals particularly important in the combustion of higher alkanes. It also provides a more extensive coverage of the reactions of nitrogen containing species.

In updating, a new data sheet has been provided for all reactions for which new data have been published since our previous work ${ }^{1}$. For reactions where no new data have become available, reference must be made back to the original compilation but the Summary Table, included in this supplement, contains the recommended rate parameters for all of the reactions evaluated by the group to date.

The general approach to updating has been to reproduce the tables of data from the previous data sheet, adding in the new data. However, for reactions where the data are particularly extensive and the new data are largely in agreement with our previous recommendations, only the new data are tabulated. In such cases the reader can gain a complete picture of the range and quality of the data from the graph (if presented) or must refer back to the original compilation ${ }^{1}$. In a very few instances where the new data consist of a single study agreeing with our previous recommendations, we have not updated, at this stage. For reasons given in 2.1 some of the combination/dissociation reactions dealt with in our previous publication are presented again despite there being no new data.

The formal cut-off point for the literature searching was January 1992, but the group continued to monitor the literature during the preparation of the manuscript and every attempt was made to incorporate more recent studies of importance, in particular the material presented at the 24th Symposium (International) on Combustion, held in 1992.

\section{Guide to the Data Sheets}

\subsection{Scope and Reaction Ordering}

For each reaction, a data sheet is presented setting out relevant thermodynamic data, rate coefficient measurements, an assessment of the reliability of the data, references, and, as well, preferred values of the rate coefficients are suggested. In deciding on a format for the presentation we have been influenced by the data sheets prepared by the CODATA Task Group for Modelling Atmospheric Chemistry ${ }^{2}$. Our format follows theirs closely but we have made more extensive use of graphs because of the need to convey some idea of the quality of the data over a wide temperature range.

In this present supplement, we have departed from this format in presenting data on the reactions of ethyl, $i$-propyl, $t$-butyl and allyl radicals. The reactions of these radicals are of key importance in modelling the combustion of higher alkanes but in most cases there are insufficient data to warrant production of a full data sheet. For most of the reactions of these species we have therefore presented our rccommendations in the form of tables, with relevent comments on the preferred values, but without detailed display of the data.

These reactions are grouped in order using a system widely adopted in publications of the National Institute of Standards and Technology. The grouping is made on the basis of the attacking atom or radical in the order set out in the following list.
O Atom Reactions
$\mathrm{O}_{2}$ Reactions
$\mathrm{H}$ Atom Reactions
$\mathrm{H}_{2}$ Reactions
OH Radical Reactions
$\mathrm{H}_{2} \mathrm{O}$ Reactions
$\mathrm{HO}_{2}$ Radical Reactions
$\mathrm{H}_{2} \mathrm{O}_{2}$ Reactions
$\mathrm{N}$ Atom Reactions
NH Radical Reactions
$\mathrm{NH}_{2}$ Radical Reactions
$\mathrm{NH}_{3}$ Reactions
C Atom Reactions
$\mathrm{C}_{2}$ Radical Reactions
$\mathrm{CH}$ Radical Reactions 


\author{
${ }^{3} \mathrm{CH}_{2}$ Radical Reactions \\ ${ }^{\mathrm{i}} \mathrm{CH}_{2}$ Radical Reactions \\ $\mathrm{CH}_{3}$ Radical Reactions \\ $\mathrm{CH}_{4}$ Reactions \\ CHO Radical Reactions \\ HCHU Reactions \\ $\mathrm{CH}_{2} \mathrm{OH}$ Radical Reactions \\ $\mathrm{CH}_{3} \mathrm{O}$ Radical Reactions \\ $\mathrm{CH}_{3} \mathrm{O}_{2}$ Radical Reactions \\ $\mathrm{CH}_{3} \mathrm{OH}$ Reactions \\ $\mathrm{CH}_{3} \mathrm{OOH}$ Reactions \\ CN Radical Reactions \\ NCO Radical Reactions \\ $\mathrm{C}_{2} \mathrm{H}$ Radical Reactions \\ $\mathrm{C}_{2} \mathrm{H}_{3}$ Radical Reactions \\ $\mathrm{C}_{2} \mathrm{H}_{4}$ Reactions \\ $\mathrm{C}_{2} \mathrm{H}_{5}$ Radical Reactions \\ $\mathrm{C}_{2} \mathrm{H}_{6}$ Reactions \\ CHCO Radical Reactions \\ $\mathrm{CH}_{2} \mathrm{CHO}$ Radical Reactions \\ $\mathrm{CH}_{3} \mathrm{CO}$ Radical Reactions \\ $\mathrm{CH}_{3} \mathrm{CHO}$ Reactions \\ $\mathrm{C}_{2} \mathrm{H}_{5} \mathrm{O}$ Radical Reactions \\ $\mathrm{C}_{2} \mathrm{H}_{5} \mathrm{OOH}$ Reactions \\ $\mathrm{C}_{3} \mathrm{H}_{5}$ Radical Reactions \\ $i-\mathrm{C}_{3} \mathrm{H}_{7}$ Radical Reactions \\ $\mathrm{C}_{3} \mathrm{H}_{8}$ Reactions \\ $t-\mathrm{C}_{4} \mathrm{H}_{9}$ Radical Reactions \\ $\mathrm{C}_{6} \mathrm{H}_{5}$ Radical Reactions \\ $\mathrm{C}_{6} \mathrm{H}_{6}$ Reactions \\ $\mathrm{C}_{6} \mathrm{H}_{5} \mathrm{O}$ Radical Reactions \\ $\mathrm{C}_{6} \mathrm{H}_{5} \mathrm{CH}_{2}$ Radical Reactions \\ $\mathrm{C}_{6} \mathrm{H}_{5} \mathrm{CH}_{3}$ Reactions \\ p $-\mathrm{C}_{6} \mathrm{H}_{4}\left(\mathrm{CH}_{3}\right)_{2}$ Reactions \\ $\mathrm{C}_{6} \mathrm{H}_{5} \mathrm{C}_{2} \mathrm{H}_{5}$ Radical Reactions
}

Thus, the reaction

$$
\mathrm{CN}+\mathrm{CH}_{4} \rightarrow \mathrm{HCN}+\mathrm{CH}_{3}
$$

will be found under $\mathrm{CN}$ radical reactions. For reactions not classified by this rule, e.g. radical-radical reactions, the rule that species higher on the list take precedence over those lower applies. Thus, the reaction

$$
\mathrm{OH}+\mathrm{CH}_{3}+\mathrm{M} \rightarrow \mathrm{CH}_{3} \mathrm{OH}+\mathrm{M}
$$

will be found under $\mathrm{OH}$ radical reactions. The same rule applies to reactions between species of a non-radical nature. For the purposes of the classification $\mathrm{O}_{2}$ and $\mathrm{NO}$ are treated as radicals only in their reactions with non-radical species.

An exception to this ordering is the placement of dissociation reactions immediately after their corresponding reverse reaction, the combination of the dissociation products. Thus the data sheet for the reaction

$$
\mathrm{C}_{2} \mathrm{H}_{6}+\mathrm{M} \rightarrow 2 \mathrm{CH}_{3}+\mathrm{M}
$$

will be found immediately following the data sheet for the reaction

$$
\mathrm{CH}_{3}+\mathrm{CH}_{3}+\mathrm{M} \rightarrow \mathrm{C}_{2} \mathrm{H}_{6}+\mathrm{M} \text {. }
$$

This arrangement is followed wherever a full analysis of the pressure dependence of pairs of such reactions is carried out. In other cases where the data do not justify such a treatment or where only the combination or the decomposition reaction is dealt with, the normal ordering prevails.

In this supplement the data sheets on dissociation/combination reactions contain more extensive graphical presentation of the recommendations than was the case in the original publication in this series (CEC, 1992) ${ }^{1}$. For completeness, therefore, the data sheets for a number of such reactions, dealt with in CEC, 1992, are presented again in this present supplement with this enhanced graphical treatment.

\subsection{Conventions Concerning Rate Coefficients}

It is assumed that all reactions in the compilation are elementary reactions.

The relationship between rate and rate coefficient for a reaction described by a stoichiometric equation such as

$$
\mathrm{A}+\mathrm{A} \rightarrow \dot{\mathrm{B}}+\mathrm{C}
$$

is given by

$$
\text { Rate }=-(1 / 2) \mathrm{d}[\mathrm{A}] / \mathrm{d} t=\mathrm{d}[\mathrm{B}] / \mathrm{d} t=\mathrm{d}[\mathrm{C}] / \mathrm{d} t=k[\mathrm{~A}]^{2} .
$$

\subsection{Guide to the Tables}

Each data sheet begins with a heading giving all the reaction paths considered feasible whether there is evidence for their occurrence or not.

These are followed by the thermodynamic quantities $\Delta H^{\circ}$ and $\Delta S^{\circ}$ at $298 \mathrm{~K}$ and an expression for the equilibrium constant, $K$, in units of atmospheres, for each of the reaction channels for which there are data available. All thermodynamic data refer to a standard state of 1 atmosphere. The source of the thermodynamic data is discussed later in this Introduction.

The kinetic data for the reactions are summarized under the two headings (i) Rate Coefficient Measurements, and (ii) Reviews and Evaluations. To keep the size of the compilation within reasonable bounds, in most cases only the rate coefficient measurements back to the most recent comprehensive review are recorded. Where there is no suitable review, or where there are only few measurements, all of the measured values are tabulated. Also to limit the size of the review, if in a particular study, measurements of the rate coefficient have been made over a range of temperatures, the results are tabulated as a temperature dependent expression (usually Arrhenius in form) rather than as the individually reported data points. For bimolecular reactions, the temperature dependence of the rate coefficient is expressed either as $k=$ $A \exp (-R / T)$ or $A T^{n} \exp (-C / T)$ whichever is the more appropriate, where $A, n, B$ and $C$ are constants. In some cases, the form with $C=0$, leading to $k=A T^{n}$, gives the best representation. The expressions used for pressure dependent combination and dissociation reactions are discussed in detail later. 
Among the Reviews and Evaluations there are a number which are referred to so frequently that rather than repetitively give their full reference, in extenso, we list them among the references in this Introduction and refer the reader back to this list. These reviews are those of the IUPAC Task Group ${ }^{2-5}$, the NASA Panel ${ }^{6}$ and our original publication referred to as CEC, $1992^{1}$.

The tables of data are supplemented by a series of Comments summarizing the experimental details. For measurements giving rate coefficient ratios, the absolute value derived from them and given in the table may be different from that quoted in the original paper because the evaluator has chosen to use a value of the reference rate coefficient different from that used by the original author. Such differences are indicated and justified by appropriate entries in the Comments section.

Under Preferred Values the rate coefficient values recommended for use by modellers are presented as a temperature dependent expression over a stated, temperature range. Wherever possible, an attempt has been made to make recommendations for high temperatures even if this requires a considerable extrapolation from the low temperature data and consequent assignment of large error limits. However, in many cases, particularly for reactions likely to have a large activation energy, or where alternative reaction channels may become important, it has not been considered safe to extrapolate much beyond the range of existing measurements.

Wherever possible, the preferred values are based almost exclusively on experimental data but in a few cases estimates have been made based on analogous reactions. No attempt has been made to include calculated values of rate parameters but theoretical and empirical estimates have not been ignored. They have often provided valuable background and guidance on whether experimental values are 'reasonable'.

The preferred rate constant expression is followed by a statement of the error limits in $\log k$ at the extremes of the recommended temperature range. Some comments on the assignment of errors are given later in this Introduction.

The section "Comments on Preferred Values" contains a brief account of how expressions for the preferred values were arrived at and comments on the quality of the available data.

The data sheets conclude with a list of the relevant references and in many cases graphs to illustrate the quality of the data. Where there are few data points for a particular reaction all are recorded but for well studied reactions, where much data are available, for the sake of clarity, expressions, rather than the original points, are displayed in some cases.

\subsection{Treatment of Combination and Dissociation Reactions}

The rates of combination and the reverse dissociation reactions

$$
\mathrm{A}+\mathrm{B}+\mathrm{M} \leftrightharpoons \mathrm{AB}+\mathrm{M}
$$

depend on the temperature, $T$, the nature, and the concentration of the third body [M]. The rate coefficients of these reactions have to be expressed in a form which is more com- plicated than those for simple bimolecular reactions. The combination reactions are described by a pseudo-second-order rate law.

$$
\frac{\mathrm{d}[A B]}{\mathrm{d} t}=k[A][B]
$$

in which the second-order rate constant depends on [M]. The low pressure third-order limit is characterized by $k_{0}$,

$$
\begin{gathered}
k_{0}([\mathrm{M}])=\lim _{[\mathrm{M}] \rightarrow 0} k([\mathrm{M}]) \\
\end{gathered}
$$

The high pressure second-order limit is characterized by $k_{\infty}$,

$$
k_{\infty}=\lim _{[\mathrm{M}] \rightarrow \infty} k([\mathrm{M}]),
$$

which is independent of [M]. For a combination reaction in the low-pressure range, the summary table gives a second-order rate constant expressed as the product of a third-order rate constant and the third body concentration. The transition between the third-order and the second-order range is represented by a reduced fall off expression of $k / k_{\infty}$ as a function of

$$
k_{0}[\mathrm{M}] / k_{\infty}=[\mathrm{M}] /[\mathrm{M}]_{\mathrm{c}},
$$

where the "centre of the fall-off curve" $[\mathrm{M}]_{\mathrm{c}}$ indicates the third body concentration for which the extrapolated $k_{0}[\mathrm{M}]$ would be equal to $k_{\infty}$. The dependence of $k$ on [M] in general is complicated and has to be analyzed by unimolecular rate theory. For moderately complex molecules at not too high temperatures, however, a simple approximate relationship holds:

$$
\begin{gathered}
k=\frac{k_{\mathrm{o}} k_{\infty}[\mathrm{M}]}{k_{\mathrm{o}}[\mathrm{M}]+k_{\infty}} F=k_{\mathrm{o}}[\mathrm{M}]\left(\frac{1}{1+[\mathrm{M}] /[\mathrm{M}]_{\mathrm{c}}}\right) F \\
=k_{\infty}\left(\frac{[\mathrm{M}] /[\mathrm{M}]_{\mathrm{c}}}{1+[\mathrm{M}] /[\mathrm{M}]_{\mathrm{c}}}\right) F
\end{gathered}
$$

where the first factors on the rhs represent the LindemannHinshelwood expression, and the additional broadening factor $F$, at not too high temperature, is approximately given by

$$
\log F \cong \frac{\log F_{\mathrm{c}}}{1+\left\{\left[\log \left([\mathrm{M}] /[\mathrm{M}]_{\mathrm{c}}\right)\right] / \mathrm{N}\right\}^{2}}
$$

where $\mathrm{N}=0.75-1.27 \log F_{\mathrm{c}}$. The temperature dependence of $F_{\mathrm{c}}$, which is sometimes significant, can be estimated by the procedure of Troe ${ }^{7-9}$. The results can usually be represented ${ }^{9}$, approximately by an equation

$$
\begin{array}{r}
F_{\mathrm{c}}=(1-\mathrm{a}) \exp \left(-T / T^{* * *}\right)+\mathrm{a} \exp \left(-T / T^{*}\right)+ \\
\exp \left(-T^{* * / T}\right),
\end{array}
$$

where a, $T^{*}, T^{* *}$, and $T^{* * *}$ are constants. The first two terms 
are of importance for atmospheric conditions, but the last term in most cases becomes relevant only at high temperatures. In this way, the three quantities, $k_{0}, k_{\infty}$, and $F_{\mathrm{c}}$ with

$$
[\mathrm{M}]_{\mathrm{c}}=\frac{k_{\infty}}{k_{\mathrm{o}}}
$$

characterize the fall-off curve for the present application. Alternatively, the three quantities $k_{\infty},[\mathrm{M}]_{\mathrm{c}}$, and $F_{\mathrm{c}}$ (or $k_{0},[\mathrm{M}]_{\mathrm{c}}$, and $F_{\mathrm{c}}$ ) can be used.

Theoretical predictions ${ }^{7-9}$ of $F_{c}$ have been derived from rigid RRKM-type models including weak collision effects. Systematic calculations of this type have been presented by Patrick and Golden ${ }^{10}$ for reactions of atmospheric interest. It is debatable whether these calculations can be applied to radical recombination reactions without barriers, where rotational effects are important. Changes in $F_{\mathrm{c}}$ would require changes in the limiting $k_{0}$ and $k_{\infty}$ values. For the purpose of this evaluation, this will be irrelevant in most cases, if the preferred $k_{0}$ and $k_{w}$ are used consistently together with the preferred $F_{\mathrm{c}}$ values.

If detailed calculations are made it is sometimes found that alternative expressions for $F_{\mathrm{c}}$ may be more appropriate.

The dependence of $k_{0}$ and $k_{\infty}$ on the temperature is represented in the $T$ exponent $n$,

$$
k \propto T^{-n}
$$

(except for the cases with an established energy barrier in the potential). We have used this form of temperature dependence because it often gives a better fit to the data over a wider range of temperature than does the Arrhenius expression.

In a few instances, the rate constant for the reaction has been measured under conditions where it is almost certainly pressure dependent but where the measurements cannot be analysed to give values of $k_{0}, k_{\infty}$, and $F_{\mathrm{c}}$. In such cases an expression for $k$ only is quoted.

To avoid ambiguity, the subscripts denoting infinite and zero pressure limiting rate constants have, in places, been written as superscripts c.g. $k^{\infty}{ }_{1}, k^{\circ}{ }_{1}$ rather than $k_{1 \infty}$ and $k_{10}$.

\subsection{Assignment of Errors}

The reliability of a preferred expression for $k$ is expressed in terms of an estimated $\Delta \log k$ at the extremes of the temperature range covered by the recommended expression. Thus a quoted $\Delta \log k= \pm X$ is equivalent to the statement that the range of values of $k$ encompassed by these error limits may be found by multiplication and division of $k$ by a factor $F$, where $X=\log F$.

No attempt has been made to assign explicit error limits to the temperature coefficient of $k$. The assignment of error limits in $\Delta \log k$ at the extremes of the temperature range indicates how the quality of the data varies with temperature without attempting to define the form which this variation takes. In the opinion of the evaluators the available data rarely merit a more elaborate assignment of errors over a wide temperature range.

The assignment of error limits in $k$ is a subjective assessment by the evaluators. Modern techniques are capable in favourable circumstances of measuring rate coefficients with the precision represented by a standard deviation as small as $10 \%$. However, data obtained in different laboratories on the same reaction and often by the same technique are rarely concordant to the extent that might be expected from the precision of the measurements; mean values may differ by many standard deviations. This is indicative of systematic errors which are difficult to detect and which cannot be simply incorporated into quoted error limits.

\subsection{Thermodynamic Data}

There are substantial uncertainties associated with the thermodynamic data of a number of species appearing in the compilation. For the sake of internal consistency the thermodynamic data have been taken from a single compilation, that prepared for the Sandia Chemkin Program ${ }^{11}$. We have also made use of the NIST compilation ${ }^{12}$ but that does not extend to temperatures sufficiently high for combustion modelling. The Sandia compilation is sufficiently comprehensive to cover most of the species appearing in the kinetics tables. In a few cases, the present evaluation of the kinetic data has led to an assignment of enthalpies of formation at variance with those in the thermodynamic data base. This has been commented on in the text but has not been incorporated into the thermodynamic data quoted. The Sandia compilation does not include data for aromatic compounds. The data for these have been derived from a variety of sources.

In the present tables the standard enthalpy change at $298 \mathrm{~K}$ and the equilibrium constant as a function of temperature are given for each reaction channel. The equilibrium constant is expressed in the form $K=A T^{\mathrm{n}} \exp (B / T)$, where $A, B$ and $n$ at constants. The quality of the thermodynamic data rarely justify the use of expressions for $\mathrm{K}(T)$ involving more than three constants even through the Sandia data compilation expresses the thermodynamic quantities in terms of polynomials involving seven coefficients. To obtain the expression for $\mathrm{K}(T)$ values of $\mathrm{K}$ were calculated from the Sandia data base at several temperatures over the range $300-6000 \mathrm{~K}$ and fitted to the three constant expressions by a least squares procedure.

Because $\mathrm{K}$ is very sensitive to the thermodynamic quantities, particularly $\Delta H^{\circ}$, any rate coefficient calculated from the equilibrium constant and the rate coefficient for the reaction in one direction may be subject to substantial uncertainty.

Wherever kinetic data are available for the rate coefficient for the reaction in both forward and reverse directions, an attempt has been made to reconcile it with the thermodynamic data quoted. For a number of important species there are no thermodynamic data available pointing to the need for experimental measurements aimed at providing such data, particularly for key radicals.

\subsection{Acknowledgments}

We gratefully acknowledge the assistance of Dr. J.T. Harrison, Mr. P. Lowing, and Mrs. M. Lesnianski in the preparation of this manuscript. 


\subsection{References}

'CEC Group on Evaluation of Kinetic Data for Combustion Modelling, D.L. Baulch, C.J. Cobos, R.A. Cox, C. Esser, P. Franck, Th. Just, J.A. Kerr, M.J. Pilling, J. Troe, R.W. Walker, and J. Warnatz, J. Phys. Chem. Ref. Data 21, 411 (1992).

${ }^{2}$ CODATA Task Group on Chemical Kinetics, D.L. Baulch, R.A. Cox, R.F. Hampson, Jr., J.A. Kerr,

J. Troe, and R.T. Watson, J. Phys. Chem. Ref. Data 9, 295 (1980).

${ }^{3}$ CODATA Task Group on Chemical Kinetics, D.L. Baulch, R.A. Cox, P.J. Crutzen, R.F. Hampson, Jr., J.A. Kerr, J. Troe, and R.T. Watson, J. Phys. Chem. Ref. Data 13, 1259 (1984).

${ }^{4}$ IUPAC Sub-committee on Gas Kinetic Data Evaluation for Atmospheric Chemistry, R. Atkinson, D.L. Baulch, R.A. Cox, R.F. Hampson, Jr., J.A. Kerr, and J. Troe, J. Phys. Chem. Ref. Data 18, 881 (1989).

'SIUPAC Sub-committee on Gas Kinetic Data Evaluation for Atmospheric Chemistry, R. Atkinson, D.L. Baulch, R.A. Cox, R.F. Hampson, Jr., J.A. Kerr, and J. Troe, J. Phys. Chem. Ref. Data 21, 1125 (1992).
${ }^{6}$ NASA Panel for Data Evaluation, Chemical Kinetics and Photochemical Data for Use in Stratospheric Modelling, Evaluation Number 9, W.B. DeMore, S.P. Sander, D.M. Golden, M.J. Molina, R.F. Hampson, M.J. Kurylo, C.J. Howard, and A.R. Ravishankara, JPL Publication 92-20 (1992). (References to the previous evaluations in this series, numbers 1-9, will be found in this reference.)

${ }^{7}$ J. Troe, J. Phys. Chem. 83, 114 (1979).

${ }^{8}$ J. Troe, Ber. Bunsenges. Phys. Chem. 87, 161 (1983).

${ }^{9}$ R.G. Gilbert, K. Luther, and J. Troe, Ber. Bunsenges. Phys. Chem. 87, 169 (1983).

${ }^{10}$ R. Patrick and D.M. Golden, Int. J. Chem. Kinet. 15, 1189 (1983).

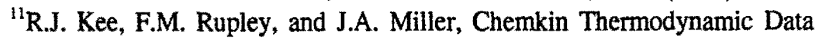
Base, Sandia Report 87-82153.UC-4 (1987).

${ }^{12}$ NIST Structures and Properties Database and Estimation Program.

\section{Errata to Reference 1}

We are grateful to a number of readers for drawing to our attention the following errors in our original set of data sheets
(Ref. 1). There are also a number of minor typographical errors which are not listed.
$\mathrm{O}+{ }^{3} \mathrm{CH}_{2} \rightarrow \mathrm{CO}+2 \mathrm{H}$$$
\rightarrow \mathrm{CO}+\mathrm{H}_{2}
$$$$
\mathrm{H}+\mathrm{CH}_{3}+\mathrm{M} \rightarrow \mathrm{CH}_{4}+\mathrm{M}
$$$$
\mathrm{OH}+\mathrm{C}_{2} \mathrm{H}_{2}+\mathrm{M} \rightarrow \mathrm{C}_{2} \mathrm{H}_{2} \mathrm{OH}+\mathrm{M}
$$$$
\mathrm{OH}+\mathrm{C}_{6} \mathrm{H}_{5} \mathrm{CH}_{3} \rightarrow \mathrm{H}_{2} \mathrm{O}+\mathrm{C}_{6} \mathrm{H}_{5} \mathrm{CH}_{2} \quad \text { p.420. }
$$$$
\text { p.428. }
$$
The value of $k$ in the first entry in the table of rate coefficients, measured by Vinckier and Debruyn should read $1.3 \times 10^{-10}$ not $1.3 \times 10^{-11}$.
$k_{0}(\mathrm{He})=6.2 \times 10^{-29}(T / 300)^{-1.8}$ not $k_{0}(\mathrm{He})=6.2 \times 10^{-29}(T / 3000)^{-1.8}$.
$k_{3}^{\circ}$ should read $5 \times 10^{-25} T^{-2}$ not $5 \times 10^{-35} T^{-2}$.
Preferred values should read $k_{1}=8.6 \times 10^{-15} T \exp (-440 / T)$ not $8.6 \times 10^{-15} \exp (-1440 / T)$.
Preferred values should read $k_{1}=8.6 \times 10^{-15} T \exp (-440 / T)$ not $8.6 \times 10^{-15} \exp (-440 / T)$.

$\mathrm{HO}_{2}+\mathrm{CH}_{3} \rightarrow \mathrm{OH}+\mathrm{CH}_{3} \mathrm{O} \quad$ p.608.

$\mathrm{OH}+\mathrm{CO} \rightarrow \mathrm{H}+\mathrm{CO}_{2} \quad$ p.569.

There is a discrepancy between the line for the recommended value drawn on the graph and the expression quoted for the recommended value. The expression quoted should be used.
The temperature range for the reliability of the preferred values should read $300-2500 \mathrm{~K}$, not $600-1200 \mathrm{~K}$.

\section{Index of Reactions and Summary Table}

\subsection{Guide to the Summary Table}

There are three tables. In Table 1 all of the reactions whose rate data were evaluated in the present programme are listed. For each reaction the preferred value of the rate coefficient, the temperature range over which it applies, and the associated error limits are given.

For many reactions more than one set of products is possible. All of the channels considered feasible are given and wherever possible rate parameters are recommended for each channel, or branching ratios are given. For such multichannel reactions, however, where the dominant channel has been identified that channel only is specified although others are conceivable.

All of the reactions evaluated are listed in Table 1 but only the rate data for bimolecular processes are given in that Table. The data for decomposition and recombination reactions are listed separately in Tables 2 and 3.

Tables 2 and 3 contain the preferred rate parameters for decomposition and combination reactions respectively. The rate data are expressed in terms of the symbolism developed by Troe and described in Sec. 2.4 . 
EVALUATED KINETIC DATA FOR COMBUSTION MODELLING

\subsection{Summary of Preferred Rate Data}

TABLE 1. Bimolecular Reactions

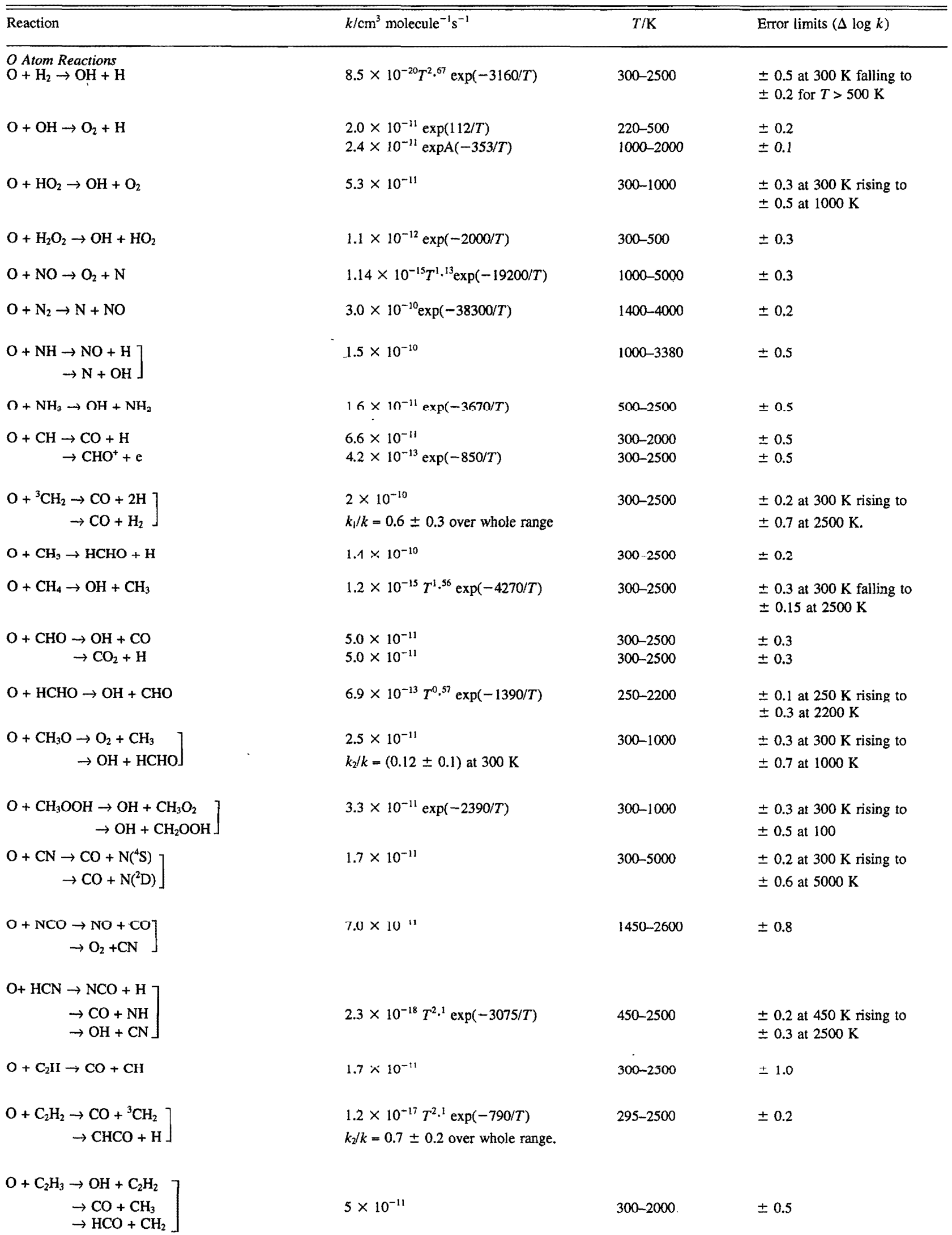


TABLE 1. Bimolecular Reactions - Continued

\begin{tabular}{|c|c|c|c|}
\hline Reaction & $k / \mathrm{cm}^{3}$ molecule ${ }^{-1} \mathrm{~s}^{-1}$ & $T / \mathrm{K}$ & Error limits $(\Delta \log k)$ \\
\hline $\left.\begin{array}{rl}\mathrm{O}+\mathrm{C}_{2} \mathrm{H}_{4} & \rightarrow \mathrm{CH}_{2} \mathrm{CHO}+\mathrm{H} \\
& \rightarrow \mathrm{HCO}+\mathrm{CH}_{3} \\
& \rightarrow \mathrm{HCHO}+\mathrm{CH}_{2} \\
& \rightarrow \mathrm{CH}_{2} \mathrm{CO}+\mathrm{H}_{2}\end{array}\right]$ & $\begin{array}{l}2.25 \times 10^{-17} T^{1.88} \exp (-90 / T) \\
k_{1} / k=0.35 \pm 0.05 \text { at } \mathrm{p}>3 \text { Torr } \\
k_{2} / k=0.6 \pm 0.10 ; k_{1} / k=0.05 \pm 0.10\end{array}$ & $300-2000$ & $\begin{array}{l} \pm 0.1 \text { for } T<1000 \mathrm{~K} \\
\text { rising to } \pm 0.3 \text { at } 2000 \mathrm{~K}\end{array}$ \\
\hline $\left.\begin{array}{rl}\mathrm{O}+\mathrm{C}_{2} \mathrm{H}_{5} & \rightarrow \mathrm{CH}_{3} \mathrm{CHO}+\mathrm{H} \\
& \rightarrow \mathrm{HCHO}+\mathrm{CH}_{3}\end{array}\right]$ & $\begin{array}{l}1.1 \times 10^{-10} \\
k_{2} / k=0.17 \pm 0.2 \text { at } 300 \mathrm{~K}\end{array}$ & $300-2500$ & $\begin{array}{l} \pm 0.3 \text { from } 300 \text { to } 1000 \mathrm{~K} \\
\pm 0.5 \text { from } 1000 \text { to } 2500 \mathrm{~K}\end{array}$ \\
\hline $\mathrm{O}+\mathrm{C}_{2} \mathrm{H}_{6} \rightarrow \mathrm{OH}+\mathrm{C}_{2} \mathrm{H}_{5}$ & $1.66 \times 10^{-15} T^{1.5} \exp (-2920 / T)$ & $300-1200$ & $\begin{array}{l} \pm 0.3 \text { at } 300 \mathrm{~K} \text { falling to } \\
\pm 0.15 \text { at } 1200 \mathrm{~K}\end{array}$ \\
\hline $\mathrm{O}+\mathrm{CHCO} \rightarrow 2 \mathrm{CO}+\mathrm{H}$ & $1.6 \times 10^{-10}$ & $300-2500$ & \pm 0.3 \\
\hline $\left.\begin{array}{rl}\mathrm{O}+\mathrm{CH}_{2} \mathrm{CO} & \rightarrow \mathrm{CH}_{2} \mathrm{O}+\mathrm{CO} \\
& \rightarrow \mathrm{HCO}+\mathrm{H}+\mathrm{CO} \\
& \rightarrow \mathrm{HCO}+\mathrm{HCO}\end{array}\right]$ & $3.8 \times 10^{-12} \exp (-680 / T)$ & $230-500$ & \pm 0.3 \\
\hline $\left.\begin{array}{rl}\mathrm{O}+\mathrm{CH}_{3} \mathrm{CO} & \rightarrow \mathrm{OH}+\mathrm{CH}_{2} \mathrm{CO} \\
& \rightarrow \mathrm{CO}_{2}+\mathrm{CH}_{3}\end{array}\right]$ & $\begin{array}{l}3.2 \times 10^{-10} \\
k_{1} / k=0.2 \pm 0.1 \text { at } 298 \mathrm{~K} \\
k_{2} / k=0.8 \pm 0.2 \text { at } 298 \mathrm{~K}\end{array}$ & $298-1500$ & $\begin{array}{l} \pm 0.3 \text { at } 298 \mathrm{~K} \text { rising to } \\
\pm 1.0 \text { at } 1500 \mathrm{~K}\end{array}$ \\
\hline $\left.\begin{array}{rl}\mathrm{O}+\mathrm{CH}_{3} \mathrm{CHO} & \rightarrow \mathrm{OH}+\mathrm{CH}_{3} \mathrm{CO} \\
& \rightarrow \mathrm{OH}+\mathrm{CH}_{2} \mathrm{CHO}\end{array}\right]$ & $9.7 \times 10^{-12} \exp (-910 / T)$ & $298-1500$ & $\begin{array}{l} \pm 0.05 \text { at } 298 \mathrm{~K} \text { rising to } \\
\pm 0.5 \text { at } 1500 \mathrm{~K}\end{array}$ \\
\hline $\left.\begin{array}{rl}\mathrm{O}+\mathrm{C}_{2} \mathrm{H}_{5} \mathrm{OOH} & \rightarrow \mathrm{OH}+\mathrm{C}_{2} \mathrm{H}_{4} \mathrm{OOH} \\
& \rightarrow \mathrm{OH}+\mathrm{C}_{2} \mathrm{H}_{5} \mathrm{OO}\end{array}\right]$ & $\begin{array}{l}3.3 \times 10^{-11} \exp (-2390 / T) \\
\text { [estimate] }\end{array}$ & $300-1000$ & $\begin{array}{l} \pm 0.3 \text { at } 300 \mathrm{~K} \text { rising to } \\
\pm 0.5 \text { at } 1000 \mathrm{~K}\end{array}$ \\
\hline $\left.\begin{array}{rl}\mathrm{O}+\mathrm{C}_{3} \mathrm{H}_{5} & \rightarrow \mathrm{CH}_{2} \mathrm{CHCHO}+\mathrm{H} \\
& \rightarrow \mathrm{HCHO}+\mathrm{C}_{2} \mathrm{H}_{3}\end{array}\right]$ & $\begin{array}{l}3.0 \times 10^{-10} \\
<3 \times 10^{-11}\end{array}$ & $\begin{array}{l}300-1000 \\
2000\end{array}$ & $\begin{array}{l} \pm 0.2 \text { over the range } 300-600 \mathrm{~K} \\
\pm 0.4 \text { over the range } 600-1000 \mathrm{~K}\end{array}$ \\
\hline $\left.\begin{array}{rl}\mathrm{O}+\mathrm{C}_{6} \mathrm{H}_{6} & \rightarrow \mathrm{OH}+\mathrm{C}_{6} \mathrm{H}_{5} \\
& \rightarrow \mathrm{C}_{6} \mathrm{H}_{6} \mathrm{O}\end{array}\right]$ & $\begin{array}{l}\left(k_{1}+k_{2}\right)=5.9 \times 10^{-23} T^{3.8} \exp (-473 / T) \\
k_{2}=3.7 \times 10^{-11} \exp (-2280 / T)\end{array}$ & $\begin{array}{l}298-2000 \\
298-1400\end{array}$ & $\begin{array}{l} \pm 0.3 \\
\pm 0.3 \text { at } 298 \mathrm{~K} \text { falling to } \\
\pm 0.2 \text { at } 1400 \mathrm{~K} .\end{array}$ \\
\hline $\mathrm{O}+\mathrm{C}_{6} \mathrm{H}_{5} \mathrm{OH} \rightarrow$ products & $2.1 \times 10^{-11} \exp (-1460 / T)$ & $290-600$ & \pm 0.3 \\
\hline $\begin{aligned} \mathrm{O}+\mathrm{C}_{6} \mathrm{H}_{5} \mathrm{CH}_{2} & \rightarrow \mathrm{HCO}+\mathrm{C}_{6} \mathrm{H}_{6} \\
& \rightarrow \mathrm{C}_{6} \mathrm{H}_{5} \mathrm{CHO}+\mathrm{H} \\
& \rightarrow \mathrm{CH}_{2} \mathrm{O}+\mathrm{C}_{6} \mathrm{H}_{5}\end{aligned}$ & $\begin{array}{l}5.5 \times 10^{-10} \\
\text { No recommendation }\end{array}$ & 300 & \pm 0.3 \\
\hline $\mathrm{O}+\mathrm{C}_{5} \mathrm{H}_{5} \mathrm{CH}_{3} \rightarrow$ products & $5.3 \times 10^{-15} T^{1.21} \exp (-1260 / T)$ & $298-2800$ & $\begin{array}{l} \pm 0.1 \text { at } 298 \mathrm{~K} \text { rising to } \\
\pm 0.4 \text { at } 2800 \mathrm{~K}\end{array}$ \\
\hline $\left.\begin{array}{rl}\mathrm{O}+\mathrm{C}_{6} \mathrm{H}_{5} \mathrm{CHO} & \rightarrow \mathrm{OH}+\mathrm{C}_{6} \mathrm{H}_{5} \mathrm{CO} \\
& \rightarrow \mathrm{OH}+\mathrm{C}_{6} \mathrm{H}_{4} \mathrm{CHO}\end{array}\right]$ & $\begin{array}{l}1.0 \times 10^{-11} \exp (-910 / T) \\
\text { No recommendation }\end{array}$ & $298-1500$ & $\begin{array}{l} \pm 0.3 \text { at } 298 \mathrm{~K} \\
\text { rising to } \pm 0.7 \text { at } 1500 \mathrm{~K}\end{array}$ \\
\hline $\mathrm{O}+p-\mathrm{C}_{6} \mathrm{H}_{4}\left(\mathrm{CH}_{3}\right)_{2} \rightarrow$ products & $5.1 \times 10^{-11} \exp (-1630 / T)$ & $298-600$ & \pm 0.3 \\
\hline $\mathrm{O}+\mathrm{C}_{6} \mathrm{H}_{5} \mathrm{C}_{2} \mathrm{H}_{5} \rightarrow$ products & $2.8 \times 10^{-11} \exp (-1840 / T)$ & $298-600$ & \pm 0.3 \\
\hline \multicolumn{4}{|l|}{$\mathrm{O}_{2}$ Reactions } \\
\hline $\mathrm{O}_{2}+\mathrm{CH}_{4} \rightarrow \mathrm{HO}_{2}+\mathrm{CH}_{3}$ & $6.6 \times 10^{-11} \exp (-28630 / T)$ & $500-2000$ & $\begin{array}{l} \pm 0.5 \text { at } 500 \mathrm{~K} \text { rising to } \\
\pm 1.0 \text { at } 2000 \mathrm{~K}\end{array}$ \\
\hline $\mathrm{O}_{2}+\mathrm{C}_{2} \mathrm{H}_{6} \rightarrow \mathrm{HO}_{2}+\mathrm{C}_{2} \mathrm{H}_{5}$ & $1.0 \times 10^{-10} \exp (-26100 / T)$ & $500-2000$ & $\begin{array}{l} \pm 0.5 \text { at } 500 \mathrm{~K} \text { rising to } \\
\pm 1.0 \text { at } 2000 \mathrm{~K}\end{array}$ \\
\hline
\end{tabular}


TABlE 1. Bimolecular Reactions - Continued

\begin{tabular}{|c|c|c|c|}
\hline Reaction & $k / \mathrm{cm}^{3}$ molecule ${ }^{-1} \mathrm{~s}^{-1}$ & $T / \mathrm{K}$ & Error limits $(\Delta \log k)$ \\
\hline $\mathrm{O}_{2}+\mathrm{HCHO} \rightarrow \mathrm{HO}_{2}+\mathrm{HCO}$ & $1.0 \times 10^{-10} \exp (-20460 / T)$ & $700-1000$ & \pm 0.5 \\
\hline $\mathrm{O}_{2}+\mathrm{CH}_{3} \mathrm{CHO} \rightarrow \mathrm{HO}_{2}+\mathrm{CH}_{3} \mathrm{CO}$ & $5.0 \times 10^{-11} \exp (-19700 / T)$ & $600-1100$ & $\begin{array}{l} \pm 0.5 \text { at } 600 \mathrm{~K} \text { rising to } \\
\pm 1.0 \text { at } 1100 \mathrm{~K} .\end{array}$ \\
\hline $\mathrm{O}_{2}+\mathrm{C}_{3} \mathrm{H}_{6} \rightarrow \mathrm{HO}_{2}+\mathrm{CH}_{2} \mathrm{CHCH}_{2}$ & $3.2 \times 10^{-12} \exp (-19700 / T)$ & $600-1000$ & $\begin{array}{l} \pm 0.3 \text { at } 800 \mathrm{~K} \text { rising to } \\
\pm 0.5 \text { at } 600 \mathrm{~K} \text { and } 1000 \mathrm{~K}\end{array}$ \\
\hline $\mathrm{O}_{2}+\mathrm{C}_{6} \mathrm{H}_{5} \mathrm{CH}_{3} \rightarrow \mathrm{HO}_{2}+\mathrm{C}_{6} \mathrm{H}_{5} \mathrm{CH}_{2}$ & $3 \times 10^{-12} \exp (-20000 / T)$ & $700-1200$ & \pm 0.7 \\
\hline \multicolumn{4}{|l|}{ H Atoms Reactions } \\
\hline $\mathrm{H}+\mathrm{O}_{2} \rightarrow \mathrm{OH}+\mathrm{O}$ & $1.62 \times 10^{-10} \exp (-7470 / T)$ & $300-5000$ & $\begin{array}{l} \pm 0.1 \text { at } 300 \mathrm{~K} \text { rising to } \\
\pm 0.5 \text { at } 5000 \mathrm{~K}\end{array}$ \\
\hline $\mathrm{H}+\mathrm{O}_{2}+\mathrm{Ar} \rightarrow \mathrm{HO}_{2}+\mathrm{Ar}$ & See Table 3 & & \\
\hline $\mathrm{H}+\mathrm{O}_{2}+\mathrm{H}_{2} \rightarrow \mathrm{HO}_{2}+\mathrm{H}_{2}$ & See Table 3 & & \\
\hline $\mathrm{H}+\mathrm{O}_{2}+\mathrm{N}_{2} \rightarrow \mathrm{HO}_{2}+\mathrm{N}_{2}$ & See Table 3 & & \\
\hline $\mathrm{H}+\mathrm{H}+\mathrm{Ar} \rightarrow \mathrm{H}_{2}+\mathrm{Ar}$ & See Table 3 & & \\
\hline $\mathrm{H}+\mathrm{H}+\mathrm{H}_{2} \rightarrow \mathrm{H}_{2}+\mathrm{H}_{2}$ & See Table 3 & & \\
\hline $\mathrm{H}+\mathrm{OH}+\mathrm{H}_{2} \mathrm{O} \rightarrow \mathrm{H}_{2} \mathrm{O}+\mathrm{H}_{2} \mathrm{O}$ & See Table 3 & & \\
\hline $\mathrm{H}+\mathrm{OH}+\mathrm{Ar} \rightarrow \mathrm{H}_{2} \mathrm{O}+\mathrm{Ar}$ & See Table 3 & & \\
\hline $\mathrm{H}+\mathrm{OH}+\mathrm{N}_{2} \rightarrow \mathrm{H}_{2} \mathrm{O}+\mathrm{N}_{2}$ & See Table 3 & & \\
\hline $\mathrm{H}+\mathrm{HO}_{2} \rightarrow \mathrm{H}_{2}+\mathrm{O}_{2}$ & $7.1 \times 10^{-11} \exp (-710 / T)$ & $300-1000$ & \pm 0.3 \\
\hline$\rightarrow 2 \mathrm{OH}$ & $2.8 \times 10^{-10} \exp (-440 / T)$ & $300-1000$ & \pm 0.3 \\
\hline$\rightarrow \mathrm{H}_{2} \mathrm{O}+\mathrm{O}$ & $5.0 \times 10^{-11} \exp (-866 / T)$ & $300-1000$ & \pm 0.3 \\
\hline $\mathrm{H}+\mathrm{H}_{2} \mathrm{O} \rightarrow \mathrm{OH}+\mathrm{H}_{2}$ & $7.5 \times 10^{-16} T^{1} \cdot 6 \exp (-9270 / T)$ & $300-2500$ & \pm 0.2 \\
\hline $\begin{aligned} \mathrm{H}+\mathrm{H}_{2} \mathrm{O}_{2} & \rightarrow \mathrm{H}_{2}+\mathrm{HO}_{2} \\
& \rightarrow \mathrm{OH}+\mathrm{H}_{2} \mathrm{O}\end{aligned}$ & $\begin{array}{l}2.8 \times 10^{-12} \exp (-1890 / T) \\
1.7 \times 10^{-11} \exp (-1800 / T)\end{array}$ & $\begin{array}{l}300-1000 \\
300-1000\end{array}$ & $\begin{array}{l} \pm 0.3 \\
\pm 0.3\end{array}$ \\
\hline $\mathrm{H}+\mathrm{NO} \rightarrow \mathrm{OH}+\mathrm{N}$ & $3.6 \times 10^{-10} \exp (-24910 / T)$ & $1500-4500$ & \pm 0.5 \\
\hline $\mathrm{H}+\mathrm{NH} \rightarrow \mathrm{H}_{2}+\mathrm{N}$ & $1.7 \times 10^{-11}$ & $1500-2500$ & \pm 1.0 \\
\hline $\mathrm{H}+\mathrm{NH}_{2} \rightarrow \mathrm{H}_{2}+\mathrm{NH}$ & $1.0 \times 10^{-11}$ & $2000-3000$ & \pm 1.0 \\
\hline $\mathrm{H}+\mathrm{CO}+\mathrm{M} \rightarrow \mathrm{HCO}+\mathrm{M}$ & See Table 3 & & \\
\hline $\mathrm{H}+{ }^{3} \mathrm{CH}_{2} \rightarrow \mathrm{H}_{2}+\mathrm{CH}$ & $1.0 \times 10^{-11} \exp (900 / T)$ & $300-3000$ & \pm 0.7 \\
\hline $\begin{aligned} \mathrm{H}+\mathrm{CH}_{3} & \rightarrow \mathrm{H}_{2}+{ }^{\mathrm{I}} \mathrm{CH}_{2} \\
& \rightarrow \mathrm{CH}_{4}\end{aligned}$ & $\begin{array}{l}1.0 \times 10^{-10} \exp (-7600 / T) \\
\text { See Table } 3\end{array}$ & $300-2500$ & \pm 1.0 \\
\hline $\mathrm{H}+\mathrm{CH}_{4} \rightarrow \mathrm{H}_{2}+\mathrm{CH}_{3}$ & $2.2 \times 10^{-20} T^{3} \cdot 0 \exp (-4045 / T)$ & $300-2500$ & $\begin{array}{l} \pm 0.2 \text { at } 300 \mathrm{~K} \text { and } 2500 \mathrm{~K} \\
\text { reducing to } \pm 0.05 \text { over } \\
\text { range } 500-1000 \mathrm{~K}\end{array}$ \\
\hline $\mathrm{H}+\mathrm{CHO} \rightarrow \mathrm{H}_{2}+\mathrm{CO}$ & $1.5 \times 10^{-10}$ & $300-2500$ & \pm 0.3 \\
\hline $\mathrm{H}+\mathrm{HCHO} \rightarrow \mathrm{H}_{2}+\mathrm{HCO}$ & $2.1 \times 10^{-16} T^{1.62} \exp (-1090 / T)$ & $300-1700$ & $\begin{array}{l} \pm 0.1 \text { at } 300 \mathrm{~K} \text { rising to } \\
\pm 0.3 \text { at } 1700 \mathrm{~K}\end{array}$ \\
\hline $\mathrm{H}+\mathrm{CH}_{3} \mathrm{O} \rightarrow \mathrm{H}_{2}+\mathrm{HCHO}$ & $3.0 \times 10^{-11}$ & $300-1000$ & \pm 0.5 \\
\hline
\end{tabular}


TABLE 1. Bimolecular Reactions - Continued

\begin{tabular}{|c|c|c|c|}
\hline Reaction & $k / \mathrm{cm}^{3}$ molecule $\mathrm{e}^{-1} \mathrm{~s}^{-1}$ & $T / \mathrm{K}$ & Error limits $(\Delta \log k)$ \\
\hline $\begin{aligned} \mathrm{H}+\mathrm{HNCO} & \rightarrow \mathrm{NH}_{2}+\mathrm{CO} \\
& \rightarrow \mathrm{H}_{2}+\mathrm{NCO}\end{aligned}$ & $\begin{array}{l}\text { No recommendation } \\
3.4 \times 10^{-10} T^{-0.27} \exp (-10190 / T)\end{array}$ & $500-1000$ & \pm 1.0 \\
\hline $\begin{aligned} \mathrm{H}+\mathrm{NCO} & \rightarrow \mathrm{NH}+\mathrm{CO} \\
& \rightarrow \mathrm{HCN}+\mathrm{O}\end{aligned}$ & $8.7 \times 10^{-11}$ & $1400-1500$ & \pm 0.5 \\
\hline $\begin{aligned} \mathrm{H}+\mathrm{C}_{2} \mathrm{H}_{2} & \rightarrow \mathrm{H}_{2}+\mathrm{C}_{2} \mathrm{H} \\
& \rightarrow \mathrm{C}_{2} \mathrm{H}_{3}\end{aligned}$ & $\begin{array}{l}1.1 \times 10^{-10} \exp (-14000 / T) \\
\text { See Table } 3\end{array}$ & $1000-3000$ & \pm 1.0 \\
\hline $\begin{aligned} \mathrm{H}+\mathrm{C}_{2} \mathrm{H}_{3} & \rightarrow \mathrm{H}_{2}+\mathrm{C}_{2} \mathrm{H}_{2} \\
& \rightarrow \mathrm{C}_{2} \mathrm{H}_{4}\end{aligned}$ & $\begin{array}{l}2.0 \times 10^{-11} \\
\text { See Table } 3\end{array}$ & $300-2500$ & \pm 0.5 \\
\hline $\begin{aligned} \mathrm{H}+\mathrm{C}_{2} \mathrm{H}_{4} & \rightarrow \mathrm{H}_{2}+\mathrm{C}_{2} \mathrm{H}_{3} \\
& \rightarrow \mathrm{C}_{2} \mathrm{H}_{5}\end{aligned}$ & $\begin{array}{l}9.0 \times 10^{-10} \exp (-7500 / T) \\
\text { See Table } 3\end{array}$ & $700-2000$ & \pm 0.5 \\
\hline $\begin{aligned} \mathrm{H}+\mathrm{C}_{2} \mathrm{H}_{5} & \rightarrow 2 \mathrm{CH}_{3} \\
& \rightarrow \mathrm{C}_{2} \mathrm{H}_{6}\end{aligned}$ & $\begin{array}{l}6.0 \times 10^{-11} \\
\text { See Table } 3\end{array}$ & $300-2000$ & $\begin{array}{l} \pm 0.3 \text { at } 300 \mathrm{~K} \text { rising to } \\
\pm 0.7 \text { at } 2000 \mathrm{~K}\end{array}$ \\
\hline $\mathrm{H}+\mathrm{C}_{2} \mathrm{H}_{6} \rightarrow \mathrm{H}_{2}+\mathrm{C}_{2} \mathrm{H}_{5}$ & $2.4 \times 10^{-15} T^{1.5} \exp (-3730 / T)$ & $300-2000$ & $\begin{array}{l} \pm 0.15 \text { at } 300 \mathrm{~K} \text { rising to } \\
\pm 0.3 \text { at } 2000 \mathrm{~K}\end{array}$ \\
\hline $\left.\mathrm{H}+\mathrm{CHCO} \rightarrow \mathrm{CH}_{2}+\mathrm{CO}\right]$ & & & \\
\hline $\left.\begin{array}{l}\rightarrow \mathrm{H}_{2}+\mathrm{C}_{2} \mathrm{O} \\
\rightarrow \mathrm{HCCOH}\end{array}\right]$ & $2.5 \times 10^{-10}$ & $300-2500$ & \pm 0.4 \\
\hline $\left.\begin{array}{rl}\mathrm{H}+\mathrm{CH}_{2} \mathrm{CO} & \rightarrow \mathrm{CH}_{3}+\mathrm{CO} \\
& \rightarrow \mathrm{CH}_{2} \mathrm{CHO}\end{array}\right]$ & $\begin{array}{l}3.0 \times 10^{-11} \exp (-1700 / T) \\
k_{2} / k \text { very small }\end{array}$ & $200-2000$ & $\begin{array}{l} \pm 0.5 \text { at } 200 \mathrm{~K} \text { rising to } \\
\pm 1.0 \text { at } 2000 \mathrm{~K}\end{array}$ \\
\hline $\left.\begin{array}{rl}\mathrm{H}+\mathrm{CH}_{3} \mathrm{CHO} & \rightarrow \mathrm{H}_{2}+\mathrm{CH}_{3} \mathrm{CO} \\
& \rightarrow \mathrm{H}_{2}+\mathrm{CH}_{2} \mathrm{CHO}\end{array}\right]$ & $6.8 \times 10^{-15} T^{1.16} \exp (-1210 / T)$ & $300-2000$ & $\begin{array}{l} \pm 0.1 \text { at } 300 \mathrm{~K} \text { rising to } \\
\pm 0.4 \text { at } 2000 \mathrm{~K}\end{array}$ \\
\hline 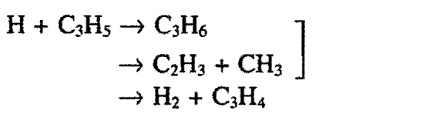 & $\begin{array}{l}\left(k_{1}^{\infty}+k_{2}\right)=2.8 \times 10^{-10} \\
3 \times 10^{-11}\end{array}$ & $\begin{array}{l}300-1000 \\
300-1000\end{array}$ & $\begin{array}{l} \pm 0.2 \text { at } 300 \mathrm{~K} \text { rising to } \\
\pm 0.5 \text { at } 1000 \mathrm{~K} \\
\pm 0.5\end{array}$ \\
\hline $\mathrm{H}+\mathrm{C}_{6} \mathrm{H}_{5}+\mathrm{M} \rightarrow \mathrm{C}_{6} \mathrm{H}_{6}+\mathrm{M}$ & See Table 3 & & \\
\hline $\begin{aligned} \mathrm{H}+\mathrm{C}_{6} \mathrm{H}_{6} & \rightarrow \mathrm{H}_{2}+\mathrm{C}_{6} \mathrm{H}_{5} \\
& \rightarrow \mathrm{C}_{6} \mathrm{H}_{7}\end{aligned}$ & $\begin{array}{l}\text { No recommendation } \\
\text { See Table } 3\end{array}$ & & \\
\hline $\mathrm{H}+\mathrm{C}_{6} \mathrm{H}_{5} \mathrm{O}+\mathrm{M} \rightarrow \mathrm{C}_{6} \mathrm{H}_{5} \mathrm{OH}+\mathrm{M}$ & See Table 3 & & \\
\hline $\begin{aligned} \mathrm{H}+\mathrm{C}_{6} \mathrm{H}_{5} \mathrm{OH} & \rightarrow \mathrm{C}_{6} \mathrm{H}_{5} \mathrm{O}+\mathrm{H}_{2} \\
& \rightarrow \mathrm{C}_{6} \mathrm{H}_{6}+\mathrm{OH}\end{aligned}$ & $\begin{array}{l}1.9 \times 10^{-10} \exp (-6240 / T) \\
3.7 \times 10^{-11} \exp (-3990 / T)\end{array}$ & $\begin{array}{l}1000-1150 \\
1000-1150\end{array}$ & $\begin{array}{l} \pm 0.3 \\
\pm 0.3\end{array}$ \\
\hline $\mathrm{H}+\mathrm{C}_{6} \mathrm{H}_{5} \mathrm{CH}_{2}+\mathrm{M} \rightarrow \mathrm{C}_{6} \mathrm{H}_{5} \mathrm{CH}_{3}+\mathrm{M}$ & See Table 3 & & \\
\hline $\begin{aligned} \mathrm{H}+\mathrm{C}_{6} \mathrm{H}_{3} \mathrm{CH}_{3} & \rightarrow \mathrm{H}_{2}+\mathrm{C}_{6} \mathrm{H}_{5} \mathrm{CH}_{2} \\
& \rightarrow \mathrm{H}_{2}+\mathrm{C}_{6} \mathrm{H}_{4} \mathrm{CH}_{3} \\
& \rightarrow \mathrm{C}_{6} \mathrm{H}_{6}+\mathrm{CH}_{3} \\
& \rightarrow \mathrm{C}_{6} \mathrm{H}_{6} \mathrm{CH}_{3}\end{aligned}$ & $\begin{array}{l}3.6 \times 10^{-19} T^{2.63} \exp (-2210 / T) \\
\text { No recommendation } \\
9.6 \times 10^{-11} \exp (-4070 / T) \\
\text { See Table } 3\end{array}$ & $\begin{array}{l}600-2500 \\
770-1100\end{array}$ & $\begin{array}{l} \pm 0.3 \\
\pm 0.3\end{array}$ \\
\hline $\mathrm{H}+p-\mathrm{C}_{6} \mathrm{H}_{4}\left(\mathrm{CH}_{3}\right)_{2} \rightarrow$ products & $5.8 \times 10^{-13}$ & 298 & \pm 0.1 \\
\hline $\begin{aligned} \mathrm{H}+\mathrm{C}_{6} \mathrm{H}_{5} \mathrm{C}_{2} \mathrm{H}_{5} & \rightarrow \mathrm{H}_{2}+\mathrm{C}_{6} \mathrm{H}_{5} \mathrm{C}_{2} \mathrm{H}_{4} \\
& \rightarrow \mathrm{C}_{6} \mathrm{H}_{6} \mathrm{C}_{2} \mathrm{H}_{5}\end{aligned}$ & $\begin{array}{l}\text { No recommendation } \\
\text { See Table } 3\end{array}$ & & \\
\hline
\end{tabular}


TABLE 1. Bimolecular Reactions - Continued

\begin{tabular}{|c|c|c|c|}
\hline Reaction & $k / \mathrm{cm}^{3}$ molecule ${ }^{-1} \mathrm{~s}^{-1}$ & $T / \mathrm{K}$ & Error limits $(\Delta \log k)$ \\
\hline \multicolumn{4}{|l|}{$\mathrm{H}_{2}$ Reactions } \\
\hline $\mathrm{H}_{2}+\mathrm{Ar} \rightarrow 2 \mathrm{H}+\mathrm{Ar}$ & See Table 2 & & \\
\hline $\mathrm{H}_{2}+\mathrm{H}_{2} \rightarrow 2 \mathrm{H}+\mathrm{H}_{2}$ & See Table 2 & & \\
\hline \multicolumn{4}{|l|}{ OH Radical Reactions } \\
\hline $\mathrm{OH}+\mathrm{H}_{2} \rightarrow \mathrm{H}_{2} \mathrm{O}+\mathrm{H}$ & $1.7 \times 10^{-16} T^{1.6} \exp (-1660 / T)$ & $300-2500$ & $\begin{array}{l} \pm 0.1 \text { at } 300 \mathrm{~K} \text { rising to } \\
\pm 0.3 \text { at } 2500 \mathrm{~K}\end{array}$ \\
\hline $\mathrm{OH}+\mathrm{OH} \rightarrow \mathrm{H}_{2} \mathrm{O}+\mathrm{O}$ & $2.5 \times 10^{-15} T^{1.14} \exp (-50 / T)$ & $250-2500$ & \pm 0.2 \\
\hline $\mathrm{OH}+\mathrm{OH}+\mathrm{M} \rightarrow \mathrm{H}_{2} \mathrm{O}_{2}+\mathrm{M}$ & See Table 3 & & \\
\hline $\mathrm{OH}+\mathrm{HO}_{2} \rightarrow \mathrm{H}_{2} \mathrm{O}+\mathrm{O}_{2}$ & $4.8 \times 10^{-11} \exp (250 / T)$ & $300-2000$ & $\begin{array}{l} \pm 0.2 \text { at } 300 \mathrm{~K} \text { rising to } \\
\pm 0.5 \text { at } 2000 \mathrm{~K}\end{array}$ \\
\hline $\mathrm{OH}+\mathrm{H}_{2} \mathrm{O}_{2} \rightarrow \mathrm{H}_{2} \mathrm{O}+\mathrm{HO}_{2}$ & $1.3 \times 10^{-11} \exp (-670 / T)$ & $300-1000$ & $\begin{array}{l} \pm 0.2 \text { at } 300 \mathrm{~K} \text { rising to } \\
\pm 0.5 \text { at } 1000 \mathrm{~K}\end{array}$ \\
\hline $\left.\begin{array}{rl}\mathrm{OH}+\mathrm{NH} & \rightarrow \mathrm{NO}+\mathrm{H}_{2} \\
& \rightarrow \mathrm{H}_{2} \mathrm{O}+\mathrm{N}\end{array}\right]$ & $8.0 \times 10^{-11}$ & $300-1000$ & \pm 0.5 \\
\hline $\begin{aligned} \mathrm{OH}+\mathrm{NH}_{2} & \rightarrow \mathrm{O}+\mathrm{NH}_{3} \\
& \rightarrow \mathrm{H}_{2} \mathrm{O}+\mathrm{NH}\end{aligned}$ & $\begin{array}{l}3.3 \times 10^{-14} T^{0.405} \exp (-250 / T) \\
\text { No recommendation }\end{array}$ & $500-2500$ & \pm 0.5 \\
\hline $\mathrm{OH}+\mathrm{CO} \rightarrow \mathrm{H}+\mathrm{CO}_{2}$ & $1.05 \times 10^{-17} T^{1} \cdot 5 \exp (250 / T)$ & $300-2000$ & $\begin{array}{l} \pm 0.2 \text { at } 300 \mathrm{~K} \text { rising to } \\
\pm 0.5 \text { at } 2000 \mathrm{~K}\end{array}$ \\
\hline \multicolumn{4}{|l|}{$\left.\mathrm{OH}+\mathrm{CH}_{3} \rightarrow \mathrm{H}+\mathrm{CH}_{2} \mathrm{OH}\right]$} \\
\hline $\begin{array}{l}\rightarrow \mathrm{H}+\mathrm{CH}_{3} \mathrm{O} \\
\rightarrow \mathrm{H}_{2} \mathrm{O}+{ }^{\prime} \mathrm{CH}_{2} \\
\rightarrow \mathrm{CH}_{3} \mathrm{OH}\end{array}$ & $\begin{array}{l}\text { No recommendation } \\
1.2 \times 10^{-11} \exp (-1400 / T) \\
\text { See Table } 3\end{array}$ & $300-1000$ & \pm 0.5 \\
\hline $\mathrm{OH}+\mathrm{CH}_{4} \rightarrow \mathrm{H}_{2} \mathrm{O}+\mathrm{CH}_{3}$ & $2.6 \times 10^{-17} T^{1.83} \exp (-1400 / T)$ & $250-2500$ & $\begin{array}{l} \pm 0.07 \text { at } 250 \mathrm{~K} \text { rising to } \\
\pm 0.15 \text { at } 1200 \mathrm{~K}\end{array}$ \\
\hline $\mathrm{OH}+\mathrm{CHO} \rightarrow \mathrm{H}_{2} \mathrm{O}+\mathrm{CO}$ & $1.7 \times 10^{-10}$ & $300-2500$ & \pm 0.3 \\
\hline $\mathrm{OH}+\mathrm{HCHO} \rightarrow \mathrm{H}_{2} \mathrm{O}+\mathrm{CHO}$ & $5.7 \times 10^{-15} T^{1.18} \exp (225 / T)$ & $300-3000$ & $\begin{array}{l} \pm 0.1 \text { at } 300 \mathrm{~K} \text { rising to } \\
\pm 0.7 \text { at } 3000 \mathrm{~K}\end{array}$ \\
\hline \multicolumn{4}{|l|}{$\mathrm{OH}+\mathrm{CN} \rightarrow \mathrm{O}+\mathrm{HCN}$} \\
\hline$\rightarrow \mathrm{NCO}+\mathrm{H}\rfloor$ & $1.0 \times 10^{-10}$ & $1500-3000$ & \pm 0.5 \\
\hline $\left.\begin{array}{rl}\mathrm{OH}+\mathrm{HCN} & \rightarrow \mathrm{H}_{2} \mathrm{O}+\mathrm{CN} \\
& \rightarrow \mathrm{HOCN}+\mathrm{H} \\
& \rightarrow \mathrm{HNCN}+\mathrm{H}\end{array}\right]$ & $\begin{array}{l}1.5 \times 10^{-11} \exp (-5400 / T) \\
\text { No recommendation }\end{array}$ & $1500-2500$ & \pm 0.5 \\
\hline $\mathrm{OH}+\mathrm{CH}_{3} \mathrm{OOH} \rightarrow \mathrm{H}_{2} \mathrm{O}+\mathrm{CH}_{3} \mathrm{OO}$ & $1.2 \times 10^{-12} \exp (130 / T)$ & $300-1000$ & $\begin{array}{l} \pm 0.2 \text { at } 300 \mathrm{~K} \text { rising to } \\
\pm 0.4 \text { at } 1000 \mathrm{~K}\end{array}$ \\
\hline$\rightarrow \mathrm{H}_{2} \mathrm{O}+\mathrm{CH}_{2} \mathrm{OOH}$ & $1.8 \times 10^{-12} \exp (220 / T)$ & $300-1000$ & $\begin{array}{l} \pm 0.1 \text { at } 300 \mathrm{~K} \text { rising to } \\
\pm 0.3 \text { at } 1000 \mathrm{~K}\end{array}$ \\
\hline $\mathrm{OH}+\mathrm{C}_{2} \mathrm{H}_{2} \rightarrow \mathrm{H}_{2} \mathrm{O}+\mathrm{C}_{2} \mathrm{H}$ & $1.0 \times 10^{-10} \exp (-6500 / T)$ & $1000-2000$ & \pm 1.0 \\
\hline $\begin{array}{l}\rightarrow \mathrm{H}+\mathrm{CH}_{2} \mathrm{CO} \\
\rightarrow \mathrm{C}_{2} \mathrm{H}_{2} \mathrm{OH}\end{array}$ & See Tabie 3 & & \\
\hline $\mathrm{OH}+\mathrm{C}_{2} \mathrm{H}_{4} \rightarrow \mathrm{H}_{2} \mathrm{O}+\mathrm{C}_{2} \mathrm{H}_{3}$ & $3.4 \times 10^{-11} \exp (-2990 / T)$ & $650-1500$ & \pm 0.5 \\
\hline $\mathrm{OH}+\mathrm{C}_{2} \mathrm{H}_{6} \rightarrow \mathrm{H}_{2} \mathrm{O}+\mathrm{C}_{2} \mathrm{H}_{5}$ & $1.2 \times 10^{-17} T^{2.0} \exp (-435 / T)$ & $250-2000$ & $\begin{array}{l} \pm 0.07 \text { at } 250 \mathrm{~K} \text { rising to } \\
\pm 0.15 \text { at } 2000 \mathrm{~K}\end{array}$ \\
\hline
\end{tabular}


TABLE 1. Bimolecular Reactions - Continued

\begin{tabular}{|c|c|c|c|}
\hline Reaction & $k / \mathrm{cm}^{3}$ molecule ${ }^{-1} \mathrm{~s}^{-1}$ & $T / \mathrm{K}$ & Error limits $(\Delta \log k)$ \\
\hline $\left.\begin{array}{rl}\mathrm{OH}+\mathrm{CH}_{2} \mathrm{CO} & \rightarrow \mathrm{CH}_{2} \mathrm{OH}+\mathrm{CO} \\
& \rightarrow \mathrm{H}_{2} \mathrm{CO}+\mathrm{HCO}\end{array}\right]$ & $1.7 \times 10^{-11}$ & $300-2000$ & \pm 1.0 \\
\hline $\left.\begin{array}{rl}\mathrm{OH}+\mathrm{CH}_{3} \mathrm{CHO} & \rightarrow \mathrm{H}_{2} \mathrm{O}+\mathrm{CH}_{3} \mathrm{CO} \\
& \rightarrow \mathrm{H}_{2} \mathrm{O}+\mathrm{CH}_{2} \mathrm{CHO}\end{array}\right]$ & $3.9 \times 10^{-14} T^{0.73} \exp (560 / T)$ & $250-1200$ & $\begin{array}{l} \pm 0.1 \text { at } 250 \mathrm{~K} \text { rising to } \\
\pm 0.3 \text { at } 1200 \mathrm{~K}\end{array}$ \\
\hline $\left.\begin{array}{rl}\mathrm{OH}+\mathrm{C}_{2} \mathrm{H}_{5} \mathrm{OOH} & \rightarrow \mathrm{H}_{2} \mathrm{O}+\mathrm{C}_{2} \mathrm{H}_{5} \mathrm{OO} \\
& \rightarrow \mathrm{H}_{2} \mathrm{O}+\mathrm{C}_{2} \mathrm{H}_{4} \mathrm{OOH}\end{array}\right]$ & $\begin{array}{l}3.0 \times 10^{-12} \exp (190 / T) \\
\text { [estimate] }\end{array}$ & $250-1000$ & $\begin{array}{l} \pm 0.3 \text { at } 250 \mathrm{~K} \text { rising to } \\
\pm 0.7 \text { at } 1000 \mathrm{~K}\end{array}$ \\
\hline $\left.\begin{array}{rl}\mathrm{OH}+\mathrm{C}_{3} \mathrm{H}_{5} & \rightarrow \mathrm{H}_{2} \mathrm{O}+\mathrm{C}_{3} \mathrm{H}_{4} \\
& \rightarrow \mathrm{CH}_{2} \mathrm{CHCH}_{2} \mathrm{OH} \\
& \rightarrow \mathrm{CH}_{2} \mathrm{CHCHO} \backslash 2 \mathrm{H}\end{array}\right]$ & $\begin{array}{l}1.0 \times 10^{-11} \\
\left(k_{\llcorner}^{\infty}, k_{s}\right)-2.5 \times 10^{-11}\end{array}$ & $\begin{array}{l}300-1000 \\
300-1000\end{array}$ & $\begin{array}{l} \pm 0.5 \\
\pm 0.3\end{array}$ \\
\hline $\begin{aligned} \mathrm{OH}+\mathrm{C}_{6} \mathrm{H}_{6} & \rightarrow \mathrm{H}_{2} \mathrm{O}+\mathrm{C}_{6} \mathrm{H}_{5} \\
& \rightarrow \mathrm{H}+\mathrm{C}_{6} \mathrm{H}_{5} \mathrm{OH} \\
& \rightarrow \mathrm{C}_{6} \mathrm{H}_{6} \mathrm{OH}\end{aligned}$ & $\begin{array}{l}2.7 \times 10^{-16} T^{1.42} \exp (-730 / T) \\
2.2 \times 10^{-11} \exp (-5330 / T) \\
\text { Scc Tablc } 3\end{array}$ & $\begin{array}{l}400-1500 \\
1000-1150\end{array}$ & $\begin{array}{l} \pm 0.3 \\
\pm 0.3\end{array}$ \\
\hline $\left.\begin{array}{rl}\mathrm{OH}+\mathrm{C}_{6} \mathrm{H}_{5} \mathrm{OH} & \rightarrow \mathrm{C}_{6} \mathrm{H}_{5}(\mathrm{OH})_{2} \\
& \rightarrow \mathrm{H}_{2} \mathrm{O}+\mathrm{C}_{6} \mathrm{H}_{5} \mathrm{O} \\
& \rightarrow \mathrm{H}_{2} \mathrm{O}+\mathrm{C}_{6} \mathrm{H}_{4} \mathrm{OH}\end{array}\right]$ & $\begin{array}{l}\text { See Table } 3 \\
1.0 \times 10^{-11}\end{array}$ & $1000-1150$ & \pm 0.5 \\
\hline $\begin{aligned} \mathrm{OH}+\mathrm{C}_{6} \mathrm{H}_{5} \mathrm{CH}_{3} & \rightarrow \mathrm{H}_{2} \mathrm{O}+\mathrm{C}_{6} \mathrm{H}_{4} \mathrm{CH}_{2} \\
& \rightarrow \mathrm{C}_{6} \mathrm{H}_{5} \mathrm{CH}_{3} \mathrm{OH}\end{aligned}$ & $\begin{array}{l}8.6 \times 10^{-15} T \exp (-440 / T) \\
\text { See Table } 3\end{array}$ & $400-1200$ & $\begin{array}{l} \pm 0.5 \text { at } 400 \mathrm{~K} \text { reducing to } \\
\pm 0.3 \text { at } 1200 \mathrm{~K}\end{array}$ \\
\hline $\left.\begin{array}{rl}\mathrm{OH}+\mathrm{C}_{6} \mathrm{H}_{5} \mathrm{CHO} & \rightarrow \mathrm{H}_{2} \mathrm{O}+\mathrm{C}_{6} \mathrm{H}_{5} \mathrm{CO} \\
& \rightarrow \mathrm{H}_{2} \mathrm{O}+\mathrm{C}_{6} \mathrm{H}_{4} \mathrm{CHO}\end{array}\right]$ & $1.3 \times 10^{-11}$ & $298-1500$ & $\begin{array}{l} \pm 0.1 \text { at } 298 \mathrm{~K} \text { rising to } \\
\pm 0.5 \text { at } 1500 \mathrm{~K}\end{array}$ \\
\hline $\begin{aligned} \mathrm{OH}+p-\mathrm{C}_{6} \mathrm{H}_{4}\left(\mathrm{CH}_{3}\right)_{2} & \rightarrow \mathrm{C}_{6} \mathrm{H}_{4} \mathrm{CH}_{2} \mathrm{CH}_{3}+\mathrm{H}_{2} \mathrm{O} \\
& \rightarrow p-\mathrm{C}_{6} \mathrm{H}_{4}\left(\mathrm{CH}_{3}\right)_{2} \mathrm{OH}\end{aligned}$ & $\begin{array}{l}6.4 \times 10^{-11} \exp (-1440 / T) \\
\text { See Table } 3\end{array}$ & $500-960$ & \pm 0.1 \\
\hline $\left.\begin{array}{rl}\mathrm{OH}+\mathrm{C}_{6} \mathrm{H}_{5} \mathrm{C}_{2} \mathrm{H}_{5} & \rightarrow \mathrm{HOC}_{6} \mathrm{H}_{5} \mathrm{C}_{2} \mathrm{H}_{5} \\
& \rightarrow \mathrm{H}_{2} \mathrm{O}+\mathrm{C}_{6} \mathrm{H}_{5} \mathrm{C}_{2} \mathrm{H}_{4} \\
& \rightarrow \mathrm{H}_{2} \mathrm{O}+\mathrm{C}_{6} \mathrm{H}_{4} \mathrm{C}_{2} \mathrm{H}_{5}\end{array}\right]$ & $\begin{array}{l}\text { See Table } 3 \\
\text { No recommendation }\end{array}$ & & \\
\hline $\mathrm{H}_{2} \mathrm{O}$ Reactions & & & \\
\hline $\begin{array}{l}\mathrm{H}_{2} \mathrm{O}+\mathrm{M} \rightarrow \mathrm{H}+\mathrm{OH}+\mathrm{M} \\
\mathrm{HO}_{2} \text { Radical Reactions }\end{array}$ & See Table 2 & & \\
\hline $\mathrm{HO}_{2}+\mathrm{HO}_{2} \rightarrow \mathrm{H}_{2} \mathrm{O}_{2}+\mathrm{O}_{2}$ & $\begin{array}{l}7.0 \times 10^{-10} \exp (-6030 / T)+ \\
2.2 \times 10^{-13} \exp (820 / T) \\
7.0 \times 10^{-10} \exp (-6030 / T)\end{array}$ & $\begin{array}{l}550-1250 \\
850-1250\end{array}$ & $\begin{array}{l} \pm 0.15 \text { between } 550-800 \mathrm{~K} \\
\text { rising to }+0.4 \text { at } 1250 \mathrm{~K}\end{array}$ \\
\hline $\left.\begin{array}{rl}\mathrm{HO}_{2}+\mathrm{NH}_{2} & \rightarrow \mathrm{NH}_{3}+\mathrm{O}_{2} \\
& \rightarrow \mathrm{HNO}+\mathrm{H}_{2} \mathrm{O}\end{array}\right]$ & $2.6 \times 10^{-11}$ & $300-400$ & \pm 0.4 \\
\hline $\begin{aligned} \mathrm{HO}_{2}+\mathrm{CH}_{3} & \rightarrow \mathrm{OH}+\mathrm{CH}_{3} \mathrm{O} \\
& \rightarrow \mathrm{O}_{2}+\mathrm{CH}_{4}\end{aligned}$ & $\begin{array}{l}3 \times 10^{-11} \\
\text { No recommendation }\end{array}$ & $300-2500$ & \pm 0.7 \\
\hline $\mathrm{HO}_{2}+\mathrm{CH}_{4} \rightarrow \mathrm{H}_{2} \mathrm{O}_{2}+\mathrm{CH}_{3}$ & $1.5 \times 10^{-11} \exp (-12440 / T)$ & $600-1000$ & $\begin{array}{l} \pm 0.2 \text { at } 600 \mathrm{~K} \text { rising to. } \\
\pm 0.3 \text { at } 1000 \mathrm{~K}\end{array}$ \\
\hline $\mathrm{HO}_{2}+\mathrm{HCHO} \rightarrow \mathrm{H}_{2} \mathrm{O}_{2}+\mathrm{CHO}$ & $5.0 \times 10^{-12} \exp (-6580 / T)$ & $600-1000$ & \pm 0.5 \\
\hline
\end{tabular}


TABLE 1. Bimolecular Reactions - Continued

\begin{tabular}{|c|c|c|c|}
\hline Reaction & $k / \mathrm{cm}^{3}$ molecule $\mathrm{e}^{-1} \mathrm{~s}^{-1}$ & $T / \mathrm{K}$ & Error limits $(\Delta \log k)$ \\
\hline $\left.\begin{array}{rl}\mathrm{HO}_{2}+\mathrm{CH}_{3} \mathrm{O}_{2} & \rightarrow \mathrm{CH}_{3} \mathrm{OOH}+\mathrm{O}_{2} \\
& \rightarrow \mathrm{HCHO}+\mathrm{H}_{2} \mathrm{O}+\mathrm{O}_{2}\end{array}\right]$ & $\begin{array}{l}4.1 \times 10^{-13} \exp (790 / T) \\
k_{1} / k=1.0 \pm 0.1 \text { over whole range }\end{array}$ & $298-700$ & $\begin{array}{l} \pm 0.1 \text { at } 298 \mathrm{~K} \text { rising to } \\
\pm 0.3 \text { at } 700 \mathrm{~K}\end{array}$ \\
\hline $\mathrm{HO}_{2}+\mathrm{C}_{2} \mathrm{H}_{4} \rightarrow \ddot{\mathrm{OH}}+\mathrm{C}_{2} \mathrm{H}_{4} \mathrm{O}$ & $3.7 \times 10^{-12} \exp (-8650 / T)$ & $600-900$ & $\begin{array}{l} \pm 0.15 \text { at } 600 \mathrm{~K} \text { rising to } \\
\pm 0.25 \text { at } 900 \mathrm{~K}\end{array}$ \\
\hline $\mathrm{HO}_{2}+\mathrm{C}_{2} \mathrm{H}_{6} \rightarrow \mathrm{H}_{2} \mathrm{O}_{2}+\mathrm{C}_{2} \mathrm{H}_{5}$ & $2.2 \times 10^{-11} \exp (-10300 / T)$ & $500-1000$ & $\begin{array}{l} \pm 0.2 \text { at } 500 \mathrm{~K} \text { rising to } \\
\pm 0.3 \text { at } 1000 \mathrm{~K}\end{array}$ \\
\hline $\mathrm{HO}_{2}+\mathrm{CH}_{3} \mathrm{CHO} \rightarrow \mathrm{H}_{2} \mathrm{O}_{2}+\mathrm{CH}_{3} \mathrm{CO}$ & $5.0 \times 10^{-12} \exp (-6000 / T)$ & $900-1200$ & \pm 0.7 \\
\hline $\mathrm{HO}_{2}+\mathrm{C}_{3} \mathrm{H}_{5} \rightarrow \mathrm{C}_{3} \mathrm{H}_{6}+\mathrm{O}_{2}$ & $4.4 \times 10^{-12}$ & $300-1000$ & $\begin{array}{l} \pm 0.3 \text { over the range } 600 \mathrm{~K} \\
\text { to } 800 \mathrm{~K} \text { rising to } 0.5 \text { at other } \\
\text { temperatures }\end{array}$ \\
\hline$\rightarrow \mathrm{CO}+$ products & $1.1 \times 10^{-11}$ & $500-900$ & \pm 0.3 \\
\hline $\mathrm{HO}_{2}+\mathrm{C}_{6} \mathrm{H}_{5} \mathrm{CH}_{3} \rightarrow \mathrm{H}_{2} \mathrm{O}_{2}+\mathrm{C}_{6} \mathrm{H}_{5} \mathrm{CH}_{2}$ & $6.6 \times 10^{-13} \exp (-7080 / T)$ & $600-1000$ & $\begin{array}{l} \pm 0.3 \text { at } 750 \mathrm{~K} \text { rising to } \\
\pm 0.5 \text { at } 600 \mathrm{~K} \text { and } 1000 \mathrm{~K}\end{array}$ \\
\hline$\rightarrow \mathrm{H}_{2} \mathrm{O}_{2}+\mathrm{C}_{6} \mathrm{H}_{4} \mathrm{CH}_{3}$ & $9.1 \times 10^{-12} \exp (-14500 / T)$ & $600-1000$ & \pm 1.0 \\
\hline $\mathrm{HO}_{2}+\mathrm{C}_{6} \mathrm{H}_{5} \mathrm{CH}_{2} \mathrm{CH}_{3} \rightarrow \mathrm{H}_{2} \mathrm{O}_{2}+\mathrm{C}_{6} \mathrm{H}_{5} \mathrm{CHCH}_{3}$ & $4.4 \times 10^{-13} \exp (-5680 / T)$ & $600-1000$ & $\begin{array}{l} \pm 0.3 \text { at } 750 \mathrm{~K} \text { rising to } \\
\pm 0.5 \text { at } 600 \mathrm{~K} \text { and } 1000 \mathrm{~K}\end{array}$ \\
\hline $\begin{array}{l}\rightarrow \mathrm{H}_{2} \mathrm{O}_{2}+\mathrm{C}_{6} \mathrm{H}_{5} \mathrm{CH}_{2} \mathrm{CH}_{2} \\
\rightarrow \mathrm{H}_{2} \mathrm{O}_{2}+\mathrm{C}_{6} \mathrm{H}_{4} \mathrm{CH}_{2} \mathrm{CH}_{3}\end{array}$ & $\begin{array}{l}5.3 \times 10^{-12} \exp (-9760 / T) \\
9 \times 10^{-12} \exp (-14500 / T)\end{array}$ & $\begin{array}{l}600-1000 \\
600-1000\end{array}$ & $\begin{array}{l} \pm 0.5 \\
\pm 1.0\end{array}$ \\
\hline
\end{tabular}

$\mathrm{H}_{2} \mathrm{O}_{2}$ Reactions

$\mathrm{H}_{2} \mathrm{O}_{2}+\mathrm{M} \rightarrow 2 \mathrm{OH}+\mathrm{M}$

See Table 2

$N$ Atom Reactions

$\mathrm{N}+\mathrm{O}_{2} \rightarrow \mathrm{NO}+\mathrm{O}$

$1.5 \times 10^{-14} T \exp (-3270 / T)$

$298-5000$

\pm 0.12 over range $300-1000 \mathrm{~K}$ rising

$\mathrm{N}+\mathrm{OH} \rightarrow \mathrm{NO}+\mathrm{H}$

$4.7 \times 10^{-11}$

$300-2500$ to +0.3 over range $1000-5000 \mathrm{~K}$

$\mathrm{N}+\mathrm{NO} \rightarrow \mathrm{N}_{2}+\mathrm{O}$

$7.1 \times 10^{-11} \exp (-790 / T)$

\pm 0.1 at $300 \mathrm{~K}$ rising to \pm 0.3 at $2500 \mathrm{~K}$

$\mathrm{N}+\mathrm{CN} \rightarrow \mathrm{N}_{2}+\mathrm{C}$

$3 \times 10^{-10}$

$1400-4000 \quad \pm 0.2$

$\mathrm{N}+\mathrm{NCO} \rightarrow \mathrm{NO}+\mathrm{CN}$

No recommendation

$\rightarrow \mathrm{N}_{2}+\mathrm{CO}$

$3.3 \times 10^{-11}$

$300-2500 \cdot \pm 1.0$

NH Radical Reactions

$$
\begin{aligned}
\mathrm{NH}+\mathrm{O}_{2} & \rightarrow \mathrm{NO}+\mathrm{OH} \\
& \rightarrow \mathrm{NO}_{2}+\mathrm{H} \\
& \rightarrow \mathrm{HNO}+\mathrm{O}
\end{aligned}
$$

$\left(k_{1}+k_{2}\right)=1.3 \times 10^{-13} \exp (-770 / T)$

$270-550 \quad \pm 0.25$

$6.5 \times 10^{-11} \exp (-9000 / T)$

$2200-3500 \pm 0.5$

$$
\left.\begin{array}{rl}
\mathrm{NH}+\mathrm{NO} & \rightarrow \mathrm{N}_{2} \mathrm{O}+\mathrm{H} \\
& \rightarrow \mathrm{HN}_{2}+\mathrm{O} \\
& \rightarrow \mathrm{N}_{2}+\mathrm{OH}
\end{array}\right]
$$

$\mathrm{NH}_{2}$ Radical Reactions

$$
\begin{aligned}
\mathrm{NH}_{2}+\mathrm{O}_{2} & \rightarrow \text { products } \\
\mathrm{NH}_{2}+\mathrm{NO} & \rightarrow \mathrm{N}_{2}+\mathrm{H}_{2} \mathrm{O} \\
& \rightarrow \mathrm{N}_{2}+\mathrm{H}+\mathrm{OH} \\
& \rightarrow \mathrm{N}_{2} \mathrm{H}+\mathrm{OH} \\
& \rightarrow \mathrm{N}_{2} \mathrm{O}+\mathrm{H}_{2}
\end{aligned}
$$$$
<3 \times 10^{-18}
$$$$
298
$$ 
TABLE 1. Bimolecular Reactions - Continued

\begin{tabular}{|c|c|c|c|}
\hline Reaction & $k / \mathrm{cm}^{3}$ molecule $^{-1} \mathrm{~s}^{-1}$ & $T / \mathrm{K}$ & Error limits $(\Delta \log k)$ \\
\hline \multicolumn{4}{|l|}{$\mathrm{NH}_{3}$ Reactions } \\
\hline $\begin{aligned} \mathrm{NH}_{3}+\mathrm{M} & \rightarrow \mathrm{NH}_{2}+\mathrm{H} \\
& \rightarrow \mathrm{NH}+\mathrm{H}_{2}\end{aligned}$ & $\begin{array}{l}\text { See Table } 2 \\
\text { No recommendation }\end{array}$ & & \\
\hline \multicolumn{4}{|l|}{ C Atom Reactions } \\
\hline $\mathrm{C}+\mathrm{N}_{2} \rightarrow \mathrm{CN}+\mathrm{N}$ & $8.7 \times 10^{-11} \exp (-22600 / T)$ & $2000-5000$ & \pm 0.2 \\
\hline $\mathrm{C}+\mathrm{NO} \rightarrow \mathrm{CN}+\mathrm{O}]$ & $2.5 \times 10^{-11}$ & 300 & \pm 0.3 \\
\hline$\rightarrow \mathrm{CO}+\mathrm{N}]$ & $\begin{array}{l}8.0 \times 10^{-11} \\
k_{1} / k_{2}=0.6 \pm 0.25 ; k_{1} / k=0.4 \pm 0.25 \\
\text { over range } 1500-4050 \mathrm{~K}\end{array}$ & $1500-4050$ & \pm 0.3 \\
\hline${ }^{1} C_{2}$ and ${ }^{3} C_{2}$ Radical Reactions & See data sheets & & \\
\hline \multicolumn{4}{|l|}{ CH Radical Reactions } \\
\hline $\left.\begin{array}{rl}\mathrm{CH}+\mathrm{O}_{2} & \rightarrow \mathrm{CHO}+\mathrm{O} \\
& \rightarrow \mathrm{CO}+\mathrm{OH}\end{array}\right]$ & $5.5 \times 10^{-11}$ & $300-2000$ & $\begin{array}{l} \pm 0.3 \text { at } 300 \mathrm{~K} \text { rising to } \\
\pm 0.5 \text { at } 2000 \mathrm{~K}\end{array}$ \\
\hline $\left.\begin{array}{rl}\mathrm{CH}+\mathrm{H}_{2} & \rightarrow \mathrm{CH}_{2}+\mathrm{H} \\
& \rightarrow \mathrm{CH}_{3}\end{array}\right]$ & $2.4 \times 10^{-10} \exp (-1760 / T)$ & $300-1000$ & \pm 0.3 \\
\hline $\mathrm{CH}+\mathrm{H}_{2} \mathrm{O} \rightarrow$ products & $9.5 \times 10^{-12} \exp (380 / T)$ & $300-1000$ & \pm 1.0 \\
\hline $\left.\begin{array}{rl}\mathrm{CH}+\mathrm{N}_{2} & \rightarrow \mathrm{HCN}+\mathrm{N} \\
& \rightarrow \mathrm{CHN}_{2}\end{array}\right]$ & $\begin{array}{l}2.6 \times 10^{-12} \exp (-9030 / T) \\
\text { at } \mathrm{p}<1 \mathrm{~atm} .\end{array}$ & $2000-4000$ & \pm 0.3 \\
\hline \multicolumn{4}{|l|}{$\mathrm{CH}+\mathrm{NO} \rightarrow \mathrm{CO}+\mathrm{NH}]$} \\
\hline $\begin{array}{l}\rightarrow \mathrm{CN}+\mathrm{OH} \\
\rightarrow \mathrm{HCN}+\mathrm{O} .\end{array}$ & $2.0 \times 10^{-10}$ & $300-4000$ & \pm 0.25 \\
\hline $\mathrm{CH}+\mathrm{CO} \rightarrow$ products & $4.6 \times 10^{-13} \exp (860 / T)$ & $300-1000$ & \pm 1.0 \\
\hline $\mathrm{CH}+\mathrm{CO}_{2} \rightarrow$ products & $5.7 \times 10^{-12} \exp (-345 / T)$ & $300-1000$ & \pm 1.0 \\
\hline $\mathrm{CH}+\mathrm{CH}_{4} \rightarrow$ products & $5.0 \times 10^{-11} \exp (200 / T)$ & $200-700$ & \pm 1.0 \\
\hline $\mathrm{CH}+\mathrm{C}_{2} \mathrm{H}_{2} \rightarrow$ products & $3.5 \times 10^{-10} \exp (61 / T)$ & $200-700$ & \pm 1.0 \\
\hline $\mathrm{CH}+\mathrm{C}_{2} \mathrm{H}_{4} \rightarrow$ products & $2.2 \times 10^{-10} \exp (173 / T)$ & $200-700$ & \pm 1.0 \\
\hline $\mathrm{CH}+\mathrm{C}_{2} \mathrm{H}_{6} \rightarrow$ products & $1.8 \times 10^{-10} \exp (132 / T)$ & $200-700$ & \pm 1.0 \\
\hline $\mathrm{CH}+\mathrm{C}_{3} \mathrm{H}_{8} \rightarrow$ products & $1.9 \times 10^{-10} \exp (240 / T)$ & $300-700$ & \pm 1.0 \\
\hline $\mathrm{CH}+n-\mathrm{C}_{4} \mathrm{H}_{10} \rightarrow$ products & $4.4 \times 10^{-10} \exp (28 / T)$ & $250-700$ & \pm 1.0 \\
\hline $\mathrm{CH}+i-\mathrm{C}_{4} \mathrm{H}_{10} \rightarrow$ products & $2.0 \times 10^{-10} \exp (240 / T)$ & $300-700$ & \pm 1.0 \\
\hline $\mathrm{CH}+$ neo- $\mathrm{C}_{5} \mathrm{H}_{12} \rightarrow$ products & $1.6 \times 10^{-10} \exp (340 / T)$ & $300-700$ & \pm 1.0 \\
\hline $\mathrm{CH}+\mathrm{CH}_{3} \mathrm{C}_{2} \mathrm{H} \rightarrow$ products & No recommendation & & \\
\hline $\mathrm{CH}+\mathrm{CH}_{2} \mathrm{O} \rightarrow$ products & $1.6 \times 10^{-10} \exp (260 / T)$ & $300-700$ & \pm 1.0 \\
\hline
\end{tabular}


TABLE 1. Bimolecular Reactions - Continued

\begin{tabular}{|c|c|c|c|}
\hline Reaction & $k / \mathrm{cm}^{3}$ molecule ${ }^{-1} \mathrm{~s}^{-1}$ & $T / \mathrm{K}$ & Error limits $(\Delta \log k)$ \\
\hline \multicolumn{4}{|l|}{${ }^{3} \mathrm{CH}_{2}$ Radical Reactions } \\
\hline $\left.\begin{array}{rl}3 \mathrm{CH}_{2}+\mathrm{O}_{2} & \rightarrow \mathrm{CO}+\mathrm{H}+\mathrm{OH} \\
& \rightarrow \mathrm{CO}_{2}+\mathrm{H}+\mathrm{H} \\
& \rightarrow \mathrm{CO}+\mathrm{H}_{2} \mathrm{O} \\
& \rightarrow \mathrm{CO}_{2}+\mathrm{H}_{2} \\
& \rightarrow \mathrm{HCHO}+\mathrm{O}\end{array}\right]$ & $4.1 \times 10^{-11} \exp (-750 / T)$ & $300-1000$ & $\begin{array}{l} \pm 0.1 \text { at } 300 \mathrm{~K} \text { rising to } \\
\pm 0.5 \text { at } 1000 \mathrm{~K}\end{array}$ \\
\hline $\left.\begin{array}{rl}{ }^{3} \mathrm{CH}_{2}+{ }^{3} \mathrm{CH}_{2} & \rightarrow \mathrm{C}_{2} \mathrm{H}_{2}+\mathrm{H}_{2} \\
& \rightarrow \mathrm{C}_{2} \mathrm{H}_{2}+2 \mathrm{H}\end{array}\right]$ & $\begin{array}{l}2.0 \times 10^{-10} \exp (-400 / T) \\
k_{2} / k=0.9 \pm 0.1 \text { over range } 300-3000 \mathrm{~K}\end{array}$ & $300-3000$ & \pm 0.5 \\
\hline${ }^{3} \mathrm{CH}_{2}+\mathrm{CH}_{3} \rightarrow \mathrm{C}_{2} \mathrm{H}_{4}+\mathrm{H}$ & $7.0 \times 10^{-11}$ & $300-3000$ & $\begin{array}{l} \pm 0.3 \text { at } 300 \mathrm{~K} \text { rising to } \\
\pm 0.5 \text { at } 3000 \mathrm{~K}\end{array}$ \\
\hline${ }^{3} \mathrm{CH}_{2}+\mathrm{C}_{2} \mathrm{H}_{2} \rightarrow \mathrm{C}_{3} \mathrm{H}_{4}$ & See Table 3 & & \\
\hline $\left.\begin{array}{rl}{ }^{3} \mathrm{CH}_{2}+\mathrm{C}_{2} \mathrm{H}_{4} & \rightarrow \mathrm{C}_{3} \mathrm{H}_{6} \\
& \rightarrow c-\mathrm{C}_{3} \mathrm{H}_{6} \\
& \rightarrow \mathrm{CH}_{2} \mathrm{CHCH}_{2}+\mathrm{H}\end{array}\right]$ & See Table 3 & & \\
\hline \multicolumn{4}{|l|}{${ }^{3} \mathrm{CH}_{2}$ Radical Reactions } \\
\hline${ }^{1} \mathrm{CH}_{2}+\mathrm{Ar} \rightarrow{ }^{3} \mathrm{CH}_{2}+\mathrm{Ar}$ & $6.0 \times 10^{-12}$ & $300-2000$ & \pm 0.3 \\
\hline${ }^{1} \mathrm{CH}_{2}+\mathrm{NO} \rightarrow$ products & $1.6 \times 10^{-10}$ & $290-650$ & \pm 0.2 \\
\hline${ }^{1} \mathrm{CH}_{2}+\mathrm{N}_{2} \rightarrow{ }^{3} \mathrm{CH}_{2}+\mathrm{N}_{2}$ & $1.0 \times 10^{-11}$ & $300-2000$ & \pm 0.3 \\
\hline${ }^{t} \mathrm{CH}_{2}+\mathrm{CH}_{4} \rightarrow{ }^{3} \mathrm{CH}_{2}+\mathrm{CH}_{4}$ & $1.2 \times 10^{-11}$ & $300-2000$ & \pm 0.4 \\
\hline${ }^{1} \mathrm{CH}_{2}+\mathrm{C}_{2} \mathrm{H}_{2} \rightarrow{ }^{3} \mathrm{CH}_{2}+\mathrm{C}_{2} \mathrm{H}_{2}$ & $8.0 \times 10^{-11}$ & $300-2000$ & \pm 0.4 \\
\hline${ }^{1} \mathrm{CH}_{2}+\mathrm{C}_{2} \mathrm{H}_{4} \rightarrow{ }^{3} \mathrm{CH}_{2}+\mathrm{C}_{2} \mathrm{H}_{4}$ & $4.0 \times 10^{-11}$ & $300-2000$ & \pm 0.4 \\
\hline${ }^{1} \mathrm{CH}_{2}+\mathrm{C}_{2} \mathrm{H}_{6} \rightarrow{ }^{3} \mathrm{CH}_{2}+\mathrm{C}_{2} \mathrm{H}_{6}$ & $3.6 \times 10^{-11}$ & $300-2000$ & \pm 0.4 \\
\hline $\left.\begin{array}{rl}{ }^{1} \mathrm{CH}_{2}+\mathrm{O}_{2} & \rightarrow \mathrm{CO}+\mathrm{H}+\mathrm{OH} \\
& \rightarrow \mathrm{CO}_{2}+\mathrm{H}_{2} \\
& \rightarrow \mathrm{CO}+\mathrm{H}_{2} \mathrm{O} \\
& \rightarrow{ }^{3} \mathrm{CH}_{2}+\mathrm{O}_{2}\end{array}\right]$ & $5.2 \times 10^{-11}$ & $300-1000$ & $\begin{array}{l} \pm 0.3 \text { at } 300 \mathrm{~K} \text { rising to } \\
\pm 0.5 \text { at } 1000 \mathrm{~K}\end{array}$ \\
\hline${ }^{1} \mathrm{CH}_{2}+\mathrm{H}_{2} \rightarrow \mathrm{CH}_{3}+\mathrm{H}$ & $1.2 \times 10^{-10}$ & $300-1000$ & $\begin{array}{l} \pm 0.1 \text { at } 300 \mathrm{~K} \text { rising to } \\
\pm 0.3 \text { at } 1000 \mathrm{~K}\end{array}$ \\
\hline $\begin{aligned}{ }^{1} \mathrm{CH}_{2}+\mathrm{C}_{2} \mathrm{H}_{2} & \rightarrow \mathrm{CH}_{2} \mathrm{CCH}_{2} \\
& \rightarrow \mathrm{CH}_{3} \mathrm{CCH} \\
& \rightarrow \mathrm{CH}_{2} \mathrm{CCH}+\mathrm{H} \\
& \rightarrow{ }^{3} \mathrm{CH}_{2}+\mathrm{C}_{2} \mathrm{H}_{2}\end{aligned}$ & $\begin{array}{l}\text { See Table } 3 \\
\text { See earlier entry }\end{array}$ & & \\
\hline $\begin{aligned}{ }^{1} \mathrm{CH}_{2}+\mathrm{C}_{2} \mathrm{H}_{4} & \rightarrow \mathrm{C}_{3} \mathrm{H}_{6} \\
& \rightarrow{ }^{3} \mathrm{CH}_{2}+\mathrm{C}_{2} \mathrm{H}_{4}\end{aligned}$ & $\begin{array}{l}\text { See Table } 3 \\
\text { See earlier entry }\end{array}$ & & \\
\hline \multicolumn{4}{|l|}{$\mathrm{CH}_{3}$ Radical Reactions } \\
\hline $\mathrm{CH}_{3}+\mathrm{M} \rightarrow \mathrm{CH}_{2}+\mathrm{H}+\mathrm{M}$ & See Table 2 & & \\
\hline $\begin{aligned} \mathrm{CH}_{3}+\mathrm{O}_{2} & \rightarrow \mathrm{CH}_{3} \mathrm{O}+\mathrm{O} \\
& \rightarrow \mathrm{HCHO}+\mathrm{OH} \\
& \rightarrow \mathrm{CH}_{3} \mathrm{O}_{2}\end{aligned}$ & $\begin{array}{l}2.2 \times 10^{10} \exp (-15800 / T) \\
5.5 \times 10^{-13} \exp (-4500 / T) \\
\text { See Table } 3\end{array}$ & $\begin{array}{l}300-2500 \\
1000-2500\end{array}$ & $\begin{array}{l} \pm 0.5 \\
\pm 0.5\end{array}$ \\
\hline $\mathrm{CH}_{3}+\mathrm{H}_{2} \rightarrow \mathrm{CH}_{4}+\mathrm{H}$ & $1.14 \times 10^{-20} T^{2.74} \exp (-4740 / T)$ & $300-2500$ & $\begin{array}{l} \pm 0.15 \text { in the range } 300-700 \mathrm{~K} \\
\pm 0.3 \text { in the range } 700-2500 \mathrm{~K}\end{array}$ \\
\hline
\end{tabular}


TABLE 1. Bimolecular Reactions - Continued

\begin{tabular}{|c|c|c|c|}
\hline Reaction & $\mathrm{k} / \mathrm{cm}^{3}$ molecule $\mathrm{s}^{-1} \mathrm{~s}^{-1}$ & $T / \mathrm{K}$ & Error limits $(\Delta \log k)$ \\
\hline $\mathrm{CH}_{3}+\mathrm{CO}+\mathrm{M} \rightarrow \mathrm{CH}_{3} \mathrm{CO}+\mathrm{M}$ & See Table 3 & & \\
\hline $\begin{aligned} \mathrm{CH}_{3}+\mathrm{CH}_{3} & \rightarrow \mathrm{C}_{2} \mathrm{H}_{5}+\mathrm{H} \\
& \rightarrow \mathrm{C}_{2} \mathrm{H}_{4}+\mathrm{H}_{2} \\
& \rightarrow \mathrm{C}_{2} \mathrm{H}_{6}\end{aligned}$ & $\begin{array}{l}5 \times 10^{-11} \exp (-6800 / T) \\
\text { No recommendation (see data sheets) } \\
\text { See Table } 3\end{array}$ & $1300-2500$ & \pm 0.6 \\
\hline $\mathrm{CH}_{3}+\mathrm{HCHO} \rightarrow \mathrm{CH}_{4}+\mathrm{HCO}$ & $1.3 \times 10^{-31} T^{6.1} \exp (-990 / T)$ & $300-2000$ & \pm 0.2 \\
\hline $\begin{aligned} \mathrm{CH}_{3}+\mathrm{C}_{2} \mathrm{H}_{2}+\mathrm{M} & \rightarrow \mathrm{C}_{3} \mathrm{H}_{5}+\mathrm{M} \\
& \rightarrow \mathrm{CH}_{4}+\mathrm{C}_{2} \mathrm{H}\end{aligned}$ & $\begin{array}{l}\text { See Table } 3 \\
\text { No recommendation }\end{array}$ & & \\
\hline $\begin{aligned} \mathrm{CH}_{3}+\mathrm{C}_{2} \mathrm{H}_{4} & \rightarrow \mathrm{CH}_{4}+\mathrm{C}_{2} \mathrm{H}_{3} \\
& \rightarrow n-\mathrm{C}_{3} \mathrm{H}_{7}\end{aligned}$ & $\begin{array}{l}6.9 \times 10^{-12} \exp (-5600 / T) \\
\text { See Table } 3\end{array}$ & $400-3000$ & \pm 0.5 \\
\hline $\begin{aligned} \mathrm{CH}_{3}+\mathrm{C}_{2} \mathrm{H}_{3} & \rightarrow \mathrm{CH}_{4}+\mathrm{C}_{2} \mathrm{H}_{4} \\
& \rightarrow \mathrm{C}_{3} \mathrm{H}_{8}\end{aligned}$ & $\begin{array}{l}1.9 \times 10^{-12} \\
\text { See Table } 3\end{array}$ & 3002000 & \pm 0.1 \\
\hline $\mathrm{CH}_{3}+\mathrm{C}_{2} \mathrm{H}_{6} \rightarrow \mathrm{CH}_{4}+\mathrm{C}_{2} \mathrm{H}_{5}$ & $2.5 \times 10^{-31} T^{6.0} \exp (-3043 / T)$ & $300-1500$ & $\begin{array}{l} \pm 0.1 \text { at } 300 \mathrm{~K} \text { rising to } \\
\pm 0.2 \text { at } 1500 \mathrm{~K}\end{array}$ \\
\hline $\begin{aligned} \mathrm{CH}_{3}+\mathrm{CH}_{3} \mathrm{CHO} & \rightarrow \mathrm{CH}_{4}+\mathrm{CH}_{3} \mathrm{CO} \\
& \rightarrow \mathrm{CH}_{4}+\mathrm{CH}_{2} \mathrm{CHO}\end{aligned}$ & $\begin{array}{l}3.3 \times 10^{-30} T^{5} \cdot 6 \exp (-1240 / T) \\
\text { No recommendation (see data sheets) }\end{array}$ & $300-1250$ & \pm 0.3 \\
\hline $\begin{aligned} \mathrm{CH}_{3}+\mathrm{C}_{3} \mathrm{H}_{5} & \rightarrow \mathrm{C}_{2} \mathrm{H}_{5} \mathrm{CHCH}_{2} \\
& \rightarrow \mathrm{CH}_{4}+\mathrm{CH}_{2} \mathrm{CCH}_{2}\end{aligned}$ & $\begin{array}{l}\text { See Table } 3 \\
3.5 \times 10^{-13}\end{array}$ & $500-1200$ & \pm 0.5 \\
\hline \multicolumn{4}{|l|}{$\mathrm{CH}_{4}$ Reactions } \\
\hline $\mathrm{CH}_{4}+\mathrm{M} \rightarrow \mathrm{CH}_{3}+\mathrm{H}+\mathrm{M}$ & See Table 2 & & \\
\hline \multicolumn{4}{|l|}{ CHO Radical Reactions } \\
\hline $\mathrm{CHO}+\mathrm{Ar} \rightarrow \mathrm{H}+\mathrm{CO}+\mathrm{Ar}$ & See Table 2 & & \\
\hline \multicolumn{4}{|l|}{$\mathrm{CHO}+\mathrm{O}_{2} \rightarrow \mathrm{CO}+\mathrm{HO}_{2} 7$} \\
\hline $\left.\begin{array}{l}\rightarrow \mathrm{OH}+\mathrm{CO}_{2} \\
\rightarrow \mathrm{HCO}_{3}\end{array}\right]$ & $5.0 \times 10^{-12}$ & $300-2500$ & \pm 0.3 \\
\hline $\mathrm{CHO}+\mathrm{CHO} \rightarrow \mathrm{HCHO}+\mathrm{CO}$ & $5.0 \times 10^{-11}$ & 300 & \pm 0.3 \\
\hline
\end{tabular}

HCHO Reactions

$\mathrm{HCHO}+\mathrm{M} \rightarrow \mathrm{H}+\mathrm{CHO}+\mathrm{M}] \quad$ See Table 2

$\rightarrow \mathrm{H}_{2}+\mathrm{CO}+\mathrm{M}$

$\mathrm{CH}_{2} \mathrm{OH}$ Reactions

$\mathrm{CH}_{2} \mathrm{OH}+\mathrm{O}_{2} \rightarrow \mathrm{CH}_{2} \mathrm{O}+\mathrm{HO}_{2}$

$2.6 \times 10^{-9} \mathrm{~T}^{-1.0}+$

$1.2 \times 10^{-10} \exp (-1800 / T)$

$\mathrm{CH}_{3} \mathrm{O}$ Radical Reactions

$\mathrm{CH}_{3} \mathrm{O}+\mathrm{M} \rightarrow \mathrm{HCHO}+\mathrm{H}+\mathrm{M}$

$\mathrm{CH}_{3} \mathrm{O}+\mathrm{O}_{2} \rightarrow \mathrm{HCHO}+\mathrm{HO}_{2}$
See Table 2
$3.6 \times 10^{-14} \exp (-880 / T)$
$300-1000 \pm 0.1$ at $500 \mathrm{~K}$ rising to \pm 0.3 at $300 \mathrm{~K}$ and $1000 \mathrm{~K}$ 
TABLE 1. Bimolecular Reactions - Continued

\begin{tabular}{|c|c|c|c|}
\hline Reaction & $k / \mathrm{cm}^{3}$ molecule ${ }^{-1} \mathrm{~s}^{-1}$ & $T / \mathrm{K}$ & Error limits $(\Delta \log k)$ \\
\hline \multicolumn{4}{|l|}{$\mathrm{CH}_{3} \mathrm{O}_{2}$ Radical Reactions } \\
\hline $\left.\begin{array}{rl}\mathrm{CH}_{3} \mathrm{O}_{2}+\mathrm{CH}_{3} \mathrm{O}_{2} & \rightarrow \mathrm{CH}_{3} \mathrm{O}+\mathrm{CH}_{3} \mathrm{O}+\mathrm{O}_{2} \\
& \rightarrow \mathrm{CH}_{3} \mathrm{OH}+\mathrm{HCHO}+\mathrm{O}_{2} \\
& \rightarrow \mathrm{CH}_{3} \mathrm{OOCH}_{3}+\mathrm{O}_{2}\end{array}\right]$ & $\begin{array}{l}9.1 \times 10^{-14} \exp (420 / T) \\
k_{1} / k_{2}=25 \exp (-1170 / T) \\
k_{3}=0 \text { over whole range }\end{array}$ & $298-700$ & $\begin{array}{l} \pm 0.1 \text { at } 298 \mathrm{~K} \text { increasing } \\
\pm 0.3 \text { at } 700 \mathrm{~K}\end{array}$ \\
\hline $\mathrm{CH}_{3} \mathrm{O}_{2}+\mathrm{C}_{3} \mathrm{H}_{5} \rightarrow \mathrm{CH}_{3} \mathrm{O}+\mathrm{CH}_{2} \mathrm{CHCH}_{2} \mathrm{O}$ & $2.0 \times 10^{-11}$ & $500-1200$ & \pm 0.5 \\
\hline \multicolumn{4}{|l|}{$\mathrm{CH}_{3} \mathrm{OH}$ Reactions } \\
\hline $\left.\begin{array}{rl}\mathrm{CH}_{3} \mathrm{OH}+\mathrm{Ar} & \rightarrow \mathrm{CH}_{3}+\mathrm{OH}+\mathrm{Ar} \\
& \rightarrow \mathrm{CH}_{2} \mathrm{OH}+\mathrm{H}+\mathrm{Ar} \\
& \rightarrow \mathrm{CH}_{2}+\mathrm{H}_{2} \mathrm{O}+\mathrm{Ar}\end{array}\right]$ & See Table 2 & & \\
\hline \multicolumn{4}{|l|}{$\mathrm{CI}_{3} \mathrm{OOHI}$ Reactions } \\
\hline $\mathrm{CH}_{3} \mathrm{OOH}+\mathrm{M} \rightarrow \mathrm{CH}_{3} \mathrm{O}+\mathrm{OH}+\mathrm{M}$ & See Table 2 & & \\
\hline \multicolumn{4}{|l|}{ CN Radical Reactions } \\
\hline $\mathrm{CN}+\mathrm{O}_{2} \rightarrow \mathrm{NCO}+\mathrm{O}$ & $1.2 \times 10^{-11} \exp (210 / T)$ & $290-4500$ & $\begin{array}{l} \pm 0.15 \text { over the range } \\
290-4500 \mathrm{~K}\end{array}$ \\
\hline $\mathrm{CN}+\mathrm{H}_{2} \rightarrow \mathrm{HCN}+\mathrm{H}$ & $3.2 \times 10^{-20} T^{2.87} \exp (-820 / T)$ & $200-3500$ & $\begin{array}{l} \pm 0.2 \text { at } 200 \mathrm{~K} \text { rising to } \\
\pm 0.5 \text { at } 3500 \mathrm{~K}\end{array}$ \\
\hline $\left.\begin{array}{rl}\mathrm{CN}+\mathrm{H}_{2} \mathrm{O} & \rightarrow \mathrm{HCN}+\mathrm{OH} \\
& \rightarrow \mathrm{HOCN}+\mathrm{H}\end{array}\right]$ & $1.3 \times 10^{-11} \exp (-3750 / T)$ & $500-3000$ & $\begin{array}{l} \pm 0.3 \text { at } 500 \mathrm{~K} \text { rising to } \\
\pm 0.5 \text { at } 3000 \mathrm{~K}\end{array}$ \\
\hline $\mathrm{CN}+\mathrm{CH}_{4} \rightarrow \mathrm{HCN}+\mathrm{CH}_{3}$ & $1.5 \times 10^{-19} T^{2.64} \exp (150 / T)$ & $290-1500$ & \pm 0.3 \\
\hline \multicolumn{4}{|l|}{ NCO Radical Reactions } \\
\hline $\mathrm{NCO}+\mathrm{M} \rightarrow \mathrm{N}+\mathrm{CO}+\mathrm{M}$ & See Table 2 & & \\
\hline $\left.\begin{array}{rl}\mathrm{NCO}+\mathrm{NO} & \rightarrow \mathrm{N}_{2} \mathrm{O}+\mathrm{CO} \\
& \rightarrow \mathrm{N}_{2}+\mathrm{CO}_{2} \\
& \rightarrow \mathrm{N}_{2}+\mathrm{CO}+\mathrm{O}\end{array}\right]$ & $2.3 \times 10^{-6} \mathrm{~T}^{-1.73} \exp (-380 / T)$ & $290-3000$ & \pm 0.25 \\
\hline \multicolumn{4}{|l|}{$C_{2} H$ Radical Reactions } \\
\hline $\left.\begin{array}{rl}\mathrm{C}_{2} \mathrm{H}+\mathrm{O}_{2} & \rightarrow \mathrm{CO}_{2}+\mathrm{CH} \\
& \rightarrow 2 \mathrm{CO}+\mathrm{H} \\
& \rightarrow \mathrm{C}_{2} \mathrm{HO}+\mathrm{O} \\
& \rightarrow \mathrm{CO}+\mathrm{HCO}\end{array}\right]$ & $3.0 \times 10^{-11}$ & 300 & \pm 0.5 \\
\hline $\mathrm{C}_{2} \mathrm{H}+\mathrm{H}_{2} \rightarrow \mathrm{C}_{2} \mathrm{H}_{2}+\mathrm{H}$ & $1.8 \times 10^{-11} \exp (-1090 / T)$ & $300-2500$ & $\begin{array}{l} \pm 0.3 \text { at } 300 \mathrm{~K} \text { rising to } \\
\pm 0.5 \text { at } 2500 \mathrm{~K}\end{array}$ \\
\hline $\mathrm{C}_{2} \mathrm{H}+\mathrm{C}_{2} \mathrm{H}_{2} \rightarrow \mathrm{C}_{4} \mathrm{H}_{2}+\mathrm{H}$ & $1.5 \times 10^{-10}$ & $300-2700$ & \pm 0.5 \\
\hline $\mathrm{C}_{2} \mathrm{H}+\mathrm{CH}_{4} \rightarrow$ products & $3.0 \times 10^{-12}$ & 298 & \pm 1 \\
\hline $\mathrm{C}_{2} \mathrm{H}+\mathrm{C}_{2} \mathrm{H}_{6} \rightarrow$ products & No recommendation & & \\
\hline
\end{tabular}


TABLE 1. Bimolecular Reactions - Continued

\begin{tabular}{|c|c|c|c|}
\hline Reaction & $k / \mathrm{cm}^{3}$ molecule $^{-1} \mathrm{~s}^{-1}$ & $T / \mathrm{K}$ & Error limits $(\Delta \log k)$ \\
\hline \multicolumn{4}{|l|}{$\mathrm{C}_{2} \mathrm{H}_{3}$ Radical Reactions } \\
\hline $\mathrm{C}_{2} \mathrm{H}_{3}+\mathrm{M} \rightarrow \mathrm{C}_{2} \mathrm{H}_{2}+\mathrm{H}+\mathrm{M}$ & See Table 2 & & \\
\hline $\left.\begin{array}{rl}\mathrm{C}_{2} \mathrm{H}_{3}+\mathrm{O}_{2} & \rightarrow \mathrm{HO}_{2}+\mathrm{C}_{2} \mathrm{H}_{2} \\
& \rightarrow \mathrm{H}_{2} \mathrm{CO}+\mathrm{CHO} \\
& \rightarrow \mathrm{C}_{2} \mathrm{H}_{3} \mathrm{O}+\mathrm{O} \\
& \rightarrow \mathrm{C}_{2} \mathrm{H}_{3} \mathrm{O}_{2}\end{array}\right]$ & $9.0 \times 10^{-12}$ & $\begin{array}{l}300-2000 \\
\pm 0.5 \text { over rang }\end{array}$ & $\begin{array}{l} \pm 0.3 \text { over range } 300-6 \\
\text { ge } 600-2000 \mathrm{~K}\end{array}$ \\
\hline \multicolumn{4}{|l|}{$\mathrm{C}_{2} \mathrm{H}_{4}$ Reactions } \\
\hline $\begin{aligned} \mathrm{C}_{2} \mathrm{H}_{4}+\mathrm{M} & \rightarrow \mathrm{C}_{2} \mathrm{H}_{2}+\mathrm{H}_{2}+\mathrm{M} \\
& \rightarrow \mathrm{C}_{2} \mathrm{H}_{3}+\mathrm{H}+\mathrm{M}\end{aligned}$ & See Table 2 & & \\
\hline \multicolumn{4}{|l|}{$\mathrm{C}_{2} \mathrm{H}_{5}$ Radical Reactions } \\
\hline $\mathrm{C}_{2} \mathrm{H}_{5}+\mathrm{M} \rightarrow \mathrm{C}_{7} \mathrm{H}_{4}+\mathrm{H}+\mathrm{M}$ & - See Table 2 & & \\
\hline $\mathrm{C}_{2} \mathrm{H}_{5}+\mathrm{O}_{2} \rightarrow \mathrm{C}_{2} \mathrm{H}_{4}+\mathrm{HO}_{2}$ & $1.7 \times 10^{-14} \exp (1100 / T)$ & $600-1200$ & \pm 0.3 \\
\hline $\mathrm{C}_{2} \mathrm{H}_{5}+\mathrm{H}_{2} \rightarrow \mathrm{C}_{2} \mathrm{H}_{k}+\mathrm{H}$ & $5.1 \times 10^{-24} T^{3.6} \exp (-4250 / T)$ & $\begin{array}{l}700-1200 \\
\pm 0.6 \text { at } 1200 \mathrm{~K}\end{array}$ & \pm 0.2 at $700 \mathrm{~K}$ rising to \\
\hline $\mathrm{C}_{2} \mathrm{H}_{5}+\mathrm{C}_{2} \mathrm{H}_{2} \rightarrow \mathrm{C}_{2} \mathrm{H}_{5} \mathrm{CHCH}$ & $5.6 \times 10^{-14} \exp (-3520 / T)$ & $300-600$ & \pm 0.5 \\
\hline $\mathrm{C}_{2} \mathrm{H}_{5}+\mathrm{C}_{2} \mathrm{H}_{4} \rightarrow n-\mathrm{C}_{4} \mathrm{H}_{9}$ & $1.8 \times 10^{-13} \exp (-3670 / T)$ & $300-600$ & \pm 0.5 \\
\hline $\begin{aligned} \mathrm{C}_{2} \mathrm{H}_{5}+\mathrm{C}_{2} \mathrm{H}_{5} & \rightarrow n-\mathrm{C}_{4} \mathrm{H}_{10} \\
& \rightarrow \mathrm{C}_{2} \mathrm{H}_{6}+\mathrm{C}_{2} \mathrm{H}_{4}\end{aligned}$ & $\begin{array}{l}\text { See Table } 3 \\
2.4 \times 10^{-12}\end{array}$ & $300-1200$ & \pm 0.4 \\
\hline $\mathrm{C}_{2} \mathrm{H}_{5}+\mathrm{C}_{2} \mathrm{H}_{5} \mathrm{CHO} \rightarrow \mathrm{C}_{2} \mathrm{H}_{6}+\mathrm{C}_{2} \mathrm{H}_{5} \mathrm{CO}$ & $2.9 \times 10^{-13} \exp (-3660 / T)$ & $300-700$ & \pm 0.3 \\
\hline $\begin{aligned} \mathrm{C}_{2} \mathrm{H}_{5}+\mathrm{C}_{3} \mathrm{H}_{5} & \rightarrow \mathrm{CH}_{3} \mathrm{CH}_{2} \mathrm{CH}_{3} \mathrm{CHCH}_{2} \\
& \rightarrow \mathrm{C}_{2} \mathrm{H}_{6}+\mathrm{CH}_{2} \mathrm{CCH}_{2} \\
& \rightarrow \mathrm{C}_{2} \mathrm{H}_{4}+\mathrm{C}_{3} \mathrm{H}_{6}\end{aligned}$ & $\begin{array}{l}\text { See Table } 3 \\
1.6 \times 10^{-12} \exp (66 / T) \\
4.3 \times 10^{-12} \exp (66 / T)\end{array}$ & $\begin{array}{l}500-1200 \\
500-1200\end{array}$ & $\begin{array}{l} \pm 0.3 \\
\pm 0.4\end{array}$ \\
\hline
\end{tabular}

$\mathrm{C}_{2} \mathrm{H}_{6}$ Reactions

$\mathrm{C}_{2} \mathrm{H}_{6}+\mathrm{M} \rightarrow \mathrm{CH}_{3}+\mathrm{CH}_{3}+\mathrm{M}$

See Table 2

CHCO Reactions

$$
\begin{aligned}
\mathrm{CHCO}+\mathrm{O}_{2} & \rightarrow \mathrm{CO}_{2}+\mathrm{HCO} \\
& \rightarrow 2 \mathrm{CO}+\mathrm{OH} \\
& \rightarrow \mathrm{C}_{2} \mathrm{O}+\mathrm{HO}_{2} \\
& \rightarrow \mathrm{CHO}_{2} \mathrm{CO}
\end{aligned}
$$

$\mathrm{CH}_{2} \mathrm{CHO}$ Radical Reactions

$$
\begin{aligned}
\mathrm{CH}_{2} \mathrm{CHO}+\mathrm{O}_{2} & \rightarrow \mathrm{HO}_{2}+\mathrm{CH}_{2} \mathrm{CO} \\
& \rightarrow \mathrm{HCHO}+\mathrm{CO}+\mathrm{OH} \\
& \rightarrow \mathrm{O}_{2} \mathrm{CH}_{2} \mathrm{CHO}
\end{aligned}
$$

$\mathrm{CH}_{3} \mathrm{CO}$ Radical Reactions

$\mathrm{CH}_{3} \mathrm{CO}+\mathrm{O}_{2}+\mathrm{M} \rightarrow \mathrm{CH}_{3} \mathrm{CO}_{3}+\mathrm{M}$

$k_{\infty}=2.6 \times 10^{-13}$

$k_{2}=3.0 \times 10^{-14}$

$2.7 \times 10^{-12} \exp (-430 / T)$

$\mathrm{M}=\mathrm{He}, 2$ Torr

$300-550 \quad \pm 0.7$
250-500 \pm 0.2

$300 \pm 0.3$

See Table 3

$\mathrm{CH}_{3} \mathrm{CHO}$ Reactions

$\mathrm{CH}_{5} \mathrm{CHO}+\mathrm{M} \rightarrow \mathrm{CH}_{3}+\mathrm{HCO}+\mathrm{M}$

See Table 2 
TABLE 1. Bimolecular Reactions - Continued

\begin{tabular}{|c|c|c|c|}
\hline Reaction & $k / \mathrm{cm}^{3}$ molecule $\mathrm{e}^{-1} \mathrm{~s}^{-1}$ & $T / \mathrm{K}$ & Error limits $(\Delta \log k)$ \\
\hline \multicolumn{4}{|l|}{$\mathrm{C}_{2} \mathrm{H}_{5} \mathrm{O}$ Reactions } \\
\hline $\left.\begin{array}{rl}\mathrm{C}_{2} \mathrm{H}_{5} \mathrm{O}+\mathrm{M} & \rightarrow \mathrm{HCHO}+\mathrm{CH}_{3}+\mathrm{M} \\
& \rightarrow \mathrm{CH}_{3} \mathrm{CHO}+\mathrm{H}+\mathrm{M}\end{array}\right]$ & See Table 2 & & \\
\hline $\mathrm{C}_{2} \mathrm{H}_{5} \mathrm{O}+\mathrm{O}_{2} \rightarrow \mathrm{CH}_{3} \mathrm{CHO}+\mathrm{HO}_{2}$ & $1.0 \times 10^{-13} \exp (-830 / T)$ & $300-1000$ & $\begin{array}{l} \pm 0.3 \text { at } 300 \mathrm{~K} \text { rising to } \\
\pm 0.5 \text { at } 1000 \mathrm{~K}\end{array}$ \\
\hline \multicolumn{4}{|l|}{$\mathrm{C}_{2} \mathrm{H}_{5} \mathrm{OOH}$ Reactions } \\
\hline $\mathrm{C}_{2} \mathrm{H}_{5} \mathrm{OOH}+\mathrm{M} \rightarrow \mathrm{C}_{2} \mathrm{H}_{5} \mathrm{O}+\mathrm{OH}+\mathrm{M}$ & See Table 2 & & \\
\hline \multicolumn{4}{|l|}{$\mathrm{C}_{3} \mathrm{H}_{5}$ Radical Reactions } \\
\hline $\mathrm{C}_{3} \mathrm{H}_{5}+\mathrm{M} \rightarrow \mathrm{CH}_{2} \mathrm{CCH}_{2}+\mathrm{H}+\mathrm{M}$ & See Table 2 & & \\
\hline $\mathrm{C}_{3} \mathrm{H}_{5}+\mathrm{O}_{2} \rightarrow \mathrm{CH}_{2} \mathrm{CCH}_{2}+\mathrm{HO}_{2}$ & $1.7-\times 10^{-12} \exp (-11400 / T)$ & $600-1200$ & $\begin{array}{l} \pm 0.3 \text { at } 600 \mathrm{~K} \text { rising to } \\
\pm 0.5 \text { at } 1200 \mathrm{~K}\end{array}$ \\
\hline$\rightarrow \mathrm{CO}+$ products & $7.6 \times 10^{-12} \exp (-9450 / T)$ & $600-1200$ & \pm 0.3 \\
\hline $\mathrm{C}_{3} \mathrm{H}_{5}+\mathrm{H}_{2} \rightarrow \mathrm{C}_{3} \mathrm{H}_{6}+\mathrm{H}$ & $1.8 \times 10^{-19} T^{2.4} \exp (-9550 / T)$ & $300-1100$ & $\begin{array}{l} \pm 0.7 \text { at } 300 \mathrm{~K} \text { reducing to } \\
\pm 0.3 \text { at } 1100 \mathrm{~K}\end{array}$ \\
\hline $\mathrm{C}_{3} \mathrm{H}_{5}+\mathrm{CH}_{4} \rightarrow \mathrm{C}_{3} \mathrm{H}_{6}+\mathrm{CH}_{3}$ & $6.6 \times 10^{-23} T^{3.4} \exp (-11670 / T)$ & $300-1200$ & \pm 0.4 \\
\hline $\begin{aligned} \mathrm{C}_{3} \mathrm{H}_{5}+\mathrm{C}_{2} \mathrm{H}_{4} & \rightarrow \mathrm{C}_{3} \mathrm{H}_{6}+\mathrm{C}_{2} \mathrm{H}_{3} \\
& \rightarrow \mathrm{c}-\mathrm{C}_{5} \mathrm{H}_{8}+\mathrm{H}\end{aligned}$ & $\begin{array}{l}6.6 \times 10^{-23} T^{3.4} \exp (-13120 / T) \\
1.0 \times 10^{-13} \exp (-9620 / T)\end{array}$ & $\begin{array}{l}600-1200 \\
600-1200\end{array}$ & $\begin{array}{l} \pm 0.5 \\
\pm 0.7\end{array}$ \\
\hline $\mathrm{C}_{3} \mathrm{H}_{5}+\mathrm{C}_{2} \mathrm{H}_{6} \rightarrow \mathrm{C}_{3} \mathrm{H}_{6}+\mathrm{C}_{2} \mathrm{H}_{5}$ & $3.9 \times 10^{-22} T^{3.3} \exp (-9990 / T)$ & $300-1200$ & \pm 0.4 \\
\hline $\begin{aligned} \mathrm{C}_{3} \mathrm{H}_{5}+\mathrm{C}_{3} \mathrm{H}_{5} & \rightarrow \mathrm{CH}_{2} \mathrm{CHCH}_{2} \mathrm{CH}_{2} \mathrm{CHCH}_{2} \\
& \rightarrow \mathrm{C}_{3} \mathrm{H}_{6}+\mathrm{CH}_{2} \mathrm{CCH}_{2}\end{aligned}$ & $\begin{array}{l}\text { See Table } 3 \\
1.0 \times 10^{-13} \exp (132 / T)\end{array}$ & $300-1000$ & \pm 0.7 \\
\hline $\mathrm{C}_{3} \mathrm{H}_{5}+\mathrm{C}_{3} \mathrm{H}_{8} \rightarrow \mathrm{C}_{3} \mathrm{H}_{6}+\mathrm{CH}_{3} \mathrm{CH}_{2} \mathrm{CH}_{2}$ & $3.9 \times 10^{-22} T^{3.3} \exp (-9990 / T)$ & $300-1200]$ & \pm 0.4 over the range 600 to \\
\hline$\rightarrow \mathrm{C}_{3} \mathrm{H}_{6}+\mathrm{CH}_{3} \mathrm{CHCH}_{3}$ & $1.3 \times 10^{-22} T^{3.3} \exp (-8660 / T)$ & $300-1200]$ & $\begin{array}{l}1000 \mathrm{~K} \text { rising to } \pm 0.7 \text { at other } \\
\text { temperatures }\end{array}$ \\
\hline $\begin{aligned} \mathrm{C}_{3} \mathrm{H}_{5}+2-\mathrm{C}_{4} \mathrm{H}_{8} & \rightarrow \mathrm{C}_{3} \mathrm{H}_{6}+\mathrm{CH}_{2} \mathrm{CHCHCH}_{3} \\
& \rightarrow \mathrm{C}_{3} \mathrm{H}_{6}+\mathrm{CH}_{3} \mathrm{CCHCH}_{3} \\
& \rightarrow \mathrm{CH}_{2} \mathrm{CHCH}_{2} \mathrm{CH}_{3}\left(\mathrm{CH}_{3}\right) \mathrm{CHCH}_{3}\end{aligned}$ & $\begin{array}{l}6.6 \times 10^{-32} \exp (-8180 / T) \\
3.3 \times 10^{-23} T^{3.4} \exp (-12160 / T) \\
\text { See Table } 3\end{array}$ & $\begin{array}{l}600-1000 \\
600-1000\end{array}$ & $\begin{array}{l} \pm 0.5 \\
\pm 0.5\end{array}$ \\
\hline $\begin{aligned} \mathrm{C}_{3} \mathrm{H}_{5}+i-\mathrm{C}_{4} \mathrm{H}_{10} & \rightarrow \mathrm{C}_{3} \mathrm{H}_{6}+\left(\mathrm{CH}_{3}\right)_{2} \mathrm{CHCH}_{2} \\
& \rightarrow \mathrm{C}_{3} \mathrm{H}_{6}+\left(\mathrm{CH}_{3}\right)_{3} \mathrm{C}\end{aligned}$ & $\begin{array}{l}5.9 \times 10^{-22} T^{3.3} \exp (-9990 / T) \\
0.7 \times 10^{-22} T^{3.3} \exp (-7800 / T)\end{array}$ & $\left.\begin{array}{l}300-1200 \\
300-1200\end{array}\right]$ & $\begin{array}{l} \pm 0.4 \text { over the range } \\
600 \text { to } 1000 \mathrm{~K} \text { rising to } \\
\pm 0.7 \text { at other temperatures }\end{array}$ \\
\hline $\mathrm{C}_{3} \mathrm{H}_{5}+\mathrm{HCHO} \rightarrow \mathrm{C}_{3} \mathrm{H}_{6}+\mathrm{HCO}$ & $1.2 \times 10^{-16} T^{1.8} \exp (-9155 / T)$ & $300-1000$ & \pm 0.4 \\
\hline $\mathrm{C}_{3} \mathrm{H}_{5}+\mathrm{C}_{6} \mathrm{H}_{5} \mathrm{CH}_{3} \rightarrow \mathrm{C}_{3} \mathrm{H}_{6}+\mathrm{C}_{6} \mathrm{H}_{5} \mathrm{CH}_{2}$ & $3.3 \times 10^{-12} \exp (-8660 / T)$ & $600-1000$ & \pm 0.4 \\
\hline
\end{tabular}

i- $\mathrm{C}_{3} \mathrm{H}_{7}$ Radical Reactions

$i-\mathrm{C}_{3} \mathrm{H}_{7}+\mathrm{M} \rightarrow \mathrm{C}_{3} \mathrm{H}_{6}+\mathrm{H}+\mathrm{M}$

See Table 2

$i-\mathrm{C}_{3} \mathrm{H}_{7}+\mathrm{O}_{2} \rightarrow \mathrm{C}_{3} \mathrm{H}_{6}+\mathrm{HO}_{2}$

$3.3 \times 10^{-14} \exp (+1290 / T)$

$600-800 \quad \pm 0.5$

$i-\mathrm{C}_{3} \mathrm{H}_{7}+\mathrm{H}_{2} \rightarrow \mathrm{C}_{3} \mathrm{H}_{8}+\mathrm{H}$

$1.3 \times 10^{-23} T^{3.28} \exp (-4360 / T)$

$300-1200 \quad \pm 0.5$

$i-\mathrm{C}_{3} \mathrm{H}_{7}+\mathrm{C}_{2} \mathrm{H}_{2} \rightarrow\left(\mathrm{CH}_{3}\right)_{2} \mathrm{CHCHCH}$

$5.3 \times 10^{-14} \exp (-3470 / T)$

$300-600 \quad \pm 0.5$

$i-\mathrm{C}_{3} \mathrm{H}_{7}+\mathrm{C}_{2} \mathrm{H}_{4} \rightarrow\left(\mathrm{CH}_{3}\right)_{2} \mathrm{CHCH}_{2} \mathrm{CH}_{2}$

$7.5 \times 10^{-14} \exp (-3470 / T)$

$300-600 \quad \pm 0.5$ 
TABLE 1. Bimolecular Reactions - Continued

\begin{tabular}{llll}
\hline \hline Reaction & $k / \mathrm{cm}^{3}$ molecule $\mathrm{s}^{-1}$ & $T / \mathrm{K}$ & Error limits $(\Delta$ log $k)$ \\
\hline$i-\mathrm{C}_{3} \mathrm{H}_{7}+i-\mathrm{C}_{3} \mathrm{H}_{7} \rightarrow \mathrm{C}_{6} \mathrm{H}_{14}$ & See Table 3 & $300-1000$ & $\begin{array}{l} \pm 0.1 \text { at } 300 \mathrm{~K} \text { rising to } \\
\pm 0.3 \text { at } 1000 \mathrm{~K}\end{array}$ \\
& $4.2 \times 10^{-12}$ & $300-1000$ & $\begin{array}{l} \pm 0.1 \text { at } 300 \mathrm{~K} \text { rising to } \\
\pm 0.5 \text { at } 1000 \mathrm{~K}\end{array}$ \\
& & & \pm 0.5 \\
& & $300-650$ & $\pm \mathrm{C}_{3} \mathrm{H}_{8}+\mathrm{C}_{3} \mathrm{H}_{6}$ \\
& & & \pm 0.5
\end{tabular}

$\mathrm{C}_{3} \mathrm{H}_{8}$ Reactions

$\mathrm{C}_{3} \mathrm{H}_{8}+\mathrm{M} \rightarrow \mathrm{CH}_{3}+\mathrm{C}_{2} \mathrm{H}_{5}+\mathrm{M}$

See Table 2

${ }_{t}-C_{4} H_{9}$ Radical Reactions

$t-\mathrm{C}_{4} \mathrm{H}_{9}+\mathrm{M} \rightarrow i-\mathrm{C}_{4} \mathrm{H}_{8}+\mathrm{H}+\mathrm{M}$

See Table 2

$t-\mathrm{C}_{4} \mathrm{H}_{9}+\mathrm{O}_{2} \rightarrow i-\mathrm{C}_{4} \mathrm{H}_{8}+\mathrm{HO}_{2}$

$5 \times 10^{-14} \exp (+2115 / T)$

$600-800 \quad \pm 0.5$

$t-\mathrm{C}_{4} \mathrm{H}_{9}+\mathrm{H}_{2} \rightarrow i-\mathrm{C}_{4} \mathrm{H}_{10}+\mathrm{H}$

$3.1 \times 10^{-26} T^{4.24} \exp (-4510 / T)$

$300-1200 \pm 0.5$

$t-\mathrm{C}_{4} \mathrm{H}_{9}+\mathrm{C}_{2} \mathrm{H}_{2} \rightarrow\left(\mathrm{CH}_{3}\right)_{3} \mathrm{CCHCH}$

$1.2 \times 10^{-13} \exp (-4320 / T)$

$300-600 \quad \pm 0.5$

$t-\mathrm{C}_{4} \mathrm{H}_{9}+\mathrm{C}_{2} \mathrm{H}_{4} \rightarrow\left(\mathrm{CH}_{3}\right)_{3} \mathrm{CCH}_{2} \mathrm{CH}_{2}$

$3.3 \times 10^{-14} \exp (-4020 / T)$

$300-650 \quad \pm 0.5$

$t-\mathrm{C}_{4} \mathrm{H}_{9}+t-\mathrm{C}_{4} \mathrm{H}_{9} \rightarrow \mathrm{C}_{8} \mathrm{H}_{18}$

See Table 3

$\rightarrow i-\mathrm{C}_{4} \mathrm{H}_{10}+i-\mathrm{C}_{4} \mathrm{H}_{8}$

$1.2 \times 10^{-7} \mathrm{~T}^{-1.73}$

$300-1000 \pm 0.15$ at $300 \mathrm{~K}$ rising to

$1.0 \times 10^{-14} \exp (-3200 / T)$

$\begin{aligned} t-\mathrm{C}_{4} \mathrm{H}_{9}+t-\mathrm{C}_{4} \mathrm{H}_{9} \mathrm{CHO} & \rightarrow i-\mathrm{C}_{4} \mathrm{H}_{10}+t-\mathrm{C}_{4} \mathrm{H}_{9} \mathrm{CO} \\ & \rightarrow i-\mathrm{C}_{4} \mathrm{H}_{10}+\mathrm{CH}_{2} \mathrm{C}\left(\mathrm{CH}_{3}\right)_{2} \mathrm{CHO}\end{aligned}$

$3.9 \times 10^{-14} \exp (-5540 / T)$

\pm 0.5 at $1000 \mathrm{~K}$

$300-700 \quad \pm 0.5$

$500-700 \quad \pm 0.5$

$\mathrm{C}_{6} \mathrm{H}_{5}$ Radical Reactions

$\left.\begin{array}{rl}\mathrm{C}_{6} \mathrm{H}_{5}+\mathrm{M} & \rightarrow \mathrm{C}_{2} \mathrm{H}_{2}+\mathrm{C}_{4} \mathrm{H}_{3}+\mathrm{M} \\ & \rightarrow \mathrm{C}_{2} \mathrm{H}_{3}+\mathrm{C}_{4} \mathrm{H}_{2}+\mathrm{M} \\ & \rightarrow \text { linear- } \mathrm{C}_{6} \mathrm{H}_{5}+\mathrm{M}\end{array}\right]$

see Table 2

$\mathrm{C}_{6} \mathrm{H}_{6}$ Reactions

$\left.\begin{array}{rl}\mathrm{C}_{6} \mathrm{H}_{6}+\mathrm{M} & \rightarrow \mathrm{C}_{6} \mathrm{H}_{5}+\mathrm{H}+\mathrm{M} \\ & \rightarrow \mathrm{C}_{4} \mathrm{H}_{4}+\mathrm{C}_{2} \mathrm{H}_{2}+\mathrm{M}\end{array}\right]$

See Table 2

$\mathrm{C}_{6} \mathrm{H}_{5} \mathrm{O}$ Radical Reactions

$\mathrm{C}_{6} \mathrm{H}_{5} \mathrm{O}+\mathrm{M} \rightarrow \mathrm{C}_{5} \mathrm{H}_{5}+\mathrm{CO}+\mathrm{M}$

See Table 2

$\mathrm{C}_{6} \mathrm{H}_{5} \mathrm{CH}_{2}$ Radical Reactions

$$
\begin{aligned}
\mathrm{C}_{6} \mathrm{H}_{5} \mathrm{CH}_{2}+\mathrm{M} & \rightarrow \mathrm{C}_{3} \mathrm{H}_{3}+2 \mathrm{C}_{2} \mathrm{H}_{2}+\mathrm{M} \\
& \rightarrow \mathrm{C}_{4} \mathrm{H}_{4}+\mathrm{C}_{3} \mathrm{H}_{3}+\mathrm{M} \\
& \rightarrow \mathrm{C}_{5} \mathrm{H}_{5}+\mathrm{C}_{2} \mathrm{H}_{2}+\mathrm{M} \\
& \rightarrow \mathrm{C}_{7} \mathrm{H}_{7}+\mathrm{M}
\end{aligned}
$$

See Table 2

$\mathrm{C}_{6} \mathrm{H}_{5} \mathrm{CH}_{3}$ Reactions

$$
\left.\begin{array}{rl}
\mathrm{C}_{6} \mathrm{H}_{5} \mathrm{CH}_{3}+\mathrm{M} & \rightarrow \mathrm{C}_{6} \mathrm{H}_{5} \mathrm{CH}_{2}+\mathrm{H}+\mathrm{M} \\
& \rightarrow \mathrm{C}_{6} \mathrm{H}_{5}+\mathrm{CH}_{3}+\mathrm{M}
\end{array}\right] \quad \text { See Table } 2
$$


TABLE 1. Bimolecular Reactions - Continued

\begin{tabular}{|c|c|c|c|}
\hline Reaction & $k / \mathrm{cm}^{3}$ molecule ${ }^{-1} \mathrm{~s}^{-1}$ & $T / \mathrm{K}$ & Error limits $(\Delta \log k)$ \\
\hline \multicolumn{4}{|l|}{$p-\mathrm{C}_{6} \mathrm{H}_{4}\left(\mathrm{CH}_{3}\right)_{2}$ Reactions } \\
\hline$p-\mathrm{C}_{6} \mathrm{H}_{4}\left(\mathrm{CH}_{3}\right)_{2}+\mathrm{M} \rightarrow \mathrm{C}_{6} \mathrm{H}_{4} \mathrm{CH}_{2} \mathrm{CH}_{3}+\mathrm{H}+\mathrm{M}$ & See Table 2 & & \\
\hline \multicolumn{4}{|l|}{$\mathrm{C}_{6} \mathrm{H}_{5} \mathrm{C}_{2} \mathrm{H}_{5}$ Reactions } \\
\hline $\left.\begin{array}{rl}\mathrm{C}_{6} \mathrm{H}_{5} \mathrm{C}_{2} \mathrm{H}_{5}+\mathrm{M} & \rightarrow \mathrm{C}_{6} \mathrm{H}_{5} \mathrm{CH}_{2}+\mathrm{CH}_{3}+\mathrm{M} \\
& \rightarrow \mathrm{C}_{6} \mathrm{H}_{6}+\mathrm{C}_{2} \mathrm{H}_{4}+\mathrm{M} \\
& \rightarrow \mathrm{C}_{6} \mathrm{H}_{5} \mathrm{CHCH}_{2}+\mathrm{H}_{2}+\mathrm{M} \\
& \rightarrow \mathrm{C}_{6} \mathrm{H}_{5}+\mathrm{C}_{2} \mathrm{H}_{5}+\mathrm{M} \\
& \rightarrow \mathrm{C}_{6} \mathrm{H}_{5} \mathrm{CHCH}_{3}+\mathrm{H}+\mathrm{M}\end{array}\right]$ & See Table 2 & & \\
\hline
\end{tabular}


TABLE 2. Decomposition Reactions

\begin{tabular}{|c|c|c|c|}
\hline Reaction & $\begin{array}{l}k_{\infty} / \mathrm{s}^{-1} \\
k_{0} / \mathrm{cm}^{3} \text { molecule }{ }^{-1} \mathrm{~s}^{-1} \\
F_{\mathrm{c}} \\
k / \mathrm{s}^{-1}=\frac{k_{0} k_{\infty}[\mathrm{M}]}{k_{0}[\mathrm{M}]+k_{\infty}} \mathrm{F}\end{array}$ & $T / K$ & Error limits $(\Delta \log k)$ \\
\hline $\mathrm{H}_{2}+\mathrm{Ar} \rightarrow 2 \mathrm{H}+\mathrm{Ar}$ & $k_{0}=3.7 \times 10^{-10} \exp (-48350 / T)$ & $2500-8000$ & \pm 0.3 \\
\hline $\mathrm{H}_{2} \mathrm{O}+\mathrm{N}_{2} \rightarrow \mathrm{H}+\mathrm{OH}+\mathrm{N}_{2}$ & $k_{0}=5.8 \times 10^{-9} \exp (-52920 / T)$ & $2000-6000$ & \pm 0.5 \\
\hline $\mathrm{H}_{2} \mathrm{O}_{2}+\mathrm{M} \rightarrow 2 \mathrm{OH}+\mathrm{M}$ & $\begin{array}{l}k_{0}(\mathrm{Ar})=3 \times 10^{-8} \exp (-21600 / T) \\
k_{0}\left(\mathrm{~N}_{2}\right)=2 \times 10^{-7} \exp (-22900 / T) \\
k_{\infty}=3 \times 10^{14} \exp (-24400 / T) \\
F_{c}(\mathrm{Ar})=0.5\end{array}$ & $\begin{array}{l}1000-1500 \\
700-1500 \\
1000-1500 \\
700-1500\end{array}$ & $\begin{array}{l} \pm 0.2 \\
\pm 0.2 \\
\pm 0.5 \\
\Delta F_{\mathrm{c}}= \pm 0.1\end{array}$ \\
\hline $\mathrm{CH}_{3}+\mathrm{M} \rightarrow \mathrm{CH}_{2}+\mathrm{H}+\mathrm{M}$ & $\ddot{k_{0}}=1.7 \times 10^{-8} \exp (-45600 / T)$ & $1500-3000$ & \pm 0.5 \\
\hline $\mathrm{CH}_{4}+\mathrm{M} \rightarrow \mathrm{CH}_{3}+\mathrm{H}+\mathrm{M}$ & $\begin{array}{l}k_{0}(\mathrm{Ar})=7.5 \times 10^{-7} \exp (-45700 / T) \\
k_{0}(\mathrm{Ar})=7.8 \times 10^{23} T^{-8} .2 \exp (-59200 / T) \\
k_{0}\left(\mathrm{CH}_{4}\right)=1.4 \times 10^{-6} \exp (-45700 / T) \\
k_{\infty}=2.4 \times 10^{16} \exp (-52800 / T) \\
F_{c}(\mathrm{Ar})=\exp (-T / 1350)+\exp (-7830 / T) \\
F_{c}\left(\mathrm{CH}_{4}\right)=0.31 \exp (-T / 90)+0.69(-T / 2210)\end{array}$ & $\begin{array}{l}1000-1700 \\
1700-5000 \\
1000-2000 \\
1000-3000 \\
1000-5000 \\
1000-2000\end{array}$ & $\begin{array}{l} \pm 0.3 \\
\pm 0.3 \\
\pm 0.3 \\
\pm 0.5 \\
\Delta F_{c}= \pm 0.1 \\
\Delta F_{c}= \pm 0.1\end{array}$ \\
\hline $\mathrm{HCO}+\mathrm{Ar} \rightarrow \mathrm{H}+\mathrm{CO}+\mathrm{Ar}$ & $k_{0}=2.6 \times 10^{-10} \exp (-7930 / T)$ & $600-2500$ & \pm 0.5 \\
\hline $\left.\begin{array}{rl}\mathrm{HCHO}+\mathrm{M} & \rightarrow \mathrm{H}+\mathrm{CHO}+\mathrm{M} \\
& \rightarrow \mathrm{H}_{2}+\mathrm{CO}+\mathrm{M}\end{array}\right]$ & $\begin{array}{l}k_{0}(\mathrm{Ar})=2.7 \times 10^{12} T^{-5.54} \exp (-48660 / T) \\
k_{0}(2) / k_{0}=0.7 \pm 0.4\end{array}$ & $\begin{array}{l}1700-3200 \\
2000-3000\end{array}$ & \pm 0.3 \\
\hline $\mathrm{CH}_{3} \mathrm{O}+\mathrm{M} \rightarrow \mathrm{HCHO}+\mathrm{H}+\mathrm{M}$ & $k_{0}=9.0 \times 10^{-11} \exp (-6790 / T)$ & $300-1700$ & \pm 0.3 \\
\hline $\left.\begin{array}{rl}\mathrm{CH}_{3} \mathrm{OH}+\mathrm{Ar} & \rightarrow \mathrm{CH}_{3}+\mathrm{OH}+\mathrm{Ar} \\
& \rightarrow \mathrm{CH}_{2} \mathrm{OH}+\mathrm{H}+\mathrm{Ar} \\
& \rightarrow{ }^{1} \mathrm{CH}_{2}+\mathrm{H}_{2} \mathrm{O}+\mathrm{Ar}\end{array}\right]$ & $\begin{array}{l}k_{0}=1.1 \times 10^{-7} \exp (-33080 / T) \\
k_{\infty}=1.7 \times 10^{16} \exp (-45740 / T) \\
F_{\mathrm{c}}=0.18 \exp (-T / 200)+0.82 \exp (-T / 1438)\end{array}$ & $\begin{array}{l}1000-2000 \\
1000-2000 \\
1000-2000\end{array}$ & $\begin{array}{l} \pm 0.3 \\
\pm 0.5 \\
\Delta F_{c}= \pm 0.1\end{array}$ \\
\hline $\mathrm{CH}_{3} \mathrm{OOH}+\mathrm{M} \rightarrow \mathrm{CH}_{3} \mathrm{O}+\mathrm{OH}+\mathrm{M}$ & $k_{\infty}=6 \times 10^{14} \exp (-21300 / T)$ & $500-800$ & $\begin{array}{l} \pm 0.2 \text { at } 600 \mathrm{~K} \text { rising to } \\
\pm 0.5 \text { at } 500 \text { and } 800 \mathrm{~K}\end{array}$ \\
\hline $\mathrm{NCO}+\mathrm{Ar} \rightarrow \mathrm{N}+\mathrm{CO}+\mathrm{Ar}$ & $k_{0}=1.7 \times 10^{-9} \exp (-23500 / T)$ & $1450-2600$ & \pm 0.4 \\
\hline $\mathrm{C}_{2} \mathrm{H}_{3}+\mathrm{M} \rightarrow \mathrm{C}_{2} \mathrm{H}_{2}+\mathrm{H}+\mathrm{M}$ & $\begin{array}{l}k_{0}=6.9 \times 10^{17} T^{-7} .5 \exp (-22900 / T) \\
k_{\infty}=2 \times 10^{14} \exp (-20000 / T) \\
F_{\mathrm{c}}=0.35\end{array}$ & $\begin{array}{l}500-2500 \\
500-2500 \\
500-2500\end{array}$ & $\begin{array}{l} \pm 0.5 \\
\pm 0.5 \\
\Delta F_{\mathrm{c}}= \pm 0.1\end{array}$ \\
\hline $\begin{aligned} \mathrm{C}_{2} \mathrm{H}_{4}+\mathrm{M} & \rightarrow \mathrm{C}_{2} \mathrm{H}_{2}+\mathrm{H}_{2}+\mathrm{M} \\
& \rightarrow \mathrm{C}_{2} \mathrm{H}_{3}+\mathrm{H}+\mathrm{M}\end{aligned}$ & $\begin{array}{l}k_{0}(\mathrm{Ar}, \mathrm{Kr})=5.8 \times 10^{-8} \exp (-36000 / T) \\
k_{0}(\mathrm{Ar})=4.3 \times 10^{-7} \exp (-48600 / T)\end{array}$ & $\begin{array}{l}1500-3200 \\
1500-3200\end{array}$ & $\begin{array}{l} \pm 0.3 \\
\pm 0.5\end{array}$ \\
\hline $\mathrm{C}_{2} \mathrm{H}_{5}+\mathrm{C}_{2} \mathrm{H}_{6} \rightarrow \mathrm{C}_{2} \mathrm{H}_{4}+\mathrm{H}+\mathrm{C}_{2} \mathrm{H}_{6}$ & $\begin{array}{l}k_{0}=1.7 \times 10^{-6} \exp (-16800 / T) \\
k_{\infty}=8.2 \times 10^{13} \exp (-200 / 0 / T) \\
F_{\mathrm{c}}=0.25 \exp (-T / 97)+0.75 \exp (-T / 1379)\end{array}$ & $\begin{array}{l}700-900 \\
700-1100 \\
700-1100\end{array}$ & $\begin{array}{l} \pm 0.3 \\
\pm 0.3 \\
\Delta F_{\xi}= \pm 0.1\end{array}$ \\
\hline $\mathrm{C}_{2} \mathrm{H}_{6}+\mathrm{M} \rightarrow 2 \mathrm{CH}_{3}+\mathrm{M}$ & $\begin{array}{l}k_{0}(\mathrm{Ar})=1.1 \times 10^{25} T^{-8.24} \exp (-47090 / T) \\
k_{0}\left(\mathrm{~N}_{2}\right)=1.1 \times 1 \mathrm{U}^{25}{ }^{8.24} \exp (-4 / 090 / \mathrm{U}) \\
k_{0}\left(\mathrm{C}_{2} \mathrm{H}_{6}\right)=4.5 \times 10^{-2} \exp (-41930 / T) \\
k_{\infty}=1.8 \times 10^{21} T^{-1.24} \exp (-45700 / T) \\
F_{c}\left(\mathrm{Ar}, \mathrm{N}_{2}\right)=0.38 \exp (-T / 73)+0.62 \exp (-T / 1180) \\
F_{\mathrm{c}}\left(\mathrm{C}_{2} \mathrm{H}_{6}\right)=0.54 \exp (-T / 1250)\end{array}$ & $\begin{array}{l}300-2000 \\
300-2000 \\
800-1000 \\
300-2000 \\
300-2000 \\
800-1000\end{array}$ & $\begin{array}{l} \pm 0.5 \\
\pm 0.5 \\
\pm 0.5 \\
\pm 0.3 \\
\Delta F_{\mathrm{c}}= \pm 0.1 \\
\Delta F_{\mathrm{c}}= \pm 0.1\end{array}$ \\
\hline
\end{tabular}


TABLE 2. Decomposition Reactions - Continued

\begin{tabular}{|c|c|c|c|}
\hline Reaction & $\begin{array}{l}k_{\infty} / \mathrm{s}^{-1} \\
k_{0} / \mathrm{cm}^{3} \text { molecule } \\
F_{\mathrm{c}} \\
k / \mathrm{s}^{-1}=\frac{k_{0} k_{\infty}[\mathrm{M}]}{k_{0}[\mathrm{M}]+k_{\infty}} \mathrm{F}\end{array}$ & $T / \mathrm{K}$ & Error limits $(\Delta \log k)$ \\
\hline $\mathrm{CH}_{3} \mathrm{CO}+\mathrm{M} \rightarrow \mathrm{CH}_{3}+\mathrm{CO}+\mathrm{M}$ & $\begin{array}{l}k_{0}(\mathrm{He})=1.0 \times 10^{-8} \exp (-7080 / T) \\
k_{u}(\mathrm{Ar})-7.0 \times 10^{-18} \\
k_{\infty}=2.8 \times 10^{13} \exp (-8630 / T) \\
F_{\mathrm{c}}(\mathrm{He})=0.5\end{array}$ & $\begin{array}{l}400-500 \\
353 \\
300-500 \\
400-500\end{array}$ & $\begin{array}{l} \pm 0.2 \\
\pm 0.1 \\
\pm 0.5 \\
\Delta F_{c}= \pm 0.1\end{array}$ \\
\hline $\mathrm{CH}_{3} \mathrm{CHO}+\mathrm{M} \rightarrow \mathrm{CH}_{3}+\mathrm{CHO}+\mathrm{M}$ & $\begin{array}{l}k(1 \mathrm{~atm})=7 \times 10^{15} \exp (-41100 / T) \\
\text { (pressure dependent region) }\end{array}$ & $750-1200$ & \pm 0.4 \\
\hline $\mathrm{C}_{2} \mathrm{H}_{3} \mathrm{O}+\mathrm{M} \rightarrow \mathrm{HCHO}+\mathrm{CH}_{3}+\mathrm{M}$ & $\begin{array}{l}k_{\infty}=8 \times 10^{33} \exp (-10830 / T) \\
\text { [cstimatc] }\end{array}$ & $300-600$ & \pm 1.0 \\
\hline $\mathrm{C}_{3} \mathrm{H}_{5}+\mathrm{M} \rightarrow \mathrm{CH}_{2} \mathrm{CCH}_{2}+\mathrm{H}+\mathrm{M}$ & $k_{\infty}=1.5 \times 10^{11} T^{0.84} \exp (-30050 / T)$ & $800-1500$ & \pm 0.3 \\
\hline $\mathrm{i}-\mathrm{C}_{3} \mathrm{H}_{7}+\mathrm{He} \rightarrow \mathrm{C}_{3} \mathrm{H}_{6}+\mathrm{H}+\mathrm{He}$ & $\begin{array}{l}k_{0}=3.6 \times 10^{-7} \exp (-14200 / T) \\
k_{x}=8.76 \times 10^{7} T^{1.76} \exp (-17870 / T) \\
F_{c}(\mathrm{He})=0.35\end{array}$ & $\begin{array}{l}750-830 \\
170-1000 \\
750-830\end{array}$ & $\begin{array}{l} \pm 0.3 \\
\pm 0.3 \\
\Delta F_{\mathrm{c}}= \pm 0.1\end{array}$ \\
\hline $\mathrm{C}_{3} \mathrm{H}_{8}+\mathrm{Ar} \rightarrow \mathrm{CH}_{3}+\mathrm{C}_{2} \mathrm{H}_{5}+\mathrm{Ar}$ & $\begin{array}{l}k_{0}=1.3 \times 10^{-5} \exp (-32700 / T) \\
k_{\infty}=1.1 \times 10^{17} \exp (-42470 / T) \\
F_{\mathrm{c}}=0.24 \exp (-T / 1946)+0.76 \exp (-T / 38)\end{array}$ & $\begin{array}{l}700-2000 \\
700-2000 \\
700-2000\end{array}$ & $\begin{array}{l} \pm 0.5 \\
\pm 0.3 \\
\Delta F_{\mathrm{c}}= \pm 0.2\end{array}$ \\
\hline$t-\mathrm{C}_{4} \mathrm{H}_{9}+\mathrm{M} \rightarrow \mathrm{i}-\mathrm{C}_{4} \mathrm{H}_{8}+\mathrm{H}+\mathrm{M}$ & $k_{\infty}=8.3 \times 10^{13} \exp (-19200 / T)$ & $300-800$ & \pm 0.5 \\
\hline 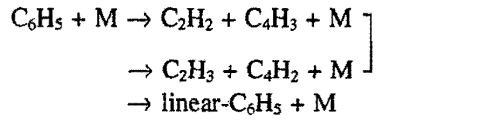 & $\begin{array}{l}\text { No recommendation } \\
4.0 \times 10^{13} \exp (-36700 / T)\end{array}$ & $1450-1900$ & \pm 0.4 \\
\hline $\left.\begin{array}{rl}\mathrm{C}_{6} \mathrm{H}_{6}+\mathrm{M} & \rightarrow \mathrm{C}_{6} \mathrm{H}_{5}+\mathrm{H}+\mathrm{M} \\
& \rightarrow \mathrm{C}_{4} \mathrm{H}_{4}+\mathrm{C}_{2} \mathrm{H}_{2}+\mathrm{M}\end{array}\right]$ & $9.0 \times 10^{15} \exp (-54060 / T)$ & $1200-2500$ & $\begin{array}{l} \pm 0.4 \text { at } 1200 \mathrm{~K} \\
\text { reducing to } \pm 0.3 \text { at } \\
2500 \mathrm{~K}\end{array}$ \\
\hline $\mathrm{C}_{6} \mathrm{H}_{5} \mathrm{O}+\mathrm{M} \rightarrow \mathrm{C}_{5} \mathrm{H}_{5}+\mathrm{CO}+\mathrm{M}$ & $2.5 \times 10^{11} \exp (-22100 / T)$ & $1000-1580$ & \pm 0.2 \\
\hline $\left.\begin{array}{rl}\mathrm{C}_{5} \mathrm{H}_{5} \mathrm{CH}_{2}+\mathrm{M} & \rightarrow \mathrm{C}_{3} \mathrm{H}_{3}+2 \mathrm{C}_{2} \mathrm{H}_{2}+\mathrm{M} \\
& \rightarrow \mathrm{C}_{4} \mathrm{H}_{4}+\mathrm{C}_{3} \mathrm{H}_{3}+\mathrm{M} \\
& \rightarrow \mathrm{C}_{5} \mathrm{H}_{5}+\mathrm{C}_{2} \mathrm{H}_{2}+\mathrm{M} \\
& \rightarrow \mathrm{C}_{7} \mathrm{H}_{7}(\mathrm{BCH})+\mathrm{M}\end{array}\right]$ & $5.1 \times 10^{13} \exp (-36370 / T)$ & $1350-1900$ & $\begin{array}{l} \pm 0.3 \text { at } 1350 \mathrm{~K} \text { rising } \\
\text { to } \pm 0.5 \text { at } 1900 \mathrm{~K}\end{array}$ \\
\hline $\begin{aligned} \mathrm{C}_{6} \mathrm{H}_{5} \mathrm{CH}_{3}+\mathrm{M} & \rightarrow \mathrm{C}_{6} \mathrm{H}_{5} \mathrm{CH}_{2}+\mathrm{H}+\mathrm{M} \\
& \rightarrow \mathrm{C}_{6} \mathrm{H}_{5}+\mathrm{CH}_{3}+\mathrm{M}\end{aligned}$ & $\begin{array}{l}3.1 \times 10^{15} \exp (-44890 / T) \\
k_{\infty}=7.8 \times 10^{18} \exp (-59400 / T)\end{array}$ & $\begin{array}{l}920-2200 \\
1500-2000\end{array}$ & $\begin{array}{l} \pm 0.3 \text { at } 920 \mathrm{~K} \text { rising to } \\
\pm 0.5 \text { at } 2200 \mathrm{~K} \\
\pm 0.7\end{array}$ \\
\hline $\begin{array}{l}p-\mathrm{C}_{6} \mathrm{H}_{4}\left(\mathrm{CH}_{3}\right)_{2}+\mathrm{M} \rightarrow \\
\mathrm{C}_{6} \mathrm{H}_{4}\left(\mathrm{CH}_{3}\right) \mathrm{CH}_{2}+\mathrm{H}+\mathrm{M}\end{array}$ & $4.0 \times 10^{15} \exp (-42600 / T)$ & $1400-1800$ & \pm 0.5 \\
\hline $\left.\begin{array}{rl}\mathrm{C}_{6} \mathrm{H}_{5} \mathrm{C}_{2} \mathrm{H}_{5}+\mathrm{M} & \rightarrow \mathrm{C}_{6} \mathrm{H}_{5} \mathrm{CH}_{2}+\mathrm{CH}_{3}+\mathrm{M} \\
& \rightarrow \mathrm{C}_{6} \mathrm{H}_{6}+\mathrm{C}_{2} \mathrm{H}_{4}+\mathrm{M} \\
& \rightarrow \mathrm{C}_{6} \mathrm{H}_{5} \mathrm{CHCH}_{2}+\mathrm{H}_{2}+\mathrm{M} \\
& \rightarrow \mathrm{C}_{6} \mathrm{H}_{5}+\mathrm{C}_{2} \mathrm{H}_{5}+\mathrm{M} \\
& \rightarrow \mathrm{C}_{6} \mathrm{H}_{5} \mathrm{CHCH}_{3}+\mathrm{H}+\mathrm{M}\end{array}\right]$ & $\begin{array}{l}6.1 \times 10^{15} \exp (-37800 / T) \\
\text { No recommendation }\end{array}$ & $770-1800$ & $\begin{array}{l} \pm 0.1 \text { at } 770 \mathrm{~K} \text { rising to } \\
\pm 0.4 \text { at } 1800 \mathrm{~K}\end{array}$ \\
\hline
\end{tabular}


TABLE 3. Combination Reactions

\begin{tabular}{|c|c|c|c|}
\hline \multirow[t]{2}{*}{ Reaction } & $\begin{array}{l}k_{o} / \mathrm{cm}^{3} \text { molecule } \mathrm{c}^{-1} \mathrm{~s}^{-1} \\
k_{d} \mathrm{~cm}^{6} \text { molecule } \mathrm{s}^{-2} \mathrm{~s}^{-1} \\
F_{\mathrm{c}}\end{array}$ & \multirow[t]{2}{*}{$T / \mathrm{K}$} & \multirow[t]{2}{*}{ Error limits $(\Delta \log k)$} \\
\hline & $k / \mathrm{cm}^{3}$ molecule ${ }^{-1} \mathrm{~s}^{-1}=\frac{k_{0} k_{\infty}[\mathrm{M}]}{k_{0}[\mathrm{M}]+k_{\infty}} F$ & & \\
\hline $\mathrm{H}+\mathrm{O}_{2}+\mathrm{Ar} \rightarrow \mathrm{HO}_{2}+\mathrm{Ar}$ & $k_{0}=1.7 \times 10^{-30} T^{-0.8}$ & $300-2000$ & \pm 0.5 \\
\hline $\mathrm{H}+\mathrm{O}_{2}+\mathrm{H}_{2} \rightarrow \cdot \mathrm{HO}_{2}+\mathrm{H}_{2}$ & $k_{0}=5.8 \times 10^{-30} T^{-0.8}$ & $300-2000$ & \pm 0.5 \\
\hline $\mathrm{H}+\mathrm{O}_{2}+\mathrm{N}_{2} \rightarrow \mathrm{HO}_{2}+\mathrm{N}_{2}$ & $k_{0}=3.9 \times 10^{-30} T^{-0.8}$ & $300-2000$ & \pm 0.5 \\
\hline $\mathrm{H}+\mathrm{H}+\mathrm{Ar} \rightarrow \mathrm{H}_{2}+\mathrm{Ar}$ & $k_{0}=1.8 \times 10^{-30} T^{-1.0}$ & $300-2500$ & \pm 0.5 \\
\hline $\mathrm{H}+\mathrm{H}+\mathrm{H}_{2} \rightarrow \mathrm{H}_{2}+\mathrm{H}_{2}$ & $k_{0}=2.7 \times 10^{-31} T^{-0.6}$ & $100-5000$ & \pm 0.5 \\
\hline $\mathrm{H}+\mathrm{OH}+\mathrm{H}_{2} \mathrm{O} \rightarrow \mathrm{H}_{2} \mathrm{O}+\mathrm{H}_{2} \mathrm{O}$ & $k_{0}=3.9 \times 10^{-25} T^{-2.0}$ & $300-3000$ & \pm 0.5 \\
\hline $\mathrm{H}+\mathrm{OH}+\mathrm{Ar} \rightarrow \mathrm{H}_{2} \mathrm{O}+\mathrm{Ar}$ & $k_{0}=2.3 \times 10^{-26} T^{-2.0}$ & $300-3000$ & \pm 0.3 \\
\hline $\mathrm{H}+\mathrm{OH}+\mathrm{N}_{2} \rightarrow \mathrm{H}_{2} \mathrm{O}+\mathrm{N}_{2}$ & $k_{0}=6.1 \times 10^{-26} T^{-2.0}$ & $300-3000$ & \pm 0.5 \\
\hline $\mathrm{H}+\mathrm{CO}+\mathrm{Ar} \rightarrow \mathrm{HCO}+\mathrm{Ar}$ & $k_{0}=5.3 \times 10^{-34} \exp (-370 / T)$ & $300-2500$ & \pm 0.5 \\
\hline $\mathrm{H}+\mathrm{CH}_{3}+\mathrm{M} \rightarrow \mathrm{CH}_{4}+\mathrm{M}$ & $\begin{array}{l}k_{0}(\mathrm{He})=1.8 \times 10^{-24} T^{-1.8} \\
k_{0}(\mathrm{Ar})=1.7 \times 10^{-24} T^{-1.8} \\
k_{0}\left(\mathrm{C}_{2} \mathrm{H}_{6}\right)=8.6 \times 10^{-24} T^{-1.8} \\
k_{\infty}=3.5 \times 10^{-10} \\
F_{\mathrm{c}}(\mathrm{He}, \mathrm{Ar})=0.63 \exp (-T / 3315)+0.37 \exp (-T / 61) \\
F_{\mathrm{c}}\left(\mathrm{C}_{2} \mathrm{H}_{6}\right)=0.71 \exp (-T / 3079)+0.29 \exp (-T / 54)\end{array}$ & $\begin{array}{l}300-1000 \\
300-1000 \\
300-1000 \\
300-1000 \\
300-1000 \\
300-1000\end{array}$ & $\begin{array}{l} \pm 0.3 \\
\pm 0.5 \\
\pm 0.5 \\
\pm 0.3 \\
\Delta F_{\mathrm{c}}= \pm 0.1 \\
\Delta F_{\mathrm{c}}= \pm 0.1\end{array}$ \\
\hline $\mathrm{H}+\mathrm{C}_{2} \mathrm{H}_{2}+\mathrm{He} \rightarrow \mathrm{C}_{2} \mathrm{H}_{3}+\mathrm{He}$ & $\begin{array}{l}k_{\infty}=1.4 \times 10^{-11} \exp (-1300 / T) \\
k_{0}=3.3 \times 10^{-30} \exp (-740 / T) \\
F_{\mathrm{c}}=0.44\end{array}$ & $\begin{array}{l}200-400 \\
200-400 \\
200-400\end{array}$ & $\begin{array}{l} \pm 0.3 \\
\pm 0.5 \\
\Delta F_{\mathrm{c}}= \pm 0.1\end{array}$ \\
\hline $\mathrm{H}+\mathrm{C}_{2} \mathrm{H}_{3}+\mathrm{M} \rightarrow \mathrm{C}_{7} \mathrm{H}_{4}+\mathrm{M}$ & No recommendation & & \\
\hline $\mathrm{H}+\mathrm{C}_{2} \mathrm{H}_{4}+\mathrm{M} \rightarrow \mathrm{C}_{2} \mathrm{H}_{5}+\mathrm{M}$ & $\begin{array}{l}k_{0}(\mathrm{He})=1.3 \times 10^{-29} \exp (-380 / T) \\
k_{0}\left(\mathrm{~N}_{2}\right)=7.7 \times 10^{-30} \exp (-380 / T) \\
k_{\infty}=6.6 \times 10^{-15} T^{1.28} \exp (-650 / T) \\
F_{\mathrm{c}}=\left(\mathrm{He}, \mathrm{N}_{2}\right) 0.24 \exp (-T / 40)+0.76 \exp (-T / 1025)\end{array}$ & $\begin{array}{l}300-800 \\
300-800 \\
200-1100 \\
300-800\end{array}$ & $\begin{array}{l} \pm 0.3 \\
\pm 0.3 \\
\pm 0.3 \\
\Delta F_{\mathfrak{c}}= \pm 0.1\end{array}$ \\
\hline $\mathrm{H}+\mathrm{C}_{2} \mathrm{H}_{5}+\mathrm{M} \rightarrow \mathrm{C}_{2} \mathrm{H}_{6}+\mathrm{M}$ & No recommendation & & \\
\hline $\begin{aligned} \mathrm{H}+\mathrm{C}_{3} \mathrm{H}_{5}+\mathrm{M} & \rightarrow \mathrm{C}_{3} \mathrm{H}_{6}+\mathrm{M} \\
& \rightarrow \mathrm{C}_{2} \mathrm{H}_{3}+\mathrm{CH}_{3}+\mathrm{M}\end{aligned}$ & $\left(k_{1}^{\infty}+k_{2}\right)=2.8 \times 10^{-10}$ & $300-1000$ & $\begin{array}{l} \pm 0.2 \text { at } 300 \mathrm{~K} \text { rising to } \\
\pm 0.5 \text { at } 1000 \mathrm{~K}\end{array}$ \\
\hline $\mathrm{H}+\mathrm{C}_{6} \mathrm{H}_{5}+\mathrm{M} \rightarrow \mathrm{C}_{6} \mathrm{H}_{6}+\mathrm{M}$ & $k_{\infty}=1.3 \times 10^{-10}$ & $1400-1700$ & \pm 0.5 \\
\hline $\mathrm{H}+\mathrm{C}_{6} \mathrm{H}_{6}+\mathrm{M} \rightarrow \mathrm{C}_{6} \mathrm{H}_{7}+\mathrm{M}$ & $k_{x}=6.7 \times 10^{-11} \exp (-2170 / T)$ & $300-1000$ & \pm 0.2 \\
\hline $\mathrm{H}+\mathrm{C}_{6} \mathrm{H}_{5} \mathrm{O}+\mathrm{M} \rightarrow \mathrm{C}_{6} \mathrm{H}_{5} \mathrm{OH}+\mathrm{M}$ & $k_{\infty}=4.2 \times 10^{-10}$ & 1000 & +0.3 \\
\hline $\mathrm{H}+\mathrm{C}_{6} \mathrm{H}_{5} \mathrm{CH}_{2}+\mathrm{M} \rightarrow \mathrm{C}_{6} \mathrm{H}_{5} \mathrm{CH}_{3}+\mathrm{M}$ & $k_{\infty}=4.3 \times 10^{-10}$ & $300-2000$ & $\begin{array}{l} \pm 0.2 \text { at } 300 \mathrm{~K} \text { rising to } \\
\pm 0.7 \text { at } 2000 \mathrm{~K}\end{array}$ \\
\hline $\mathrm{H}+\mathrm{C}_{6} \mathrm{H}_{5} \mathrm{CH}_{3}+\mathrm{M} \rightarrow \mathrm{C}_{6} \mathrm{H}_{6} \mathrm{CH}_{3}+\mathrm{M}$ & $k_{\infty}=1.2 \times 10^{-13}$ & 298 & \pm 0.2 \\
\hline $\mathrm{H}+\mathrm{C}_{6} \mathrm{H}_{5} \mathrm{C}_{2} \mathrm{H}_{5}+\mathrm{M} \rightarrow \mathrm{C}_{6} \mathrm{H}_{6} \mathrm{C}_{2} \mathrm{H}_{5}+\mathrm{M}$ & $k_{\infty}=3.3 \times 10^{-13}$ & 298 & \pm 0.1 \\
\hline $\mathrm{OH}+\mathrm{OH}+\mathrm{M} \rightarrow \mathrm{H}_{2} \mathrm{O}_{2}+\mathrm{M}$ & $\begin{array}{l}k_{0}\left(\mathrm{~N}_{2}\right)=6.1 \times 10^{-29} \mathrm{~T}^{-0.76} \\
k_{0}\left(\mathrm{H}_{2} \mathrm{O}\right)=4 \times 10^{-30} \\
k_{\infty}=1.2 \times 10^{-10} \mathrm{~T}^{-0.37} \\
F_{\mathrm{c}}\left(\mathrm{N}_{2}\right)-0.5\end{array}$ & $\begin{array}{l}250-1400 \\
300-400 \\
200-1500 \\
200-1500\end{array}$ & $\begin{array}{l} \pm 0.4 \\
\pm 0.4 \\
\pm 0.5 \\
\Delta F_{\mathrm{c}}- \pm 0.2\end{array}$ \\
\hline
\end{tabular}


TABLE 3. Combination Reactions - Continued

\begin{tabular}{|c|c|c|c|}
\hline Reaction & $\begin{array}{l}k_{\alpha} / \mathrm{cm}^{3} \text { molecule }{ }^{-1} \mathrm{~s}^{-1} \\
k_{d} / \mathrm{cm}^{6} \text { molecule } \\
F_{\mathrm{c}} \\
k / \mathrm{cm}^{3} \mathrm{~s}^{-1} \\
\text { molecule }^{-1} \mathrm{~s}^{-1}=\frac{k_{0} k_{\infty}[\mathrm{M}]}{k_{0}[\mathrm{M}]+k_{\infty}} F\end{array}$ & $T / \mathrm{K}$ & Error limits $(\Delta \log k)$ \\
\hline $\mathrm{OH}+\mathrm{CH}_{3}+\mathrm{M} \rightarrow \mathrm{CH}_{3} \mathrm{OH}+\mathrm{M}$ & $\begin{array}{l}k_{0}(\mathrm{He})=2.3 \times 10^{-27} \\
k_{0}(\mathrm{Ar})=4.4 \times 10^{-4} T^{-8.2} \\
k_{\infty}=1.0 \times 10^{-10} \\
F_{\mathrm{c}}(\mathrm{Ar})=0.18 \exp (-T / 200)+0.82(-T / 1438)\end{array}$ & $\begin{array}{r}300 \\
1000-2000 \\
300-2000 \\
1000-2000\end{array}$ & $\begin{array}{l} \pm 0.3 \\
\pm 0.5 \\
\pm 0.3 \\
\Delta F_{\mathrm{c}}= \pm 0.1\end{array}$ \\
\hline $\mathrm{OH}+\mathrm{C}_{2} \mathrm{H}_{2}+\mathrm{M} \rightarrow \mathrm{C}_{2} \mathrm{H}_{2} \mathrm{OH}+\mathrm{M}$ & See data sheet & & \\
\hline $\left.\begin{array}{rl}\left(\mathrm{H}+\mathrm{C}_{3} \mathrm{H}_{5}+\mathrm{M}\right. & \rightarrow \mathrm{CH}_{2} \mathrm{CHCH}_{2} \mathrm{OH}+\mathrm{M} \\
& \rightarrow \mathrm{CH}_{2} \mathrm{CHCHO}+2 \mathrm{H}+\mathrm{M}\end{array}\right]$ & $\left(k_{1}^{\infty}+k_{2}\right)=2.5 \times 10^{-11}$ & $300-1000$ & \pm 0.3 \\
\hline $\mathrm{OH}+\mathrm{C}_{6} \mathrm{H}_{6}+\mathrm{M} \rightarrow \mathrm{C}_{6} \mathrm{H}_{6} \mathrm{OH}+\mathrm{M}$ & $k_{\infty}=3.8 \times 10^{-12} \exp (-340 / T)$ & $240-340$ & \pm 0.2 \\
\hline $\mathrm{OH}+\mathrm{C}_{6} \mathrm{H}_{5} \mathrm{OH}+\mathrm{M} \rightarrow \mathrm{C}_{6} \mathrm{H}_{5}(\mathrm{OH})_{2}+\mathrm{M}$ & $k_{\infty}=2.8 \times 10^{-11}$ & 298 & \pm 0.1 \\
\hline $\mathrm{OH}+\mathrm{C}_{6} \mathrm{H}_{5} \mathrm{CH}_{3}+\mathrm{M} \rightarrow \mathrm{HOC}_{6} \mathrm{H}_{5} \mathrm{CH}_{3}+\mathrm{M}$ & $k_{\infty}=3.8 \times 10^{-12} \exp (180 / T)$ & $200-300$ & \pm 0.4 \\
\hline $\mathrm{OH}+\mathrm{C}_{6} \mathrm{H}_{4}\left(\mathrm{CH}_{3}\right)_{2}+\mathrm{M} \rightarrow \mathrm{C}_{6} \mathrm{H}_{4}\left(\mathrm{CH}_{3}\right)_{2} \mathrm{OH}+\mathrm{M}$ & $k_{\infty}=1.4 \times 10^{-11}$ & 300 & \pm 0.1 \\
\hline $\mathrm{OH}+\mathrm{C}_{6} \mathrm{H}_{5} \mathrm{C}_{2} \mathrm{H}_{5}+\mathrm{M} \rightarrow \mathrm{HOC}_{6} \mathrm{H}_{5} \mathrm{C}_{2} \mathrm{H}_{5}+\mathrm{M}$ & $7.5 \times 10^{-12}$ at $p \leqslant 1 \mathrm{~atm}$ & 298 & \pm 0.1 \\
\hline${ }^{3} \mathrm{CH}_{2}+\mathrm{C}_{2} \mathrm{H}_{2}+\mathrm{M} \rightarrow \mathrm{C}_{3} \mathrm{H}_{4}+\mathrm{M}$ & $2.0 \times 10^{-11} \exp (-3330 / T)$ at $p=\leqslant 10$ Torr. & $300-1000$ & \pm 0.3 \\
\hline${ }^{3} \mathrm{CH}_{2}+\mathrm{C}_{2} \mathrm{H}_{4}+\mathrm{M} \rightarrow \mathrm{C}_{3} \mathrm{H}_{6}+\mathrm{M}$ & & & \\
\hline $\left.\begin{array}{l}\rightarrow c-C_{3} \mathrm{H}_{6}+\mathrm{M} \\
\rightarrow \mathrm{C}_{3} \mathrm{H}_{5}+\mathrm{H}+\mathrm{M}\end{array}\right]$ & $5.3 \times 10^{-12} \exp (-2060 / T)$ & $300-1000$ & $\begin{array}{l} \pm 0.2 \text { at } 300 \mathrm{~K} \text { rising to } \\
\pm 0.3 \text { at } 1000 \mathrm{~K}\end{array}$ \\
\hline${ }^{\prime} \mathrm{CH}_{2}+\mathrm{C}_{2} \mathrm{H}_{2}+\mathrm{M} \rightarrow \mathrm{CH}_{2} \mathrm{CCH}_{2}+\mathrm{M}$ & & & \\
\hline $\left.\begin{array}{l}\rightarrow \mathrm{CH}_{3} \mathrm{CCH}+\mathrm{M} \\
\rightarrow \mathrm{CH}_{2} \mathrm{CCH}+\mathrm{H}+\mathrm{M}\end{array}\right]$ & $2.9 \times 10^{-10}$ independent of $p$ & $300-1000$ & $\begin{array}{l} \pm 0.3 \text { at } 300 \mathrm{~K} \text { rising to } \\
\pm 0.7 \text { at } 1000 \mathrm{~K}\end{array}$ \\
\hline${ }^{t} \mathrm{CH}_{2}+\mathrm{C}_{2} \mathrm{H}_{4}+\mathrm{M} \rightarrow \mathrm{C}_{3} \mathrm{H}_{6}+\mathrm{M}$ & $1.6 \times 10^{-10}$ independent of $p$ & $30 n-1000$ & $\begin{array}{l}+0.2 \text { at } 300 \mathrm{~K} \text { rising to } \\
\pm 0.5 \text { at } 1000 \mathrm{~K}\end{array}$ \\
\hline $\mathrm{CH}_{3}+\mathrm{O}_{2}+\mathrm{M} \rightarrow \mathrm{CH}_{3} \mathrm{O}_{2}+\mathrm{M}$ & $\begin{array}{l}k_{0}(\mathrm{Ar})=1.55 \times 10^{-22} T^{-3.3} \\
k_{0}\left(\mathrm{~N}_{2}\right)=1.6 \times 10^{-22} T^{-3.3} \\
k_{\infty}=1.3 \times 10^{-15} T^{\mathrm{i} . .^{2}} \\
F_{c}=0.466-1.30 \times 10^{-4} \mathrm{~T}\end{array}$ & $\begin{array}{l}300-800 \\
300-800 \\
300-800 \\
300-800\end{array}$ & $\begin{array}{l} \pm 0.3 \\
\pm 0.3 \\
\pm 0.3 \\
\Delta F_{c}= \pm 0.1\end{array}$ \\
\hline $\mathrm{CH}_{3}+\mathrm{CO}+\mathrm{M} \rightarrow \mathrm{CH}_{3} \mathrm{CO}+\mathrm{M}$ & $\begin{array}{l}k_{0}(\mathrm{He})=3.0 \times 10^{-34} \exp (-1910 / T) \\
k_{0}\left(\mathrm{~N}_{2}\right)=4.2 \times 10^{-36} \\
k_{\infty}=8.4 \times 10^{-13} \exp (-3460 / T) \\
F_{\mathrm{c}}(\mathrm{He})=0.5 \\
F_{\mathrm{c}}\left(\mathrm{N}_{2}\right)-0.6\end{array}$ & $\begin{array}{l}400-500 \\
300-350 \\
300-500 \\
400-500 \\
300-350\end{array}$ & $\begin{array}{l} \pm 0.2 \\
\pm 0.5 \\
\pm 0.5 \\
\Delta F_{\mathrm{c}}= \pm 0.1 \\
\Delta F_{\mathrm{c}}= \pm 0.1\end{array}$ \\
\hline $\mathrm{CH}_{3}+\mathrm{CH}_{3}+\mathrm{Ar} \rightarrow \mathrm{C}_{2} \mathrm{H}_{6}+\mathrm{Ar}$ & $\begin{array}{l}k_{\infty}=6.0 \times 10^{-11} \\
k_{0}=3.5 \times 10^{-7} T^{-7.0} \exp (-1390 / T) \\
F_{c}=0.38 \exp (-T / 73)+0.62 \exp (-T / 1180)\end{array}$ & $\begin{array}{l}300-2000 \\
300-2000 \\
300-2000\end{array}$ & $\begin{array}{l} \pm 0.3 \\
\pm 0.3 \\
\Delta F_{c}= \pm 0.1\end{array}$ \\
\hline $\mathrm{CH}_{3}+\mathrm{C}_{2} \mathrm{H}_{2}+\mathrm{M} \rightarrow \mathrm{C}_{3} \mathrm{H}_{5}+\mathrm{M}$ & $k_{\infty}=1 \times 10^{-12} \exp (-3900 / T)$ & $300-600$ & \pm 0.5 \\
\hline $\mathrm{CII}_{3}+\mathrm{C}_{2} \mathrm{H}_{4}+\mathrm{M} \rightarrow n-\mathrm{C}_{3} \mathrm{I}_{7}+\mathrm{M}$ & $3.5 \times 10^{-13} \exp (3700 / T)$ & $300-600$ & \pm 0.3 \\
\hline $\mathrm{CH}_{3}+\mathrm{C}_{2} \mathrm{H}_{5}+\mathrm{M} \rightarrow \mathrm{C}_{3} \mathrm{H}_{8}+\mathrm{M}$ & $k_{\infty}=5.6 \times 10^{-11}$ & $300-2000$ & \pm 0.3 \\
\hline $\mathrm{CH}_{3}+\mathrm{C}_{3} \mathrm{H}_{5}+\mathrm{M} \rightarrow \mathrm{C}_{2} \mathrm{H}_{5} \mathrm{CHCH}_{2}+\mathrm{M}$ & $k_{\infty}=1.7 \times 10^{-10} T^{-0.32} \exp (66 / T)$ & $500-1200$ & \pm 0.2 \\
\hline $\mathrm{C}_{2} \mathrm{H}_{5}+\mathrm{C}_{2} \mathrm{H}_{5}+\mathrm{M} \rightarrow n-\mathrm{C}_{4} \mathrm{H}_{10}+\mathrm{M}$ & $k_{\infty}=1.9 \times 10^{-11}$ & $300-1200$ & \pm 0.3 \\
\hline $\mathrm{C}_{2} \mathrm{H}_{5}+\mathrm{C}_{3} \mathrm{H}_{5}+\mathrm{M} \rightarrow \mathrm{CH}_{3} \mathrm{CH}_{2} \mathrm{CH}_{2} \mathrm{CHCH}_{2}+\mathrm{M}$ & $k_{\infty}=3.3 \times 10^{-11} \exp (G \sigma / T)$ & $500-1200$ & \pm 0.3 \\
\hline
\end{tabular}


BAULCH ET AL.

TABLE 3. Combination Reactions - Continued

\begin{tabular}{|c|c|c|c|}
\hline \multirow[t]{2}{*}{ Reaction } & $\begin{array}{l}k_{\mathrm{o}} / \mathrm{cm}^{3} \text { molecule } \mathrm{c}^{-1} \mathrm{~s}^{-1} \\
k_{0} / \mathrm{cm}^{6} \text { molecule } \mathrm{s}^{-1} \\
F_{\mathrm{c}}\end{array}$ & \multirow[t]{2}{*}{$T / \mathrm{K}$} & \multirow[t]{2}{*}{ Error limits $(\Delta \log k)$} \\
\hline & $k / \mathrm{cm}^{3}$ molecule $^{-1} \mathrm{~s}^{-1}=\frac{k_{0} k_{\infty}[\mathrm{M}]}{k_{0}[\mathrm{M}]+k_{\infty}} F$ & & \\
\hline $\mathrm{CH}_{3} \mathrm{CO}+\mathrm{O}_{2}+\mathrm{M} \rightarrow \mathrm{CH}_{3} \mathrm{CO}_{3}+\mathrm{M}$ & $2 \times 10^{-12}$ for $p=1-4$ Torr. & 300 & \pm 0.3 \\
\hline $\mathrm{C}_{3} \mathrm{H}_{5}+\mathrm{C}_{3} \mathrm{H}_{5}+\mathrm{M} \rightarrow$ & $k_{\infty}=1.7 \times 10^{-11} \exp (132 / T)$ & $300-600$ & \pm 0.2 \\
\hline $\mathrm{CH}_{2} \mathrm{CHCH}_{2} \mathrm{CH}_{2} \mathrm{CHCH}_{2}+\mathrm{M}$ & $k_{\infty}=2.0 \times 10^{-11}$ & $600-1000$ & \pm 0.4 \\
\hline $\begin{array}{l}\mathrm{C}_{3} \mathrm{H}_{5}+2-\mathrm{C}_{4} \mathrm{H}_{8}+\mathrm{M} \rightarrow \\
\quad \mathrm{CH}_{2} \mathrm{CHCH}_{2} \mathrm{CH}\left(\mathrm{CH}_{3}\right) \mathrm{CHCH}_{3}+\mathrm{M}\end{array}$ & $k_{\infty}=1.0 \times 10^{-13} \exp (-9620 / T)$ & $600-1200$ & \pm 0.7 \\
\hline $\begin{array}{l}i-\mathrm{C}_{3} \mathrm{H}_{7}+\mathrm{i}-\mathrm{C}_{3} \mathrm{H}_{7}+\mathrm{M} \rightarrow \\
\quad\left(\mathrm{CH}_{3}\right)_{2} \mathrm{CHCH}_{2} \mathrm{CH}_{2}+\mathrm{M}\end{array}$ & $\begin{array}{l}k_{\infty}=6.8 \times 10^{-12} \\
\text { to } \pm 0.3 \text { at } 1000 \mathrm{~K}\end{array}$ & $300-1000$ & $\begin{array}{l} \pm 0.1 \text { at } 300 \mathrm{~K} \text { rising } \\
\text { to } \pm 0.3 \text { at } 1000 \mathrm{~K}\end{array}$ \\
\hline$t-\mathrm{C}_{4} \mathrm{H}_{9}+t-\mathrm{C}_{4} \mathrm{H}_{9}+\mathrm{M} \rightarrow \mathrm{C}_{8} \mathrm{H}_{18}$ & $k_{\infty}=5.2 \times 10^{-8} T^{-1.73}$ & $300-1000$ & $\begin{array}{l} \pm 0.15 \text { at } 300 \mathrm{~K} \text { rising } \\
\text { to } \pm 0.3 \text { at } 1000 \mathrm{~K}\end{array}$ \\
\hline
\end{tabular}




\section{Data Sheets}

$$
\mathrm{O}+\mathrm{NO} \rightarrow \mathrm{O}_{2}+\mathrm{N}
$$

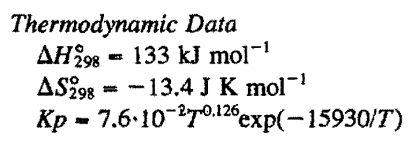

Rate Coefficient Data

\begin{tabular}{|c|c|c|c|}
\hline$k / \mathrm{cm}^{3}$ molecule $\mathrm{e}^{-1} \mathrm{~s}^{-1}$ & $T / \mathrm{K}$ & Reference & Comments \\
\hline \multicolumn{4}{|l|}{ Rate Coefficient Measurements } \\
\hline $6.03 \cdot 10^{-12} \exp (-19900 / T)$ & $1575-1665$ & Kaufman and Decker, $1959^{\prime}$ & (a) \\
\hline $6.0 \cdot 10^{-13}$ & 5000 & Wray and Teare, $1962^{2}$ & (b) \\
\hline $1.48 \cdot 10^{-14}$ & 3000 & Clark et al., $1969^{3}$ & (c) \\
\hline $3.89 \cdot 10^{-15} T \exp (-19450 / T)$ & $2500-4100$ & Hanson et al, $1974^{4}$ & (d) \\
\hline $2.89 \cdot 10^{-15} T \exp (-19450 / T)$ & $1750-2100$ & McCullough, $1977^{5}$ & (e) \\
\hline \multicolumn{4}{|l|}{ Reviews and Evaluations } \\
\hline $2.5 \cdot 10^{-15} T \exp (-19450 / T)$ & $1000-3000$ & Baulch et al., $1973^{6}$ & (f) \\
\hline $6.3 \cdot 10^{-15} T \exp (-20850 / T)$ & $1500-5000$ & Hanson and Salimian, $1984^{7}$ & (g) \\
\hline $1.4 \cdot 10^{-15} T^{\mathrm{i} .} \exp (-19250)$ & $1000-5000$ & Cohen, $1991^{8}$ & (g) \\
\hline
\end{tabular}

\section{Comments}

(a) Static reactor study using $\left[\mathrm{O}_{2}\right] /[\mathrm{NO}]$ mixtures in ratios from 0 to 40 . Reaction progress monitored by UV absorption spectrometry of unreacted NO. Equilibrium of $\mathrm{O}$ atoms with $\mathrm{O}_{2}$ was assumed.

(b) Shock tube study of $\mathrm{NO} / \mathrm{O}_{2} / \mathrm{Ar}$ mixtures, with monitoring of NO bchind the shock by absorption at $127 \mathrm{~nm}$. Data fitting was performed with a detailed kinetic mechanism, however, only data acquired in $\mathrm{NO} / \mathrm{O}_{2} / \mathrm{Ar}=0.5 \% / 0.25 \% /$ $99.25 \%$ mixtures near $5000 \mathrm{~K}$ were sufficiently insensitive to other rate constants to derive $k$.

(c) Reflected shock study of $\mathrm{N}_{2} \mathrm{O}$ decomposition using mass spectrometric detection of $\mathrm{NO}, \mathrm{O}_{2}$ and $\mathrm{O} . k$ derived from small changes in measured $\mathrm{NO}$ concentration.

(d) Shock tube study of $\mathrm{N}_{2} \mathrm{O} / \mathrm{Ar}$ or $\mathrm{N}_{2} \mathrm{O} / \mathrm{Kr}$ mixtures with [NO] decays monitored at $5.3 \mu \mathrm{m}$. Rate constant derived by fitting obscrved [NO] decay to a dctailed kinetic model.

(e) Flow tube study with NO/Ar mixtures, decomposition of NO as a function of flow rate monitored by chemiluminescence. Detailed modelling of kinetics and flow used to derive $k$.

(f) Based primarily on data for reverse reaction.

(g) Based on data from Refs. 1-5.

\section{Preferred Values}

$k=1.14 \cdot 10^{-15} T^{\mathrm{l} .13} \exp (-19200 / T) \mathrm{cm}^{3}$ molecule ${ }^{-1} \mathrm{~s}^{-1}$ over range $1000-5000 \mathrm{~K}$.

\section{Reliability}

$\Delta \log k= \pm 0.3$

\section{Comments on Preferred Values}

The experimental data available for this reaction are confined to temperatures above $1500 \mathrm{~K}$. All of the studies are in good agreement. The data have been most recently reviewed by Ilanson and Salimian ${ }^{7}$ and by Cohen ${ }^{8}$ who derive very similar expressions for $k$. We accept their analysis and recommend an expression for $k$ very similar to Cohen's.

\section{References}

${ }^{1}$ F. Kaufman and L.J. Decker. 7th Symp. (Int.) Combust.. 57 (1959).

${ }^{2}$ K.L. Wray and J.D. Teare, J. Chem. Phys. 36, 2582 (1962).

${ }^{3}$ T.C. Clark, S.H. Garnett, and K.B. Kistiakowsky, J. Chem. Phys. 51, 2885 (1969).

${ }^{4}$ R.K. Hanson. W.L. Flower, and C.H. Kruger. Combust. Sci. Technol. 9. 79 (1974).

${ }^{5}$ R.W. McCullough, C.H. Kruger, and R.K. Hanson, Combust. Sci. Technol. 15, 213 (1977).

${ }^{6}$ D.I. Raulch, D.D. Drysdale, and D.F. Home, Fvalıated Kinetic Data for High Temperature Reaction, Vol. 3, Butterworths, London.

'R.K. Hanson and S. Salimian in "Combustion Chemistry", Ed. W.C. Gardiner, Springer-Verlag (1984).

${ }^{8} \mathrm{~N}$ Cohen, The Aerospace Corporation, Aerospace Report No. ATR90(8512)-1, El Segundo, California (1991). 
BAULCH ET AL.

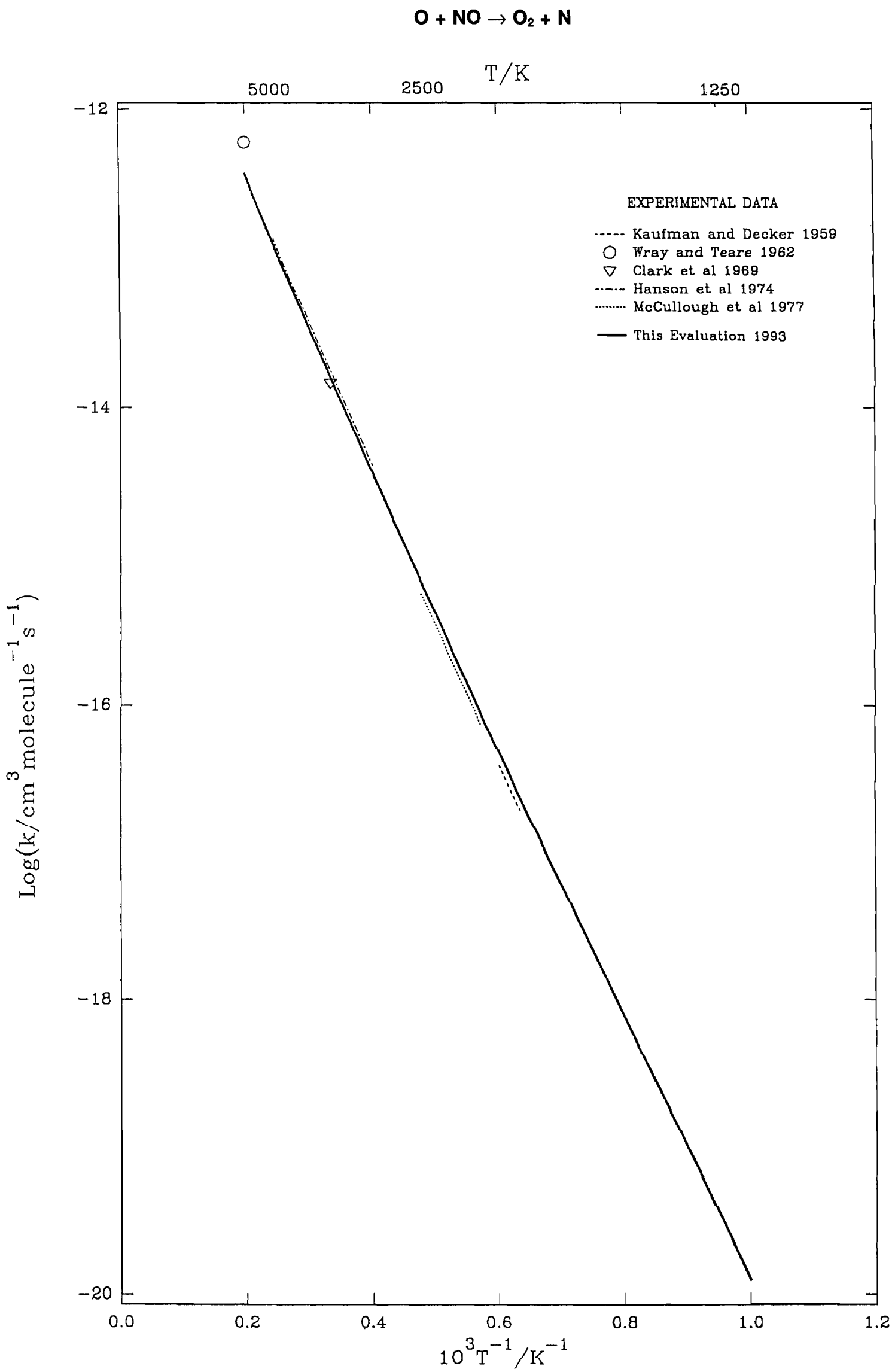




$$
\mathrm{O}+\mathrm{N}_{\mathbf{2}} \rightarrow \mathrm{N}+\mathrm{NO}
$$

Thermodynamic Data

$\Delta H_{298}^{\circ}=313.5 \mathrm{~kJ} \mathrm{~mol}^{-1}$

$\Delta S_{298}^{\circ}=11.3 \mathrm{~J} \mathrm{~K}^{-1} \mathrm{~mol}^{-1}$

$K p=1.98 T^{0.097} \exp (-37690 / T)$

Rate Coefficient Data

\begin{tabular}{|c|c|c|c|}
\hline$k / \mathrm{cm}^{3}$ molecule $\mathrm{e}^{-1} \mathrm{~s}^{-1}$ & $T / \mathrm{K}$ & Reference & Comments \\
\hline \multicolumn{4}{|l|}{ Rate Coefficient Measurements } \\
\hline $1.1 \cdot 10^{-10} \exp (-38000 / T)$ & $2000-3000$ & Duff and Davidson, $1959^{1}$ & (a) \\
\hline $2.82 \cdot 10^{-16}$ & 2880 & Livesey, Roberts, and Williams, $1971^{2}$ & (b) \\
\hline $8.3 \cdot 10^{-11} \exp (-37900 / T)$ & $1900-2250$ & Bachmaier, Eberius, and Just, $1973^{3}$ & (c) \\
\hline $2.2 \cdot 10^{-10} \exp (-37900 / T)$ & $1900-2400$ & Iverach, Basden, and Kirov, $1973^{4}$ & (d) \\
\hline $3.0 \cdot 10^{-10} \exp (-38000 / T)$ & $2120-2480$ & Hanis, Nasralla, and Williams, $1976^{5}$ & (c) \\
\hline $1.25 \cdot 10^{-10} \exp (-38200 / T)$ & $1880-2350$ & Blauwens, Smets, and Peeters, $1977^{6}$ & (f) \\
\hline $3.06 \cdot 10^{-10} \exp (-38370 / T)$ & $2380-3850$ & Monat, Hanson, and Kruger, $1979^{7}$ & (g) \\
\hline $2.95 \cdot 10^{-10} \exp (-38370 / T)$ & $2120-2230$ & Seery and Zabielski, $1980^{8}$ & (h) \\
\hline $3.0 \cdot 10^{-10} \exp (-38300 / T)$ & $2400-4100$ & Thielen and Roth, $1984^{\circ}$ & (i) \\
\hline \multicolumn{4}{|l|}{ Reviews and Evaluations } \\
\hline $1.3 \cdot 10^{-10} \exp (-38000 / T)$ & $2000-5000$ & Baulch, Drysdale, and Horne, $1973^{10}$ & (j) \\
\hline $3.0 \cdot 10^{-10} \exp (-38370 / T)$ & $2000-4000$ & Hansun and Salinian, 1984" & (k) \\
\hline $4.3 \cdot 10^{-13} T^{0.8} \exp (-37370 / T)$ & $1500-4100$ & Cohen, $1991^{12}$ & (1) \\
\hline
\end{tabular}

\section{Comments}

(a) Determined by detailed analysis of the results from the single-pulse shock tube study of Glick et al.$^{13}$ in which NO was measured behind a shock wave through mixtures of air in an inert diluent.

(b) NO concentration profile measured by probe sampling and chemical analysis in the burned gas of an atmospheric pressure premixed propane-oxygen flame to which $\mathrm{N}_{2}$ had been added. $O$ atoms were assumed to be in equilibrium with $\mathrm{OH}$ which was measured by line absorption spectroscopy. Single value of $k$ at the mean flame temperature was obtained by fitting to a simple mechanism and an $A$-factor calculated assuming an activation energy of $315 \mathrm{~kJ} \mathrm{~mol}^{-1}$. However, [O] was overestimated by a factor of 2 owing to use of a low value for the $\mathrm{OH}$ oscillator strength leading to a factor of 2 underestimate in $k$. The corrected value reported here is based on the oscillator strength $f(0,0)=1.10 \cdot 10^{-3}$ reported by Smith and Crosley ${ }^{14}$.

(c) NO concentration profiles in atmospheric pressure premixed hydrocarbon-air flames measured by probe sampling and UV absorption spectroscopy. The expression for $k$ obtained by fitting the rate of formation of NO in fuel-lean flames to the simple Zeldovich mechanism, assuming equilibrium concentrations of $\mathrm{O}$ atoms.

(d) NO concentration profiles in flat, premixed lean or slightly fuel-rich hydrocarbon-air flames measured by probe sampling and IR analysis. [O] calculated assuming equilibrium of $\mathrm{O}$ with $\mathrm{O}_{2}, \mathrm{CO}$ and $\mathrm{CO}_{2}$ which were also measured. Expression for $k$ derived by fitting rate of NO formation to an extended Zeldovich mechanism.

(e) NO concentration profiles in the burned gas region of fuel-lean, premixed $\mathrm{CH}_{4}-\mathrm{O}_{2}-\mathrm{N}_{2}$ flames measured by probe sampling and chemiluminescent detection. $O$ atoms assumed to be in equilibrium with $\mathrm{OH}$ which was measured by line absorption spectroscopy. Assuming the activation energy recommended by Baulch $e t$ al.$^{10}$, the $A$-factor was adjusted to give the best fit of the data to an extended Zeldovich mechanism. However, as in reference (2), $k$ was underestimated by a factor of 2 owing to use of a low value of the $\mathrm{OH}$ oscillator strength (see comment(b)). The reported expression for $k$ was corrected to the value shown here using the oscillator strength given by Smith and Crosley ${ }^{14}$.

(f) NO and $\mathrm{O}$ concentration profiles measured in post-flame region of low-pressure hydrocarbon- $\mathrm{O}_{2}-\mathrm{N}_{2}$ flames using molecular beam sampling mass spectrometry. Temperatures were inferred from partial equilibrium considerations and species concentration measurements. Rate coefficients obtained by fitting to the Zeldovich mechanism and found to agree to within $\pm 20 \%$ of the expression previously recommended by Baulch $e t a l .^{10}$, which was the expression reported.

(g) Shock tube study. $\mathrm{O}$ atoms generated by pyrolysis of $\mathrm{N}_{2} \mathrm{O}$ in $\mathrm{N}_{2} / \mathrm{O}_{2} / \mathrm{Kr}$ mixtures optimised to maximise the sensitivity of the results to $k$. [NO] measured behind the incident shock wave by IR emission at $5.3 \mu \mathrm{m}$ and absorption of $\mathrm{CO}$ laser radiation at $5.17 \mu \mathrm{m}$. Results fitted to a 9-step kinetic mechanism to derive $k$. Uncertainty estimated to be $\pm 35 \%$ over the temperature range.

(h) NO and $\mathrm{N}_{2}$ concentration profiles measured in post-flame region of low pressure $\mathrm{CH}_{4}$-air flames using molecular beam sampling mass spectrometry and microprobe sampling with chemiluminescence analysis. $[\mathrm{OH}]$ profiles measured by resonance absorption and partial equilibrium assumptions used to infer [O]. Expression for $k$ derived by fitting to Zeldovich mechanism. 
(i) Shock tube study. $\mathrm{O}$ atoms generated by pyrolysis of $\mathrm{N}_{2} \mathrm{O}$ in $\mathrm{N}_{2} / \mathrm{N}_{2} \mathrm{O} / \mathrm{Ar}$ mixtures. [O] and [N] measured by atomic resonance absorption spectroscopy as a function of time behind reflected shock wave to give $k$ directly. Uncertainty in $k$ estimated to be $\pm 40 \%$.

(j) Review of pre-1973 studies. Value derived from low temperature data for reverse reaction obtained by Clyne and Thrush ${ }^{15,16}$ was revised downward by a factor of $\sim 2$ to accommodate results from the early shock tube studies of the forward reaction. Estimated uncertainty is $\Delta \log$ $k= \pm 0.3$.

(k) Comprehensive review of all previous direct and indirect determinations of $k$ to 1980 . Recommends rate expression determined by Monat et al. ${ }^{7}$ Uncertainty estimated to be $\pm 35 \%$.

(l) Review of studies of the reaction in the forward and reverse direction since 1973 . The recommended threeparameter Arrhenius expression for $k$ is a fit to the experimental data of Monat et al..$^{7}$ and Thielen and Roth ${ }^{9}$ for the forward reaction and the data of Davidson and Hanson $^{17}$ for the reverse reaction. Estimated uncertainty is $\Delta \log k= \pm 0.3$.

\section{Preferred Value}

$k=3.0 \cdot 10^{-10} \exp (-38300 / T) \mathrm{cm}^{3}$ molecule $\mathrm{e}^{-1} \mathrm{~s}^{-1}$ over the range $1400-4000 \mathrm{~K}$.

\section{Reliability \\ $\Delta \log k= \pm 0.2$ over the range $1400-4000 \mathrm{~K}$.}

\section{Comments on Preferred Values}

There is complete agreement among all the studies in the value of the activation energy of the reaction, and with the exception of the result of Blauwens et al. ${ }^{6}$, there is good agreement among the measurements of the $A$-factor made since 1973. The most direct determinations of $k$ are considered to be those of Monat et al. ${ }^{7}$ and Thielen and Roth ${ }^{9}$ which are in excellent agreement and are the basis of the present recommendation. There have been two recent shock tube measurements of $k$ for the reverse reaction at temperatures overlapping the range covered by Monat et al. ${ }^{7}$ and Thielen and Roth ${ }^{9}$. The temperature dependent results of Davidson and Hanson ${ }^{17}$ are entirely consistent with the equilibrium constant and the preferred rate for the forward reaction, but the temperature independent data for $k(\mathrm{~N}+\mathrm{NO})$ of Koshi et al. ${ }^{18}$ are not.

\section{References}

${ }^{1}$ R.E. Duff and N. Davidson, J. Chem. Phys. 31, 1018 (1959).

${ }^{2}$ J.B. Livesey, A.L. Roberts, and A. Williams, Comb. Sci. Technol. 4, 9 (1971).

${ }^{3}$ F. Bachmaier, K.H. Eberius, and Th. Just, Comb. Sci. Tech. 7, 77 (1973).

${ }^{4}$ D. Iverach, K.S. Basden, and N.Y. Kirov, 14th Symp. (Int.) Comb., 767 (1973).

${ }^{5}$ R.J. Harris, M. Nasralla, and A. Williams, Comb. Sci. Tech. 14, 85 (1976)

${ }^{6}$ J. Blauwens, B. Smets, and J. Peeters, 16th Symp. (Int.) Comb., 1055 (1977).

7J.P. Monat, R.K. Hanson, and C.H. Kruger, 17th Symp. (Int.) Comb., 543 (1979).

${ }^{8}$ D.J. Seery and M.F. Zabielski, "Laser Probes for Combustion Chemistry", American Chemical Society, Washington DC, p375 (1980).

${ }^{9} \mathrm{~K}$. Thielen and P. Roth, 20th Symp. (Int.) Comb., 685 (1984).

${ }^{10}$ D.L. Baulch, D.D. Drysdale, and D.G. Horne, "Evaluated Kinetic Data for High Temperature Reactions", Vol. 2, Butterworths, London (1973).

${ }^{11}$ R.K. Hanson and S. Salimian, in "Combustion Chemistry", p361, ed. W.C. Gardiner, Springer-Verlag (1984).

${ }^{12} \mathrm{~N}$. Cohen, The Aerospace Corporation, Aerospace Report No. ATR90(8512)-1, E1 Segundo, California (1991).

${ }^{13}$ H.S. Glick, J.J. Klein, and W. Squire, J. Chem. Phys., 27, 850 (1957).

${ }^{14}$ G.P. Smith and D.R. Crosley, 18th Symp. (Int.) Comb., 1511 (1981).

${ }^{15}$ M.A.A. Clyne and B.A. Thrush, Proc. Royal Soc. A, 261, 259 (1961).

${ }^{16}$ M.A.A. Clyne and B.A. Thrush, Nature, 189, 56 (1961).

${ }^{17}$ D.F. Davidson and R.K. Hanson, Int. J. Chem. Kin. 22, 843 (1990).

${ }^{18}$ M.Koshi, M. Yoshimura, F. Fukuda, H. Matsui, K. Saito, M. Watanabe, A. Imamura, and C. Chen, J. Chem. Phys. 93, 8703 (1990). 


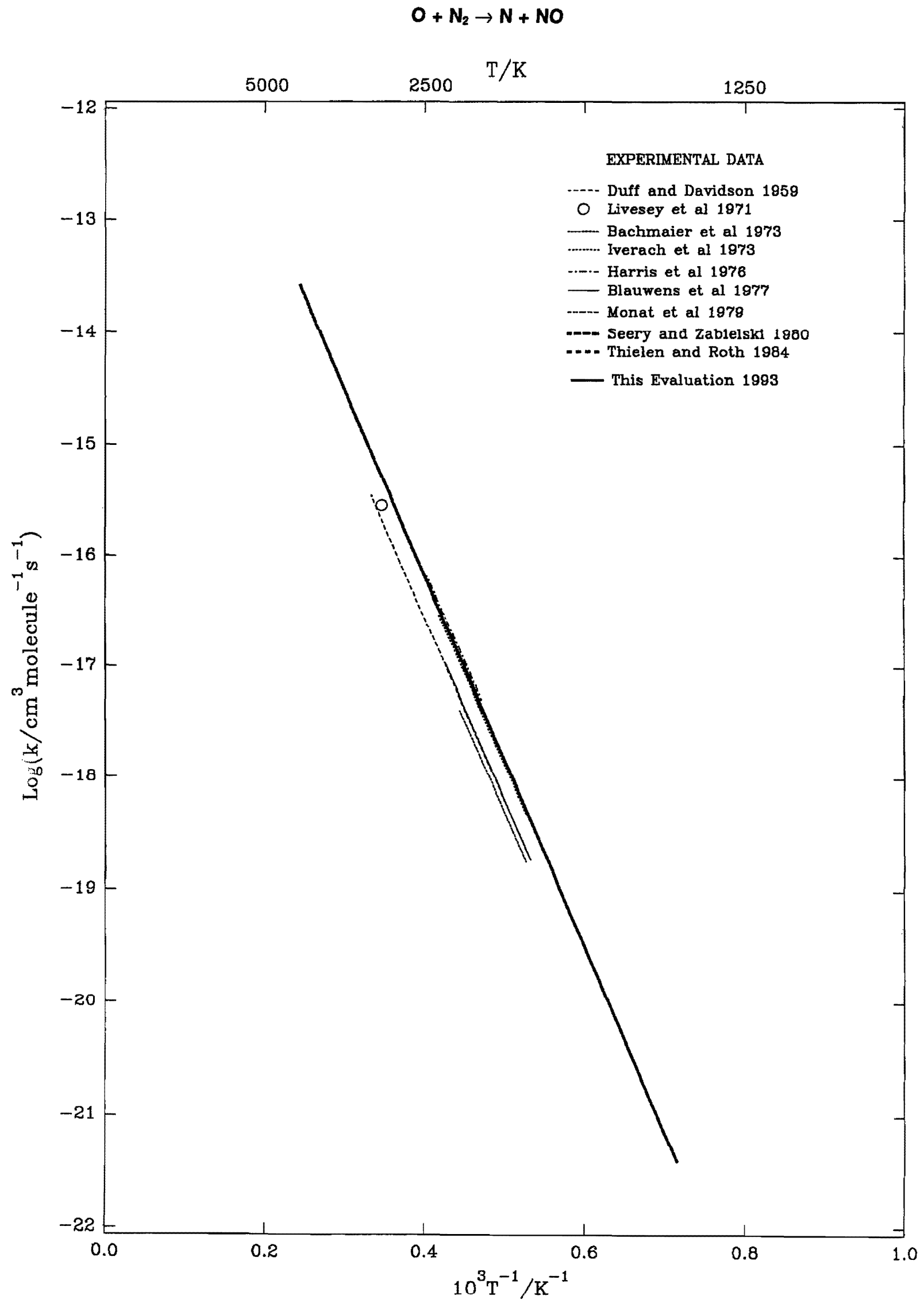


Thermodynamic Data

$\Delta I_{298}^{\circ}(1)=297.3 \mathrm{~kJ} \mathrm{~mol}^{-1}$

$\Delta S_{298}^{\circ}(1)=-16.8 \mathrm{~J} \mathrm{~K}^{-1} \mathrm{~mol}^{-1}$

$\Delta I I_{298}^{\circ}(2)=94.2 \mathrm{~kJ} \mathrm{~mol}^{-1}$

$K p(1)=3.6 \cdot 10^{-10} T^{2.23} \exp (+38460 / T)$

$\Delta S_{298}^{\circ}(2)=-5.3 \mathrm{~J} \mathrm{~K}^{-1} \mathrm{~mol}^{-1}$

$K p(2)=1.5 \cdot 10^{-2} T^{0.40} \exp (+12140 / T)$

Rate Coefficient Data $\left(k=k_{1}+k_{2}\right)$

\begin{tabular}{lll}
\hline$k / \mathrm{cm}^{3}$ molecule & & Reference \\
\hline $\begin{array}{l}\text { Rate Coefficient Measurements } \\
1.5 \cdot 10^{-10}\end{array}$ & $2730-3380$ & Mertens et al, $1991^{1}$ \\
\hline
\end{tabular}

\section{Comments}

(a) Shock tube study of $\mathrm{HNCO} / \mathrm{N}_{2} \mathrm{O} / \mathrm{Ar}$ mixtures with $\mathrm{NH}\left(\mathrm{X}^{3} \mathrm{\Sigma}\right)$ monitored at $336 \mathrm{~nm}$ by laser absorption. [NH] profiles fitted to reaction mechanism. [NH] shown to be sensitive to $k$ and insensitive to value of the branching ratio.

\section{Preferred Values}

$k=1.5 \cdot 10^{-10} \mathrm{~cm}^{3}$ molecule ${ }^{-1} \mathrm{~s}^{-1}$ over the range $1000-3380 \mathrm{~K}$.

\section{Reliability}

$\Delta \log k= \pm 0.5$ over the range $1000-3380 \mathrm{~K}$.

\section{Comments on Preferred Values}

The only study of this reaction at elevated temperatures, by Mertens et al.$^{1}$, gives a temperature independent rate constant of $1.5 \cdot 10^{-10} \mathrm{~cm}^{3}$ molecule $\mathrm{cm}^{-1}$ over the range $2730-3380 \mathrm{~K}$. Another study, by Temps ${ }^{2}$, is reported in Ref. 1 to give a value of $8.3 \cdot 10^{-10} \mathrm{~cm}^{3}$ molecule ${ }^{-1} \mathrm{~s}^{-1}$ at $298 \mathrm{~K}$ which would require an activation energy of approximately -8 $\mathrm{kJ} \mathrm{mol}^{-1}$ for the two studies to be compatible. A temperature coefficient of $k$ of this magnitude could possibly be accommodated by a combination of the error limits of the measurements and/or changes in the mechanism with temperature. However, we limit our recommendation to the value of Mertens et al. ${ }^{1}$ extending their temperature range but increasing the error limits to take into account the possibility of a small temperature coefficient for $k$.

There are no experimental studies of the branching ratios. A theoretical study of Melius and Binkley ${ }^{3}$ suggests that both channels are likely to be of comparable importance.

\section{References}

1J.D. Mertens, A.Y. Chang, R.K. Hanson, and C.T Bowman, Int I Chem. Kinet. 23, 173 (1991).

${ }^{2}$ F. Temps, Ber.-Max-Planck-Inst. Stromungsforsch. 4, 140 (1983).

${ }^{3}$ C.F. Melius and J.S. Binkley, in "The Chemistry of Combustion Processes", T.M. Sloane, Ed., A.C.S. Symp. Series 249, 103 (1984).

$$
\begin{aligned}
\mathrm{O}+\mathrm{CH}_{3} \mathrm{OOH} & \rightarrow \mathrm{OH}+\mathrm{CH}_{3} \mathrm{OO} \\
& \rightarrow \mathrm{OH}+\mathrm{CH}_{2} \mathrm{OOH}
\end{aligned}
$$

Rate Coefficient Data $\left(k=k_{1}+k_{2}\right)$

\begin{tabular}{lcc}
\hline$k / \mathrm{cm}^{3}$ molecule $\mathrm{s}^{-1}$ & Reference & Comments \\
\hline $\begin{array}{l}\text { Rate Coefficient Measurements } \\
1.06 \cdot 10^{-14}\end{array}$ & 297 & Vaghjiani and Ravishankara, 1990' \\
$\begin{array}{l}\text { Reviews and Evaluations } \\
6.9 \cdot 10^{-13} T^{0.57} \exp (-1390 / T)\end{array}$ & $300-1000$ & CEC, $1992^{2}$
\end{tabular}




\section{Comments}

(a) Pulsed photolysis-resonance fluorescence technique. $\mathrm{O}\left({ }^{3} \mathrm{P}\right)$ generated by $\mathrm{O}_{3}$ photolysis at $532 \mathrm{~nm}$ in the presence of excess $\mathrm{CH}_{3} \mathrm{OOH}$.

(b) Based on analogy with $\mathrm{O}+\mathrm{HCHO}$ reaction.

\section{Preferred Value}

$k=3.3 \cdot 10^{-11} \exp (-2390 / T) \mathrm{cm}^{3}$ molecule ${ }^{-1} \mathrm{~s}^{-1}$ over the range $300-1000 \mathrm{~K}$.

\section{Reliability}

$\Delta \log k= \pm 0.5$ at $1000 \mathrm{~K}$ reducing to \pm 0.3 at $300 \mathrm{~K}$.

\section{Comments on Preferred Values}

The room temperature data of Vaghjiani and Ravishankara ${ }^{\mathrm{t}}$ are the only reported experimental values of the rate constant for the reaction of $\mathrm{O}\left({ }^{3} \mathrm{P}\right)$ with $\mathrm{CH}_{3} \mathrm{OOH}$. The preferred temperature dependence is obtained assuming an $A$-factor for the reaction of $\mathrm{O}$ with $\mathrm{CH}_{3} \mathrm{OOH}$ equal to that for $\mathrm{O}+\mathrm{CH}_{3} \mathrm{OH}$, given in the evaluation of Herron ${ }^{3}$. Comparison with the rate constant for the reaction: $\mathrm{O}+\mathrm{H}_{2} \mathrm{O}_{2}=\mathrm{OH}+\mathrm{HO}_{2}\left(1.7 \cdot 10^{-15}\right.$ $\mathrm{cm}^{3}$ molecule ${ }^{-1} \mathrm{~s}^{-1}$ at $298 \mathrm{~K}$ ) indicates that abstraction of the peroxidic $\mathrm{H}$ is slower suggesting that channel (2) is dominant.

\section{References}

'G.L. Vaghjiani and A.R. Ravishankara, Int. J. Chem. Kinet. 22, 351 (1990). ${ }^{2} \mathrm{CEC}, 1992$ (see references in Introduction).

${ }^{3}$ J.T. Herron, J. Phys. Chem. Ref. Data, 17, 967 (1988).

$$
\begin{aligned}
\mathrm{O}+\mathrm{C}_{2} \mathrm{H}_{2} & \rightarrow \mathrm{CO}+{ }^{3} \mathrm{CH}_{2} \\
& \rightarrow \mathrm{C}_{2} \mathrm{HO}+\mathrm{H}
\end{aligned}
$$

Thermodynamic Data
$\Delta H_{298}^{\circ}(1)=-200 \mathrm{~kJ} \mathrm{~mol}^{-1}$
$\Delta S_{298}^{\circ}(1)=31.2 \mathrm{~J} \mathrm{~K}^{-1} \mathrm{~mol}^{-1}$
$K p(1)=7.31 \cdot 10^{5} \mathrm{~T}^{-1.40} \exp (+23500 / T)$

$$
\begin{aligned}
& \Delta H_{298}^{\circ}(2)=-80.4 \mathrm{~kJ} \mathrm{~mol}^{-1} \\
& \Delta S_{298}^{\circ}(2)=6.9 \mathrm{~J} \mathrm{~K}^{-1} \mathrm{~mol}^{-1} \\
& K p(2)=1,17 T^{0.15} \exp (+9600 / T)
\end{aligned}
$$

\begin{tabular}{|c|c|c|c|}
\hline$k / \mathrm{cm}^{3}$ molecule ${ }^{-1} \mathrm{~s}^{-1}$ & $T / \mathrm{K}$ & Reference & Comments \\
\hline \multicolumn{4}{|l|}{ Rate Coefficient Measurements } \\
\hline$k_{2} / k=0.5$ & 1000 & Homann and Wellman. $1983^{1}$ & (a) \\
\hline$k_{2} / k=0.6$ & $290-540$ & Peeters, Schaeker, and Vinckier, $1986^{2}$ & (b) \\
\hline$k_{2} / k=0.8$ & 287 & Peeters et al., $1987^{3}$ & (c) \\
\hline $1.1 \cdot 10^{-19} T^{2.6} \exp (-330 / T)$ & $290-1510$ & Mahmud and Fontijn, $1987^{4}$ & (d) \\
\hline $6.6 \cdot 10^{-11} \exp (-1900 / T)$ & $370-876$ & Russell et al., $1988^{5}$ & (e) \\
\hline $1.78 \cdot 10^{-10} \exp (-2714 / T)$ & $850-1950$ & Michael and Wagner, $1990^{\circ}$ & (f) \\
\hline \multicolumn{4}{|l|}{$k_{2} / k=0.80$} \\
\hline $2.3 \cdot 10^{-11} \exp (-1527 / T)$ & $200-284$ & Bohn and Stuhl, $1990^{7}$ & (g) \\
\hline \multicolumn{4}{|l|}{ Reviews and Evaluations } \\
\hline $3.6 \cdot 10^{-20} T^{2.8} \exp (-250 / T)$ & $300-2500$ & CEC, $1992^{8}$ & (h) \\
\hline
\end{tabular}

Rate Coefficient Data $\left(k=k_{1}+k_{2}\right)$

\section{Comments}

(a) Discharge flow $\left(\mathrm{O} / \mathrm{C}_{2} \mathrm{H}_{2} / \mathrm{He}\right)$, nozzle beam sampling with mass spectrometric detection.

(b) Flow reactor, $\mathrm{O}$ generated by discharge through $\mathrm{O}_{2}$, molecular beam sampling with mass spectrometric detection.

(c) Flow reactor, $\mathrm{O}$ and $\mathrm{H}$ generated by discharge. $k_{2} / k$ determined from the dependence of the $\mathrm{CH}_{2}$ signal on [H]/[O], based on secondary generation of $\mathrm{CH}_{2}$ via $\mathrm{H}+\mathrm{HCCO}$.

(d) Flash photolysis, resonance fluorescence. $\mathrm{O}$ generated from photolysis of $\mathrm{O}_{2}$ or $\mathrm{CO}_{2}$. (e) Laser flash photolysis, photoionization mass spectrometry. O generated from photolysis of $\mathrm{SO}_{2}, \mathrm{C}_{2} \mathrm{H}_{2}$ from photolysis of $\mathrm{C}_{2} \mathrm{H}_{3} \mathrm{Br}$.

(f) Flash photolysis, shock tube study. $\mathrm{O}$ atoms generated from photolysis of $\mathrm{NO}$ and detected by resonance absorption. Branching ratio from $\mathrm{H}$ yield of $\mathrm{O}+\mathrm{C}_{2} \mathrm{H}_{2}$ vs $\mathrm{H}$ yield from $\mathrm{O}+\mathrm{H}_{2}$. An analysis of the available kinetic data gave $k=1.2 \cdot 10^{-17} T^{2.09} \exp (-786 / T) \mathrm{cm}^{3}$ molecule ${ }^{-1} \mathrm{~s}^{-1}$ over the temperature range $195-2500 \mathrm{~K}$.

(g) $\mathrm{O}$ atoms generated by $\mathrm{H}_{2}$ laser photolysis $(160 \mathrm{~nm})$ of $\mathrm{NO}$ and detected by the $\mathrm{O}+\mathrm{NO}$ chemiluminescence.

(h) Review of all studies up to 1989. 


\section{Preferred Values}

$k=1.2 \cdot 10^{-17} T^{2.1} \exp (-786 / T) \mathrm{cm}^{3}$ molecule $^{-1} \mathrm{~s}^{-1}$ over range $195-2500 \mathrm{~K}$.

$k_{2} / k=0.7$ over range $300-2500 \mathrm{~K}$.

Reliability

$\Delta \log k= \pm 0.2$

$\Delta\left(k_{2} / k\right)= \pm 0.2$

\section{Comments on Preferred Values}

The recent shock tube measurements of Michael and Wagner $^{6}$ are in excellent agreement with the data of Russell et al.$^{5}$, in the region in which they overlap and their recommendation, which incorporates earlier measurements, has been adopted. It appears that the measurements of Mahmud and Fontijn ${ }^{4}$ are in error, especially in the middle temperature range.
Michael and Wagner's ${ }^{6}$ determination of $k_{2} / k$ is the most direct because the $\mathrm{H}$ yield was calibrated directly against that for $\mathrm{O}+\mathrm{H}_{2}$ but to obtain our recommended value, for a wide temperature range, their value has been combined with the lower temperature data of Peeters et al.$^{2,3}$ and Homann and Wellman'.

\section{References}

${ }^{1}$ K.H. Homann and Ch. Wellman, Ber. Bunsenges. Phys. Chem. 87, 609 (1983).

${ }^{2}$ J. Peeters, M. Schaeker, and C. Vinckier, J. Phys. Chem. 90, 6552 (1986),

${ }^{3}$ J. Peeters, W. Boullart, P. van de Ven, and C. Vinckier, Joint Meeting, French/Italian Secs., Comb. Inst. (1987).

${ }^{4} \mathrm{~K}$. Mahmud and A. Fontijn, J. Phys. Chem. 91, 1918 (1987).

5J.J. Russell, S.M. Senkan, J.A. Seetula, and D. Gutman, 22nd Symp. (Int.) Combust., 1007 (1988).

${ }^{6} J . V$. Michael and A.F. Wagner, J. Phys. Chem. 94, 2453 (1990).

${ }^{7}$ B. Bohn and F. Stuhl, J. Phys. Chem. 94, 8010 (1990).

${ }^{8} \mathrm{CEC}, 1992$ (see references in Introduction). 


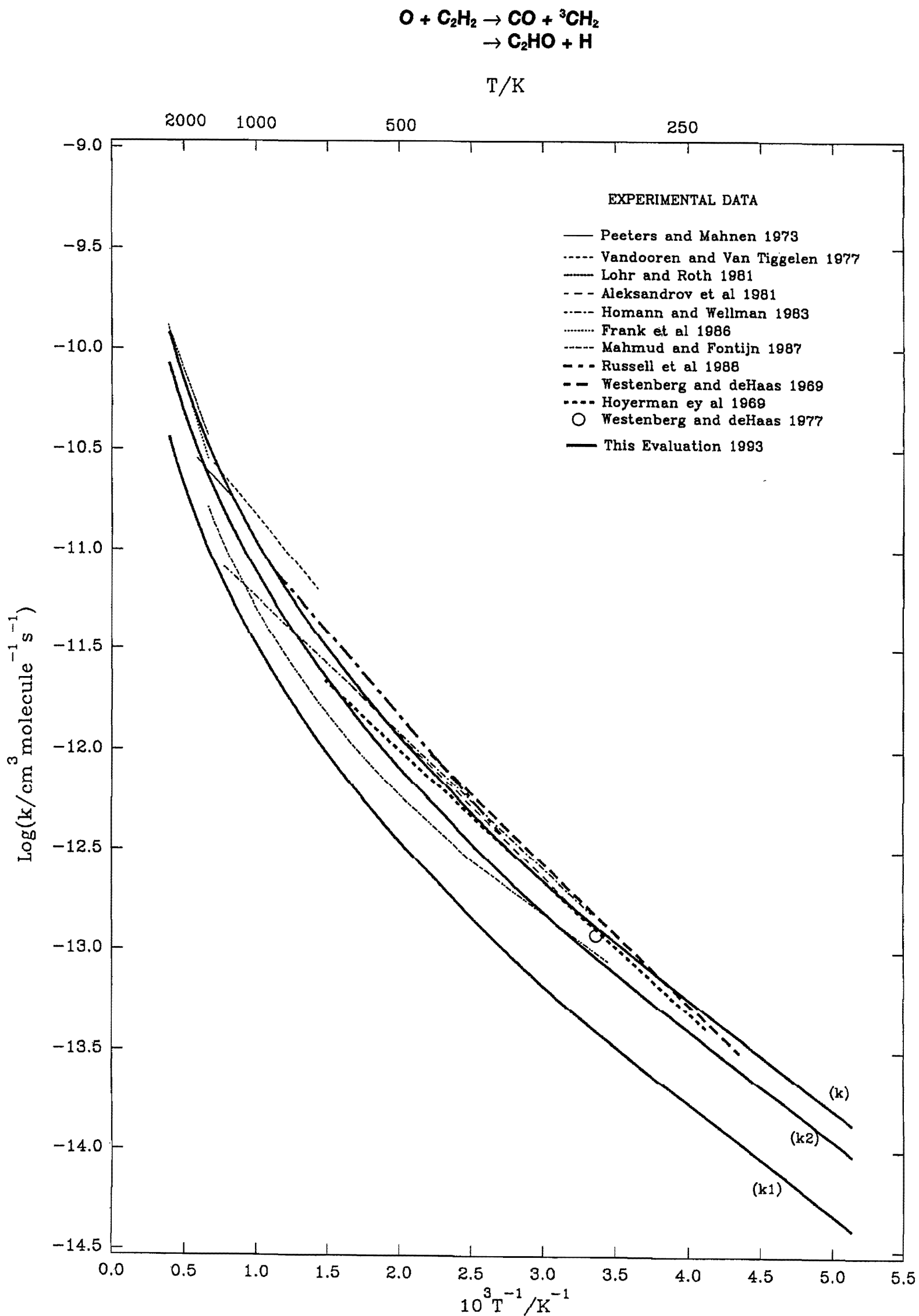




$$
\begin{aligned}
\mathrm{O}+\mathrm{C}_{2} \mathrm{H}_{4} & \rightarrow \mathrm{CH}_{2} \mathrm{CHO}+\mathrm{H} \\
& \rightarrow \mathrm{HCO}+\mathrm{CH}_{3} \\
& \rightarrow \mathrm{HCHO}+\mathrm{CH}_{2} \\
& \rightarrow \mathrm{CH}_{2} \mathrm{CO}+\mathrm{H}_{2}
\end{aligned}
$$

Thermodynamic data

$\Delta H_{298}^{\circ}(1)=-58.5 \mathrm{~kJ} \mathrm{~mol}^{-1}$

$\Delta S_{298}^{\circ}(1)=2.3 \mathrm{~J} \mathrm{~K}^{-1} \mathrm{~mol}^{-1}$

$K p(1)=0.127 T^{0.415} \exp (+7030 / T)$

$\Delta H_{298}^{\circ}(3)=-30.5 \mathrm{~kJ} \mathrm{~mol}^{-1}$

$\Delta S_{298}^{\circ}(3)=33.9 \mathrm{~J} \mathrm{~K}^{-1} \mathrm{~mol}^{-1}$

$K p(3)=6.08 \cdot 10^{4} T^{-0.948} \exp (+3210 / T)$

$$
\begin{aligned}
& \Delta H_{298}^{\circ}(2)=-112 \mathrm{~kJ} \mathrm{~mol}^{-1} \\
& \Delta S_{298}^{29}(2)=38.5 \mathrm{~J} \mathrm{~K}^{-1} \mathrm{~mol}^{-1} \\
& K p(2)=4.5 \cdot 10^{4} \mathrm{~T}^{-0.114} \exp (+13100 / T) \\
& \Delta H_{298}^{\circ}(4)=-353.0 \mathrm{~kJ} \mathrm{~mol}^{-1} \\
& \Delta S_{298}^{\circ}(4)=-7.7 \mathrm{~J} \mathrm{~K}^{-1} \mathrm{~mol}^{-1} \\
& K p(4)=0.369 T^{0.143} \exp (+42280 / T)
\end{aligned}
$$

Rate Coefficient Data $\left(k=k_{1}+k_{2}+k_{3}+k_{4}\right)$

\begin{tabular}{llll}
\hline \hline$k / \mathrm{cm}^{3}$ molecule & Comments \\
\hline $\begin{array}{l}\text { Rate Coefficient Measurements } \\
1.3 \cdot 10^{-10} \exp (-2770 / T)\end{array}$ & $1052-2284$ & Klemm et al., $1990^{1}$ & (a) \\
$\begin{array}{l}\text { Reviews and Evaluations } \\
5.75 \cdot 10^{-18} T^{2.08}\end{array}$ & $300-2000$ & CEC, $1992^{2}$ & (b)
\end{tabular}

\section{Comments}

(a) High temperature study using the flash photolysis-shock tube technique. $\mathrm{O}$ atoms produced by photolysis of NO and monitored by atomic resonance absorption spcctrometry. Pseudo first order decay of $\mathrm{O}$ in excess $\mathrm{C}_{2} \mathrm{H}_{4}$. Also give an expression for $k$ based on data from Refs. $3-11$ of $k=9.3 \cdot 10^{-12} \exp (-752 / T)+1.5 \cdot 10^{-10}$ $\exp (-3450 / T) \mathrm{cm}^{3}$ molecule $\mathrm{s}^{-1}$ over range 300 $2300 \mathrm{~K}$.

(b) Based on the analysis of Klemm et al..$^{3}$ of a large body of literature data.

\section{Preferred Values}

$k=2.25 \cdot 10^{-17} T^{1.88} \exp (-92 / T) \mathrm{cm}^{3}$ molecule ${ }^{-1} \mathrm{~s}^{-1}$ over range $300-2000 \mathrm{~K}$.

$k_{1} / k=0.35$ at $\mathrm{P}>3$ Torr and $T>300 \mathrm{~K}$.

$k_{2} / k=0.60$

$k_{4} / k=0.05$

\section{Reliability}

$\Delta \log k= \pm 0.1$ for $T<1000 \mathrm{~K}$ increasing to \pm 0.3 at $2000 \mathrm{~K}$.

$\Delta k_{1} / k= \pm 0.05$

$\Delta k_{2} / k= \pm 0.10$

$\Delta k_{4} / k= \pm 0.10$

\section{Comments on Preferred Values}

The new measurements of Klemm et al. ${ }^{1}$ substantially extend the temperature range of the experimental data base, and agree reasonably well with the data from Mahmud et al.$^{12}$ at temperatures in the range $1100-1500 \mathrm{~K}$. Klemm et al. ${ }^{1}$ note that the discrepancy between the bi-exponential expression reported earlier by them ${ }^{3}$ and that reported by Mahmud et al..$^{12}$ arises mainly from the lower temperature data of Mahmud et $a l^{12}$. Klemm et al. ${ }^{1}$ give the following expression obtained from a fit to all the data including those of Mahmud et al.$^{12}$ : $k=9.4 \cdot 10^{-12} \exp (-749 / T)+1.8 \cdot 10^{-10} \exp (-3740 / T) \mathrm{cm}^{3}$ molecule $\mathrm{e}^{-1} \mathrm{~s}^{-1}$.

The preferred cxpression is derived by performing a three parameter, $A T^{n} \exp (B / T)$, fit to the curve generated from the bi-exponential expression of Klemm et al. ${ }^{1}$ over the range $300-2000 \mathrm{~K}$, from the data of Klemm et al. ${ }^{3}$ and those in Refs. 4-11.

New data for the yield of $\mathrm{H}$ atoms ${ }^{13}$ confirms that the branching ratio $k_{1} / k$ is pressure dependent at low pressures. The recommendation based on earlier work of Smalley et al.$^{14}$ and Koda et al.$^{15,16}$ is unchanged.

\section{References}

'R.B. Klemm, J.W. Sutherland, M.A. Wickramaaratchi, and G. Yarwood, J. Phys. Chem. 94, 3354 (1990).

${ }^{2} \mathrm{CEC}, 1992$ (see references in Introduction).

${ }^{3}$ R.B. Klemm, F.L. Nesbitt, E.G. Skolnik, J.H. Lee, and J.F. Smalley, J. Phys. Chem. 91, 1574 (1987).

${ }^{4}$ N. deHaas and A.A. Westenberg, 12th Symp. Int. Comb. p289 (1969).

${ }^{5}$ L. Elias, J. Chem. Phys. 38, 989 (1963).

${ }^{6}$ D.D. Davis, R.E. Huie, J.T. Herron, M.J. Kurylo, and W. Braun, J. Chem. Phys. 56, 4868 (1972).

${ }^{7}$ D.L. Singleton and R.J. Cvetanovic, J. Am. Chem. Soc. 98, 6812 (1976).

${ }^{8}$ R. Atkinson and J.N. Pitts, Jr., J. Chem. Phys. 67, 38 (1977)

'R. Browarzik and F. Stuhl, J. Phys. Chem. 88, 6004 (1984).

${ }^{10}$ J.M. Nicovich and A.R. Ravishankara, 19th Symp. Int. Comb. p23 (1982).

"R.A. Perry, J. Chem. Phys. 80, 153 (1984).

${ }^{12}$ K. Mahmud, P. Marshall, and A. Fontijn, J. Phys. Chem. 91, 1568 (1987).

${ }^{13}$ V.S. Arutyunov, V.I. Vedeneev, and V.D. Knyazev, Arm. Khim. Zh. 44, 71 (1990).

${ }^{14}$ J.F. Smalley, F.L. Nesbitt, and R.B. Klemm, J. Phys. Chem. 90, 491 (1986).

${ }^{15}$ S. Koda, Y. Endo, E. Hirota, and S. Tsuchiya, J. Phys. Chem. 91, 5840 (1987).

${ }^{16}$ S. Koda, Y. Endo, S. Tsuchiya, and E. Hirota, J. Phys. Chem. 95, 1214 (1991). 
EVALUATED KINETIC DATA FOR COMBUSTION MODELLING

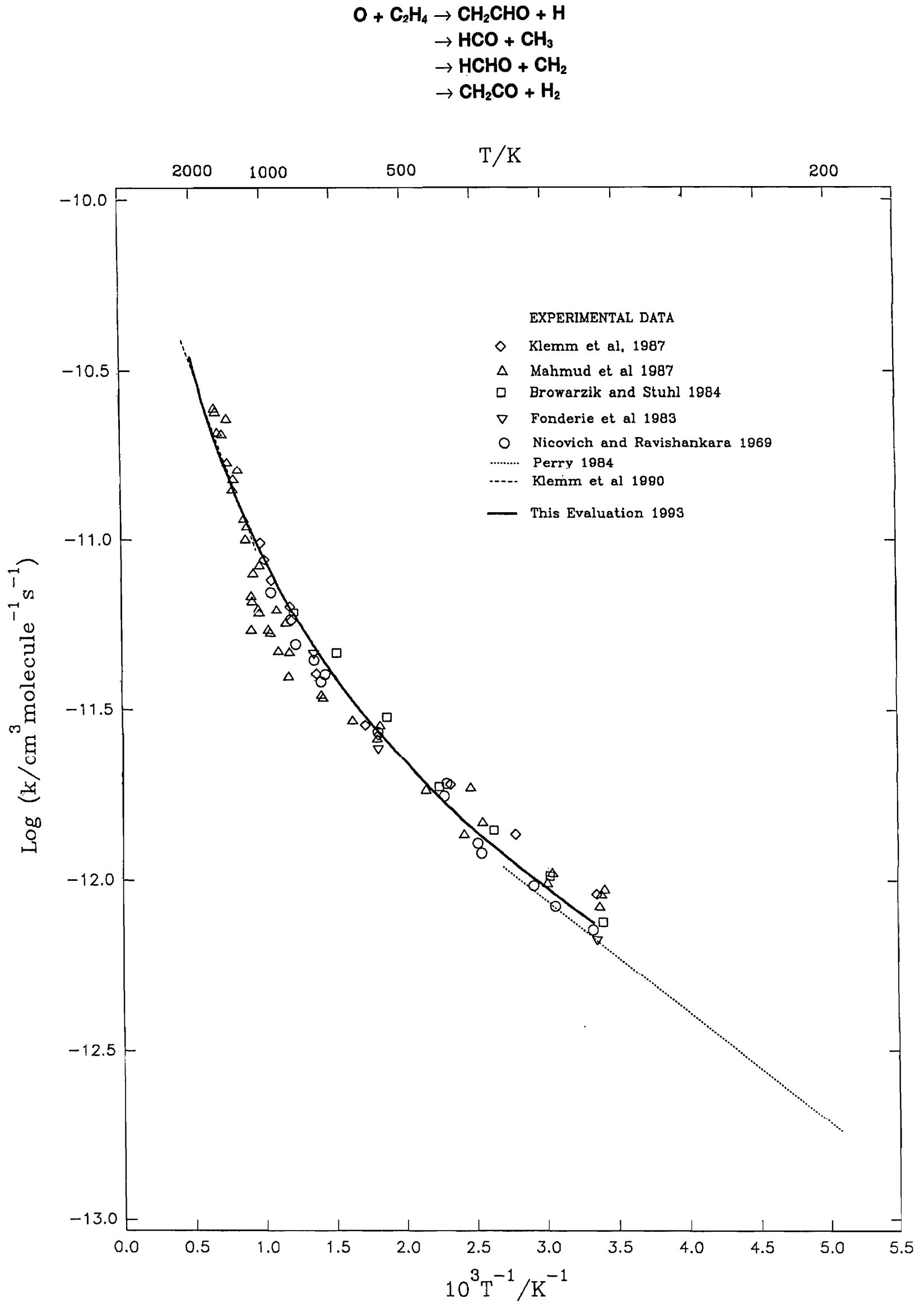


BAULCH ET AL.

$$
\begin{aligned}
\mathrm{O}+\mathrm{CH}_{3} \mathrm{CO} & \rightarrow \mathrm{OH}+\mathrm{CH}_{2} \mathrm{CO} \\
& \rightarrow \mathrm{CO}_{2}+\mathrm{CH}_{3}
\end{aligned}
$$

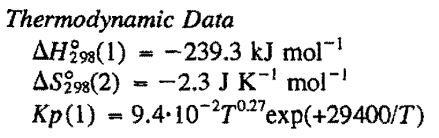

$$
\begin{aligned}
& \Delta H_{298}^{\circ}=-474.0 \mathrm{~J} \mathrm{~K}^{-1} \mathrm{~mol}^{-1} \\
& \Delta S_{988}^{\circ}(2)=-19.9 \mathrm{~J} \mathrm{~K}^{-1} \mathrm{~mol}^{-1} \\
& K p(2)=3.0 \cdot 10^{-2} T^{0.07} \exp (+57700 / T)
\end{aligned}
$$

Rate Coefficient Data $\left(k=k_{1}+k_{2}\right)$

\begin{tabular}{lclc}
\hline \hline$k / \mathrm{cm}^{3}$ molecule $\mathrm{s}^{-1}$ & $T / \mathrm{K}$ & Reference & Comments \\
\hline Rate Coefficient Measurements & 295 & Miyoshi, Matsui, and Washida, 1989 & \\
$3.2 \cdot 10^{-10}$ & & & \\
$k_{1} / k=0.22$ & & & \\
$k_{2} / k=0.76$ & & & \\
& $>300$ & Wamatz, $1984^{2}$ & (a) \\
Reviews and Evaluations & 3002500 & Tsang and Hampson, $1986^{3}$ & (c) \\
$3.3 \cdot 10^{-11}$ & $300-2000$ & Herron, $1988^{4}$ & (d) \\
$1.6 \cdot 10^{-11}$ & & & \\
$1.0 \cdot 10^{-10}$ & & & \\
\hline
\end{tabular}

\section{Comments}

(a) Discharge flow system. Reactants and products monitored by photoionization mass spectrometry. $k$ measured relative to $k\left(\mathrm{CH}_{3} \mathrm{CO}+\mathrm{O}_{2}\right) \cdot k_{\text {ref }} / k=(6.3 \pm 0.5) \cdot 10^{-3}$ from the effect of $\left[\mathrm{O}_{2}\right]$ on the yield of $\mathrm{CH}_{3} \mathrm{CO}$ in the reaction of acetaldehyde in excess oxygen atoms. Given value of $k$ based on $k\left(\mathrm{CH}_{3} \mathrm{CO}+\mathrm{O}_{2}\right)=2.0 \cdot 10^{-12} \mathrm{~cm}^{3}$ molecule ${ }^{-1}$ $\mathrm{s}^{-1}$ from present evaluation. Branching ratio $k_{1} / k$ from the yield of ketene and $k_{2} / k$ from the yield of methyl radicals, both measured independently.

(b) Estimate.

(c) Estimate based on analogy of $\mathrm{O}$ atom reactions with alkyl radicals. Suggest channel (2) is dominant.

(d) As (c) but higher value preferred.

\section{Preferred Value}

$k=3.2 \cdot 10^{-10} \mathrm{~cm}^{3}$ molecule $\mathrm{s}^{-1}$ over the range $298-1500 \mathrm{~K}$.

$k_{1} / k=0.2$ at $298 \mathrm{~K}$.

$k_{2} / k=0.8$ at $298 \mathrm{~K}$.

\section{Reliability}

$\Delta \log k= \pm 1.0$ at $1500 \mathrm{~K}$ reducing to \pm 0.3 at $298 \mathrm{~K}$. $\Delta k_{1} / k= \pm 0.1$ at $298 \mathrm{~K}$. $\Delta k_{2} / k= \pm 0.2$ at $298 \mathrm{~K}$.

\section{Comments on Preferred Values}

The preferred values are based on the experimental measurements of Miyoshi et al. ${ }^{1}$, which are consistent with the kinetics of other O-atom + radical reactions of similar type. In view of the rapid rate of this reaction, little, if any, temperature dependence of the rate is expected. The branching ratio, which is also based on the measurements of Miyoshi et al. ${ }^{1}$, may change with temperature and the values can only be recommended with any confidence for room temperature.

\section{References}

'A. Miyoshi, H. Matsui, and N. Washida, J. Phys. Chem. 93, 5813 (1989).

${ }^{2}$ J. Warnatz, in 'Combustion Chemistry', W.C. Gardiner, Jr., ed., Springer Verlag, New York p.197 (1984).

${ }^{3}$ W. Tsang and R.F. Hampson, J. Phys. Chem. Ref. Data 15, 1087 (1986). ${ }^{4}$ J.T. Herron, J. Phys. Chem. Ref. Data 17, 967 (1988). 


$$
\begin{aligned}
\mathrm{O}+\mathrm{CH}_{3} \mathrm{CHO} & \rightarrow \mathrm{OH}+\mathrm{CH}_{3} \mathrm{CO} \\
& \rightarrow \mathrm{OH}+\mathrm{CH}_{2} \mathrm{CHO}
\end{aligned}
$$

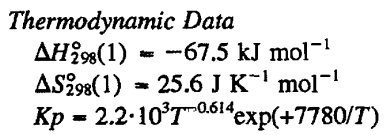

Rate Coefficient Data $\left(k=k_{1}+k_{2}\right)$

\begin{tabular}{llll}
\hline \hline$/ \mathrm{cm}^{3}$ molecule ${ }^{-1} \mathrm{~s}^{-1}$ & $T / \mathrm{K}$ & Reference & Comments \\
\hline $\begin{array}{l}\text { Rate Coefficient Measurements } \\
3.9 \cdot 10^{-13}\end{array}$ & 295 & Miyoshi, Matsui, and Washida, 1989 & (a) \\
$\begin{array}{l}\text { Reviews and Evaluations } \\
9.7 \cdot 10^{-12} \text { exp(-910/T) }\end{array}$ & $298-1500$ & CEC, 1992 $2^{2}$ & (b) \\
\end{tabular}

\section{Comments}

(a) Discharge flow system. Reactants and products monitored by photoionization mass spectrometry. Pseudo first order decay of $\mathrm{CH}_{3} \mathrm{CHO}$ in excess oxygen atoms.

(b) See Comments on Preferred Values.

\section{Preferred Value}

$k=9.7 \cdot 10^{-12} \exp (-910 / T) \mathrm{cm}^{3}$ molecule ${ }^{-1} \mathrm{~s}^{-1}$ over the range $298-1500 \mathrm{~K}$.

\section{Reliability}

$\Delta \log k= \pm 0.5$ at $1500 \mathrm{~K}$ reducing to \pm 0.05 at $298 \mathrm{~K}$.

\section{Comments on Preferred Values}

The new room temperature data agree with previous measurements within the experimental uncertainty. There is no change in the preferred values which are based on the low temperature data of Mack and Thrush ${ }^{3}$, Michael and Lee ${ }^{4}$ and Singleton et al. ${ }^{5}$. No information is available on the branching ratio. If it is assumed that $k_{2}=1 / 2 k\left(\mathrm{O}+\mathrm{C}_{2} \mathrm{H}_{6}\right)$ then the second channel only becomes significant $\left(k_{2} / k>0.1\right)$ at $T>$ $700 \mathrm{~K}$. However, the extrapolated value is a factor of 2 higher than the overall rate given by Beeley et al ${ }^{6}$. The contribution of the second channel is negligible at $T<500 \mathrm{~K}$, where the only reliable studies were conducted.

\section{References}

${ }^{1}$ A. Miyoshi, H. Matsui, and N. Washida, J. Phys. Chem. 93, 5813 (1989). ${ }^{2} \mathrm{CEC}, 1992$ (see references in Introduction).

${ }^{3}$ G.P.R. Mack and B.A. Thrush, J. Chem. Soc., Faraday Trans. I 70, 178 (1974).

${ }^{4}$ J.V. Michael and J.H. Lee, Chem. Phys. Lett. 51, 303 (1977).

${ }^{5}$ D.L. Singleton, R.S. Irwin, and R.J. Cvetanovic, Can. J. Chem. 55, 3321 (1977).

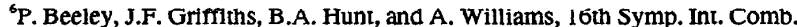
p1013 (1976).

$$
\begin{aligned}
\mathrm{O}+\mathrm{C}_{2} \mathrm{H}_{5} \mathrm{OOH} & \rightarrow \mathrm{OH}+\mathrm{C}_{2} \mathrm{H}_{5} \mathrm{OO} \\
& \rightarrow \mathrm{OH}+\mathrm{C}_{2} \mathrm{H}_{4} \mathrm{OOH}
\end{aligned}
$$

\section{Comment}

There are no experimental data for the reaction of $O\left({ }^{3} \mathrm{P}\right)$ with $\mathrm{C}_{2} \mathrm{H}_{5} \mathrm{OOH}$. The same rate expression as for the
$\mathrm{O}+\mathrm{CH}_{3} \mathrm{OOH}$ reaction is recommended: $k-3.3 \cdot 10^{-11}$ $\exp (-2390 / T) \mathrm{cm}^{3}$ molecule $\mathrm{s}^{-1}$, with channel (2) dominant. 
Rate Coefficient Data $\left(k=k_{1}+k_{2}\right)$

\begin{tabular}{|c|c|c|c|}
\hline$k / \mathrm{cm}^{3}$ molecule $\mathrm{e}^{-1} \mathrm{~s}^{-1}$ & $T / \mathrm{K}$ & Reference & Comments \\
\hline \multicolumn{4}{|l|}{ Rate Coefficient Measurements } \\
\hline $6.0 \cdot 10^{-14}$ & 298 & Mani and Sauer, $1968^{1}$ & (a) \\
\hline $2.5 \cdot 10^{-10} \exp (-2768 / T)$ & $883-963$ & Mkryan, Oganesyan, and Nalbandyan, $1971^{2}$ & (b) \\
\hline$k_{1}=5.3 \cdot 10^{-10} \exp (-3019 / T)$ & $1300-1700$ & Fujii and Asaba, $1972^{3}$ & (c) \\
\hline$k_{2}=6.3 \cdot 10^{-11} \exp (-2214 / T)$ & $255-305$ & Bonnano et al., $1972^{4}$ & (d) \\
\hline $2.4 \cdot 10^{-14}$ & 300 & Atkinson and Pitts, $1974^{5}$ & (a) \\
\hline $1.8 \cdot 10^{-11} \exp (-2214 / T)$ & $298-462$ & Colussi et al ., $1975^{\circ}$ & (e) \\
\hline $1.8 \cdot 10^{-11} \exp (-2003 / T)$ & $299-392$ & Atkinson and Pitts, $1975^{7}$ & (e) \\
\hline $1.7 \cdot 10^{-11} \exp (-2010 / T)$ & $299-440$ & Atkinson and Pitts, $1979^{8}$ & (f) \\
\hline $4.6 \cdot 10^{-11} \exp (-2470 / T)$ & $298-867$ & Nicovich, Gump, and Ravishankara, $1982^{9}$ & (g) \\
\hline$k_{1}=5.3 \cdot 10^{-10} \exp (-3020 / T)$ & $1600-2300$ & Hsu, Lin, and Lin, $1984^{10}$ & (h) \\
\hline $3.5 \cdot 10^{-11} \exp (-2250 / T)$ & $300-670$ & Tappe, Schiephake, and Wagner, $1989^{11}$ & (i) \\
\hline$k_{2}=4 \cdot 10^{-11} \exp (-2350 / T)$ & $1200-1450$ & Leidreiter and Wagner, $1989^{12}$ & (j) \\
\hline$k_{2}=5.4 \cdot 10^{-11} \exp (-2611 / T)$ & $600-1300$ & Ko, Adusei, and Fontijn, $1991^{13}$ & (k) \\
\hline \multicolumn{4}{|l|}{ Reviews and Evaluations } \\
\hline $2.5-10^{-11} \exp (-2130 / T)$ & $298-600$ & Cretanovic, $1987^{14}$ & (l) \\
\hline $1.2-10^{-22} T^{3.68} \exp (-570 / T)$ & $300-1000$ & CEC, $1992^{15}$ & (m) \\
\hline
\end{tabular}

\section{Comments}

(a) Pulse radiolysis with product analysis by gas chromatography. $\mathrm{O}$ atoms originate from radiolysis of $\mathrm{CO}_{2}$ and $\mathrm{NO}_{2}$ at high pressures. Rate coefficient from absorption profiles of transient species.

(b) Evaluation of an overall rate coefficient from a flow reactor study.

(c) Single pulse shock tube with gas chromatographic analysis of stable products and absorption/emission measurements during the progress of the reaction were used to investigate the kinetic behaviour of benzene/argon mixtures containing small amounts of oxygen.

(d) Flow system study. The decrease of $\mathrm{O}$ atoms was monitored by ESR detection and changes in benzene concentration were followed by mass spectrometry. It was found that $\mathrm{O}$ atoms removal is much faster than benzene decrease. Therefore it was assumed that the $O$ atoms react with radicals produced in the initiation reaction. The rate coefficient for channel (2) was evaluated from the mass spectrometric measurements.

(c) Phase shift, $\mathrm{O}+\mathrm{NO}$ chemiluminescence. $\mathrm{O}$ atoms are generated by $\mathrm{Hg}$ photosensitized decomposition of $\mathrm{NO}_{2}$.

(f) Flash photolysis-resonance fluorescence. $\mathrm{O}$ atoms are generated by VUV photolysis of $\mathrm{O}_{2}$ and NO.

(g) Flash photolysis-resonance fluorescence. $\mathrm{O}$ atoms are generated by VUV photolysis of $\mathrm{O}_{2}$.

(h) The oxidation of benzene under fuel lean conditions was studied behind reflected shock waves using a stabilized cw $\mathrm{CO}$ laser to monitor $\mathrm{CO}$ production. The formed $\mathrm{CO}$ was modelled by a 25 step reaction mechanism. A rate coefficient for channel (1) was determined.

(i) Flow reactor, mass spectrometric detection of O-atoms produced by microwave discharge in $\mathrm{O}_{2}$. O-atom concentration in excess by factors 32-80. Total pressure range: 2.4-11.6 mbar, $T$-range: $300-870 \mathrm{~K}$. At temperatures above $670 \mathrm{~K}$ an upward curvature of the Arrhenius plot is observed. Authors therefore recommend a rate expression only up to $T \approx 670 \mathrm{~K}$.

(j) Reaction studied under well isolated conditions (100-160 ppm benzene) behind incident shock waves at total densities of about $1-10^{-5} \mathrm{~mol} \mathrm{~cm} \mathrm{~cm}^{-3}$. Thermal decomposition of ozone (6-25 ppm) was used as $O$ atom source. $O\left({ }^{3} \mathrm{P}\right)$ atoms monitored by ARAS at $130.5 \mathrm{~nm}$. Values of $k_{2}$ from this work found to fit well with extrapolation of lower temperature data for $k$ from Refs. 6-9.

(k) High temperature fast flow reactor study. $\mathrm{O}\left({ }^{3} \mathrm{P}\right)$ generated by $193 \mathrm{~nm}$ photolysis of $\mathrm{SO}_{2}$ and monitored by resonance fluorescence in excess $\mathrm{C}_{6} \mathrm{H}_{6}$. Results for rate of removal of $\mathrm{O}\left({ }^{3} \mathrm{P}\right)$ consistent with low temperature data and with higher temperature rcsults of Lcidreiter and Wagner ${ }^{12}$. It is concluded that the same reaction channel is dominant up to $1400 \mathrm{~K}$ (channel 2) and fit to all these data gives expression for $k_{2}$ very similar to that recommended here.

(l) Critical evaluation and compilation of chemical kinetic data of $\mathrm{O}\left({ }^{3} \mathrm{P}\right)$ atoms with unsaturated hydrocarbons.

(m) Fit to the data from Refs. 1-10. 


\section{Preferred Values}

$k=5.9 \cdot 10^{-23} T^{3.8} \exp (-473 / T) \mathrm{cm}^{3}$ molecule $\mathrm{e}^{-1} \mathrm{~s}^{-1}$ over range $300-2000 \mathrm{~K}$.

$k_{2}-3.7 \cdot 10^{-11} \exp (2280 / T) \mathrm{cm}^{3}$ molcculc $^{-1} \mathrm{~s}^{-1}$ over range $298-1400 \mathrm{~K}$.

\section{Reliability}

$\Delta \log k= \pm 0.3$ over range $298-2000 \mathrm{~K}$.

$\Delta \log k_{2}= \pm 0.3$ at $298 \mathrm{~K}$ falling to \pm 0.2 at $1400 \mathrm{~K}$.

\section{Comments on Preferred Values}

There is a large variety of studies on benzene oxidation in the lower temperature range, up to $\approx 900 \mathrm{~K}$. The shock tube data for the higher temperature range are derived from reaction systems with reduced sensitivity. The preferred value for $k_{2}$ is based mainly on the measurements of Refs. $5-9,11,12$, 15. From the excellent agreement between these data and from thermochemical arguments (see also Ref. 12) it is concluded that below about $1500 \mathrm{~K}$ reaction pathway (1) plays only a minor role with respect to the addition channel (2).

\section{References}

${ }^{1}$ I. Mani and M.C. Sauer, Jr., Advanc. Chem. Ser. 82, 142 (1968).

${ }^{2}$ T.G. Mkryan, K.T. Oganesyan, and A.B. Nalbandyan, Arm. Khim. Zh. 24, 299 (1971).

${ }^{3}$ N. Fujii and T. Asaba, 14th Symp. (Int.) Combust., 433 (1972).

${ }^{4}$ R.A. Bonnano, P. Kim. J.H. Lee, and R.B. Timmons, J. Chem. Phys. 57, 1377 (1972).

${ }^{5}$ R. Atkinson and J.N. Pitts, Jr., J. Phys. Chem. 78, 1780 (1974).

${ }^{6}$ A.J. Colussi, D.L. Singleton, R.S. Irwin, and R.J. Cvetanovic, J. Phys. Chem. 79, 1900 (1975).

${ }^{7}$ R. Atkinson and J.N. Pitts, Jr., J. Phys. Chem. 79, 295 (1975).

${ }^{8}$ R. Atkinson and J.N. Pitts, Jr., Chem. Phys. Lett. 63, 485 (1979).

${ }^{9}$ J.M. Nicovich, C.A. Gump, and A.R. Ravishankara, J. Phys. Chem. 86, 1684 (1982).

${ }^{i 0}$ D.S.Y. Hsu, C.Y. Lin, and M.C. Lin, 20th Symp. (Int.) Combust., 623 (1984).

"M. Tappe, V. Schliephake, and H.Gg. Wạgner, Zeits. P. Phys. Chemie N.F. 162. 129 (1989).

${ }^{12}$ H.I. Leidreiter and H.Gg. Wagner, Zeits. f. Phys. Chemie N.F. 165, 1 (1989).

${ }^{12}$ I. Ko, G.Y. Aduse1, and A. Fontijn, J. Phys. Chem. 95, 8745 (1991).

${ }^{14}$ R.J. Cvetanovic, J. Phys. Chem. Ref. Data 16, 261 (1987).

${ }^{15} \mathrm{CEC}, 1992$ (see references in Introduction).

\section{$\mathrm{O}+\mathrm{C}_{6} \mathrm{H}_{5} \mathrm{OH} \rightarrow$ products}

Rate Coefficient Data

\begin{tabular}{llll}
\hline \hline$k / \mathrm{cm}^{3}$ molecule ${ }^{-1 \mathrm{~s}-1}$ & $T / \mathrm{K}$ & Reference & Comments \\
\hline $\begin{array}{l}\text { Rate Coefficient Measurements } \\
2.1 \cdot 10^{-11} \exp (-1455 / T)\end{array}$ & $292-873$ & Frerichs et al., 1990' & (a) \\
\hline
\end{tabular}

\section{Commente}

(a) Flow reactor, mass spectrometric detection, $\mathrm{O}$ atoms produced in microwave discharge of $\mathrm{O}_{2} . \mathrm{O}$ atom concentration in excess by factors $70-580$. Total pressure range: 2.3-3.4 mbar.

\section{Preferred Values}

$k=2.1 \cdot 10^{-11} \exp (-1455 / T) \mathrm{cm}^{3}$ molecule $\mathrm{s}^{-1}$ over range $290-600 \mathrm{~K}$.

\section{Reliability}

$\Delta \log k= \pm 0.3$ over range $290-600 \mathrm{~K}$.
Comments on Preforred Values

The preferred value is based on the only available measurement of Ref. 1. It is restricted to temperatures below $600 \mathrm{~K}$. At higher temperatures this study indicates an upward curvature of the Arrhenius plot.

\section{References}

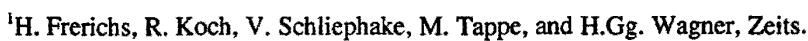
f. Phys. Chemie N.F. 166, 145 (1990). 


$$
\begin{aligned}
\mathrm{O}+\mathrm{C}_{6} \mathrm{H}_{5} \mathrm{CHO} & \rightarrow \mathrm{OH}+\mathrm{C}_{6} \mathrm{H}_{5} \mathrm{CO} \\
& \rightarrow \mathrm{OH}+\mathrm{C}_{6} \mathrm{H}_{4} \mathrm{CHO} \\
\mathrm{O}+\mathrm{C}_{6} \mathrm{H}_{5} \mathrm{CHO}(+\mathrm{M}) & \rightarrow \mathrm{C}_{6} \mathrm{H}_{5}(\mathrm{O}) \mathrm{CHO}_{(+\mathrm{M})}
\end{aligned}
$$

Rate Coefficient Data $\left(k=k_{1}+k_{2}+k_{3}\right)$

\begin{tabular}{lccc}
\hline \hline$k / \mathrm{cm}^{3}$ molecule $\mathrm{s}^{-1}$ & $T / \mathrm{K}$ & Reference & Comments \\
\hline $\begin{array}{c}\text { Kate Coefficient Measurements } \\
4.8 \cdot 10^{-13}\end{array}$ & 298 & Filby and Gusten, 1978 ${ }^{1}$ & (a) \\
\hline
\end{tabular}

\section{Comments}

(a) Discharge flow; time resolved EPR detection of $O$ in excess benzaldehyde. Pressure $=4.7$ Torr He.

\section{Preferred Values}

$k_{1}=1.0 \cdot 10^{-11} \exp (-910 / T) \mathrm{cm}^{3}$ molecule ${ }^{-1} \mathrm{~s}^{-1}$ over range $298-1500 \mathrm{~K}$.

\section{Reliability}

$\Delta \log k= \pm 0.7$ at $1500 \mathrm{~K}$ reducing to \pm 0.3 at $298 \mathrm{~K}$.

\section{Comments on Preferred Values}

The only experimental kinetic data for this reaction are at room temperature. The $k$ value is essentially identical to that for the reaction of $\mathrm{O}$ atoms with acetaldehyde, indicating that the main channel is $\mathrm{H}$ - abstraction from the carbonyl group. The preferred rate expression applies to channel (1) and is based on the room temperature measurement and the temperature dependence for $\mathrm{O}+\mathrm{CH}_{3} \mathrm{CHO}$ (see this evaluation). There is no direct information on the alternative channels (2) and (3) where $O$ attacks the aromatic ring. The importance of these channels can be assessed from the $\mathrm{O}+\mathrm{C}_{6} \mathrm{H}_{6}$ reaction. Applying the recommended expression from this evaluation for $k\left(\mathrm{O}+\mathrm{C}_{6} \mathrm{H}_{6}\right)=1.2 \cdot 10^{-22} T^{3.68} \exp (-570 / T) \mathrm{cm}^{3}$ molecule $\mathrm{e}^{-1} \mathrm{~s}^{-1}$ to the other channels, $\left(k_{2}+k_{3}\right)$ is approximately a factor of 40 lower than $k_{1}$ at $300 \mathrm{~K}$ but the rates are about equal to $1000 \mathrm{~K}$.

\section{References}

'W.G. Filby and H. Gusten, Atm. Environ. 12, 1563 (1978). 
$\mathrm{O}+\mathrm{p}-\mathrm{C}_{8} \mathrm{H}_{4}\left(\mathrm{CH}_{3}\right)_{2} \rightarrow$ products

Rate Coefficient Data

\begin{tabular}{|c|c|c|c|}
\hline $6 / \mathrm{cm}^{3}$ molecule $\mathrm{e}^{-1 \mathrm{~s}-1}$ & $T / \mathrm{K}$ & Reference & Comments \\
\hline \multicolumn{4}{|l|}{ Rate Coefficient Measurements } \\
\hline $7.5 \cdot 10^{-13}$ & 298 & Mani and Sauer, $1968^{1}$ & (a) \\
\hline $1.8 \cdot 10^{-13}$ & 300 & Atkinson and Pitts, Jr., $1974^{2}$ & (b) \\
\hline $1.3 \cdot 10^{-11} \exp (-1280 / T)$ & $299-392$ & Atkinson and Pitts, Jr., $1975^{3}$ & (b) \\
\hline $3.9 \cdot 10^{-11} \exp (-1540 / T)$ & $298-600$ & Nicovich, Gump, and Ravishankara, $1982^{4}$ & (c) \\
\hline $4.3 \cdot 10^{-11} \exp (-1540 / T)$ & $298-868$ & Frerichs et al., $1989^{5}$ & (d) \\
\hline \multicolumn{4}{|l|}{ Reviews and Evaluations } \\
\hline $2.6 \cdot 10^{-11} \exp (-1409 / T)$ & $298-600$ & Cvetanovic, $1987^{6}$ & (e) \\
\hline $2.6 \cdot 10^{-11} \exp (-1409 / T)$ & $298-600$ & CEC, $1992^{7}$ & (f) \\
\hline
\end{tabular}

\section{Comments}

(a) $\mathrm{O}$ from pulse radiolysis of $\mathrm{CO}_{2}$ or $\mathrm{N}_{2} \mathrm{O} . k$ from absorption spectra of transients (not positively identified). $p \approx 60 \mathrm{bar}$.

(b) Phase shift- $\mathrm{O}+\mathrm{NO}$ chemiluminescence. $\mathrm{O}$ atoms from $\mathrm{Hg}$-photosensitized decomposition of $\mathrm{N}_{2} \mathrm{O} . p \approx 72 \mathrm{mbar}$.

(c) Flash photolysis-resonance fluorescence. $\mathrm{O}$ atoms from VUV photolysis of $\mathrm{O}_{2}$. Diluent $\mathrm{N}_{2}$ or $\mathrm{Ar}$ at $76 \mathrm{mbar}$.

(d) Flow reactor with mass spectrometric detection, $\mathrm{O}$ atoms produced by microwave discharge in $\mathrm{O}_{2} . \mathrm{O}$ atom concentration in excess by factors $45-172$. Total pressure range: 2.2-4.5 mbar.

(e) Critical evaluation and compilation of chemical kinetic data of $\mathrm{O}\left({ }^{3} \mathrm{P}\right)$ atoms with unsaturated hydrocarbons.

(f) Accepts evaluation of Cvetanovic. ${ }^{6}$

\section{Preferred Values}

$k=5.1 \cdot 10^{-11} \exp (-1630 / T) \mathrm{cm}^{3}$ molecule $\mathrm{s}^{-1}$ over range $298-600 \mathrm{~K}$.

Reliability

$\Delta \log k= \pm 0.3$ over range $298-600 \mathrm{~K}$.

\section{Comments on Preferred Values}

In our previous recommendation the evaluation of Cvetanovic ${ }^{6}$ was accepted. The new study of Frerichs et al..$^{5}$ provides further reliable results over an extended temperature range. The preferred value is based on the measurements of Refs. 2-5 but is still restricted to temperatures below $600 \mathrm{~K}$. Above this value, the results of two studies ${ }^{4,5}$ indicate an upward curvature of the Arrhenius plot which requires further study.

\section{References}

'I. Mani and M.C. Sauer, Jr., Advanc. Chem. Ser. 82, 142 (1968).

${ }^{2}$ R. Atkinson and J.N. Pitts, Jr., J. Phys. Chem, 78, 1780 (1974).

${ }^{3}$ R. Atkinson and J.N. Pitts. Ir.. J. Phys. Chem. 79. 295 (1975).

${ }^{4}$ J.M. Nicovich, C.A. Gump, and A.R. Ravishankara, J. Phys. Chem. 86, 1690 (1982).

${ }^{5}$ H. Frerichs, V. Schliephake, M. Tappe, and H.Gg. Wagner, Zeits. f. Phys. Chemie N.F. 165, 9 (1989).

${ }^{6}$ R.J. Cvetanovic, J. Phys. Chem. Ref. Data 16, 261 (1987).

${ }^{7}$ CEC, 1992 (see references in Introduction). 
BAULCH ET AL.

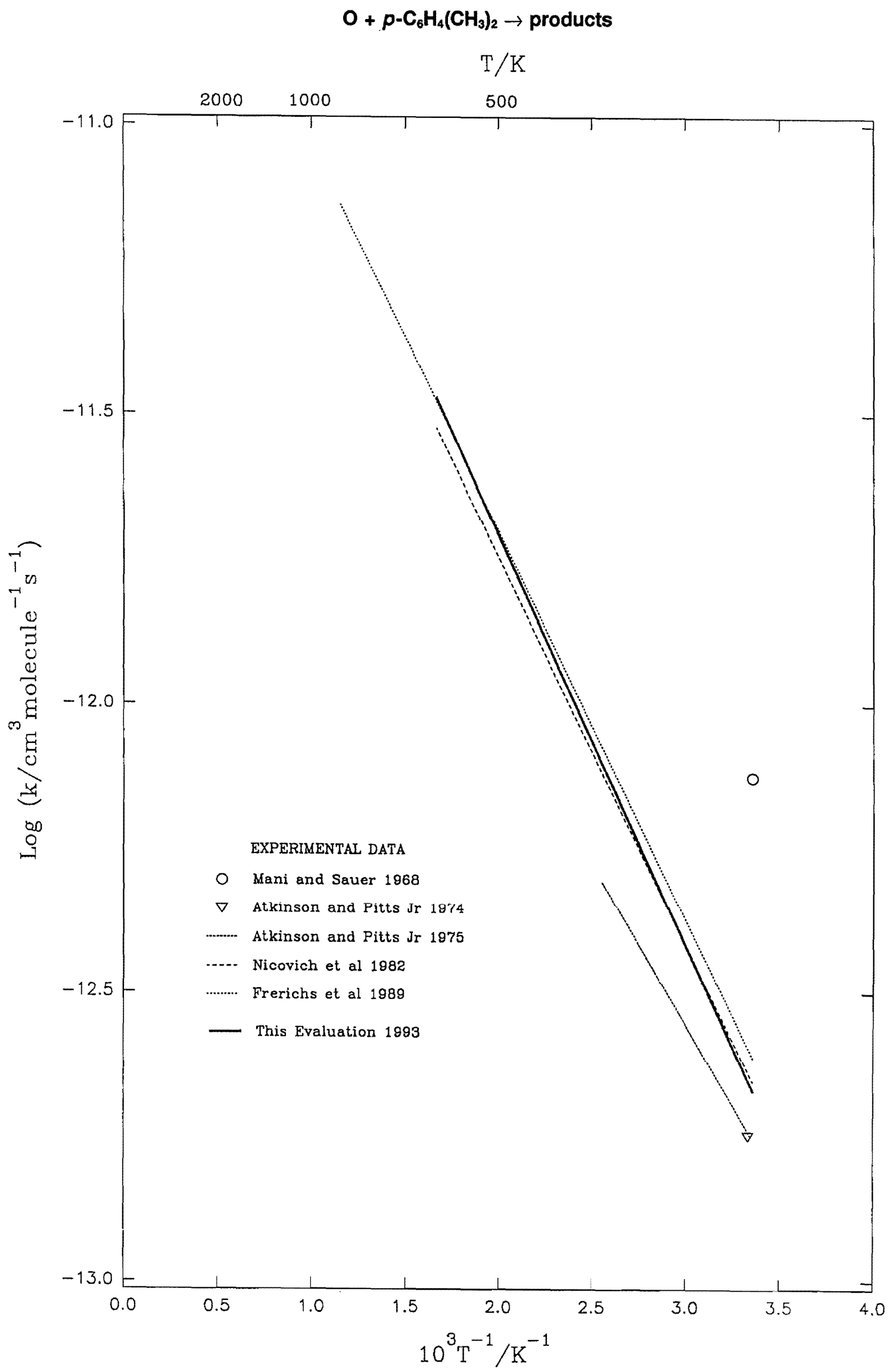




$$
\mathrm{O}+\mathrm{C}_{6} \mathrm{H}_{5} \mathrm{CH}_{3} \rightarrow \text { products }
$$

Rate Coefficient Data

\begin{tabular}{|c|c|c|c|}
\hline$k / \mathrm{cm}^{3}$ molecule $\mathrm{e}^{-1 \mathrm{~s}-1}$ & $T / \mathrm{K}$ & Reference & Comments \\
\hline \multicolumn{4}{|l|}{ Rate Coefficient Measurements } \\
\hline $2.4 \cdot 10^{-11} \exp (-1640 / T)$ & $393-495$ & Jones and Cvetanovic, $1961^{1}$ & (a) \\
\hline $8.9 \cdot 10^{-14}$ & 303 & Grovenstein and Mosher, $1970^{2}$ & (b) \\
\hline $2.3 \cdot 10^{-13}$ & 298 & Mani and Sauer, $1968^{3}$ & (c) \\
\hline $7.5 \cdot 10^{-14}$ & 300 & Atkinson and Pitts, $1974^{4}$ & (d) \\
\hline $3.8 \cdot 10^{-11} \exp (-1942 / T)$ & $298-462$ & Colussi et al., $1975^{5}$ & (d) \\
\hline $1.4 \cdot 10^{-11} \exp (-1560 / T)$ & $299-392$ & Atkinson and Pitts, $1975^{6}$ & (d) \\
\hline $8.3 \cdot 10^{-12} \exp (-1359 / T)$ & $373-648$ & Furuyama and Ebara, $1975^{7}$ & (e) \\
\hline $1.6 \cdot 10^{-11} \exp (-1535 / T)$ & $299-440$ & Atkinson and Pitts, $1979^{8}$ & (f) \\
\hline $1.7 \cdot 10^{-10} \exp (-3625 / T)$ & $1700-2800$ & McLain, Jachimowski, and Wilson, $1979^{9}$ & (g) \\
\hline $4.3 \cdot 10^{-11} \exp (-1910 / T)$ & 298-932 & Nicovich, Gump, and Ravishankara, $1982^{10}$ & (h) \\
\hline $2.8 \cdot 10^{-11} \exp (-1770 / T)$ & $306-630$ & Tappe, Schliephake, and Wagner, $1989^{11}$ & (i) \\
\hline \multicolumn{4}{|l|}{ Reviews and Evaluations } \\
\hline $2.7 \cdot 10^{-11} \exp (-1720 / T)$ & $298-932$ & Cvetanovic, $1987^{12}$ & (j) \\
\hline $5.3 \cdot 10^{-15} T^{1.21} \exp (-1260 / T)$ & $298-2800$ & CEC, $1992^{13}$ & (k) \\
\hline
\end{tabular}

\section{Comments}

(a) $\mathrm{O}$ atoms from $\mathrm{Hg}$ photosensitized decomposition of $\mathrm{N}_{2} \mathrm{O}$. Ratio derived from relative $k$ data in competitive studies. Reference reaction was $\mathrm{O}+$ cyclopentene $\rightarrow$ products. Evaluated by Cvetanovic. ${ }^{12}$

(b) Same method as in (a). Reference reaction was $\mathrm{O}+$ benzene $\rightarrow$ products. Evaluated by Cvetanovic. ${ }^{12}$

(c) $\mathrm{O}$ atoms from pulse radiolysis of $\mathrm{CO}_{2}$ and $\mathrm{N}_{2} \mathrm{O}$ at high pressures. Rate coefficient from absorption spectra of transient species.

(d) Phase shift, $\mathrm{O}+\mathrm{NO}$ chemiluminescence. $\mathrm{O}$ atoms from $\mathrm{Hg}$ photosensitized decomposition of $\mathrm{N}_{2} \mathrm{O}$.

(e) Microwave discharge-fast flow reactor. $\mathrm{O}$ atoms from $\mathrm{N}+\mathrm{NO}$.

(f) Flash photolysis-resonance fluorescence. $\mathrm{O}$ atoms from VUV photolysis of $\mathrm{O}_{2}$ and NO.

(g) Incident shock wave investigation of the oxidation mechanism of $\mathrm{C}_{6} \mathrm{H}_{6} / \mathrm{O}_{2} / \mathrm{Ar}$ and $\mathrm{C}_{6} \mathrm{H}_{5} \mathrm{CH}_{3} / \mathrm{O}_{2} / \mathrm{Ar}$ mixtures by monitoring UV and IR emission of $\mathrm{CO}, \mathrm{CO}_{2}$. Arrhenius expression for the product channel $\mathrm{C}_{6} \mathrm{H}_{5} \mathrm{CH}_{2}+\mathrm{OH}$ estimated by comparison with data for benzene.

(h) Flash photolysis-resonance fluorescence. $\mathrm{O}$ atoms from VUV photolysis of $\mathrm{O}_{2}$.

(i) Flow reactor with mass spectrometric detection, $\mathrm{O}$-atoms produced by microwave discharge in $\mathrm{O}_{2}$. $\mathrm{O}$ atom concentration in excess by factors $86-518$. Total pressure range: 3.9-11.9 mbar. $T$-range: $300-870 \mathrm{~K}$. At temperatures above $630 \mathrm{~K}$ an upward curvature of the Arrhenius plot is observed.

(j) Critical evaluation and compilation of chemical kinetic data of $\mathrm{O}\left({ }^{3} \mathrm{P}\right)$ atoms with unsaturated hydrocarbons.

(k) See Comments on Preferred Values.

\section{Preferred Values}

$k=5.3 \cdot 10^{-15} T^{1.21} \exp (-1260 / T) \mathrm{cm}^{3}$ molecule ${ }^{-1} \mathrm{~s}^{-1}$ over range $298-2800 \mathrm{~K}$.
Reliability

$\Delta \log k= \pm 0.4$ at $2800 \mathrm{~K}$ reducing to \pm 0.1 at $300 \mathrm{~K}$.

\section{Comments on Preferred Values}

Our previous recommendations remain unchanged. ${ }^{13}$

The results of nine studies (Refs. 2-6, 8-11) in which the rate coefficient for total $O$ consumption by toluene was measured, are in excellent agreement for the range from room temperature up to about $1000 \mathrm{~K}$. The temperature dependence of the rate coefficient at higher temperatures is difficult to define because the only available rate expression has not been measured directly, but has been estimated from modelling a relatively complex reaction system. It has been assumed that at higher temperatures the reaction proceeds predominantly by direct abstraction of a $\mathrm{H}$ atom. The reliability at $2800 \mathrm{~K}$ has been estimated by comparing the shock tube values with the values obtained by linear extrapolation of the $k$ values in the $T$-range $300^{-} 1000 \mathrm{~K}$.

\section{References}

${ }^{1}$ G.R.H. Jones and R.J. Cvetanovic, Can. J. Chem. 39, 2444 (1961).

${ }^{2}$ E. Grovenstein, Jr. and A.J. Mosher, J. Am. Chem. Soc. 92, 3810 (1970).

${ }^{3}$ I. Mani and M.C. Sauer, Advanc. Chem. Ser. No. 82, 142 (1968).

${ }^{4}$ R. Atkinson and J.N. Pitts, Jr., J. Phys. Chem. 78, 1780 (1974).

${ }^{5}$ A.J. Colussi, D.L. Singleton, R.S. Irwin, and R.J. Cvetanovic, J. Phys. Chem. 79, 1900 (1975).

${ }^{6}$ R. Atkinson and J.N. Pitts, Jr., J. Phys. Chem. 79, 295 (1975).

${ }^{7}$ S. Furuyama and N. Ebara, Int. J. Chem. Kinet. 7, 689 (1975).

${ }^{8}$ R. Atkinson and J.N. Pitts, Jr., Chem. Phys. Lett 63, 485 (1979).

${ }^{9}$ A.G. McLain, C.J. Jachimowski, and C.H. Wilson, NASA TP-1472 (1979).

${ }^{10}$ J.M. Nicovich, C.A. Gump, and A.R. Ravishankara, J. Phys. Chem. 86, 1648 (1982).

${ }^{11}$ M. Tappe, V. Schliephake, and H.Gg. Wagner, Zeits. f. Phys. Chemie N.F. 162, 129 (1989).

${ }^{12}$ R.J. Cvetanovic, J. Phys. Chem. Ref. Data 16, 261 (1987).

${ }^{13} \mathrm{CEC}, 1992$ (see references in Introduction). 
BAULCH ET AL.

$$
\mathrm{O}+\mathrm{C}_{6} \mathrm{H}_{5} \mathrm{C}_{2} \mathrm{H}_{5} \rightarrow \text { products }
$$

Rate Coefficient Data

\begin{tabular}{|c|c|c|c|}
\hline$k / \mathrm{cm}^{3}$ molecule ${ }^{-1 \mathrm{~s}-1}$ & $T / \mathrm{K}$ & Reference & Comments \\
\hline \multicolumn{4}{|l|}{ Rate Coefficient Measurements } \\
\hline $5.3 \cdot 10^{-13}$ & 298 & Mani and Sauer, $1968^{!}$ & (a) \\
\hline $1.0 \cdot 10^{-13}$ & 303 & Grovenstein and Mosher, $1970^{2}$ & (b) \\
\hline $2.8 \cdot 10^{-11} \exp (-1840 / T)$ & $300-600$ & Tappe et al., $1989^{3}$ & (c) \\
\hline \multicolumn{4}{|l|}{ Reviews and Evaluations } \\
\hline $1.0 \cdot 10^{-13}$ & 298 & Cvetanovic, $1987^{4}$ & (d) \\
\hline $1.0 \cdot 10^{-13}$ & $298(1 \mathrm{bar})$ & CEC, $1992^{5}$ & (e) \\
\hline
\end{tabular}

\section{Comments}

(a) $\mathrm{O}$ from pulse radiolysis of $\mathrm{CO}_{2}$ or $\mathrm{N}_{2} \mathrm{O} . k$ from absorption spectra of transicnts (not positivcly identificd). $p \sim 53$ bar.

(b) Ratio derived from relative $k$ data in competition experiments. Reference reaction was $\mathrm{O}+$ benzene $\rightarrow$ products. $p \approx 1$ bar. Evaluated by Cvetanovic. ${ }^{4}$

(c) Flow reactor with mass spectrometric detection, $\mathrm{O}$-atoms produced by microwave discharge in $\mathrm{O}_{2}$. $\mathrm{O}$-atom concentration in excess by factors 107-346. Total pressure range: $2.2-4.3 \mathrm{mbar}$. $T$-range: $300-870 \mathrm{~K}$. At temperatures above $600 \mathrm{~K}$ an upward curvature of the Arrhenius plot is observed.

(d) Critical evaluation and compilation of chemical kinetic data of $\mathrm{O}\left({ }^{3} \mathrm{P}\right)$ atoms with hydrocarbons.

(e) Accepts the evaluation of Cvetanovic. ${ }^{4}$

\section{Preferred Values}

$k=2.8 \cdot 10^{-11} \exp (-1840 / T) \mathrm{cm}^{3}$ molecule ${ }^{-1} \mathrm{~s}^{-1}$ over range $298-600 \mathrm{~K}$.
Reliability

$\Delta \log k= \pm 0.3$ over range $298-600 \mathrm{~K}$.

\section{Comments on Preferred Values}

The preferred expression is that obtained in the recent study of Tappe et al. ${ }^{3}$ which is in reasonable agreement at $300 \mathrm{~K}$ with the earlier results of Grovenstein and Mosher ${ }^{2}$ which were the basis of our previous recommendations. ${ }^{5}$

\section{References}

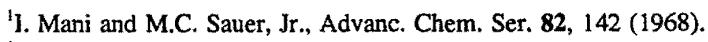

${ }^{2}$ E. Grovenstein, Jr. and A.J. Mosher, J. Am. Chem. Soc. 92, 3810 (1970).

${ }^{3}$ M. Tappe, V. Schliephake, and H.Gg. Wagner, Zeits.f. Phys. Chemie N.F. 162, 129 (1989).

${ }^{4}$ R.J. Cvetanovic, J. Phys. Chem. Ref. Data 16, 261 (1987).

${ }^{5} \mathrm{CEC}, 1992$ (see references in Introduction).

\section{$\mathrm{O}_{2}+\mathrm{C}_{3} \mathrm{H}_{6} \rightarrow \mathrm{HO}_{2}+\mathrm{CH}_{2} \mathrm{CHCH}_{2}$}

Thermodynamic Data

$\Delta H_{298}^{\circ}=151.7 \mathrm{~kJ} \mathrm{~mol}^{-1}$

$\Delta S_{298}^{\circ}=37.4 \mathrm{~J} \mathrm{~K}^{-1} \mathrm{~mol}^{-1}$

$K p=0.488 T^{0.01} \exp (-18170 / T)$

Rate Coefficient Data

\begin{tabular}{|c|c|c|c|}
\hline$k / \mathrm{cm}^{3}$ molecule ${ }^{-1} \mathrm{~s}^{-1}$ & $T / \mathrm{K}$ & Reference & Comments \\
\hline \multicolumn{4}{|c|}{ Rate Coefficient Measurements } \\
\hline $3.2 \cdot 10^{-12} \exp (-19670 / T)$ & $673-793$ & Stothard and Waiker, $1991^{1}$ & (a) \\
\hline \multicolumn{4}{|l|}{ Reviews and Evaluations } \\
\hline $1 \cdot 10^{-10} \exp (-23950 / T)$ & - & Tsang, $1991^{2}$ & (b) \\
\hline
\end{tabular}




\section{Comments}

(a) Oxidation of $\mathrm{C}_{3} \mathrm{H}_{6}$ under conditions where chain length is low. $k$ obtained by equating rate of initiation to rate of termination, which was determined directly. Minor corrections $(<20 \%)$ made for radical branching reactions.

(b) Estimate based on view that rate of abstraction should be similar to that of secondary $\mathrm{C}-\mathrm{H}$ in alkanes.

\section{Preferred Value}

$k=3.2 \cdot 10^{-12} \exp (-19700 / T) \mathrm{cm}^{3}$ molecule $\mathrm{s}^{-1} \mathrm{~s}^{-1}$ over range $600-1000 \mathrm{~K}$.

\section{Reliability} $600 \mathrm{~K}$.

$\Delta \log k= \pm 0.3$ at $800 \mathrm{~K}$ rising to \pm 0.5 at $1000 \mathrm{~K}$ and

\section{Comments on Preferred Values}

Although there are no other independent data to compare with the one available experimental study ${ }^{1}$, the rate coefficient values are in excellent agreement with those of the analogous reaction $\mathrm{O}_{2}+\mathrm{HCHO} \rightarrow \mathrm{HO}_{2}+\mathrm{HCO}$ for which $k$ $=3.4 \cdot 10^{-11} \exp (-19580 / T) \mathrm{cm}^{3}$ molecule ${ }^{-1} \mathrm{~s}^{-1}$ was obtained ${ }^{3}$ between 713 and $813 \mathrm{~K}$, the enthalpies of reaction being the same within $\pm 4 \mathrm{~kJ} \mathrm{~mol}^{-1}$. The low $A$ factor for $\mathrm{O}_{2}$ $+\mathrm{C}_{3} \mathrm{H}_{6}$ is consistent with loss of entropy of activation due to the emerging electron-delocalized allyl radical.

\section{References}

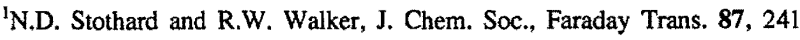
(1991).

${ }^{2}$ W. Tsang, J. Phys. Chem. Ref. Data 20, 231 (1991).

${ }^{3}$ R.R. Baldwin, A.R. Fuller, D. Longthom, and R.W. Walker, J. Chem. Soc., Faraday Trans. 1, 70, 1257 (1974).

$$
\mathrm{O}_{2}+\mathrm{C}_{6} \mathrm{H}_{5} \mathrm{CH}_{3} \rightarrow \mathrm{HO}_{2}+\mathrm{C}_{6} \mathrm{H}_{5} \mathrm{CH}_{2}
$$

Thermodynamic Data

$\Delta H_{298}^{\circ}=165.0 \mathrm{~kJ} \mathrm{~mol}^{-1}$

$\Delta S_{298}^{\circ}=23.9 \mathrm{~J} \mathrm{~K}^{-1} \mathrm{~mol}^{-1}$

$K p=1.93 \cdot T^{n .331} \exp (-19860 / T)$

Rate Coefficient Data

\begin{tabular}{llll}
\hline \hline$k / \mathrm{cm}^{3}$ molecule $\mathrm{s}^{-1}$ & $T / \mathrm{K}$ & Reference & Comments \\
\hline Rate Coefficient Measurements & & & \\
$5.5 \cdot 10^{-10} \exp (-19100 / T)$ & $\sim 1000$ & Bittker, 1988 & \\
$5 \cdot 10^{-10} \exp (-20800 / T)$ & $1000-1200$ & Emdee, Brezinsky, and Glassman, 1992 & (a) \\
\hline
\end{tabular}

\section{Comments}

(a) Reported by Fmdee et al. in Ref. 2. Rased on computer modelling fit in studies of toluene oxidation at about $1000 \mathrm{~K}$.

(b) Based on computer modelling fit to data obtained on the oxidation of toluene at atmospheric pressure between 1100 and $1200 \mathrm{~K}$. Authors claim high sensitivity of the rate of toluene consumption to the value for $k$ and hence estimate value of $k$. Activation energy estimated from reaction endothermicity, and pre-exponential factor adjusted to achieve best fit to the rate of toluene consumption. At $1100 \mathrm{~K}$ the value of $k$ is a factor of about 5 lower than recommended by Bittker. Mechanism still very uncertain and very complex, and any radical branching not isolated will result in high values of $k$.

\section{Preferred Value}

$k=3 \cdot 10^{-12} \exp (-20,000 / T) \mathrm{cm}^{2}$ molecule $\mathrm{s}^{-1} \mathrm{~s}^{-1}$ over range $700-1200 \mathrm{~K}$.

\section{Reliability}

$\Delta \log k= \pm 0.7$ over range $700-1200 \mathrm{~K}$.

\section{Comments on Preferred Values}

Although the activation energies given by Bittker ${ }^{1}$ and by Fmdee et $a l .^{2}$ are reasonable since $\Delta H \approx \mathrm{E}$, the $A$ factor is probably about two orders of magnitude too high. Directly determined values of $k_{\mathrm{If}}=3.4 \cdot 10^{-11} \exp (-19580 / T) \mathrm{cm}^{3}$ molecule $\mathrm{e}^{-1} \mathrm{~s}^{-1}$ for $\mathrm{HCHO}+\mathrm{O}_{2} \rightarrow \mathrm{HCO}+\mathrm{HO}_{2}{ }^{3}$ and $k_{1 p}=$ $3.2 \cdot 10^{-12} \exp (-19670 / T) \mathrm{cm}^{3}$ molecule ${ }^{-1} \mathrm{~s}^{-1}$ for $\mathrm{C}_{3} \mathrm{H}_{6}+\mathrm{O}_{2}$ $\rightarrow \mathrm{C}_{3} \mathrm{H}_{5}+\mathrm{HO}_{2}^{4}$ confirm the validity of $\Delta H \approx E$ for the primary initiation reaction $\mathrm{RH}+\mathrm{O}_{2} \rightarrow \mathrm{R}+\mathrm{HO}_{2}$. However, $A$ for $\mathrm{C}_{6} \mathrm{H}_{5} \mathrm{CH}_{3}+\mathrm{O}_{2}$ is a factor of 10 greater than $A_{1 \mathrm{f}}$ and a factor of 100 greater than $A_{1}$. Stothard and Walker ${ }^{4}$ have suggested that $A_{1 \mathrm{f}} / A_{1 p} \approx 10$ is reasonable and arises from an increased loss of entropy of activation due to electron delocalization in the emerging allyl radical. Formation of the benzyl radical also involves electron delocalization and the recommendation is thus based on equal $A$ factors for $\mathrm{C}_{3} \mathrm{H}_{6}+\mathrm{O}_{2}$ and $\mathrm{C}_{6} \mathrm{H}_{5} \mathrm{CH}_{3}+$ $\mathrm{O}_{2}$. Support ${ }^{5}$ for this view comes from the value of $k\left(\mathrm{HO}_{2}+\right.$ $\left.\mathrm{HCHO} \rightarrow \mathrm{HCO}+\mathrm{HO}_{2}\right) / k\left(\mathrm{HO}_{2}+\mathrm{C}_{6} \mathrm{H}_{5} \mathrm{CH}_{3} \rightarrow \mathrm{C}_{6} \mathrm{H}_{5} \mathrm{CH}_{2}+\right.$ $\left.\mathrm{H}_{2} \mathrm{O}_{2}\right)=14$ at $750 \mathrm{~K}$, the two reactions having the same activation energy to within $4 \mathrm{~kJ} \mathrm{~mol}{ }^{1}$, so that the difference in rate constants arises mostly from the much lower $A$ factor for $\mathrm{HO}_{2}+\mathrm{C}_{6} \mathrm{H}_{5} \mathrm{CH}_{3}$.

In addition, thermochemical calculation of the rate constant for the reverse reaction, $\mathrm{HO}_{2}+\mathrm{C}_{6} \mathrm{H}_{5} \mathrm{CH}_{2} \rightarrow \mathrm{O}_{2}+\mathrm{C}_{6} \mathrm{H}_{5} \mathrm{CH}_{3}$ 
from the Emdee et al. data ${ }^{2}$ gives a value of $3.5 \cdot 10^{-10} \mathrm{~cm}^{3}$ molecule $\mathrm{e}^{-1} \mathrm{~s}^{-1}$ at $1100 \mathrm{~K}$ which is at least a factor of 10 too high and compares with $k=3.3 \cdot 10^{-12}$ between 700 and $800 \mathrm{~K}$ determined experimentally for $\mathrm{C}_{3} \mathrm{H}_{5}+\mathrm{HO}_{2} \rightarrow \mathrm{C}_{3} \mathrm{H}_{6}+\mathrm{O}_{2}$. Use of the recommended value of $k$ gives a value of $2.0 \cdot 10^{-12} \mathrm{~cm}^{3}$ molecule ${ }^{-1} \mathrm{~s}^{-1}$ for the reverse reaction, $\mathrm{HO}_{2}+\mathrm{C}_{6} \mathrm{H}_{5} \mathrm{CH}_{2} \rightarrow$ $\mathrm{C}_{6} \mathrm{H}_{5} \mathrm{CH}_{3}+\mathrm{O}_{2}$.

\section{References}

'D.A, Bittker, Detailed Mechanism of Toluene Oxidation and Comparison with Benzene: NASA Tech. Memo. 100261, 1988.

${ }^{2}$ J.L. Emdee, K. Brezinsky, and J. Glassman, J. Phys. Chem. 96, 2151 (1992). ${ }^{3}$ R.R. Baldwin, A.R. Fuller, D. Longthorn, and R.W. Walker, J. Chem. Soc., Faraday Trans. 1, 70, 1257 (1974).

${ }^{4}$ N.D. Stothard and R.W. Walker, J. Chem. Soc., Faraday Trans. 87, 241 (1991).

${ }^{5}$ M. Scott and R.W. Walker, J. Chem. Soc., Faraday Trans. (to be published).

$$
\mathrm{H}+\mathrm{O}_{2} \rightarrow \mathrm{OH}+\mathrm{O}
$$

Thermodynamic Data

$\Delta H_{298}^{\circ}=70.2 \mathrm{~kJ} \mathrm{~mol}^{-1}$

$\Delta S_{298}^{\circ}=24.9 \mathrm{~J} \mathrm{~K}^{-1} \mathrm{~mol}^{-1}$

$K p=3.02 \cdot 10^{2} T^{-0.374} \exp (-8620 / T)$

Rate Coefficient Data

\begin{tabular}{llll}
\hline \hline$k / \mathrm{cm}^{3}$ molecule $^{-1} \mathrm{~s}^{-1}$ & $T / \mathrm{K}$ & Reference & Comments \\
\hline Rate Coefficient Measurements & $1900-2650$ & Fujii and Shin, $1988^{1}$ & (a) \\
$9.96 \cdot 10^{-10} \exp (-11427 / T)$ & $1450-3370$ & Masten et al. $1990^{2}$ & $(\mathrm{~b})$ \\
$1.55 \cdot 10^{-10} \exp (-7440 / T)$ & $1050-2700$ & Yuan et al. $1991^{3}$ & $(\mathrm{c})$ \\
$2.64 \cdot 10^{-7} T^{-0.927} \exp (-8493 / T)$ & $1102-2055$ & Shin and Michael, $1991^{4}$ & (d) \\
$1.15 \cdot 10^{-10} \exp (-6917 / T)$ & $2050-5305$ & Du and Hessler, $1992^{5}$ & $(\mathrm{e})$ \\
$1.55 \cdot 10^{-10} \exp (-7270 / T)$ & & & \\
Reviews and Evaluations & $300-2500$ & CEC, $1992^{6}$ & $($ (f) \\
$3.3 \cdot 10^{-10} \exp (-8456 / T)$ & & & \\
\hline
\end{tabular}

\section{Comments}

(a) The concentration growth of $\mathrm{OH}$ radicals was measured in rich shock-heated $\mathrm{H}_{2}-\mathrm{O}_{2}-\mathrm{Ar}$ mixtures by $\mathrm{cw}$ laser absorption spectroscopy.

(b) Shock tube study. $\mathrm{OH}$ was detected by $\mathrm{OH}$ laser absorption. Additional $\mathrm{H}$ atom production was measured with ARAS. Combination of these results with those of Pirraglia et al..$^{9}$ gives $k=5.84 \cdot 10^{-8} T^{-0.7} \exp (-8580 / T) \mathrm{cm}^{3}$ molecule $\mathrm{s}^{-1}$.

(c) A shock tube/laser absorption/detailed modelling study. Total pressure 1.57-3.13 atm. $\mathrm{H}_{2} / \mathrm{O}_{2}$ was diluted in Argon. The reaction progress was measured in situ by stateselective laser absorption of $\mathrm{OH}$ radicals.

(d) Laser photolysis/shock tube study. H- or D-atom detection by atomic resonance absorption spectroscopy (ARAS). Total density during shock in range (1.668$3.364) \cdot 10^{+18} \mathrm{~cm}^{-3}$.

(e) Tunable laser/flash absorption technique used to monitor $\mathrm{OH}$ in shock heated $\mathrm{H}_{2} / \mathrm{O}_{2} / \mathrm{Ar}$ or $\mathrm{Kr}$ mixtures. Results were combined with previous measurements ${ }^{2,4,9}$ to give the expression $k=1.62 \cdot 10^{-10} \exp (-7474 / T) \mathrm{cm}^{3}$ molecule ${ }^{-1} \mathrm{~s}^{-1}$ over range $960-5300 \mathrm{~K}$.

(f) Based on earlier evaluation of Baulch et al. ${ }^{7}$ and results of Frank and Just ${ }^{8}$ and Pirraglia et al. ${ }^{9}$

\section{Preferred Values}

$k=1.62 \cdot 10^{-10} \exp (-7474 / T)$ over range $300-5000 \mathrm{~K}$.

\section{Reliability}

$\Delta \log k= \pm 0.2$ at $300 \mathrm{~K}$ rising to \pm 0.5 at $5000 \mathrm{~K}$.

\section{Comments on Preferred Values}

The expression derived by Du and Hessler ${ }^{5}$ is preferred. It lies within the error limits of the previous CEC recommenations ${ }^{6}$ but incorporates the new results of Fujii and Shin ${ }^{1}$, Masten $e t a l .{ }^{2}$ and Shin and Michael ${ }^{4}$ and extends the temperature range.

References to earlier results shown on the graph may be found in CEC, $1992^{6}$.

\section{References}

'S. Fujii and K.S. Shin, Chem. Phys. Lett. 151, 461 (1988).

${ }^{2}$ D.A. Masten, R.K. Hansen, and C.T. Bowman, J. Phys. Chem. 94, 7119 (1990).

${ }^{3}$ T. Yuan, C. Wang, C.L. Yu, M. Frenklach, and M.J. Rabinowitz, J, Phys. Chem. 95, 1258 (1991).

${ }^{4}$ K.S. Shin and J.V. Michael, J. Chem. Phys. 95, 262 (1991).

${ }^{5}$ H. Du and J.P. Hessler, J. Chem. Phys. 96, 1077 (1992).

${ }^{6} \mathrm{CEC}, 1992$ (see references in Introduction).

${ }^{7}$ D.L. Baulch, D.D. Drysdale, D.G. Horne, and A.C. Lloyd, 'Evaluated Kinetic Data for High Temperature Reactions', Vol. 1 ' Homogeneous Gas Phase Reactions of the $\mathrm{H}_{2}-\mathrm{O}_{2}$ System.' Butterworths, London (1972).

${ }^{8}$ P. Frank and Th. Just, Ber. Bunsenges. Phys. Chem. 89, 181 (1985).

${ }^{9}$ A.N. Pirraglia, J.V. Michael, J.W. Sutherland, and R.B. Klemm, J. Phys. Chem. 93, 282 (1989). 


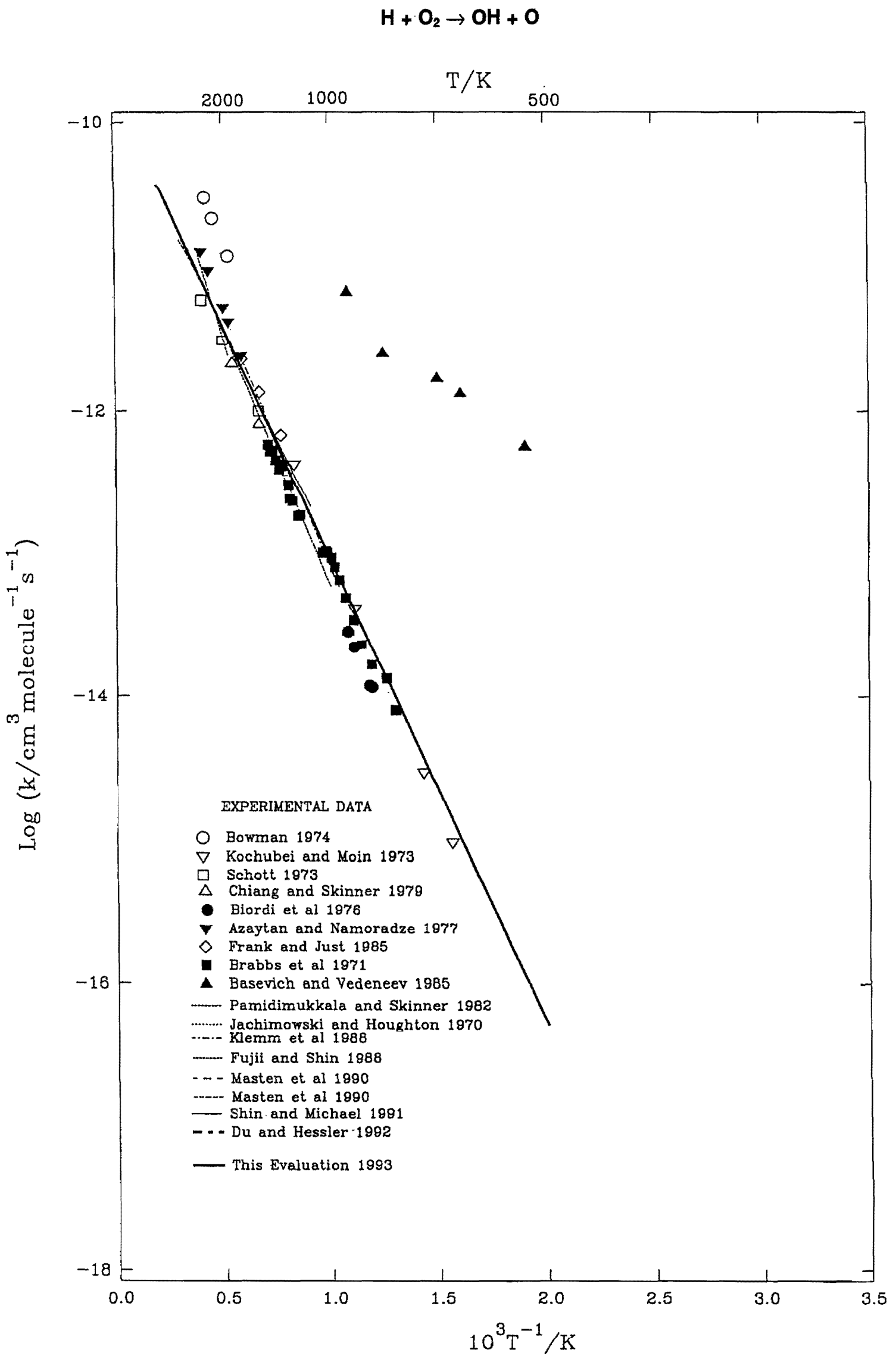




$$
\mathrm{H}+\mathrm{O}_{2}(+\mathrm{M}) \rightarrow \mathrm{HO}_{2}(+\mathrm{M})
$$

Thermodynamic Data

$\Delta H_{298}^{\circ}=-208 \mathrm{~kJ} \mathrm{~mol}^{-1}$

$\Delta S_{298}^{\circ}=-90.6 \mathrm{~J} \mathrm{~K}^{-1} \mathrm{~mol}^{-1}$

$K p=6.9 \cdot 10^{-3} T^{-0.95} \exp (+24800 / T) \mathrm{atm}^{-1}$

Rate Coefficient Data

\begin{tabular}{|c|c|c|c|c|c|}
\hline$k / \mathrm{cm}^{6}$ molecule $\mathrm{e}^{-2} \mathrm{~s}^{-1}$ & $T / \mathrm{K}$ & $\mathrm{p} /$ Torr & $M$ & Reference & Comments \\
\hline \multicolumn{6}{|c|}{ Rate Coefficient Measurements } \\
\hline $0.99 \cdot 10^{-32}$ & 800 & $100-243$ & $\mathrm{~N}_{2}$ & Hanning-Lee et al., $1991^{1}$ & (a) \\
\hline $2.95 \cdot 10^{-32}$ & 825 & $100-243$ & $\mathrm{~N}_{2}$ & & \\
\hline $3.45 \cdot 10^{-32}$ & 850 & $100-243$ & $\mathrm{~N}_{2}$ & & \\
\hline \multicolumn{6}{|c|}{ Reviews and Evaluations } \\
\hline $1.8 \cdot 10^{-29} \mathrm{~T}^{-1}$ & $300-2500$ & & $\mathrm{O}_{2}, \mathrm{~N}_{2}$ & Tsang and Hampson, $1986^{2}$ & (b) \\
\hline $1.7 \cdot 10^{-30} T^{-0.8}$ & $300-2000$ & & $\mathrm{Ar}$ & CEC, $1992^{3}$ & (c) \\
\hline $3.9 \cdot 10^{-30} T^{-0.8}$ & $300-2000$ & & $\mathrm{~N}_{2}$ & & \\
\hline $5.8 \cdot 10^{-30} T^{-0.8}$ & $300-2000$ & & $\mathrm{H}_{2}$ & & \\
\hline
\end{tabular}

\section{Comments}

(a) Flow reactor; $\mathrm{H}$ generated by microwave discharge or by thermal decomposition on a W filament. $[\mathrm{H}]$ by resonance absorption, $[\mathrm{OH}]$ by resonance fluorescence.

(b) Based on evaluations by the CODATA ${ }^{4}$ and $\mathrm{NASA}^{5}$ Groups.

(c) See comments on Preferred Values.

\section{Preferred Values}

$k=1.7 \cdot 10^{-30} \mathrm{~T}^{-0.8} \mathrm{~cm}^{6}$ molecule ${ }^{-2} \mathrm{~s}^{-1}$ over range 300 $2000 \mathrm{~K}$ for $\mathrm{M}=\mathrm{Ar}$.

$k=5.8 \cdot 10^{-30} T^{-0.8} \mathrm{~cm}^{6}$ molecule ${ }^{-2} \mathrm{~s}^{-1}$ over range 300 $2000 \mathrm{~K}$ for $\mathrm{M}=\mathrm{H}_{2}$.

$k=3.9 \cdot 10^{-30} T^{-0.8} \mathrm{~cm}^{6}$ molecule ${ }^{-2} \mathrm{~s}^{-1}$ over range $300-$ $2000 \mathrm{~K}$ for $\mathrm{M}=\mathrm{N}_{2}$.

Reliability

$\Delta \log k= \pm 0.5$ over range $300-2000 \mathrm{~K}$.

\section{Comments on Preferred Values}

The recommendations are unchanged from our previous evaluation which were based largely on the recommendations of Baulch et al. ${ }^{6 .}$ The new data of Hanning-Lee et al. ${ }^{1}$ are in agreement within the error limits.

\section{References}

${ }^{1}$ M.A. Hanning-Lee, M.J. Pilling, and J.F. Jonathan, J. Chem. Soc. Faraday Trans. 15, 2907 (1991).

${ }^{2}$ W. Tsang, R.F. Hampson, J. Phys. Chem. Ref. Data 15, 1087 (1986).

${ }^{3} \mathrm{CEC}, 1992$ (see references in Introduction).

${ }^{4}$ D.L. Baulch, R.A. Cox, P.J. Crutzen, R.F. Hampson, J.A. Kerr, J. Troe, and R.T. Watson, J. Phys. Chem. Ref. Data, 13, 1259 (1984).

${ }^{5}$ W.B. DeMore, D.M. Golden, R.F. Hampson, C.J. Howard, M.J. Kurylo, M.J. Molina, A.R. Ravishankara, and R.J. Watson, JPL Publ. 85-37 (1985).

${ }^{6}$ D.L. Baulch, D.D. Drysdale, D.G. Horne, and A.C. Lloyd, "Evaluated Kinetic Data for High Temperature Reactions", Vol. 1; "Homogeneous Gas Phase Reactions of the $\mathrm{H}_{2}-\mathrm{O}_{2}$ System", London, Butterworths (1972). 


$$
\mathrm{H}+\mathrm{NO} \rightarrow \mathrm{OH}+\mathrm{N}
$$

Thermodynamic Data

$\Delta H_{298}^{\circ}=203.1 \mathrm{~kJ} \mathrm{~mol}^{-1}$

$\Delta S_{298}^{\circ}=11.6 \mathrm{~J} \mathrm{~K}^{-1} \mathrm{~mol}^{-1}$

$K p=24.4 T^{0.257} \exp (-24560 / T)$

Rate Coefficient Data

\begin{tabular}{|c|c|c|c|}
\hline $\mathrm{k} / \mathrm{cm}^{3}$ molecule $\mathrm{e}^{-1} \mathrm{~s}^{-1}$ & $T / \mathrm{K}$ & Reference & Comments \\
\hline \multicolumn{4}{|l|}{ Rate Coefficient Measurements } \\
\hline $5.76 \cdot 10^{-10} \exp (-23940 / T)$ & $2530-3020$ & Bradley and Craggs, $1975^{1}$ & (a) \\
\hline $4.28 \cdot 10^{-10} \exp (-24560 / T)$ & $2200-3250$ & Duxbury and Pratt, $1975^{2}$ & (b) \\
\hline $8,32 \cdot 10^{-11} \exp (-24510 / T)$ & $2400-3500$ & Ando and Asaba, $1976^{3}$ & (c) \\
\hline $3.71 \cdot 10^{-10} \exp (-25410 / T)$ & $2400-4200$ & Flower et al.. $1977^{4}$ & (d) \\
\hline $2.89 \cdot 10^{-10} \exp (-24760 / T)$ & $1750-2040$ & McCullough et al., $1977^{5}$ & (e) \\
\hline \multicolumn{4}{|l|}{ Reviews and Evaluations } \\
\hline $2.82 \cdot 10^{-10} \exp (-24560 / T)$ & $1750-4200$ & Hanson and Salimian, $1984^{6}$ & (f) \\
\hline
\end{tabular}

\section{Comments}

(a) Shock tube study with fluorescence detection of NO at $226 \mathrm{~nm}$ and $\mathrm{OH}$ at $306.4 \mathrm{~nm}$. Computer simulation of concentration profiles used to derive rate constant.

(b) Shock tube study using highly diluted $\mathrm{H}_{2} / \mathrm{NO} / \mathrm{Ar}$ mixtures with monitoring of $\mathrm{NO}, \mathrm{OH}, \mathrm{NH}_{3}$ and $\mathrm{NH}$ in absorption. Computer modelling of $[\mathrm{OH}]$ and $[\mathrm{NO}]$ profiles used to derive rate constant.

(c) Reanalysis of the data of Koshi et al. ${ }^{7}$, who carried out a shock tube study on $\mathrm{NO} / \mathrm{H}_{2} / \mathrm{Ar}$ mixtures, monitoring [O] by $\mathrm{NO} / \mathrm{O}$ chemiluminescence at $650 \mathrm{~nm}$ and [NO] in emission at $5.22 \mu \mathrm{m}$.

(d) Shock tube study of $\mathrm{NO} / \mathrm{H}_{2}$ /inert gas mixtures. IR emission from NO and $\mathrm{H}_{2} \mathrm{O}$ at 5.3 and $6.3 \mu \mathrm{m}$ monitored. Comparison of computed with experimental profiles used to derive $k$.

(e) Dilute mixtures of $\mathrm{NO} / \mathrm{H}_{2} / \mathrm{Ar}$ passed through alumina packed flow reactor heated to temperatures in the range 1750-2040. Fractional decomposition of NO monitored as a function of flow rate using chemiluminescence detection.

(f) Based on Duxbury and Pratt ${ }^{2}$, Flower et al.$^{4}$, McCullough et al..$^{5}$.

\section{Preferred Values}

$k=3.6 \cdot 10^{-10} \exp (-24910 / T) \mathrm{cm}^{3}$ molecule $^{-1} \mathrm{~s}^{-1}$ over the range $1500-4500 \mathrm{~K}$.

Reliability

$\Delta \log k= \pm 0.5$.

\section{Comments on Preferred Values}

All of the studies of this reaction are in good agreement on the temperature coefficient of $k$ but the absolute values show considerable scatter in the temperature region where the studies overlap.

Our recommendations are based on the studies of Duxbury and Pratt ${ }^{2}$, Flower et al.$^{4}$, and McCullough et al. ${ }^{5}$ and are very similar to those of Hanson and Salimian ${ }^{6}$. The temperature coefficient from the three studies ${ }^{2,4.5}$ was averaged and a preexponential factor was derived from the temperature coefficient and a mean value of $k$ at $2500 \mathrm{~K}$.

The recommended expressions for $k$ for the forward and reverse reactions give an expression for the equilibrium constant considerably different from the thermodynamic expression but within the substantial error limits of the kinetic data.

\section{References}

'J.N. Bradley and P. Craggs, 15th Symp. (Int.) Combust., 833 (1975).

${ }^{2}$ J. Duxbury and N.H. Pratt, 15th Symp. (Int.) Combust., 843 (1975).

${ }^{3}$ H. Ando and T. Asaba, Int. J. Chem. Kinet. 8, 259 (1976).

${ }^{4}$ W.L. Flower, R.K. Hanson, and C.H. Kruger, Comb. Sci. Tech. 15, 115 (1977).

${ }^{5}$ R.W. McCullough, C.H. Kruger, and R.K. Hanson, Combust. Sci. Tech. 15, 213 (1977).

${ }^{6}$ R.K. Hanson and S. Salimian in Combustion Chemistry, Ed. W.C. Gardiner, Springer-Verlag (1984).

${ }^{7}$ M. Koshi, H. Ando, M. Oya, and T. Asaba, 15th Symp. (Int.) Combust., 809 (1975). 


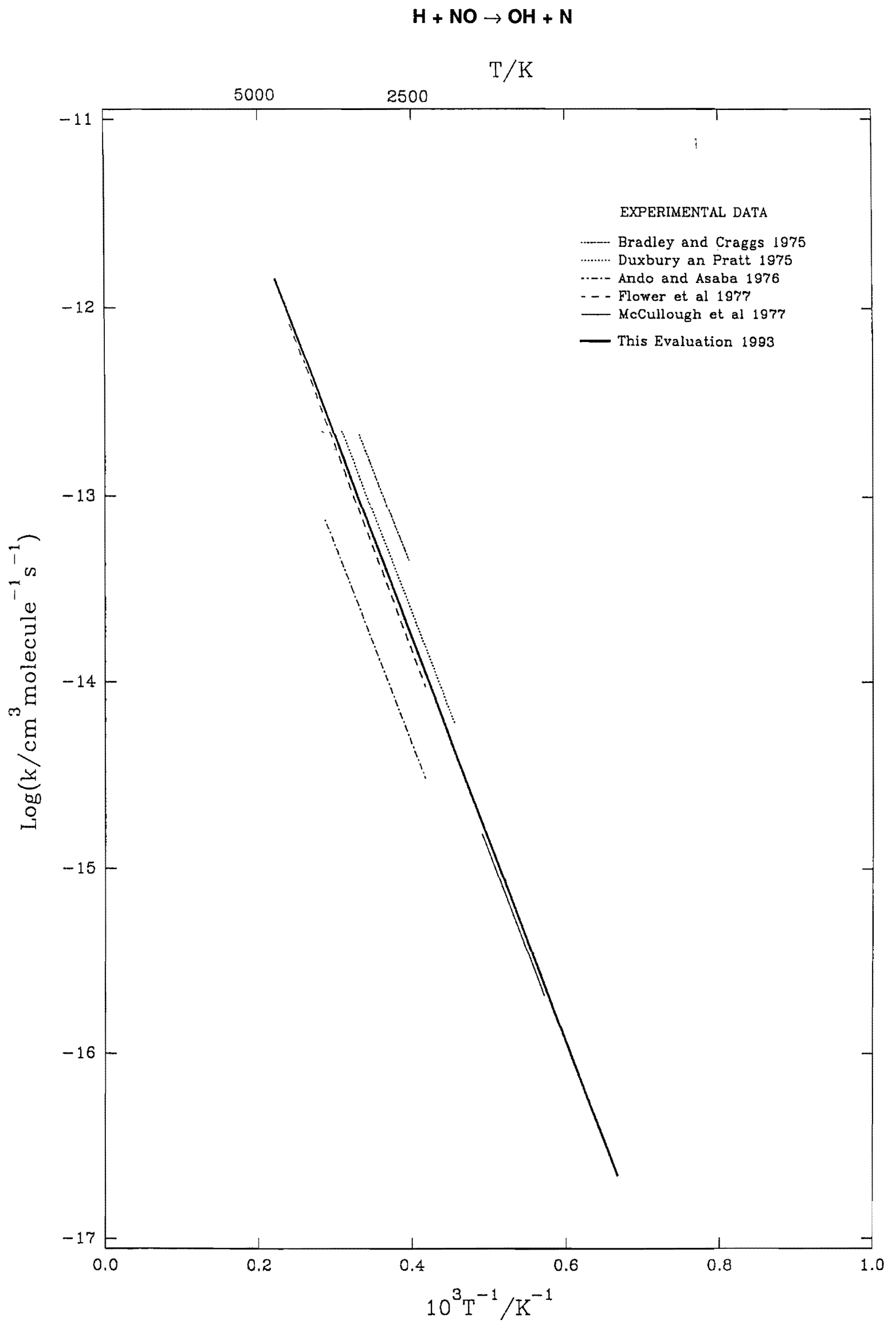




$$
\mathrm{H}+\mathrm{CO}(+\mathrm{M}) \rightarrow \mathrm{HCO}(+\mathrm{M})
$$

Thermodynamic data

$\Delta H_{298}^{\circ}=-63.9 \mathrm{~kJ} \mathrm{~mol}^{-1}$

$\Delta S_{298}^{\circ}=-20.9 \mathrm{~J} \mathrm{~K}^{-1} \mathrm{~mol}^{-1}$

$K p=1.5 \cdot 10^{-2} T^{-1.0} \exp (+7560 / T) \mathrm{atm}^{-1}$

\section{Rate Coefficient Data}

\begin{tabular}{|c|c|c|c|c|}
\hline$k / \mathrm{cm}^{3}$ molecule $\mathrm{e}^{-1} \mathrm{~s}^{-1}$ & $T / \mathrm{K}$ & {$[\mathrm{M}] /$ molecule $\mathrm{cm}^{-3}$} & References & Comments \\
\hline \multicolumn{5}{|l|}{ Rate Coefficient Measurements } \\
\hline \multicolumn{5}{|l|}{ Low Pressure Range } \\
\hline$[\operatorname{Ar}](7.2 \pm 1.1) \cdot 10^{-35}$ & 298 & $(1.9-5.2) \cdot 10^{19}$ & Hikida, Eyre and Dorfman, $1971^{1}$ & (a) \\
\hline$\left[\mathrm{H}_{2}\right](1.1 \pm 0.2) \cdot 10^{-34}$ & & $(0.7-4.5) \cdot 10^{19}$ & & \\
\hline$[\mathrm{He}] 3.3 \cdot 10^{-34}$ & 298 & $(1.6-8.1) \cdot 10^{18}$ & Bennet and Blackmore, $1971^{2}$ & (b) \\
\hline$[\mathrm{He}] 4.7 \cdot 10^{-35}$ & 298 & $(3.4-19) \cdot 10^{18}$ & Ahumada, Michael, and Osborne, $1972^{3}$ & (c) \\
\hline$[\mathrm{Ne}] 4.1 \cdot 10^{-35}$ & & $(3.3-19) \cdot 10^{18}$ & & \\
\hline$[\mathrm{Ar}] 5.3 \cdot 10^{-35}$ & & $(1.7-19) \cdot 10^{18}$ & & \\
\hline$[\mathrm{Kr}] 7.3 \cdot 10^{-35}$ & & $(3.2 \cdot 19) \cdot 10^{18}$ & & \\
\hline$\left[\mathrm{H}_{2}\right] 7.5 \cdot 10^{-35}$ & & $(1.8-19) \cdot 10^{18}$ & & \\
\hline$\left[\mathrm{H}_{2}\right] 6.3 \cdot 10^{-34}$ & 773 & - & Baldwin et al ., $1972^{4}$ & (d) \\
\hline$\left[\mathrm{H}_{2}\right] 2.2 \cdot 10^{-33} \exp (-1064 / T)$ & $298-373$ & $(0.7-4.5) \cdot 10^{19}$ & Wang, Eyre, and Dorfman, $1973^{5}$ & (e) \\
\hline$[\mathrm{Ar}](2.7 \pm 0.2) \cdot 10^{-34}$ & 425 & $(0.6-1.7) \cdot 10^{17}$ & Campbell and Handy, $1978^{6}$ & (f) \\
\hline$\left[N_{2}\right](4.0 \pm 0.3) \cdot 10^{-34}$ & & $(7.0-7.9) \cdot 10^{16}$ & & \\
\hline$[\mathrm{CO}](9.9 \pm 2.5) \cdot 10^{-35}$ & & $(2.5-7.4) \cdot 10^{19}$ & & \\
\hline$\left[\mathrm{CH}_{4}\right](1.6 \pm 0.2) \cdot 10^{-34}$ & & $2.5 \cdot 10^{19}$ & & \\
\hline \multicolumn{5}{|l|}{ Reviews and Evaluations } \\
\hline$k_{0}=\left[\mathrm{H}_{2}\right] 1.6 \cdot 10^{-34} T^{0.11}$ & $1400-3000$ & & Browne, White, and Smookler, $1969^{8}$ & (h) \\
\hline$k_{0}=\left[\mathrm{H}_{2}\right] 2.0 \cdot 10^{-33} \exp (-850 / T)$ & $298-773$ & & Baulch et al., $1976^{\circ}$ & (i) \\
\hline$k_{0}=\left[\mathrm{H}_{2}\right] 1,4 \cdot 10^{-33} \exp (-760 / T)$ & 1100 & & Cherian et al., $1981^{10}$ & (j) \\
\hline$k_{0}=\left[\mathrm{H}_{2}\right] 1.9 \cdot 10^{-33} \exp (-842 / T)$ & $300-2000$ & & Warnatz, $1984^{11}$ & $(\mathrm{k})$ \\
\hline $\begin{aligned} k_{0} & =\left[\mathrm{N}_{2}\right] 1.74 \cdot 10^{-27} T^{-1.82} \\
& \exp (-1856 / T)\end{aligned}$ & $800-2500$ & & Tsang and Hampson, $1986^{12}$ & (1) \\
\hline
\end{tabular}

\section{Comments}

(a) $\mathrm{H}$ atoms generated by pulse radiolysis of $\mathrm{H}_{2}$ and detected by Lyman- $\alpha$ spectrophotometry. Diffusion of $\mathrm{H}$ atoms to the wall taken into account.

(b) Fast-flow study. $\mathrm{H}$ atoms were generated by a hot tungsten wire or by a high-pressure microwave discharge and detected by ESR.

(c) $\mathrm{H}$ atums formed by mercury photosensitization of $\mathrm{H}_{2}$ and monitored by Lyman- $\alpha$ absorption spectrophotometry. Steady state conditions and decay of $[\mathrm{H}]$ followed after the end of the light pulse.

(d) Thermal reaction of $\mathrm{H}_{2} / \mathrm{CO} / \mathrm{O}_{2}$ mixtures. Study of the second explosion limit in $\mathrm{KCl}$ and $\mathrm{CsCl}$ coated vessels.

(e) Pulse radiolysis of $\mathrm{H}_{2} . \mathrm{H}$ monitored by Lyman- $\alpha$ spectrophotometry. An activation energy of $\mathrm{E}_{2}=2.0 \pm 0.4 \mathrm{kcal}$ $\mathrm{mol}^{-1}$ was determined. The value of the pre-exponential factor given here is based on the $k_{0}$ data from Ref. 1 .

(f) Discharge flow stirred reaction study of $\mathrm{O}_{2}-\mathrm{H}_{2}-\mathrm{CO}-\mathrm{N}_{2}$ (or Ar) mixtures. The experiments were conducted over the ranges $90 \leqslant[\mathrm{CO}] /[\mathrm{O}] \leqslant 950$ and $0.2 \leqslant[\mathrm{H}] /[\mathrm{O}] \leqslant 3$.

(g) Flash photolysis of $\mathrm{H}_{2} \mathrm{O}$ vapour in the presence of $\mathrm{CO}$. [HCO] monitored by UV absorption at $230 \mathrm{~nm}$. The competing reaction $\mathrm{H}+\mathrm{HCO} \rightarrow \mathrm{H}_{2}+\mathrm{CO}$ is significant during the formation of $\mathrm{HCO}$. From the amount of $\mathrm{H}_{2} \mathrm{O}$ photodissociated (using the $\mathrm{H}_{2} \mathrm{O}+\mathrm{CH}_{4}$ system as an actinometer) and a computer modelling of the formation and decay rates of $\mathrm{HCO}$ values of $k$ were obtained.

(h) Expression recommended for modelling of shock heated $\mathrm{H}_{2} / \mathrm{CO} / \mathrm{O}_{2}$ mixtures. Evaluation based on data from Ref. 7.

(i) Evaluation of the literature up to 1975.

(j) Modelling of $\mathrm{CO}$ oxidation in flames.

(k) Review of literature rate data.

(l) Data evaluation and construction of RRKM fall-off curves.

\section{Preferred Values}

$k_{\mathrm{o}}=[\mathrm{Ar}] 5.3 \cdot 10^{-34} \exp (-370 / T) \mathrm{cm}^{3}$ molecule $\mathrm{e}^{-1} \mathrm{~s}^{-1}$ over range $300-2500 \mathrm{~K}$.

\section{Reliability}

$\Delta \log k_{\mathrm{o}}= \pm 0.5$ for $\mathrm{M}=$ Ar over range $300-2500 \mathrm{~K}$.

\section{Comments on Preferred Values}

The absolute values of $k_{0}$ close to room temperature and the temperature dependence of $k_{0}$ remain considerably uncertain. Most previous evaluations of the temperature dependence have been based on the reverse dissociation reaction. Here, we have converted the recommended $k_{\mathrm{o}}$ values for the dissociation reaction to recombination using the calculated equi- 
librium constant as given above. The preferred values of $k_{\mathrm{o}}$ are consistent with an average energy transferred per collision of $20[T / 300] \mathrm{cm}^{-1}$. Figure 1 shows the temperature dependence of $k_{\mathrm{o}}$ from several sources together with our recommendation.

\section{References}

${ }^{1}$ T. Hikida, J.A. Eyre, and L.M. Dorfman, J. Chem. Phys. 54, 3422 (1971). ${ }^{2}$ J.E. Bennet and D.R. Blackmore, 13th Symp. Int. Combust., 51 (1971).

${ }^{3}$ I.I. Ahumada, J.V. Michael, and D.T. Oshome, I. Chem. Phys. 57. 3736 (1972).

${ }^{4}$ R.R. Baldwin, D. Jackson, A. Melvin, and B.N. Rossiter, Int. J. Chem. Kinet. 4, 277 (1972)

${ }^{5}$ H.Y. Wang, J.A. Eyre, and L.M. Dorfman, J. Chem. Phys. 59, 5199 (1973).

${ }^{6}$ I.M. Campbell and B.J. Handy, J. Chem. Soc., Faraday Trans. I 74, 316 (1978).
${ }^{7}$ C.J. Hochanadel, T.J. Sworsky, and P.J. Ogren, J. Phys. Chem. 24, 231 (1980).

${ }^{8}$ W.G. Browne, D.R. White, and G.R. Smookler, 12th Symp. Int. Combust., 557 (1969).

${ }^{9}$ W.G. Browne, R.P. Porter, J.D. Verlin, and A.H. Clark, 12th Symp. Int. Combust., 1035 (1969).

${ }^{10}$ D.L. Baulch, D.D. Drysdale, J. Duxbury, and S. Grant, "Evaluated Kinetic Data for High Temperature Reactions", Vol. 3: Homogeneous Gas Phase Reactions of the $\mathrm{O}_{2}-\mathrm{O}_{3}$ System, the $\mathrm{CO}-\mathrm{O}_{2}-\mathrm{H}_{2}$ System, and of Sulphur-Containing Species", London, Butterworths (1976).

"M.A. Cherian. P. Rhodes. R.J. Simpson. and G. Dixon-Lewis, 18th Symp. Int. Combust., 385 (1981).

${ }^{12} \mathrm{~J}$. Wamatz, in "Combustion Chemistry", ed. W.C. Gardiner, Springer-Verlag, New York, (1984).

${ }^{13}$ W. Tsang and R.F. Hampson, J. Phys. Chem. Ref. Data 15, 1087 (1986).

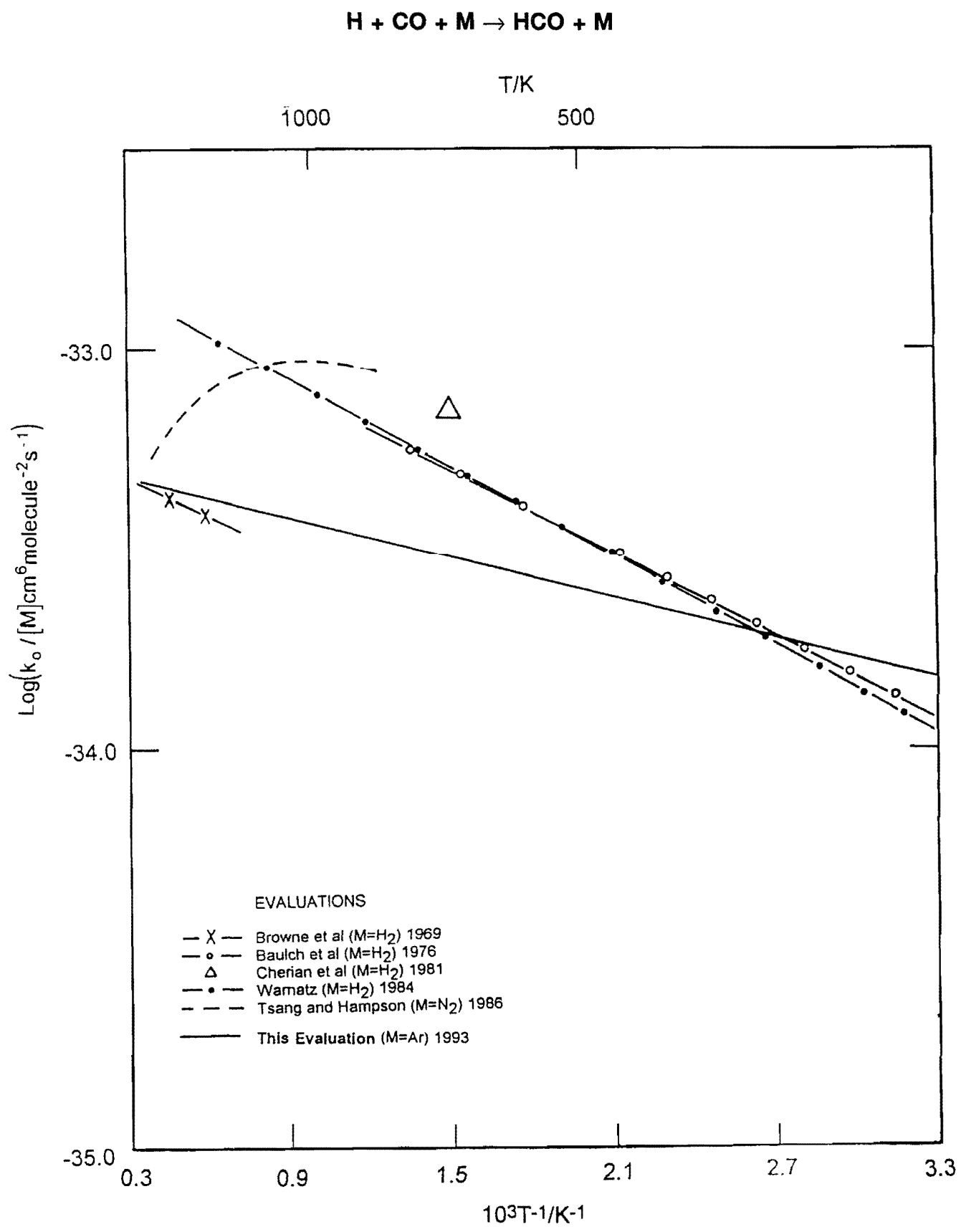


$\mathrm{HCO}(+\mathrm{M}) \rightarrow \mathrm{H}+\mathrm{CO}(+\mathrm{M})$

Thermodynamic data

$\Delta H_{298}^{\circ}=63.9 \mathrm{~kJ} \mathrm{~mol}^{-1}$

$\Delta S_{298}^{\circ}=20.9 \mathrm{~J} \mathrm{~K}^{-1} \mathrm{~mol}^{-1}$

$K p=6.6 \cdot 10^{+1} T^{1.0} \exp (-7560 / T)$ atm

Rate Coefficient Data

\begin{tabular}{|c|c|}
\hline$k / \mathrm{s}^{-1}$ & $T / \mathrm{K}$ \\
\hline \multicolumn{2}{|l|}{ Rate Coefficient Measurements } \\
\hline \multicolumn{2}{|l|}{ Low Pressure Range } \\
\hline$[\mathrm{Ar}] 2.6 \cdot 10^{-10} \exp (-7400 / T)$ & $1400-2200$ \\
\hline$[\mathrm{Ar}] 3.3 \cdot 10^{-11} T^{0.5} \exp (-14400 / T)$ & $1350-1900$ \\
\hline$[\mathrm{Ar}] 2.5 \cdot 10^{-10} \exp (-7340 / T)$ & $1700-2710$ \\
\hline$[$ Ar $] 1.7 \cdot 10^{-9} \exp (-7699 / T)$ & $1350-1450$ \\
\hline$[\mathrm{He}] 3.80 \cdot 10^{-7} T^{-1} \exp (-8600 / T)$ & $637-832$ \\
\hline \multicolumn{2}{|l|}{$[A r] 3.09 \cdot 10^{-7} T^{-1} \exp (-8555 / T)$} \\
\hline \multicolumn{2}{|l|}{$\left[\mathrm{N}_{2}\right] 3.07 \cdot 10^{-7} T^{-1} \exp (-8555 / T)$} \\
\hline \\
\hline \multicolumn{2}{|l|}{$\begin{array}{l}{\left[\mathrm{H}_{2}\right] 5.79 \cdot 10^{-7} T^{-1} \exp (-8555 / T)} \\
{[\mathrm{Ne}, \mathrm{Ar}] 8.3 \cdot 10^{-11} \exp (-8455 / T)}\end{array}$} \\
\hline \multicolumn{2}{|l|}{ Reviews and Evaluations } \\
\hline$k_{0}=[\mathrm{Ar}] 1.2 \cdot 10^{-10} \exp (-7550 / T)$ & $1000-1700$ \\
\hline$k_{0}=[\mathrm{Ar}] 4.2 \cdot 10^{-10} \exp (-8455 / T)$ & $700-2500$ \\
\hline $\begin{array}{l}k_{0}=\left[\mathrm{N}_{2}\right] 8.5 \cdot 10^{-3} T^{-2.14} \\
\exp (-10278 / T)\end{array}$ & $1000-2000$ \\
\hline
\end{tabular}

\section{Comments}

(a) Shock tube study of the thermal dissociation of $\mathrm{H}_{2} \mathrm{CO}$. The reactant was monitored by UV absorption at $366 \mathrm{~nm}$ and by $\mathrm{IR}$ emission at $3.5 \mu \mathrm{m}$.

(b) Shock tube study of $\mathrm{CH}_{4}-\mathrm{O}_{2}$ mixtures in Ar. The reaction was followed by IR emission from $\mathrm{CO}, \mathrm{CO}_{2}$ and $\mathrm{H}_{2} \mathrm{O}$ and by the laser schlieren method. Modelling with 14 reactions.

(c) Pyrolysis of $0.1 \%, 0.5 \%$ and $1 \% \mathrm{CH}_{2} \mathrm{O}$ in $\mathrm{Ar} . \mathrm{CH}_{2} \mathrm{O}$ monitored by IR emission at $3.5 \mu \mathrm{m}$ behind reflected shocks.

(d) Thermal decomposition of $\mathrm{HCO}$ in a molecular beam. Kinetics followed by mass spectrometry.

(e) HCO radicals were generated by $308 \mathrm{~nm}$ photodissociation of $\mathrm{CH}_{3} \mathrm{CHO}$ in a heatable tubular quartz reactor. The [HCO] decay was monitored using a photoionization mass spectrometer. The rates were measured from $637 \mathrm{~K}$ to $832 \mathrm{~K}$ and extrapolated from $300 \mathrm{~K}$ to $3000 \mathrm{~K}$ using an RRKM model adapted to treat the extremely sparse density of vibrational states of $\mathrm{HCO}$.

(f) Thermal decomposition of methanol studied by laser schlieren densitometry and dynamic mass spectrometry. Modelling with a mechanism of 28 reactions.

(g) Numerical analysis of $\mathrm{C}_{2} \mathrm{H}_{2}-\mathrm{O}_{2}$ flames measured previously ${ }^{8}$. The analysis includes rich and lean $\mathrm{C}_{2} \mathrm{H}_{2}$ flames and rich $\mathrm{C}_{2} \mathrm{H}_{2}$ flames with added $\mathrm{CO}$ or $\mathrm{H}_{2}$.

(h) Review of literature rate data.

(i) Data evaluation. The recommended value is based on rate data for the reverse process.

6

\section{Preferred Values}

$k_{0}=[\mathrm{Ar}] 2.6 \cdot 10^{-10} \exp (-7930 / T) \mathrm{s}^{1}$ over range 600 $2500 \mathrm{~K}$.
$\mathrm{M}] /$ molecule $\mathrm{cm}^{-3} \quad$ References

Comments
Schecker and Jost, $1969^{\mathrm{I}}$

Bowman, $1970^{2}$

Dean et al., $1979^{3}$

Timonen et al., $1987^{5}$

$(3.5-7.1) \cdot 10^{16}$

$7.1 \cdot 10^{16}$

$7.1 \cdot 10^{16}$

$7.1 \cdot 10^{16}$

$1.0 \cdot 10^{18}$ de Guertechin et al., $1983^{4}$
Cribb, Dove, and Yamazaki, $1992^{6}$

Browne et al., $1969^{7}$

Wamatz, $1984^{9}$

Tsang and Hampson, $1986^{10}$ (a)

(b)

(i)
Reliability

$\Delta \log k_{\circ}= \pm 0.5$ for $\mathrm{M}=$ Ar over range $600-2500 \mathrm{~K}$.

\section{Comments on Preferred Values}

All available measurements have been done in the low pressure region. The present recommended values for $k_{\mathrm{o}}$ are based on a theoretical analysis ${ }^{1 \mathrm{t}}$ of the data of Refs. 1, 3 and 5 . In order to reproduce the absolute values and the temperature dependence of $k_{0}$, an average energy transferred per collision of $-\Delta \mathbf{E}-=20[T / 300] \mathrm{cm}^{-1}$ was employed. In this way collisional efficiencies between 0.065 to 0.050 between $600 \mathrm{~K}$ and $2500 \mathrm{~K}$ were obtained. The figure shows the given cxperimental data together with the data of recent compilations and the recommended expression for $k_{0}$.

\section{References}

'H.G. Schecker and W. Jost, Ber. Bunsenges. Phys. Chem. 73, 521 (1969). ${ }^{2}$ C.T, Bowman, Combust. Sci. Tech. 2, 161 (1970).

${ }^{3}$ A.M. Dean, B.L. Craig, R.L. Johnson, M.C. Schuitz, and E.E. Wang, 17th Symp. Int. Combust., 577 (1979).

${ }^{4}$ L.O. de Guertechin, J. Vandooren, and P.J. van Tiggelen, Bull. Soc. Chim. Belg. 92, 663 (1983).

${ }^{5}$ R.S. Timonen, E. Ratajczak, D. Gutman, and A.F. Wagner, J. Phys. Chem. 91, 5325 (1987).

${ }^{6}$ P.H. Cribb, J.E. Dove, and S. Yamazaki, Comb. Flame 88, 169 (1992).

${ }^{7}$ W.G. Browne, R.P. Porter, J.D. Verlin, and A.H. Clark, 12th Symp. Int. Combust. 1035 (1969).

${ }^{8}$ R.P. Porter, A.H. Clark, W.E. Kaskan, and W.E. Browne, 11th Symp. Int. Combust. 907 (1967).

'J. Warnatz. in "Combustion Chemistry", ed. W.C. Gardiner. Springer-Verlag, New York, (1984).

${ }^{10}$ W. Tsang and R.F. Hampson, J. Phys. Chem. Ref. Data 15, 1087 (1986).

${ }^{11}$ J. Troe, J. Chem. Phys. 66, 4758 (1977). 


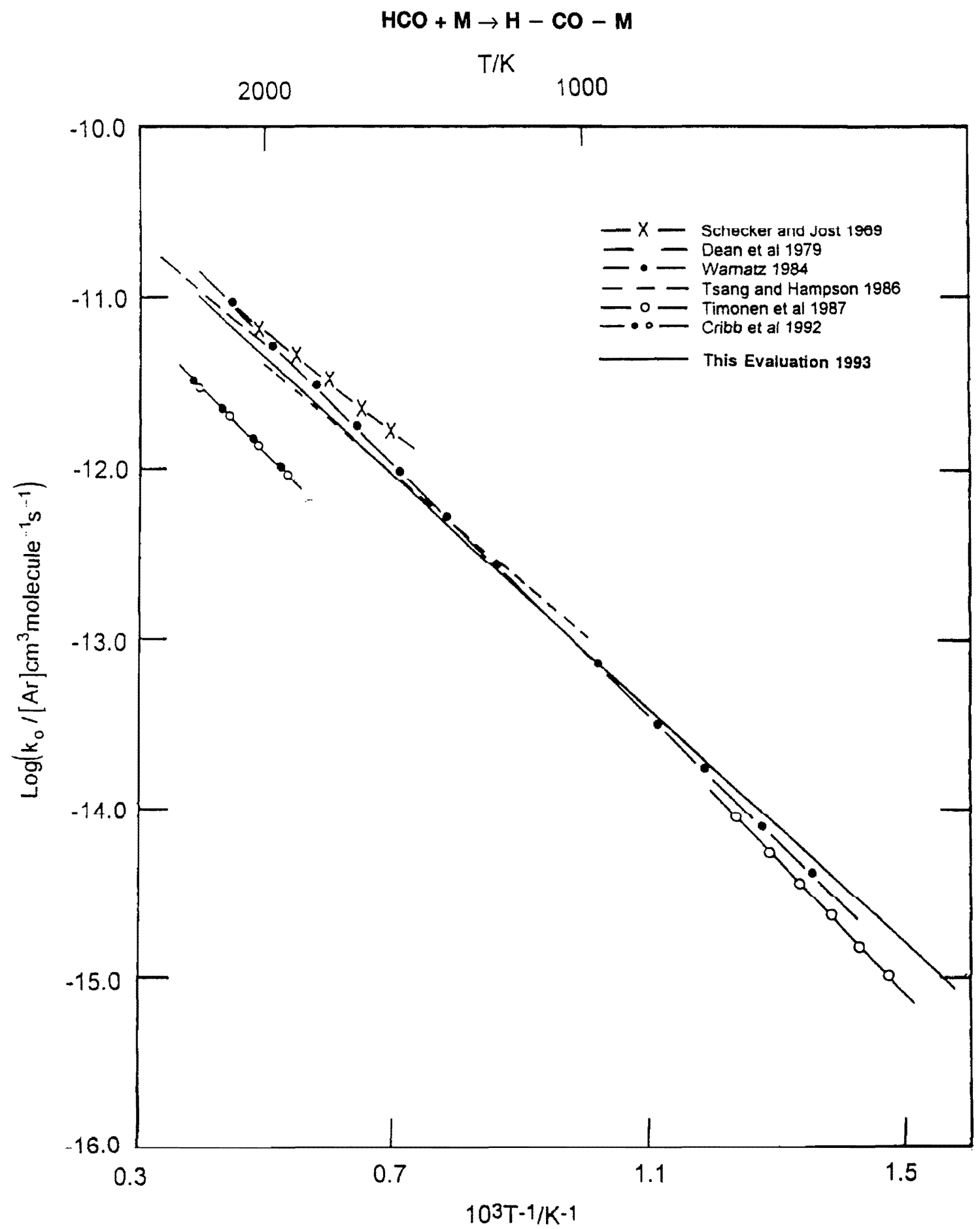




$$
\mathrm{H}+\mathrm{CH}_{3}(+\mathrm{M}) \rightarrow \mathrm{CH}_{4}(+\mathrm{M})
$$

hermodynamic Data

$\Delta H_{298}^{\circ}=-439 \mathrm{~kJ} \mathrm{~mol}^{-1}$

$\Delta S_{298}^{\mathrm{o}}=-123 \mathrm{~J} \mathrm{~K}^{-1} \mathrm{~mol}^{-1}$

$K p=1.76 \cdot 10^{-4} T^{-1.06} \exp (+52700 / T) \mathrm{atm}^{-1}$

Rate Coefficient Data

\begin{tabular}{|c|c|c|c|c|}
\hline${ }^{\prime} \mathrm{cm}^{3}$ molecule ${ }^{-1} \mathrm{~s}^{-1}$ & $T / \mathrm{K}$ & {$[\mathrm{M}] /$ molecule $\mathrm{cm}^{-3}$} & Reference & Comments \\
\hline \multicolumn{5}{|c|}{ ate Coefficient Measurements } \\
\hline ow Pressure Range & & & & \\
\hline$[\mathrm{He}] 3.2 \cdot 10^{-29}$ & 504 & $(4.8-76.6) \cdot 10^{17}$ & Brouard et al., 1985' & (a) \\
\hline$[\mathrm{He}] 4.0 \cdot 10^{-29}$ & $300-600$ & $(4.8-163.5) \cdot 10^{17}$ & Brouand et al., $1989^{2}$ & (a) \\
\hline \multicolumn{5}{|c|}{ uermediate Fall-off Range } \\
\hline $6.6 \cdot 10^{-12}$ & 298 & $(5.2-10.0) \cdot 10^{16}(\mathrm{Ar})$ & Brown et al., $1966^{3}$ & (b) \\
\hline $1.7 \cdot 10^{-11}$ & 293 & $2.2 \cdot 10^{17}(\mathrm{He})$ & Dodonov et al., $1969^{4}$ & (c) \\
\hline $3.9 \cdot 10^{-12}$ & 290 & $2.7 \cdot 10^{17}(\mathrm{Ar})$ & Halstead et al., $1970^{5}$ & (d) \\
\hline $6.6 \cdot 10^{-12}$ & & $5.4 \cdot 10^{17}$ & & \\
\hline $1.8 \cdot 10^{-12}$ & $303-603$ & $2.0 \cdot 10^{16}\left(\mathrm{H}_{2}\right)$ & Teng and Jones, $1972^{6}$ & (e) \\
\hline $2.0 \cdot 10^{-12}$ & 300 & $2.4 \cdot 10^{16}(\mathrm{He})$ & Michael et al., $1973^{7}$ & (f) \\
\hline $5.5 \cdot 10^{-12}$ & & $8.1 \cdot 10^{16}$ & & \\
\hline $8.0 \cdot 10^{-12}$ & & $11.1 \cdot 10^{16}$ & & \\
\hline $1.8 \cdot 10^{-12}$ & $503-753$ & $1.3 \cdot 10^{17}(\mathrm{Ar})$ & Camilleri et al., $1974^{8}$ & (g) \\
\hline $3.6 \cdot 10^{-12}$ & & $2.6 \cdot 10^{17}$ & & \\
\hline $3.0 \cdot 10^{-12}$ & 295 & $2.0: 10^{17}(\mathrm{He})$ & Pratt and Veltmann, $1974^{\circ}$ & (h) \\
\hline $7.4 \cdot 10^{-12}$ & & $4.9 \cdot 10^{17}$ & & \\
\hline $6.7 \cdot 10^{-12}$ & 321 & $2.4 \cdot 10^{17}(\mathrm{He})$ & Pratt and Veltmann, $1976^{10}$ & (h) \\
\hline $5.2 \cdot 10^{-12}$ & 415 & $1.9: 10^{17}$ & & \\
\hline $3.4 \cdot 10^{-12}$ & 521 & $1.5 \cdot 10^{17}$ & & \\
\hline $0.53 \cdot 10^{-10}$ & 308 & $0.94 \cdot 10^{18}\left(\mathrm{C}_{2} \mathrm{H}_{6}\right)$ & Cheng and Yeh, $1977^{11}$ & (i) \\
\hline $1.8 \cdot 10^{-10}$ & & $3.1 \cdot 10^{18}$ & & \\
\hline $2.5 \cdot 10^{-10}$ & & $9.4 \cdot 10^{18}$ & & \\
\hline $2.8 \cdot 10^{-10}$ & & $25.1 \cdot 10^{18}$ & & \\
\hline $3.0 \cdot 10^{-10}$ & & $72.1 \cdot 10^{18}$ & & \\
\hline $2.6 \cdot 10^{-12}$ & $640-818$ & $9: 8 \cdot 10^{16}(\mathrm{Ar})$ & Sepehrad et al., $1979^{12}$ & (j) \\
\hline $4.7 \cdot 10^{-12}$ & & $18.5 \cdot 10^{16}$ & & \\
\hline $2.0 \cdot 10^{-10}$ & 296 & $2.5 \cdot 10^{17}\left(\mathrm{~N}_{2}, \mathrm{H}_{2}\right)$ & Sworski et al., $1980^{13}$ & (k) \\
\hline $1.52 \cdot 10^{-11}$ & 504 & $4.8 \cdot 10^{17}(\mathrm{He})$ & Brouard et al., $1985^{1}$ & (a) \\
\hline $1.86 \cdot 10^{-11}$ & & $9.6 \cdot 10^{17}$ & & \\
\hline $3.44 \cdot 10^{-11}$ & & $19.3 \cdot 10^{17}$ & & \\
\hline $5.31 \cdot 10^{-11}$ & & $38.5 \cdot 10^{17}$ & & \\
\hline $7.75 \cdot 10^{-14}$ & & $76.7 \cdot 10^{17}$ & & \\
\hline $2.26 \cdot 10^{-11}$ & 301 & $0.81 \cdot 10^{18}(\mathrm{He})$ & Brouard et al., $1989^{2}$ & (a) \\
\hline $3.52 \cdot 10^{-11}$ & & $1.6 \cdot 10^{18}$ & & \\
\hline $6.36 \cdot 10^{-11}$ & & $3.3 \cdot 10^{18}$ & & \\
\hline $14.0 \cdot 10^{-11}$ & & $9.8 \cdot 10^{18}$ & & \\
\hline $18.2 \cdot 10^{-11}$ & & $16.3 \cdot 10^{18}$ & & \\
\hline $1.35 \cdot 10^{-11}$ & 401 & $0.61 \cdot 10^{18}$ & & \\
\hline $2.52 \cdot 10^{-11}$ & & $1.2 \cdot 10^{18}$ & & \\
\hline $4.44 \cdot 10^{-11}$ & & $2.4 \cdot 10^{18}$ & & \\
\hline $10.1 \cdot 10^{-11}$ & & $8.4 \cdot 10^{18}$ & & \\
\hline $14.4 \cdot 10^{-11}$ & & $14.7 \cdot 10^{18}$ & & \\
\hline $2.11 \cdot 10^{-11}$ & 601 & $1.7 \cdot 10^{18}$ & & \\
\hline $3.78 \cdot 10^{-11}$ & & $4.9 \cdot 10^{18}$ & & \\
\hline $6.18 \cdot 10^{-11}$ & & $11.4 \cdot 10^{18}$ & & \\
\hline \multicolumn{5}{|l|}{ High Pressure Range } \\
\hline $1.5 \cdot 10^{-10}$ & 300 & $(1.6-32.2) \cdot 10^{18}\left(\mathrm{Ar}, \mathrm{SF}_{6}\right)$ & Patrick et al., $1980^{14}$ & (l) \\
\hline $3.5 \cdot 10^{-10}$ & 504 & $(4.8-76.7): 10^{17}(\mathrm{He})$ & Brouard et al., 1985' & (a) \\
\hline $4.7 \cdot 10^{-10}$ & 300 & $(8.1-16.4) \cdot 10^{18}(\mathrm{He})$ & Brouard and Pilling, $1986^{15}$ & (a) \\
\hline $4.7 \cdot 10^{-10}$ & $300-600$ & $(8.1-16.4) \cdot 10^{18}(\mathrm{He})$ & Brouard et al., $1989^{2}$ & (a) \\
\hline
\end{tabular}


BAULCH ET AL.

$\mathrm{H}+\mathrm{CH}_{3}(+\mathrm{M}) \rightarrow \mathrm{CH}_{4}(+\mathrm{M})-$ Continued

Rate Coefficient Data

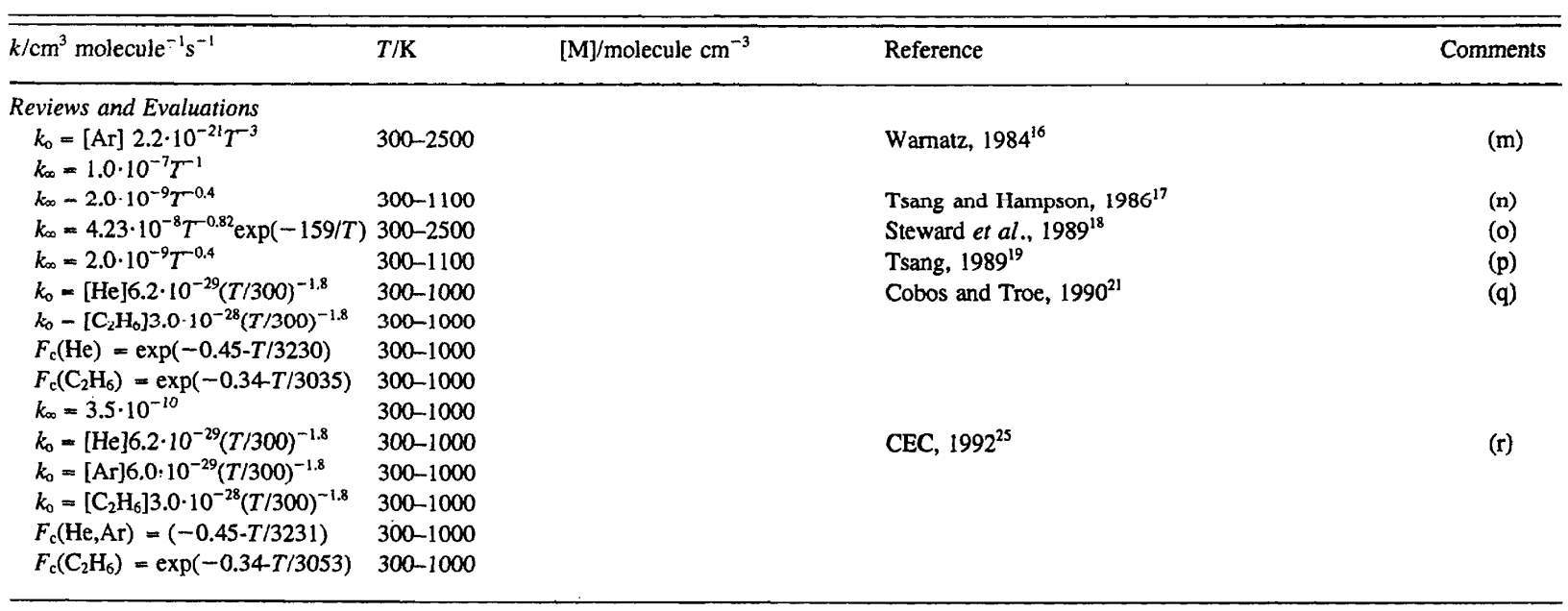

\section{Comments}

(a) $193 \mathrm{~nm}$ photolysis of acetone, $\left[\mathrm{CH}_{3}\right]$ and $[\mathrm{H}]$ by time-resolved UV absorption and resonance fluorescence respectively. $\left[\mathrm{CH}_{3}\right] \gg[\mathrm{H}] . k_{\infty}$ by $\mathrm{RRKM} /$ master equation fit.

(b) Discharge flow study of $\mathrm{H}+\mathrm{C}_{2} \mathrm{H}_{4}$ system. $\mathrm{CH}_{3}$ generated by $\mathrm{H}+\mathrm{C}_{2} \mathrm{H}_{5} \rightarrow 2 \mathrm{CH}_{3}$. ESR detection of $\mathrm{H}$.

(c) Mass spectrometric study of species distribution in diffusion cloud; $\mathrm{CH}_{3}$ generated from $\mathrm{H}+\mathrm{C}_{2} \mathrm{H}_{4}, \mathrm{H}+\mathrm{C}_{3} \mathrm{H}_{6} ; \mathrm{H}$ generated in discharge.

(d) Discharge flow study of $\mathrm{H}+\mathrm{C}_{2} \mathrm{H}_{4}$ system; used GC analysis of $\mathrm{CH}_{4}, \mathrm{C}_{2} \mathrm{H}_{6}, \mathrm{C}_{3} \mathrm{H}_{8}$, and $\mathrm{C}_{4} \mathrm{H}_{10}$.

(e) Discharge flow study of $\mathrm{H}+\mathrm{C}_{2} \mathrm{H}_{4}$ system, products analysed by $\mathrm{GC}$ and simulated by numerical integration.

(f) Comparison of $\mathrm{H}+\mathrm{C}_{2} \mathrm{H}_{4}$ data from high pressure pulsed $\mathrm{Hg}$ photosensitization-resonance absorption and low pressure discharge flow-mass spectrometry. Radicalatom reactions make greater contribution in latter study. Numerical integration.

(g) Discharge flow study of $\mathrm{H}+\mathrm{C}_{2} \mathrm{H}_{6}$ system. $\mathrm{GC}$ detection of $\mathrm{CH}_{4}, \mathrm{C}_{2} \mathrm{H}_{4}$, and $\mathrm{C}_{3} \mathrm{H}_{8}$. Rate coefficients from fitting the reaction scheme using numerical integration. Assumed $k_{1}$ independent of temperature.

(h) Discharge flow study of $\mathrm{H}+\mathrm{C}_{2} \mathrm{H}_{4}$ system. Products detected by mass spectrometry. Rate coefficients by fitting 7 reaction scheme using numerical integration.

(i) Stcady-state $\mathrm{Hg}$ photosensitisation of $\mathrm{C}_{2} \mathrm{II}_{6}$. Products dctected by mass spectrometry. $k_{\infty}$ by Lindemann plot.

(j) Discharge flow study of $\mathrm{H}+\mathrm{CH}_{4}$ system. Products detected by gas chromatography. Rate coefficients from numerical integration of 14 reaction scheme.

(k) $160 \mathrm{~nm}$ photolysis of $\mathrm{H}_{2} \mathrm{O} / \mathrm{CH}_{4}$ mixtures. $\mathrm{CH}_{3}$ detected as function of time at $216 \mathrm{~nm}$. Rate coefficient determined by fitting to 11 reaction scheme with $\mathrm{H}_{2}$ and $\mathrm{N}_{2}$ diluent.

(1) Flash photolysis of azomethane/ethene mixtures. Products analysed by gas chromatography. Rate coefficient deter- mined by numerical integration of 9 reaction scheme, but probably low because (i) reaction (1) competes primarily with $\mathrm{CH}_{3}+\mathrm{CH}_{3}$ and low rate coefficient was used for $\mathrm{CH}_{3}$ recombination, (ii) $\mathrm{H}+$ azomethane was neglected. $k_{\infty}$ by RRKM fit.

(m) Review of literature prior to 1980.

(II) The results of Cheng et al . ${ }^{11}$, Sworski et al.$^{13}$, and Patrick et al.${ }^{14}$ have been combined with the reverse rate determination of Chen et al . ${ }^{20}$ to derive the recommended expression. A tabulation of $\log k / k_{\infty}$ over the temperature range $300-2500 \mathrm{~K}$ from RRKM calculations is also given.

(o) Single-channel hindered Gorin model RRKM calculations of the $\mathrm{CH}_{4}$ decomposition with a fit to experimental results. Conversion to $k_{\infty}$ via the equilibrium constant.

(p) The results of Cheng et al.$^{11}$, Sworski et al. ${ }^{13}$, and Patrick et al.${ }^{14}$ have been combined with the reverse rate determination of Chen et al.$^{20}$ to derive the recommended expression.

(q) Theoretical calculation based on $k_{0}$ calculations from Ref. 22 , the representation of fall-off curves from Ref. 23 , and the $k_{\infty}$ treatment from Ref. 24. Collision efficiencies $\beta_{c}$ at $300 \mathrm{~K}$ of 0.07 for $\mathrm{M}=\mathrm{He}$ and of 0.15 for $\mathrm{M}=\mathrm{C}_{2} \mathrm{H}_{6}$ point to particularly inefficient energy transfer for which $\langle\Delta E\rangle$ values may increase proportional to the temperature. Therefore, the temperature coefficient of $k_{\mathrm{o}}$ at $T \leqslant$ $1000 \mathrm{~K}$ was chosen as in the strong collision limit, i.e. assuming $\beta_{\mathrm{c}}$ to be temperature independent. The temperature coefficient of $k_{\infty}$ was derived from SACM-modified PST calculations of Ref. 24 which also predicts the absolute value of $k_{\infty}$ to be as recommended. The broadening factors contain a considerable weak collision contribution, strong collision broadening factors being given by $F_{\mathrm{c}}^{\mathrm{sc}}=\exp (-0.09-T / 3320)$.

(r) See Comments on Preferred Values. 


\section{Preferred Values}

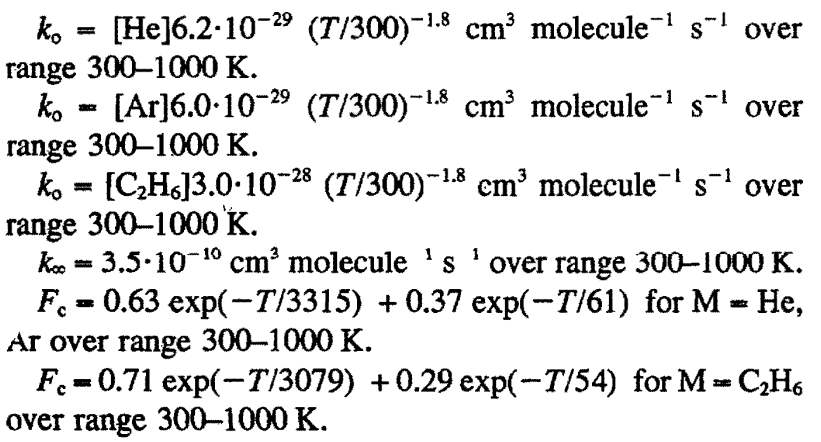

\section{Reliability}

$\Delta \log k_{\circ}= \pm 0.3$ for $\mathrm{M}=\mathrm{He}$ over range $300-1000 \mathrm{~K}$. $\Delta \log k_{\mathrm{o}}= \pm 0.5$ for $\mathrm{M}=\mathrm{Ar}, \mathrm{C}_{2} \mathrm{H}_{6}$ over range $300-1000 \mathrm{~K}$. $\Delta \log k_{\infty}= \pm 0.3$ over range $300-1000 \mathrm{~K}$.

$\Delta F_{\mathrm{c}}= \pm 0.1$ over range $300-1000 \mathrm{~K}$.

\section{Comments on Preferred Values}

No measurements for this reaction have been reportcd since our previous compilation ${ }^{25}$. Therefore, the preferred values for $k_{\mathrm{o}}$ and $k_{\infty}$ of Ref. 25 remain unaltered, but the format of the $F_{\mathrm{c}}$ has been modified. In Fig. 1 representative fall-off curves are shown. Recombination and dissociation rate data are related via the above given equilibrium constant.

\section{References}

${ }^{1}$ M. Brouard, M.T. Macpherson, M.J. Pilling, J.M. Tulloch, and A.P. Williamson, Chem. Phys. Lett. 113, 413 (1985).
${ }^{2}$ M. Brouard, M.T. Macpherson, and M.J. Pilling, J. Phys. Chem. 93, 4047 (1989).

${ }^{3}$ J.M. Brown, P.B. Coates, and B.A. Thrush, Chem. Comm., 843 (1966).

${ }^{4}$ A.F. Dodonov, G.K. Lavroskaya, and V.L. Tal'roze, Kinet. Catal. 10, 391 (1969).

${ }^{5}$ M.P. Halstead, D.A. Leathard, R.M. Marshall, and J.H. Pumell, Proc. Roy. Soc. A316, 575 (1970)

${ }^{6}$ L. Teng and W.E. Jones, J. Chem. Soc. Faraday Trans. 1, 68, 1267 (1972). JJ.V. Michael, D.T. Osbome, and G.N. Suess, J. Chem. Phys. 58, 2800 (1973).

${ }^{8}$ P. Camilleri, R.M. Marshall, and J.H. Purnell, J. Chem. Soc. Faraday Trans. 1, 70, 1434 (1974).

${ }^{9}$ G. Pratt and I. Veltmann, J. Chem. Soc. Faraday Trans. 1, 70, 1840 (1974).

${ }^{10} \mathrm{G}$. Pratt and I. Veltmann, J. Chem. Soc. Faraday Trans. 1, 72, 1733 (1976).

"1J.T. Cheng and C.-T. Yeh, J. Phys. Chem. 81, 1982 (1977).

${ }^{12}$ A. Sepehrad, R.M. Marshall, and J.H. Purnell, J. Chem. Soc. Faraday Trans. $1,75,835(1979)$.

${ }^{13}$ T.J. Sworski, C.J. Hochanadel, and P.J. Ogren, J. Phys. Chem. 84, 129 (1980).

I4R. Patrick, M.J. Pilling, and G.J. Rogers, Chem. Phys. 53, 279 (1980).

${ }^{15} \mathrm{M}$. Brouard and M.J. Pilling, Chem. Phys. Lett. 129, 439 (1986).

${ }^{16} \mathrm{~J}$. Warnatz, in "Combustion Chemistry", ed. W.C. Gardiner, Springer-Verlag, New York (1984).

${ }^{17}$ W. Tsang and R.F. Hampson, J. Phys. Chem. Ref. Data 15, 1087 (1986).

${ }^{18}$ P.H. Stewart, G.P. Smith, and D.M. Golden, Int. J. Chem. Kin. 21, 923 (1989).

${ }^{19}$ W. Tsang, Comb. Flame 78, 71 (1989).

${ }^{20}$ C.J. Chen, M.H. Back, and R.A. Back, Can. J. Chem. 53, 3580 (1975). ${ }^{21}$ C.J. Cobos and J. Troe, Z. Phys. Chem. NF, 167, 129 (1990).

${ }^{22}$ J. Troe, J. Chem. Phys. 66, 4758 (1977); J. Phys. Chem. 83, 114 (1979).

${ }^{23}$ J. Troe, Ber. Bunsenges. Phys. Chem. 87, 161 (1983); R.G. Gilbert, K. Luther, and J. Troe, Ber. Bunsenges. Phys. Chem. 87, 169 (1983).

${ }^{24} \mathrm{~J}$. Troe, Z. Phys. Chem. NF 161, 209 (1989); J. Chem. Soc. Faraday Trans. 87, 2299 (1991).

${ }^{25} \mathrm{CEC}, 1992$ (see references in Introduction). 


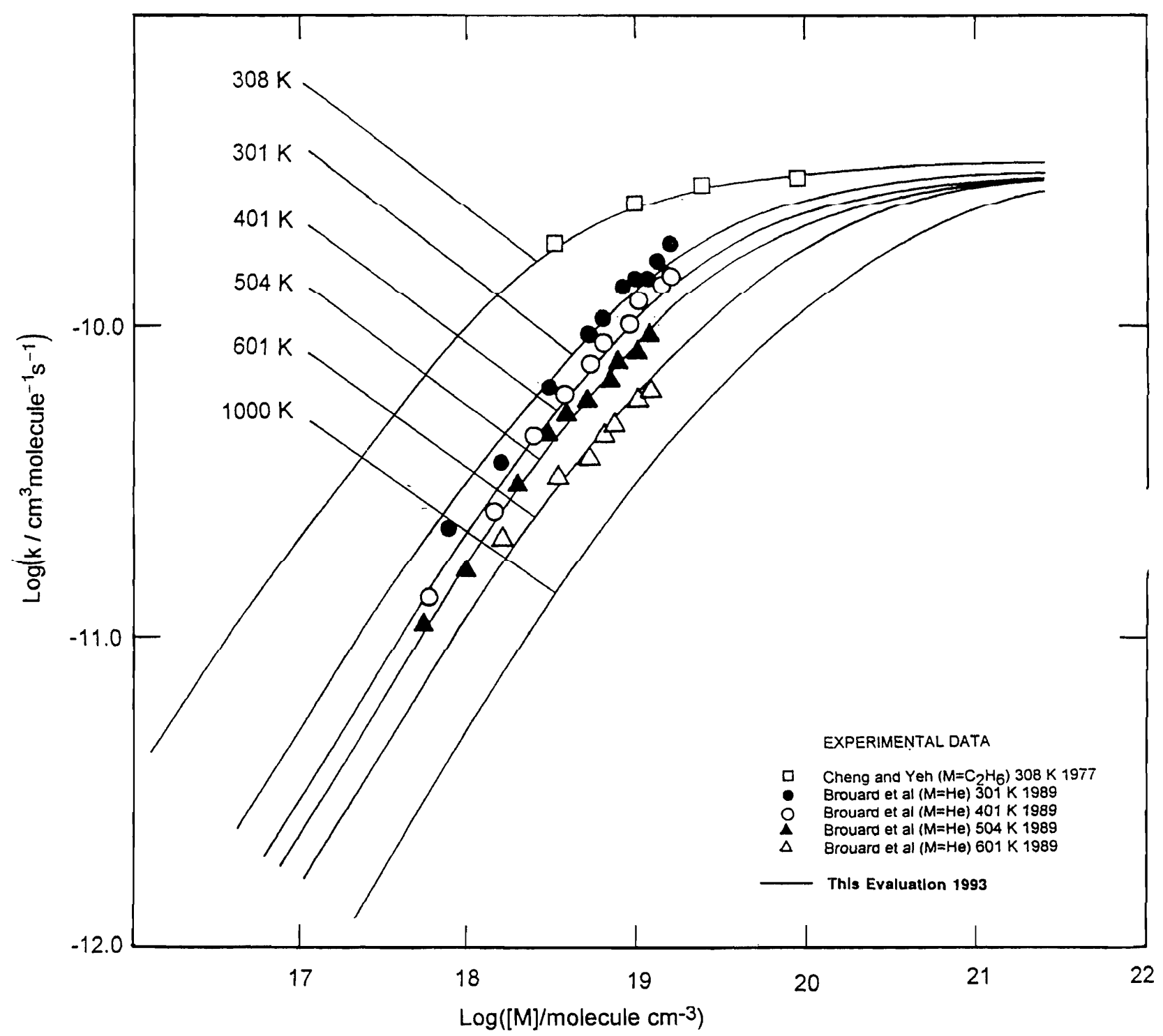


$\mathrm{CH}_{4}(+\mathrm{M}) \rightarrow \mathrm{CH}_{3}+\mathrm{H}(+\mathrm{M})$

Thermodynamic data

$\Delta H_{298}^{\circ}=439 \mathrm{~kJ} \mathrm{~mol}^{-1}$

$\Delta S_{298}^{\circ}=123 \mathrm{~J} \mathrm{~K}^{-1} \mathrm{~mol}^{-1}$

$K p=5.68 \cdot 10^{3} T^{1.06} \exp (-52700 / T)$ atm

Rate Coefficient Data

\begin{tabular}{|c|c|c|c|c|}
\hline$k / \mathrm{s}^{-1}$ & $T / \mathrm{K}$ & {$[\mathrm{M}] /$ molecule $\mathrm{cm}^{-3}$} & Reference & Comments \\
\hline \multicolumn{5}{|l|}{ Rate Coefficient Measurements } \\
\hline \multicolumn{5}{|l|}{ Low Pressure Range } \\
\hline$[$ Ar $] 3.3 \cdot 10^{-7} \exp (-44800 / T)$ & $1850-2500$ & $(3.3-90.0) \cdot 10^{19}$ & Hartig et al., $1971^{1}$ & (a) \\
\hline$[\mathrm{Ar}] 6.8 \cdot 10^{-8} \exp (-44900 / T)$ & $1726-2134$ & $3 \cdot 10^{18}$ & Klemm et al., $1992^{2}$ & (b) \\
\hline$[\mathrm{Ar}] 5.7 \cdot 10^{-7} \exp (-46770 / T)$ & $1794-2326$ & $(2-15) \cdot 10^{18}$ & Davidson et al., $1992^{3}$ & (c) \\
\hline$[\mathrm{Ar}, \mathrm{Kr}] 3.2 \cdot 10^{23} \mathrm{~T}^{-8.106}$ & $1600-4200$ & $(6.5-18) \cdot 10^{17}$ & Kiefer and Kumaran, $1993^{4}$ & (d) \\
\hline $\exp (-59084 / T)$ & & & & \\
\hline \multicolumn{5}{|l|}{ Intermediate Fall-Off Range } \\
\hline $2.5 \cdot 10^{13} \exp (-48300 / T)$ & $1850-2500$ & $3.3 \cdot 10^{19}(\mathrm{Ar})$ & Hartig et al., $1971^{1}$ & (a) \\
\hline $4.0 \cdot 10^{14} \exp (-50800 / T)$ & & $9.0 \cdot 10^{20}(\mathrm{Ar})$ & & \\
\hline $1.4 \cdot 10^{12} \exp (-51800 / T)$ & $1750-2575$ & $-5.0 \cdot 10^{17}(\mathrm{Ar})$ & Dean and Kistiakowsky, $1971^{5}$ & (e) \\
\hline $3.8 \cdot 10^{13} \exp (-47100 / T)$ & $1750-2700$ & $4.0 \cdot 10^{19}(\mathrm{Ar})$ & Napier and Subrahmanyan, $1972^{6}$ & (f) \\
\hline $4.0 \cdot 10^{9} \exp (-31700 / T)$ & $2000-2700$ & $2.4 \cdot 10^{18}(\mathrm{Ne})$ & Vompe, $1973^{7}$ & (g) \\
\hline $4.7 \cdot 10^{12} \exp (-46900 / T)$ & $1700-2300$ & $6.0 \cdot 10^{18}(\mathrm{Ar})$ & Roth and Just, $1975^{8}$ & (h) \\
\hline $2.3 \cdot 10^{8} \exp (-32500 / T)$ & $2000-2700$ & $6.0 \cdot 10^{17}(\mathrm{Ar})$ & Gardiner et al., $1975^{\circ}$ & (i) \\
\hline $2.3 \cdot 10^{9} \exp (-32500 / T)$ & & $6.0 \cdot 10^{18}(\mathrm{Ar})$ & & \\
\hline $0.74 \cdot 10^{-8}$ & 995 & $0.5 \cdot 10^{18}\left(\mathrm{CH}_{4}\right)$ & Chen et al., $1975^{10}$ & (j) \\
\hline $1.32 \cdot 10^{-8}$ & & $3.2 \cdot 10^{18}$ & & \\
\hline $2.82 \cdot 10^{-8}$ & & $7.2 \cdot 10^{18}$ & & \\
\hline $0.39 \cdot 10^{-7}$ & 1038 & $0.3 \cdot 10^{17}$ & & \\
\hline $1.38 \cdot 10^{-7}$ & & $3.1 \cdot 10^{18}$ & & \\
\hline $2.57 \cdot 10^{-7}$ & & $0.9 \cdot 10^{18}$ & & \\
\hline $0.98 \cdot 10^{-7}$ & 1068 & $0.23 \cdot 10^{18}$ & & \\
\hline $4.9 \cdot 10^{-7}$ & & $2.1 \cdot 10^{18}$ & & \\
\hline $8.71 \cdot 10^{-7}$ & & $6.7 \cdot 10^{18}$ & & \\
\hline $0.69 \cdot 10^{-6}$ & 1103 & $0.43 \cdot 10^{18}$ & & \\
\hline $2.06 \cdot 10^{-6}$ & & $2.0 \cdot 10^{18}$ & & \\
\hline $3.86 \cdot 10^{-6}$ & & $6.5 \cdot 10^{18}$ & & \\
\hline $8 \cdot 10^{12} \exp (-44500 / T)$ & $1875-2240$ & $1.2 \cdot 10^{19}(\mathrm{Ar})$ & Bowman, $1975^{11}$ & (k) \\
\hline$\therefore .2 \cdot 10^{12} \exp (-45400 / T)$ & $2000-2700$ & $6.0 \cdot 10^{18}(\mathrm{Ar})$ & Heffington et al., $1977^{12}$ & (l) \\
\hline $6 \cdot 10^{12} \exp (-45400 / T)$ & & $17 \cdot 10^{18}$ & & \\
\hline $2.3 \cdot 10^{11} \exp (-43200 / T)$ & $1950-2770$ & $1.4 \cdot 10^{18}(\mathrm{Ar})$ & Tabayashi and Bauer, $1979^{13}$ & (m) \\
\hline $9.1 \cdot 10^{11} \exp (-43200 / T)$ & & $5.4 \cdot 10^{18}$ & & (III) \\
\hline $1.13 \cdot 10^{-5}$ & 1098 & $2.0 \cdot 10^{20}(\mathrm{He})$ & Barnes, Pratt, and Wood, $1989^{14}$ & (n) \\
\hline $1.37 \cdot 10^{-5}$ & & $3.3 \cdot 10^{20}$ & & \\
\hline $2.52 \cdot 10^{-5}$ & 1123 & $6.5 \cdot 10^{19}$ & & \\
\hline $3.17 \cdot 10^{-5}$ & & $1.9 \cdot 10^{20}$ & & \\
\hline $4.12 \cdot 10^{-5}$ & & $3.2 \cdot 10^{20}$ & & \\
\hline $5.30 \cdot 10^{-5}$ & 1148 & $3.2 \cdot 10^{19}$ & & \\
\hline $8.30 \cdot 10^{-5}$ & & $1.9 \cdot 10^{20}$ & & \\
\hline $10.1 \cdot 10^{-5}$ & & $3.2 \cdot 10^{20}$ & & \\
\hline $4.44 \cdot 10^{-6}$ & 1073 & $1.0 \cdot 10^{20}(\mathrm{Ar})$ & & \\
\hline $5.28 \cdot 10^{-6}$ & & $3.4 \cdot 10^{20}$ & & \\
\hline $9.80 \cdot 10^{-6}$ & 1098 & $6.6 \cdot 10^{19}$ & & \\
\hline $1.20 \cdot 10^{-5}$ & & $2.0 \cdot 10^{20}$ & & \\
\hline $1.46 \cdot 10^{-5}$ & & $3.3 \cdot 10^{20}$ & & \\
\hline $1.87 \cdot 10^{-5}$ & 1123 & $3.2 \cdot 10^{19}$ & & \\
\hline $2.31 \cdot 10^{-5}$ & & $6.5 \cdot 10^{19}$ & & \\
\hline $3.19 \cdot 10^{-5}$ & & $1.9 \cdot 10^{20}$ & & \\
\hline $4.32 \cdot 10^{-5}$ & 1148 & $3.2 \cdot 10^{19}$ & & \\
\hline $5.39 \cdot 10^{-5}$ & & $6.3 \cdot 10^{19}$ & & \\
\hline $3.04 \cdot 10^{-6}$ & 1073 & $3.4 \cdot 10^{19}\left(\mathrm{CH}_{4}\right)$ & & \\
\hline $5.11 \cdot 10^{-6}$ & 1073 & $1.4 \cdot 10^{20}$ & & \\
\hline $4.93 \cdot 10^{-6}$ & & $3.4 \cdot 10^{20}$ & & \\
\hline $8.25 \cdot 10^{-6}$ & 1098 & $3.3 \cdot 10^{19}$ & & \\
\hline $1.52 \cdot 10^{-5}$ & & $1.3 \cdot 10^{20}$ & & \\
\hline $1.55 \cdot 10^{-5}$ & & $3.3 \cdot 10^{20}$ & & \\
\hline $2.27 \cdot 10^{-5}$ & 1123 & $3.2 \cdot 10^{19}$ & & \\
\hline
\end{tabular}


BAULCH ET AL.

$\mathrm{CH}_{4}(+\mathrm{M}) \rightarrow \mathrm{CH}_{3}+\mathrm{H}(+\mathrm{M})-$ Continued

Rate Coefficient Data

\begin{tabular}{|c|c|c|c|c|}
\hline$k / \mathrm{s}^{-1}$ & $T / \mathrm{K}$ & {$[\mathrm{M}] /$ molecule $\mathrm{cm}^{-3}$} & Reference & Comments \\
\hline $3.63 \cdot 10^{-5}$ & & $1.3 \cdot 10^{20}$ & & \\
\hline $4.20 \cdot 10^{-5}$ & & $3.2 \cdot 10^{20}$ & & \\
\hline $6.03 \cdot 10^{-5}$ & 1148 & $3.2 \cdot 10^{19}$ & & \\
\hline $8.50 \cdot 10^{-5}$ & & $1.3 \cdot 10^{20}$ & & \\
\hline $1.20 \cdot 10^{-4}$ & & $3.2 \cdot 10^{20}$ & & \\
\hline \multicolumn{5}{|l|}{ High Pressure Range } \\
\hline $1.3 \cdot 10^{15} \exp (-52300 / T)$ & $1850-2500$ & $(3.3-90.0) \cdot 10^{19}(\mathrm{Ar})$ & Hartig et al., $1971^{1}$ & (a) \\
\hline $2.8 \cdot 10^{16} \exp (-54100 / T)$ & $995-1103$ & $(0.43-7.2) \cdot 10^{18}\left(\mathrm{CH}_{4}\right)$ & Chen et al., $1975^{7}$ & (j) \\
\hline $1.75 \cdot 10^{16} \exp (-53000 / T)$ & $1073-1148$ & $(3.2-33.4) \cdot 10^{39}\left(\mathrm{CH}_{4}\right)$ & Bames, Pratt, and Wood, $1989^{14}$ & (n) \\
\hline \multicolumn{5}{|l|}{ Reviews and Evaluations } \\
\hline$k_{\infty}=2.0 \cdot 10^{15} \exp (-52300 / T)$ & & & Benson and O'Neal, $1970^{15}$ & (o) \\
\hline$k_{0}=[\mathrm{Ar}] 3.3 \cdot 10^{-7} \exp (-44500 / T)$ & $1500-3000$ & & Warnatz, $1984^{16}$ & (p) \\
\hline$k_{\infty}=1.0 \cdot 10^{15} \exp (-50500 / T)$ & $1000-3000$ & & & \\
\hline$k_{\omega}-3.7 \cdot 10^{15} \exp (-52200 / T)$ & 3002500 & & Tsang and Hampson, $1986^{17}$ & (q) \\
\hline$k_{\infty}=3.7 \cdot 10^{17} \mathrm{~T}^{-0.558} \exp (-52782 / T)$ & $300-2500$ & & Stewart et al., $1989^{18}$ & $(r)$ \\
\hline$k_{0}=[\mathrm{Ar}] 7.5 \cdot 10^{-7} \exp (-45700 / T)$ & $1000-3000$ & & Cobos and Troe, $1990^{19}$ & (s) \\
\hline$k_{0}=\left[\mathrm{CH}_{4}\right] 1.4 \cdot 10^{-6} \exp (-45700 / T)$ & $1000-3000$ & & & \\
\hline$k_{w}-2.1 \cdot 10^{16} \exp (-52800 / T)$ & 10003000 & & & \\
\hline$F_{\mathrm{c}}(\mathrm{Ar})=\exp (-0.45-T / 3230)$ & $1000-3000$ & & & \\
\hline$F_{\mathrm{c}}\left(\mathrm{CH}_{4}\right)=\exp (-0.37-T / 2210)$ & $1000-3000$ & & & \\
\hline$k_{0}=[\mathrm{Ar}] 1.2 \cdot 10^{-6} \exp (-47000 / T)$ & $1000-3000$ & & CEC, $1992^{23}$ & $(\mathrm{t})$ \\
\hline$k_{0}=\left[\mathrm{CH}_{4}\right] 1.4 \cdot 10^{-5} \exp (-48100 / T)$ & $1000-2000$ & & & \\
\hline$k_{\infty}=2.4 \cdot 10^{16} \exp (-52800 / T)$ & $1000-3000$ & & & \\
\hline$F_{c}(\mathrm{Ar})=\exp (-0.45-T / 3231)$ & $1000-3000$ & & & \\
\hline$F_{\mathrm{c}}\left(\mathrm{CH}_{4}\right)=\exp (-0.37-T / 2210)$ & $1000-3000$ & & & \\
\hline $\begin{aligned} k_{0} & =[\mathrm{Ar}] 7.8 \cdot 10^{23} T^{-8.2} \\
& \exp (-59200 / T)\end{aligned}$ & $1700-5000$ & & Cobos and Troe, $1992^{24}$ & (u) \\
\hline $\begin{array}{l}F_{\mathrm{c}}(\mathrm{Ar})=\exp (-T / 1350) \\
\quad+\exp (-7834 / T)\end{array}$ & $1000-5000$ & & & \\
\hline$k_{00}-2.46 \cdot 10^{16} \operatorname{cxp}(-52800 / T)$ & $1000-5000$ & & & \\
\hline
\end{tabular}

\section{Comments}

(a) Shock wave study of $\mathrm{CH}_{4} / \mathrm{Ar}$ mixtures. The reaction was followed by infrared emission of $\mathrm{CH}_{4}$ and by infrared emission and ultraviolet absorption of the formed species.

(b) Shock tube study of the pyrolysis of $\mathrm{CH}_{4} . \mathrm{H}$ atoms monitored directly using atomic resonance absorption spectroscopy. Absolute $\mathrm{H}$ concentration determined using calibration by $\mathrm{N}_{2} \mathrm{O} / \mathrm{H}_{2} / \mathrm{Ar}$ mixtures. Modelling with 17 reactions. RRKM and master equation calculations.

(c) Study of the decomposition of $\mathrm{CH}_{4}$ in reflected shock waves. $\mathrm{CH}_{3}$ concentrations detected by narrow-line-width laser absorption at $216.6 \mathrm{~nm}$. Reaction mechanism with 38 reactions.

(d) Study of the pyrolysis of $\mathrm{CH}_{4}$ in incident shock waves with the laser-schlieren technique. Measurements in mixtures of $2 \% \mathrm{CH}_{4}-\mathrm{Kr}, 2 \% \mathrm{CH}_{4}$ - $\mathrm{Ar}$ and $0.5 \% \mathrm{CH}_{4}-\mathrm{Ar}$ at pressures of 230-660 Torr have been done between $2800-4300 \mathrm{~K}$. RRKM analysis of data between 1600 $4200 \mathrm{~K}$

(e) Shock wave study of $\mathrm{CH}_{4} / \mathrm{O}_{2} / \mathrm{CO} / \mathrm{Ar}$ mixtures. The reaction was followed by measuring infrared emissions from $\mathrm{CO}$ and $\mathrm{O}_{2}$.

(f) The $\mathrm{CH}_{4}$ pyrolysis was investigated by a shock waves technique.

(g) Shock wave study of $\mathrm{CH}_{4} / \mathrm{Ne}$ mixtures. The reaction was analysed by time-of-flight mass spectrometry.

(h) Direct measurements of the time dependent $\mathrm{H}$ atom concentration during the pyrolysis of $\mathrm{CH}_{4} / \mathrm{Ar}$ mixtures using shock waves technique.

(i) Pyrolysis of $\mathrm{CH}_{4}$ in shock waves. The reaction was followed by time-of-flight mass spectrometry, infrared laser absorption, and laser schlieren technique.

(j) Pyrolysis of $\mathrm{CH}_{4}$ in a static system. Initial rates based on analysis of $\mathrm{H}_{2}, \mathrm{C}_{2} \mathrm{H}_{6}$, and $\mathrm{C}_{2} \mathrm{H}_{4} . k_{\infty}$ values extrapolated with RRKM theory.

(k) Shock waves study of $\mathrm{CH}_{4} / \mathrm{O}_{2} / \mathrm{Ar}$ mixtures. Reaction followed by absorption measurements of $\mathrm{OH}$ and by emission from the chemiluminescent reaction $\mathrm{O}+\mathrm{CO}$.

(1) Shock waves study of $\mathrm{CH}_{4}$ pyrolysis. The reaction was followed monitoring the $\mathrm{CH}_{4}$ emission and absorption at $3.392 \mu \mathrm{m}$.

(m) Shock waves measurements of $\mathrm{CH}_{4} / \mathrm{Ar}$ mixtures. Modelling of 12 reactions.

(n) Pyrolysis of $\mathrm{CH}_{4}$ at very early stages $(0.003-0.05 \%$ reaction) in a quartz-lined flow reactor. Reactant andproducts (ethane, ethylene, acetylene, and propylene) detected by gas chromatography.

(o) Review of literature previous to 1966. 
(p) Review of literature previous to 1980.

(q) The $k_{\infty}$ recommended is based on the Hartig et al.${ }^{1}$ results scaled up by a factor 3 .

(r) Single-channel hindered Gorin model RRKM calculations of the $\mathrm{CH}_{4}$ decomposition with a fit to experimental results.

(s) The experiments by Hartig et al. ${ }^{1}$ have been re-evaluated taking into account the increasing amount of IR emissions from species other than $\mathrm{CH}_{4}$ as documented in Ref. 1 . These corrections become most pronounced in the high pressure experiments. The theoretical calculations were done using the $k_{\mathrm{o}}$ formalism from Ref. 20, fall-off expression from Ref. 21 and SACM-modified PST calculations from Ref. 22 which lead to a nearly temperature independent value of $k_{\infty}$ for the reverse recombination $\mathrm{H}$ $+\mathrm{CH}_{3} \rightarrow \mathrm{CH}_{4}$ of $3.5 \cdot 10^{-10} \mathrm{~cm}^{3}$ molecule ${ }^{-1} \mathrm{~s}^{-1}$.

(t) Critical evaluation of gas phase chemical reactions for use in modelling combustion processes.

(u) Re-analysis of the kinetic data from Refs. 3 and 4 in terms of the theory of unimolecular reactions ${ }^{20,21}$. The analysis leads to an energy transferred per collision of $50 \pm 20$ $\mathrm{cm}^{-1}$ for $\mathrm{M}=$ Ar over the temperature range $1000-$ $5000 \mathrm{~K}$.

\section{Preferred Values}

$k_{0}=[\mathrm{Ar}] 7.5 \cdot 10^{-7} \exp (-45700 / T)$ over range 1000 $1700 \mathrm{~K}$.

$k_{\mathrm{o}}=[\mathrm{Ar}] 7.8 \cdot 10^{23} \mathrm{~T}^{-8.2} \exp (-59200 / T)$ over range $1700-$ $5000 \mathrm{~K}$.

$k_{\mathrm{o}}=\left[\mathrm{CH}_{4}\right] 1.4 \cdot 10^{-6} \exp (-45700 / T)$ over range 1000 $2000 \mathrm{~K}$

$k_{\infty}=2.4 \cdot 10^{16} \exp (-52800 / T)$ over range $1000-3000 \mathrm{~K}$

$F_{\mathrm{c}}=\exp (-T / 1350)+\exp (-7834 / T)$ for $\mathrm{M}-\mathrm{Ar}$ over range $1000-5000 \mathrm{~K}$.

$F_{\mathrm{c}}=0.31 \exp (-T / 91)+0.69 \exp (-T / 2207)$ for $\mathrm{M}=\mathrm{CH}_{4}$ uver range $1000-2000 \mathrm{~K}$.

\section{Reliability}

$\Delta \log k_{0}= \pm 0.3$ over range $1000-5000 \mathrm{~K}$.

$\Delta \log k_{\infty}= \pm 0.5$ over range $1000-3000 \mathrm{~K}$.

$\Delta F_{\mathrm{c}}= \pm 0.1$ over range $1000-5000 \mathrm{~K}(\mathrm{M}=\mathrm{Ar})$.

$\Delta F_{\mathrm{c}}= \pm 0.1$ over range $1000-2000 \mathrm{~K}\left(\mathrm{M}=\mathrm{CH}_{4}\right)$.

\section{Comments on Preferred Values}

The recommended values for $k_{0}$ result from a detailed analysis of the experimental data from Refs. 1,3,4,8,10-13 in terms of the theory of unimolecular reaction ${ }^{20-22}$ as given in
Refs. 19 and 24. From this evaluation a $\beta_{c}=0.11$ was derived near $1000 \mathrm{~K}$ for $\mathrm{M}=\mathrm{CH}_{4}{ }^{19}$ and $\beta_{\mathrm{c}}$ from 0.06 to 0.006 between 1000 to $5000 \mathrm{~K}$ for $\mathrm{M}=\mathrm{Ar}^{24}$. These last values are consistent with an average energy transferred per collision of $50 \pm 20$ $\mathrm{cm}^{-1}$. The recommended $k_{\infty}$ values are consistent with a nearly temperature independent $k_{\infty}$ of $3.5 \cdot 10^{-10} \mathrm{~cm}^{3}$ molecule ${ }^{-1} \mathrm{~s}^{-1}$ for the reverse association reaction. Figures 1 and 2 show the temperature dependence of $k_{0}$ and $k_{\infty}$ respectively. Figure 3 shows a set of fall-off curves over the range $300-4300 \mathrm{~K}$ for the recombination $\mathrm{H}+\mathrm{CH}_{3} \rightarrow \mathrm{CH}_{4}{ }^{24}$. The high temperature dissociation rate coefficients were converted to recombination rate coefficients with the $k_{\mathrm{c}}$ given above. Finally, in Fig. 4 dissociation fall-off curves for $M=$ $\mathrm{CH}_{4}{ }^{19}$ are depicted.

\section{References}

${ }^{1}$ R. Hartig, J. Troe, and H.Gg. Wagner, 13th Symp. (Int.) Combust. 147 (1971).

${ }^{2}$ R.B. Klemm, J.W. Sutherland, M.J, Rabinowitz, P.M. Patterson, J.M. Quartemont, and W. Tao, J. Phys. Chem. 96, 1786 (1992).

${ }^{3}$ D.F. Davidson, M.D. DiRosa, A.Y. Chang, R.K. Hanson, and C.T. Bowman, 2.4th Symp. (Int.) Combust 589 (1992).

${ }^{4}$ J.H. Kiefer and S.S. Kumaran, J. Phys. Chem. 97, 414 (1993).

${ }^{5}$ A.M. Dean and G.A. Kistiakowsky, J. Chem. Phys. 54, 1718 (1971).

${ }^{6}$ D.H. Napier and N. Subrahmanyan, J. Appl. Chem. Biotechnol. 22, 303 (1972).

${ }^{7}$ G.A. Vompe, Russ. J. Phys. Chem. 47, 788 (translated from Zh. Fiz. Khim. 47, 1396 (1.973)).

${ }^{8} \mathrm{P}$. Roth and Th. Just, Ber. Bunsenges. Phys. Chem. 79, 682 (1975).

${ }^{9}$ W.C. Gardiner, Jr, I.H Owen, T.C. Clark, I.F. Dove, S.H. Bauer, I.A. Miller, and W.J. McLean, 15th Symp. (Int.) Combust., 857 (1975).

${ }^{10}$ C.J. Chen, M.H. Back, and R.A. Back, Can. J. Chem. 53, 3580 (1975).

"C.T. Bowman, 15th Symp. (Int.) Combust., 869 (1975).

${ }^{12}$ W.M. Heffington, G.E. Parks, K.G.P. Sulzmann, and S.S. Penner, 16th Symp. (Int.) Combust., 997 (1977).

${ }^{13}$ K. Tabayashi and S.H. Bauer, Comb. Flame 34, 63 (1979).

${ }^{14}$ R.W. Bames, G.L. Pratt, and S.W. Wood, J. Chem. Soc., Faraday Trans. 2, 85, 229 (1989)

${ }^{15}$ S.W. Benson and H.W. O'Neal, Nat. Std. Ref. Data Series NSRDS-NBS 21, $381(1970)$

${ }^{16} \mathrm{~J}$. Warnatz, in "Combustion Chemistry", ed. W.C. Gardiner, Springer-Verlag, New York (1984).

${ }^{17}$ W. Tsang and R.F. Hampson, J. Phys. Chem. Ref. Data 15, 1087 (1986). ${ }^{18}$ P.H. Stewart, G.P. Smith, and D.M. Golden, Int. J. Chem. Kin. 21, 923 (1989).

${ }^{19}$ C.J. Cobos and J. Troe, Z. Phys. Chem. NF 167, 129 (1990).

${ }^{20}$ J. Troe, J. Chem. Phys. 66, 4758 (1977); J. Phys. Chem. 83, 114 (1989).

${ }^{21}$ J. Troe, Ber. Bunsenges. Phys. Chem. 87, 161 (1983); R.G. Gilbert, K. Luther, and J. Troe, Ber. Bunsenges. Phys. Chem. 87, 169 (1983).

22 J. Trae, Z. Phys. Chem. NF 161, 209 (1989).

${ }^{23} \mathrm{CEC}, 1992$ (see references in Introduction).

${ }^{24}$ C.J. Cobos and J. Troe, Z. Phys. Chem. 176, 161 (1992).

${ }^{25}$ M. Brouard, M.T. Macpherson, and M.J. Pilling, J. Phys. Chem. 93, 4047 (1989).

${ }^{26}$ J.T. Cheng and C.T. Yeh, J. Phys. Chem. 81, 1982 (1977). 
$\mathrm{CH}_{4}+\mathrm{M} \rightarrow \mathrm{H}+\mathrm{CH}_{3}+\mathrm{M}$

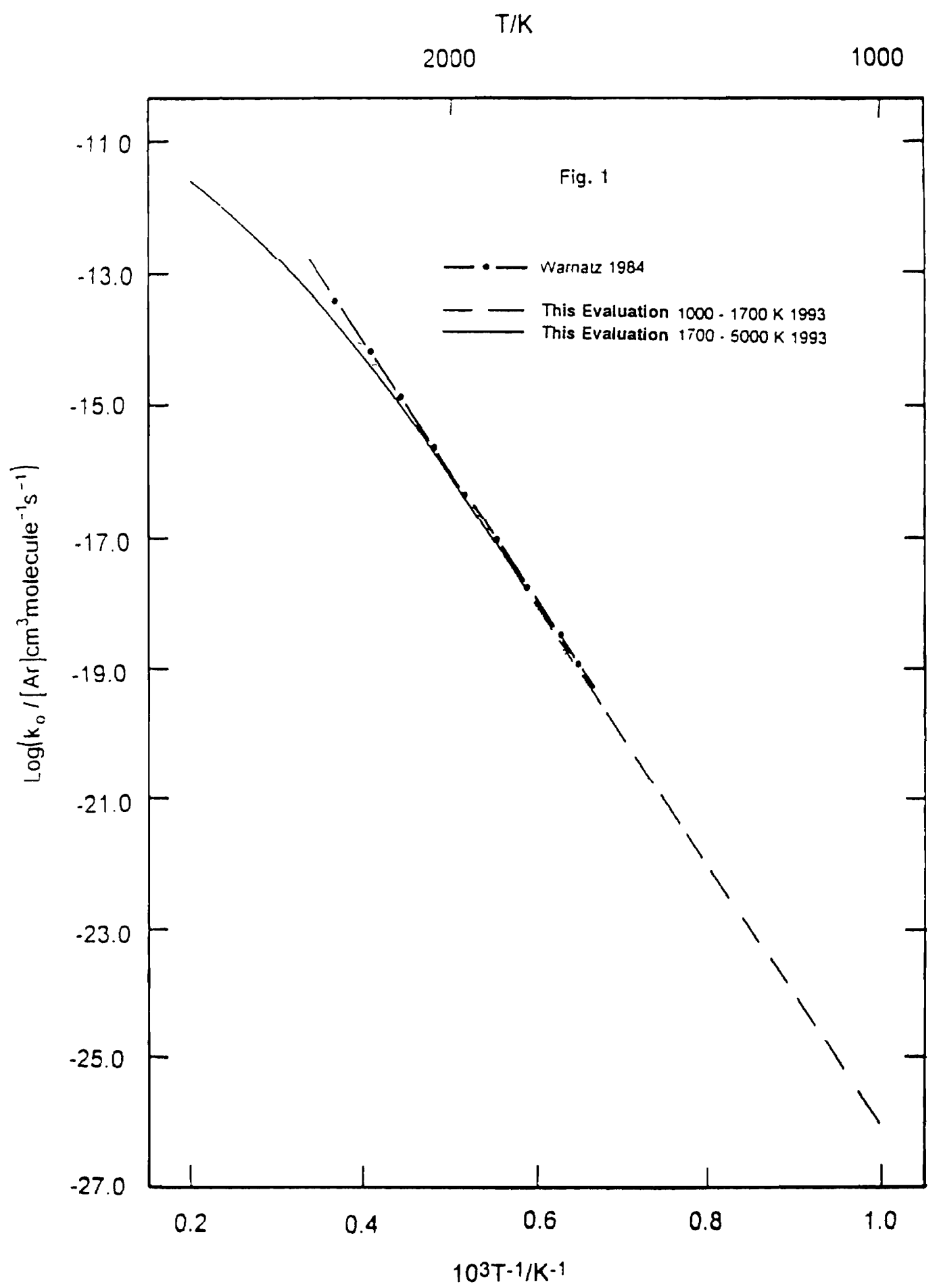




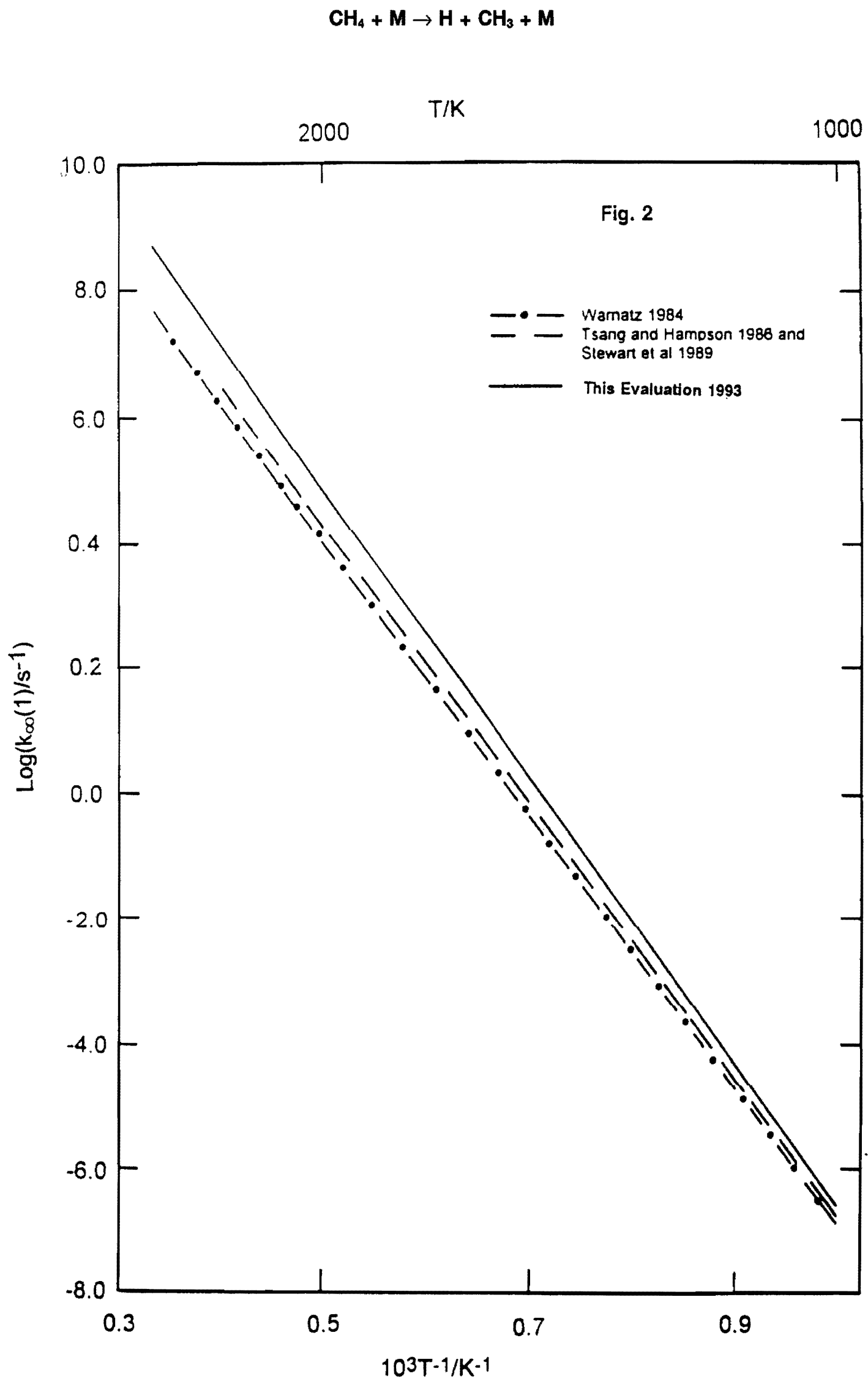


$\mathrm{CH}_{4}+\mathrm{M} \rightarrow \mathrm{H}-\mathrm{CH}_{3}+\mathrm{M}$

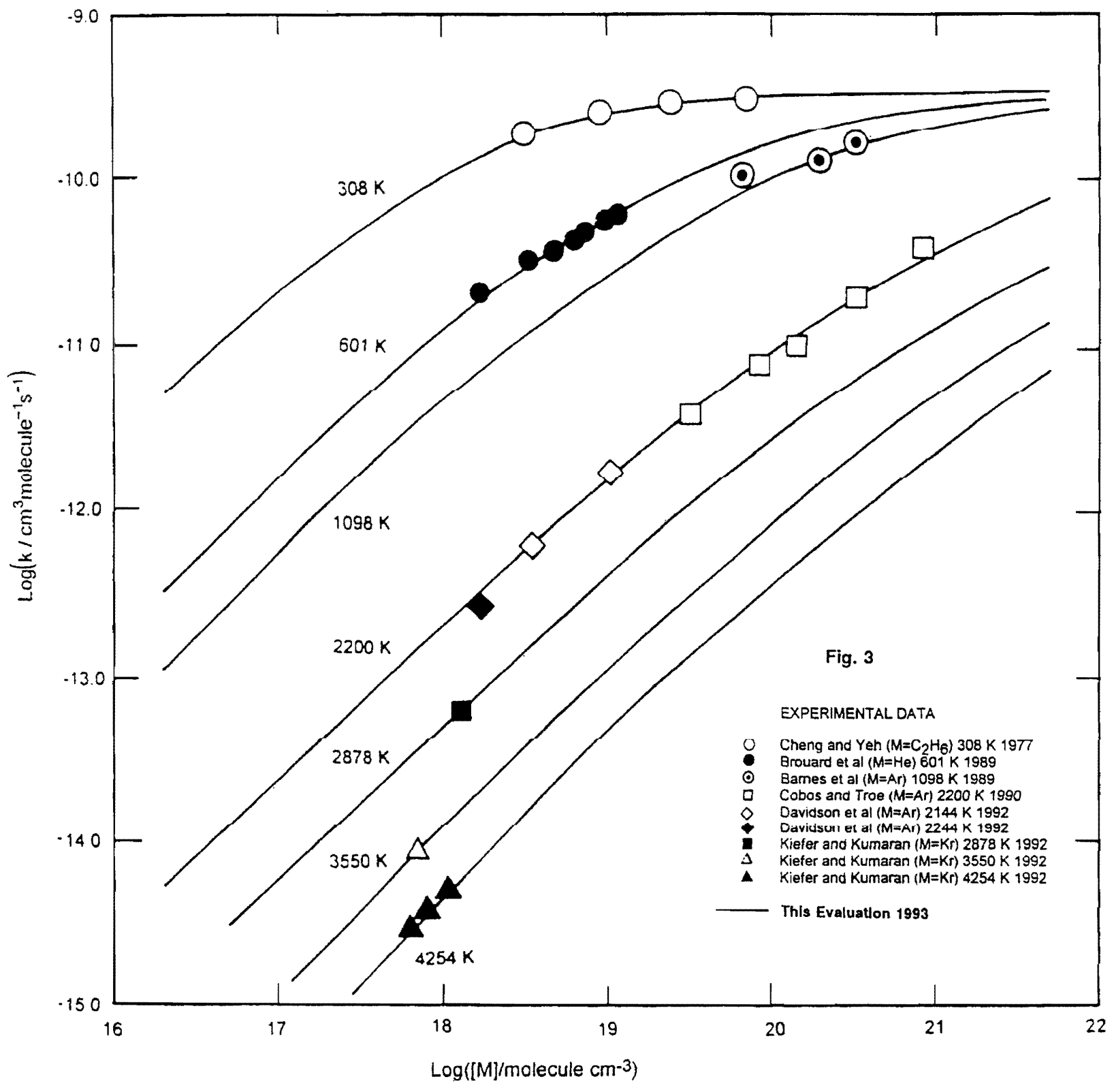




$$
\mathrm{CH}_{4}+\mathrm{M} \rightarrow \mathrm{H}+\mathrm{CH}_{3}+\mathrm{M}
$$

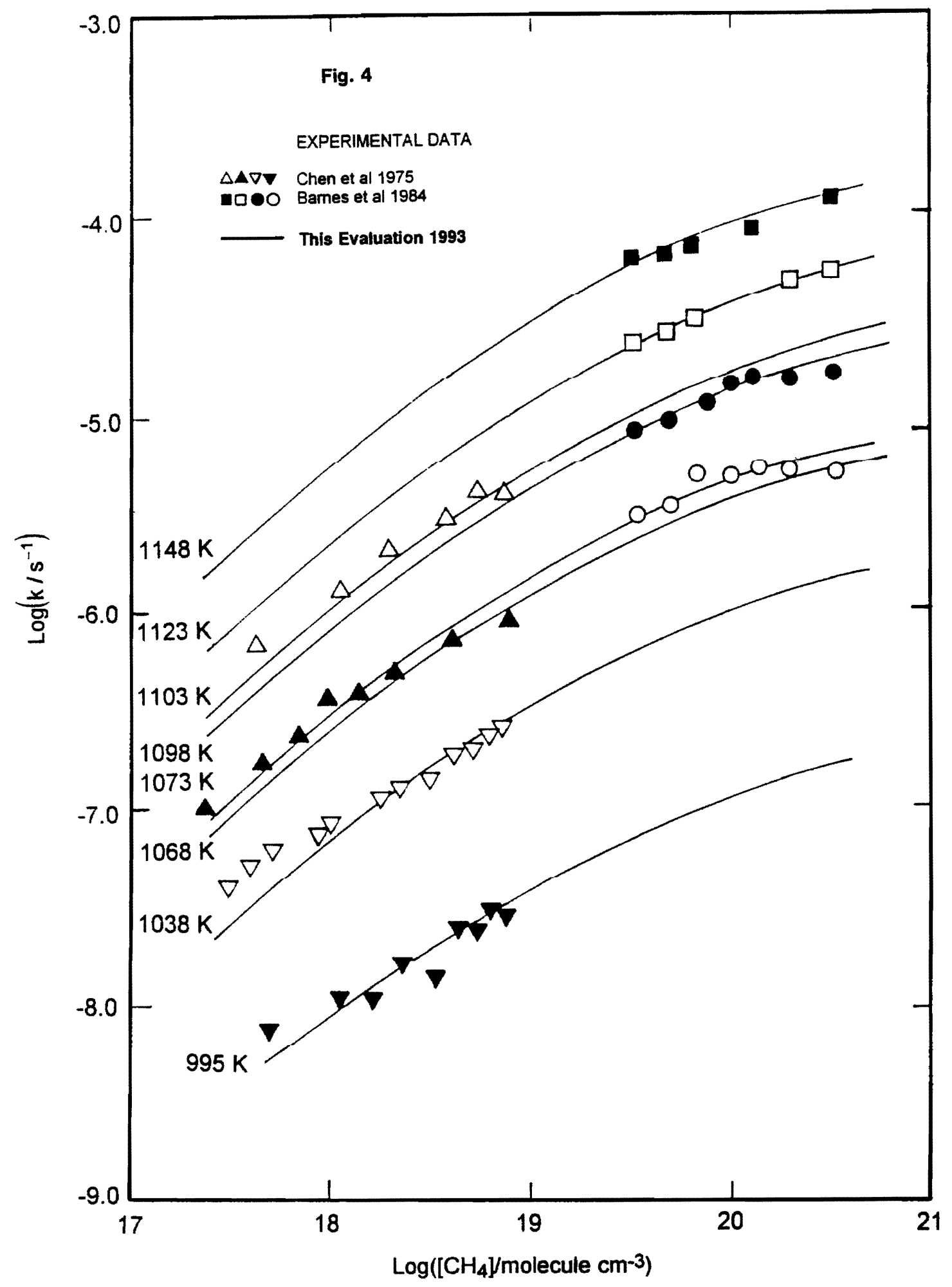


$\mathrm{H}+\mathrm{HCHO} \rightarrow \mathrm{H}_{2}+\mathrm{HCO}$

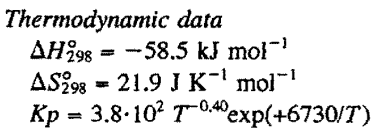

Rate Coefficient Data

\begin{tabular}{|c|c|c|c|}
\hline $\mathrm{k} / \mathrm{cm}^{3}$ molecule $^{-1} \mathrm{~s}^{-1}$ & $T / \mathrm{K}$ & Reference & Comments \\
\hline \multicolumn{4}{|l|}{ Rate Coefficient Measurements } \\
\hline $3.7 \cdot 10^{-12}$ & 813 & Baldwin and Cowe, $1962^{1}$ & (a) \\
\hline $2.2 \cdot 10^{-11} \exp (-1892 / T)$ & $297-652$ & Westenberg and deHaas, $1972^{2}$ & (b) \\
\hline $5.4 \cdot 10^{-14}$ & 297 & Ridley et al., $1972^{3}$ & (c) \\
\hline $3.3 \cdot 10^{-11} \exp (-1847 / T)$ & $264-479$ & Klemm, $1979^{4}$ & (d) \\
\hline $5.5 \cdot 10^{-10} \exp (-5280 / T)$ & $1700-2500$ & Dean, Johnson, and Steiner, $1980^{5}$ & (e) \\
\hline $3.3 \cdot 10^{-11}$ & $1470-1570$ & Vandooren et al., $1986^{6}$ & (f) \\
\hline $4.8 \cdot 10^{-11} \exp (-1879 / T)$ & $1180-1690$ & Choudhury and Lin, $1989^{7}$ & (g) \\
\hline \multicolumn{4}{|l|}{ Reviews and Evaluations } \\
\hline $3.8 \cdot 10^{-14} T^{1.05} \exp (-1650 / T)$ & $300-2200$ & CEC, $1992^{8}$ & (h) \\
\hline
\end{tabular}

\section{Comments}

(a) Inhibition of $\mathrm{H}_{2}+\mathrm{O}_{2}$ reaction at the second limit by $\mathrm{HCHO}$.

(b) Microwave discharge $\mathrm{H}_{2} / \mathrm{He}$; behaviour of $\mathrm{H}$ atoms in the presence of excess $\mathrm{HCHO}$ determined by ESR.

(c) Pulsed vacuum UV photolysis of $\mathrm{HCHO}$; behaviour of $\mathrm{H}$ atoms in the presence of excess $\mathrm{HCHO}$ determined by Lyman $\alpha$ resonance fluorescence.

(d) Flash photolysis; resonance fluorescence detection of $\mathrm{H}$ atoms.

(e) $\mathrm{HCHO} / \mathrm{O}_{2} / \mathrm{Ar}$ and $\mathrm{HCHO} / \mathrm{N}_{2} \mathrm{O} / \mathrm{Ar}$ mixtures investigated in reflected shock waves; $\mathrm{HCHO}$ detected by IR emission.

(f) Molecular beam mass spectrometric measurements in a lean $\mathrm{HCHO}-o x y g e n$ flame. $k$ derived from kinetic analysis of flane cluemistry.

(g) Shock wave pyrolysis of methyl nitrate/1,3,5-trioxane mixtures; $\mathrm{CO}$ production by time resolved resonance absorption. $k$ determined by kinetic modelling and was sensitive primarily to the values of $k(\mathrm{H}+\mathrm{HCO})=$ $1.2 \cdot 10^{-10} \mathrm{~cm}^{3}$ molecule ${ }^{-1} \mathrm{~s}^{-1}$ and $k(\mathrm{HCO}+\mathrm{M})=$ $3.16 \cdot 10^{-7} \mathrm{~T}^{-10} \exp (-8566 / T) \mathrm{cm}^{3}$ molecule ${ }^{-1} \mathrm{~s}^{-1}$.

(h) Based on the data of Ridley et al. ${ }^{5}, \mathrm{Klemm}^{4}$, and Dean et al. ${ }^{5}$.

\section{Preferred Values}

$k=2.1 \cdot 10^{-16} T^{1.62} \exp (-1090 / T) \mathrm{cm}^{3}$ molecule ${ }^{-1} \mathrm{~s}^{-1}$ over range $300-1700 \mathrm{~K}$.

Reliability

$\Delta \log k= \pm 0.3$ at $1700 \mathrm{~K}$ reducing to \pm 0.1 at $300 \mathrm{~K}$.

\section{Comments on Preferred Values}

The preferred value is the expression derived by Chondhury and $\mathrm{Lin}^{7}$ from a non-linear least squares analysis of their recent high temperature data and of the low temperature data of Baldwin and Cowe ${ }^{i}$, Westenberg and deHaas $^{2}$, Ridley et al. ${ }^{3}$ and Klemm ${ }^{4}$. The data of Choudhury and Lin appear to be more reliable than the earlier high temperature data of Shecker and Jost ${ }^{9}$ and Dean et al.$^{5}$.

\section{References}

${ }^{\prime}$ R.R. Baldwin and D.W. Cowe, Trans. Faraday Soc., 58, 1768 (1962) ${ }^{3}$ A.A. Westentery and N. UeHaas, J. Pliys. Chem. 76, 2213 (1972).

${ }^{3}$ B.A. Ridley, J.A. Davenport, L.J. Stief, and K.H. Welge, J. Chem. Phys. 57, 520 (1972).

${ }^{4}$ R.B. Klemm, J. Chem. Phys. 71, 1987 (1979).

'A.M. Dean, R.L. Juluson, and D.C. Stciner, Comb. Flame 37, 41 (1980).

${ }^{6} \mathrm{~J}$. Vandooren, L. Olenhove de Guertechin, and P.J. Van Tiggelen, Combust. Flame 64, 127 (1986).

${ }^{7}$ T.K. Choudhury and M.C. Lin, Combust. Sci. Technol. 64, 19 (1989).

${ }^{8} \mathrm{CEC}, 1992$ (sec references in Introduction).

${ }^{9}$ H.G. Schecker and W. Jost, Ber. Bunsenges. Phys. Chem. 73, 521 (1969). 
EVALUATED KINETIC DATA FOR COMBUSTION MODELLING

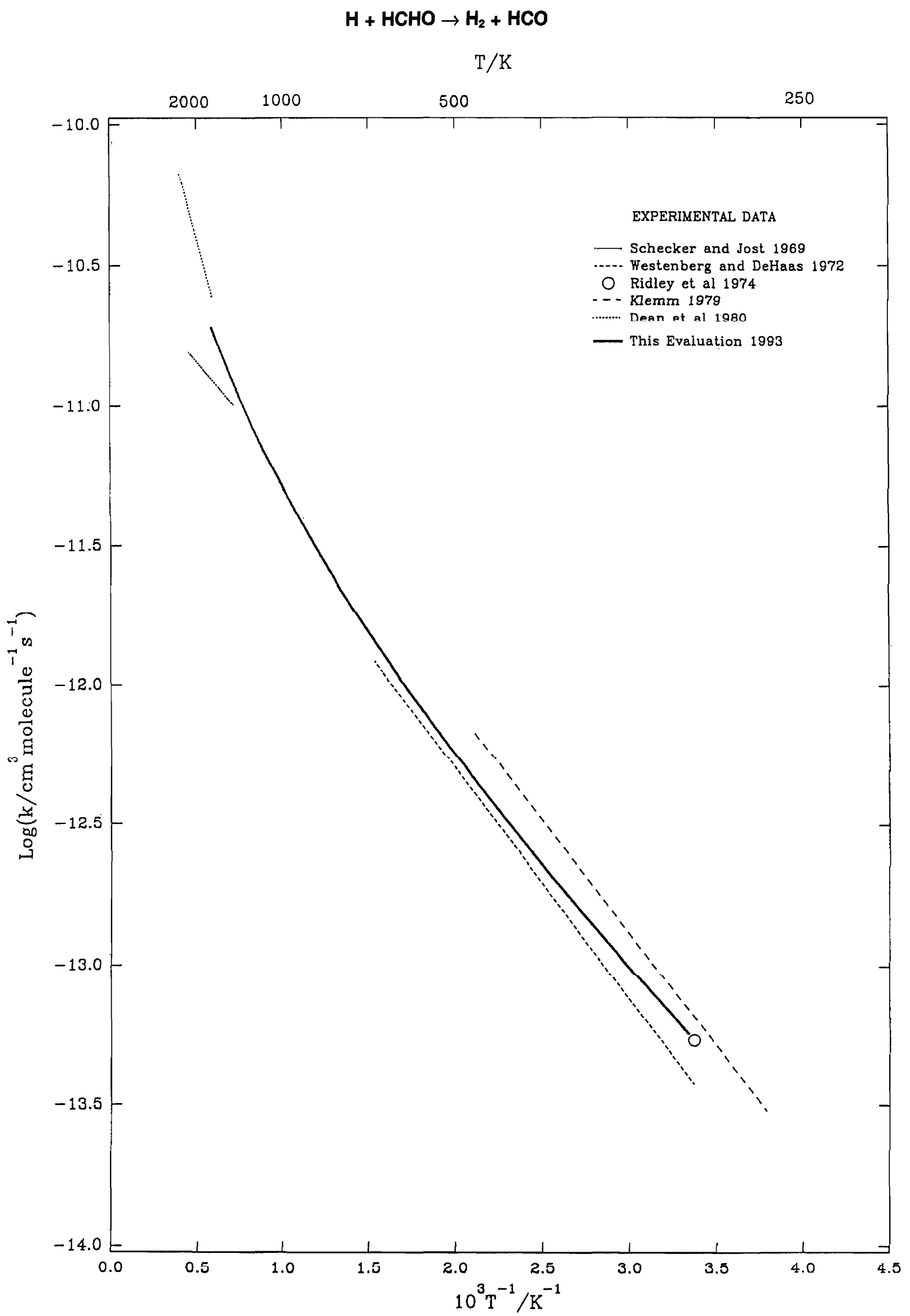




\section{$\mathrm{H}+\mathrm{C}_{2} \mathrm{H}_{4}(+\mathrm{M}) \rightarrow \mathrm{C}_{2} \mathrm{H}_{5}(+\mathrm{M})$}

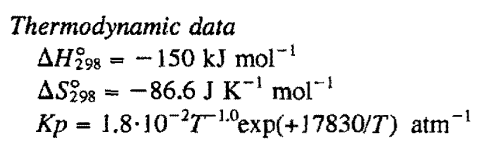

Rate Coefficient Data

\begin{tabular}{|c|c|c|c|c|}
\hline$k / \mathrm{cm}^{3}$ molecule $^{-1} \mathrm{~s}^{-1}$ & $T / \mathrm{K}$ & {$[\mathrm{M}] /$ molecule $\mathrm{cm}^{-3}$} & References & Comments \\
\hline \multicolumn{5}{|l|}{ Low Pressure Range } \\
\hline [He] $1.4 \cdot 10^{-29} \exp (-569 / T)$ & $285-604$ & $(8-140) \cdot 10^{17}$ & Lightfoot and Pilling, $1987^{\prime}$ & (a) \\
\hline \multicolumn{5}{|l|}{ Intermediate Fall-Off Range } \\
\hline $3.2 \cdot 10^{-13}$ & 300 & $1.6 \cdot 10^{17}(\mathrm{He})$ & Braun and Lenzi, $1967^{2}$ & (b) \\
\hline $4.3 \cdot 10^{-13}$ & & $3.2 \cdot 10^{17}$ & & \\
\hline $6.7 \cdot 10^{-13}$ & & $9.3 \cdot 10^{17}$ & & \\
\hline $1.9 \cdot 10^{-13}$ & & $1.6 \cdot 10^{17}\left(\mathrm{~N}_{2}\right)$ & & \\
\hline $4.0 \cdot 10^{-13}$ & & $4.8 \cdot 10^{17}$ & & \\
\hline $8.0 \cdot 10^{-13}$ & & $24 \cdot 10^{17}$ & & \\
\hline $3.3 \cdot 10^{-13}$ & 300 & $1.6 \cdot 10^{17}(\mathrm{He})$ & Kurylo, Peterson, and Braun, $1970^{3}$ & (c) \\
\hline $7.7 \cdot 10^{-13}$ & & $32 \cdot 10^{17}$ & & \\
\hline $1.2 \cdot 10^{-12}$ & & $162 \cdot 10^{17}$ & & \\
\hline $56 \cdot 10^{-14}$ & $30 n$ & $1.3 \cdot 10^{16}(\mathrm{He})$ & Barker ef al., 1970 & (d) \\
\hline $2.5 \cdot 10^{-13}$ & & $24 \cdot 10^{16}$ & & \\
\hline $3.7 \cdot 10^{-13}$ & & $81 \cdot 10^{16}$ & & \\
\hline $1.3 \cdot 10^{-12} \exp (-367 / T)$ & $303-603$ & $(2.6-4.3) \cdot 10^{16}\left(\mathrm{H}_{2}\right)$ & Teng and Jones, $1972^{5}$ & (e) \\
\hline $8.7 \cdot 10^{-14}$ & 300 & $0.16 \cdot 10^{17}(\mathrm{He})$ & Michael, Osborne, and Suess, $1973^{\circ}$ & (f) \\
\hline $6.1 \cdot 10^{-13}$ & & $24 \cdot 10^{17}$ & & \\
\hline $1.1 \cdot 10^{-12}$ & & $193 \cdot 10^{17}$ & & \\
\hline $4.1 \cdot 10^{-13}$ & 298 & $9.7 \cdot 10^{16}(\mathrm{Ar})$ & Laupert and von Bünau, $1974^{7}$ & (g) \\
\hline $3.23 \cdot 10^{-12}$ & 775 & $2.5 \cdot 10^{18}(\mathrm{He})$ & Brouard, Lightfoot, and Pilling, $1986^{8}$ & (h) \\
\hline $2.97 \cdot 10^{-12}$ & 800 & $2.4 \cdot 10^{18}$ & & \\
\hline $2.79 \cdot 10^{-12}$ & 825 & $2.3 \cdot 10^{18}$ & & \\
\hline $2.0 \cdot 10^{-12}$ & 800 & $1.2 \cdot 10^{18}(\mathrm{He})$ & Hanning-Lee et al., $1993^{\circ}$ & (i) \\
\hline $3.1 \cdot 10^{-12}$ & & $3.6 \cdot 10^{18}$ & & \\
\hline $4.7 \cdot 10^{-12}$ & & $7.2 \cdot 10^{18}$ & & \\
\hline \multicolumn{5}{|l|}{ High Pressure Range } \\
\hline $1.0 \cdot 10^{-12}$ & 300 & $(1.6-29) \cdot 10^{17}\left(\mathrm{~N}_{2}\right)$ & Braun and Lenzi, $1967^{2}$ & (b) \\
\hline $1.36 \cdot 10^{-12}$ & 300 & $(1.6-16) \cdot 10^{17}\left(\mathrm{~N}_{2}\right)$ & Kurylo, Peterson, and Braun, $1970^{3}$ & (c) \\
\hline $9.1 \cdot 10^{-13}$ & 298 & $(2.4-5.7) \cdot 10^{19}\left(\mathrm{H}_{2}\right)$ & Eyre, Hikida, and Dorfman, $1970^{10}$ & (j) \\
\hline $9.1 \cdot 10^{-13}$ & 298 & $(2.4-5.7) \cdot 10^{19}\left(\mathrm{H}_{2}\right)$ & Hikida, Eyre, and Dorfman, $1971^{11}$ & (k) \\
\hline $1.3 \cdot 10^{-11} \exp (-755 / T)$ & $303-478$ & $5.7 \cdot 10^{19}\left(\mathrm{CO}_{2}\right)$ & Penzhorn and Darwent, $1971^{12}$ & (l) \\
\hline $1.6 \cdot 10^{-12}$ & 300 & $(8.8-12900) \cdot 10^{15}(\mathrm{He})$ & Michael, Osborne, and Suess, $1973^{\circ}$ & (f) \\
\hline $1.25 \cdot 10^{-12}$ & 300 & $(2.6-5.3) \cdot 10^{19}(\mathrm{He})$ & Mihelcic et al., $1975^{13}$ & (m) \\
\hline $3.67 \cdot 10^{-11} \exp (-1042 / T)$ & $198-300$ & $(1.5-2.3) \cdot 10^{19}(\mathrm{Ar})$ & Lee et al., 1978 & (n) \\
\hline $1.1 \cdot 10^{-12}$ & 298 & $(6.5-39) \cdot 10^{18}\left(\mathrm{H}_{2}\right)$ & Ishiwara et al ., $1978^{15}$ & (o) \\
\hline $7.8 \cdot 10^{-13}$ & 298 & $(6.5-32) \cdot 10^{17}\left(\mathrm{H}_{2}\right)$ & Oka and Cvetanović, $1979^{16}$ & (p) \\
\hline $4.7 \cdot 10^{-11} \exp (-1096 / T)$ & $211-461$ & & Sugawara, Okazaki, and Satu, $1981^{17}$ & (q) \\
\hline $1.1 \cdot 10^{-12}$ & 300 & & Ellul et al., $1981^{18}$ & (r) \\
\hline $4.39 \cdot 10^{-11} \operatorname{cxp}(-1087 / T)$ & $285-604$ & $(8-140) \cdot 10^{17}(\mathrm{II} \mathrm{c})$ & Lightfoot and rilling, $1987^{1}$ & (a) \\
\hline \multicolumn{5}{|l|}{ Reviews and Evaluations } \\
\hline$k_{\infty}=1.6 \cdot 10^{-10} \exp (-1410 / T)$ & $300-800$ & & Kerr and Parsonage, $1972^{19}$ & (s) \\
\hline$k_{\infty}=1.7 \cdot 10^{-11} \exp (-758 / T)$ & $300-2000$ & & Warnatz, $1984^{20}$ & (t) \\
\hline$k_{x}=1.42 \cdot 10^{-15} T^{1.49} \mathrm{exp}(-499 / T)$ & $300-900$ & & Tsang and Hampson, $1986^{21}$ & (u) \\
\hline $\begin{array}{l}k_{\infty}=1.795 \cdot 10^{-12} T^{0.454} \\
\exp (-917 / T)\end{array}$ & $185-1100$ & & Feng et al., $1993^{22}$ & (v) \\
\hline
\end{tabular}




\section{Comments}

(a) Laser flash photolysis-resonance fluorescence study of the reaction $\mathrm{H}+\mathrm{C}_{2} \mathrm{H}_{4}$. $\mathrm{H}$ atoms were generated by photolysis of $\mathrm{N}_{2} \mathrm{O}$ at $193 \mathrm{~nm}$ in the presence of $\mathrm{H}_{2}$ and monitored by resonance fluorescence.

(b) Flash photolysis of $\mathrm{C}_{2} \mathrm{H}_{4}$; detection via Lyman- $\alpha$ absorption of $\mathrm{H}$ atoms. High pressure extrapolation to gas densities greater than $2.4 \cdot 10^{18}$ molecule $\mathrm{cm}^{-3}$.

(c) Vacuum UV flash photolysis of $\mathrm{C}_{2} \mathrm{H}_{4}$. Analysis of $\mathrm{H}$ atom concentration by resonance fluorescence and absorption of Lyman- $\alpha$ radiation at $121.6 \mathrm{~nm}$. Extrapolation to the high pressure limit via Lindemann plots.

(d) Three different experimental techniques were employed: (a) discharge flow system with Lyman- $\alpha$ absorption detection of $\mathrm{H}$ atoms; (b) reactive Lyman- $\alpha$ photometric experiments with $\mathrm{H}$ atoms generated from $\mathrm{Hg}$-photosensitized decomposition of $\mathrm{H}_{2}$; (c) discharge flow system with time-of-flight mass spectrometry.

(e) $\mathrm{H}$ atoms generated in a Wood-Bonhoeffer discharge; products $\mathrm{C}_{2} \mathrm{H}_{6}, \mathrm{C}_{3} \mathrm{H}_{8}, n-\mathrm{C}_{4} \mathrm{H}_{10}$ and $\mathrm{CH}_{4}$ determined by GC.

(f) Time-resolved Lyman- $\alpha$ absorption; $\mathrm{H}$ produced by $\mathrm{Hg}$ photosensitization of $\mathrm{H}_{2}$.

(g) Discharge flow system; product analysis by MS.

(h) ArF excimer laser flash photolysis of $\mathrm{C}_{2} \mathrm{H}_{4}$ with detection of $\mathrm{H}$ atoms by Lyman- $\alpha$ resonance fluorescence. The approach to the $\mathrm{H}+\mathrm{C}_{2} \mathrm{H}_{4} \rightleftharpoons \mathrm{C}_{2} \mathrm{H}_{5}$ equilibrium was directly observed.

(i) Direct measurements of the approach to the $\mathrm{H}+\mathrm{C}_{2} \mathrm{H}_{4}$ tharohall $\mathrm{C}_{2} \mathrm{H}_{5}$ equilibrium. $\mathrm{H}$ atoms formed by photolysis at $193 \mathrm{~nm}$ of $\mathrm{C}_{2} \mathrm{H}_{4}-\mathrm{He}$ mixtures and detected by time-resolved resonance fluorescence. Master equation analysis of data.

(j) Pulse radiolysis of $\mathrm{H}_{2}$ with direct observation of $\mathrm{H}$ atoms by Lyman $-\alpha$ absorption spectroscopy.

(k) See comment (i).

(l) Photolysis of $\mathrm{HI}$ in the presence of $\mathrm{C}_{2} \mathrm{H}_{4}$; rate coefficients determined relative to the reaction $\mathrm{H}+\mathrm{HI} \rightarrow \mathrm{H}_{2}+\mathrm{I}$ for which a value $k=2.0 \cdot 10^{-11} \mathrm{~cm}^{3}$ molecule ${ }^{-1} \mathrm{~s}^{-1}$ was employed.

(m) Pulse radiolysis of $\mathrm{H}_{2}$ with Lyman- $\alpha$ detection of II atoms.

(n) Flash photolysis-resonance fluorescence measurements. Photolysis of $\mathrm{C}_{2} \mathrm{H}_{4}$ at $\lambda \geqslant 110 \mathrm{~nm}$ and detection of $\mathrm{H}$ atoms by resonance fluorescence in $\mathrm{Ar}$ diluent.

(o) Pulse radiolysis of $\mathrm{H}_{2}$ with detection of $\mathrm{H}$ atoms by Lyman- $\alpha$ absorption.

(p) Irradiation of $\mathrm{Hg} / \mathrm{NO} / \mathrm{H}_{2} / \mathrm{C}_{2} \mathrm{H}_{4}$ mixtures with modulated light at $253.7 \mathrm{~nm}$ in a flow system. Measurements of the luminescence of HNO ('A").

(q) Pulse radiolysis of $\mathrm{H}_{2}$; resonance absorption detection of $\mathrm{H}$.

(r) Pulsed $\mathrm{Hg}$-sensitized photolysis of $\mathrm{H}_{2}$; resonance absorption detection of $\mathrm{H}$.

(s) Review of literature up to 1970.

(t) Review of literature prior to 1980.

(u) The recommended values were obtained by combination of the room temperature rate coefficients with results of the reverse dissociation reaction at higher temperatures. A tabulation of $\log k / k_{\infty}$ over the temperature range 300 $2500 \mathrm{~K}$ from RRKM calculation is also given.

(v) Expression based on the results of Refs. 1 and 9 and transition state model calculations.

\section{Preferred Values}

$k_{\infty}=6.6 \cdot 10^{-15} T^{1.28} \exp (-650 / T) \mathrm{cm}^{3}$ molecule $\mathrm{e}^{-1} \mathrm{~s}^{-1}$ over range $200-1100 \mathrm{~K}$.

$k_{0}=[\mathrm{He}] 1.3 \cdot 10^{-29} \exp (-380 / T) \mathrm{cm}^{3}$ molecule $\mathrm{e}^{-1} \mathrm{~s}^{-1}$ over range $300-800 \mathrm{~K}$.

$k_{0}=\left[\mathrm{N}_{2}\right] 7.7 \cdot 10^{-30} \exp (-380 / T) \mathrm{cm}^{3}$ molecule ${ }^{-1} \mathrm{~s}^{-1}$ over range $300-800 \mathrm{~K}$.

$F_{\mathrm{c}}=0.24 \exp (-T / 40)+0.76 \exp (-T / 1025)$ for $\mathrm{M}=\mathrm{He}$ and $\mathrm{N}_{2}$ over range $300-800 \mathrm{~K}$.

\section{Reliability}

$\Delta \log k_{\infty}= \pm 0.3$ over range $200-1100 \mathrm{~K}$.

$\Delta \log k_{\mathrm{o}}= \pm 0.3$ over range $300-800 \mathrm{~K}$.

$\Delta F_{\mathrm{c}}= \pm 0.1$ over range $300-800 \mathrm{~K}$.

\section{Comments on Preferred Values}

This reaction has been extensively studied at low temperatures. The $k_{\infty}$ value at $300 \mathrm{~K}$ is well established. The average of all experimental measurements is $(1.2 \pm 0.3) \cdot 10^{-12} \mathrm{~cm}^{3}$ molecule $\mathrm{e}^{-1} \mathrm{~s}^{-1}$. The analysis of the reaction is based on theoretical fall-off curves $^{23}$ and strong collision low pressure rate coefficients $^{23,24}$ which were calculated using a reaction threshold of $154.78 \mathrm{~kJ} \mathrm{~mol}^{-122}$. From this analysis the above recommended limiting rate coefficients were derived. The temperature dependence of $k_{0}$ and $k_{\infty}$ is depicted in Figs. 1 and 2. The resulting collision efficiencies for $M=\mathrm{He}$ are approximately independent of temperature, $\beta_{\mathrm{c}} \approx 0.07$, over the range $300-800 \mathrm{~K}$. This finding is consistent with a temperature dependence of $-\left\langle\Delta E>\right.$ of about $T^{+0.8}$ in good agreement with recent results ${ }^{22}$. Figure 3 shows the room temperature data from Kurylo et al.$^{3}$ and data at higher temperatures by Pilling and co-workers ${ }^{1,8,9}$. At atmospheric pressure and $300 \mathrm{~K}$ the reaction is very close to the high pressure limit, i.e. $\mathrm{k} / k_{\infty} \approx 0.9$, while at $800 \mathrm{~K}$ it is in the fall-off regime. The recombination and the dissociation rate coefficients are related via the equilibrium constant given above $\mathrm{e}^{22}$. The expression for $k_{\mathrm{o}}$ for $\mathrm{M}=\mathrm{N}_{2}$ is based on the early work of Braun and I.enzi ${ }^{2}$ which requires confirmation.

\section{References}

'P.D. Lightfoot and M.J. Pilling, J. Phys. Chem. 91, 3373 (1987).

${ }^{2}$ B.W. Braun and M. Lenzi, Disc. Faraday Soc. 44, 252 (1967).

${ }^{3}$ M.J. Kurylo, N.C. Peterson, and W. Braun, J. Chem. Phys. 53, 2776 (1970).

${ }^{4}$ J.R. Barker, D.G. Keil, J.V. Michael, and D.T. Osborne, J. Chem. Phys. 52, 2079 (1970).

${ }^{5}$ L. Teng and W.E. Jones, J. Chem. Soc., Faraday Trans. 1 68, 1267 (1972).

${ }^{6}$ J.V. Michael, D.T. Osborne, and G.W. Suess, J. Chem. Phys. 58, 2800 (1973).

${ }^{7}$ R. Laupert and G. yon Bünau, Z. Naturforsch. A 29, 642 (1974).

${ }^{8}$ M. Brouard, P.D. Lightfoot, and M.J. Pilling, J. Phys. Chem. 90,445 (1986).

${ }^{9}$ M.A. Harning-Lee, N.J.B. Green, M.J. Pilling, and S.H. Robertson, J. Phys. Chem. 97, 860 (1993).

${ }^{10}$ J.A. Eyre, T. Hikida, and L.M. Dorfman, J. Chem. Phys. 53, 1281 (1970). 
"T. Hikida, J.A. Eyre, and L.M. Dorfman, J. Chem. Phys. 54, 3422 (1971).

${ }^{12}$ R.D. Penzhorn and B. de B. Darwent, J. Chem. Phys. 55, 1508 (1971).

${ }^{13}$ D. Mihelcic, V. Shubert, F. Höffer, and P. Potzinger, Ber. Bunsenges. Phys. Chem. 79, 1230 (1975).

${ }^{14}$ J.H. Lee, J.V. Michael, W.A. Payne, and L.J. Stief, J. Chem. Phys. 68, 1817 (1978).

${ }^{15}$ Y. Ishiwara, M. Yamabe, A. Noda, and S. Sato, Bull. Chem. Soc. Jpn. 51, 2488 (1978).

${ }^{16}$ K. Oka, and R.J. Cvetanović, Can J. Chem. 57, 777 (1979).

${ }^{17}$ K. Sugawara, K. Okazaki, and S. Sato, Bull. Chem. Soc. Jpn. 54, 2872 (1981).

${ }^{18}$ R. Ellul, P. Potzinger, B. Reimann, and P. Camilleri, Ber. Bunsenges. Phys. Chem. 85, 407 (1981).
${ }^{19}$ J.A. Kerr and M.J. Parsonage, "Evaluated Kinetic Data on Gas Phase Addition Reactions. Reactions of atoms and radicals with alkenes and aromatic compounds", Butterworths, 1972.

${ }^{20} \mathrm{~J}$. Warnatz in "Combustion Chemistry" Ed. W.C. Gardiner, Jr., SpringerVerlag, New York, p. 196, 1984.

${ }^{21}$ W. Tsang and R.F. Hampson, J. Phys. Chem. Ref. Data 15, 1087 (1986).

${ }^{22}$ Y. Feng, J.T. Nirraueu, A. Bencsura, V.D. Kuyaaev, D. Gutman, and W.

Tsang, J. Phys. Chem. 97, 871 (1993).

${ }^{23}$ J. Troe, J. Phys. Chem. 83, 114 (1979).

${ }^{24}$ J. Troe, J. Chem. Phys. 66, 4758 (1977).

\section{$\mathrm{H}+\mathrm{C}_{2} \mathrm{H}_{4}+\mathrm{M} \rightarrow \mathrm{C}_{2} \mathrm{H}_{5}+\mathrm{M}$}

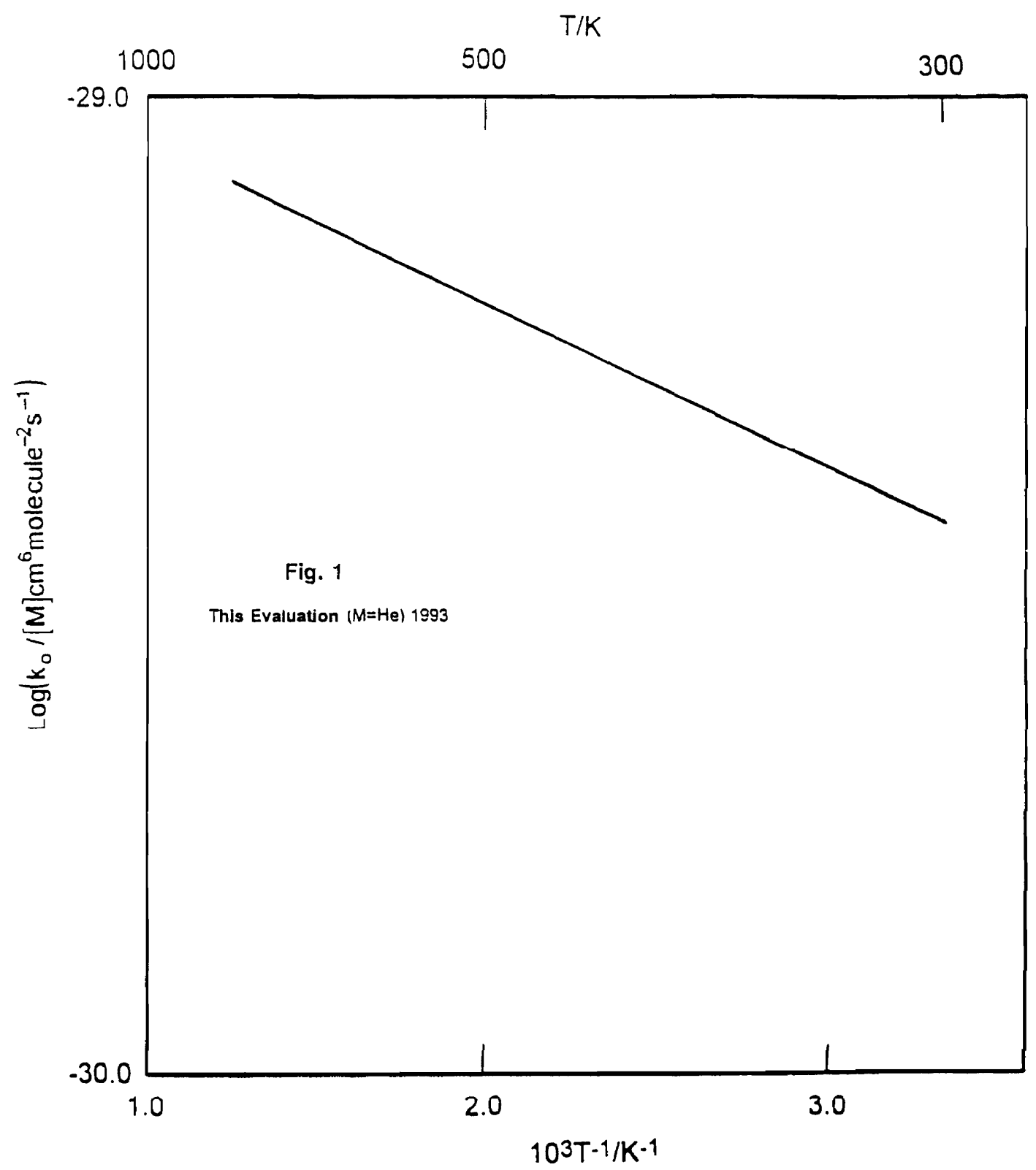




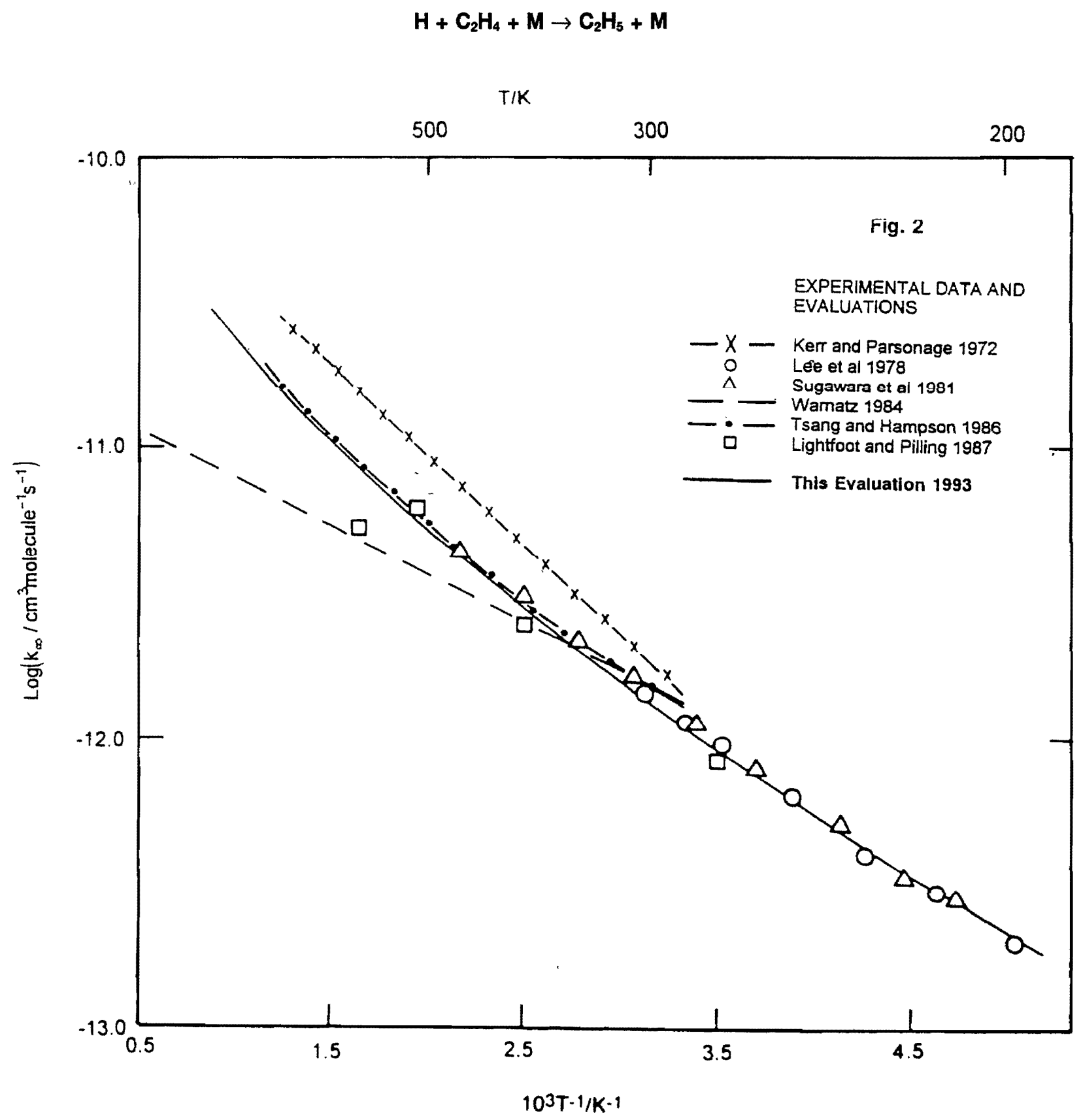


$\mathrm{H}+\mathrm{C}_{2} \mathrm{H}_{4}+\mathrm{M} \rightarrow \mathrm{C}_{2} \mathrm{H}_{5}+\mathrm{M}$

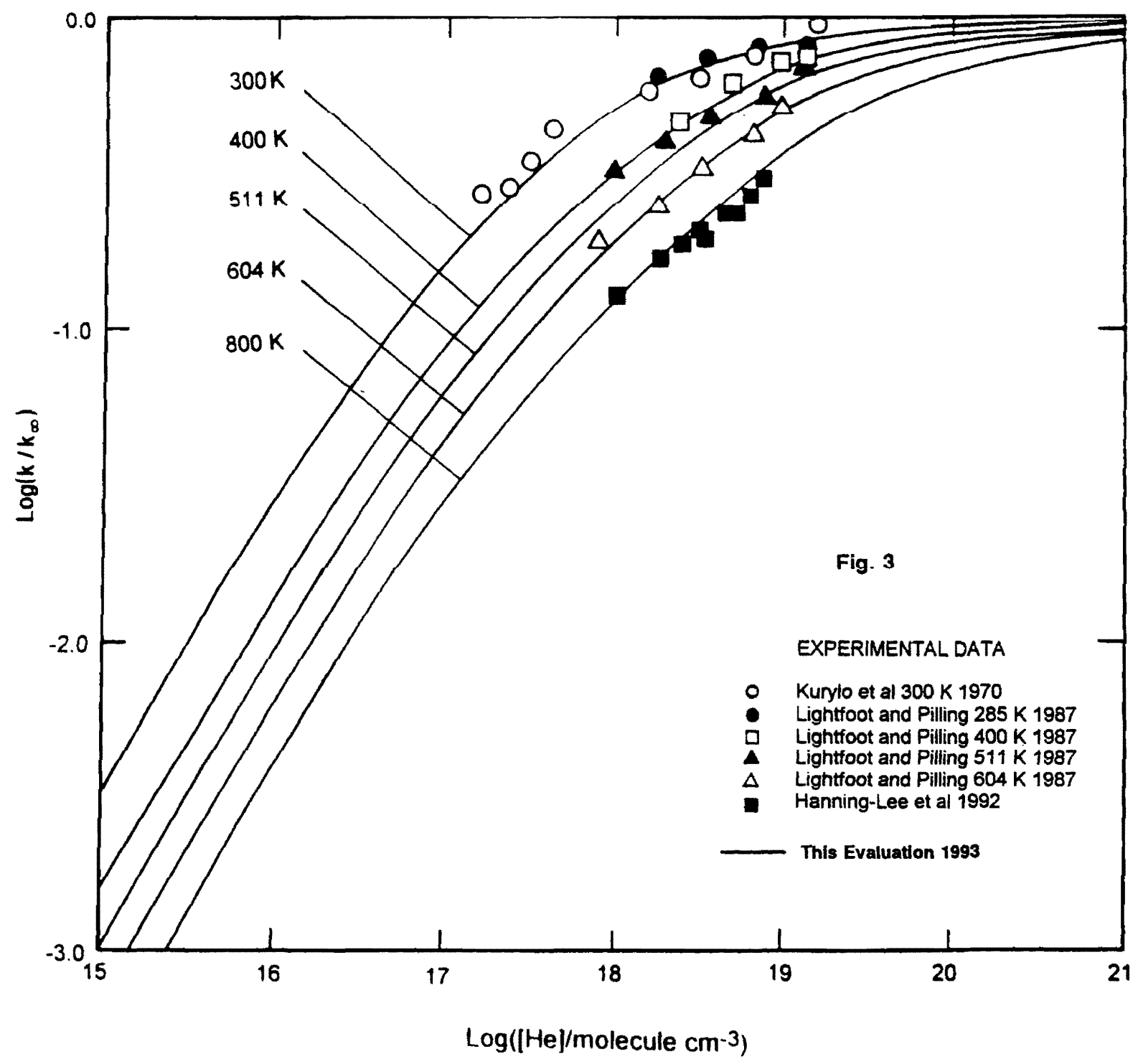


$\mathrm{C}_{2} \mathrm{H}_{5}(+\mathrm{M}) \rightarrow \mathrm{C}_{2} \mathrm{H}_{4}+\mathrm{H}(+\mathrm{M})$

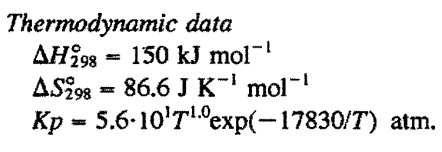

\section{Rate Coefficient Data}

\begin{tabular}{|c|c|c|c|c|}
\hline$k / s^{-1}$ & $T / \mathrm{K}$ & {$[\mathrm{M}] /$ molecule $\mathrm{cm}^{-3}$} & Reference & Comments \\
\hline \multicolumn{5}{|l|}{ Rate Coefficient Measurements } \\
\hline \multicolumn{5}{|l|}{ Low Pressure Range } \\
\hline$\left[\mathrm{C}_{2} \mathrm{H}_{6}\right] 3.0 \cdot 10^{-6} \exp (-16300 / T)$ & $823-913$ & $(4.4-68) \cdot 10^{17}$ & Lin and Back, $1966^{1}$ & (a) \\
\hline$\left[\mathrm{C}_{2} \mathrm{H}_{6}\right] 1.1 \cdot 10^{-6} \exp (-16000 / T)$ & $673-773$ & $(0.52-120) \cdot 10^{17}$ & Loucks and Laidler, $1967^{4}$ & (b) \\
\hline [Ar] $1.7 \cdot 10^{-8} \exp (-15100 / T)$ & $900-1350$ & $(2.7-180) \cdot 10^{18}$ & Glänzer and Troe, $1973^{5}$ & (c) \\
\hline$\left[\mathrm{C}_{2} \mathrm{H}_{6}\right] 8.3 \cdot 10^{-15}$ & 902 & $(1.1-27.2) \cdot 10^{17}$ & Pacey and Wimalasena, $1984^{6}$ & (d) \\
\hline$\left[\mathrm{C}_{2} \mathrm{H}_{6}\right] 3.3 \cdot 10^{-\gamma} \exp (-17560 / T)$ & $793-813$ & $(0.12-37) \cdot 10^{17}$ & Simon, Foucaut and Scacchi, $1988^{8}$ & (e) \\
\hline \multicolumn{5}{|l|}{ Intermediate Fall-Off Range } \\
\hline $1.4 \cdot 10^{14} \exp (-19800 / T)$ & $673-773$ & $7 \cdot 10^{18}\left(\mathrm{C}_{2} \mathrm{H}_{5}\right)$ & Bywater and Steacie, $1951^{9}$ & (f) \\
\hline $4.4 \cdot 10^{2}$ & 822.7 & $0.78 \cdot 10^{18}\left(\mathrm{C}_{2} \mathrm{H}_{6}\right)$ & Lin and Back, $1966^{1}$ & (a) \\
\hline $9.2 \cdot 10^{2}$ & & $1.9 \cdot 10^{18}$ & & \\
\hline $1.6 \cdot 10^{3}$ & & $6.9 \cdot 10^{18}$ & & \\
\hline $1.2 \cdot 10^{3}$ & 857.7 & $0.70 \cdot 10^{18}$ & & \\
\hline $3.0 \cdot 10^{3}$ & & $3.1 \cdot 10^{18}$ & & \\
\hline $4.5 \cdot 10^{3}$ & & $6.6 \cdot 10^{18}$ & & \\
\hline $2.8 \cdot 10^{3}$ & 913 & $0.38 \cdot 10^{18}$ & & \\
\hline $4.7 \cdot 10^{3}$ & & $0.72 \cdot 10^{18}$ & & \\
\hline $9.2 \cdot 10^{3}$ & & $2.1 \cdot 10^{18}$ & & \\
\hline 1.3 & 673 & $0.76 \cdot 10^{17}\left(\mathrm{C}_{2} \mathrm{H}_{6}\right)$ & Loucks and Laidler, $1967^{4}$ & (b) \\
\hline 3.5 & & $5.6 \cdot 10^{17}$ & & \\
\hline 8.8 & & $3.2 \cdot 10^{17}$ & & \\
\hline 3.1 & 703 & $0.55 \cdot 10^{17}$ & & \\
\hline 5.7 & & $2.7 \cdot 10^{17}$ & & \\
\hline $2.4 \cdot 10^{1}$ & & $9.1 \cdot 10^{17}$ & & \\
\hline $2.3 \cdot 10^{1}$ & 773 & $0.44 \cdot 10^{17}$ & & \\
\hline $6.9 \cdot 10^{1}$ & & $3.6 \cdot 10^{17}$ & & \\
\hline $2.7 \cdot 10^{2}$ & & $7.7 \cdot 10^{17}$ & & \\
\hline $7.7 \cdot 10^{2}$ & 902 & $1.1 \cdot 10^{17}\left(\mathrm{C}_{2} \mathrm{H}_{6}\right)$ & Pacey and Wimalasena, $1984^{6}$ & (d) \\
\hline $2.5 \cdot 10^{3}$ & & $6.6 \cdot 10^{17}$ & & \\
\hline $5.6 \cdot 10^{3}$ & & $27 \cdot 10^{17}$ & & \\
\hline $1.2 \cdot 10^{3}$ & 963 & $(1.0-25) \cdot 10^{17}\left(\mathrm{C}_{2} \mathrm{H}_{6}\right)$ & & \\
\hline $1.2 \cdot 10^{12} \exp (-17612 / T)$ & $1200-1700$ & $1.4 \cdot 10^{19}(\mathrm{Ar})$ & Hidaka et al., $1985^{10}$ & (g) \\
\hline $1.0 \cdot 10^{2}$ & 841 & $1.6 \cdot 10^{17}\left(\mathrm{C}_{2} \mathrm{H}_{6}\right)$ & Trenwith, $1986^{11}$ & (h) \\
\hline $4.7 \cdot 10^{2}$ & & $13 \cdot 10^{17}$ & & \\
\hline $1.2 \cdot 10^{3}$ & & $110 \cdot 10^{17}$ & & \\
\hline $1.3 \cdot 10^{2}$ & 872.5 & $0.88 \cdot 10^{17}$ & & \\
\hline $6.9 \cdot 10^{2}$ & & $8.3 \cdot 10^{17}$ & & \\
\hline $2.3 \cdot 10^{3}$ & & $105 \cdot 10^{17}$ & & \\
\hline $5.7 \cdot 10^{2}$ & 913 & $1.2 \cdot 10^{17}$ & & \\
\hline $2.3 \cdot 10^{3}$ & & $12 \cdot 10^{17}$ & & \\
\hline $5.6 \cdot 10^{3}$ & & $99 \cdot 10^{17}$ & & \\
\hline $9.57 \cdot 10^{\mathrm{t}}$ & 775 & $2.5 \cdot 10^{18}(\mathrm{He})$ & Brouard, Lightfoot, and Pilling, $1986^{12}$ & (i) \\
\hline $1.62 \cdot 10^{2}$ & 800 & $2.4 \cdot 10^{18}$ & & \\
\hline $3.62 \cdot 10^{2}$ & 825 & $2,3 \cdot 10^{18}$ & & \\
\hline $2.28 \cdot 10^{1}$ & 793 & $0.37 \cdot 10^{17}\left(\mathrm{C}_{2} \mathrm{H}_{6}\right)$ & Simon, Foucaut, and Scacchi, $1988^{8}$ & (e) \\
\hline $1.01 \cdot 10^{2}$ & & $3.7 \cdot 10^{17}$ & & \\
\hline $2.72 \cdot 10^{2}$ & & $37 \cdot 10^{17}$ & & \\
\hline $1.63 \cdot 10^{1}$ & 813 & $0.12 \cdot 10^{17}$ & & \\
\hline $1.82 \cdot 10^{2}$ & & $3.6 \cdot 10^{17}$ & & \\
\hline $5.54 \cdot 10^{2}$ & & $36 \cdot 10^{17}$ & & \\
\hline $3.26 \cdot 10^{2}$ & 1094 & $0.71 \cdot 10^{16}$ & Feng et al., $1992^{13}$ & (j) \\
\hline $9.27 \cdot 10^{\mathrm{I}}$ & 901 & $4.22 \cdot 10^{16}$ & & \\
\hline $4.49 \cdot 10^{2}$ & 927 & $15.8 \cdot 1^{\prime}$ & & \\
\hline
\end{tabular}




\section{$\mathrm{C}_{2} \mathrm{H}_{5}(+\mathrm{M}) \rightarrow \mathrm{C}_{2} \mathrm{H}_{4}+\mathrm{H}(+\mathrm{M})-$ Continued}

Rate Coefficient Data

\begin{tabular}{|c|c|c|c|c|}
\hline$k / \mathrm{s}^{-1}$ & $T / \mathrm{K}$ & {$[\mathrm{M}] /$ molecule $\mathrm{cm}^{-3}$} & Reference & Comments \\
\hline \multicolumn{5}{|l|}{ High Pressure Range } \\
\hline $1.0 \cdot 10^{13} \exp (-20130 / T)$ & $693-803$ & $(1.8-21) \cdot 10^{17}(\mathrm{n}$-butane $)$ & Purnell and Quinn, $1962^{14}$ & (k) \\
\hline $3.8 \cdot 10^{13} \exp (-19120 / T)$ & $822.7-913$ & $(3.8-69) \cdot 10^{17}\left(\mathrm{C}_{2} \mathrm{H}_{6}\right)$ & Lin and Back, $1966^{1}$ & (a) \\
\hline $2.7 \cdot 10^{14} \exp (-20580 / T)$ & $673-773$ & $(0.52-120) \cdot 10^{17}\left(\mathrm{C}_{2} \mathrm{H}_{6}\right)$ & Loucks and Laidler, $1967^{4}$ & (b) \\
\hline $1.3 \cdot 10^{13} \exp (-20130 / T)$ & $900-1350$ & $(2.7-180) \cdot 10^{18}(\mathrm{Ar})$ & Glänzer and Troe, $1973^{5}$ & (c) \\
\hline $3.2 \cdot 10^{13} \exp (-21050 / T)$ & $941-1073$ & $6.0 \cdot 10^{18}(\mathrm{Ar})$ & Pratt and Rogers, $1979^{15}$ & (l) \\
\hline $2.7 \cdot 10^{4}$ & 902 & $(1.1-27.2) \cdot 10^{17}\left(\mathrm{C}_{2} \mathrm{H}_{6}\right)$ & Pacey and Wimalasena, $1984^{6}$ & (d) \\
\hline $8.9 \cdot 10^{12} \exp (-19120 / T)$ & $841-913$ & $(0.9-110) \cdot 10^{17}\left(\mathrm{C}_{2} \mathrm{H}_{6}\right)$ & Trenwith, $1986^{11}$ & (h) \\
\hline $1.6 \cdot 10^{13} \exp (-19120 / T)$ & $793-813$ & $(0.12-37) \cdot 10^{17}\left(\mathrm{C}_{2} \mathrm{H}_{6}\right)$ & Simon, Foucaut, and Scacchi, $1988^{8}$ & (e) \\
\hline \multicolumn{5}{|l|}{ Reviews and Evaluations } \\
\hline $\begin{aligned} k_{0}= & {[\mathrm{M} \text { undefined }] } \\
& 1.7 \cdot 10^{-7} \mathrm{exp}(-15640 / T)\end{aligned}$ & $700-1500$ & & Warnatz, $1984^{16}$ & (m) \\
\hline$k_{\infty}=2.0 \cdot 10^{13} \exp (-19970 / T)$ & $500-2000$ & & & \\
\hline$k_{\infty}=4.9 \cdot 10^{9} T^{1.19} \exp (-18722 / T)$ & & & Tsang and Hampson, $1986^{17}$ & (n) \\
\hline $\begin{aligned} k_{\infty} & =1.11 \cdot 10^{10} T^{1.037} \\
& \exp (-18504 / T)\end{aligned}$ & $200-1100$ & & Feng et al., $1993^{13}$ & (j) \\
\hline $\begin{aligned} k_{0}= & {[\mathrm{He}] 6.63 \cdot 10^{9} T^{4.99} } \\
& \exp (-20130 / T)\end{aligned}$ & $200-1100$ & & & \\
\hline
\end{tabular}

\section{Comments}

(a) Pyrolysis of $\mathrm{C}_{2} \mathrm{H}_{6}$ in a conventional static system. Measurements of the rate of production of $\mathrm{CH}_{4}$ and $\mathrm{C}_{4} \mathrm{H}_{10}$. Rate coefficients measured relative to the reaction $\mathrm{C}_{2} \mathrm{H}_{5}+$ $\mathrm{C}_{2} \mathrm{H}_{5} \rightarrow \mathrm{C}_{4} \mathrm{H}_{10}$ for which a value of $k=3.3 \cdot 10^{-11} \mathrm{~cm}^{3}$ molecule $\mathrm{s}^{-1} \mathrm{~s}^{-1}$ was employed ${ }^{2}$. Mechanism with six reactions. Limiting rate coefficients obtained by extrapolation using the method of Ref. 3 .

(b) The mercury-photosensitized decomposition of $\mathrm{C}_{2} \mathrm{H}_{6}$ in a static system was used to generate $\mathrm{C}_{2} \mathrm{H}_{5}$ radicals. Products measured by volumetry and gas chromatography. Mechanism with four reactions. Rate coefficients measured relative to $\mathrm{C}_{2} \mathrm{H}_{5}+\mathrm{C}_{2} \mathrm{H}_{5} \rightarrow \mathrm{C}_{4} \mathrm{H}_{10}$ for which a value of $k=3.3 \cdot 10^{-11} \mathrm{~cm}^{3}$ molecule ${ }^{-1} \mathrm{~cm}^{-1}$ was used ${ }^{2}$. Extrapolation towards the limiting rate coefficients employing Lindemann plots.

(c) Shock wave study of the thermal decomposition of $\mathrm{C}_{2} \mathrm{H}_{3} \mathrm{NO}_{2}$. From the concentration profiles of $\mathrm{C}_{2} \mathrm{H}_{5} \mathrm{NO}_{2}$ and the product $\mathrm{NO}_{2}$ the subsequent $\mathrm{C}_{2} \mathrm{H}_{5}$ decomposition was analysed.

(d) Pyrolysis of $\mathrm{C}_{2} \mathrm{H}_{6}$ in a flow system. The products $\mathrm{CH}_{4}$ and $\mathrm{C}_{2} \mathrm{H}_{4}$ were measured by gas chromatography. Steadystate approximation for a mechanism with nine reactions. Extrapolation based on Ref. 7.

(e) Pyrolysis of $\mathrm{C}_{2} \mathrm{H}_{6}$ in a static system. The main products were $\mathrm{CH}_{4}$ and $\mathrm{C}_{2} \mathrm{H}_{4}$ and were analysed by gas chromatography. Analysis of literature values employing the RRKM and Troe models.

(f) Mercury-photosensitized decomposition of $\mathrm{C}_{2} \mathrm{H}_{6}$. Analysis of $\mathrm{CH}_{4}$ and $\mathrm{H}_{2}$.

(g) Pyrolysis of $\mathrm{C}_{2} \mathrm{H}_{6}$ behind shock waves. Monitoring of $\mathrm{C}_{2} \mathrm{H}_{4}, \mathrm{C}_{2} \mathrm{H}_{2}$ and $\mathrm{CH}_{4}$ concentrations by absorption spectroscopy.

(h) Thermal decomposition of $\mathrm{C}_{2} \mathrm{H}_{6}$. The concentrations of $\mathrm{CH}_{4}$ and $\mathrm{C}_{2} \mathrm{H}_{6}$ determined by gas chromatography. Rate coefficients derived from $\mathrm{CH}_{4}$ and $\mathrm{C}_{2} \mathrm{H}_{4}$ yields on the basis of a mechanism with five reactions.

(i) ArF excimer flash photolysis of $\mathrm{C}_{2} \mathrm{H}_{4}$ with detection of $\mathrm{H}$ atoms by Lyman- $\alpha$ resonance fluorescence. The approach to the $\mathrm{H}+\mathrm{C}_{2} \mathrm{H}_{4} \rightleftarrows \mathrm{C}_{2} \mathrm{H}_{5}$ equilibrium was directly observed.

(j) Thermal decomposition of $\mathrm{C}_{2} \mathrm{H}_{5}$ monitored by using photoionization mass spectrometry. $\mathrm{C}_{2} \mathrm{H}_{5}$ radicals generated by $193 \mathrm{~nm}$ laser photolysis of 3-pentanone. Weak collision effects studied using modified strong collision and master equation analysis.

(k) Pyrolysis of $\mathrm{n}$-butane. The reaction rates were measured by analysing chromatographically the products after short residence times. Extrapolation of the limiting high pressure rate coefficients using the method of Ref. 3 .

(l) Pyrolysis of $\mathrm{C}_{2} \mathrm{H}_{6}$ in a wall-less reactor. Analysis performed by gas chromatography. Mechanism with seven reactions.

(m) Revicw of litcrature data.

(n) The recommended values were obtained by combination of the room temperature rate coefficients for the recombination reaction with studies of the dissociation reaction at higher temperatures.

\section{Preferred Values}

$k_{\infty}=8.2 \cdot 10^{13} \exp (-20070 / T) \mathrm{s}^{-1}$ over range $700-1100 \mathrm{~K}$. $k_{\mathrm{o}}=\left[\mathrm{C}_{2} \mathrm{H}_{6}\right] 1.7 \cdot 10^{-6} \mathrm{exp}(-16800 / T) \mathrm{s}^{-1}$ over range $700-$ $900 \mathrm{~K}$.

$F_{\mathrm{c}}=0.25 \exp (-T / 97)+0.75 \exp (-T / 1379)$ for $\mathrm{M}=\mathrm{C}_{2} \mathrm{H}_{6}$ over range $700-1000 \mathrm{~K}$.

\section{Reliability}

$\Delta \log k_{\infty}= \pm 0.3$ over range $700-1100 \mathrm{~K}$.

$\Delta \log k_{\mathrm{o}}= \pm 0.3$ over range $700-900 \mathrm{~K}$.

$\Delta F_{\mathrm{c}}= \pm 0.1$ over range $700-1100 \mathrm{~K}$. 


\section{Comments on Preferred Values}

Several studies of the temperature and the pressure dependencies of this reaction have been published. We have selected the experimental measurements of Refs. 4, 6, 8 and 13 to analyse this reaction. Theoretical fall-off curves ${ }^{18}$ were fitted to these data and the resulting $k_{\mathrm{o}}$ values were analysed using the low pressure unimolecular rate theory from Refs. 18 and 19 employing a reaction threshold of $154.78 \mathrm{~kJ} \mathrm{~mol}^{-1}{ }^{13}$. Figures 1 and 2 compare our recommended values of $k_{\circ}$ and $k_{\infty}$ with those reported in previous recommendations. Collisional efficiencies of about 0.14 for $\mathrm{M}=\mathrm{C}_{2} \mathrm{H}_{6}$ between 700 and $800 \mathrm{~K}$ were derived, which are consistent with an average energy transferred per collision of $-\langle\Delta E\rangle=150$ to $210 \mathrm{~cm}^{-1}$. Similarly, from the experiments of Ref. 13 a value of $-\langle\Delta \mathrm{E}\rangle$ $=13 \mathrm{~cm}^{-1}$ for $\mathrm{M}=\mathrm{Ar}$ was obtained. Figure 3 shows the fall-off curves constructed in this evaluation. The dissociation and recombination rate coefficients are related via the equilibrium constant given above ${ }^{13}$.

\section{References}

'M.C. Lin and M.H. Back, Can. J. Chem. 44, 505, 2357 (1966).

${ }^{2}$ A. Shepp and K.O. Kutschke, J. Chem. Phys. 26, 1020 (1957).
${ }^{3}$ R.E. Powell, J. Chem. Phys. 30, 724 (1959).

${ }^{4}$ L.F. Loucks and K. Laidler, Can J. Chem. 45, 2795 (1967).

${ }^{5}$ K. Glänzer and J. Troe, Helv. Chim. Acta, 56, 577 (1973).

${ }^{6}$ P.D. Pacey and J.H. Wimalasena, J. Phys. Chem. 88, 5657 (1984); Chem. Phys. Lett. 76, 433 (1981); Can. J. Chem. 62, 293 (1984).

${ }^{7}$ J. Troe, J. Phys. Chem. 83, 114 (1979).

${ }^{8}$ Y. Simon, J.F. Foucaut, and G. Scacchi, Can. J. Chem. 66, 2142 (1988).

${ }^{9}$ S. Bywater and E.W.R. Steacie, J. Chem. Phys. 19, 326 (1951).

${ }^{10} \mathrm{Y}$. Hidaka, S. Shiba, H. Takuma, and M. Suga, Int. J. Chem. Kinet. 17, 441 (1985).

"A.B. Trenwith, J. Chem. Soc., Faraday Trans. II, 82, 457 (1986).

${ }^{12}$ M. Brouard, P.D. Lightfoot, and M.J. Pilling, J. Phys. Chem. 90, 445 (1986).

${ }^{13}$ Y. Feng, J.T. Niiraneu, A. Bencsura, V.D. Kuyazev, D. Gutman, and W. Tsang, J. Phys. Chem., 97, 871 (1993).

${ }^{14}$ J.H. Purnell and C.P. Quinn, Proc. Roy. Soc. A270, 267 (1962).

${ }^{15}$ G.L. Pratt and D. Rogers, J. Chem. Soc., Faraday Trans. I 75, 1089 (1979).

${ }^{16}$ J. Warnatz in "Combustion Chemistry", Ed. W.C. Gardiner, Jr., SpringerVerlag, New York, 1984, p.196.

${ }^{17}$ W. Tsang and R.F. Hampson, J. Phys. Chem. Ref. Data 15, 1087 (1986).

${ }^{18}$ J. Troe, J. Phys: Chem. 83, 114 (1979).

${ }^{19} \mathrm{~J}$. Troe, J. Chem. Phys. 66, 4758 (1977).

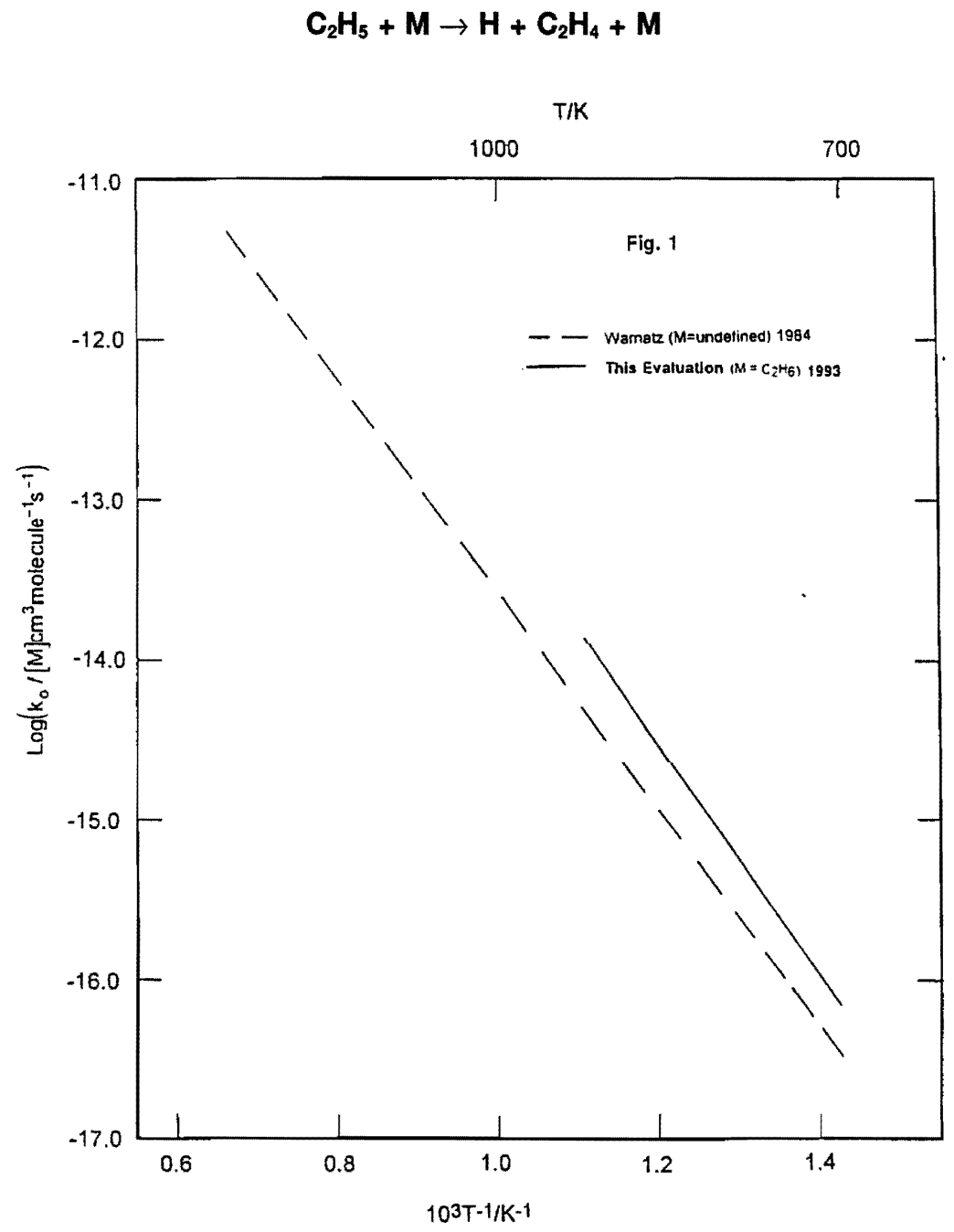




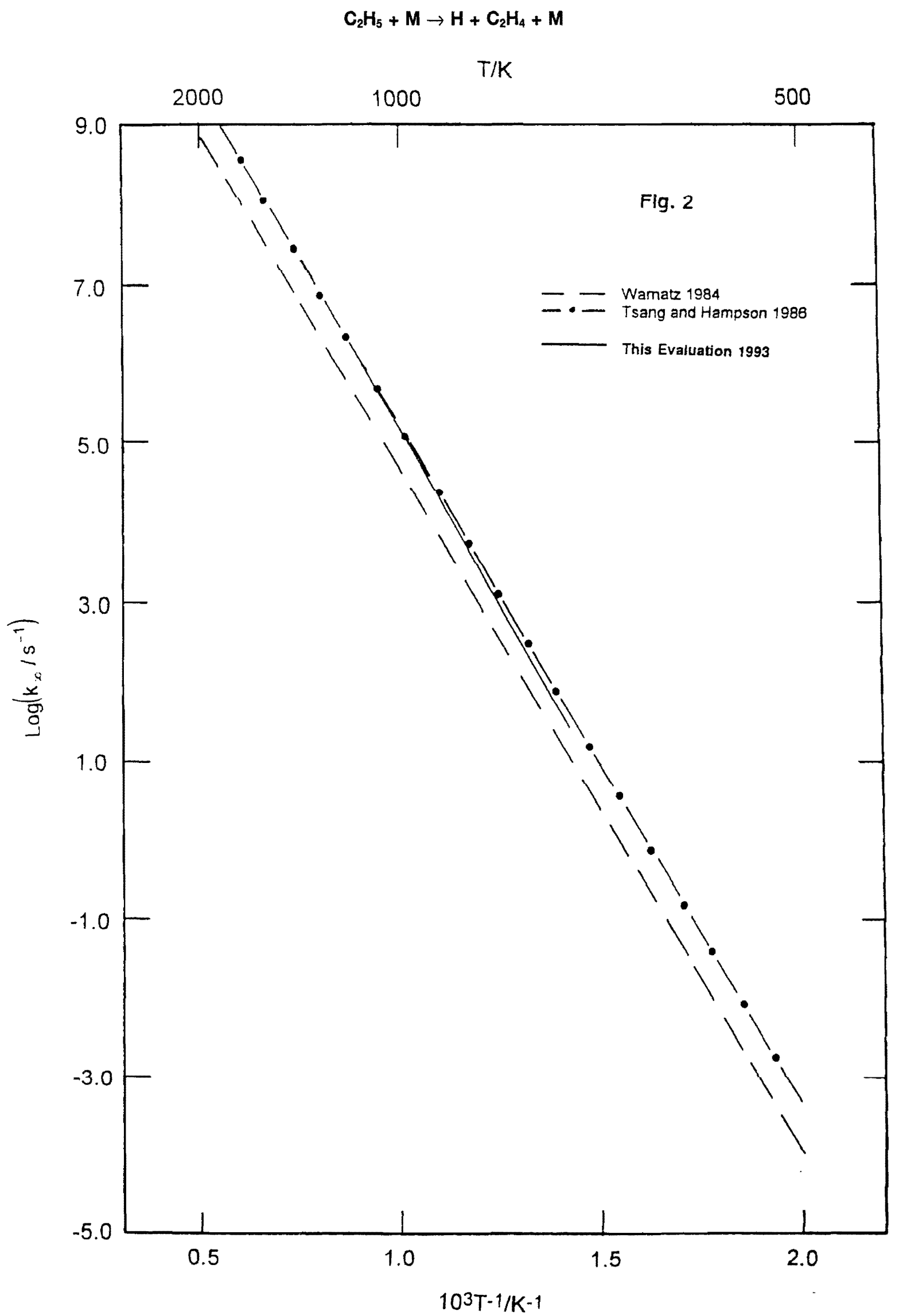


$\mathrm{C}_{2} \mathrm{H}_{5}+\mathrm{M} \rightarrow \mathrm{H}+\mathrm{C}_{2} \mathrm{H}_{4}+\mathrm{M}$

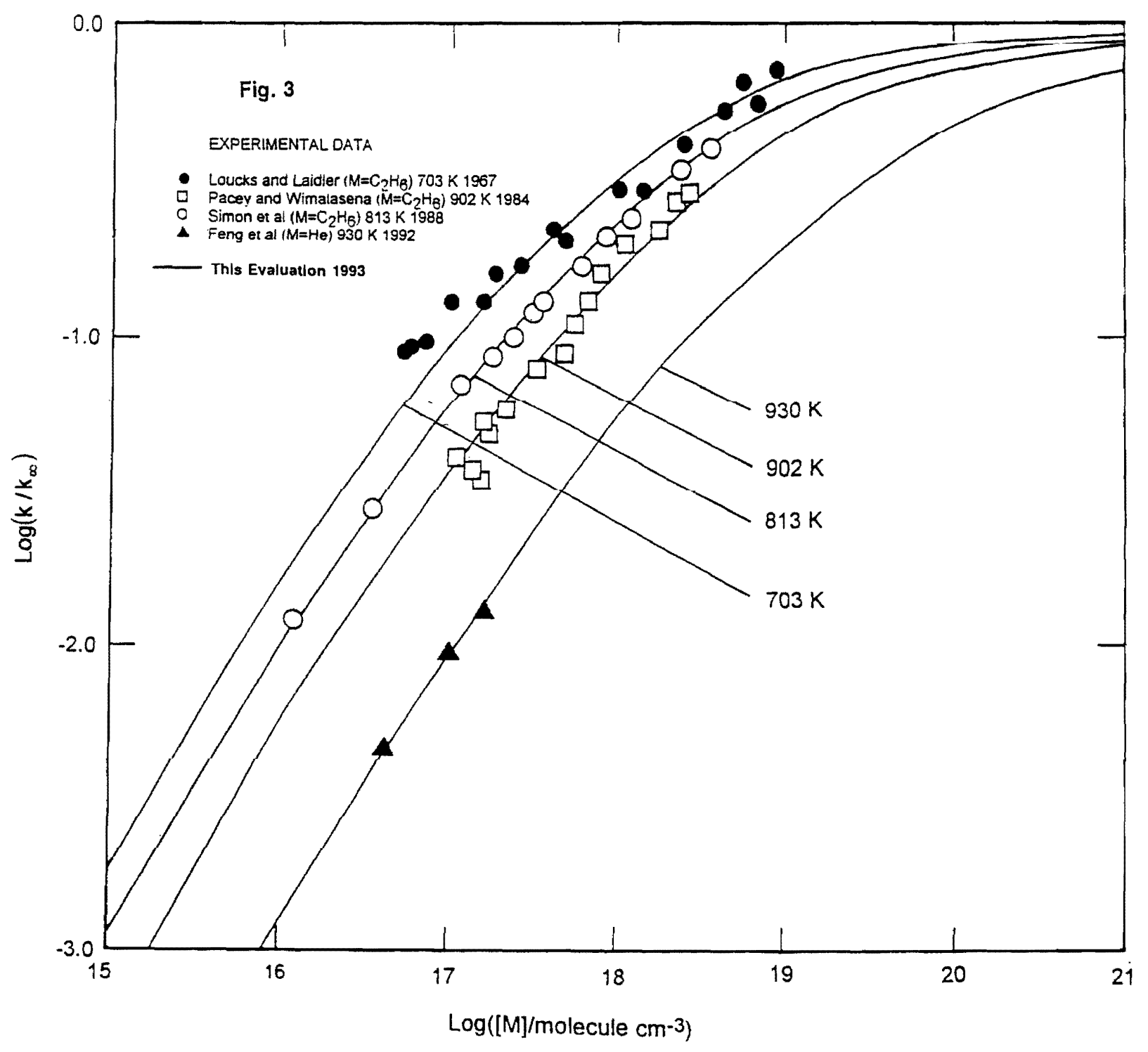




$$
\mathrm{H}+\mathrm{C}_{6} \mathrm{H}_{5} \mathrm{CH}_{2}(+\mathrm{M}) \rightarrow \mathrm{C}_{6} \mathrm{H}_{5} \mathrm{CH}_{3}(+\mathrm{M})
$$

Thermodynamic Data

$\Delta H_{298}^{\circ}=-368.0 \mathrm{~kJ} \mathrm{~mol}^{-1}$

$\Delta S_{298}^{\circ}=-110.9 \mathrm{~J} \mathrm{~K}^{-1} \mathrm{~mol}^{-1}$

$K p=1.8 \cdot 10^{-2} T^{-1.49} \exp (+44028 / T) \mathrm{atm}^{-1}$

Rate Coefficient Data

\begin{tabular}{llll}
\hline \hline$k / \mathrm{cm}^{3}$ molecule $\mathrm{s}^{-1}$ & $T / \mathrm{K}$ & Reference & Comments \\
\hline Rate Coefficient Measurements & $1450-1900$ & & \\
$1.3 \cdot 10^{-10}-1.3 \cdot 10^{-9}$ & 298 & Brouwer et al., $1988^{1}$ & (a) \\
$5.5 \cdot 10^{-10}$ & 300 & Bartels et al., $1989^{2}$ & (b) \\
$4.3 \cdot 10^{-10}$ & $1300-1650$ & Ackermann et al., $1990^{3}$ & (c) \\
$4.3 \cdot 10^{-10}$ & & & (d) \\
\hline
\end{tabular}

\section{Comments}

(a) The thermal decomposition of toluene has been reinvestigated in shock wave experiments. The absorption signals of toluene, benzyl, and assumed benzyl fragments were monitored. The rate coefficient was determined from modelling studies.

(b) The reaction of benzyl radicals with $\mathrm{H}$ and $\mathrm{O}$ atoms were studied in a flow reactor at room temperature and at pressures around $1 \mathrm{mbar}$. Molecular beam sampling and mass spectrometric detection were applied. The rate for the recombination was measured with reference to the reaction of methyl radicals with deuterium atoms.

(c) Reaction rate measured using: (1) pulse radiolysis of $\mathrm{Ar} /$ toluene mixtures at 1 bar pressure; $\left[\mathrm{C}_{6} \mathrm{H}_{5} \mathrm{CH}_{2}\right]$ monitored by light absorption at $305.3 \mathrm{~nm}$, (2) flash photolysis and pulsed laser photolysis of Ar/toluene mixtures; $[\mathrm{H}]$ monitored by resonance absorption. Results from the different techniques in good agreement.

(d) Shock tube study on $\mathrm{Ar} / \mathrm{C}_{6} \mathrm{H}_{5} \mathrm{CH}_{2} \mathrm{I} / \mathrm{C}_{2} \mathrm{H}_{5} \mathrm{I}$ mixturcs. $\left[\mathrm{C}_{6} \mathrm{H}_{5} \mathrm{CH}_{2}\right]$ monitored by light absorption at $260 \mathrm{~nm}$. No temperature dependence of $k$ could be detected.

\section{Preferred Values}

$k_{\infty}=4.3 \cdot 10^{-10} \mathrm{~cm}^{3}$ molecule ${ }^{-1} \mathrm{~s}^{-1}$ over the range $300-$ $2000 \mathrm{~K}$

\section{Reliability}

$\Delta \log k_{\infty}= \pm 0.2$ at room temperature rising to \pm 0.5 at $2000 \mathrm{~K}$.

\section{Comments on Preferred Values}

The available data at $300 \mathrm{~K}^{2,3}$ are in good agreement. At higher temperatures the results of Ackermann et al. ${ }^{3}$ are accepted rather than those from the less direct study of Brouwer et al. ${ }^{1}$. As might be expected for such a fast recombination reaction there is no evidence for a significant temperature dependence of the rate constant.

\section{References}

'L.D. Brouwer, W. Mueller-Markgraf, and J. Troe, J. Phys. Chem. 92, 4905 (1988).

${ }^{2}$ M. Bartels, J. Edelbuettel-Einhaus, and K. Hoyermann, 22nd Symp. (Int.) Combust., 1041 (1989).

${ }^{3}$ L. Ackermann, H.Hippler, P. Pagsberg, C. Reihs, and J. Troe, J. Phys. Chem. 94, 5247 (1990). 


\author{
$\mathrm{H}+\mathrm{C}_{6} \mathrm{H}_{5} \mathrm{CH}_{3} \rightarrow \mathrm{H}_{2}+\mathrm{C}_{6} \mathrm{H}_{5} \mathrm{CH}_{2}$ \\ $\rightarrow \mathrm{H}_{2}+\mathrm{C}_{6} \mathrm{H}_{4} \mathrm{CH}_{3}$ \\ $\rightarrow \mathrm{CH}_{3}+\mathrm{C}_{6} \mathrm{H}_{6}$ \\ (1) \\ (2) \\ (3) \\ $\mathrm{H}+\mathrm{C}_{6} \mathrm{H}_{5} \mathrm{CH}_{3}(+\mathrm{M}) \rightarrow \mathrm{C}_{6} \mathrm{H}_{6} \mathrm{CH}_{3}(+\mathrm{M})$

Thermodynamic Data

$\Delta H_{298}^{\circ}(1)=-68.0 \mathrm{Jmol}^{-1}$

$\Delta S_{298}^{\circ}(1)=12.3 \mathrm{~J} \mathrm{~K}^{-1} \mathrm{~mol}^{-1}$

$K p(1)=2.4 T^{0.171} \exp (+8060 / T)$

$\Delta S_{298}^{\circ}(3)=-39.4 \mathrm{~J} \mathrm{~K}^{-1} \mathrm{~mol}^{-1}$

$\Delta H_{298}^{\circ}(3)=28.9 \mathrm{~kJ} \mathrm{~mol}^{-1}$

$K p(3)=2.1 \cdot 10^{4} T^{0.940} \exp (+4400 / T)$
$\Delta H_{298}^{\circ}(2)=37.5 \mathrm{~kJ} \mathrm{~mol}^{-1}$
$\Delta S_{298}^{\circ}(2)=12.1 \mathrm{~J} \mathrm{~K}^{-1} \mathrm{~mol}^{-1}$
$K p(2)=2.5 T^{0.158} \exp (-4630 / T)$

Rate Coefficient Data $\left(k=k_{1}+k_{2}+k_{3}+k_{4}\right)$

\begin{tabular}{|c|c|c|c|}
\hline$k / \mathrm{cm}^{3}$ molecule ${ }^{-1 \mathrm{~s}-1}$ & $T / \mathrm{K}$ & Reference & Comments \\
\hline \multicolumn{4}{|l|}{ Rate Coefficient Measurements } \\
\hline$k_{3}=3.3 \cdot 10^{-12} \exp (-755 / T)$ & 633 & Benson and Shaw, $1967^{\prime}$ & (a) \\
\hline$k_{4}=1.7 \cdot 10^{-13}$ & 298 & Sauer and Ward, $1967^{2}$ & (b) \\
\hline$k_{1}=1.4 \cdot 10^{-10} \exp (-4630 / T)$ & $863-963$ & Mkryan, Oganesyan, and Nalbandyan, $1972^{3}$ & (c) \\
\hline$k_{4}=8.5 \cdot 10^{-14}$ & 303 & Knutti and Buehler, $1975^{4}$ & (d) \\
\hline$k_{1}-8.3 \cdot 10^{-11} \exp (-1864 / T)$ & $1500-1800$ & Astholz, Durant, and Troe, $1981^{5}$ & (e) \\
\hline$k_{1}=1.3 \cdot 10^{-28} T^{5.5} \exp (-171 / T)$ & $600-1700$ & Rao and Skinner, $1984^{6}$ & (f) \\
\hline$k_{1}=5.4 \cdot 10^{-9} \exp (-7548 / T)$ & $1600-2150$ & Pamidimukkala and Kem, $1985^{7}$ & (g) \\
\hline$k_{2}=5.4 \cdot 10^{-9} \exp (-9561 / T)$ & $1600-2150$ & & \\
\hline$k_{3}=2.1 \cdot 10^{-12} \exp (-1862 / T)$ & $1600-2150$ & & \\
\hline$k_{1}=1.8 \cdot 10^{-20} T^{3.0} \exp (-1183 / T)$ & $950-1100$ & Robaugh and Tsang, $1986^{8}$ & (h) \\
\hline$k_{3}=1.1 \cdot 10^{-21} T^{3.0} \exp (+377 / T)$ & $950-1100$ & & \\
\hline$k_{1}=7.3 \cdot 10^{-24} T^{4.0} \exp (-1057 / T)$ & $1300-1800$ & Kiefer and Mizerka, $1986^{\circ}$ & (i) \\
\hline $9.7 \cdot 10^{-13}$ & 773 & Baldwin, Scott and Walker, $1987^{10}$ & (j) \\
\hline$k_{3}=5.0 \cdot 10^{-13}$ & 773 & & \\
\hline$k_{2}=4.2 \cdot 10^{-10} \exp (-8052 / T)$ & $1600-2100$ & Pamidimukkala et al., $1987^{12}$ & (k) \\
\hline$k_{1}=8.3 \cdot 10^{-10} \exp (-6290 / T)$ & $1380-1700$ & Braun-Unkhoff, Frank, and Just, $1989^{13}$ & (l) \\
\hline$k_{1}=2.1 \cdot 10^{-9} \exp (-7460 / T)$ & $1300-1700$ & Hippler, Reihs, and Troe, $1990^{14}$ & $(\mathrm{~m})$ \\
\hline \multicolumn{4}{|l|}{ Reviews and Evaluations } \\
\hline$k_{1}=2.1 \cdot 10^{-10} \exp (-4210 / T)$ & $600-1800$ & Hippler, Reihs, and Troe, $1990^{14}$ & $(\mathrm{~m})$ \\
\hline$k_{1}=6.6 \cdot 10^{-22} T^{3.44} \exp (-1570 / T)$ & $600-2500$ & CEC, $1992^{15}$ & (n) \\
\hline$k_{4}=1.2 \cdot 10^{-13}$ & 298 & & \\
\hline
\end{tabular}

\section{Comments}

(a) Static system. Detection by gas chromatography and mass spectrometry. Rate expression for channel (3) deduced by comparison with $\mathrm{H}$ addition to benzene.

(b) Pulse radiolysis with product analysis by gas chromatography. Transient species were monitored as function of time by absorption in the wavelength range $260-340 \mathrm{~nm}$. $A k$-value for reaction (4) at room temperature was deduced.

(c) Evaluation of a $k$-expression for channel (1) from a flow reactor study.

(d) Fast flow reactor with product analysis by mass spectrometry. $\mathrm{H}$ atoms produced in microwave discharge. Rate expression evaluated for the reaction (assumed to be channel (4)).

(e) Shock tube study with toluene/Ar mixtures. Toluene and benzyl were monitored as function of time by absorption in the 200-350 $\mathrm{nm}$ range. A rate expression for channel (1) was derived on the assumption that the henzyl radical exhibits sufficient thermal stability. (f) Shock tube study with initial mixtures of toluene- $\mathrm{d}_{8} / \mathrm{Ar}$ and neopentane/toluene- $\mathrm{d}_{8} / \mathrm{Ar}$. D and $\mathrm{H}$ atoms were monitored as function of time by ARAS. Investigation covered a temperature range from $1200-1460 \mathrm{~K}$ for neopentane/toluene, and from $1410-1730 \mathrm{~K}$ for toluene experiments. Together with unpublished results of Ravishankara and Nicovich, a non-Arrhenius expression for $T$ $=600-1700 \mathrm{~K}$ was deduced for channel (1).

(g) Shock tube study with mixtures of toluene and ethylbenzene. Products were monitored as function of time by time-of-flight mass spectrometry. The rate expression for formation of benzyl radicals and hydrogen (channel (1) )re-evaluated using data of Ref. 6. Rate expressions for the formation of methyl phenyl radicals and hydrogen(channel (2)) and of benzene and methyl radicals (channel (3)) are deduced.

(h) Single pulse shock tube. The source of $\mathrm{H}$ atoms was the thermal decay of small quantities of hexamethylethane. The $k$-values have been derived on the basis of the competitive process $\mathrm{H}+\mathrm{CH}_{4} \rightarrow \mathrm{CH}_{3}+\mathrm{H}_{2}$ with $k=2.2-$ $10^{-20} T^{3.0} \exp (-4045 / T) \mathrm{cm}^{3}$ molecule ${ }^{-1} \mathrm{~s}^{-1}$. Rate ex- 
pressions for the formation of benzene and methyl radicals (channel (3)) and of benzyl radicals and hydrogen (channel (1)) were obtained.

(i) Shock tube study on high temperature pyrolysis of ethylbenzene with the laser schlieren technique.

(j) Small amounts of toluene $(0.05-0.5 \%)$ added to slowly reacting mixtures of hydrogen and oxygen at $773 \mathrm{~K}$. Under the experimental conditions the $\mathrm{H}_{2}+\mathrm{O}_{2}$ system provides a reproducible source of $\mathrm{H}, \mathrm{O}$, and $\mathrm{OH}$ radicals. The measurements of the relative consumption of $\mathrm{H}_{2}$ and of the additive permits the evaluation of rate constants for the reaction of $\mathrm{H}, \mathrm{O}$, and $\mathrm{OH}$ with toluene.

(k) Two independent shock tube techniques (time-of-flight mass spectrometry and laser schlieren densitometry) were used to investigate the high temperature pyrolysis of toluene in mixtures with $\mathrm{Kr}$ and $\mathrm{Ne}$, respectively. A rate coefficient for the formation of methyl pheny] (channel (2)) was obtained.

(1) Shock tube study with very low initial concentrations of toluene in Ar. Hydrogen atom formation is monitored by ARAS. The measured $\mathrm{H}$ profiles were sensitive to $k_{1}$ in the later stage of observation time. A rate constant expression for channel (1) was deduced which is slightly smaller than that of Rao and Skinner ${ }^{6}$.

(m) Study using reflected shock waves with the pyrolysis of ethyl iodide as a hydrogen atom source. Toluene and ethyl iodide mole fractions covered range $100-2000 \mathrm{ppm}$. Temperature range, $1300-1700 \mathrm{~K}$. Absorption signals at $260 \mathrm{~nm}$ recorded. At this wavelength the absorption coefficient of benzyl radicals exceeds that of toluene by a factor of 100 , allowing very small conversions of toluene to benzyl to be detected. Together with the data of Ref. 8 and unpublished results of Ravishankara and Nicovich, the authors derive an Arrhenius expression for channel (1) for the temperature range $6001800 \mathrm{~K}$.

(ii) See Comments on Preferred Values.

\section{Preferred Values}

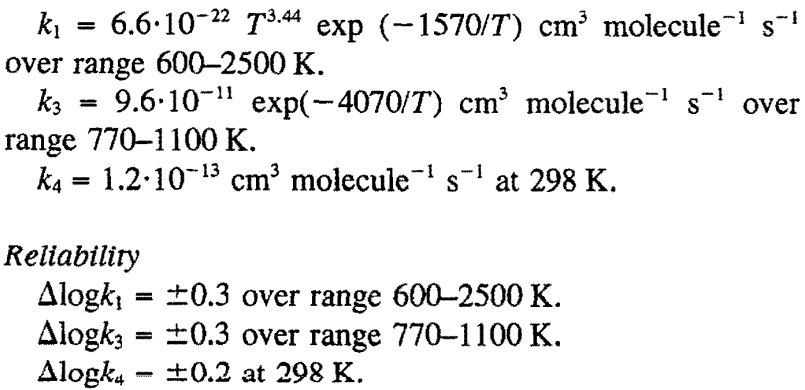

\section{Comments on Preferred Values}

An expression for $k_{3}$ has been derived but the other recommendations are unchanged from our previous evaluation.

Most of the available measurements give evidence for the product channel (1) leading to benzyl radicals and molecular hydrogen. Only a few experiments permit a discrimination between the channels at elevated temperatures. Therefore, for the majority of the studies, the different product pathways have been deduced not by direct measurement of product distribution and concentration but by modelling with the aid of plausible reaction systems. To reconcile the few room temperature data with the rate constant values at elevated temperatures, it has to be assumed that a change in the reaction mechanism occurs, possibly from channel (4) at room temperature to channel (1) dominating at temperatures above $1000 \mathrm{~K}^{11}$. In the range between room temperature and $1000 \mathrm{~K}$ channel (3) appears to be significant. Channel (2) would only be expected to be important at elevated temperatures $(>2560 \mathrm{~K})$ and there are insufficient data available to recommend an expression for $k_{2}$. For the addition reaction (4) it is only possible to evaluate a room temperature value. Furthermore the data are insufficient to justify recommendation of a rate expression for the overall $\mathrm{H}$-consuming reaction over the whole temperature range.

\section{References}

'S.W. Benson and R. Shaw, J. Phys. Chem. 47, 4052 (1967); S.W. Benson and R. Shaw, J. Am. Chem. Soc. 89, 5351 (1967).

${ }^{2}$ M.C. Sauer and B. Ward, J. Phys. Chem. 71, 3971 (1967).

${ }^{3}$ T.G. Mkryan, K.T. Oganesyan, and A.B. Nalbandyan, Arm. Khim. Zh. 25, 893 (1972).

${ }^{4} \mathrm{~K}$. Knutt1 and K. Buenler, Chem. Hnys. 7, 229 (1975).

${ }^{5}$ D.C. Astholz, J. Durant, and J. Troe, 18th Symp. (Int.) Combust., 885 (1981).

${ }^{6}$ V.S. Rao and G.B. Skinner, J. Phys. Chem. 88, 4362 (1984).

${ }^{7}$ K.M. Pammidimukkala and R.D. Kern, Poster Paper, Int. Cont. on Chem. Kinetics, Gaithersburg, MD (1985).

${ }^{8}$ D. Robaugh and W. Tsang, J. Phys. Chem. 90, 4159 (1986).

${ }^{9}$ J.H. Kiefer and L.J. Mizerka, Int. J. Chem. Kinet. 18, 363 (1984).

${ }^{10}$ R.R. Baldwin, M. Scott and R.W. Walker, 21st Symp. (Int.) Combust., 991 (1986).

"A. Amano, O. Horie, and N.H. Hank, Int. J. Chem. Kinet. 8, 321 (1976).

${ }^{12}$ K. Pamidimukkala, R.D. Kern, M.R. Patel, H.C. Wei, and J.H. Kiefer, J. Phys. Chem. 91, 2148 (1987).

${ }^{13}$ M. Braun-Unkhoff, P. Frank, and Th. Just, 22nd Symp. (Int.) Combustion, 1053 (1989).

${ }^{14} \mathrm{H}$. Hippler, C. Reihs, and J. Troe, Zeits. f. Phys. Chemie N.F. 167, 1 (1990).

${ }^{15} \mathrm{CEC}, 1992$ (see reterences in Introduction). 
$\mathrm{OH}+\mathrm{HO}_{2} \rightarrow \mathrm{H}_{2} \mathrm{O}+\mathrm{O}_{2}$

Thermodynamic Data

$\Delta H_{298}^{\circ}=-291 \mathrm{~kJ} \mathrm{~mol}^{-1}$

$\Delta S_{298}^{\circ}=-18.8 \mathrm{~J} \mathrm{~K}^{-1} \mathrm{~mol}^{-1}$

$K p=0.517 T^{-0.25} \exp (+35000 / T)$

Rate Coefficient Data

\begin{tabular}{|c|c|c|c|}
\hline$k / \mathrm{cm}^{3}$ molecule $^{-1} \mathrm{~s}^{-1}$ & $T / \mathrm{K}$ & Reference & Comments \\
\hline \multicolumn{4}{|c|}{ Rate Coefficient Measurements } \\
\hline $4.8 \cdot 10^{-11} \exp (+250 / T)$ & $254-382$ & Keyser, $1988^{1}$ & (a) \\
\hline $8.0 \cdot 10^{-11}$ & 298 & Schwab et al., $1989^{2}$ & (b) \\
\hline $4.98 \cdot 10^{-11}$ & 1100 & Hippler, Troe and Willner, $1990^{3}$ & (c) \\
\hline \multicolumn{4}{|l|}{ Reviews and Evaluations } \\
\hline $4.8 \cdot 10^{-11} \exp (250 / T)$ & $300-2000$ & CEC, $1992^{4}$ & (d) \\
\hline $4.8 \cdot 10^{-11} \exp (250 / T)$ & $250-400$ & IUPAC, $1992^{5}$ & (e) \\
\hline
\end{tabular}

\section{Comments}

(a) Discharge flow study with [OH] measured by resonance fluorescence and $\left[\mathrm{HO}_{2}\right]$ via conversion to $\mathrm{OH}$ with NO. $\mathrm{NO}_{2}$ used to remove $\mathrm{O}$ and $\mathrm{H}$ atoms. Total pressure, 1 Torr. The author concludes little or no pressure dependence of $k$ over the range 1-1000 Torr. because of the good agreement with measurements at $1 \mathrm{~atm}$.

(b) Discharge flow reactor with laser magnetic resonance and resonance fluorescence detection. Decay of $[\mathrm{OH}]$ in excess $\mathrm{HO}_{2}$ under pseudo first order conditions at a pressure of 2 Torr.

(c) Shock wave study in $\left(\mathrm{CH}_{3} \mathrm{O}\right)_{2} / \mathrm{O}_{2} / \mathrm{Ar}$ mixtures and in $\mathrm{H}_{2} \mathrm{O}_{2} / \mathrm{Ar}$ mixtures. $\left[\mathrm{HO}_{2}\right]$ and $\left[\mathrm{H}_{2} \mathrm{O}_{2}\right]$ monitored by UV absorption in reflected shock waves. $[\mathrm{OH}]$ profiles measured behind incident waves. Later reanalysis ${ }^{6}$ of the results from this study gives $k=3.3 \cdot 10^{-11} \mathrm{~cm}^{3}$ molecule ${ }^{-1}$ $\mathrm{s}^{-1}$ over the range 950-1250 K.

(d) See Comments on Preferred Values.

(e) Accepts expression of Keyser'.

\section{Preferred Values}

$k=4.8 \cdot 10^{-11} \exp (+250 / T) \mathrm{cm}^{3}$ molecule $\mathrm{e}^{-1} \mathrm{~s}^{-1}$ over range $300-2000 \mathrm{~K}$.
Reliability

$\Delta \log k= \pm 0.2$ at $300 \mathrm{~K}$ rising to \pm 0.5 at $2000 \mathrm{~K}$.

Comments on Preferred Values

The expression of Keyser ${ }^{1}$ was accepted as our previous recommendation which is unchanged here.

The new experimental results of Schwab et al. ${ }^{2}$ at low temperatures are in good agreement and the higher temperature studies of Hippler and Troe ${ }^{3}$ are also compatible with the extrapolation of the Keyser expression. Gonzales et al. ${ }^{7}$ have carried out a theoretical study of the reaction. By combining their calculated temperature dependence with the mean of the experimental values at $298 \mathrm{~K}$ they derive the expression $k=$ $7.1 \cdot 10^{-11}(T / 300)^{-0.21} \exp (113 / R T) \mathrm{cm}^{3}$ molecule ${ }^{-1} \mathrm{~s}^{-1}$ which agrees closely with our preferred expression.

\section{References}

'L.F. Keyser, J. Phys. Chem. 92, 1193 (1988).

${ }^{2}$ J.J. Schwab, W.H. Brune, and J.G. Anderson, J. Phys. Chem. 93, 1030 (1989).

${ }^{3}$ H. Hippler, J. Troe, and J. Willner, J. Chem. Phys. 93, 1755 (1990).

${ }^{4} \mathrm{CEC}, 1992$ (see references in Introduction).

${ }^{5}$ IUPAC, 1992 (see references in Introduction).

${ }^{6} \mathrm{H}$. Hippler and J. Troe, Chem. Phys. Lett. 192, 333 (1992).

${ }^{7}$ C. Gonzales, J. Theisen, H. Schlegel, B. Bernhard, W.L. Hase and E.W. Kaiser, J. Phys. Chem. 96, 1767 (1992). 


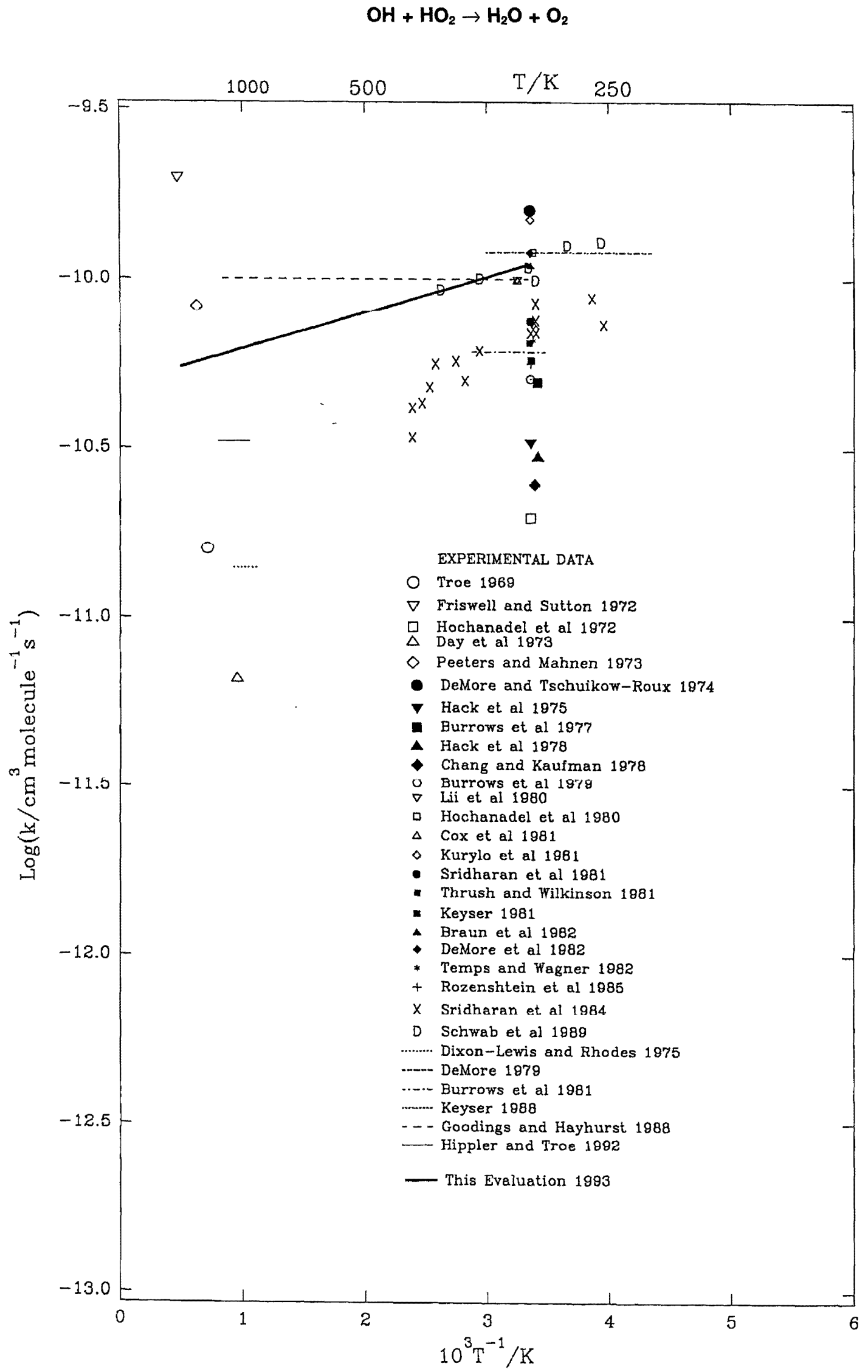




$$
\mathrm{OH}+\mathrm{H}_{2} \mathrm{O}_{2} \rightarrow \mathrm{H}_{2} \mathrm{O}+\mathrm{HO}_{2}
$$

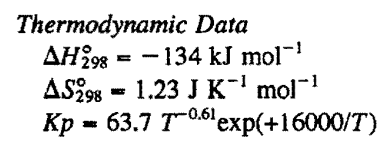

Rate Coefficient Data

\begin{tabular}{llll}
\hline \hline$k / \mathrm{cm}^{3}$ molecule $^{-1} \mathrm{~s}^{-1}$ & $T / \mathrm{K}$ & Reference & Comments \\
\hline Rate Coefficient Measurements & 1100 & Hippler, Troe and Willner, $1990^{1}$ & (a) \\
$4.98 \cdot 10^{-12}$ & $250-1250$ & Hippler and Troe, $1992^{2}$ & (b) \\
$1.66 \cdot 10^{-12}+9.63 \cdot 10^{-10} \exp (-4810 / T)$ & & & \\
& $300-1100$ & CEC, $1992^{3}$ & \\
Reviews and Evaluations & $240-460$ & IUPAC, $1992^{4}$ & (c) \\
$1.3 \cdot 10^{-11} \exp (-670 / T)$ & & (d) \\
$2.9 \cdot 10^{-12} \exp (-160 / T)$ & & \\
\hline
\end{tabular}

\section{Comments}

(a) Shock wave study in $\left(\mathrm{CH}_{3} \mathrm{O}\right)_{2} / \mathrm{O}_{2} / \mathrm{Ar}$ mixtures and in $\mathrm{H}_{2} \mathrm{O}_{2} / \mathrm{Ar}$ mixtures. $\left[\mathrm{HO}_{2}\right]$ and $\left[\mathrm{H}_{2} \mathrm{O}_{2}\right]$ by $U V$ absorption in reflected shock waves. $[\mathrm{OH}]$ profiles measured behind incident waves.

(b) Shock tube study in $\mathrm{H}_{2} \mathrm{O}_{2} / \mathrm{Ar}$ mixtures. Techniques similar to previous study (comment (a)).

(c) See Comments on Preferred Values.

(d) Accepts the expression obtained by Kurylo et al. ${ }^{5}$ :

\section{Preferred Values}

$k=1.3 \cdot 10^{-11} \exp (-670 / T) \mathrm{cm}^{3}$ molecule ${ }^{-1} \mathrm{~s}^{-1}$ over range $300-1000 \mathrm{~K}$.

\section{Reliability}

$\Delta \log k= \pm 0.2$ at $300 \mathrm{~K}$ rising to \pm 0.5 at $1000 \mathrm{~K}$.

\section{Comments on Preferred Values}

The low temperature studies on this reaction indicate a very small temperature coefficient for the rate constant, as reflected in the IUPAC preferred value for the range $240-460 \mathrm{~K}$. Measurements at higher temperatures $(>1000 \mathrm{~K})$ show considerable scatter but in general indicate higher values for $k$ than are obtained by extrapolation from the low temperature data. Recent work by Hippler and Troe suggests that this is due to a very rapid increase in the temperature coefficient of $k$ above about $800 \mathrm{~K}$.

Our previous recommendation was a compromise, attempting to represent these differences in behaviour of $k$ at low and high temperatures by a simple expression. Until the behaviour observed by Hippler and Troe is confirmed, we retain this preferred expression but in recognition of its limitations we increase the error limits at high temperatures and continue to limit our recommendations to temperature less than $1000 \mathrm{~K}$.

\section{References}

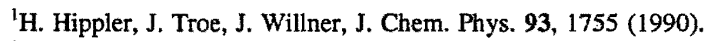

${ }^{2}$ H. Hippler, J. Troe, Chem. Phys. Lett. 192, 333 (1992).

${ }^{3} \mathrm{CEC}, 1992$ (see references in Introduction).

${ }^{4}$ IUPAC, 1992 (see references in Introduction).

${ }^{5}$ M.J. Kurylo, J.L. Murphy, G.S. Haller, and K.D. Comett, Int. J. Chem. Kin. 14, 1149 (1982). 
Thermodynamic Data

$\Delta H_{298}^{\circ}(1)=16.1 \mathrm{~kJ} \mathrm{~mol}^{-1}$

$\Delta S_{298}^{\circ}(1)=-16.7 \mathrm{~J} \mathrm{~K}^{-1} \mathrm{~mol}^{-1}$

$K p(1)=1.50 \cdot 10^{4} I^{0.97} \exp (-1570 / l)$

$\Delta H_{298}^{\circ}(3)=-300.9 \mathrm{~kJ} \mathrm{~mol}^{-1}$

$\Delta S_{298}^{\circ}(3)=-28.4 \mathrm{~J} \mathrm{~K}^{-1} \mathrm{~mol}^{-1}$

$K p(3)=7.94 \cdot 10^{-3} T^{0.17} \exp (+36300 / T)$

$\Delta H_{298}^{\circ}(5)=-386.5 \mathrm{~kJ} \mathrm{~mol}^{-1}$

$\Delta S_{298}^{\circ}(5)=-137.9 \mathrm{~J} \mathrm{~K}^{-1} \mathrm{~mol}^{-1}$

$K p(5)=1.26 \cdot 10^{-7} T^{-0.289} \exp (+46700 / T) \mathrm{atm}^{-1}$
$\Delta H_{298}^{\circ}(2)=49.6 \mathrm{~kJ} \mathrm{~mol}^{-1}$

$\Delta S_{298}^{\circ}(2)=-34.6 \mathrm{~J} \mathrm{~K}^{-1} \mathrm{~mol}^{-1}$

$K p(2)=3.73 \cdot 10^{-3} T^{0.78} \exp (-5470 / T)$

$\Delta H_{298}^{\circ}(4)=-1.8 \mathrm{~kJ} \mathrm{~mol}^{-1}$

$\Delta S_{298}^{\circ}(4)=-0.2 \mathrm{~J} \mathrm{~K}^{-1} \mathrm{~mol}^{-1}$

$K p(4)=26.7 T^{-0.48} \exp (+47 / T)$

Rate Coefficient Data $\left(k=k_{1}+k_{2}+k_{3}+k_{4}+k_{5}\right)$

\begin{tabular}{|c|c|c|c|}
\hline$k / \mathrm{cm}^{3}$ molecule ${ }^{-1} \mathrm{~s}^{-1}$ & $T / \mathrm{K}$ & Reference & Comments \\
\hline \multicolumn{4}{|l|}{ Rate Coefficient Measurements } \\
\hline$k_{2}=3.3 \cdot 10^{-8} \exp (-13800 / T)$ & $1700-2300$ & Bhaskaran. Frank. and Just. $1979^{1}$ & (a) \\
\hline$k_{1}$ or $k_{2}=1.5 \cdot 10^{-9} \exp (-7800 / T)$ & $1850-2500$ & Roth and Just, $1984^{2}$ & (b) \\
\hline$k_{4} \leqslant 5 \cdot 10^{-12}$ & 300 & Oser et al., $1992^{3}$ & (c) \\
\hline$k_{4}=1.2 \cdot 10^{-10} \exp (-1400 / T)$ & $300-480$ & Oser et al., 1992 & (d) \\
\hline \multicolumn{4}{|l|}{$k_{5}$ (see next data sheet) } \\
\hline \multicolumn{4}{|l|}{ Reviews and Evaluations } \\
\hline $9 \cdot 10^{-11}$ & $300-2500$ & Tsang and Hampson, $1986^{5}$ & (e) \\
\hline $6 \cdot 10^{-11}$ & $300-2000$ & CEC, $1992^{6}$ & (f) \\
\hline
\end{tabular}

\section{Comments}

(a) Shock tube decomposition of $\mathrm{C}_{2} \mathrm{H}_{6} / \mathrm{O}_{2}$ mixtures with direct detection of $\mathrm{H}$ and $\mathrm{O}$ by atomic resonance absorption spectrometry. $k_{2}$ derived from a computer simulation of the experimental $[\mathrm{H}]$ and $[\mathrm{O}]$ profiles. It was suggested that channel (2) proceeds via the sequence $\mathrm{OH}+\mathrm{CH}_{3} \rightarrow$ $\mathrm{H}+\mathrm{CH}_{3} \mathrm{O}$ and $\mathrm{CH}_{3} \mathrm{O} \rightarrow \mathrm{CH}_{2} \mathrm{O}+\mathrm{H}$, i.e. overall reaction $\mathrm{OH}+\mathrm{CH}_{3} \rightarrow 2 \mathrm{H}+\mathrm{CH}_{2} \mathrm{O}$.

(b) Similar study to that of Bhaskaran et al. ${ }^{1}$ (see comment (a)) with $\mathrm{CH}_{4} / \mathrm{O}_{2}$ mixtures.

(c) Fast-flow Teflon reactor; $\mathrm{CH}_{3}$ from $\mathrm{F}+\mathrm{CH}_{4}$ and $\mathrm{OH}$ from $\mathrm{H}+\mathrm{NO}_{2} ; k_{5}$ data derived for computer modelling of $\mathrm{CH}_{3}$ and $\mathrm{OH}$ profiles measured by mass spectrometry. Data for $k_{4}$ derived from measurements of products, $\mathrm{H}_{2} \mathrm{O}$ relative to $\mathrm{CH}_{3} \mathrm{OH}$.

(d) Experimental system similar to note (c) but with $k_{4}$ derived from measurements of products, HDO relative to $\mathrm{CH}_{3} \mathrm{OD}$, in experiments with $\mathrm{OD}$ replacing $\mathrm{OH}$.

(e) Based on data of Bhaskaran et al. ${ }^{1}$, Roth and $\mathrm{Just}^{2}$, and Sworski et al.?

(f) Bascd on data of Bhaskaran et al. ${ }^{\prime}$, and Roth and Just ${ }^{2}$.

\section{Preferred Values.}

$k_{4}=1.2 \cdot 10^{-10}(-1400 / T) \mathrm{cm}^{3}$ molecule $\mathrm{s}^{-1} \mathrm{~s}^{-1}$ over range $300-1000 \mathrm{~K}$.

Reliability

$\Delta \log k_{4}= \pm 0.5$ over range $300-1000 \mathrm{~K}$.

\section{Comments on Preferred Values}

We recommend the data of Oser et al ${ }^{4}$ for channel (4), based on their product formation study of the yields of $\mathrm{H}_{2} \mathrm{O}$. It should be noted, however, that the recommended value of $k_{4}$ is not consistent with the rate coefficient of the reverse reaction, $k_{-4}=(1-2) \cdot 10^{-10} \mathrm{~cm}^{3}$ molecule ${ }^{-1} \mathrm{~s}^{-1}$, based on direct measurements ${ }^{8}$ of $\mathrm{CH}_{2}$ and $\mathrm{OH}$. A reconciliation of these results is possible if $\Delta H^{\circ}(4)$ is wrong, which seems most likely to be due to an error in the presently accepted value of $\Delta H_{\mathrm{f}}^{\circ}\left(\mathrm{CH}_{2} \mathrm{CO}\right)$.

The need remains for more experimental work on the branching ratio of the $\mathrm{OH}+\mathrm{CH}_{3}$ reaction, particularly at higher temperatures.

\section{References}

'K.A. Bhaskaran, P. Frank, and Th. Just, "High Temperature Methyl Radical Reactions with Atomic and Molecular Oxygen", Proc. 12th Symp. on Shock Tubes and Waves, (The Magnes Press, Jerusalem) 503 (1979).

${ }^{2}$ P. Roth and Th. Just, 20th Symp. (Int.) Combust., 807 (1984).

${ }^{3}$ H. Oser, N.D. Stothard, R. Humpfer, and H.H. Grotheer, J. Phys. Chem., 96, 5359 (1992).

${ }^{4}$ H. Oser, N.D. Stothard, R. Humpfer, H.H. Grotheer and Th. Just, 24th Symp. (Int.) Combust., 597 (1992).

${ }^{5}$ W. Tsang and R.F, Hampson, J. Phys. Chem. Ref. Data, 15, 1087 (1986). ${ }^{6} \mathrm{CEC}, 1992$ (see references in Introduction).

'T.J. Sworski, C.J. Hochanadel, and P.J. Ogren, J. Phys. Chem. 84, 129 (1980).

${ }^{8}$ W. Hack, H.Gg. Wagner, and A. Wilms, Ber. Bunsenges. Phys. Chem. 92 , 620 (1988). 


$$
\begin{aligned}
\mathrm{OH}+\mathrm{CH}_{3}(+\mathrm{M}) & \rightarrow \mathrm{CH}_{3} \mathrm{OH}(+\mathrm{M}) \\
\mathrm{OH}+\mathrm{CH}_{3} & \rightarrow \mathrm{CH}_{2} \mathrm{OH}+\mathrm{H} \\
& \rightarrow \mathrm{CH}_{3} \mathrm{O}+\mathrm{H} \\
& \rightarrow \mathrm{HCHO}^{1} \mathrm{H}_{2} \\
& \rightarrow{ }^{1} \mathrm{CH}_{2}+\mathrm{H}_{2} \mathrm{O}
\end{aligned}
$$

Thermodynamic Data

\begin{tabular}{|c|c|c|c|c|}
\hline$k / \mathrm{cm}^{3}$ molecule $^{-1} \mathrm{~s}^{-1}$ & $T / \mathrm{K}$ & {$[\mathrm{M}] /$ molecule $\mathrm{cm}^{-3}$} & Reference & Comments \\
\hline \multicolumn{5}{|l|}{ Rate Coefficient Measurements } \\
\hline \multicolumn{5}{|l|}{ Low Pressure Range } \\
\hline$[\mathrm{He}](2.5 \pm 1) \cdot 10^{-27}$ & 300 & $(7.2-150) \cdot 10^{15}$ & Oser et al., 1992 ${ }^{1}$ & (a) \\
\hline$[\mathrm{He}](1 \pm 1) \cdot 10^{-27}$ & 480 & $(1.6-14) \cdot 10^{16}$ & Oser et at., $1992^{3}$ & (b) \\
\hline \multicolumn{5}{|l|}{ Intermediate Fall-off Range } \\
\hline $1.4 \cdot 10^{-11}$ & 1200 & $5.7 \cdot 10^{18}(\mathrm{Ar})$ & Bott and Cohen, $1991^{4}$ & (c) \\
\hline $8.0 \cdot 10^{-12}$ & 300 & $7.2 \cdot 10^{15}(\mathrm{He})$ & Oser et al., 1992' & (a) \\
\hline $2.2 \cdot 10^{-11}$ & & $2.7 \cdot 10^{16}$ & & \\
\hline $6.0 \cdot 10^{-11}$ & & $1.5 \cdot 10^{17}$ & & \\
\hline $1.2 \cdot 10^{-11}$ & 480 & $1.6 \cdot 10^{16}(\mathrm{He})$ & Oser et al., $1992^{3}$ & (b) \\
\hline $2.2 \cdot 10^{-11}$ & & $3.8 \cdot 10^{16}$ & & \\
\hline $4.4 \cdot 10^{-11}$ & & $1.4 \cdot 10^{17}$ & & \\
\hline \multicolumn{5}{|l|}{ High Pressure Range } \\
\hline $9.3 \cdot 10^{-11}$ & 296 & $2.5 \cdot 10^{19}\left(\mathrm{~N}_{2}, \mathrm{H}_{2}\right)$ & Sworski et al., $1980^{2}$ & (d) \\
\hline $9.4 \cdot 10^{-11}$ & 298 & $2.5 \cdot 10^{19}\left(\mathrm{Ar}-\mathrm{SF}_{6}\right)$ & Anastasi et al., $1991^{5}$ & (e) \\
\hline $7.6 \cdot 10^{-11}$ & 290 & $(2.5-230) \cdot 10^{17}(\mathrm{He})$ & Hughes et al., $1992^{6}$ & (f) \\
\hline \multicolumn{5}{|l|}{ Reviews and Evaluations } \\
\hline $9.0 \cdot 10^{-11}$ & $300-2500$ & $(2.9-24) \cdot 10^{18}\left(\mathrm{~N}_{2}\right)$ & Tsang and Hampson, $1986^{7}$ & (g) \\
\hline $1.9 \cdot 10^{-4}(T / 298)^{-8.2} \exp (-5874 / T)$ & $600-2500$ & $(2.9-12) \cdot 10^{18}\left(\mathrm{~N}_{2}\right)$ & Dean and Westmoreland, $1987^{8}$ & (h) \\
\hline$k \infty=1.7 \cdot 10^{-10}$ & 300 & & Jordan et al., 1991 ${ }^{9}$ & (i) \\
\hline$k \infty=2.9 \cdot 10^{-10}$ & 2000 & & & \\
\hline
\end{tabular}

$\Delta H_{298}^{\circ}(1)=-386.5 \mathrm{~kJ} \mathrm{~mol}^{-1}$

$\Delta S_{298}^{\circ}(1)=-137.9 \mathrm{~J} \mathrm{~K}^{-1} \mathrm{~mol}^{-1}$

$K_{p}(1)=1.26 \cdot 10^{-7} T^{0.289} \exp (+46700 / T) \mathrm{atm}^{-1}$

Rate Coefficient Data $\left(k=k_{1}\right)$

\section{Comments}

(a) Flow system study. $\mathrm{CH}_{3}$ generated by the reactions $\mathrm{CH}_{4}+$ $\mathrm{F} \rightarrow \mathrm{CH}_{3}+\mathrm{HF}$ and $\mathrm{OH}$ by the reaction $\mathrm{H}+\mathrm{NO}_{2} \rightarrow \mathrm{NO}+$ $\mathrm{OH}$. The $\mathrm{CH}_{3}$ radicals were calibrated using the reaction $\mathrm{CH}_{3}+\mathrm{NO}_{2} \rightarrow \mathrm{CH}_{3} \mathrm{O}+\mathrm{NO}$, while the $\mathrm{OH}$ radicals were calibrated by using an excess of $\mathrm{CH}_{3} \mathrm{CHO}$ as scavenger. Both radicals were detected using a time-of-flight mass spectrometer. Mechanism with 15 reactions. Fall-off curves constructed using $k_{\infty}=9.3 \cdot 10^{-11} \mathrm{~cm}^{3}$ molecule ${ }^{-1}$ $\mathrm{s}^{-12}$ and $\mathrm{F}_{\mathrm{c}}=0.6$.

(b) See comment (a).

(c) Shock tube study of t-butyl hydroperoxide (generation of $\mathrm{OH}$ ) and t-butylperoxide (generation of $\mathrm{CH}_{3}$ ) mixtures. $\mathrm{OH}$ radicals monitored by UV absorption at $309 \mathrm{~nm}$. Mechanism with 6 reactions. A formation yield of $\mathrm{CH}_{3} \mathrm{OH}$ of 0.75 was found.

(d) Flash photolysis of $\mathrm{H}_{2} \mathrm{O}$ vapour in $\mathrm{CH}_{4} \cdot \mathrm{CH}_{3}$ radicals generated by reaction of $\mathrm{OH}$ with $\mathrm{CH}_{4}$. The $\mathrm{CH}_{3}$ concentrations were monitored by absorption at $216 \mathrm{~nm}$. Modelling with 11 reactions. Total rate coefficients given.

(e) Pulse radiolysis of mixtures of $\mathrm{CH}_{4} / \mathrm{H}_{2} \mathrm{O}$ in the presence of $\mathrm{Ar}$ (940 Torr) and $\mathrm{SF}_{6}$ (50 Torr). The reactants $\mathrm{CH}_{3}$ and $\mathrm{OH}$ were generated by the reactions of $\mathrm{F}$ atoms with
$\mathrm{CH}_{4}$ and with $\mathrm{H}_{2} \mathrm{O}$ respectively. $\mathrm{CH}_{3}$ radicals monitored by UV absorption at $216.4 \mathrm{~nm}$.

(f) $\mathrm{CH}_{3}$ and $\mathrm{OH}$ radicals formed hy $193 \mathrm{~nm}$-photolysis of acetone-nitric acid mixtures diluted in $\mathrm{He}$. The $\mathrm{CH}_{3}$ was monitored by absorption spectroscopy and $\mathrm{OH}$ by LIF measurements in a pump/probe mode. In all conditions $\left[\mathrm{CH}_{3}\right] \gg[\mathrm{OH}]$. The data were modelled together with those of Ref. 3 using a master equation/inverse Laplace transform procedure.

(g) Literanure review. The given value is for the total reaction in the pressure independent regime.

(h) Theoretical analysis using the QRRK model.

(I) Variational transition state theory calculations with a sinusoidal rotor model.

\section{Preferred Values}

$k_{\infty}=1.0 \cdot 10^{-10} \mathrm{~cm}^{3}$ molecule $\mathrm{c}^{-1} \mathrm{~s}^{-1}$ over range $300-2000 \mathrm{~K}$. $k_{\infty}=[\mathrm{He}] 2.3 \cdot 10^{-27} \mathrm{~cm}^{3}$ molecule $\mathrm{e}^{-1} \mathrm{~s}^{-1}$ at $300 \mathrm{~K}$.

$k_{\circ}=[\mathrm{Ar}] 1.1 \cdot 10^{-28}(T / 1000)^{-8.2} \mathrm{~cm}^{3}$ molecule ${ }^{-1} \mathrm{~s}^{-1}$ over range $1000-2000 \mathrm{~K}$.

$F_{c}=0.18 \exp (-T / 200)+0.82 \exp (-T / 1438)$ for $\mathrm{M}=\mathrm{Ar}$ over range $1000-2000 \mathrm{~K}$. 


\section{Reliability}

$\Delta \log k_{\infty}= \pm 0.3$ over range $300-2000 \mathrm{~K}$.

$\Delta \log k_{\mathrm{o}}= \pm 0.3$ for $\mathrm{M}^{\circ}=\mathrm{He}$ at $300 \mathrm{~K}$.

$\Delta \log k_{\mathrm{o}}= \pm 0.5$ for $\mathrm{M}=$ Ar over range $1000-2000 \mathrm{~K}$.

$\Delta F_{\mathrm{c}}= \pm 0.1$ over range $1000-2000 \mathrm{~K}$.

\section{Comments on Preferred Values}

The available database is still limited and more measurements are needed. Figure 1 shows the recent values of Refs. $1-3,5$ and 6 and the high temperature value of Bott and Cohen'. The fit to the room temperature values leads to a collisional efficiency $\beta_{\mathrm{c}}=0.32^{10,11}$. The preferred $k^{\infty}$ is consistent with SACM estimates following Ref. 12. As Fig. 1 shows, the rate coefficients measured at $480 \mathrm{~K}$ are notably higher when they are compared with an estimation of the fall-off curve using a temperature independent $-\langle\Delta \mathbf{E}\rangle=160$ $\mathrm{cm}^{-1}$ (as determined from the above $\beta_{\mathrm{c}}$ value at $300 \mathrm{~K}$ ). More measurements at higher temperatures are necessary. The $k_{0}$ values for $\mathrm{M}=\mathrm{Ar}$ were estimated from the corresponding reverse dissociation process via $K_{c}$. The importance of the other reaction channels is still unknown ${ }^{6}$

\section{References}

${ }^{1}$ H. Oser, N.D. Stothard, R. Humpfer, and H.H. Grotheer, J. Phys. Chem. 96, 5359 (1992).

${ }^{2}$ T.J. Sworski, C.J. Hochanadel, and P.J. Ogren, J. Phys. Chem. 84, 129 (1980).

${ }^{3}$ H. Oser, N. Stothard, R. Humpfer, H.H. Grotheer, and Th. Just, 24th Symp. (Int.) on Combustion, 70 (1992).

${ }^{4}$ J.F. Bott and N. Cohen, Int. J. Chem. Kinet. 23, 1017 (1991).

${ }^{5}$ C. Anastasi, S. Beverton, T. Ellermann, and P. Pagsberg, J. Chem. Soc., Faraday Trans. 87, 2325 (1991).

${ }^{6}$ K.J. Hughes, A.R. Pereira, and M.J. Pilling, Ber. Bunsenges. Phys. Chem. 96, 1352 (1992).

${ }^{7}$ W. Tsang and R.F. Hampson, J. Phys. Chem. Ref. Data 15, 1087 (1986). ${ }^{8}$ M. Dean and P.R. Westmoreland, Int. J. Chem. Kinet. 19, 207 (1987).

${ }^{9}$ M.J.T. Jordan, S.C. Smith, and R.G. Gilbert, J. Phys. Chem. 95, 8685 (1991).

${ }^{10}$ J. Troe, J. Chem. Phys. 66, 4758 (1977).

"IJ. Troe, J. Phys. Chem. 83, 114 (1979).

${ }^{12}$ J. Troe. Z. Phys. Chem. NF 161, 209 (1989).

\section{$\mathrm{OH}+\mathrm{CH}_{3}+\mathrm{M} \rightarrow \mathrm{CH}_{3} \mathrm{OH}+\mathrm{M}$}

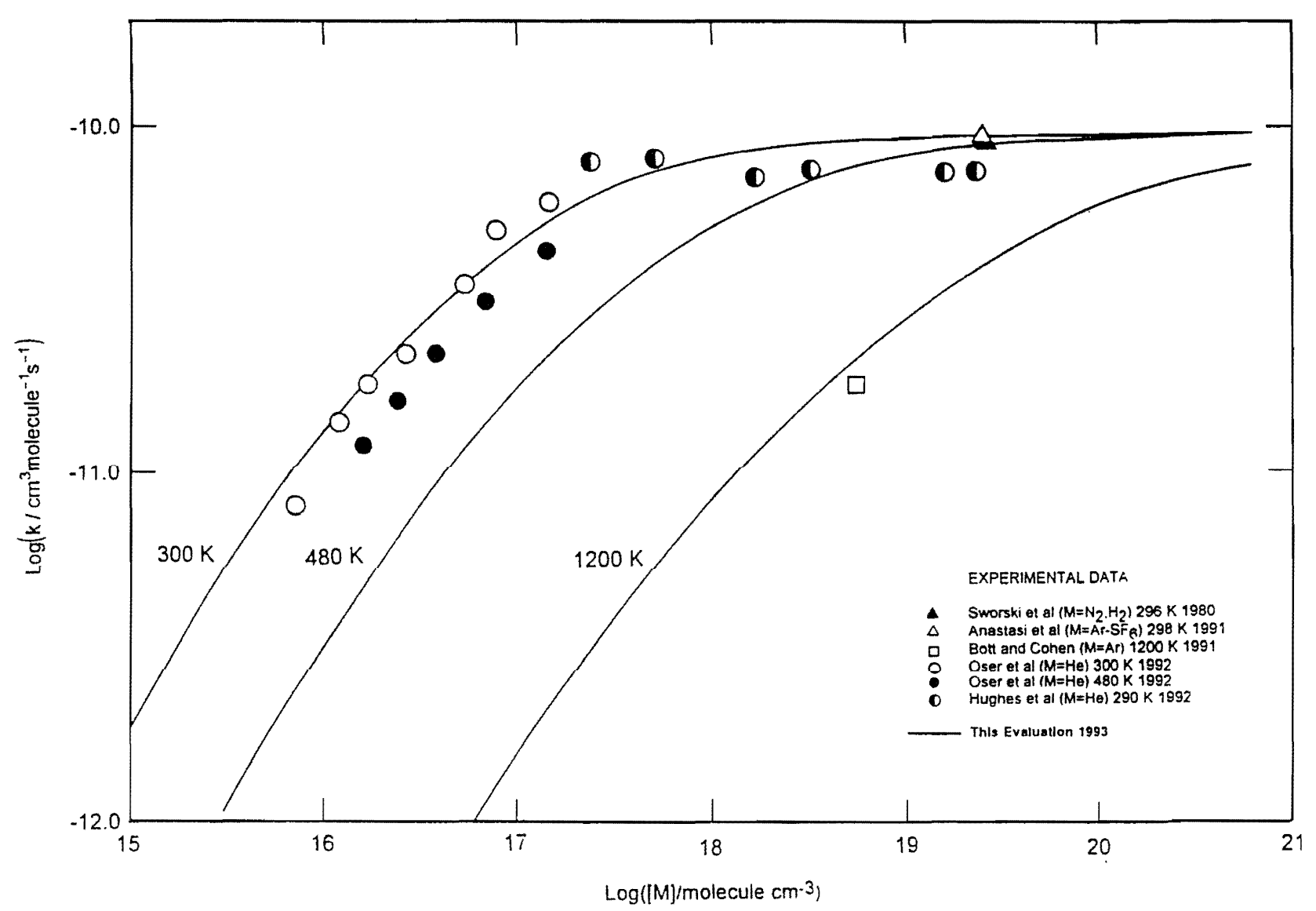




\section{$\mathrm{CH}_{3} \mathrm{OH}(+\mathrm{M}) \rightarrow \mathrm{CH}_{3}+\mathrm{OH}(+\mathrm{M})$ \\ $\rightarrow \mathrm{CH}_{2} \mathrm{OH}+\mathrm{H}(+\mathrm{M})$ \\ $\rightarrow{ }^{1} \mathrm{CH}_{2}+\mathrm{H}_{2} \mathrm{O}+\mathrm{M}$}

(1)
$\Delta H_{298}^{\circ}(2)=401.9 \mathrm{~kJ} \mathrm{~mol}^{-1}$

$\Delta S_{298}^{\circ}(2)=121.3 \mathrm{~J} \mathrm{~K}^{-1} \mathrm{~mol}^{-1}$

$K p(2)=1.19 \cdot 10^{3} T^{1.26} \exp (-5220 / T)$ atm.

Rate Coefficient Data $\left(k=k_{1}\right)$

\begin{tabular}{|c|c|c|c|c|}
\hline$k / \mathrm{s}^{-1}$ & $T / \mathrm{K}$ & {$[\mathrm{M}] /$ molecule $\mathrm{cm}^{-3}$} & References & Comments \\
\hline \multicolumn{5}{|l|}{ Rate Coefficient Measurements } \\
\hline \multicolumn{5}{|l|}{ Low Pressure Range } \\
\hline$[\mathrm{Ar}] 6.6 \cdot 10^{-9} \exp (-34200 / T)$ & $1545-2180$ & $(6.0-17) \cdot 10^{18}$ & Bowman, 1975: & (a) \\
\hline$[\mathrm{Ar}] 3.3 \cdot 10^{-1} \exp (-34400 / T)$ & $1600-2100$ & $(7-230) \cdot 10^{11}$ & Spindler and Wagner, $1982^{2}$ & (b) \\
\hline$[\mathrm{Ar}] 5.5 \cdot 10^{-8} \exp (-33213 / T)$ & $1372-1842$ & $(1.1-1.3) \cdot 10^{19}$ & Hidaka et al., $1989^{3}$ & (c) \\
\hline \multicolumn{5}{|l|}{ Intermediate Fall-Off Range } \\
\hline $2.1 \cdot 10^{11} \exp (-45790 / T)$ & $1070-1225$ & $6.4 \cdot 10^{18}\left(\mathrm{~N}_{2}\right)$ & Aranowitz, Naegeli, and Glassman, $1977^{4}$ & (d) \\
\hline $1.9 \cdot 10^{13} \exp (-40280 / T)$ & $1000-2180$ & $3.7 \cdot 10^{18}\left(\mathrm{~N}_{2}\right)$ & Westbrook and Dryer, $1979^{5}$ & (e) \\
\hline $6.4 \cdot 10^{11} \exp (-34730 / T)$ & $600-700$ & $2.8 \cdot 10^{18}\left(\mathrm{~N}_{2}\right)$ & Cathonnet, Boettner, and James, $1979^{6}$ & (f) \\
\hline $1.3 \cdot 10^{12} \exp (-35730 / T)$ & & $5.5 \cdot 10^{18}$ & & \\
\hline $6.0 \cdot 10^{12} \exp (-37280 / T)$ & $1300-1750$ & $6.0 \cdot 10^{18}(\mathrm{Ar})$ & Tsubi and Hashimoto, $1981^{7}$ & (g) \\
\hline $3.5 \cdot 10^{13} \exp (-37770 / T)$ & & $3.0 \cdot 10^{19}$ & & \\
\hline $8.7 \cdot 10^{13} \exp (-38250 / T)$ & & $6.0 \cdot 10^{19}$ & & \\
\hline $3.1 \cdot 10^{1}$ & 1600 & $7.0 \cdot 10^{17}(\mathrm{Ar})$ & Spindler and Wagner, $1982^{2}$ & (b) \\
\hline $1.4 \cdot 10^{2}$ & & $4.0 \cdot 10^{18}$ & & \\
\hline $4.0 \cdot 10^{2}$ & 1600 & $2.3 \cdot 10^{19}$ & & \\
\hline $3.4 \cdot 10^{2}$ & 1800 & $7.0 \cdot 10^{17}(\mathrm{Ar})$ & & \\
\hline $1.6 \cdot 10^{3}$ & & $4.0 \cdot 10^{18}$ & & \\
\hline $4.9 \cdot 10^{3}$ & & $2.3 \cdot 10^{19}$ & & \\
\hline $2.3 \cdot 10^{3}$ & 2000 & $7.0 \cdot 10^{17}(\mathrm{Ar})$ & & \\
\hline $1.1 \cdot 10^{4}$ & & $4.0 \cdot 10^{18}$ & & \\
\hline $3.7 \cdot 10^{4}$ & & $2.3 \cdot 10^{19}$ & & \\
\hline $7.9 \cdot 10^{36} T^{-7.08} \exp (-45290 / T)$ & $1800-2660$ & $1.2 \cdot 10^{18}\left(\mathrm{~N}_{2}\right)$ & Cribb, Dove, and Yamazaki, $1985^{8}$ & $(\mathrm{~h})$ \\
\hline $5.6 \cdot 10^{-2}$ & 1200 & $5.7 \cdot 10^{18}(\mathrm{Ar})$ & Bott and Cohen, $1991^{9}$ & (i) \\
\hline $1.2 \cdot 10^{22} \mathrm{~T}^{-8.0} \exp (-45295 / T)$ & $1800-2700$ & $1.0 \cdot 10^{18}(\mathrm{Ne}, \mathrm{Ar})$ & Cribb, Dove, and Yamazaki, $1992^{10}$ & (j) \\
\hline \multicolumn{5}{|l|}{ High Pressure Range } \\
\hline $9.4 \cdot 10^{15} \exp (-45220 / T)$ & $1600-2100$ & $(7-230) \cdot 10^{17}(\mathrm{Ar})$ & Spindler and Wagner, $1982^{2}$ & (b) \\
\hline \multicolumn{5}{|l|}{ Reviews and Evaluations } \\
\hline $\begin{array}{l}k_{0}=[\text { Ar }] 3.3 \cdot 10^{-7} \\
\exp (-34400 / T)\end{array}$ & $1000-2500$ & & Warnatz, $1989^{11}$ & $(\mathrm{k})$ \\
\hline$k_{\infty}=9.4 \cdot 10^{15} \exp (-45220 / T)$ & $1000-2500$ & & & \\
\hline$k_{\infty}=1.9 \cdot 10^{16} \mathrm{exp}(-46192 / T)$ & $300-2500$ & & Tsang. $1987^{12}$ & (1) \\
\hline$k_{\infty}=1.9 \cdot 10^{16} \exp (-46186 / T)$ & $973-2000$ & & Norton and Dryer, $1990^{13}$ & (m) \\
\hline
\end{tabular}




\section{Comments}

(a) Oxidation of methanol behind shock waves. The concentrations of $\mathrm{O}, \mathrm{OH}, \mathrm{H}_{2} \mathrm{O}$ and $\mathrm{CO}$ were measured using spectroscopic techniques. Mechanism with 19 reactions.

(b) Study of the methanol pyrolysis behind reflected shock waves in Ar. The concentration of $\mathrm{CH}_{3}$ and $\mathrm{OH}$ were monitored by absorption at 216 and $308 \mathrm{~nm}$ respectively. High and low pressure rate coefficients obtained by extrapolation of the fall-off curves. Channel (1) contributes about $75 \%$ and channel (2) about $25 \%$ to the total rate.

(c) Thermal decomposition of methanol behind reflected shock waves. IR laser kinetic spectroscopy, and GC analysis of reaction products. Mechanism with 26 reactions.

(d) Pyrolysis of methanol in an adiabatic turbulent flow reactor. Meclianisu will 19 steps.

(e) Mechanism for the oxidation of methanol with 89 elementary reactions.

(f) Thermal decomposition of methanol in a static reactor. Measurement of $\mathrm{CH}_{2} \mathrm{O}$ by gas chromatography. Mechanism with 10 reactions.

(g) Shock tube study of the thermal oxidation of methanoloxygen mixtures highly diluted with Ar. Mechanism with 57 steps.

(h) Pyrolysis of methanol studied by the laser schlieren method in incident shock waves and by dynamic spectrometry in reflected shock waves. The reaction occurs by both channels with $k_{1} / k=0.8$.

(i) Shock wave study of t-butyl hydroperoxide (generation of $\mathrm{HO}$ ) and $t$-butylperoxide (generation of $\mathrm{CH}_{3}$ ) mixtures. HO concentration monitored by UV absorption at 309 nm. Mechanism with six reactions. In the present work, the resulting recombination rate data have been transformed to dissociation data via the given equilibrium constant.

(j) Pyrolysis of methanol studied by laser schlieren densitometry and dynamic mass spectrometry. Modelling with a mechanism of 28 reactions.

(k) Data evaluation.

(l) Data evaluation and construction of RRKM fall-off curves.

(m) Evaluation of static, flow and shock tube experiments. Mechanism with 66 reactions.

\section{Preferred Values}

$k_{\infty}=1.7 \cdot 10^{16} \exp (-45740 / T) \mathrm{s}^{-1}$ over range $1000-2000 \mathrm{~K}$. $k_{\mathrm{o}}=[\mathrm{Ar}] 1.1 \cdot 10^{-7} \exp (-33080 / T) \mathrm{s}^{-1}$ over range 1000 $2000 \mathrm{~K}$.

$F_{\mathrm{c}}=0.18 \exp (-T / 200)+0.82 \exp (-T / 1438)$ for $\mathrm{M}=\mathrm{Ar}$ over range $1000-2000 \mathrm{~K}$.

\section{Reliability}

$\Delta \log k_{\infty}= \pm 0.5$ over range $1000-2000 \mathrm{~K}$.

$\Delta \log k_{\mathrm{o}}= \pm 0.3$ over range $1000-2000 \mathrm{~K}$.

$\Delta F_{\mathrm{c}}= \pm 0.1$ over range $1000-2000 \mathrm{~K}$.

\section{Comments on Preferred Values}

The recommended values are mainly based on the theoretical analysis of the rate data from Ref. 2 in terms of unimolecular rate theory ${ }^{14-16}$. The modelling leads to the almost temperature independent value $k_{\infty}$ of $7.0 \cdot 10^{-11} \mathrm{~cm}^{3}$ molecule ${ }^{-1} \mathrm{~s}^{-1}$ between $300-2000 \mathrm{~K}$ for the reverse recombination reaction in good agreement with recent data by Sworski et al ${ }^{17}$ and Anastasi et al.$^{18}$. Therefore, because the available experiments are far away from the high pressure regime, we derived the recommended $k_{\infty}$ using a recombination coefficient of $k_{\infty}$ $=1.0 \cdot 10^{-10} \mathrm{~cm}^{3}$ molecule ${ }^{-1} \mathrm{~s}^{-1}$ and the given equilibrium constant. Figure 1 shows the temperature dependence of $k_{\mathrm{o}}$ in comparison with the values recommended by Warnat ${ }^{11}$. Figure 2 shows that the recommended $k_{\infty}$ agrees with previous compilations. The value of Tsang ${ }^{12}$ and Norton and Dryer ${ }^{13}$ are virually the same as the recommended values and thus, for simplicity, are omitted from Figure 2. Figure 3 shows fall-off curves derived from the preferred $k_{\circ}$ and $k_{\infty}$ values. The resulting collision efficiencies range from 0.1 to 0.05 over the range $1600-2000 \mathrm{~K}$. The curves also fit the oldest data of Cribb et al ${ }^{8}$ very well and are in good agreement with the recombination data measured by Bott and Cohen ${ }^{9}$ after conversion to dissociation rates. However, the more recent experiments by Cribb et al.$^{10}$ yield rate coefficients $2-3$ times higher than those reported here at Ar gas density of $1 \cdot 10^{18}$ molecules $\mathrm{cm}^{-3}$. According to Refs. 2,8 and 10 , the rate coefficient for channel (2) is markedly lower than that of reaction (1). The importance of channel (3) is still unknown.

\section{References}

'C.T. Bowman, Comb. Flame 25, 343 (1975).

${ }^{2}$ K. Spindler and H.Gg. Wagner, Ber. Bunsenges. Phys. Chem. 86, 2 (1982).

${ }^{3}$ Y. Hidaka, T. Oki, H. Kawano, and T. Higashihara, J. Phys. Chem. 93, 7134 (1989).

${ }^{4}$ D. Aronowitz, D.W. Naegeli, and J. Glassman, J. Phys. Chem. 81, 2555 (1977).

${ }^{5}$ C.K. Westbrook and F.L. Dryer, Combust. Sci. Technol. 20, 125 (1979). ${ }^{6} \mathrm{M}$. Cathonnet, J.C. Boettner, and H. James, J. Chim. Phys. 76, 183 (1979).

${ }^{7}$ T. Tsubi and K. Hashimoto, Comb. Flame, 42, 61 (1981).

${ }^{8}$ P.H. Cribb, J.E. Dove, and S. Yamazaki, 20th Symp. Int. Combust. 779 (1985).

${ }^{9}$ J.F. Bott and N. Cohen, Int. J. Chem. Kinet. 23, 1017 (1991).

${ }^{10}$ P.H. Cribb, J.E. Dove, and S. Yamazaki, Comb. Flame 88, 169 (1992).

"J. Warnatz in "Combustion Flame", W.C. Gardiner, Jr., Ed., Springer-Verlag, p.196 (1984).

12W. Tsang, J. Phys. Chem. Ref. Data 16, 171 (1987).

${ }^{13}$ T.S. Norton and F.L. Dryer, Int. J. Chem. Kinet. 22, 219 (1990).

${ }^{14} \mathrm{~J}$. Troe, J. Chem. Phys. 66, 4758 (1977).

${ }^{15}$ J. Troe, J. Phys. Chem. 83, 114 (1979).

${ }^{16}$ J. Troe, Z. Phys. Chem. N.F. 161, 209 (1989),

${ }^{17}$ T.J. Sworski, C.J. Hochanadel, and P. Ogren, J. Phys. Chem. 84, 129 (1980).

${ }^{18}$ C. Anastasi, S. Beverton, T. Ellermann, and P. Pagsberg, J. Chem. Soc., Faraday Trans. 87, 2325 (1991). 
$\mathrm{CH}_{3} \mathrm{OH}+\mathrm{M} \rightarrow \mathrm{CH}_{3}+\mathrm{OH}+\mathrm{M}$

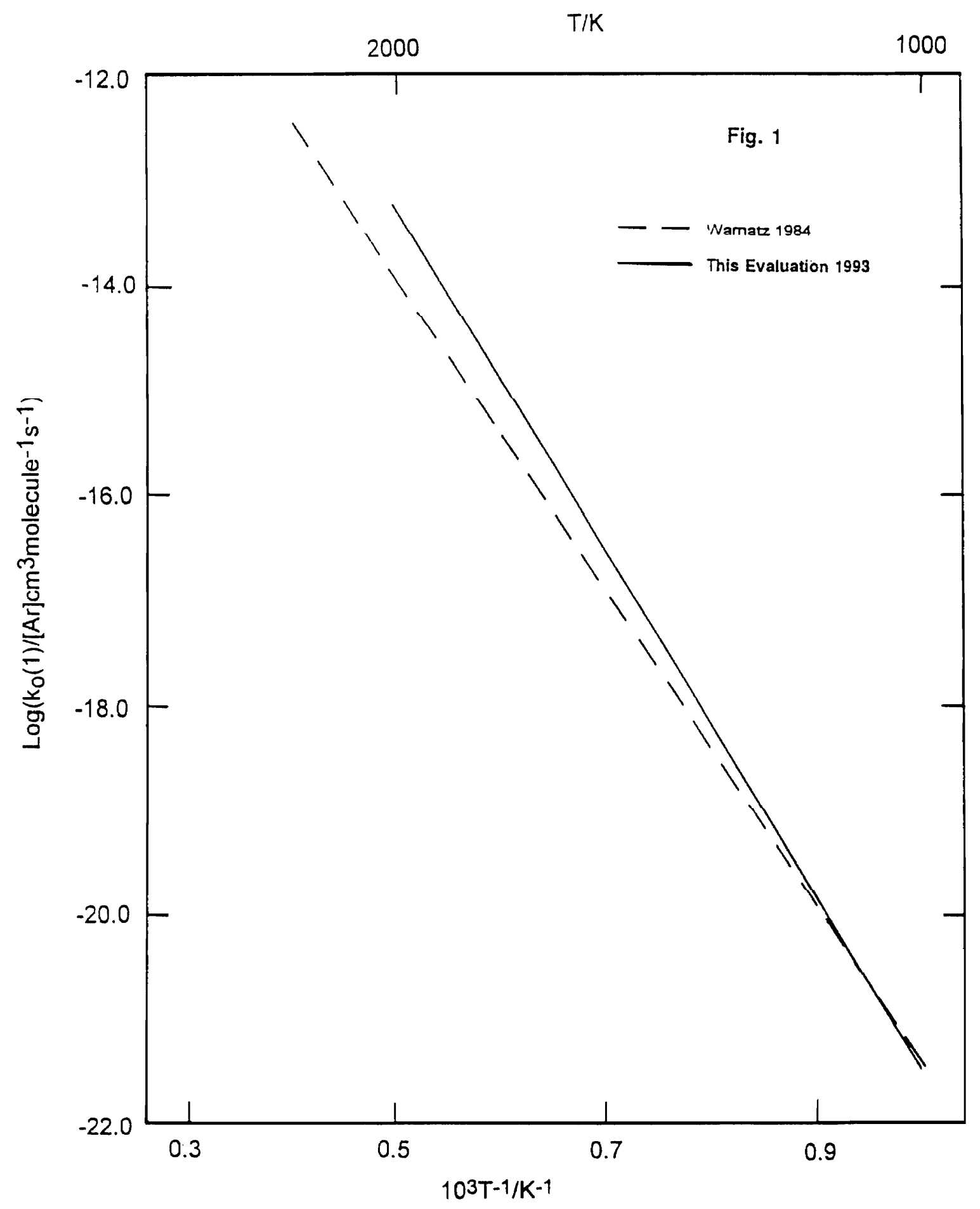


$\mathrm{CH}_{3} \mathrm{OH}+\mathrm{M} \rightarrow \mathrm{CH}_{3}+\mathrm{OH}+\mathrm{M}$

$T / K$

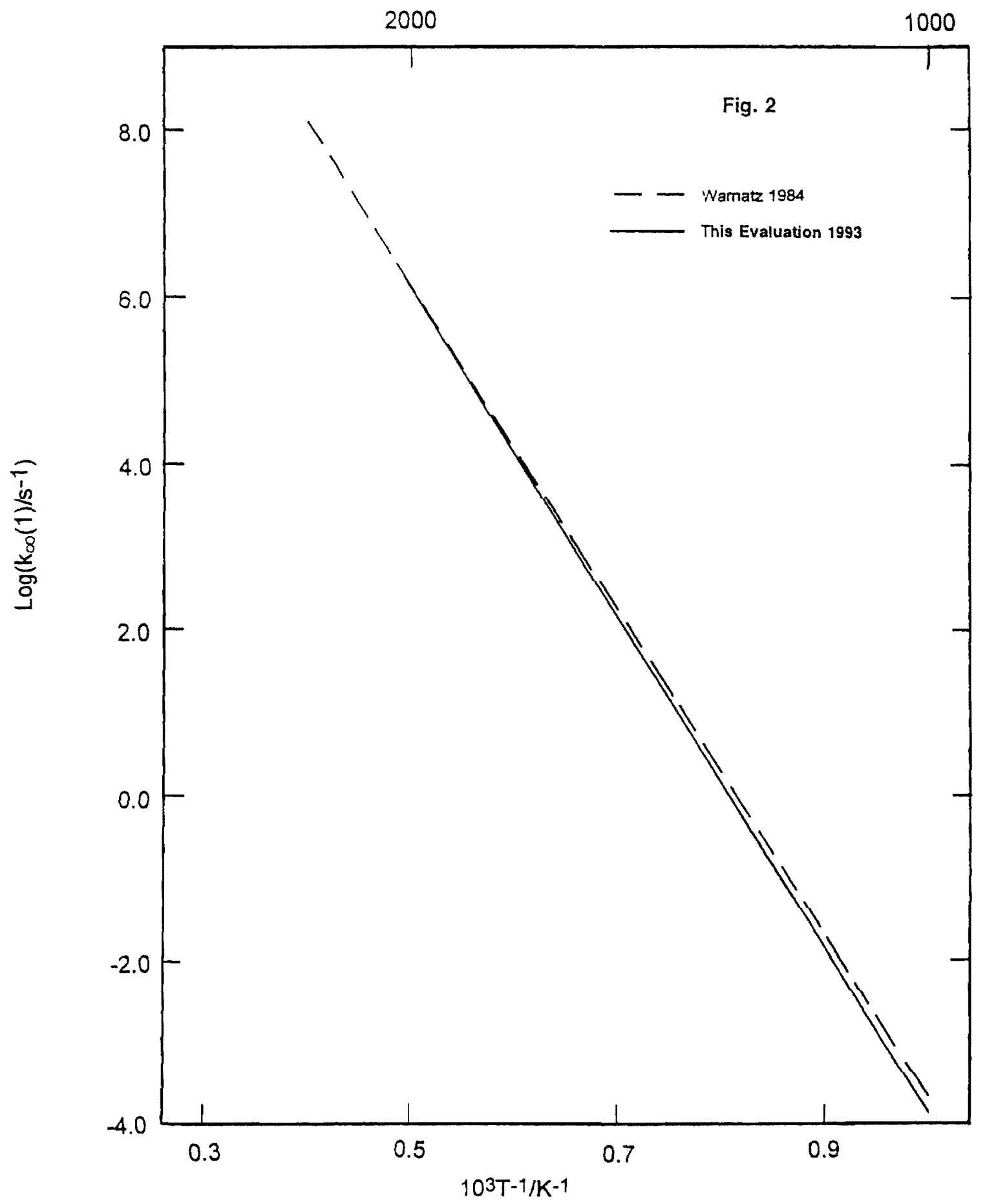




$$
\mathrm{CH}_{3} \mathrm{OH}+\mathrm{M} \rightarrow \mathrm{CH}_{3}+\mathrm{OH}+\mathrm{M}
$$

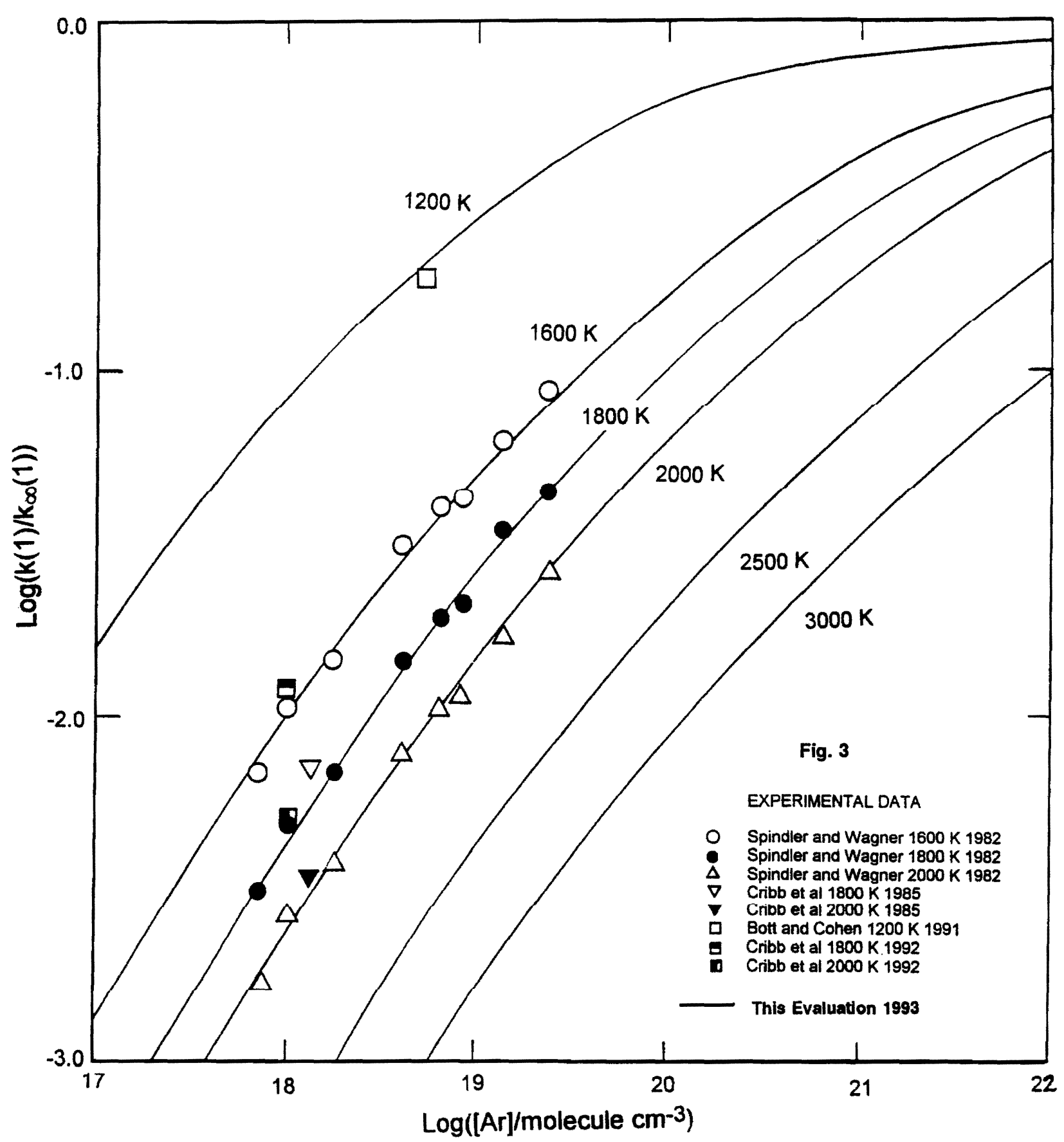




$$
\begin{aligned}
\mathrm{OH}+\mathrm{C}_{6} \mathrm{H}_{5} \mathrm{CH}_{3} & \rightarrow \mathrm{H}_{2} \mathrm{O}+\mathrm{C}_{6} \mathrm{H}_{5} \mathrm{CH}_{2} \\
& \rightarrow \mathrm{H}_{2} \mathrm{O}+\mathrm{C}_{6} \mathrm{H}_{4} \mathrm{CH}_{3} \\
\mathrm{OH}+\mathrm{C}_{6} \mathrm{H}_{5} \mathrm{CH}_{3}(+\mathrm{M}) & \rightarrow \mathrm{C}_{6} \mathrm{H}_{5}(\mathrm{OH}) \mathrm{CH}_{3}(+\mathrm{M}) \\
& \\
& \Delta H_{298}^{\circ}(2)=-17.6 \mathrm{~kJ} \mathrm{~mol}^{-1} \\
& \Delta S_{298}^{\circ}(2)=1.4 \mathrm{~J} \mathrm{~K}^{-1} \mathrm{~mol}^{-1} \\
& K p(2)=3.7 \cdot 10^{-1} \exp (+2130 / T)
\end{aligned}
$$

\begin{tabular}{|c|c|c|c|}
\hline $\mathrm{k} / \mathrm{cm}^{3}$ molecule $^{-1 \mathrm{~s}-1}$ & $T / \mathrm{K}$ & Reference & Comments \\
\hline \multicolumn{4}{|l|}{ Rate Coefficient Measurements } \\
\hline$k_{1}=5.0 \cdot 10^{-12} \exp (-453 / T)$ & $380-473$ & Perry, Atkinson, and Pitts, $1977^{1}$ & (a) \\
\hline$k_{3}=3.2 \cdot 10^{-13} \exp (+805 / T)$ & $296-325$ & & \\
\hline$k_{1}=1.7 \cdot 10^{-11} \exp (-1510 / T)$ & $1700-2800$ & McLain, Jachimowski, and Wilson, $1979^{2}$ & (b) \\
\hline$k_{1}=2.1 \cdot 10^{11} \exp (-1300 / T)$ & $500-1000$ & Tully et al., $1981^{3}$ & (c) \\
\hline$k_{3}=3.8 \cdot 10^{-12} \exp (+180 / T)$ & $213-298$ & & \\
\hline$k_{3}=6.4 \cdot 10^{-12}$ & 298 & Ohta and Ohyama, $1985^{4}$ & (d) \\
\hline$k_{3}=5.4 \cdot 10^{-12}$ & 298 & Eoney, Kleindienst, and Corse, $1986^{5}$ & (e) \\
\hline $4.8 \cdot 10^{-12}$ & 773 & Baldwin, Scott and Walker, $1987^{\circ}$ & (f) \\
\hline$k_{3}^{o}=[\mathrm{He}] 5 \cdot 10^{-30} \exp (+1300 / T)$ & $298-353$ & Bourmada et al., $1988^{7}$ & (g) \\
\hline$k_{3}^{\infty}=4.6 \cdot 10^{-13} \exp (+760 / T)$ & $298-353$ & & \\
\hline \multicolumn{4}{|l|}{ Reviews and Evaluations } \\
\hline $1.81 \cdot 10^{-12} \exp (355 / T)$ & $213-324$ & Atkinson, $1989^{8}$ & (h) \\
\hline $7.58 \cdot 10^{-18} T^{2} \exp (11 / T)$ & $473-1046$ & & \\
\hline$k_{1}=8.6 \cdot 10^{-15} T \exp (-440 / T)$ & $400-1200$ & CEC, $1992^{9}$ & (i) \\
\hline
\end{tabular}

Thermodynamic Data

$\Delta H_{298}^{\circ}(1)=-130.8 \mathrm{~kJ} \mathrm{~mol}^{-1}$

$\Delta S_{298}^{\circ}(1)=1.4 \mathrm{~J} \mathrm{~K}^{-1} \mathrm{~mol}^{-1}$

$K p(1)=3.2 \cdot 10^{-1} \cdot T^{0.23} \exp (+15730 / T)$

Rate Coefficient Data $\left(k=k_{1}+k_{2}+k_{3}\right)$

\section{Comments}

(a) Flash photolysis-resonance fluorescence technique at total pressures around 10 Torr. The addition channel (2) is the dominant reaction pathway for temperatures below $325 \mathrm{~K}$. The $\mathrm{H}$ abstraction reaction (1) was found to be the dominant reaction pathway for temperatures above $380 \mathrm{~K}$.

(b) Incident shock wave investigation of the oxidation mechanism of $\mathrm{C}_{6} \mathrm{H}_{6} / \mathrm{O}_{2} / \mathrm{Ar}$ and $\mathrm{C}_{6} \mathrm{H}_{5} \mathrm{CH}_{3} / \mathrm{O}_{2} / \mathrm{Ar}$ mixtures by monitoring UV and IR emission of $\mathrm{CO}, \mathrm{CO}_{2}$ and the product concentrations [O], [CO]. Arrhenius expression for the products $\mathrm{C}_{6} \mathrm{H}_{5} \mathrm{CH}_{2}+\mathrm{H}_{2} \mathrm{O}$ (channel (1)) was estimated by comparison with data for benzene.

(c) Flash photolysis-resonance fluorescence technique. $\mathrm{OH}$ reactions with benzene, toluene, and selectively deuterated toluenes were studied in the temperature range 213 to $1150 \mathrm{~K}$. The results indicate that the addition channel (2) is the dominant reaction pathway below $300 \mathrm{~K}$ and that the side-chain hydrogen abstraction channel (1) is the dominant reaction routes at higher temperatures. The rate expression for channel (1) was estimated.

(d) Hexane was used as a reference compound. Photolysis of $\mathrm{H}_{2} \mathrm{O}_{2}$ was the source of $\mathrm{OH}$. Rate coefficient for $\mathrm{OH}$ consumption by (channel (3)) was evaluated at atmospheric pressure.

(e) Rate constant value for reaction (3) derived by using a relative rate technique. Photolysis of methyl nitrite was the source of $\mathrm{OH}$.

(f) Small amounts of toluene $(0.05-0.5 \%)$ were added to slowly reacting mixtures of $\mathrm{H}_{2}+\mathrm{O}_{2}$ at $773 \mathrm{~K}$. Under the experimental conditions the hydrogen/oxygen system provides a reproducible source of radicals such as $\mathrm{H}, \mathrm{O}$, and $\mathrm{OH}$. Measurement of the relative consumption of the additive and molecular hydrogen permits the evaluation of the rate constants for the reaction of $\mathrm{H}, \mathrm{O}$, and $\mathrm{OH}$ with the toluene.

(g) Discharge flow study with $\mathrm{OH}$ detection by resonance fluorescence. He used as carrier gas. Measurements performed at 298 and $353 \mathrm{~K}$ in the fall-off pressure range between 0.5 and 9.8 Torr. Authors derived from their measurements $k_{\mathrm{o}}$ and $k_{\infty}$ using Troe's formalism with $F_{\mathrm{c}}$ $=0.6$. The rate constant expressions are given here in Arrhenius form.

(h) Low temperature recommendations based on data from Refs. 1, 3, and 10. High temperature recommendations based on data fiom Refs. 1 and 3.

(i) See Comments on Preferred Values.

\section{Preferred Values}

$k_{1}=8.6 \cdot 10^{-15} T \exp (-440 / T) \mathrm{cm}^{3}$ molecule ${ }^{-1} \mathrm{~s}^{-1}$ over range $400-1200 \mathrm{~K}$.

\section{Reliability}

$\Delta \log k_{1}= \pm 0.5$ at $400 \mathrm{~K}$ reducing to \pm 0.3 at $1200 \mathrm{~K}$.

\section{Comments on Preferred Values}

The recommendations are unchanged from our previous evaluation ${ }^{9}$. The recent study of Bourmada et $a l .^{7}$ is in agreement with the previous studies which indicate that the dominant reaction pathway at and below room temperature is the addition of the $\mathrm{OH}$ radical (channel (3)). Side-chain hydrogen abstraction seems to be the main reaction at higher tempera- 
tures (channel (1)). The new data are considered reliable, but owing to the pressure dependence of reaction (3) a rate expression is not recommended for that channel. For channel (1) the indirect data of Ref. 2 have not been considered in deriving the rate constant expression and the recommendation for channel (1) is only made for an intermediate temperature range of about 800 degrees.

\section{References}

${ }^{1}$ R.A. Perry, R. Atkinson, and J.N. Pitts, Jr., J. Phys. Chem. 81, 296 (1977). ${ }^{2}$ A.G. McLain, C.J. Jachimowski, and C.H. Wilson, NASA TP-1472 (1979).
${ }^{3}$ F.P. Tully, A.R. Ravishankara, R.L. Thompson, J.M. Nicovich, R.C. Shah, N.M. Kreutter, and P.H. Wine, J. Phys. Chem. 85, 2262 (1981).

${ }^{4}$ T. Ohta and T. Ohyama, Bull. Chem. Soc. Jpn. 58, 3029 (1985).

${ }^{s}$ E.O. Edney, T.E. Kleindienst, and E.W. Corse, Int. J. Chem. Kinet. 18, 1355 (1986).

${ }^{6}$ R.R. Baldwin, M. Scott, and R.W. Walker, 21st Symp. (Int.) Combust., 991 (1986).

${ }^{7}$ M. Bourmada, M. Charlier, J.-F. Pauwels, P. Devolder, Journ. de Chimie Physique, 85, 881 (1988).

${ }^{8}$ R. Atkinson, J. Phys. Chem. Ref. Data, Monograph 1 (1989)

${ }^{9} \mathrm{CEC}, 1992$ (see references in Introduction).

${ }^{10}$ D.A. Hansen, R. Atkinson, and J.N. Pitts, Jr., J. Phys. Chem. 79, 1763 (1975).

$$
\begin{aligned}
\mathrm{OH}+\mathrm{C}_{6} \mathrm{H}_{5} \mathrm{CHO} & \rightarrow \mathrm{H}_{2} \mathrm{O}+\mathrm{C}_{6} \mathrm{H}_{5} \mathrm{CO} \\
& \rightarrow \mathrm{H}_{2} \mathrm{O}+\mathrm{C}_{6} \mathrm{H}_{4} \mathrm{CHO}
\end{aligned}
$$

Rate Coefficient Data $\left(k=k_{1}+k_{2}\right)$

\begin{tabular}{llll}
\hline \hline$k / \mathrm{cm}^{3}$ molecule $\mathrm{s}^{-1}$ & $T / \mathrm{K}$ & Reference & Comments \\
\hline $\begin{array}{l}\text { Rate Coefficient Measurements } \\
1.4 \cdot 10^{-11} \\
1.18 \cdot 10^{-11}\end{array}$ & 298 & Niki et al. $1978^{1}$ & (a) \\
Reviews and Evaluations & 298 & Kerr and Sheppard. $1981^{2}$ & (b) \\
$1.29 \cdot 10^{-11}$ & & & \\
& 298 & Atkinson, $1989^{3}$ & (c) \\
\hline
\end{tabular}

\section{Comments}

(a) Photolysis of $\mathrm{C}_{6} \mathrm{H}_{5} \mathrm{CHO} / \mathrm{C}_{2} \mathrm{D}_{4} / \mathrm{HONO}$ mixtures. Loss of reactants monitored by FTIR. $k$ measured relative to $k\left(\mathrm{OH}+\right.$ ethylene- $\left.\mathrm{d}_{4}\right)=8.78 \cdot 10^{-12} \mathrm{~cm}^{3}$ molecule $^{-1} \mathrm{~s}^{-1}$, which was measured relative to $k\left(\mathrm{OH}+\mathrm{C}_{2} \mathrm{H}_{4}\right)$ in the same study. The value used to calculate the entry in the table is taken from Ref. 3, i.e. $k\left(\mathrm{OH}+\mathrm{C}_{2} \mathrm{H}_{4}\right)=8.52 \cdot 10^{-12}$ $\mathrm{cm}^{3}$ molecule $\mathrm{e}^{-1} \mathrm{~s}^{-1}$.

(b) Photolysis of $\mathrm{C}_{2} \mathrm{H}_{5} \mathrm{CHO} / \mathrm{C}_{2} \mathrm{H}_{4} / \mathrm{HONO}$ mixtures. Loss of reactants monitored by gas chromatography. $k$ measured relative to $k\left(\mathrm{OH}+\mathrm{C}_{2} \mathrm{H}_{4}\right)=8.52 \cdot 10^{-12} \mathrm{~cm}^{3}$ molecule ${ }^{-1}$ $\mathrm{s}^{-1}$.

(c) Based on the data of Niki et al. ${ }^{1}$ and Kerr and Sheppard ${ }^{2}$.

\section{Preferred Value}

$k=1.3 \cdot 10^{-11} \mathrm{~cm}^{3}$ molecule ${ }^{-1} \mathrm{~s}^{-1}$ over the range 298$1500 \mathrm{~K}$.

\section{Reliability}

$\Delta \log k= \pm 0.5$ at $1500 \mathrm{~K}$ reducing to \pm 0.1 at $298 \mathrm{~K}$.

\section{Comments on Preferred Values}

Only relative rate determinations at room temperature appear to have been carried out for this reaction. The room temperature data agree well and the techniques used have proved reliable for other reactions for which direct measurements are available. The preferred value follows the recommendation of Atkinson ${ }^{3}$ which is the simple mean of the two determinations. At room temperature it is apparent that the reaction proceeds entirely $(>90 \%)$ by abstraction of the benzylic $\mathrm{H}$-atom; this is expected to be the dominant process up to at least $1000 \mathrm{~K}$. Data for reactions of $\mathrm{OH}$ with other aldehydes suggest that the temperature coefficient of $k$ will be small.

\section{References}

${ }^{1}$ H. Niki, P.D. Maker, C.M. Savage, and L.P. Breitenbach, J. Phys. Chem. 82, 132 (1978).

${ }^{2}$ J.A. Kerr and D.W. Sheppard, Environ. Sci. Technol. 15, 960 (1981).

${ }^{3}$ R. Atkinson, J. Phys. Chem. Ref. Data Monograph 1 (1989). 


$$
\mathrm{HO}_{2}+\mathrm{HO}_{2} \rightarrow \mathrm{H}_{2} \mathrm{O}_{2}+\mathrm{O}_{2}
$$

Thermodynamic Data

$\Delta H_{298}^{\circ}=-165.3 \mathrm{~kJ} \mathrm{~mol}^{-1}$

$\Delta S_{298}^{\circ}=-20.5 \mathrm{~J} \mathrm{~K}^{-1} \mathrm{~mol}^{-1}$

$K p=8.1 \cdot 10^{-3} T^{0.36} \exp (+19800 / T)$

Rate Coefficient Data

\begin{tabular}{|c|c|c|c|}
\hline$k / \mathrm{cm}^{3}$ molecule $^{-1} \mathrm{~s}^{-1}$ & $T / \mathrm{K}$ & Reference & Comments \\
\hline $\begin{array}{l}\text { Rate Coefficient Measurements } \\
7.0 \cdot 10^{-10} \exp (-6030 / T)+ \\
2.2 \cdot 10^{-13} \exp (+820 / T) \\
\text { (At } 1 \text { atmosphere pressure) }\end{array}$ & $300-1100$ & Hippler, Troe and Willner, $1990^{1}$ & (a) \\
\hline $\begin{array}{c}\text { Reviews and Evaluations } \\
3.1 \cdot 10^{-11} \exp (-775 / T) \\
2.2 \cdot 10^{-13} \exp (600 / T)\end{array}$ & $\begin{array}{l}550-1250 \\
230-420\end{array}$ & $\begin{array}{l}\text { CEC, } 1992^{2} \\
\text { IUPAC, } 1992^{3}\end{array}$ & $\begin{array}{l}\text { (b) } \\
\text { (c) }\end{array}$ \\
\hline
\end{tabular}

\section{Comments}

(a) Shock tube studies between 750 and $1120 \mathrm{~K}$. Two different $\mathrm{HO}_{2}$ sources were used, the thermal dissociation of $\mathrm{CH}_{3} \mathrm{O}_{2} \mathrm{CH}_{3}$ in the presence of excess $\mathrm{O}_{2}$, and the thermal dissociation of $\mathrm{H}_{2} \mathrm{O}_{2}$. The rate constant expression was obtained by combination with low temperture data which are reviewed fully in the IUPAC compilation ${ }^{3}$. The new data are also in excellent agreement with Troe' $\mathrm{s}^{4}$ original shock tube data point obtained in 1969. However, particularly at the higher temperatures, the data are sensitive to $k\left(\mathrm{OH}+\mathrm{H}_{2} \mathrm{O}_{2}\right)$ in a relatively complex interpretation.

(b) Based on data obtained by Lightfoot, Veyret and Lesclaux ${ }^{5}$ between 298 and $777 \mathrm{~K}$, which showed some evidence of a minimum at about $700 \mathrm{~K}$, and on Troe's ${ }^{4}$ single shock tube point at about $1100 \mathrm{~K}$.

(c) Accepts expression of Kircher and Sander ${ }^{5}$.

\section{Preferred Values}

$$
\begin{aligned}
k= & 7.0 \cdot 10^{-10} \exp (-6030 / T)+ \\
2.2 \cdot 10^{-13} \exp (+820 / T) \text { between } 550 \text { and } 1250 \mathrm{~K} . & \\
k & =7.0 \cdot 10^{-10} \exp (-6030 / T) \text { between } 850 \text { and } 1250 \mathrm{~K} .
\end{aligned}
$$

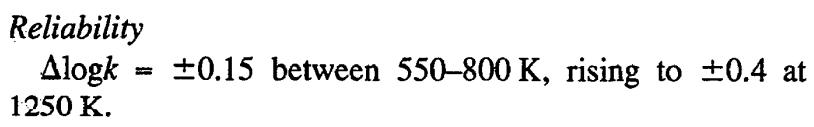

\section{Comments on Preferred Values}

The expression given by Hippler, Troe and Willner ${ }^{1}$ is accepted between 550 and $1250 \mathrm{~K}$, over the range where $k$ appears to be independent of pressure ${ }^{2.3}$. The new data confirm the existence of a deep minimum in the range 700$750 \mathrm{~K}$, and are in excellent agreement with Troe's original data point at $1100 \mathrm{~K}$. A theoretical estimate of $k$ by Patrick, Golden and Barker ${ }^{7}$ predicts a minimum in the value of $k$ but at the slightly higher temperature of $1000 \mathrm{~K}$. The experimentally observed increase in $k$ above $800 \mathrm{~K}$ is unusually marked and, although theoretically possible, confirmation of the observation both for this reaction and related reactions would be helpful. Fortunately at temperatures above $1250 \mathrm{~K}$, the role of $\mathrm{HO}_{2}$ radicals in combustion becomes less important. Below $550 \mathrm{~K}, k$ becomes pressure dependent and is particularly sensitive to polar gases such as $\mathrm{H}_{2} \mathrm{O}$ and $\mathrm{NH}_{3}$. Between 550 and $850 \mathrm{~K}$, use of the bi-exponential expression is necessary. However, between 850 and $1200 \mathrm{~K}$, use of the recommended single exponential expression is sufficiently accurate. Full details of the low temperature data are given in the IUPAC compilation ${ }^{3}$.

\section{References}

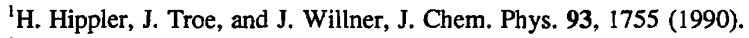

${ }^{2} \mathrm{CEC}, 1992$ (see references in Introduction).

${ }^{3}$ IUPAC, 1992 (see references in Introduction).

${ }^{4} J$. Troe, Ber. Bunsenges. Phys. Chem. 73, 946 (1969).

${ }^{5}$ P.D. Lightfoot, B. Veyret, and R. Lesclaux, Chem. Phys. Lett. 150, 120 (1988).

${ }^{\circ}$ C.C. Kircher and S.P. Sander, J. Phys. Chem. 88, 2082 (1984).

${ }^{7}$ R. Patrick, J.R. Barker, and D.M. Golden, J. Phys. Chem. 88, 128 (1984). 


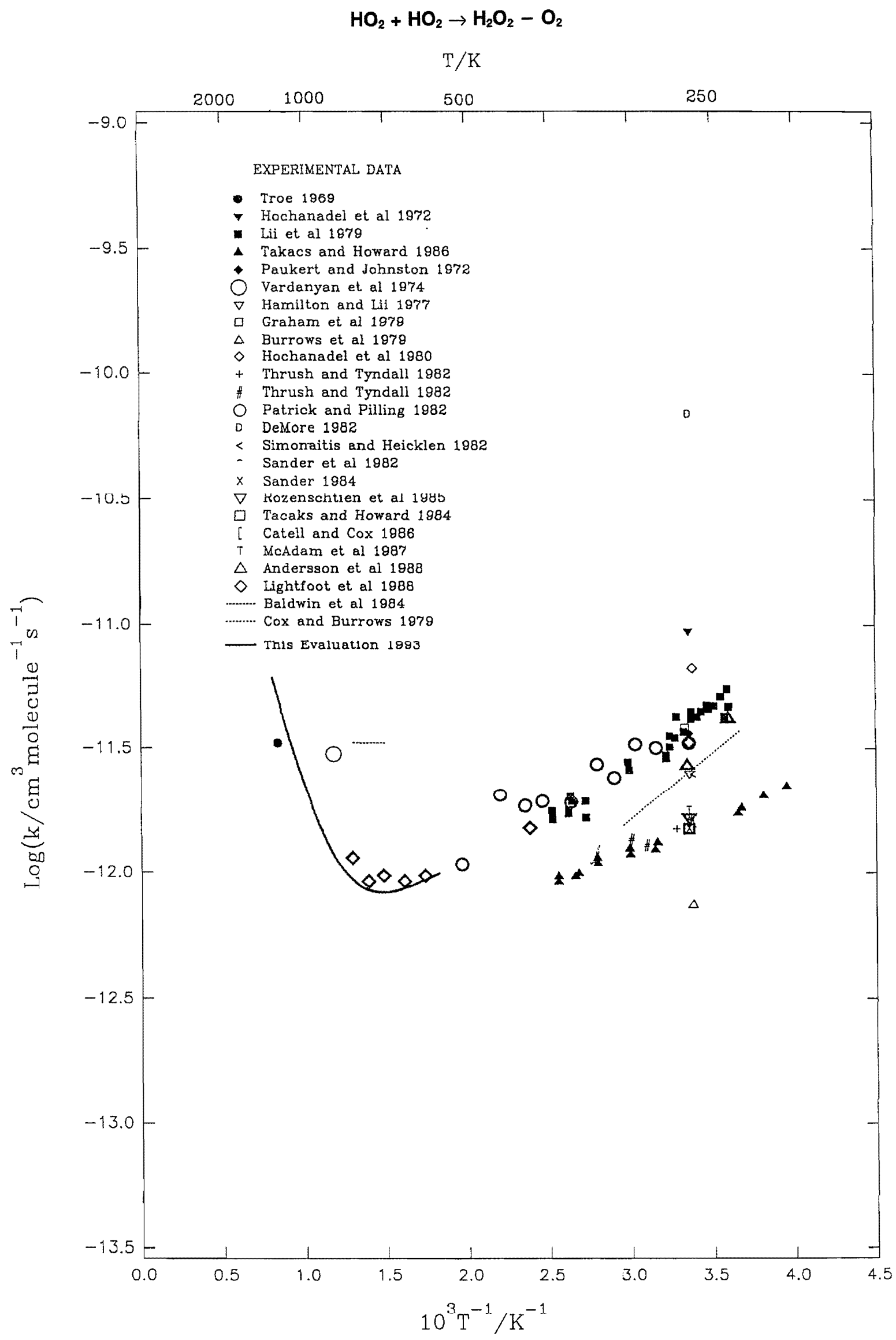




$$
\begin{aligned}
\mathrm{HO}_{2}+\mathrm{CH}_{3} \mathrm{O}_{2} & \rightarrow \mathrm{CH}_{3} \mathrm{OOH}+\mathrm{O}_{2} \\
& \rightarrow \mathrm{HCHO}+\mathrm{H}_{2} \mathrm{O}+\mathrm{O}_{2}
\end{aligned}
$$

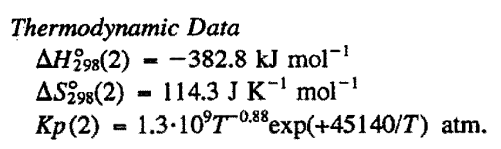

\begin{tabular}{|c|c|c|c|}
\hline$k / \mathrm{cm}^{3}$ molecule $\mathrm{e}^{-1} \mathrm{~s}^{-1}$ & $T / \mathrm{K}$ & Reference & Comments \\
\hline \multicolumn{3}{|l|}{ Rate Coefficient Measurements } & (a) \\
\hline $\begin{array}{l}k=4.8 \cdot 10^{-12} \\
k_{1}=3.5 \cdot 10^{-12}\end{array}$ & 300 & Moortgat et al., $1989^{1}$ & (b) \\
\hline$k=4.4 \cdot 10^{-13} \exp (780 / T)$ & $248-573$ & Lightfoot, Veyret, and Lesclaux, $1990^{2}$ & (c) \\
\hline$k=2.9 \cdot 10^{-13} \exp (862 / T)$ & $248-678$ & Lightfoot et al., $1991^{3}$ & (d) \\
\hline \multicolumn{4}{|l|}{ Branching Ratio Measurements } \\
\hline$k_{1} / k=0.92[700 \mathrm{Torr}]$ & 295 & Wallington and Japar, $1990^{4}$ & (e) \\
\hline$k_{1} / k=0.92[15-700$ Torr $]$ & 295 & Wallington, $1991^{5}$ & (e) \\
\hline \multicolumn{4}{|l|}{ Reviews and Evaluations } \\
\hline$k=3.8 \cdot 10^{-13} \exp (800 / T)$ & $200-400$ & NASA, $1992^{6}$ & (f) \\
\hline$k=3.8 \cdot 10^{-13} \exp (780 / T)$ & $225-580$ & IUPAC, $1992^{7}$ & (g) \\
\hline$k=5.6 \cdot 10^{-13} \exp (6 \Delta N / T)$ & $250-6 n 0$ & Wallington, Dagaut, and Kurylo, $1992^{8}$ & (h) \\
\hline$k=4.1 \cdot 10^{-13} \exp (790 / T)$ & $230-680$ & Lightfoot et al., $1992^{9}$ & (i) \\
\hline
\end{tabular}

Rate Coefficient Data $\left(k=k_{1}+k_{2}\right)$

\section{Comments}

(a) Rate coefficient determinations made prior to 1989 have not been listed explicitly. The measurements can be found in references $(10-17)$ and these have been reviewed in earlier evaluations ${ }^{6,7}$.

(b) Modulated photolysis of $\mathrm{CH}_{3} \mathrm{CHO} / \mathrm{O}_{2} / \mathrm{N}_{2}$ mixtures at atmospheric pressure with long pathlength UV and FTIR absorption detection. Composite absorptions due to $\mathrm{CH}_{3} \mathrm{O}_{2}$ and $\mathrm{HO}_{2}$ recorded at 220 and $250 \mathrm{~nm}$. The waveforms were analysed simultaneously with an assumed reaction scheme. The absorption cross-sections used were for $\mathrm{CH}_{3} \mathrm{O}, \mathrm{u}_{250}\left[\mathrm{CH}_{3} \mathrm{O}_{2}\right]=4.16 \cdot 10^{-18} \mathrm{~cm}^{2}$ molecule ${ }^{-1}$, $\sigma_{220} / \sigma_{250}=0.81$ and for $\mathrm{HO}_{2}, \sigma_{220}\left[\mathrm{HO}_{2}\right]=4.0 \cdot 10^{-18} \mathrm{~cm}^{2}$ molecule ${ }^{-1}, \sigma_{220}\left[\mathrm{HO}_{2}\right]=0.5 \cdot 10^{-18} \mathrm{~cm}^{2}$ molecule ${ }^{-1} k_{1}$ was determined hy simulating the growth of $\left[\mathrm{CH}_{3} \mathrm{OOH}\right]$ and the concentration of other products with an assumed reaction scheme.

(c) Flash photolysis of $\mathrm{Cl}_{2} / \mathrm{CH}_{4} / \mathrm{CH}_{3} \mathrm{OH} / \mathrm{O}_{2} / \mathrm{N}_{2}$ mixtures with UV absorption detection at 210 and $260 \mathrm{~nm}$. Simultaneous analysis of composite absorption profiles. Crosssections of $\mathrm{CH}_{3} \mathrm{O}_{2}$ and $\mathrm{HO}_{2}$ at the two wavelengths derived from studies on the two self-reactions (with either $\mathrm{CH}_{3} \mathrm{OH}$ or $\mathrm{CH}_{4}$ removed) and $\mathrm{NOCl}$ used as an actinometer $\left(\sigma_{260}\left[\mathrm{CH}_{3} \mathrm{O}_{2}\right]=3.6 \cdot 10^{-18}, \sigma_{210}\left[\mathrm{CH}_{3} \mathrm{O}_{2}\right]=\right.$ $2.5 \cdot 10^{-18} \mathrm{~cm}^{2}$ molecule ${ }^{-1}$ and $\sigma_{210}\left[\mathrm{HO}_{2}\right]=5.3 \cdot 10^{-18}$, $\sigma_{260}\left[\mathrm{HO}_{2}\right]=0.3 \times 10^{-18}, \sigma_{260}\left[\mathrm{HO}_{2}\right]=0.3 \cdot 10^{-18} \mathrm{~cm}^{2}$ molecule ${ }^{-1}$ ).

(d) Flash photolysis of $\mathrm{O}_{2} / \mathrm{CH}_{4} / \mathrm{CH}_{3} \mathrm{OH}$ mixtures between 600 and $719 \mathrm{~K}$ with UV absorption detection. The earlier data of Lightfoot et al. ${ }^{2}$ were reanalysed using temperature dependent absorption cross-sections ${ }^{18}$ and combined with the results of this study. (e) Growth of $\mathrm{CH}_{3} \mathrm{OOH}$ compared to loss of $\mathrm{CH}_{4}$ following the photolysis of $\mathrm{F}_{2} / \mathrm{CH}_{4} / \mathrm{H}_{2}$ /air mixtures using long pathlength FTIR spectroscopy ${ }^{4}$. Conditions arranged so that $\mathrm{CH}_{3} \mathrm{O}_{2}$ reacted predominantly with $\mathrm{HO}_{2}$. Complications due to secondary chemistry were mainly avoided by using $\mathrm{F}_{2}$. The yield of $\mathrm{CH}_{3} \mathrm{OOH}$ appeared independent of pressure between 15 and 700 Torr although corrections due to $\mathrm{CH}_{3} \mathrm{~F}$ formation were made at the lowest pressures ${ }^{5}$.

(f) The preferred value at $298 \mathrm{~K}$ is a mean of the rate parameters derived by Cox and Tyndall ${ }^{11}$, McAdam et al.$^{13}$, Kurylo and Wallington ${ }^{14}$ (as amended in Dāgaut et al. ${ }^{17}$ ), Jenkin et al. ${ }^{16}$, Moortgat et al. ${ }^{1}$ and Lightfoot et al. ${ }^{2}$. The temperature coefficient was obtained as a rounded-off average of the three temperature-dependent studies ${ }^{2,11,17}$ with the $A$-factor adjusted to give the recommended value of $k_{298}$.

(g) The recommended rate coefficient at $298 \mathrm{~K}$ is the mean of those reported by Dāgaut et al. ${ }^{17}$, Jenkin et al.$^{16}$, Moortgat et al. ${ }^{1}$, Lightfoot $e t a l .{ }^{2}$ and Cox and Tyndall ${ }^{11}$. The temperature coefficient is taken from Lightfoot et al. ${ }^{2}$ and the $A$-factor adjusted to give the preferred value of $k$ at $298 \mathrm{~K}$.

(h) Based on a single Arrhenius fit of all the available kinetic data excluding the determination by Kan et al..$^{12}$. Both values reported by Jenkin et al..$^{16}$ and Moortgat et al. ${ }^{1}$ were included. The reaction was assumed to give only $\mathrm{CH}_{3} \mathrm{OOH}$ and $\mathrm{O}_{2}$ as reported by Wallington and Japar ${ }^{4}$.

(i) The preferred value at $298 \mathrm{~K}$ is a simple mean of the rate parameters derived by Cox and Tyndall ${ }^{11}$, Jenkin et al. ${ }^{16}$, Moortgat et al. ${ }^{1}$, and Lightfoot et al. ${ }^{2,3}$, which excludes the low values reported by Kurylo et al..$^{15}$ and Kan et al. ${ }^{12}$. The temperature coefficient was obtained as a rounded-off average of the three latest temperature- 
dependent studies (Dagaut et al.$^{17}$, Lightfoot et al.$^{2}$ and Lightfoot et $a l .^{3}$ ), with the $A$-factor adjusted to give the recommended value of $k_{298}$.

The recent work of Wallington and Japar ${ }^{4}$, and Wallington $^{5}$ suggests that the only product channel is that leading to the formation of $\mathrm{CH}_{3} \mathrm{OOH}$ and $\mathrm{O}_{2}$.

\section{Preferred Value}

$k=4.1 \cdot 10^{-13} \cdot \exp (790 / T)$ over the range $298-700 \mathrm{~K}$.

$k_{1} / k=1.0 \pm 0.1$ over the range $298-700 \mathrm{~K}$.

\section{Reliability \\ $\Delta \log k= \pm 0.1$ at $298 \mathrm{~K}$ increasing to \pm 0.3 at $700 \mathrm{~K}$.}

\section{Comments on Preferred Values}

The independent reviews undertaken by Wallington et al. ${ }^{8}$ and Lightfoot et al. ${ }^{9}$ have critically evaluated all the kinetic and mechanistic data available on this reaction. The preferred value is that given by Lightfoot et al.$^{9}$ rather than that determined by Wallington et al.$^{8}$ due to the incorporation of the more extensive high temperature data from the Bordeaux group $^{3}$ in the recommendation made by Lightfoot et al. ${ }^{9}$. Wallington et $a l .^{8}$ included the kinetic measurements of Kurylo et al.$^{15}$ in their Arrhenius analysis which gives a value of the rate constant significantly lower at $298 \mathrm{~K}$ than all the other direct measurements. The temperature dependence reported by Kurylo and co-workers (Dagaut et al. ${ }^{17}$ ) is, however, in very good agreement with the other recent temperature dependent studies, suggesting a possible systematic error in their absolute $k$ values. The latest IUPAC evaluation ${ }^{7}$ does not include the recent study by the Bordeaux group ${ }^{3}$, and, for that reason, differs slightly from the present evaluation.

The recent studies of Wallington and Japar ${ }^{4}$ and Wallington $^{5}$ indicate that channel (1) is the major reaction pathway and this should be assumed for modelling purposes. Further support for this is provided by Lightfoot et al. ${ }^{3}$ who could only interpret their high temperature data if the reaction was assumed to give mainly $\mathrm{CH}_{3} \mathrm{OOH}$ and $\mathrm{O}_{2}$.

\section{References}

${ }^{1}$ G.K. Moortgat, R.A. Cox, G. Schuster, J.P. Burrows, and G.S. Tyndall, J. Chem. Soc., Faraday Trans. 2 85, 809 (1989).

${ }^{2}$ P.D. Lightfoot, B. Veyret, and R. Lesclaux, J. Phys. Chem. 94, 708 (1990). ${ }^{3}$ P.D. Lightfoot, P. Roussel, F. Caralp, and R. Lesclaux, J. Chem, Soc., Faraday Trans. 87, 3213 (1991).

${ }^{4}$ T.J. Wallington and S.M. Japar, Chem. Phys. Lett. 167, 513 (1990).

${ }^{5}$ T.J. Wallington, J. Chem. Soc., Faraday Trans. 87, 2379 (1991).

WASA Evaluation No. 10, 1992 (see references in Introduction).

'IUPAC, 1992 (see references in Introduction).

${ }^{8}$ T.J. Wallington, P. Dagaut, and M.J. Kurylo, Chem. Rev. 92, 667 (1992).

${ }^{9}$ P.D. Lightfoot, R.A. Cox, J.N. Crowley, M. Destriau, G.D. Hayman, M.E. Jenkin, G.K. Moortgat, and F. Zabel, Atmos. Environ., 26A, 1805 (1992). ${ }^{10}$ R.A. Cox and G.S. Tyndall, Chem. Phys. Lett. 65, 357 (1979).

${ }^{11}$ R.A. Cox and G.S. Tyndall, J. Chem. Soc., Faraday Trans. 2 76, 153 (1980). ${ }^{12}$ C.S. Kan, J.G. Calvert, and J.H. Shaw, J. Phys. Chem. 84, 3411 (1980).

${ }^{13}$ K. McAdam, B. Veyret, and R. Lesclaux, Chem. Phys. Lett. 133, 39 (1987)

${ }^{14}$ M.J. Kurylo and T.J. Wallington, Chem. Phys. Lett. 138, 543 (1987).

${ }^{15}$ M.J. Kurylo, P. Dagaut, T.J. Wallington, and D.M. Neuman, Chem. Phys. Lett. 139, 513 (1987).

${ }^{16}$ M.E. Jenkin, R.A. Cox, G.D. Hayman, and L.J. Whyte, J. Chem. Soc., Faraday Trans, 2 84, 913 (1988).

${ }^{17}$ P. Dagaut, T.J. Wallington, and M.J. Kurylo, J. Phys. Chem. 92, 3833 (1988).

${ }^{18}$ P.D. Lightfoot and A.A. Jemi-Alade, J. Photochem. 59, 1 (1991). 


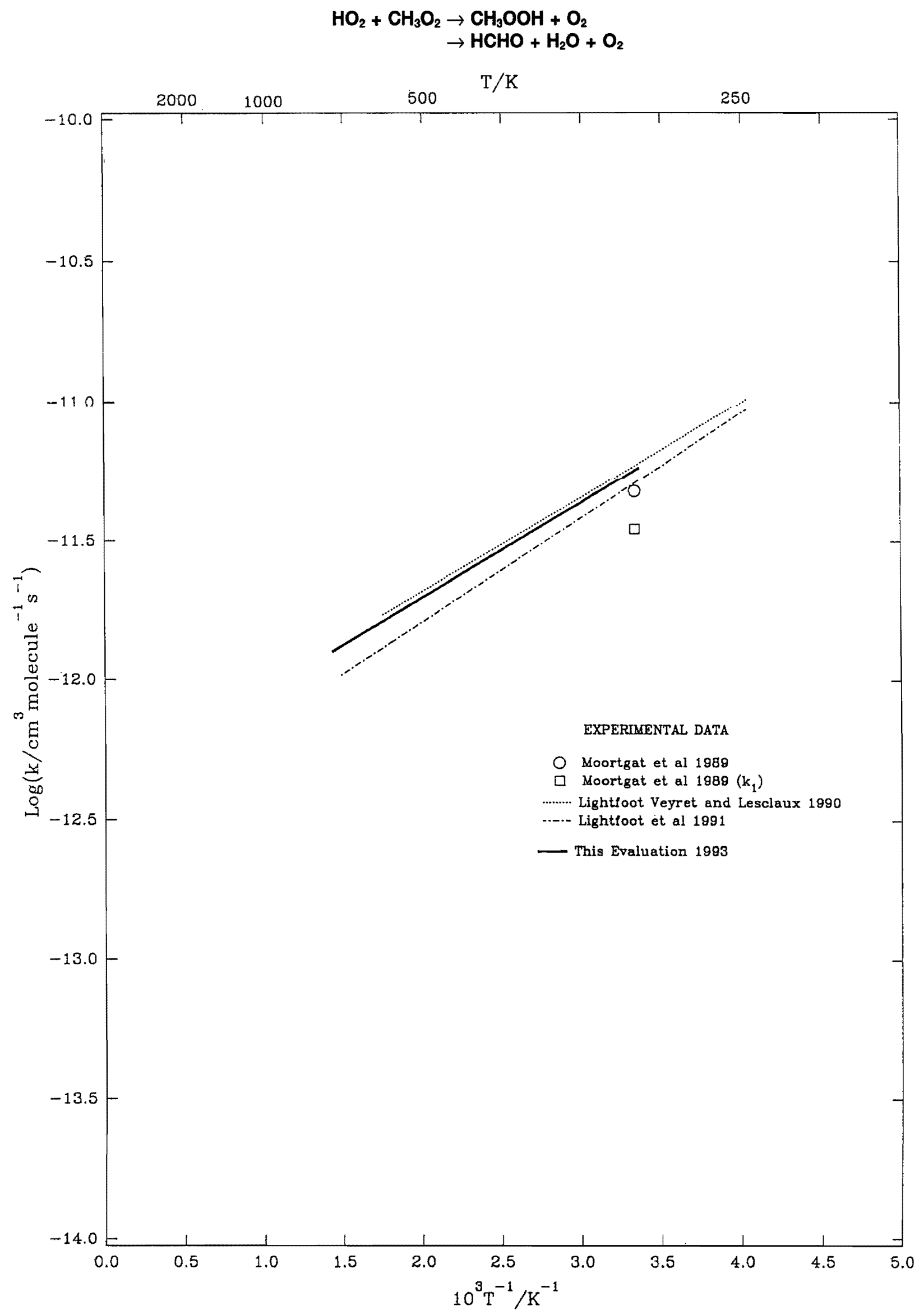




$$
\begin{aligned}
\mathrm{HO}_{2}+\mathrm{C}_{6} \mathrm{H}_{5} \mathrm{CH}_{3} & \rightarrow \mathrm{H}_{2} \mathrm{O}_{2}+\mathrm{C}_{6} \mathrm{H}_{5} \mathrm{CH}_{2} \\
& \rightarrow \mathrm{H}_{2} \mathrm{O}_{2}+\mathrm{C}_{6} \mathrm{H}_{4} \mathrm{CH}_{3}
\end{aligned}
$$

Rate Coefficient Data $\left(k=k_{1}+k_{2}\right)$

\begin{tabular}{lcc}
\hline \hline$k / \mathrm{cm}^{3}$ molecule $\mathrm{s}^{-1}$ & $T / \mathrm{K}$ & Reference \\
\hline $\begin{array}{l}\text { Rate Coefficient Measurements } \\
6.9 \cdot 10^{-17}\end{array}$ & 773 & Baldwin, Scott, and Walker, 1986 \\
\hline
\end{tabular}

\section{Comments}

(a) Studies of the relative rate of consumption of $\mathrm{H}_{2}$ and toluene when traces of toluene were added to slowly reacting mixtures of $\mathrm{H}_{2}+\mathrm{O}_{2}$ at $773 \mathrm{~K}$. Interpretation of results gave $\left(k_{1}+k_{2}\right) / k_{3}{ }^{1 / 2}=6.5 \cdot 10^{-10}\left(\mathrm{~cm}^{3}\right.$ molecule $^{-1}$ $\left.\mathrm{s}^{-1}\right)^{1 / 2} ; k_{3}=3.1 \cdot 10^{-12} \exp (-775 / T) \mathrm{cm}^{3}$ molecule ${ }^{-1} \mathrm{~s}^{-1}$ for $\mathrm{HO}_{2}+\mathrm{HO}_{2} \rightarrow \mathrm{H}_{2} \mathrm{O}_{2}+\mathrm{O}_{2}$ (see present recommended value).

\section{Preferred Values}

$k_{1}=6.6 \cdot 10^{-13} \exp (-7080 / T) \mathrm{cm}^{3}$ molecule $\mathrm{e}^{-1} \mathrm{~s}^{-1}$ over range $600-1000 \mathrm{~K}$.

$k_{2}=9 \cdot 10^{-12} \exp (-14500 / T) \mathrm{cm}^{3}$ molecule ${ }^{-1} \mathrm{~s}^{-1}$ over range $600-1000 \mathrm{~K}$.

\section{Reliability}

$\Delta \log k_{1}= \pm 0.3$ at $750 \mathrm{~K}$ rising to \pm 0.5 at $600 \mathrm{~K}$ and $1000 \mathrm{~K}$.

$\Delta \log k_{2}= \pm 1.0$

\section{Comments on Preferred Values}

The value at $773 \mathrm{~K}$ is the only experimental determination of $\left(k_{1}+k_{2}\right)$. The value of $\left(k_{1}+k_{2}\right) / k_{3}{ }^{1 / 2}$ is reliable, where $k_{3}$ refers to the reaction $\mathrm{HO}_{2}+\mathrm{HO}_{2} \rightarrow \mathrm{H}_{2} \mathrm{O}_{2}+\mathrm{O}_{2}$, and any error in $k_{3}$ is reduced by $50 \%$ in calculating $\left(k_{1}+k_{2}\right)$. On thermochemical grounds $k_{2} \leqslant 0.001 k_{1}$ at $773 \mathrm{~K}$. The preferred values of $k_{1}$ and $k_{2}$ are based on the $A$ factor for $\mathrm{HO}_{2}+$ $\left(\mathrm{CH}_{3}\right)_{3} \mathrm{CC}\left(\mathrm{CH}_{3}\right)_{3}$ (per $\mathrm{C}-\mathrm{H}$ bond) ${ }^{2}$ with a reduction in $A_{1}$ by a factor of 8 (per $\mathrm{C}-\mathrm{H}$ bond) due to loss of entropy of activation from increased electron delocalization in the emerging $\mathrm{C}_{6} \mathrm{H}_{5} \mathrm{CH}_{2}$ radical. If $k_{1}$ and $k_{2}$ obey the non-Arrhenius equation $A T^{n} \exp (-E / R T)$ with $n$ likely to be between 2 and 3 , then extrapolation will lead to low values of $k_{1}$ and $k_{2}$ above $1000 \mathrm{~K}$.

\section{References}

${ }^{1}$ R.R. Baldwin, M. Scott, and R.W. Walker, 21st Symp. (Int.) Combust., 991 (1986).

${ }^{2}$ R.R. Baldwin, M.W.M. Hisham, A. Keen, and R.W. Walker, J. Chem. Soc., Faraday Trans. 177,1165 (1982),

$$
\begin{aligned}
\mathrm{HO}_{2}+\mathrm{C}_{6} \mathrm{H}_{5} \mathrm{CH}_{2} \mathrm{CH}_{3} & \rightarrow \mathrm{H}_{2} \mathrm{O}_{2}+\mathrm{C}_{6} \mathrm{H}_{5} \mathrm{CHCH}_{3} \\
& \rightarrow \mathrm{H}_{2} \mathrm{O}_{2}+\mathrm{C}_{6} \mathrm{H}_{5} \mathrm{CH}_{2} \mathrm{CH}_{2} \\
& \rightarrow \mathrm{H}_{2} \mathrm{O}_{2}+\mathrm{C}_{6} \mathrm{H}_{4} \mathrm{CH}_{2} \mathrm{CH}_{3}
\end{aligned}
$$

\begin{tabular}{|c|c|c|c|}
\hline$k / \mathrm{cm}^{3}$ molecule $^{-1} \mathrm{~s}^{-1}$ & $T / \mathrm{K}$ & Reference & Comments \\
\hline $\begin{array}{l}\text { Rate Coefficient Mea } \\
\quad 3.0 \cdot 10^{-16}\end{array}$ & 773 & Baldwin, Scott, and Walker, $1992^{1}$ & (a) \\
\hline
\end{tabular}

Rate Coefficient Data

\section{Comments}

(a) Studies of the relative rate of consumption of $\mathrm{H}_{2}+$ ethylbenzene when traces of ethylbenzene were added to slowly reacting mixtures of $\mathrm{H}_{2}+\mathrm{O}_{2}$ at $773 \mathrm{~K}$. Interpretation of results gave $\left(k_{1}+k_{2}+k_{3}\right) / k_{4}{ }^{1 / 2}=2.8 \cdot 10^{-9}\left(\mathrm{~cm}^{3}\right.$ molecule $\left.\mathrm{s}^{-1}\right)^{1 / 2} ; \quad k_{4}=3.1 \cdot 10^{-12} \exp (-775 / T) \mathrm{cm}^{3}$ molecule $\mathrm{s}^{-1}$ for $\mathrm{HO}_{2}+\mathrm{HO}_{2} \rightarrow \mathrm{H}_{2} \mathrm{O}_{2}+\mathrm{O}_{2}$ (see present recommended value).

\section{Preferred Values}

$k_{1}=4.4 \cdot 10^{-13} \exp \left(-5680 / T^{\prime}\right) \mathrm{cm}^{3}$ molecule ${ }^{-1} \mathrm{~s}^{-1}$ between 600 and $1000 \mathrm{~K}$.

$k_{2}=5.3 \cdot 10^{-12} \exp (-9760 / T) \mathrm{cm}^{3}$ molecule ${ }^{-1} \mathrm{~s}^{-1}$ between 600 and $1000 \mathrm{~K}$. $k_{3}=9 \cdot 10^{-12} \exp (-14500 / T) \mathrm{cm}^{3}$ molecule $\mathrm{e}^{-1} \mathrm{~s}^{-1}$ between 600 and $1000 \mathrm{~K}$.

\section{Reliability}

$\Delta \log k_{1}= \pm 0.3$ at $750 \mathrm{~K}$ rising to \pm 0.5 at $600 \mathrm{~K}$ and $1000 \mathrm{~K}$.

$\Delta \log k_{2}= \pm 0.5$
$\Delta \log k_{3}= \pm 1.0$

Comments on Preferred Values

The value at $773 \mathrm{~K}$ is the only experimental determination of $\left(k_{1}+k_{2}+k_{3}\right)$. The value of $\left(k_{1}+k_{2}+k_{3}\right) / k_{4}^{1 / 2}$ is reliable, where $k_{4}$ refers to the reaction $\mathrm{HO}_{2}+\mathrm{HO}_{2} \rightarrow \mathrm{H}_{2} \mathrm{O}_{2}+\mathrm{O}_{2}$, and any error in $k_{4}$ is reduced by $50 \%$ in calculating $\left(k_{1}+k_{2}+k_{3}\right)$. On thermochemical grounds $k_{3} \approx 0.00025 k_{1}$ at $773 \mathrm{~K}$. Assuming $k_{2}-0.5 k\left(\mathrm{HO}_{2}, \mathrm{C}_{2} \mathrm{H}_{6}\right)$, then with $k_{1}+k_{2}-3.0 \cdot 10^{-16}$ and 
$k\left(\mathrm{HO}_{2}+\mathrm{C}_{2} \mathrm{H}_{6}\right)=3.5 \cdot 10^{-17} \mathrm{~cm}^{3}$ molecule ${ }^{-1} \mathrm{~s}^{-1}$ (Ref. 2), then $k_{2}=1.75 \cdot 10^{-17}$ and $k_{1}=2.8 \cdot 10^{-16} \mathrm{~cm}^{3}$ molecule ${ }^{-1} \mathrm{~s}^{-1}$ at $773 \mathrm{~K}$. The preferred values of $k_{1}, k_{2}$ and $k_{3}$ are based on the $A$ factor for $\mathrm{HO}_{2}+\left(\mathrm{CH}_{3}\right)_{3} \mathrm{CC}\left(\mathrm{CH}_{3}\right)_{3}$ (per $\mathrm{C}-\mathrm{H}$ bond) $)^{3}$ with a reduction in $A_{1}$ by a factor of 8 (per $\mathrm{C}-\mathrm{H}$ bond) due to loss of entropy of activation from increased electron delocalization in the emerging $\mathrm{C}_{6} \mathrm{H}_{5} \mathrm{CHCH}_{3}$ radical. If $k_{1}, k_{2}$ and $k_{3}$ obey the non-Arrhenius equation $k=A T^{n} \exp (-E / R T)$ with $n$ likely to be between 2 and 3 , then extrapolation will lead to low values of $k_{1}$ and $k_{2}$ above $1000 \mathrm{~K}$.

\section{References}

'R.R. Baldwin, M. Scott, and R.W. Walker, J. Chem. Soc., Faraday Trans. 1992 (submitted for publication).

${ }^{2}$ R.R. Baldwin, C.E. Dean, M.R. Honeyman, and R.W. Walker, J. Chem. Soc., Faraday Trans. I 82, 89 (1986).

${ }^{3}$ R.R. Baldwin, M.W.M. Hisham, A. Keen, and R.W. Walker, J. Chem. Soc., Faraday Trans. I 78, 1165 (1982).

$$
\mathrm{N}+\mathrm{O}_{2} \rightarrow \mathrm{NO}+\mathrm{O}
$$

Thermodynamir Data

$\Delta H_{298}^{\circ}=-133 \mathrm{~kJ} \mathrm{~mol}^{-1}$

$\Delta S_{298}^{\circ}=13.4 \mathrm{~J} \mathrm{~K}^{-1} \mathrm{~mol}^{-1}$

$K p=13.21 T^{-0.13} \exp (+15930 / T)$

Rate Coefficient Data

\begin{tabular}{|c|c|c|c|}
\hline$k / \mathrm{cm}^{3}$ molecule $^{-1} \mathrm{~s}^{-1}$ & $T / \mathrm{K}$ & Reference & Comments \\
\hline \multicolumn{4}{|l|}{ Rate Coefficient Measurements } \\
\hline $3 \cdot 10^{-12} \exp (-3100 / T)$ & $390-520$ & Kistiakowsky and Volpi, $1957^{1}$ & (a) \\
\hline $3 \cdot 10^{-12}$ & 1575 & Kaufman and Decker, $1959^{2}$ & (b) \\
\hline $1.4 \cdot 10^{-11} \exp (-3600 / T)$ & $412-755$ & Clyne and Thrush, $1961^{3}$ & (c) \\
\hline $6.3 \cdot 10^{-12} \exp (-3500 / T)$ & $453-603$ & Vlastaras and Winkler, $1967^{4}$ & (d) \\
\hline $2.34 \cdot 10^{-11} \exp (-4000 / T)$ & $300-910$ & Wilson, $1967^{5}$ & (e) \\
\hline $5.5 \cdot 10^{-12} \exp (-3200 / T)$ & $280-333$ & Becker, Groth, and Kley, $1969^{6}$ & (f) \\
\hline $1.08 \cdot 10^{-16}$ & 302 & Clarke and Wayne, $1970^{7}$ & (g) \\
\hline $7.5 \cdot 10^{-17}$ & 300 & Westenberg, Roscoe, and de Haas, $1970^{8}$ & (h) \\
\hline $2.6 \cdot 10^{-11}$ & 2880 & Livesey, Roberts, and Williams, $1971^{9}$ & (i) \\
\hline $7.2 \cdot 10^{-17}$ & 298 & Winkler et al., $1986^{10}$ & (j) \\
\hline $8.8 \cdot 10^{-17}$ & 298 & Barnett, Marston and Wayne, $1987^{11}$ & (k) \\
\hline \multicolumn{4}{|l|}{ Reviews and Evaluations } \\
\hline $1.1 \cdot 10^{-14} T \exp (-3150 / T)$ & $300-3000$ & Baulch, Drysdale, and Horne, $1973^{12}$ & (l) \\
\hline $1.5 \cdot 10^{-11} \exp (-3600 / T)$ & $200-300$ & NASA, $1990^{13}$ & (m) \\
\hline $1.5 \cdot 10^{-14} T \exp (-3270 / T)$ & $298-5000$ & Cohen, $1991^{14}$ & (n) \\
\hline $4.4 \cdot 10^{-12} \exp (-3220 / T)$ & $280-333$ & IUPAC, $1992^{15}$ & (o) \\
\hline
\end{tabular}

\section{Comments}

(a) $\mathrm{N}$ atoms produced in a discharge reacted with $\mathrm{O}_{2}$ in a low pressure stirred flow reactor. $k$ determined from the reduction in the steady-state concentration of $\mathrm{N}$ atoms detected by mass spectrometry upon addition of various amounts of $\mathrm{O}_{2}$.

(b) Oxygen-sensitized decay of NO observed in static reactor using UV spectrophotometric detection of $\mathrm{NO}_{2} . k$ calculated from the ratio $k\left(\mathrm{~N}+\mathrm{O}_{2}\right) / k(\mathrm{~N}+\mathrm{NO})=0.07$ measured at $1575 \mathrm{~K}$ and the $\mathrm{N}+\mathrm{NO}$ rate coefficient at this temperature recommended in this evaluation.

(c) Discharge flow study. $k$ derived directly from the first-order decay of $\mathrm{N}$ atoms in the presence of excess $\mathrm{O}_{2}$. [N] measured along the tube by end-point titration with NO.

(d) Discharge flow study. $k$ determined by measuring [O] and $[\mathrm{N}]$ at points along the tube. Total [O], including that produced by reaction was measured by titration with excess $\mathrm{NO}_{2}$ downstream of conversion of unreacted $\mathrm{N}$ atoms to $\mathrm{O}$ by end-point titration with NO. (e) Direct measurement of $k$ using discharge flow method with detection of $\mathrm{N}$ atoms by electron spin resonance under pseudo-first-order conditions with $\mathrm{O}_{2}$ in excess.

(f) Static system with nitrogen discharge at low total pressure $\left(10^{-4}-10^{-1}\right.$ Torr $)$ in a stainless steel vessel. $k$ determined from the decay of the intensity of the first positive bands of the $\mathrm{N}$-atom recombination afterglow emission in the presence of $\mathrm{O}_{2}$.

(g) Discharge flow study with $\left[\mathrm{O}_{2}\right] \gg[\mathrm{N}]$. $k$ determined by measuring $[\mathrm{N}]$ at points along tube by adding excess NO and measuring $\Delta[\mathrm{NO}]$ from change in photoionization current when discharge turned off.

(h) Direct measurement of $k$ using discharge flow method with $\left[\mathrm{O}_{2}\right] \gg[\mathrm{N}]$ and detection of $\mathrm{N}$ atoms by electron spin resonance.

(i) NO concentration profile measured by probe sampling and chemical analysis in the burned gas of an atmospheric pressure premixed propane-oxygen flame to which $\mathrm{N}_{2}$ had been added. Single value of $k$ at the mean flame temperature was obtained by fitting to a simple mecha- 
nism which was more sensitive to $k$ for $\mathrm{O}+\mathrm{N}_{2}$ reaction than for $\mathrm{N}+\mathrm{O}_{2} . k$ is misquoted in abstract of the original reference.

(j) Vibrational state distribution of NO product measured using saturated multi-photon ionization in a discharge flow system. The ratio $k / k(\mathrm{~N}+\mathrm{NO})$ obtained for $\mathrm{NO}$ in specific vibrational states from the slope of the variation of the steady-state $[\mathrm{NO}(\mathrm{v})]$ with $\left[\mathrm{O}_{2}\right]$. About $34 \%$ of the available exothermicity appears in vibrational levels up to $v=7$. Using the recommended $298 \mathrm{~K}$ value $^{13}$ of $k(\mathrm{~N}+$ $\mathrm{NO})=3.4 \cdot 10^{-11} \mathrm{~cm}^{3}$ molecule ${ }^{-1} \mathrm{~s}^{-1}$ gives the value of $k$ $=\Sigma k(\mathrm{v})$ quoted.

(k) Direct measurement of $k$ using discharge flow method with $\left[\mathrm{O}_{2}\right] \gg[\mathrm{N}]$. Decay of $[\mathrm{N}]$ along tube measured by monitoring intensity of the emission of the first positive band of $\mathrm{N}_{2}$ resulting from the recombination of $\mathrm{N}$ atoms.

(1) Evaluation of data measured up to 1971. Recommended expression gives best fit to high and low temperature data.

(m) Recommendation derived from least squares fit to the data of references $(1,5,6,7,8,10$ and 11$)$.

(n) Review of measurements of $k$ for forward and reverse reaction. Recommended expression derived by combining low temperature data of references $(3,4,6-8)$ with equilibrium constant and the value of $k$ for reverse reaction at high temperatures recommended by Hanson and Salimian ${ }^{17}$, and assuming pre-exponential temperature exponent $n=1.0$.

(o) Previous CODATA recommendation ${ }^{16}$, based on mean of $298 \mathrm{~K}$ data in references $(3,5-8)$ and activation energy of Becker et al. ${ }^{6}$, unchanged because of good agreement with recent studies of Winkler et al ${ }^{10}$, and Barnett et al. ${ }^{11}$.

\section{Preferred Value}

$k=1.5 \cdot 10^{-14} \mathrm{~T} \exp (-3270 / T) \mathrm{cm}^{3}$ molecule ${ }^{-1} \mathrm{~s}^{-1}$ over the range $298-5000 \mathrm{~K}$.

\section{Reliability}

$\Delta \log k= \pm 0.12$ over the range $298-1000 \mathrm{~K}$ rising to \pm 0.3 over the range $1000-5000 \mathrm{~K}$.

\section{Comments on Preferred Values}

The recommended expression of Cohen ${ }^{14}$ is adopted here, with the same uncertainty limits. This not only gives a good fit to the low temperature data, but also to the less well-determined high temperature measurements and is consistent with the rate of the reverse reaction.

\section{References}

${ }^{1}$ G.B. Kistiakowsky and G.G. Volpi, J. Chem. Phys. 27, 1141 (1957).

${ }^{2}$ F. Kaufman and L.J. Decker, 7th Symp. (Int.) Comb., 57 (1959).

${ }^{3}$ M.A.A. Clyne and B.A. Thrush, Proc. Royal Soc. A, 261, 259 (1961).

${ }^{4}$ A.S. Vlastaras and C.A. Winkler, Can, J. Chem. 45, 2837 (1967).

${ }^{5}$ W.E. Wilson, J. Chem. Phys. 46, 2017 (1967).

${ }^{6}$ K.H. Becker, W. Groth, and D. Kley, Z. Naturforsch. 24A, 1280 (1969).

${ }^{7}$ I.D. Clarke and R.P. Wayne, Proc. Royal Soc. A 316, 539 (1970).

${ }^{8}$ A.A. Westenberg, J.M. Roscoe, and N. de Haas, Chem. Phys. Lett. 7, 597 (1970).

${ }^{9}$ J.B. Livesey, A.L. Roberts, and A. Williams, Comb. Sci. Technol. 4, 9 (1971).

${ }^{10}$ I.C. Winkler, R.A. Stachnik, J.I. Steinfeld, and S.M. Miller, J. Chem. Phys. 85, 890 (1986)

${ }^{11}$ A.J. Barnett, G. Marston, and R.P. Wayne, J. Chem. Soc., Faraday Trans. 2 83, 1453 (1987).

${ }^{12}$ D.L. Baulch, D.D. Drysdale, and D.G. Horne, "Evaluated Kinetic Data for High Temperature Reactions", Vol. 2, Butterworths, London (1973).

${ }^{13} \mathrm{NASA}, 1990$ (see references in Introduction).

${ }^{14} \mathrm{~N}$. Cohen, The Aerospace Corporation, Aerospace Report No. ATR90(8512)-1, E1 Segundo, California (1991).

${ }^{15}$ IUPAC, 1992 (see references in Introduction).

${ }^{16}$ CODATA, 1980 (see references in Introduction).

${ }^{17}$ R.K. Hanson and S. Salimian, in "Combustion Chemistry", p361, ed. W.C. Gardiner, Springer-Verlag (1984). 


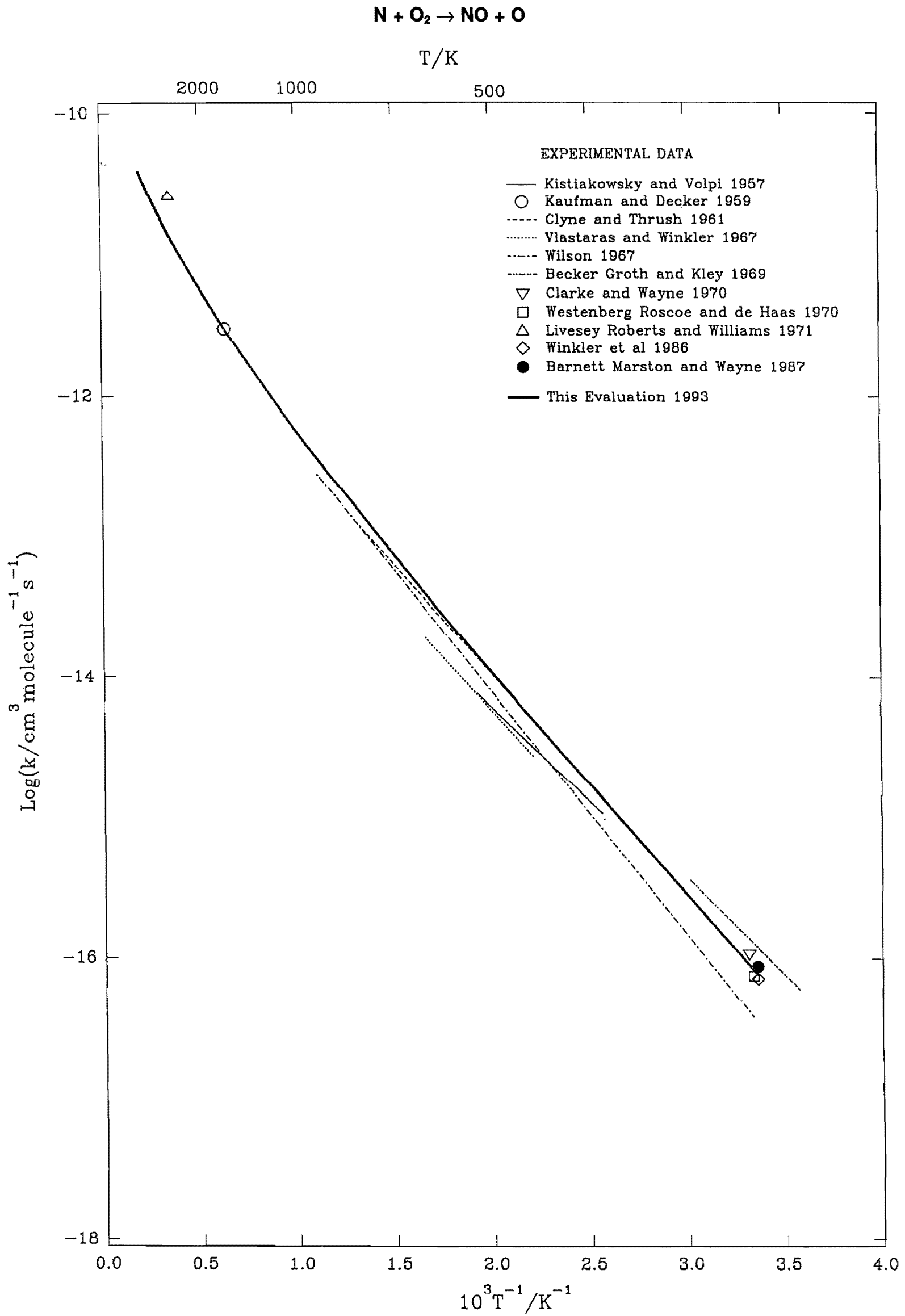


Thermodynamic Data

$\Delta H_{298}^{\circ}=-203.1 \mathrm{~kJ} \mathrm{~mol}^{-1}$

$\Delta S_{298}^{\circ}=-11.6 \mathrm{~J} \mathrm{~K}^{-1} \mathrm{~mol}^{-1}$

$K p=4.1 \cdot 10^{-2} T^{0.26} \exp (+24555 / T)$

Rate Coefficient Data

\begin{tabular}{|c|c|c|c|}
\hline$k / \mathrm{cm}^{3}$ molecule ${ }^{-1} \mathrm{~s}^{-1}$ & $T / \mathrm{K}$ & Reference & Comments \\
\hline \multicolumn{4}{|c|}{ Rate Coefficient Measurements } \\
\hline $4.2 \cdot 10^{-11}$ & 320 & Campbell and Thrush, $1968^{\prime}$ & (a) \\
\hline $7.1 \cdot 10^{-11} \exp (-790 / T)$ & $1950-2380$ & Haynes, $1977^{2}$ & (b) \\
\hline $5 \cdot 10^{-11}$ & 298 & Howard and Smith, $1980^{3}$ & (c) \\
\hline $2.21 \cdot 10^{-10} T^{-0.25}$ & $250-515$ & Howard and Smith, $1981^{4}$ & (c) \\
\hline $7.1 \cdot 10^{-11} \exp (-790 / T)$ & $1790-2200$ & Morley, $1981^{5}$ & (d) \\
\hline $4.2 \cdot 10^{-11}$ & 300 & Brune, Schwab and Anderson, $1983^{6}$ & (e) \\
\hline \multicolumn{4}{|l|}{ Reviews and Evaluations } \\
\hline $1.7 \cdot 10^{-10}$ & $300-2500$ & Bowman, $1975^{7}$ & (f) \\
\hline $6.3 \cdot 10^{-11}$ & $300-2500$ & Miller et al., $1984^{8}$ & (g) \\
\hline $3.8 \cdot 10^{11} \exp (+85 / T)$ & $250 \div 500$ & IUPAC, $1992^{\circ}$ & (h) \\
\hline
\end{tabular}

\section{Comments}

(a) The ratio $k / k(\mathrm{O}+\mathrm{OH})=1.4$ was determined by measuring the catalytic removal of $\mathrm{N}$ and $\mathrm{O}$ atoms followed photometrically when $\mathrm{NO}$ and $\mathrm{H}_{2}$ were added to a flow of $\mathrm{N}$ atoms produced in a discharge. Use of the recommended value ${ }^{10}$ for $k(\mathrm{O}+\mathrm{OH})=3.0 \cdot 10^{-11} \mathrm{~cm}^{3}$ molecule ${ }^{-1} \mathrm{~s}^{-1}$ leads to the value of $k$ quoted.

(b) Concentration profiles of $\mathrm{HCN}, \mathrm{NO}$ and total $\mathrm{NH}_{i}$ species $(i=0-3)$ measured in the burned gases of premixed, fuel-rich ethylene- and acetylene- air flames seeded with $\mathrm{NH}_{3}$, pyridine or $\mathrm{NO}$, using a probe sampling method. $\mathrm{N}+\mathrm{OH}$ and $\mathrm{N}+\mathrm{NO}$ identified as the NO forming and removing reactions. The ratio $k(\mathrm{~N}+\mathrm{OH}) / k(\mathrm{~N}+\mathrm{NO})=$ 1.0 , independent of temperature was determined from analysis of the NO profiles, assuming reactions of the $\mathrm{NH}_{i}$ species to be internally equilibrated. Use of the recommended value for $k(\mathrm{~N}+\mathrm{NO})$ from this evaluation gives the value of $k$ quoted.

(c) Discharge flow system used to generate steady-state concentration of $\mathrm{N}$ atoms; $\mathrm{OH}$ radicals formed by flash photolysis of $\mathrm{H}_{2} \mathrm{O}$ and their decay monitored by resonance fluorescence under pseudo-first-order conditions with $[\mathrm{N}]$ $\gg[\mathrm{OH}]$. [N] determined by end-point titration with NO.

(d) The ratio $k(\mathrm{~N}+\mathrm{OH}) / k(\mathrm{~N}+\mathrm{NO})=1$ estimated from profiles of NO detected by laser-induced fluorescence in $\mathrm{H}_{2}$ flames seeded with nitrogen compounds. Use of the recommended valuc for $k(\mathrm{~N}+\mathrm{NO})$ from this evaluation gives the value of $k$ quoted.

(e) Direct measurement of $k$ using discharge flow method with $[\mathrm{N}] \gg[\mathrm{OH}]$. OH generated in a movable injector by $F+\mathrm{H}_{2} \mathrm{O}$ reaction, with $F$ produced in a $\mathrm{CF}_{4}$ discharge, and detected by resonance fluorescence or laser magnetic resonance; $[\mathrm{N}]$ determined by converting to $\mathrm{O}$ atoms with excess $\mathrm{NO}$ and measuring calibrated $\mathrm{O}$-atom resonance absorption signal.

(f) Rate coefficient derived by combining the low temperature measurement of Campbell and Thrush ${ }^{1}$ with the equi- librium constant and high temperature measurements of $k$ for the reverse reaction ${ }^{11-13}$.

(g) Value of $k$ derived for modelling NO formation in combustion systems by combining low temperature measurements of Howard and Smith ${ }^{4}$ with shock tube measurements of the reverse rate of Flower et al.$^{14}$. The authors point out that extrapolation of the expression of Howard and Smith to high temperatures produced values of $k$ much lower than calculated from the reverse rate data.

(h) Recommendation unchanged from earlier CODATA evaluation ${ }^{15}$ which was based on the data of Howard and Smith ${ }^{3.4}$.

\section{Preferred Value}

$k=4.7 \cdot 10^{-11} \mathrm{~cm}^{3}$ molecule ${ }^{-1} \mathrm{~s}^{-1}$ over the range $300-$ $2500 \mathrm{~K}$.

Reliability

$\Delta \log k= \pm 0.1$ at $300 \mathrm{~K}$ rising to \pm 0.3 at $2500 \mathrm{~K}$.

\section{Comments on Preferred Values}

The only direct measurements of $k$ are at low temperature $(250-500 \mathrm{~K})$. The data are in good agreement, but are sufficiently scattered to make it impossible to discern any temperature dependence of $k$. The preferred value is the mean of all the low temperature measurements ${ }^{1,34,6}$ and falls within the range of values of $k$ calculated from the ratio $k / k(\mathrm{~N}+\mathrm{NO})$ reported in the two flame studics ${ }^{2.5}$. The inconsistency between the measured values of $k$ and the higher value calculated from the equilibrium constant and data for the reverse reaction still needs to be resolved.

\section{References}

II.M. Campbell and B.A. Thrush, Trans. Faraday Soc. 64, 1265 (1968).

${ }^{2}$ B.S. Haynes, Combust. Flame 28, 81 (1977).

${ }^{3}$ M.J. Howard and I.W.M. Smith, Chem. Phys. Lett. 69, 40 (1980).

${ }^{4}$ M.J. Howard and I.W.M. Smith, J. Chem. Soc., Faraday Trans. 2 77, 997 (1981). 
${ }^{3}$ C. Morley, 18th Symp. (Int.) Comb. 23 (1981).

${ }^{6}$ W.H. Brune, J.J. Schwab, and J.G. Anderson, J. Phys. Chem. 87, 4503

(1983).

${ }^{7}$ C.T. Bowman, Prog. Energy Comb. Sci. 1, 33 (1975).

${ }^{8}$ J.A. Miller, M.C. Branch, W.J. McLean, D.W. Chandler, M.D. Smooke, and R.J. Kee, 20th Symp. (Int.) Comb,, 673 (1984).

"IUPAC, 1992 (see references in Introduction).

${ }^{10} \mathrm{CEC}, 1992$ (see references in Introduction).
${ }^{11}$ W.L. Flower, R.K. Hanson, and C.H. Kruger, 15th Symp. (Int.) Comb., 823 (1975).

${ }^{12}$ J. Duxbury and N.H. Pratt, 15th Symp. (Int.) Comb., 843 (1975).

${ }^{13}$ J.N. Bradley and P. Craggs, 15th Symp. (Int.) Comb., 833 (1975).

${ }^{14}$ W.L. Flower, R.K. Hanson, and C.H. Kruger, Comb. Sci. Tech. 15, 115 (1977).

${ }^{15}$ CODATA, 1982 (see references in Introduction).

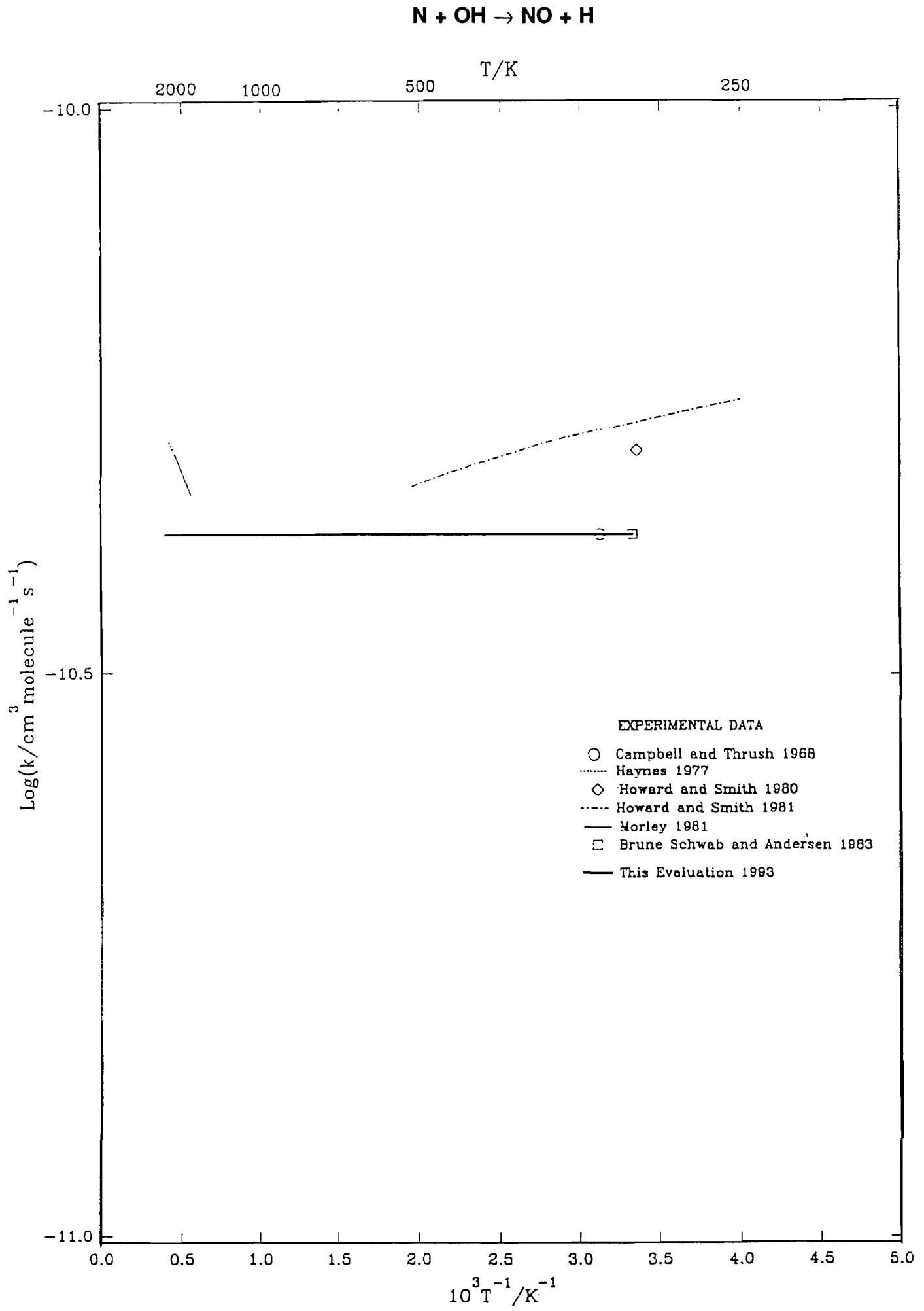


Thermodynamic Data

$\Delta H_{298}^{\circ}=-313.5 \mathrm{~kJ} \mathrm{~mol}^{-1}$

$\Delta S_{298}^{\circ}=-11.3 \mathrm{~J} \mathrm{~K}^{-1} \mathrm{~mol}^{-1}$

$K p=0.51 T^{0.10} \exp (+37690 / T)$

Rate Coefficient Data

\begin{tabular}{|c|c|c|c|}
\hline$k / \mathrm{cm}^{3}$ molecule $^{-1} \mathrm{~s}^{-1}$ & $T / \mathrm{K}$ & Reference & Comments \\
\hline \multicolumn{4}{|l|}{ Rate Coefficient Measurements } \\
\hline $5.4 \cdot 10^{-14} T \exp (230 / T)$ & $476-755$ & Clyne and Thrush, $1961^{1}$ & (a) \\
\hline $1.7 \cdot 10^{-11}$ & 300 & Herron, $1961^{2}$ & (b) \\
\hline $2.2 \cdot 10^{-11}$ & 298 & Phillips and Schiff, $1962^{3}$ & (c) \\
\hline $1.8 \cdot 10^{-11}$ & $\sim 350$ & Takezaki and Mori, $1967^{4}$ & (d) \\
\hline $3 \cdot 10^{-11}$ & 298 & Lin, Parkes, and Kaufman, $1970^{5}$ & (e) \\
\hline $8.2 \cdot 10^{-11} \exp (-410 / T)$ & $298-670$ & Clyne and McDermid, $1975^{6}$ & (f) \\
\hline $3.4 \cdot 10^{-11}$ & $196-400$ & Lee, et al., $1978^{7}$ & (g) \\
\hline $4.5 \cdot 10^{-11}$ & 300 & Husain and Slater, $1980^{8}$ & (h) \\
\hline $3.4 \cdot 10^{-11}$ & 298 & Cheah and Clyne, $1980^{\circ}$ & (i) \\
\hline $1.9 \cdot 10^{-11}$ & 298 & Sugawara, Ishikawa, and Sato, $1980^{10}$ & (j) \\
\hline $2.2 \cdot 10^{-11}$ & $1600-2300$ & Koshi, et al., $1990^{11}$ & (k) \\
\hline $7.12 \cdot 10^{-11} \exp (-787 / T)$ & $1400-3500$ & Davidson and Hanson, $1990^{12}$ & (1) \\
\hline $2.4 \cdot 10^{-11}$ & 298 & Jeoung, Choo, and Benson, $1991^{13}$ & (m) \\
\hline \multicolumn{4}{|l|}{ Reviews and Evaluations } \\
\hline $2.7 \cdot 10^{-11}$ & $300-5000$ & Baulch, Drysdale, and Horne, $1973^{14}$ & (n) \\
\hline $5.4 \cdot 10^{-12} T^{0.3}$ & $300-4000$ & Miller, et al., $1984^{15}$ & (o) \\
\hline $3.1 \cdot 10^{-11}$ & $200-400$ & IUPAC, $1992^{16}$ & (p) \\
\hline $3.4 \cdot 10^{-11}$ & $200-300$ & NASA, $1990^{17}$ & (q) \\
\hline $3.2 \cdot 10^{-11}+1.3 \cdot 10^{-14} T \exp (230 / T)$ & $200-4100$ & Cohen, $1991^{18}$ & (r) \\
\hline
\end{tabular}

\section{Comments}

(a) Discharge flow study. Large excess of $\mathrm{O}_{2}$ added to flow of $\mathrm{N}$ atoms produced residual [NO] in the effluent gas determined by $\mathrm{NO}+\mathrm{O}$ afterglow intensity. Variation of residual $[\mathrm{NO}]$ with $\left[\mathrm{O}_{2}\right]$ gave the ratio $k\left(\mathrm{~N}+\mathrm{O}_{2}\right) / k(\mathrm{~N}+$ $\mathrm{NO})=0.28 \exp (-3500 / T)$. Use of the preferred value for $k\left(\mathrm{~N}+\mathrm{O}_{2}\right)$ from this evaluation gives the value of $k$ quoted.

(b) Discharge flow study with mass spectrometric detection of $\mathrm{N}$, and isotopically labelled $\mathrm{NO}$ and $\mathrm{N}_{2} . k$ determined from analysis of concentration-time profiles.

(c) Discharge flow study, with mass spectrometric detection of NO. $k$ determined from consumption of NO when added to flow of $\mathrm{N}$ atoms.

(d) Pulsed $N_{2}$ discharge flow study with time-of-flight mass spectrometric detection of $\mathrm{N}$ and NO.

(e) Discharge flow study. $\mathrm{N}$ atoms detected by atomic resonance absorption spectroscopy calibrated by chemical titration with NO. Variation of measured absorption with [NO] at fixed reaction time gave $k$.

(f) Direct measurement of $k$ using the discharge flow method with detection of $\mathrm{N}$ atoms by mass spectrometry under pseudo-first-order conditions, $[\mathrm{NO}] \gg[\mathrm{N}]$.

(g) Direct determination of $k$ using two different techniques, both under pseudo-first-order conditions with [NO] $\gg$ [N] and detection of $\mathrm{N}$ atoms by atomic resonance fluorescence. A discharge flow study $(p=1-2$ Torr $\mathrm{He})$ gave $k=2.7 \cdot 10^{-11} \mathrm{~cm}^{3}$ molecule ${ }^{-1} \mathrm{~s}^{-1}$; a flash photolysis study $\left(p=20-700\right.$ Torr $\mathrm{N}_{2}$ ) gave $k=4.0 \cdot 10^{-11} \mathrm{~cm}^{3}$ molecule ${ }^{-1}$ $\mathrm{s}^{-1}$. No temperature or pressure dependence of $k$ could be claimed with certainty because of scatter in the data nor could any other cause of the discrepancy be identified, so the mean value of the two determinations was reported with $25 \%$ error limits.

(h) Direct measurement of $k$ by VUV flash photolysis of $\mathrm{N}_{2} \mathrm{O}$ in the presence of $\mathrm{N}_{2}$ and $\mathrm{NO}$ and time-resolved atomic resonance fluorescence detection of $\mathrm{N}$ atoms, with [NO] $\gg[\mathrm{N}]$.

(i) Direct measurement of $k$ using discharge-flow method with atomic resonance fluorescence detection of $\mathrm{N}$ atoms in excess NO.

(j) Direct measurement of $k$ by pulsed radiolysis of $\mathrm{N}_{2}$ to generate $\mathrm{N}$ atoms in the presence of excess NO. Pseudofirst-order decay of [N] followed by time-resolved atomic resonance absorption.

(k) Direct measurement of $k$ using shock tube technique. $\mathrm{N}$ atoms generated behind reflected shock waves by $193 \mathrm{~nm}$ laser photolysis of NO and first-order decay of [N] followed by atomic resonance absorption spectroscopy. No temperature dependence of $k$ was observed.

(1) Direct measurement of $k$ using shock tube technique. $\mathrm{N}$ atoms generated by $193 \mathrm{~nm}$ laser photolysis of shock heated NO in Ar and [N] decay followed under first-order conditions by atomic resonance absorption spectroscopy. Uncertainty in $k$ estimated to be $\pm 20 \%$ at $1400 \mathrm{~K}$ to $\pm 10 \%$ at $3500 \mathrm{~K}$.

(m) $\mathrm{N}$ atoms produced by a microwave discharge, reacted with NO in a very low pressure reactor and detected by mass spectrometry. $k$ derived from the variation of the 
steady-state concentration of $\mathrm{N}$ with the steady-state concentration of NO in the reactor.

(n) Evaluation of data measured before 1973. Temperature independent value of $k$ recommended based on the mean of the measurements of Phillips and Schiff ${ }^{3}$ and Lin et al. 5 .

(o) Expression derived for the purpose of modelling $\mathrm{NO}_{\mathrm{x}}$ chemistry in combustion to obtain consistency between the rate coefficients for the reaction in the forward and reverse directions and the equilibrium constant. The low temperature recommendation of Baulch et al..$^{14}$ for the forward reaction was combined with the values calculated from the high temperature measurements of the reverse reaction by Monat et $a l^{19}$ and the equilibrium constant to derive $k$.

(p) Recommendation unchanged from earlier CODATA ${ }^{20}$ evaluation which was based on the mean of the measurements reported in Refs. 6-10. Uncertainty estimated as $\Delta \log k= \pm 0.15$ at $298 \mathrm{~K}$.

(q) Recommendation based on low temperature results of Lee et al.?

(r) Recommended expression for $k$ is a fit to the combined data sets of Refs. 6, 7, 8 and 12 for the reaction in the forward direction and Monat et al. ${ }^{19}$ and Thielen and Roth $^{21}$ for the reverse reaction.

\section{Preferred Value}

$k=7.1 \cdot 10^{-11} \exp (-790 / T) \mathrm{cm}^{3}$ molecule ${ }^{-1} \mathrm{~s}^{-1}$ over the range $1400-4000 \mathrm{~K}$.

\section{Reliability}

$\Delta \log k= \pm 0.2$ over the range $1400-4000 \mathrm{~K}$.

\section{Comments on Preferred Values}

There is quite considerable scatter in the measurements of $k$ even at room temperature, where there are numerous measurements, and uncertainty as to whether or not $k$ is temperature dependent. The only two high temperature studies, which used very similar shock tube methods, have also yielded conflicting results. The data of Koshi et al ${ }^{11}$ suggest that the rate constant is temperature independent. The very detailed study of Davidson and Hanson ${ }^{12}$ over a large temperature range suggest a small positive temperature dependence in agreement with the low temperature data of Clyne and McDermid ${ }^{6}$. Extrapolation of the Arrhenius expression of Davidson and Hanson $^{12}$ cannot accommodate the low temperature data. However, the data of Davidson and Hanson are entirely consistent with the equilibrium constant and the recommended rate of the reverse reaction which is based on measurements made in the same laboratory over the same temperature range. The data of Davidson and Hanson ${ }^{12}$ are considered to be the most reliable at high temperatures and their expression is taken for the preferred value of $k$ over the stated temperature range. More data are required at intermediate temperatures to establish the temperature dependence of $k$ down to $300 \mathrm{~K}$.

\section{References}

'M.A.A. Clyne and B.A. Thrush, Proc. Roy. Soc. A 261, 259 (1961),

${ }^{2}$ J.T. Herron, J. Chem, Phys. 35, 1138 (1961).

${ }^{3}$ L.F. Phillips and H.I. Schiff, J. Chem. Phys. 36, 150 (1262).

${ }^{4} Y$. Takezaki and S. Mori, Bull. Inst. Chem. Res. Kyoto 45, 388 (1967).

${ }^{5}$ C. - L. Lin, D.A. Parkes, and F. Kaufman, J. Chem. Phys. 53, 3896 (1970).

${ }^{6}$ M.A.A. Clyne and I.S. McDermid, J. Chem. Soc., Faraday Trans. 1 71, 2189 (1075).

${ }^{7}$ J.H. Lee, J.V. Michael, W.A. Payne, and L.J. Stief, J. Chem. Phys. 69, 3069 (1978).

${ }^{8}$ D. Husain and N.K.H. Slater, J. Chem. Soc., Faraday Trans. 2 76, 606 (1980).

${ }^{9}$ C.T. Cheah and M.A.A. Clyne, J. Chem. Soc., Faraday Trans. 2 76, 1543 (1980).

${ }^{10}$ K. Sugawara, Y. Ishikawa, and S. Sato, Bull. Chem. Soc. Jpn. 53, 3159 (1980).

${ }^{11}$ M. Koshi, M. Yoshimura, K. Fukuda, M. Matsui, K. Saito, M. Watanabe, A. Imamura, and C. Chen, J. Chem. Phys. 93, 8703 (1990).

${ }^{12}$ D.F. Davidson and R.K. Hanson, Int. J. Chem. Kin. 22, 843 (1990).

${ }^{13}$ S.C. Jeoung, K.Y. Choo, and S.W. Benson, J. Phys. Chem. 95,7282 (1991).

${ }^{14}$ D.L. Baulch, D.D. Drysdale, and D.G. Horne, "Evaluated Kinetic Data for High Temperature Reactions", Vol. 2, Butterworths, London (1973).

${ }^{15}$ J.A. Miller, M.C. Branch, W.J. McLean, D.W. Chandler, M.D. Smooke, and R.J. Kee, 20th Symp. (Int.) Comb. 673 (1984).

${ }^{16}$ IUPAC, 1992 (see references in Introduction).

${ }^{17}$ NASA, 1990 (see references in Introduction).

${ }^{18} \mathrm{~N}$. Cohen, The Aerospace Corporation, Aerospace Report No. ATR90(8512)-1, E1 Segundo, Califurnia (1991).

${ }^{19}$ J.P. Monat, R.K. Hanson, and C.H. Knuger, 17th Symp. (Int.) Comb. 543 (1979).

${ }^{20} \mathrm{CODATA}, 1982$ (see references in Introduction),

${ }^{21} \mathrm{~K}$. Thielen and P. Roth, 20th Symp. (Int,) Comb. 685 (1984). 


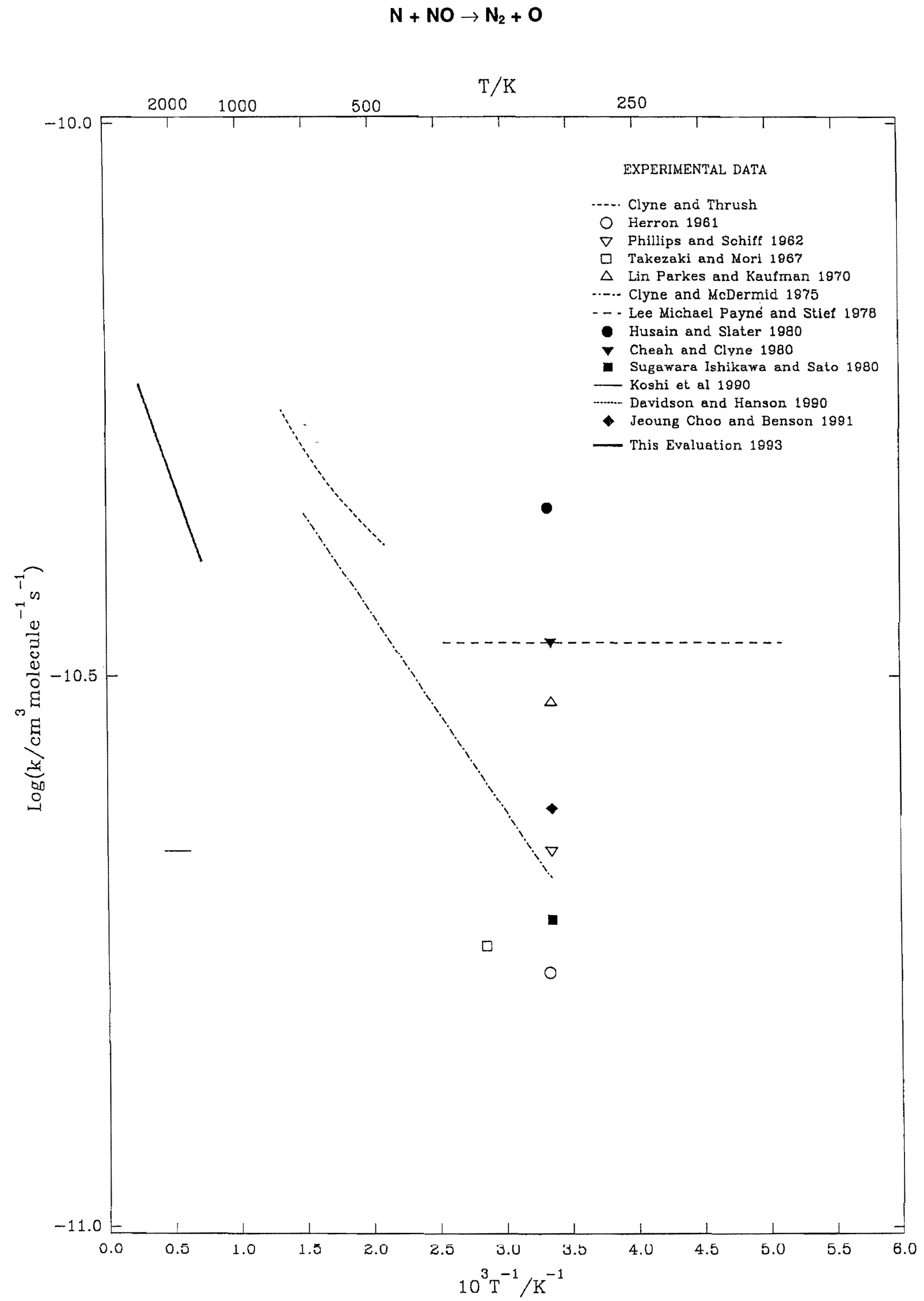




$$
\begin{aligned}
\mathrm{NH}+\mathrm{O}_{2} & \rightarrow \mathrm{NO}+\mathrm{OH} \\
& \rightarrow \mathrm{NO}+\mathrm{H} \\
& \rightarrow \mathrm{HNO}+\mathrm{O}
\end{aligned}
$$

Thermodynamic Data (See Comments on Preferred Values)

$\Delta H_{298}^{\circ}(1)=-227 \mathrm{~kJ} \mathrm{~mol}^{-1}$

$\Delta S_{298}^{\circ}(1)=8.05 \mathrm{~J} \mathrm{~K}^{-1} \mathrm{~mol}^{-1}$
$K p(1)=8.27 T^{-0.15} \exp (+27200 / T)$

$\Delta H_{298}^{\circ}(2)=-105 \mathrm{~kJ} \mathrm{~mol}^{-1}$

$\Delta H_{298}^{\circ}(3)=-7.73 \mathrm{~kJ} \mathrm{~mol}^{-1}$

$\Delta S_{298(3)}^{\circ}=-4.65 \mathrm{~J} \mathrm{~K}^{-1} \mathrm{~mol}^{-1}$

\begin{tabular}{|c|c|c|c|}
\hline$k / \mathrm{cm}^{3}$ molecule $^{-1} \mathrm{~s}^{-1}$ & $T / \mathbf{K}$ & Reference & Comments \\
\hline \multicolumn{4}{|l|}{ Rate Coefficient Measurements } \\
\hline $8.5 \cdot 10^{-15}$ & 296 & Zetzsch and Hansen, $1978^{1}$ & (a) \\
\hline$<3.32 \cdot 10^{-14}$ & 300 & Pagsberg et al., $1979^{2}$ & (b) \\
\hline $1.26 \cdot 10^{-13} \operatorname{cxp}(-770 / T)$ & $268-543$ & Hack, Kurzke, and Wagner, $1985^{3}$ & (c) \\
\hline$k_{1}=7.47 \cdot 10^{-11} \exp (-5000 / T)$ & $1523-2254-$ & Bain et al., $1986^{4}$ & (d) \\
\hline $5.81 \cdot 10^{-11} \exp (-8600 / T)$ & $2200-3270$ & Mertens et al., $1991^{5}$ & (e) \\
\hline \multicolumn{4}{|l|}{ Reviews and Evaluations } \\
\hline & & Hanson and Salimian, $1984^{\circ}$ & (f) \\
\hline $1.26 \cdot 10^{-13} \exp (-770 / T)$ & $270-550$ & CEC, $1992^{8}$ & (g) \\
\hline
\end{tabular}

$K p(3)-9.64 \cdot 10^{-2} T^{0.24} \exp (+1060 / T)$

\section{Rate Coefficient Data $\left(k=k_{1}+k_{2}+k_{3}\right)$}

\section{Comments}

(a) Flash photolysis study. NH generated by photolysis of $\mathrm{NH}_{3} / \mathrm{O}_{2} / \mathrm{He}$ mixtures. [NH] monitored by resonance fluorescence. No effect of changes in total pressure observed.

(b) Pulsed radiolysis of $\mathrm{NH}_{3} / \mathrm{O}_{2}$ mixtures. $[\mathrm{NH}]$ monitored by absorption spectroscopy. Decay of $[\mathrm{NH}]$ fitted by computer modelling of 23 reaction mechanism.

(c) Discharge flow system. $\mathrm{NH}$ produced by the sequence $\mathrm{F}+\mathrm{NH}_{3} \rightarrow \mathrm{NH}_{2}+\mathrm{HF} ; \mathrm{NH}_{2}+\mathrm{F} \rightarrow \mathrm{NH}+\mathrm{HF}$. [O] and [H] monitored by resonance fluorescence and $[\mathrm{NH}]$ and $[\mathrm{OH}]$ by laser induced fluorescence. Reaction $\mathrm{NH}+\mathrm{O}_{2}\left({ }^{1} \Delta g\right) \rightarrow$ products, also studied; $k \leqslant(1 \pm 2) \cdot 10^{-15} \mathrm{~cm}^{3}$ molecule ${ }^{-1}$ $\mathrm{s}^{-1}$ obtained.

(d) Ammonia-oxygen flame study with molecular beam sampling coupled to a mass spectrometer. Results fitted to a complex mechanism, for NO formation, involving numerous assumptions.

(e) Shock tube study. NH produced by the thermal dissociation of HNCO. Time histories of $\mathrm{NH}\left(X^{3} \Sigma\right)$ and $\mathrm{OH}\left(\mathrm{X}^{2} \Pi\right)$ measure behind the shock waves by $\mathrm{cw}$ laser absorption at $336 \mathrm{~nm}$ and $307 \mathrm{~nm}$, respectively. Results fitted to a large reaction mechanism.

(f) Review of all data to 1984; no expression recommended.

(g) Review of all data to 1991; recommendation based on study of Hack et al. ${ }^{3}$.

\section{Preferred Values}

$\left(k_{1}+k_{2}\right)=1.3 \cdot 10^{-13} \exp (-770 / T) \mathrm{cm}^{3}$ molecule $\mathrm{s}^{-1} \mathrm{~s}^{-1}$ over range $270-550 \mathrm{~K}$.

$k_{3}=6.5 \cdot 10^{-11} \exp (-9000 / T) \mathrm{cm}^{3}$ molecule $\mathrm{s}^{-1}$ over range $2200-3500 \mathrm{~K}$.

\section{Reliability $\Delta \log \left(k_{1}+k_{2}\right)= \pm 0.25$ over range $270-550 \mathrm{~K}$. $\Delta \log k_{3}= \pm 0.5$ over range $2200-3500 \mathrm{~K}$.}

\section{Comments on Preferred Values}

There are two sets of measurements at high temperatures which differ considerably in their values of $k$. The more direct study of Mertens et al..$^{4}$ is preferred but we assign substantial error limits.

At low temperatures the values of Zetzsch and Hansen ${ }^{1}$ and Hack et $a l .^{3}$ are in good agreement. These are the basis of our previous recommendations. It was recognized in our previous evaluation that there could be an appreciable increase in $E / R$ at higher temperatures because of changes in the relative importance of the different reaction channels. The results of Mertens et al. ${ }^{4}$ are in agreement with this expectation.

The measurements of Hack et al. ${ }^{3}$ indicate that reaction (1) is the predominant channel at low temperatures but at high temperatures the calculations of Melius and Binkley ${ }^{7}$ suggest that channel (3) will be more important than (1) and (2). By extrapolating the expression of Hack et al..$^{3}$ for $k\left(=k_{1}+k_{2}\right)$ at low temperatures and substracting from the measured high temperature values of $k$, Mertens et al.$^{4}$ derived the expression $k_{3}=6.5 \cdot 10^{-11} \exp (-9000 / T) \mathrm{cm}^{3}$ molecule ${ }^{-1} \mathrm{~s}^{-1}$, which is recommended for the range $2200-3500 \mathrm{~K}$. A recent theoretical study by Miller and Melius ${ }^{9}$ suggests that channel (3) may be predominant down to $1500 \mathrm{~K}$.

Measurements in the range $300-2000 \mathrm{~K}$ are needed to characterize the curvature in the Arrhenius plot.

The thermodynamic data should be used with caution. There are significant uncertainties associated with the data on NH. 


\section{References}

${ }^{1}$ C. Zetzsch and I. Hansen, Ber. Bunsenges. Phys. Chem. 82, 830 (1978). ${ }^{2}$ P.B. Pagsberg, J. Eriksen, and H. Christensen, J. Phys. Chem. 83, 582 (1979).

${ }^{3}$ W. Hack, H. Kurzke, and H.Gg. Wagner, J. Chem. Soc., Faraday Trans. 2 81, 949 (1985).

${ }^{4} \mathrm{~J}$. Bain, J. Vandooren, and P.J. Van Tïggelen, 21st Symp. (Int.) Combust. 953 (1986).
SJ.D. Mertens, A.Y. Chang, R.K. Hanson, and C.T. Bowman, Int. J. Chem. Kinet. 23, 173 (1991).

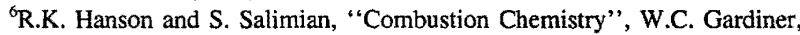
Ed., Springer-Verlag, New York (1984).

'C.F. Melius and J.S. Binkley, in "The Chemistry of Combustion Processes", T.M. Sloane, Ed., A.C.S. Symp. Series 249, 103 (1984).

${ }^{8} \mathrm{CEC}, 1992$ (see references in Introduction).

${ }^{9}$ J.A. Miller and C.F. Melius, 24th Symp. (Int.) Combust., 719 (1992).

$$
\begin{aligned}
\mathrm{NH}+\mathrm{NO} & \rightarrow \mathrm{H}+\mathrm{N}_{2} \mathrm{O} \text { (1) } \\
& \rightarrow \mathrm{HN}_{2}+\mathrm{O} \\
& \rightarrow \mathrm{N}_{2}+\mathrm{OH}
\end{aligned}
$$

Thermodynamic Data (See Comments on Preferred Values)

$\Delta H_{298}^{\circ}(1)=-147 \mathrm{kJmol}^{-1}$

$\Delta S_{298}^{\circ}(1)=-57.3 \mathrm{~J} \mathrm{~K}^{-1} \mathrm{~mol}^{-1}$

$K p(1)=4.64 \cdot 10^{-7} T^{1.10} \exp (+18100 / T)$

$\Delta H_{298}^{\circ}(2)=47.5 \mathrm{~kJ} \mathrm{~mol}^{-1}$

$\Delta S_{298}^{\circ}(2)=-6.48 \mathrm{~J} \mathrm{~K}^{-1} \mathrm{~mol}^{-1}$

$\Delta H_{298}^{\circ}(3)=-408 \mathrm{~kJ} \mathrm{~mol}^{-1}$

$\Delta S_{298}^{\circ}(3)=-16.7 \mathrm{~J} \mathrm{~K}^{-1} \mathrm{~mol}^{-1}$

$K p(3)=0.484 T^{0.18} \exp (+49000 / T)$

\begin{tabular}{|c|c|c|c|}
\hline$k / \mathrm{cm}^{3}$ molecule $\mathrm{e}^{-1} \mathrm{~s}^{-1}$ & $T / \mathrm{K}$ & Reference & Comments \\
\hline \multicolumn{4}{|c|}{ Rate Coefficient Measurements } \\
\hline $4.8 \cdot 10^{-11}$ & 300 & Cox, Neison, and McDonald, $1985^{1}$ & (a) \\
\hline $5.78 \cdot 10^{-11}$ & $269-373$ & Harrison, Whyte, and Phillips, $1986^{2}$ & (b) \\
\hline $2.8 \cdot 10^{-10} \exp (-6400 / T)$ & $2220-3350$ & Mertens et al., $1991^{3}$ & (c) \\
\hline$k_{1}=3.3 \cdot 10^{-12}$ & 2000 & Vandooren et al., $1991^{4}$ & (d) \\
\hline \multicolumn{4}{|l|}{$k_{3}=2.0 \cdot 10^{-11}$} \\
\hline \multicolumn{4}{|l|}{$k_{3}=1.4 \cdot 10^{-11}$} \\
\hline \multicolumn{4}{|l|}{ Reviews and Evaluations } \\
\hline- & - & Hanson and Salimian, $1984^{5}$ & (e) \\
\hline $5.0 \cdot 10^{-11}$ & $269-373$ & $\mathrm{CEC}, 1992^{6}$ & (f) \\
\hline
\end{tabular}

Rate Coefticient Data $\left(k=k_{1}+k_{2}+k_{3}\right)$

\section{Comments}

(a) Pulsed laser photolysis of $\mathrm{N}_{2} \mathrm{H}_{4} / \mathrm{He} / \mathrm{NO}$ mixtures at 266 $\mathrm{nm}$ in flowing system. $[\mathrm{NH}]$ decay monitored by laser induced fluorescence at $304.85 \mathrm{~nm}$.

(b) Pulsed laser photolysis of $\mathrm{N}_{2} \mathrm{H}_{4} / \mathrm{Ar} / \mathrm{NO}$ mixtures at 248 $\mathrm{nm}$ in flowing system. [NH] decay monitored by laser induced fluorescence at $336 \mathrm{~nm}$. $\mathrm{He}, \mathrm{N}_{2}$ and $\mathrm{N}_{2} \mathrm{O}$ also used as carrier gases give same result.

(c) Shock tube study. NH produced by the thermal dissociation of HNCO. Time histories of $\mathrm{NH}\left(\mathrm{X}^{3} \Sigma\right)$ and $\mathrm{OH}$ $\left(\mathrm{X}^{2} \Pi\right)$ measured behind the shock waves by cw laser absorption at $336 \mathrm{~nm}$ and $307 \mathrm{~nm}$, respectively. Results fitted to a large reaction mechanism.

(d) Ammonia oxygen flame study, with fitting to a complex mechanism. Two values of $k_{3}$ given corresponding to different values for the rate constant of the $\mathrm{NH}_{2}+\mathrm{NO}$ reaction to which the measurements are sensitive at 2000 $\mathrm{K}$. Our evaluation of the $\mathrm{NH}_{2}+\mathrm{NO}$ rate data favours the value of $k_{3}(\mathrm{NH}+\mathrm{NO})=2.0 \cdot 10^{-11} \mathrm{~cm}^{3}$ molecule ${ }^{-1} \mathrm{~s}^{-1}$.

(e) Review of data to 1985 ; no recommendation.

(f) Recommendations made for low temperatures only; see Comments on Preferred Values.

\section{Preferred Values}

$k=5.0 \cdot 10^{11} \mathrm{~cm}^{2}$ molecule ${ }^{1} \mathrm{~s}^{-1}$ over the range 270 $380 \mathrm{~K}$.

$k=2.8 \cdot 10^{-10} \exp (-6400 / T) \mathrm{cm}^{3}$ molecule $\mathrm{e}^{-1} \mathrm{~s}^{-1}$ over range $2220-3350 \mathrm{~K}$.

\section{Reliability}

$\Delta \log k= \pm 0.2$ over the range $270-380 \mathrm{~K}$.

$\Delta \log k= \pm 0.5$ over the range $2220-3350 \mathrm{~K}$.

\section{Comments on Preferred Values}

The recent study of Mertens et al..$^{3}$ is the first direct measurement of $k$ at high temperatures. The previous work of $\mathrm{Nip}^{7}$, Roose et al. ${ }^{8}$, Peterson ${ }^{9}$ and Morley ${ }^{10}$ all involved indirect techniques and gave scattered values much lower than those of Mertens et al..$^{3}$ which are preferred in this high temperature regime. The single value of Vandooren et al.$^{4}$ at $2000 \mathrm{~K}$ is in agreement with the results of Mertens et al. ${ }^{3}$.

At low temperatures there is excellent agreement between all of the available studies ${ }^{1,2,11,12}$, our preferred value is based on all of them and is unchanged from our previous evaluation ${ }^{6}$. In the only temperature dependent study ${ }^{2}$ at low temper- 
atures no variation of $k$ with temperature could be detected over the range 269-373 K. However, the high temperature results give values of $k$ equal to or slightly less than the values found at ambient temperatures. A value of $E / R$ of $-520 \mathrm{~K}$ is required for the low temperature values to extrapolate to the values obtained by Mertens et al. ${ }^{3}$ at high temperatures.

By monitoring, $\mathrm{OH}$ production, Mertens et al. ${ }^{3}$ were also able to show that over the range $2940-3040 \mathrm{~K}$ channel (3) contributes to the extent of $(0.19 \pm 0.10)$ of the total $k$. This is in accord with calculations made by Miller and Melius ${ }^{13}$ which suggest that channel (1) is likely to predominate up to $3500 \mathrm{~K}$, and at high temperatures there is a contribution from both channels (2) and (3). It is suggested that the contribution from channel (3), explains the small positive temperature coefficient found by Mertens et al. ${ }^{3}$.

More work is required, particularly in the $300-2000 \mathrm{~K}$ temperature range to establish the temperature dependence. Provisionally, we make separate recommendations for the two temperature ranges with substantial error limits in the case of the high temperature values.
The thermodynamic data should be used with caution. There are significant uncertainties associated with the data on NH:

\section{References}

'J.W. Cox, H.H. Nelson, and J.R. McDonald, Chem Phys. 96, 175 (1985). ${ }^{2}$ J.A. Harrison, A.R. Whyte, and L.F. Phillips, Chem. Phys. Lett. 129, 346 (1986).

${ }^{3}$ J.D. Mertens, A.Y. Chang, R.K. Hanson, and C.T. Bowman, Int. J. Chem. Kinet. 23, 173 (1991).

${ }^{4}$ J. Vandooren, O.M. Sarkisov, V.P. Balakhnin, and P.J. Van Tiggelen, Chem. Phys. Lett. 184, 294 (1991).

${ }^{5}$ R.K. Hanson and S. Salimian, "Chemistry of Combustion Processes", W:C. Gardiner, Ed., Springer-Verlag, New York, 1984.

${ }^{6} \mathrm{CEC}, 1992$ (see references in Introduction).

${ }^{7}$ W.S. Nip, Ph.D. Thesis, U. of Toronto (1974), reported in Ref. 3.

${ }^{8}$ T.R. Roose, R.K. Hanson, and C.H. Kruger, 18th Symp. (Int.) Combust. 853 (1981).

${ }^{9}$ R.C. Petersen, Ph.D. Thesis, Purdue University (1981), reported in Ref. 3. ${ }^{10} \mathrm{C}$. Morley, 18th Symp. (Int.) Combust. 23 (1981).

"S. Gordon, W. Mulac, and P. Nangia, J. Phys. Chem. 75, 2087 (1971).

${ }^{12}$ I. Hansen, K. Höinghaus, C. Zetzsch, and F. Stuhl, Chem. Phys. Lett 42, 37 (1976).

${ }^{13}$ J.A. Miller and C.F. Melius, 24th Symp. (Int.) Combust., 719 (1992). 


$$
\begin{aligned}
\mathrm{NH}+\mathrm{NO} & \rightarrow \mathrm{H}+\mathrm{N}_{2} \mathrm{O} \\
& \rightarrow \mathrm{HN}_{2}+\mathrm{O} \\
& \rightarrow \mathrm{N}_{2}+\mathrm{OH}
\end{aligned}
$$

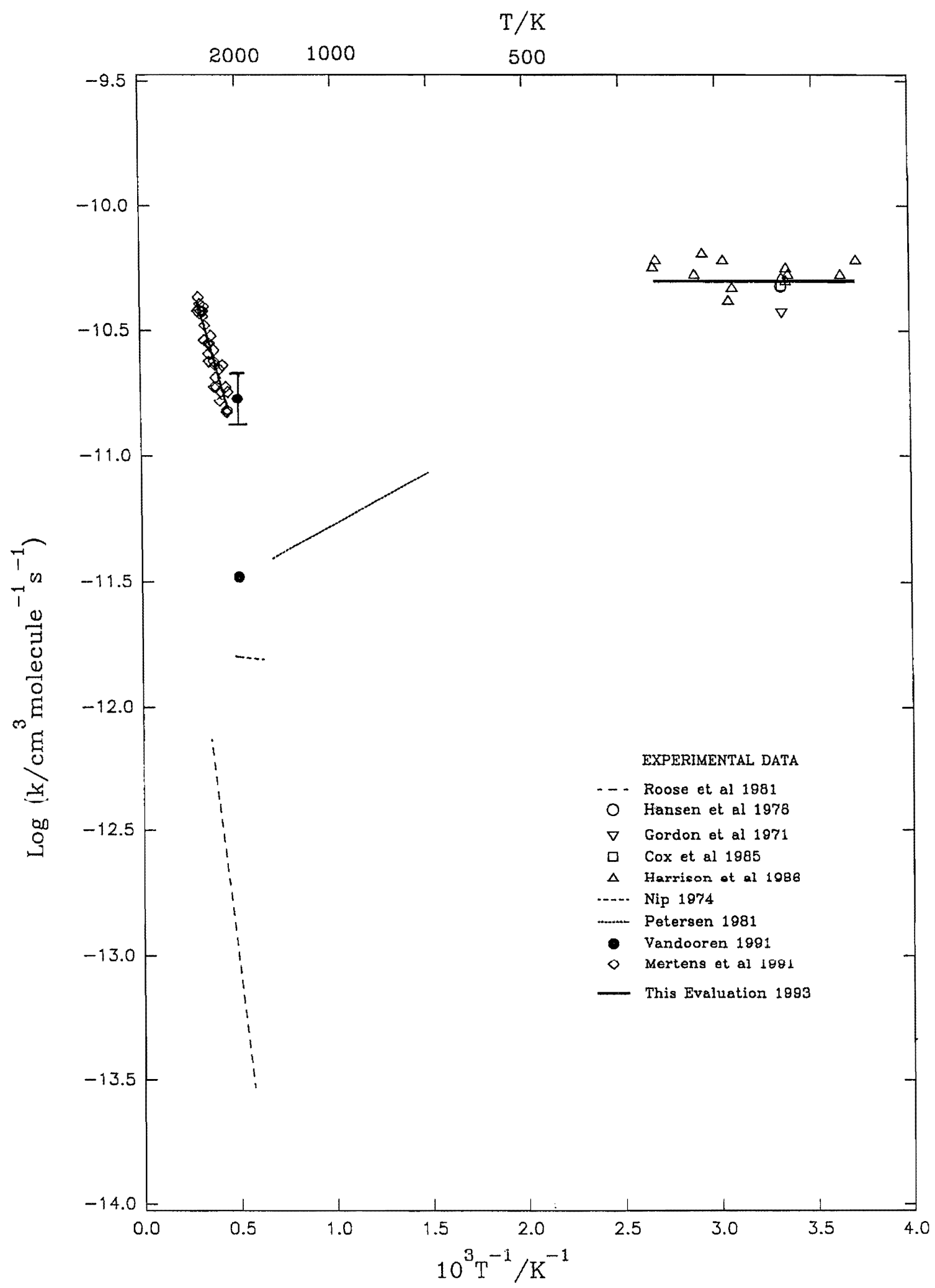




$$
\begin{aligned}
\mathrm{NH}_{3}(+\mathrm{M}) & \rightarrow \mathrm{NH}_{2}+\mathrm{H}(+\mathrm{M}) \\
& \rightarrow \mathrm{NH}+\mathrm{H}_{2}(+\mathrm{M})
\end{aligned}
$$
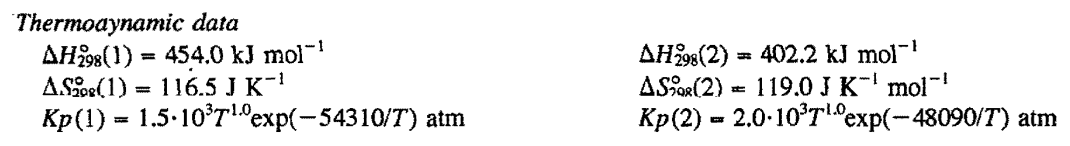

\begin{tabular}{|c|c|c|c|c|}
\hline$k / \mathrm{s}^{-1}$ & $T / \mathrm{K}$ & {$[\mathrm{M}] /$ molecule $\mathrm{cm}^{-3}$} & References & Comments \\
\hline \multicolumn{5}{|l|}{ Rate Coefficient Measurements } \\
\hline \multicolumn{5}{|l|}{ Low Pressure Range } \\
\hline$[\mathrm{Ar}] 7.2 \cdot 10^{-9} \exp (-40000 / T)$ & $2100-2900$ & $(7.2-60) \cdot 10^{18}$ & Michel and Wagner, $1965^{\prime}$ & (a) \\
\hline$[\mathrm{Ar}] 4.2 \cdot 10^{-8} \exp (-45800 / T)$ & $2100-2900$ & & Henrici, $1966^{2}$ & (b) \\
\hline$[\mathrm{Ar}] 3.8 \cdot 10^{-0} \exp (-35800 / T)$ & $2500-3000$ & & Takeyama and Miyanna, $1966^{3}$ & (c) \\
\hline$[\mathrm{Ar}] 6.6 \cdot 10^{-9} \exp (-41870 / T)$ & $2200-3450$ & $(1.7-18) \cdot 10^{17}$ & Bradley, Butlin, and Lewis, $1967^{4}$ & (d) \\
\hline$[\mathrm{Ar}] 9.6 \cdot 10^{-9} \exp (-38748 / T)$ & $2000-3000$ & $(2.7-12) \cdot 10^{16}$ & Genich, Zhimov, and Manelis, $1975^{5}$ & (e) \\
\hline$[\mathrm{Kr}] 2.0 \cdot 10^{-8} \exp (-45790 / T)$ & $2500-3000$ & $1.0 \cdot 10^{18}$ & Dove and Nip, $1979^{6}$ & $(f)$ \\
\hline$[A T] 4.2 \cdot 10^{-8} \exp (-47200 / T)$ & $2200-3450$ & - & Ruuse, Hansuni, and Kıuge1, $1980^{7}$ & (g) \\
\hline$[\mathrm{Ar}] 6.6 \cdot 10^{-8} \exp (-47270 / T)$ & $2200-3300$ & $(7.5-880) \cdot 10^{17}$ & Holzrichter and Wagner, $1981^{8}$ & (h) \\
\hline$[\mathrm{Ar}] 3.0 \cdot 10^{-8} \exp (-46350 / T)$ & $1740-3050$ & $(2.7-108) \cdot 10^{17}$ & Yumura and Asaba, $1981^{9}$ & (i) \\
\hline \multicolumn{5}{|l|}{ Intermediate Fall-Off Range } \\
\hline$[\mathrm{Ar}] 2.3 \cdot 10^{-8} \exp (-45592 / T)$ & $2050-3070$ & $(3.0-5.4) \cdot 10^{17}(\mathrm{Ar})$ & Yamura et al., $1980^{10}$ & (j) \\
\hline $2.1 \cdot 10^{2}$ & 2400 & $1.1 \cdot 10^{18}(\mathrm{Ar})$ & Holzrichter and Wagner, $1981^{8}$ & (h) \\
\hline $2.2 \cdot 10^{3}$ & & $1.1 \cdot 10^{19}$ & & \\
\hline $1.1 \cdot 10^{4}$ & 2400 & $8.1 \cdot 10^{30}(\mathrm{Ar})$ & & \\
\hline $1.6 \cdot 10^{3}$ & 2700 & $1.1 \cdot 10^{18}(\mathrm{Ar})$ & & \\
\hline $1.4 \cdot 10^{4}$ & & $1.1 \cdot 10^{19}$ & & \\
\hline $7.2 \cdot 10^{4}$ & & $8.1 \cdot 10^{19}$ & & \\
\hline $4.4 \cdot 10^{3}$ & 2900 & $7.5 \cdot 10^{17}(\mathrm{Ar})$ & & \\
\hline $4.0 \cdot 10^{4}$ & & $1.1 \cdot 10^{19}$ & & \\
\hline $1.0 \cdot 10^{5}$ & & $2.2 \cdot 10^{19}$ & & \\
\hline \multicolumn{5}{|l|}{ High Pressure Range } \\
\hline $5.5 \cdot 10^{15} \exp (-54240 / T)$ & $2200-3300$ & & Holzrichter and Wagner, $1981^{8}$ & (h) \\
\hline \multicolumn{5}{|l|}{ Reviews and Evaluations } \\
\hline$k_{0}=[\mathrm{Ar}] 1.5 \cdot 10^{-8} \exp (-42400 / T)$ & $2000-3000$ & & Baulch, Drysdale, and Home, $1973^{11}$ & (k) \\
\hline$k_{0}=[\mathrm{Ar}] 4.2 \cdot 10^{-8} \exp (-47200 / T)$ & $1740-3450$ & & Hanson and Salimian, $1984^{12}$ & (l) \\
\hline$k_{0}=[\operatorname{Ar}] 3.7 \cdot 10^{-8} \exp (-47040 / T)$ & $1740-3300$ & & Davidson et al, $1990^{13}$ & (m) \\
\hline
\end{tabular}

Rate Coefficient Data $\left(k=k_{1}+k_{2}\right)$

\section{Comments}

(a) Shock tube study. Decay of $\left[\mathrm{NH}_{3}\right]$ monitored by UV absorption at $230-250 \mathrm{~nm}$. Results indicate that the decomposition of $\mathrm{NH}_{3}$ is unimolecular. No conclusion was given on the mechanism.

(b) Shock tube study of $\mathrm{NH}_{3}$ dissociation using UV absorption technique to monitor $\left[\mathrm{NH}_{3}\right]$ at $230 \mathrm{~nm}$ and $[\mathrm{NH}]$ at $336 \mathrm{~nm}$. Induction period at lower temperatures.

(c) Shock tube study of $1 \% \mathrm{NH}_{3} / \mathrm{Ar}$ mixtures. Decay of $\left[\mathrm{NH}_{3}\right]$ behind reflected shock monitored at $224.5 \mathrm{~nm}$. Induction period observed at $T<2400 \mathrm{~K}$. Rate coefficients derived from the initial decay rates at higher temperatures. Pressures not quoted, probably several atmospheres.

(d) Shock tube study. Decay of $\mathrm{NH}_{3}$ monitored by IR emission at $3 \mu \mathrm{m}$. Rate coefficients obtained from initial decay rates.

(e) Pyrolysis of $\mathrm{NH}_{3}$ in shock waves. $\left[\mathrm{NH}_{3}\right]$ monitored by UV absorption at $220 \mathrm{~nm}$. (f) Pyrolysis of $\mathrm{NH}_{3}$ behind reflected shock waves. Mass spectrometric analysis during the reaction. Concentration profiles of $\mathrm{NH}_{3}, \mathrm{NH}_{2}, \mathrm{NH}$, and $\mathrm{N}_{2}$ measured. Rate coefficient extracted from a computer simulation with 10 reactions.

(g) Shock tube study. Rate coefficients measured behind in cident shocks. IR emission of the species $\mathrm{NH}_{3}, \mathrm{NH}_{2}$ and $\mathrm{NH}$ was monitored.

(h) Study of $\mathrm{NH}_{3}$ decomposition behind incident and reflected shocks in (7.5-880) $10^{17}$ molecule $\mathrm{cm}^{-3}$ of Ar. The rate coefficients were obtained from the initial slope of the $\left[\mathrm{NH}_{3}\right]$ decay as monitored by UV absorption.

(i) Shock tube study. $\mathrm{H}$-atom generation monitored behind incident shocks using atomic resonance absorption at $121.6 \mathrm{~nm}$. Mechanism with correction for boundary layer and wall absorption effects.

(j) Pyrolysis of $\mathrm{NH}_{3}$ in shock waves. $\mathrm{H}$ atoms monitored by Lyman- $\alpha$ absorption at $121.5 \mathrm{~nm}$.

(k) Evaluation of the literature up to 1971

(l) Evaluation of the literature up to 1981. 
(m) Re-evaluation of the data of Refs. 6, 8, 9 and 14 using a value of $1.14 \cdot 10^{-10} \exp (-13216 / R T) \mathrm{cm}^{3}$ molecule $^{-1}$ $\mathrm{s}^{-115}$ for the reaction $\mathrm{NH}_{3}+\mathrm{H} \rightarrow \mathrm{NH}_{2}+\mathrm{H}_{2}$ in the simulation of the pyrolysis of $\mathrm{NH}_{3}$.

\section{Preferred Values}

$k_{\infty}=8.3 \cdot 10^{15} \exp (-55170 / T) \mathrm{s}^{-1}$ over range $2000-3000 \mathrm{~K}$. $k_{0}=[\mathrm{Ar}] 7.4 \cdot 10^{-9} \exp (-41560 / \mathrm{T}) \mathrm{s}^{-1}$ over range 2000 $3000 \mathrm{~K}$.

$F_{\mathrm{c}}=0.58 \exp (-T / 4581)+0.42 \exp (-T / 102)$ for $\mathrm{M}=\mathrm{Ar}$ over range $2000-3000 \mathrm{~K}$.

\section{Reliability}

$\Delta \log k_{\infty}= \pm 0.4$ over range $2000-3000 \mathrm{~K}$.

$\Delta \log k_{0}= \pm 0.3$ over range $2000-3000 \mathrm{~K}$.

$\Delta F_{\mathrm{c}}= \pm 0.1$ for $\mathrm{M}=$ Ar over range $2000-3000 \mathrm{~K}$.

\section{Comments on Preferred Values}

The available experimental data are far away from the limiting high pressure rate coefficients. The preferred values of $k_{\infty}$ are based on an SACM analysis for the reverse recombination process ${ }^{16}$ and the evaluated equilibrium constant. We have chosen the data from Refs. 2, 6 and 8 to fit theoretical fall-off curves ${ }^{17}$. This procedure leads to collisional efficiencies of about 0.05 when the extrapolated $k_{0}$ values are compared with the strong collision limiting low pressure rate coefficients ${ }^{17.18}$ evaluated here. In Figs. 1 and 2, the temperature dependence of $k_{\mathrm{o}}$ and $k_{\infty}$ is presented. Figure 3 shows the calculated fall-off curves and selected experimental dissociation rate coefficients.

The rate coefficients for the spin-forbidden reaction (2) are about a factor of 40 lower than those of reaction $(1)^{6,12}$.

\section{References}

${ }^{1}$ K.W. Michel and H.Gg. Wagner, 10th Symp. Int. Combust. 353 (1965). ${ }^{2}$ H. Henrici, Ph.D. Thesis, Göttingen, Germany, (1966).

${ }^{3}$ T. Takeyama and H. Miyama, Bull. Chem. Soc. Japan 39, 2352 (1966). ${ }^{4}$ J.N. Bradley, R.N. Butlin, and D. Lewis, Trans. Faraday Soc. 63, 2962 (1967)

${ }^{5}$ A.P. Genich, A.A. Zhimov, and G.B. Manelis, Kinet. Catal. 16, 726 (1975). ${ }^{6}$ J.E. Dove and W.S. Nip, Can J. Chem. 57, 689 (1979).

${ }^{7}$ T.R. Roose, R.K. Hanson, and C.H. Kruger, Proc. 12th Int. Symp. Shock Tubes and Waves, Magnus Hebrew Univ. Press, Jerusalem, 476 (1980). ${ }^{8}$ K. Holzrichter and H.Gg. Wagner, 18th Symp. Int. Combust. 769 (1981).

${ }^{9} \mathrm{M}$. Yumura and T. Asaba, 18th Symp. Int. Combust. 863 (1981).

${ }^{10} \mathrm{M}$. Yumura, T. Asaba, Y. Matsumoto, and H. Matsui, Int. J. Chem. Kinet. 12, 439 (1980).

"D.L. Baulch, D.D. Drysdale, and D.G. Horne, Evaluated Kinetic Data for High Temperature Reactions, Vol. 2, Butterworths, London, 1973.

${ }^{12}$ R.K. Hanson and S. Salimian, in "Combustion Chemistry", W.C. Gardiner, Jr., Ed., Springer-Verlag, 1984, p.361.

${ }^{13}$ D.F. Davidson, K. Kohse-Höinghaus, A.Y. Chang, and R.K. Hanson, Int. J. Chem. Kinet. 22, 513 (1990).

${ }^{14}$ T.R. Roose, Ph.D. Thesis, Stanford University 1981.

${ }^{15}$ J.V. Michael, J.W. Sutherland, and R.B. Klemm, Int. J. Chem. Kinet. 17, 315 (1985).

${ }^{16}$ J. Troe, Z. Phys. Chem., N.F. 161, 209 (1989).

${ }^{17}$ J. Troe, J. Phys. Chem. 83, 114 (1979).

${ }^{18}$ J. Troe, J. Chem. Phys. 66, 4758 (1977). 


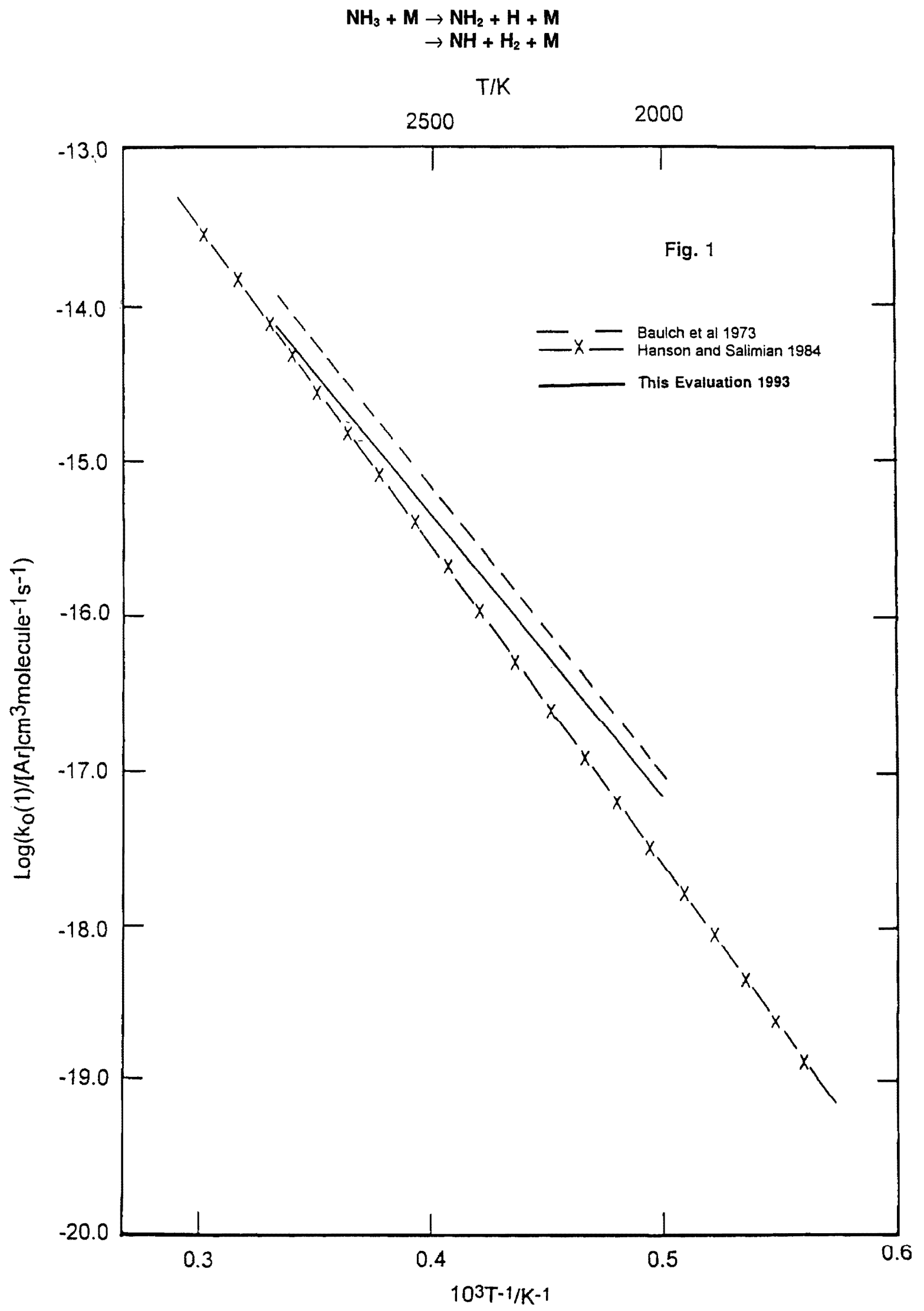



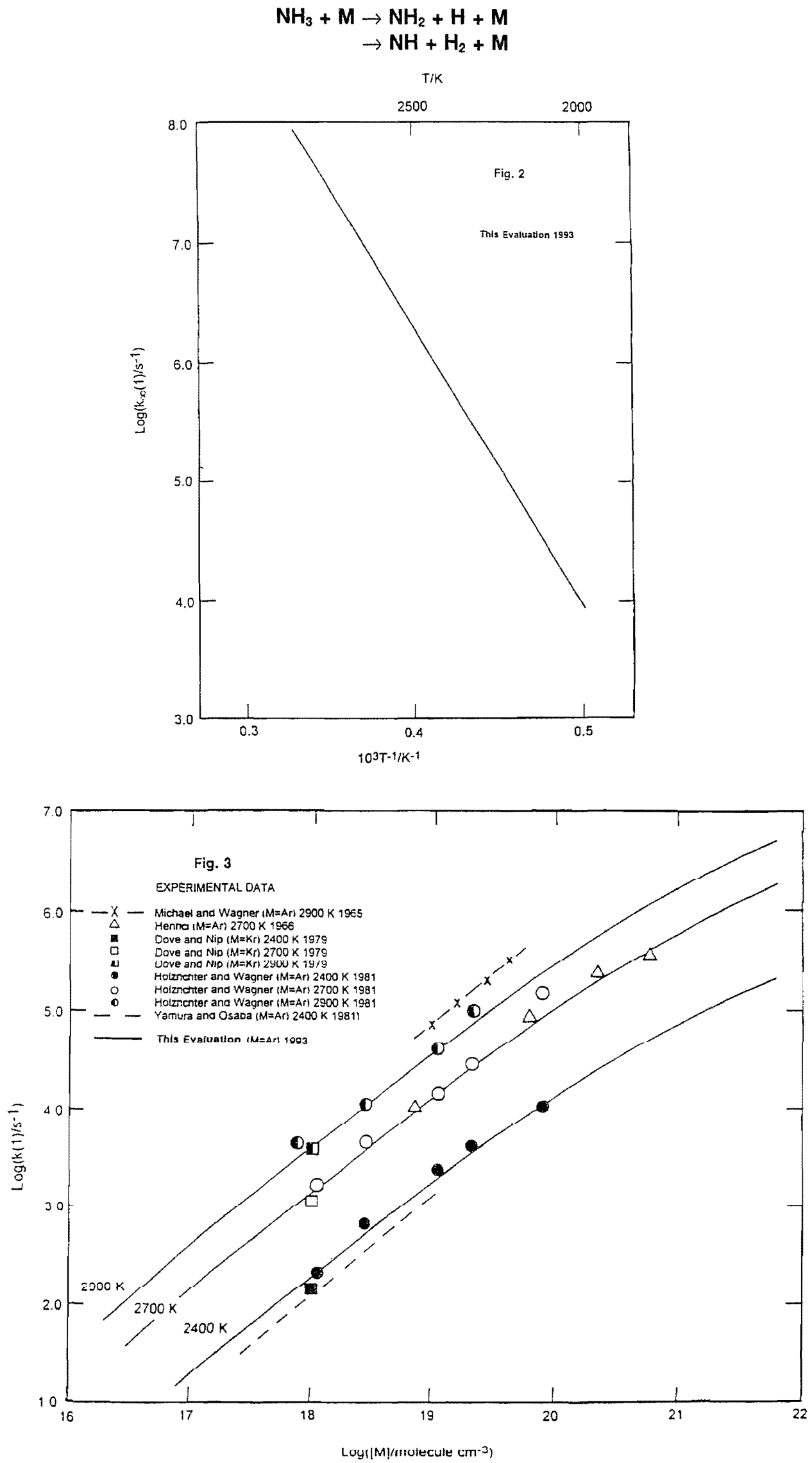


$$
\mathrm{C}+\mathrm{N}_{2} \rightarrow \mathrm{CN}+\mathrm{N}
$$

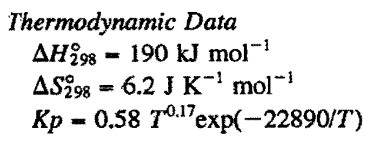

Rate Coefficient Data

\begin{tabular}{lll}
\hline \hline$k / \mathrm{cm}^{3}$ molecule & Reference & Comments \\
\hline $\begin{array}{c}\text { Rate Coefficient Measurements } \\
k=7.5 \cdot 10^{-11} \exp (-22000 / T)\end{array}$ & $2350-3290$ & Lindackers, Burmeister, and Roth, 1990 \\
$k=1.0 \cdot 10^{-10} \exp (-23160 / T)$ & $2660-4660$ & Dean, Hanson and Bowman, 1990 \\
\hline
\end{tabular}

\section{Comments}

(a) Shock tube study. $\mathrm{C}$ atoms generated by pyrolysis of $\mathrm{CH}_{4}$ or $\mathrm{C}_{2} \mathrm{H}_{6}$ in $\mathrm{Ar}$ and detccted behind reflected shock wave by atomic resonance absorption spectroscopy (ARAS). Analysis of perturbations to [C] on addition of $\mathrm{N}_{2}$ gave $k$. $\mathrm{N}$ atoms also detected by atomic resonance absorption spectroscopy. The $A$-factor is misquoted in abstract of original reference.

(b) Shock tube study. $\mathrm{C}$ atoms generated by pyrolysis of $\mathrm{C}_{3} \mathrm{O}_{2}$ in $\mathrm{Ar}$ and $\mathrm{N}_{2}$ and decay of [C] followed behind reflected shock wave under first-order conditions by atomic resonance absorption spectroscopy.

\section{Preferred Value}

$k=8.7 \cdot 10^{-11} \exp (-22600 / T) \mathrm{cm}^{3}$ molecule ${ }^{-1} \mathrm{~s}^{-1}$ over the range $2000-5000 \mathrm{~K}$.
Reliability

$\Delta \log k= \pm 0.2$ over the range $2000-5000 \mathrm{~K}$.

Comments on Preferred Values

The two direct measurements of $k$ using very similar shock tube techniques, are in excellent agreement. The preferred value is derived from averaging the Arrhenius parameters of each expression. It lies well within the broad range of values calculated from the equilibrium constant and indirect measurements of the reverse rate coefficient, which differ by over an order of magnitude.

\section{References}

'D. Lindackers, M. Burmeister, and P. Roth, 23rd Symp. (Int.) Comb., 251 (1990).

${ }^{2}$ A.J. Dean, R.K. Hanson, and C.T. Bowman, 23rd Symp. (Int.) Comb., 259 (1990). 


$$
\begin{aligned}
\mathrm{C}+\mathrm{NO} & \rightarrow \mathrm{CN}+\mathrm{O} \\
& \rightarrow \mathrm{CO}+\mathrm{N}
\end{aligned}
$$

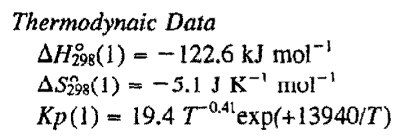

\begin{tabular}{|c|c|c|c|}
\hline$k / \mathrm{cm}^{3}$ molecule $^{-1} \mathrm{~s}^{-1}$ & $T / \mathrm{K}$ & References & Comments \\
\hline \multicolumn{4}{|c|}{ Rate Coefficient Measurements } \\
\hline $1.1 \cdot 10^{-10}$ & 300 & Braun et al., 1968' & (a) \\
\hline $7.3 \cdot 10^{-11}$ & 300 & Husain and Kirsch, $1971^{2}$ & (b) \\
\hline $4.8 \cdot 10^{-11}$ & 300 & Husain and Young, $1975^{3}$ & (c) \\
\hline $1.6 \cdot 10^{-11}$ & 300 & Becker, Brockmann, and Wiesen, $1988^{4}$ & (d) \\
\hline $8.0 \cdot 10^{11}$ & $1550-4050$ & Dean, Hanson, and Bowman, $1991^{3}$ & (e) \\
\hline$k_{\mathrm{l}} / k=0.42 \pm 0.18$ & $2430-4040$ & & \\
\hline $2.7 \cdot 10^{-11}$ & 300 & Dorthe et al., $1991^{6}$ & (f) \\
\hline
\end{tabular}

Rate Coefficient Data $\left(k=k_{1}+k_{2}\right)$

\section{Comments}

(a) Single shot flash photolysis of $\mathrm{C}_{3} \mathrm{O}_{2}$. [C] monitored by light absorption in the $166 \mathrm{~nm}$ region and photographic plate photometry. Total pressure 150 Torr.

(b) Single shot flash photolysis of $\mathrm{C}_{3} \mathrm{O}_{2},[\mathrm{C}]$ monitored by resonance absorption at $166 \mathrm{~nm}$. Total pressure 53 Torr and 527 Torr. No pressure dependence of $k$ observed.

(c) Repetitive flash photolysis of $\mathrm{C}_{3} \mathrm{O}_{2}$. [C] monitored by resonance absorption at $166 \mathrm{~nm}$ with signal averaging. Total pressure 27 Torr.

(d) Pulsed laser photolysis at $248 \mathrm{~nm}$ of slowly flowing $\mathrm{CH}_{2} \mathrm{Br}_{2} / \mathrm{He}$ mixtures. [C] monitored by two-photon LIF at $143.5 \mathrm{~nm}$. Total pressure 2 Torr.

(e) Shock tube study. $\mathrm{C}$ atoms produced by pyrolysis of $\mathrm{C}_{3} \mathrm{O}_{2}$ in $\mathrm{C}_{3} \mathrm{O}_{2} / \mathrm{Ar}$ mixtures at temperatures $2435-3737 \mathrm{~K}$, and by laser photolysis at $193 \mathrm{~nm}$ of $\mathrm{C}_{3} \mathrm{O}_{2} / \mathrm{Ar}$ mixtures in temperature range $1576-1940 \mathrm{~K}$. [C] monitored by ARAS at $156.1 \mathrm{~nm}$. Possible reaction products, CN, N, O, were studied using laser absorption or ARAS. Computer modelling of large reaction scheme shows [CN] profile particularly sensitive to branching ratio.

(f) Fast flow reactor; $\mathrm{C}$ atoms produced by discharge in $\mathrm{CO} / \mathrm{He}$ mixtures. [C] monitored by detection of chemiluminescence from $\mathrm{C}+\mathrm{OCS}$ reaction.

\section{Preferred Values}

$k=2.5 \cdot 10^{-11} \mathrm{~cm}^{3}$ molecule ${ }^{-1} \mathrm{~s}^{-1}$ at $300 \mathrm{~K}$.

$k=8.0 \cdot 10^{-11} \mathrm{~cm}^{3}$ molcculc ${ }^{-1} \mathrm{~s}^{-1}$ over the range $1500-$ $4050 \mathrm{~K}$.

$k_{1} / k=0.40 ; k_{2} / k=0.60$ over the range $2400-4050 \mathrm{~K}$.

Reliability

$\Delta \log k= \pm 0.3$ at $300 \mathrm{~K}$.

$\Delta \log k= \pm 0.3$ over the range $1500-4050 \mathrm{~K}$.

$\Delta k_{1} / k=\Delta k_{2} / k= \pm 0.25$.

\section{Comments on Preferred Values}

The measured values of $k$ at low temperatures range over a factor of 7 . It has been suggested ${ }^{4}$ that in the earlier studies, by flash photolysis, this scatter might be due to the high photolysis flash intensities used. The trend in values of $k$ with time as detection methods improved and lower flash intensities could be employed is in accord with this. The most recent study, employing pulsed laser photolysis ${ }^{4}$, has produced the lowest value of $k$ yet obtained.

The alternative explanation involves pressure dependence of $k$ but in the sole investigation of pressure effects Braun et al. ${ }^{1}$ found no evidence for them. In a recent discharge flow study Dorthe et al.$^{6}$ also obtain a low value of $k$, identical with that of Becker et al. ${ }^{4}$, if the usual plug flow assumptions were made, but $65 \%$ higher on making corrections for the flow pattern in their flow tube. Our recommendations at $300 \mathrm{~K}$ are based on the work of Becker et al. ${ }^{4}$ and Dorthe et al ${ }^{6}$.

At high temperatures $(1550-4050 \mathrm{~K})$ there is only one study, by Dean et al ${ }^{5}$. The work seems sound and their results are accepted with slightly enhanced error limits until confirmed by other studies. More studies are required to establish the temperature dependence of $k$ between 300 and $1500 \mathrm{~K}$.

The only investigation of the branching ratio is in the high temperature work of Dean et al..$^{5}$ which is accepted as the basis of our recommendations.

\section{References}

'W. Braun, A.M. Bass, D.D. Davies, and J.D. Simmons, Proc. Roy. Soc. A 312, 417 (1969).

${ }^{2}$ D. Husain and L.J. Kirsch, Trans. Faraday Soc. 67, 2025 (1971).

${ }^{3}$ D. Husain and A.N. Young. J. Chem. Soc., Faraday Trans. 2, 71, 525 (1975). ${ }^{4}$ K.H. Becker, K.J. Brockmann, and P. Wiesen, J. Chem. Soc., Faraday Trans. $2,84,455(1988)$.

${ }^{5}$ A.J. Dean, R.K. Hanson, and C.T. Bowman, J. Phys. Chem. 95, 3180 (1991).

${ }^{6} \mathrm{G}$. Dorthe, Ph. Caubet, Th. Vias, B. Barrere, and J. Marchais, J. Phys. Chem. 95, 5109 (1991). 


$$
\begin{aligned}
\mathrm{CH}+\mathrm{N}_{2} & \rightarrow \mathrm{HCN}+\mathrm{N} \\
\mathrm{CH}+\mathrm{N}_{2}(+\mathrm{M}) & \rightarrow \mathrm{CHN}_{2}(+\mathrm{M})
\end{aligned}
$$

Thermodynamic Data

$\Delta H_{298}^{\circ}(1)=13.6 \mathrm{~kJ} \mathrm{~mol}^{-1}$

$\Delta S_{298}^{\circ}(1)=19.5 \mathrm{~J} \mathrm{~K}^{-1} \mathrm{~mol}^{-1}$

$K p(1)=5.0 \cdot 10^{2} T^{-0.55} \exp (-1420 / T)$

\begin{tabular}{|c|c|c|c|}
\hline$k / \mathrm{cm}^{3}$ molecule ${ }^{-1} \mathrm{~s}^{-1}$ & $T / \mathrm{K}$ & Reference & Comments \\
\hline \multicolumn{4}{|l|}{ Rate Coefficient Measurements } \\
\hline $7.14 \cdot 10^{-14}$ & 300 & Braun, McNesby, and Bass, $1967^{1}$ & (a) \\
\hline $1.01 \cdot 10^{-12}$ & 300 & Bosnali and Perner, $1971^{2}$ & (b) \\
\hline $1.3 \cdot 10^{-12} \exp (-5540 / T)$ & $1530-1900$ & Blauwens, Smets, and Peeters, $1977^{3}$ & (c) \\
\hline $9.3 \cdot 10^{-13}$ & 300 & Butler et al., $1980^{4}$ & (d) \\
\hline$k_{\infty}-6.3 \cdot 10^{-13}$ & 300 & Wagal ot al., $1982^{5}$ & (e) \\
\hline \multicolumn{4}{|l|}{$k_{0}=2.6 \cdot 10^{-31} \mathrm{~cm}^{6}$ molecule ${ }^{-2} \mathrm{~s}^{-1}$} \\
\hline $\begin{array}{l}1.7 \cdot 10^{-14} \exp (975 / T) \text { at } 100 \text { Torr } \mathrm{Ar} \\
k_{\infty}=2 \cdot 10^{-11}\end{array}$ & $297-675$ & Berman and Lin, $1983^{6}$ & (f) \\
\hline \multicolumn{4}{|l|}{$\begin{array}{l}k_{\infty}=2 \cdot 10 \\
k_{0}-2.8 \cdot 10^{-31} \mathrm{~cm}^{6} \text { molecule } \mathrm{e}^{-2} \mathrm{~s}^{-1}\end{array}$} \\
\hline $7.1 \cdot 10^{-14}$ & 300 & Duncanson and Guillory, $1983^{7}$ & (g) \\
\hline $2.0 \cdot 10^{-12} \exp (-6840 / T)$ & $1700-2200$ & Matsui and Yuuki, $1985^{8}$ & (h) \\
\hline $8.0 \cdot 10^{-14}$ & 300 & Becker, Engelhardt, and Wiesen, $1989^{\circ}$ & (i) \\
\hline $1.0 \cdot 10^{-12} \exp (-7000 / T)$ & $2632-2859$ & Lindackers, Burmeister, and Roth, $1990^{10}$ & (j) \\
\hline $7.3 \cdot 10^{-12} \exp (-11060 / T)$ & $2500-3820$ & Dean, Hanson, and Bowman, $1990^{11}$ & (k) \\
\hline $2.58 \cdot 10^{-15} \exp (1150 / T)$ at $20 \mathrm{Torr} \mathrm{Ar}$ & $301-894$ & Becker et al., $1992^{12}$ & (l) \\
\hline
\end{tabular}

Rate Coefficient Data $\left(k=k_{1}+k_{2}\right)$

\section{Comments}

(a) Flash photolysis of $\mathrm{CH}_{4} \cdot[\mathrm{CH}]$ monitored by flash absorption using photographic recording. Pressures 1-40 Torr.

(b) Pulse radiolysis of $\mathrm{CH}_{4} \cdot[\mathrm{CH}]$ monitored by absorption spectroscopy. Pressure not given but likely to be approximately $1 \mathrm{~atm}$.

(c) Flat, nitrogen diluted, flames of $\mathrm{C}_{2} \mathrm{H}_{4}, \mathrm{C}_{2} \mathrm{H}_{6}$, or $\mathrm{CH}_{4}$ burning in $\mathrm{O}_{2}$ studied at pressures in range $18-43$ Torr. Concentration profiles of $\mathrm{NO}, \mathrm{O}, \mathrm{OH}, \mathrm{H}, \mathrm{CH}, \mathrm{CH}_{2}, \mathrm{C}_{2}, \mathrm{C}_{2} \mathrm{H}$ and $\mathrm{C}$ measured by molecular beam sampling and mass spectrometry. Concentration of both $\mathrm{CH}$ and $\mathrm{CH}_{2}$ shown to correlate with prompt NO. Results can be interpreted in terms of $\mathrm{CH}+\mathrm{N}_{2}$ reaction or $\mathrm{CH}_{2}+\mathrm{N}_{2}$ reaction.

(d) Pulsed laser photolysis at $193 \mathrm{~nm}$ of slowly flowing mixtures of $\mathrm{CHBr} / \mathrm{Ar}^{2} / \mathrm{N}_{2}$. CH produced by multiphoton absorption by $\mathrm{CHBr}_{3}$ and $[\mathrm{CH}]$ monitored by LIF near 430 nm. Total pressure 30-100 Torr.

(e) $\mathrm{CH}$ produced by pulsed $\mathrm{CO}_{2}$ laser multiphoton dissociation of $\mathrm{CH}_{3} \mathrm{NH}_{2}, \mathrm{CH}_{3} \mathrm{CN}$, or $\mathrm{c}-\mathrm{C}_{3} \mathrm{H}_{6}$. [CH] monitored hy LIF. Slowly flowing mixtures of source gas and $\mathrm{N}_{2}$ in $\mathrm{Ar}$ buffer gas used at total pressures over range 1-80 Torr. Limiting $k_{\circ}$ and $k_{\text {linfin }}$ values obtained using simple Lindemann model.

(f) Pulsed laser photolysis at $266 \mathrm{~nm}$ of slowly flowing mixtures of $\mathrm{CHBr}_{3} / \mathrm{Ar} / \mathrm{N}_{2}$. [CH] monitored by LIF at 429.8 $\mathrm{nm}$. Total pressure varied over range 25-787 Torr at $297 \mathrm{~K}$, and temperature varied over range $297-675 \mathrm{~K}$ at 100 Torr total pressure.

(g) $\mathrm{CH}$ produced by pulsed $\mathrm{CO}_{2}$ laser multiphoton dissociation of $\mathrm{CH}_{3} \mathrm{OH}$. [CH] monitored by $\mathrm{LIF}$ at $430.0 \mathrm{~nm}$. Ar (10 Torr) used as buffer gas.

(h) Study of premixed, flat $\mathrm{CH}_{4} /$ air flames by light absorption, by saturation ion current measurements, and by mi- croprobe sample extraction and analysis for total hydrocarbons and $\mathrm{NO}_{\mathrm{x}}$. Total pressure, 760 Torr.

(i) Pulsed laser photolysis at $248 \mathrm{~nm}$ of slowly flowing $\mathrm{CH}_{2} \mathrm{Br}_{2} / \mathrm{Ar} / \mathrm{N}_{2}$ and $\mathrm{CHClBr} / 2 / \mathrm{Ar} / \mathrm{N}_{2}$ mixtures. [CH] monitored by LIF at $430 \mathrm{~nm}$. Total pressure, 2 Torr.

(j) Technique as in (i) but total pressure 20 Torr.

(k) Reflected shock waves in $\mathrm{C}_{2} \mathrm{H}_{\delta} / \mathrm{N}_{2} / \mathrm{Ar}$ mixtures at pressures $1.5-1.79$ bar. [N] profiles monitored by atomic resonance absorption. [N] profiles fitted by computer simulation of reaction scheme. Fitting shown to be sensitive to $k$.

(l) Shock tube studies on $\mathrm{CH}_{4} / \mathrm{N}_{2} / \mathrm{Ar}$ and $\mathrm{C}_{2} \mathrm{H}_{6} / \mathrm{N}_{2} / \mathrm{Ar}$ mixtures at pressures $0.62-1.02 \mathrm{~atm}$. [CH] profile monitored by laser absorption at $431.131 \mathrm{~nm}$. [N] profile monitored in some experiments by atomic resonance absorption. $[\mathrm{CH}]$ profiles fitted using computer simulation of reaction scheme; fitting shown to be sensitive to $k$.

\section{Preferred Value}

$k=2.6 \cdot 10^{-12} \exp (-9030 / T) \mathrm{cm}^{3}$ molecule $\mathrm{e}^{-1} \mathrm{~s}^{-1}$ over the range $2000-4000 \mathrm{~K}$ at $p<760$ Torr.

\section{Reliability}

$\Delta \log k= \pm 0.3$ over range $2000-4000 \mathrm{~K}$ at $p<760$ Torr.

\section{Comments on Preferred Values}

Since this reaction was first suggested as a source of 'prompt' NO in flames its kinetics have been the subject of a number of studies. At low temperatures the rate constant has been shown to be pressure dependent and to have a negative temperature coefficient ${ }^{6}$. When the effects of pressure are allowed for the measured values of the rate constant are in good agreement. 
The pressure dependence of $k$ has been investigated by Wagal et al..$^{5}$ and by Berman and Lin $^{6}$. The mechanism proposed for the reaction is

$$
\begin{aligned}
\mathrm{CH}+\mathrm{N}_{2} \stackrel{a}{\rightarrow} \mathrm{CHN}_{2} * & \stackrel{b}{\rightarrow} \mathrm{HCN}+\mathrm{N} \\
& \stackrel{c}{\rightarrow} \mathrm{CHN}_{2} \\
& \mathrm{M}
\end{aligned}
$$

The effects of pressure on $k$ and the negative temperature coefficient at low temperatures are accounted for by competition between collisional stabilization of the energized $\mathrm{CHN}_{2}{ }^{*}$ adduct and decomposition back to $\mathrm{CH}+\mathrm{N}_{2}$. This competition has been modelled by Wagal et al.$^{5}$ using a simple Lindemann treatment and by Berman and Lin $^{6}$ who used RRKM theory. The experimental results were obtained under conditions far removed from the high pressure limit of $k$ and much closer to the low pressure limit. Not surprisingly, therefore, the two different treatments give values of $k_{\mathrm{o}}$ in good agreement but there are very large differences in the values of $k_{\infty}$

At sufficiently high temperatures the rate constant has a positive temperature coefficient and appears to be independent of pressure ${ }^{3,8}$. Path $b$ is included in the above mechanism to account for this. At high temperatures, path $b$ becomes more important than the decomposition of the adduct back to $\mathrm{CH}+\mathrm{N}_{2}$ and any pressure effect would be due to competition between $b$ and $c$ until, at sufficiently high temperatures, $b$ dominates completely and $k$ becomes pressure independent. From the modelling studies of Berman and $\mathrm{Lin}^{6}$ and Lindackers et al.$^{10}$ it seems that adduct formation will dominate at low temperatures and will contribute to the overall rate constant at $T<2000 \mathrm{~K}$ and $p<760$ Torr. This transition temperature region will move to higher values of $T$ at higher pressures.

There are high temperature values of $k$ based on both flame $e^{3,8}$ and shock tube studies ${ }^{10,11}$. They exhibit considerable differences both in the absolute values of $k$ and its temperature coefficient. The flame studies were performed at lower temperatures and hence may have some contribution from adduct stabilization, channel 2 . The slightly lower values of $E / R$ obtained in these studies may be evidence of this. Our recommendations, therefore, are based on the shock tube work of Lindackers et al. ${ }^{10}$ and Dean et al. ${ }^{11}$. These give significantly different values of $E / R$, probably more than can be explained by contributions from adduct formation at the temperatures and pressures employed. For the temperature coefficient, we take a mean value of $E / R$ from these two studies and the pre-exponential factor is based on this value of $E / R$ and the virtually identical value of $k$ at $2000 \mathrm{~K}$ given by the expression of Dean et al. ${ }^{11}$ and Lindackers et al.$^{10}$. Our recommendations are limited to high temperatures and pressures where channel 1 is expected to be dominant. Some direct confirmation that the products of the reaction at high temperatures are $\mathrm{HCN}+\mathrm{N}$ comes from the work of Dean et al. ${ }^{11}$ where the [N] profile was measured and modelled satisfactorily.

\section{References}

'W. Braun, J.R. McNesby, and A.M. Bass, J. Chem. Phys. 46, 2071 (1967). ${ }^{2}$ M.W. Bosnali and D. Perner, Z. Naturforsch. 26A, 1768 (1971).

${ }^{3}$ J. Blauwens, B. Smets, and J. Peeters, 16th Symp. Int. Comb. 1055 (1977). ${ }^{4}$ J.E. Butler, J.W. Fleming, L.P. Goss, and M.C. Lin, Am. Chem. Soc. ACS Symp. Ser. 134, 397 (1980).

${ }^{5}$ S.S. Wagal, T. Carrington, S.V. Filseth, and C.M. Sadowski, Chem. Phys. 69, 61 (1982).

${ }^{6}$ M.R. Berman and M.C. Lin, J. Phys. Chem. 87, 3933 (1983).

7J.A. Duncanson and W.A. Guillory, J. Chem. Phys. 78, 4958 (1983).

${ }^{8}$ Y. Matsui and A. Yuuki, J. Appl. Phys. 24, 598 (1985).

${ }^{9}$ K.H. Becker, B. Engelhardt, P. Wiesen, and K.D. Bayes, Chem. Phys. Lett. 154, 342 (1989).

${ }^{10}$ D.L. Lindackers, M. Burmeister, and P. Roth, 23rd Symp. (Int.) Combust., 251 (1992).

${ }^{11}$ A.J. Dean, R.K. Hanson, and C.T. Bowman, 23rd Symp. (Int.) Combust., 259 (1990).

${ }^{12}$ K.H. Becker, B. Engelhardt, H. Geiger, R. Kurtenbach, G. Schrey, and P. Wiesen, Chem. Phys. Letl. 195, 322 (1992). 
$\mathrm{CH}+\mathrm{N}_{2} \rightarrow \mathrm{HCN}+\mathrm{N}$

$\mathrm{CH}+\mathrm{N}_{2}(+\mathrm{M}) \rightarrow \mathrm{CHN}_{2}(+\mathrm{M})$

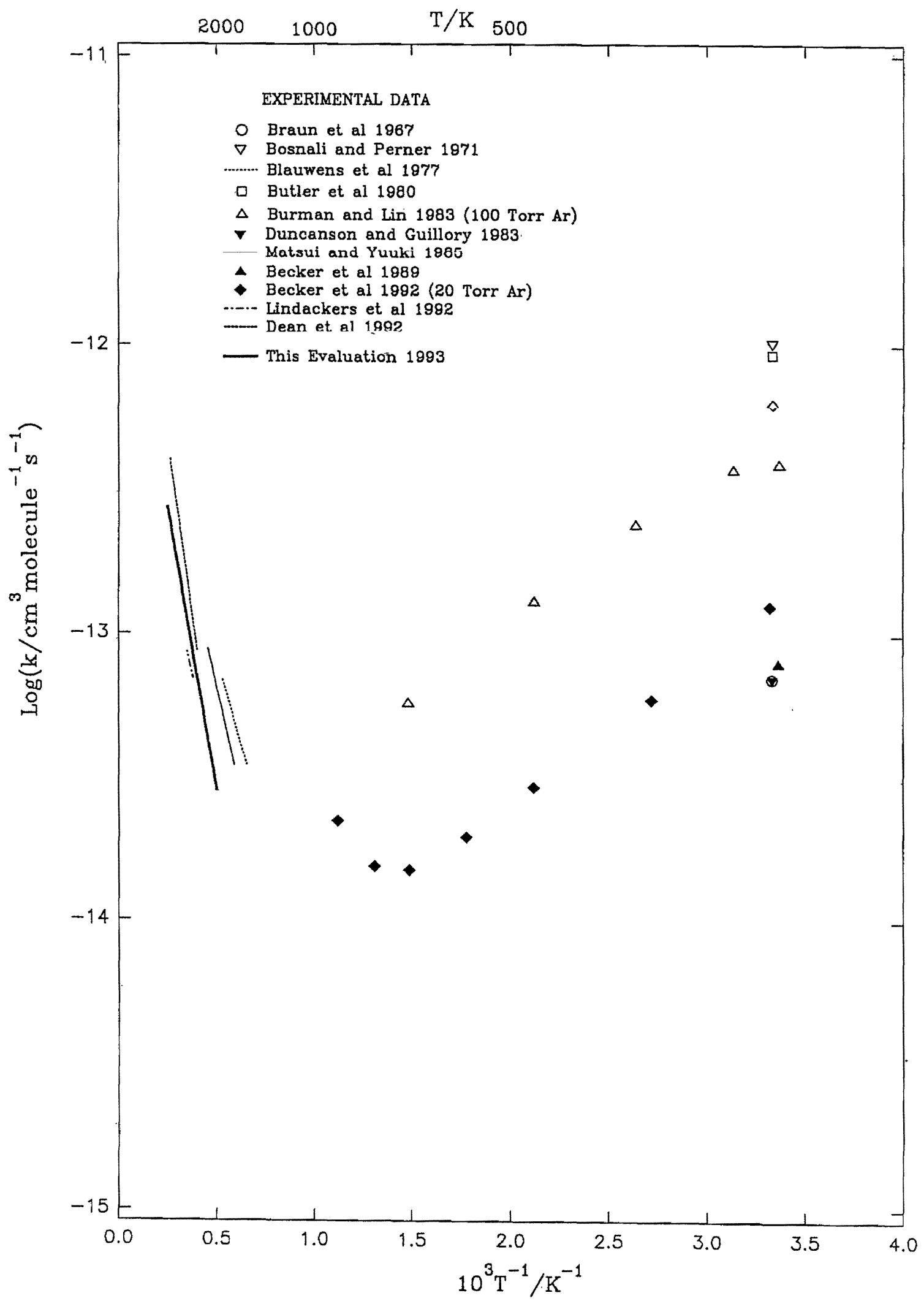




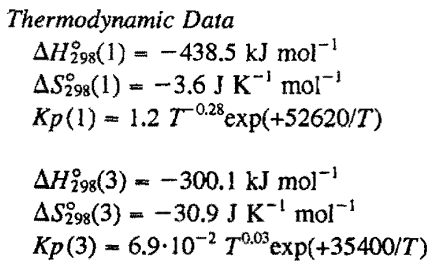

Rate Coefficient Data $\left(k=k_{1}+k_{2}+k_{3}\right)$

\begin{tabular}{|c|c|c|c|}
\hline $\mathrm{k} / \mathrm{cm}^{3}$ molecule ${ }^{-1} \mathrm{~s}^{-1}$ & $T / \mathrm{K}$ & References & Comments \\
\hline \multicolumn{4}{|c|}{ Rate Coefficient Measurements } \\
\hline $2.9 \cdot 10^{-10}$ & 300 & Butler et al., $1980^{1} ; 1981^{2}$ & (a) \\
\hline $1.9 \cdot 10^{-10}$ & $297-676$ & Berman et al., $1982^{3}$ & (b) \\
\hline $2.0 \cdot 10^{-10}$ & $300^{\circ}$ & Wagal et al., $1982^{4}$ & (c) \\
\hline $2.5 \cdot 10^{-10}$ & 300 & Lichtin et al., $1983^{5} ; 1984^{6}$ & (d) \\
\hline $1.66 \cdot 10^{-10}$ & $2570-3790$ & Dean et al., $1991^{7}$ & (e) \\
\hline
\end{tabular}

\section{Comments}

(a) Pulsed laser photolysis at $193 \mathrm{~nm}$ of slowly flowing mixtures of $\mathrm{CHBr}_{3} / \mathrm{Ar} / \mathrm{NO}$ at pressures of 100 Torr. $\mathrm{CH}$ produced by multiphoton absorption by $\mathrm{CHBr}_{3}$ and $[\mathrm{CH}]$ monitored by LIF near $430 \mathrm{~nm}$.

(b) Pulsed laser photolysis at $266 \mathrm{~nm}$ of slowly flowing mixtures of $\mathrm{CHBr}_{3} / \mathrm{Ar} / \mathrm{NO}$ at pressures of 100 Torr. [CH] monitored by LIF in $430 \mathrm{~nm}$ region.

(c) $\mathrm{CH}$ produced by multiphoton pulsed laser dissociation . $\left(\mathrm{CO}_{2}\right.$ laser $)$ of $\mathrm{CH}_{3} \mathrm{NH}_{2}, \mathrm{CH}_{3} \mathrm{CN}$ or $\mathrm{c}-\mathrm{C}_{3} \mathrm{H}_{6}$. [CH] monitored by LIF. Slowly flowing mixtures of source gas with $\mathrm{Ar}$ and $\mathrm{NO}$ at total pressures of approximately 5 Torr.

(d) Pulsed laser photolysis at $266 \mathrm{~nm}$ of slowly flowing mixtures of $\mathrm{CHBr}_{3} / \mathrm{Ar} / \mathrm{NO}$ at 21 Torr. Emissions from excited states of $\mathrm{CH}$ and from $\mathrm{NH}$ observed. $\mathrm{NH}$ emission monitored at $336.2 \mathrm{~nm}$ used to obtain $k$.

(e) Shock tube study. Pyrolysis of $\mathrm{C}_{2} \mathrm{H}_{6} / \mathrm{NO} / \mathrm{Ar}$ or $\mathrm{CH}_{4} / \mathrm{NO} /$ Ar mixtures. $\mathrm{CH}, \mathrm{NH}$ and $\mathrm{OH}$ detected by narrow-linewidth laser absorption. [CH] profile in presence and absence of NO compared. $k$ derived by fitting $[\mathrm{CH}]$ profiles using large reaction mechanism. Checks carried out to show $[\mathrm{CH}]$ profile sensitive to $k$.

\section{Preferred Values}

$k=2.0 \cdot 10^{-10} \mathrm{~cm}^{3}$ molecule ${ }^{-1} \mathrm{~s}^{-1}$ over the range 300 $4000 \mathrm{~K}$.

\section{Reliability}

$\Delta \log k= \pm 0.25$ over the range $300-4000 \mathrm{~K}$.

\section{Comments on Preferred Values}

The studies at low temperatures ${ }^{1-6}$ are in good agreement. All of them have used the pulsed laser photolysis of slowly flowing gas mixtures but with a variety of $\mathrm{CH}$ sources. There is agreement between results whether obtained by monitoring $\mathrm{NH}$ production or from measuring $[\mathrm{CH}]$ decay.
In the only high temperature study ${ }^{7}$, the value of $k$ obtained agrees well with the low temperature measurements. There are no published measurements in the intermcdiatc tcmpcrature range but unpublished results of Casleton and Morgantown are quoted in Ref. 7 as giving $k=1.5 \cdot 10^{-10} \mathrm{~cm}^{3}$ molecule $\mathrm{e}^{-1} \mathrm{~s}^{-1}$ over the range $300-1500 \mathrm{~K}$. As might be expected from such a fast reaction there is no evidence for an appreciable temperature coefficient for $k$.

As well as the three listed, there are a number of other possible exothermic reaction channels leading to $\mathrm{H}+\mathrm{NCO}, \mathrm{N}$ $+\mathrm{HCO}, \mathrm{H}+\mathrm{CNO}$. Objections to all of these have been raised ${ }^{8}$ and the only experimental study ${ }^{7}$ has been aimed at seeking products from channels 1,2 or 3 . From the yicld of $\mathrm{NH}$ it was concluded that channel 1 contributes less than $10 \%$ to $k$ and measurements of the $\mathrm{OH}$ yield suggested that channel 2 was also a minor contributor (certainly less than $30 \%$ and likely to be less than 10\%). Attempts to confirm the predominence of channel 3 by measuring $O$ atom profiles was hindered by interfering reactions and experimental difficulties in the detection method. The assumption that reaction 3 is the main pathway therefore requires confirmation and no recommendation is made for the branching ratios.

\section{References}

${ }^{1}$ J.E. Butler, J.W. Fleming, L.P. Goss, and M.C. Lin, Am. Chem. Soc. ACS Symp. Ser. 134, 397 (1980).

${ }^{2}$ J.E. Butler, J.W. Fleming, L.P. Goss, and M.C. Lin, Chem. Phys. 56, 355 (1981).

${ }^{3}$ M.R. Berman, J.W. Fleming, A.B. Harvey, and M.C. Lin, 19th Symp Int Combust., 73 (1982).

${ }^{4}$ S.S. Wagal, T. Carrington, S.V. Filseth, and C.M. Sadowski, Chem. Phys. 69, 61 (1982).

${ }^{5}$ D.A. Lichtin, M.R. Berman, and M.C. Lin, Bull. Soc. Chim. Belg. 92, 656 (1983).

${ }^{6}$ D.A. Lichtin, M.R. Berman, and M.C. Lin, Chem. Phys. Lett. 108, 18 (1984).

${ }^{7}$ A.J. Dean, R.K. Hanson, and C.T. Bowman, J. Phys. Chem. 95, 3180 (1991). ${ }^{8}$ J.A. Miller and C.T. Bowman, Prog. Energy Combust. Sci. 15, 287 (1989). 
${ }^{1} \mathrm{CH}_{2}+\mathrm{NO} \rightarrow$ Products

Rate Coefficient Data

\begin{tabular}{|c|c|c|c|}
\hline$k / \mathrm{cm}^{3}$ molecule ${ }^{-1} \mathrm{~s}^{-1}$ & $T / \mathbf{K}$ & References & Comments \\
\hline \multicolumn{4}{|c|}{ Rate Coefficient Measurements } \\
\hline$<4 \cdot 10^{-11}$ & 300 & Laufer and Bass, $1974^{1}$ & (a) \\
\hline $1.6 \cdot 10^{-10}$ & 300 & Langford, Petek, and Moore, $1983^{2}$ & (b) \\
\hline $1.65 \cdot 10^{-10}$ & $295-431$ & Biggs et al., $1991^{3}$ & (c) \\
\hline $1.63 \cdot 10^{-10}$ & $296-645$ & Hancock and Heal, $1992^{4}$ & (d) \\
\hline
\end{tabular}

\section{Comments}

(a) Flash photolysis of ketene with product analysis by G.C. Rate constants obtained from the decrease in yield of $\mathrm{C}_{2} \mathrm{H}_{2}$ with increasing amounts of NO.

(b) ${ }^{1} \mathrm{CH}_{2}$ produced from the photolysis of ketene at $308 \mathrm{~nm}$. $\left[{ }^{1} \mathrm{CH}_{2}\right]$ monitored in absorption between 590 and $610 \mathrm{~nm}$.

(c) Laser flash photolysis of ketene at $308 \mathrm{~nm}$. $\left[{ }^{1} \mathrm{CH}_{2}\right]$ monitored using $\mathrm{cw}$ resonance absorption at $590.5 \mathrm{~nm}$.

(d) As in (c) but quartz cell used instead of stainless steel.

\section{Preferred Values}

$k=1.6 \cdot 10^{-10} \mathrm{~cm}^{3}$ molecule $\mathrm{e}^{-1} \mathrm{~s}^{-1}$ over range $290-650 \mathrm{~K}$.

\section{Comments on Preferred Values}

All of the available data are in good agreement. By comparing the temperature coefficient of physical quenching (e.g. with Ar) with the lack of any such effect on $k$ of varying [NO], Hancock and $\mathrm{Heal}^{4}$ conclude that reactive quenching must be important and perhaps be the predominant means of ${ }^{\prime} \mathrm{CH}_{2}$ removal.

\section{References}

${ }^{1}$ A.H. Laufer and A.M. Bass, J. Phys. Chem. 78, 1344 (1974).

${ }^{2}$ A.O. Langford, H. Petek, and C.B. Moore, J. Chem. Phys. 78, 6650 (1983).

${ }^{3}$ P. Biggs, G. Hancock, M.R. Heal, D.J. McGarvey, and A.D. Parr, Chem. Phys. Lett. 180, 533 (1991).

${ }^{4}$ G. Hancock and M.R. Heal, J. Phys. Chem. 96, 10316 (1992).

\section{Reliability}

$\Delta \log k= \pm 0.2$ over range $290-650 \mathrm{~K}$.

$$
\begin{aligned}
{ }^{1} \mathrm{CH}_{2}+\mathrm{C}_{2} \mathrm{H}_{4}(+\mathrm{M}) & \rightarrow \mathrm{C}_{3} \mathrm{H}_{6}(+\mathrm{M}) \\
& \rightarrow{ }^{3} \mathrm{CH}_{2}+\mathrm{C}_{2} \mathrm{H}_{4}
\end{aligned}
$$

$\Delta H_{298}^{\circ}(2)=-37.7 \mathrm{~kJ} \mathrm{~mol}^{-1}$

Thermodynamic Data

$\Delta H_{298}^{\circ}(1)=-457 \mathrm{~kJ} \mathrm{~mol}^{-1}$

$\Delta S_{298}^{\circ}(1)=150 \mathrm{~J} \mathrm{~K}^{-1} \mathrm{~mol}^{-1}$

$\Delta S_{298}^{\circ}(2)=6.8 \mathrm{~J} \mathrm{~K}^{-1} \mathrm{~mol}^{-1}$

$K p(1)=25.7 T^{0.57} \exp (+55400 / T) \mathrm{atm}^{-1}$

\begin{tabular}{|c|c|c|c|}
\hline$k / \mathrm{cm}^{3}$ molecule ${ }^{-1} \mathrm{~s}^{-1}$ & $T / \mathrm{K}$ & References & Comments \\
\hline \multicolumn{4}{|c|}{ Rate Coefficient Measurements } \\
\hline $1.5 \cdot 10^{- \text {in }}$ & 295 & Langford, Perek, and Moore, $1983^{1}$ & (a) \\
\hline$k_{1}=2.1 \cdot 10^{-10}$ & 295 & Canosa-Mas, Frey, and Walsh, $1985^{2}$ & (b) \\
\hline$k_{2} / k=0.13$ & 295 & Bohland, Temps, and Wagner, $1985^{3}$ & (c) \\
\hline $2.3 \cdot 10^{-10}$ & 298 & Hack et al., $1989^{4}$ & (d) \\
\hline$k_{2} / k=0.2$ & 298 & & \\
\hline \multicolumn{4}{|l|}{ Reviews and Evaluations } \\
\hline $1.5 \cdot 10^{-10}$ & $300-1000$ & CEC, $1992^{5}$ & (e) \\
\hline$k_{2} / k=0.13$ & & & \\
\hline
\end{tabular}

$K p(2)=2.17 T^{0.016} \exp (+4520 / T)$

Rate Coefficient Data $\left(k=k_{1}+k_{2}\right)$ 


\section{Comments}

(a) Excimer laser flash photolysis of ketene $(308 \mathrm{~nm})$ followed by time resolved detection of ${ }^{1} \mathrm{CH}_{2}$ by $\mathrm{cw}$ dye laser absorption.

(b) Excimer laser flash photolysis of ketene $(308 \mathrm{~nm})$ in the presence of $\mathrm{Ar}$ and $\mathrm{C}_{2} \mathrm{H}_{4}$. Products detected by GC. Pressure approximately. 400 Torr. Product distribution simulated by numerical integration. Assumed same rate coefficient for ${ }^{1} \mathrm{CH}_{2}+\mathrm{C}_{2} \mathrm{H}_{4}$ and ${ }^{1} \mathrm{CH}_{2}+\mathrm{CH}_{2} \mathrm{CO}$.

(c) Excimer laser flash photolysis of ketene (308 nm). LMR detection of ${ }^{3} \mathrm{CH}_{2}$. Assumed zero triplet quantum yield at $308 \mathrm{~nm}$. The $k_{2} / k$ value represents an upper limit.

(d) Puised laser photolysis of ketene, with LIF monitoring of ${ }^{1} \mathrm{CH}_{2}$ and $\mathrm{LMR}$ monitoring of ${ }^{3} \mathrm{CH}_{2}$.

(e) Value of Langford et al. ${ }^{1}$ accepted.

\section{Preferred Values}

$k=2.0 \cdot 10^{-10} \mathrm{~cm}^{3}$ molecule $\mathrm{e}^{-1} \mathrm{~s}^{-1}$ over range $300-1000 \mathrm{~K}$. $k_{2} / k=0.2$.
Reliability

$\Delta \log k= \pm 0.5$ at $1000 \mathrm{~K}$ reducing to \pm 0.2 at $300 \mathrm{~K}$.

$\Delta\left(k_{2} / k\right)= \pm 0.1$.

Comments on Preferred Values

There is excellent agreement between the two direct determinations of $k^{1,4}$; the recommendation is a rounded mean of these two values. Hack et al.$^{4}$ used a similar technique to Bohland et al..$^{3}$ to determine $k_{2} / k_{1}$, but with an improved method of data analysis; the value of Hack et al.$^{4}$ has been adopted. At higher temperatures the fall-off effects will cause the rate constant to decrease.

\section{References}

${ }^{1}$ A.O. Langford, H. Petek, and C.B. Moore, J. Chem. Phys. 78, 6650 (1983). ${ }^{2}$ C.E. Canosa-Mas, H.M. Frey, and R. Walsh, J. Chem. Soc., Faraday Trans. 2 81, 283 (1985).

${ }^{3}$ T Bohland, F. Temps, and H.Gg. Wagner, Ber. Bunsenges. Phys. Chem 80 1013 (1985).

${ }^{4}$ W. Hack, M. Koch, R. Wasgener, and H.Gg. Wagner, Ber. Bunsenges. Phys. Chem. 93, 165 (1989).

${ }^{5} \mathrm{CEC}, 1992$ (see references in Introduction)

$$
\begin{aligned}
{ }^{3} \mathrm{CH}_{2}+\mathrm{O}_{2} & \rightarrow \mathrm{CO}+\mathrm{OH}+\mathrm{H} \\
& \rightarrow \mathrm{CO}_{2}+\mathrm{H}_{2} \\
& \rightarrow \mathrm{CO}+\mathrm{H}_{2} \mathrm{O} \\
& \rightarrow \mathrm{CH}_{2} \mathrm{O}+\mathrm{O} \\
& \rightarrow \mathrm{CO}_{2}+2 \mathrm{H}
\end{aligned}
$$

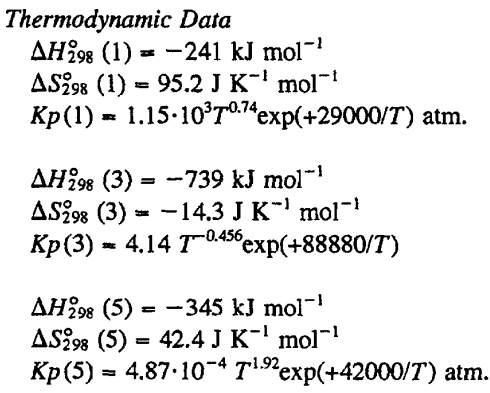

Rate Coefficient Data $\left(k=k_{1}+k_{2}+k_{3}+k_{4}+k_{5}\right)$

\begin{tabular}{lccc}
\hline \hline$k / \mathrm{cm}^{3}$ molecule $\mathrm{s}^{-1}$ & $T / \mathrm{K}$ & References & Comments \\
\hline $\begin{array}{l}\text { Rate Cnefficient Measurements } \\
3.24 \cdot 10^{-12}\end{array}$ & 293 & Darwin et al., 1989 & (a) \\
$\begin{array}{l}\text { Reviews and Evaluations } \\
4.1 \cdot 10^{-11} \exp (-750 / T)\end{array}$ & $300-1000$ & C.F., $1992^{2}$ & (b) \\
\hline
\end{tabular}

\section{Comments}

(a) Laser flash kinetic spectrometric study with photolysis of ketene at $351 \mathrm{~nm}$ used as the source of ${ }^{3} \mathrm{CH}_{2}$ which was detected at $883.3 \mathrm{~cm}^{-1}$ by $\mathrm{cw}$ diode laser absorption.

(b) Review of all studies up to 1989. Recommended $E / R$ based on Ref. 3 and combined with the room temperature measurement of Bohland et al. ${ }^{4}$ to give $A$ factor.

\section{Preferred Values}

$k=4.1 \cdot 10^{-11} \exp (-750 / T) \mathrm{cm}^{3}$ molecule ${ }^{-1} \mathrm{~s}^{-1}$ over range $300-1000 \mathrm{~K}$

Reliability

$\Delta \log k= \pm 0.5$ at $1000 \mathrm{~K}$ reducing to \pm 0.1 at $300 \mathrm{~K}$. 


\section{Comments on Preferred Values}

The direct measurement of Darwin et al.$^{1}$ confirms that of Bohland et al ${ }^{4}$. This value has been adopted together with the temperature dependence of Vinckier and Debruyn ${ }^{3}$. The limited information on the channel efficiencies was discussed in the previous evaluation ${ }^{2}$.

\section{References}

'D.C. Darwin, A.T. Young, H.S. Johnston, and C.B. Moore, J. Phys. Chem. 93, 1074 (1989).

${ }^{2} \mathrm{CEC}, 1992$ (sce references in Introduction).

${ }^{3}$ C. Vinckier and W. Debruyn, J. Phys. Chem. 83, 2057 (1979).

${ }^{4} \mathrm{~T}$. Bohland, F.Temps, and H.Gg. Wagner, Ber. Bunsenges. Phys. Chem. 88, 1222 (1984).

$$
\mathrm{CH}_{3}+\mathrm{CO}(+\mathrm{M}) \rightarrow \mathrm{CH}_{3} \mathrm{CO}(+\mathrm{M})
$$

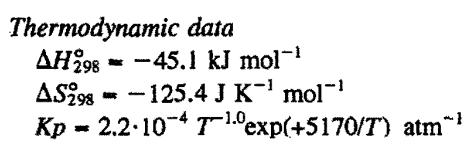

Rate Coefficient Data

\begin{tabular}{|c|c|c|c|c|}
\hline $\mathrm{k} / \mathrm{cm}^{3}$ molecule $^{-1} \mathrm{~s}^{-1}$ & $T / \mathrm{K}$ & {$[\mathrm{M}] /$ molecule $\mathrm{cm}^{-3}$} & References & Comments \\
\hline \multicolumn{5}{|c|}{ Rate Coefficient Measurements } \\
\hline \multicolumn{5}{|l|}{ Low Pressure Range } \\
\hline$[\mathrm{CO}] 5.7 \cdot 10^{-36}$ & 303 & $(3-24) \cdot 10^{18}$ & Anastasi and Maw, $1982^{1}$ & (a) \\
\hline$[\mathrm{CO}] 10.7 \cdot 10^{-36}$ & 343 & & & \\
\hline \multicolumn{5}{|l|}{ Intermodiate Fall-Off Range } \\
\hline $6.8 \cdot 10^{-15} \exp (-1964 / T)$ & 300 & $\begin{array}{l}(2.4-7.2) \cdot 10^{18} \\
\left(\left(\mathrm{CH}_{3}\right)_{2} \mathrm{~N}_{2}, \mathrm{CO},\left(\mathrm{CH}_{3}\right)_{4} \mathrm{C}\right)\end{array}$ & Kerr and Calvert, $1965^{2}$ & (b) \\
\hline $1.0 \cdot 10^{-18}$ & 273 & $\begin{array}{l}2.9 \cdot 10^{18} \\
\left(\left(\mathrm{CH}_{3}\right)_{2} \mathrm{~N}_{2}, \mathrm{CO}, \mathrm{SF}_{6}\right)\end{array}$ & Watkins and Word, $1979^{3}$ & (c) \\
\hline $1.8 \cdot 10^{-18}$ & & $12 \cdot 10^{18}$ & & \\
\hline $3.6 \cdot 10^{-18}$ & & $96 \cdot 10^{18}$ & & \\
\hline $1.8 \cdot 10^{-18}$ & 298 & $3.2 \cdot 10^{18}(\mathrm{CO})$ & Parkes, $1981^{4}$ & (d) \\
\hline $6 \cdot 10^{-18}$ & & $24 \cdot 10^{18}$ & & \\
\hline $3.6 \cdot 10^{-18}$ & 303 & $3.0 \cdot 10^{18}(\mathrm{CO})$ & Anastasi and Maw, $1982^{1}$ & (a) \\
\hline $5.6 \cdot 10^{-18}$ & & $1.6 \cdot 10^{19}$ & & \\
\hline $7.9 \cdot 10^{-18}$ & & $2.4 \cdot 10^{19}$ & & \\
\hline $6.1-10^{-18}$ & 343 & $3.0 \cdot 10^{18}$ & & \\
\hline $1.6 \cdot 10^{-17}$ & & $1.6 \cdot 10^{19}$ & & \\
\hline $1.7 \cdot 10^{-17}$ & & $2.1 \cdot 10^{19}$ & & \\
\hline \multicolumn{5}{|l|}{ High Pressure Range } \\
\hline $2.64 \cdot 10^{-13} \exp (-3010 / T)$ & $260-413$ & $\begin{array}{l}(1.8-10) \cdot 10^{19} \\
\left(\left(\mathrm{CH}_{3}\right)_{2} \mathrm{~N}_{2}, \mathrm{CO}, \mathrm{SF}_{6}\right)\end{array}$ & Watkins and Word, $1974^{3}$ & (c) \\
\hline$>1 \cdot 10^{-17}$ & 298 & & Parkes, $1981^{4}$ & (d) \\
\hline $1.6 \cdot 10^{-17}$ & 303 & $(3-24) \cdot 10^{18}(\mathrm{CO})$ & Anastasi and Maw, $1982^{1}$ & (a) \\
\hline $5.7 \cdot 10^{-17}$ & 343 & & & \\
\hline \multicolumn{5}{|l|}{ Reviews and Evaluations } \\
\hline $\begin{aligned} \lambda_{0} & =\left[N_{2}\right] 4.0 \cdot 10^{-10} T^{-7.56} \\
& \exp (-5490 / T)\end{aligned}$ & \multicolumn{2}{|l|}{$300-1700$} & Tsang and Hampson, $1986^{5}$ & (c) \\
\hline \multicolumn{3}{|c|}{$k_{\infty}=7.64 \cdot 10^{-13} \exp (-3073 / T) 260-507$} & Bencsura et al., $1992^{6}$ & (f) \\
\hline
\end{tabular}

\section{Comments}

(a) Molecular modulation technique; photolysis of azomethane/CO mixtures. UV absorption detection of $\mathrm{CH}_{3}$ and $\mathrm{CH}_{3} \mathrm{CO}$.

(b) Photolysis of azomethane at $366 \mathrm{~nm}$ in the presence of $\mathrm{CO}$ and $\mathrm{CH}_{3} \mathrm{CHO}$.

(c) Photolysis of azomethane in the presence of $\mathrm{CO}$ and $\mathrm{SF}_{6}$. Product analysis by gas chromotography. Rate coefficients determined relative to the rate coefficient of the reaction $\mathrm{CH}_{3}+\mathrm{CH}_{3}$ for which a value of $3.65 \cdot 10^{-11} \mathrm{~cm}^{3}$ molecule ${ }^{-1} \mathrm{~s}^{-1}$, independent of temperature was used.
Lindemann-Hinselwood extrapolation used to obtain $k_{\infty}$.

(d) Molecular modulation technique; photolysis of azomethane/CO mixtures. UV absorption detection of $\mathrm{CH}_{3}$ and $\mathrm{CH}_{3} \mathrm{CO}$ at 214 and $223 \mathrm{~nm}$ respectively. $\sigma\left(\mathrm{CH}_{3} \mathrm{CO}\right)=1.0 \cdot 10^{-17} \mathrm{~cm}^{3}$ molecule ${ }^{-1}$ at $223 \mathrm{~nm}$ was used.

(e) Based on data of references 1, 3 and 4 and an RRKM treatment.

(f) Study of the pyrolysis of $\mathrm{CH}_{3} \mathrm{CO}$. $\mathrm{CH}_{3} \mathrm{CO}$ generated by photolysis of 2-butanone and detected by mass spectrometry. $k_{\infty}$ was theoretically estimated. 


\section{Preferred Values}

$k_{\infty}=8.4 \cdot 10^{-13} \exp (-3455 / T) \mathrm{s}^{-1}$ over range $300-500 \mathrm{~K}$. $k_{\mathrm{o}}=[\mathrm{He}] 3.0 \cdot 10^{-34} \mathrm{exp}(-1910 / T) \mathrm{s}^{-1}$ over range 400 $500 \mathrm{~K}$.

$k_{\mathrm{o}}=\left[\mathrm{N}_{2}\right] 4.2 \cdot 10^{-36} \mathrm{~s}^{-1}$ over range $300-350 \mathrm{~K}$.

$F_{\mathrm{c}}=0.5$ for $\mathrm{M}=\mathrm{He}$ over range $400-500 \mathrm{~K}$.

$F_{\mathrm{c}}=0.6$ for $\mathrm{M}=\mathrm{N}_{2}$ over range $300-350 \mathrm{~K}$.

\section{Reliability}

$\Delta \log k_{\infty}= \pm 0.5$ over range $300-500 \mathrm{~K}$.

$\Delta \log k_{0}= \pm 0.2$ for $\mathrm{M}=\mathrm{He}$ over range $400-500 \mathrm{~K}$.

$\Delta \log k_{0}= \pm 0.5$ for $\mathrm{M}=\mathrm{N}_{2}$ over range $300-350 \mathrm{~K}$.

$\Delta F_{\mathrm{c}}= \pm 0.1$ for $\mathrm{M}=\mathrm{He}$ over range $400-500 \mathrm{~K}$.

$\Delta F_{\mathrm{c}}= \pm 0.1$ for $\mathrm{M}=\mathrm{N}_{2}$ over range $300-350 \mathrm{~K}$.

\section{Comments on Preferred Values}

The preferred rate coefficients $k_{\infty}$ and $k_{\mathrm{o}}$ were derived from the preferred dissociation rate coefficients and $K_{c}$. The value of $K_{\mathrm{c}}$ of Bencsura et $a l .{ }^{6}$ was adopted. In deriving the expressions for $k_{0}$ the values of $k_{0}\left(\mathrm{M}=\mathrm{N}_{2}\right)$ were assumed to be equal to $k_{\circ}(\mathrm{M}=\mathrm{CO})$. Figures 1 and 2 show the temperature dependence of the limiting rate coefficients. The analysis of the $k_{\mathrm{o}}$ values with the theory of Ref. 7 yields a $\beta_{\mathrm{c}}=0.11$ at $420 \mathrm{~K}$ and 0.093 at $500 \mathrm{~K}$ for $\mathrm{M}=$ He. Experimental and fitted fall-off curves ${ }^{8}$ are depicted in Fig. 3. More direct determinations of the kinetics of this reaction are required.

\section{References}

${ }^{1}$ C. Anastasi and P.R. Maw, J. Chem. Soc., Faraday Trans. 1 78, 2423 (1982). ${ }^{2}$ J.A. Kerr and J.G. Calvert, J. Phys. Chem. 69, 1022 (1965).

${ }^{3}$ K.W. Watkins and W.W. Word, Int. J. Chem. Kinet. 6, 855 (1975).

${ }^{4}$ D.A. Parkes, Chem. Phys. Lett. 77, 527 (1981).

${ }^{5}$ W. Tsang and R.F. Hampson, J. Phys. Chem. Ref. Data, 15, 1087 (1986).

${ }^{6}$ A. Bencsura, V.D. Kuyazer, I.R. Slagle, D. Gutman, and W. Tsang, Ber. Bunsenges. Phys. Chem. 96, 1338 (1992).

${ }^{7}$ J. Troe, J. Chem. Phys. 66, 4758 (1977).

${ }^{8}$ J. Troe, J. Phys. Chem. 83, 114 (1979).

$$
\mathrm{CH}_{3}+\mathrm{CO}+\mathrm{M} \rightarrow \mathrm{CH}_{3} \mathrm{CO}+\mathrm{M}
$$

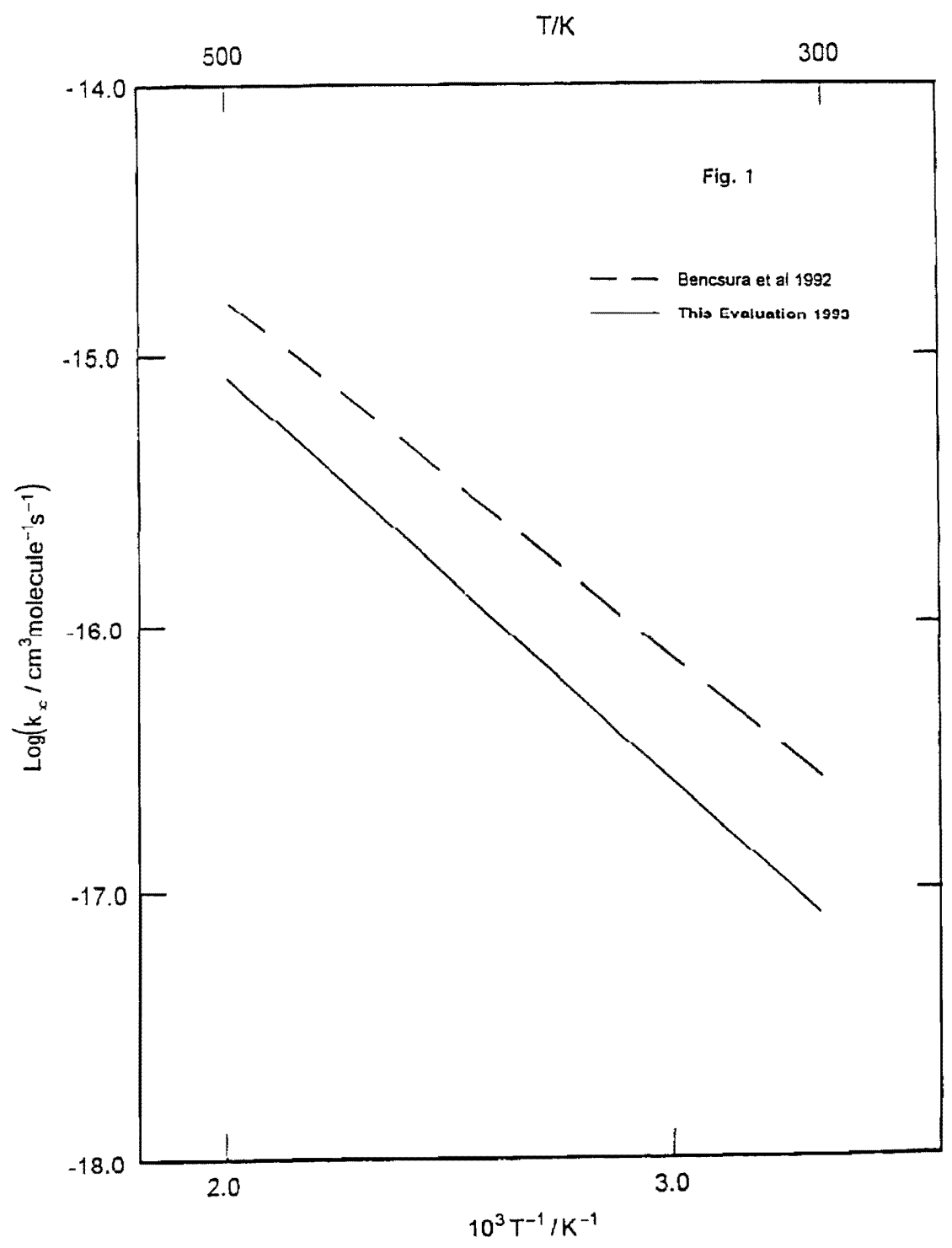


$\mathrm{CH}_{3}+\mathrm{CO}+\mathrm{M} \rightarrow \mathrm{CH}_{3} \mathrm{CO}+\mathrm{M}$
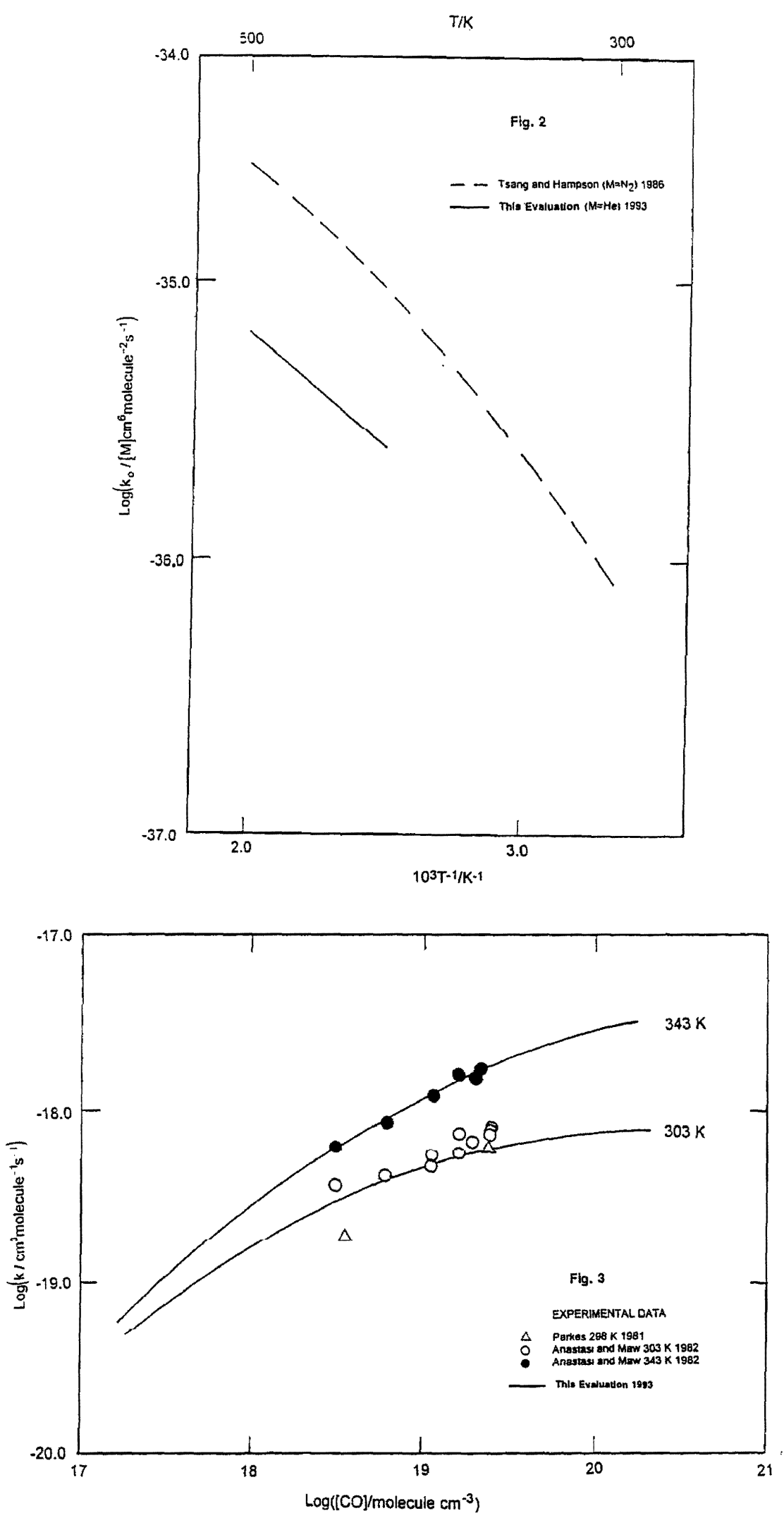


\section{$\mathrm{CH}_{3} \mathrm{CO}(+\mathrm{M}) \rightarrow \mathrm{CH}_{3}+\mathrm{CO}(+\mathrm{M})$}

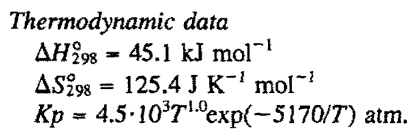

Rate Coefficient Data

\begin{tabular}{|c|c|c|c|c|}
\hline$k / \mathrm{s}^{-1}$ & $T / \mathrm{K}$ & {$[\mathrm{M}] /$ molecule $\mathrm{cm}^{-3}$} & References & Comments \\
\hline \multicolumn{5}{|l|}{ Rate Coefficient Measurements } \\
\hline \multicolumn{5}{|l|}{ Low Pressure Range } \\
\hline$[\mathrm{CO}] 3.1 \cdot 10^{-17}$ & 343 & $(3-21) \cdot 10^{18}$ & Anastasi and Maw, $1982^{1}$ & (a) \\
\hline$[\mathrm{He}] 6.7 \cdot 10^{-9} \exp (-6921 / T)$ & $420-500$ & $(3-18) \cdot 10^{16}$ & Bencsura et al., $1992^{2}$ & (b) \\
\hline \multicolumn{5}{|l|}{ Intermediate Fall-Off Range } \\
\hline 1.71 & 325.7 & $1.8 \cdot 10^{17}$ & Frey and Vinall, $1973^{3}$ & (c) \\
\hline 5.17 & & $6.0 \cdot 10^{17}$ & & \\
\hline 7.36 & & $10.3 \cdot 10^{17}$ & & \\
\hline $5.0 \cdot 10^{2}$ & 506.7 & $6.6 \cdot 10^{17}$ & Szirovicza and Walsh, $1979^{4}$ & (d) \\
\hline $31 \cdot 10^{2}$ & & $67.1 \cdot 10^{17}$ & & \\
\hline $51 \cdot 10^{2}$ & & $136 \cdot 10^{17}$ & & \\
\hline 13 & 323 & $1.1 \cdot 10^{19}(\mathrm{CO})$ & Anastasi and Maw, $1982^{1}$ & (a) \\
\hline 16 & & $1.7 \cdot 10^{19}$ & & \\
\hline 30 & & $2.2 \cdot 10^{19}$ & & \\
\hline 31 & 343 & $0.3 \cdot 10^{19}$ & & \\
\hline 40 & & $1.1 \cdot 10^{19}$ & & \\
\hline 52 & & $2.1 \cdot 10^{19}$ & & \\
\hline 23 & 353 & $6.8 \cdot 10^{18}(\mathrm{Ar})$ & Baldwin et al., $1987^{5}$ & (e) \\
\hline 52 & & $20 \cdot 10^{18}$ & & \\
\hline 100 & & $49 \cdot 10^{18}$ & & \\
\hline $6.06 \cdot 10^{1}$ & 440 & $6,0 \cdot 10^{16}(\mathrm{He})$ & Bencsura et al., $1992^{2}$ & (b) \\
\hline $1.62 \cdot 10^{2}$ & & $18 \cdot 10^{16}$ & & \\
\hline $1.31 \cdot 10^{2}$ & 460 & $6.0 \cdot 10^{16}(\mathrm{He})$ & & \\
\hline $3.55 \cdot 10^{2}$ & & $18 \cdot 10^{16}$ & & \\
\hline $1.98 \cdot 10^{2}$ & 500 & $3.0 \cdot 10^{16}(\mathrm{He})$ & & \\
\hline $3.88 \cdot 10^{2}$ & & $6.0 \cdot 10^{16}$ & & \\
\hline \multicolumn{5}{|l|}{ High Pressure Range } \\
\hline $1.6 \cdot 10^{13} \exp (-8660 / T)$ & $260-413$ & $(1.8-8) \cdot 10^{19}$ & Watkins and Word, $1974^{6}$ & (f) \\
\hline 186 & 343 & $(3-21) \cdot 10^{18}$ & Anastasi and Maw, $1982^{1}$ & (a) \\
\hline $2.0 \cdot 10^{13} \exp (-8806 / T)$ & $332-478$ & $(6.8-49) \cdot 10^{18}$ & Baldwin et al., $1987^{5}$ & (e) \\
\hline \multicolumn{5}{|l|}{ Reviews and Evaluations } \\
\hline$k_{0}=[C O] 2.0 \cdot 10^{-9} \exp (-6302 / T)$ & $300-500$ & & Warnatz, $1984^{7}$ & (g) \\
\hline$k_{\infty}=3.0 \cdot 10^{12} \exp (-8420 / T)$ & $300-500$ & & & \\
\hline$k_{0}=\left[\mathrm{N}_{2}\right] 1.4 \cdot 10^{19} \mathrm{~T}^{-8.62}$ & $300-2000$ & & Tsang and Hampson, $1986^{8}$ & (h) \\
\hline $\exp (-11284 / T)$ & & & & \\
\hline$k_{\infty}=2.5 \cdot 10^{13} \exp (-8244 / T)$ & $260-507$ & & Bencsura et al., $1992^{2}$ & (b) \\
\hline
\end{tabular}

\section{Comments}

(a) Modulated photolysis of azomethane in the presence of excess of $\mathrm{CO} ; \mathrm{CH}_{3}$ and $\mathrm{CH}_{3} \mathrm{CO}$ detected by molecular modulation-UV absorption at 216 and $223 \mathrm{~nm}$ respectively. An empirical procedure based on Kassel integrals was used to evaluate $k_{\infty}$ from the measurements at $343 \mathrm{~K}$.

(b) Laser photolysis of 2-butanone at $248 \mathrm{~nm}$ was used to generate $\mathrm{CH}_{3} \mathrm{CO}$ radicals. Decay monitored by time-resolved mass spectrometry. Theoretical analysis using a master equation formalism. The experiments were fitted using a threshold energy of $65.3 \mathrm{~kJ} \mathrm{~mol}^{-1}$. $k_{\infty}$ was theoretically evaluated.

(c) Photolysis of 3,3-dimethylbutan-2-one at $313 \mathrm{~nm}$. Analysis of the products by gas chromotography. Mechanism with 15 rcactions. Rate coefficients determined relative to the reaction $\mathrm{CH}_{3} \mathrm{CO}+\mathrm{CH}_{3} \mathrm{CO} \rightarrow \mathrm{CH}_{3} \mathrm{COCOCH}_{3}$ for which a value $3.7 \cdot 10^{-11} \mathrm{~cm}^{3}$ molecule ${ }^{-1} \mathrm{~s}^{-1}$ was assumed.

(d) $\mathrm{CH}_{3} \mathrm{CO}$ formed as secondary product of the reactions of HI with ketene at $498-525 \mathrm{~K}$. Products detected by chromatography. RRKM analysis of the thermal decomposition of $\mathrm{CH}_{3} \mathrm{CO}$.

(e) Photolysis of methyl cyclobutyl ketone at $313 \mathrm{~nm}$ (steady state) and $308 \mathrm{~nm}$ (laser photolysis) in Ar. Product analysis by gas chromatography. $k_{\infty}$ obtained by modelling of the mechanism and RRKM theory using step sizes for deactivation of $250 \mathrm{~cm}^{-1}$. Rate coefficients depend on $k\left(\mathrm{CH}_{3}+\mathrm{CH}_{3}\right)$ and also $k\left(\mathrm{CH}_{3} \mathrm{CO}+\mathrm{CH}_{3} \mathrm{CO}\right)$ for which values from Ref. 1 were used. 
(f) Photolysis of azomethane in the presence of $\mathrm{CO}$ diluted in $\mathrm{SF}_{6}$; product analysis by gas chromatography. The value of $k$ depends on the values of the rate coefficients for the reactions $\mathrm{CH}_{3}+\mathrm{CH}_{3}$ and $\mathrm{CH}_{3}+\mathrm{CH}_{3} \mathrm{CO}$. Short Lindemann-Hinshelwood extrapolation used to obtain $k_{\mathrm{w}}$.

(g) Review of literature prior to 1980.

(h) RRKM treatment of data in Refs. 1 and 5 using a step size of $450 \mathrm{~cm}^{-1}$.

\section{Preferred Values}

$k_{\infty}=2.8 \cdot 10^{13} \exp (-8630 / T) \mathrm{s}^{-1}$ over range $300-500 \mathrm{~K}$.

$k_{\mathrm{o}}=[\mathrm{He}] 1.0 \cdot 10^{-8} \exp (-7080 / T) \mathrm{s}^{-1}$ over range $400-500 \mathrm{~K}$.

$k_{\mathrm{o}}=[\mathrm{Ar}] 7.0 \cdot 10^{-18} \mathrm{~s}^{-1}$ at $353 \mathrm{~K}$.

$F_{\mathrm{c}}=0.5$ for $\mathrm{M}=\mathrm{He}$ over range $400-500 \mathrm{~K}$.

\author{
Reliability \\ $\Delta \operatorname{lng} k_{\infty}= \pm 0.5$ over range $300-500 \mathrm{~K}$. \\ $\Delta \log k_{\mathrm{o}}= \pm 0.2$ for $\mathrm{M}=\mathrm{He}$ over range $400-500 \mathrm{~K}$. \\ $\Delta \log k_{\mathrm{o}}= \pm 0.4$ for $\mathrm{M}=\mathrm{Ar}$ at $353 \mathrm{~K}$ \\ $\Delta F_{\mathrm{c}}= \pm 0.1$ over range $400-500 \mathrm{~K}$.
}

\section{Comments on Preferred Values}

The $k_{\infty}$ value adopted is based on the results of Refs. 1, 5 and 6 . In order to reconcile the dissociation and the reconbination results we have taken for $k_{\infty}$ a value two times greater than the average value of the results from these references. The preferred $k_{\mathrm{o}}$ values for $\mathrm{M}=\mathrm{He}$ were derived from the fit to the data of Bencsura et al.$^{2}$. Figures 1 and 2 show the temperature dependence of the $k_{\infty}$ and $k_{\mathrm{o}}$ together with values from previous compilations. The equilibrium constant given above was evaluated using recent thermodynamic values for the $\mathrm{CH}_{3} \mathrm{CO}$ radical ${ }^{2,9}$. Figure 3 shows the fall-off curves constructed ${ }^{10}$ with the recommended $k_{\infty}$ and $k_{\mathrm{o}}$ values and the experimental data. An analysis of the $k_{\mathrm{o}}$ values in terms of the unimolecular rate theory from Ref. 11 and a threshold energy of $E_{o}=65.3$ $\mathrm{kJ} \mathrm{mol}^{-12}$ leads to collisional efficiencies for $\mathrm{M}=\mathrm{He}$ of 0.11 and 0.093 at $420 \mathrm{~K}$ and $500 \mathrm{~K}$ respectively. These values are consistent with an average energy transferred per collision of $60 \mathrm{~cm}^{-1}$.

\section{References}

${ }^{1}$ C. Anastasi and P.R. Maw, J. Chem. Soc., Faraday Trans. I 78, 2423 (1982).

${ }^{2}$ A. Bencsura, V.D. Kuyazev, I.R. Slagle, D. Gutman, and W. Tsang, Ber. Bunsenges. Phys. Chem. 96, 1338 (1992).

${ }^{3}$ H.M. Frey and I.C. Vinall, Int I. Chem. Kinet 5, 523 (1973).

${ }^{4}$ L. Szirovicza and R. Walsh, J. Chem. Soc., Faraday Trans. I 70, 33 (1974)

${ }^{5}$ P.Baldwin, C.E. Canosa-Mas, H.M. Frey, and R. Walsh, Int. J. Chem. Kinet. 19, 997 (1987).

${ }^{6}$ K.W. Watkins and W.W. Word, Int. J. Chem. Kinet. 6, 855 (1975).

${ }^{7}$ J. Warnatz in "Combustion Chemistry", Ed. W.C. Gardiner, Jr., SpringerVerlag, New York, 1984, p. 196.

${ }^{8}$ W. Tsang and R. F. Hampson, J. Phys. Chem. Ref. Data 15, 1087 (1986).

${ }^{9} \mathrm{I}$ T Niiranen, D. Gutman, and L.N. Krasnoperov, J. Phys. Chem. 96, 5881 (1992).

${ }^{10}$ J. Troe, J. Phys. Chem. 83, 114 (1979).

"J. Troe, J. Chem. Phys. 66, 4758 (1977) 


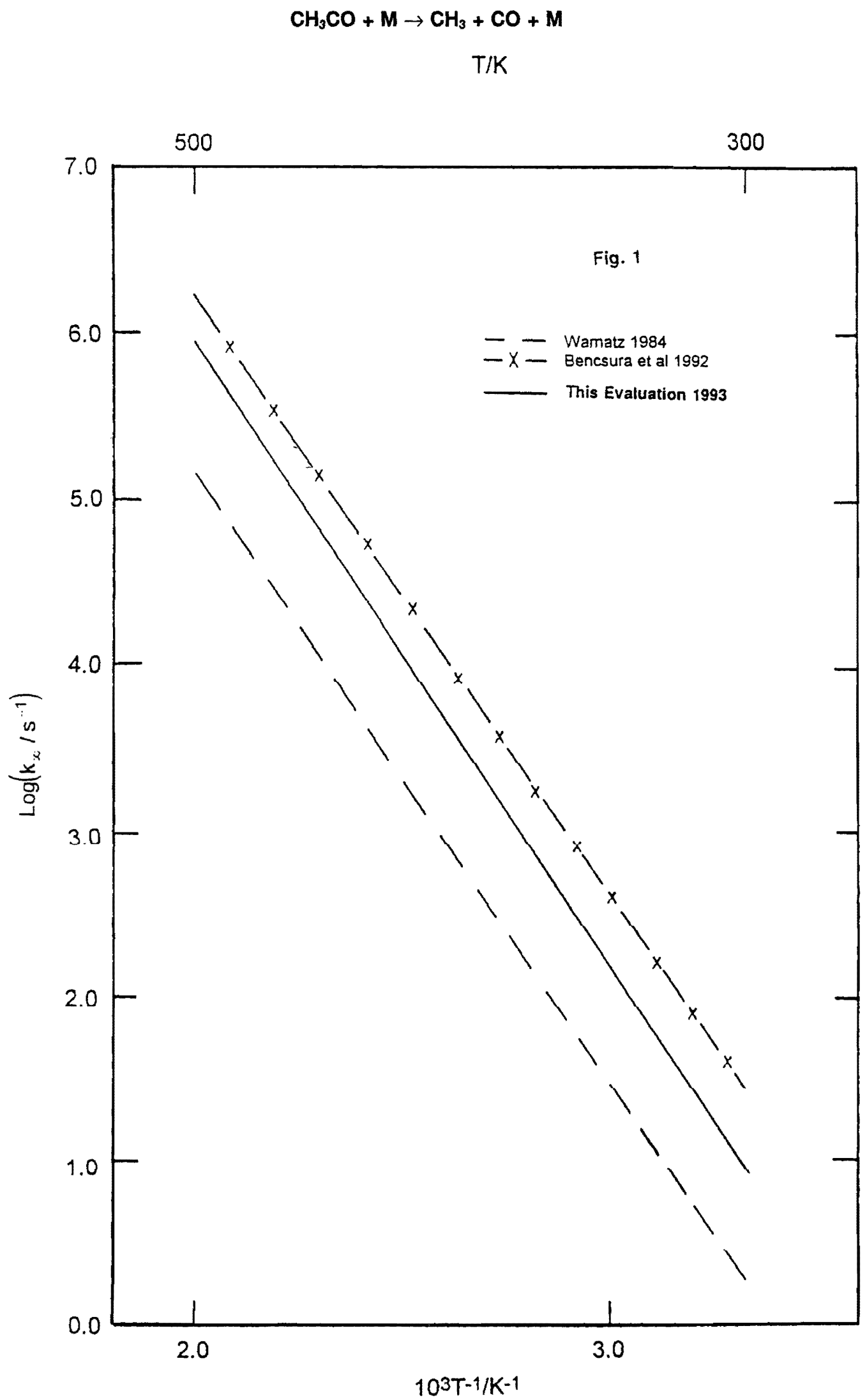


$\mathrm{CH}_{3} \mathrm{CO}+\mathrm{M} \rightarrow \mathrm{CH}_{3}+\mathrm{CO}+\mathrm{M}$
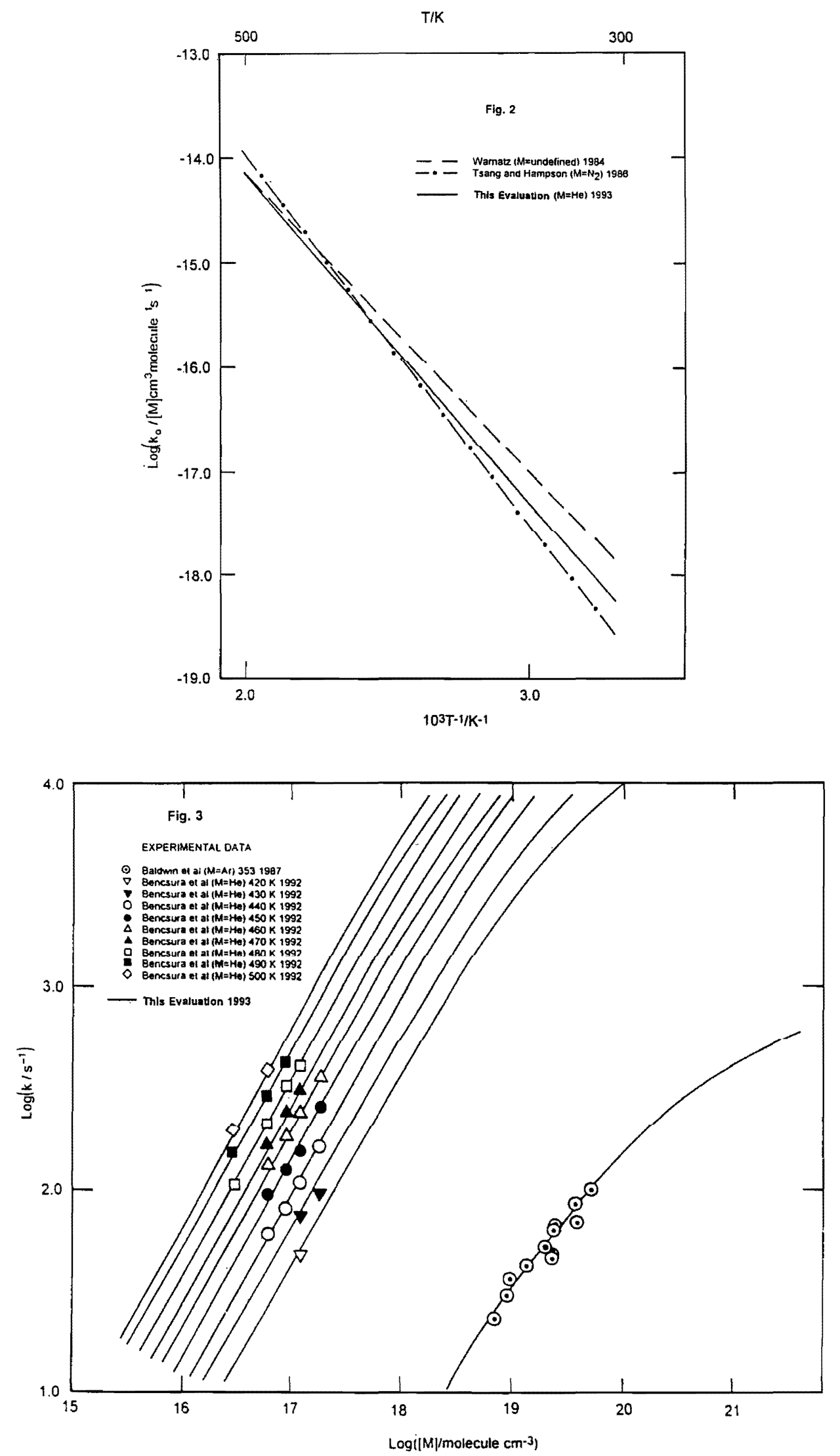
BAULCH ET AL.

\section{$\mathrm{CH}_{3}+\mathrm{CH}_{3}(+\mathrm{M}) \rightarrow \mathrm{C}_{2} \mathrm{H}_{6}(+\mathrm{M})$}

Thermodynamic dato

$\Delta H_{298}^{\circ}=-375 \mathrm{~kJ} \mathrm{~mol}^{-1}$

$\Delta S_{298}^{\circ}=-159 \mathrm{~J} \mathrm{~K}^{-1} \mathrm{~mol}^{-1}$

$K p=2.41 \cdot 10^{-10} T^{0.236} \exp (+45700 / T) \mathrm{atm}^{-1}$

Rate Coefficient Data

\begin{tabular}{|c|c|c|c|c|}
\hline$k / \mathrm{cm}^{3}$ molecule ${ }^{-1} \mathrm{~s}^{-1}$ & $T / \mathrm{K}$ & {$[\mathrm{M}] /$ molecule $\mathrm{cm}^{-3}$} & Reference & Comments \\
\hline \multicolumn{5}{|c|}{ Rate Coefficient Measurements } \\
\hline \multicolumn{5}{|c|}{ Intermediate Fall-Off Range } \\
\hline $4.0 \cdot 10^{-11}$ & $250-450$ & $(3.2-29.4) \cdot 10^{18}\left(\mathrm{~N}_{2}\right)$ & Parkes et al., $1976^{1}$ & (a) \\
\hline $5.5 \cdot 10^{11}$ & 295 & $1.6 \cdot 10^{18}\left(\mathrm{~N}_{2}\right)$ & Callear and Metcalfe, $1976^{2}$ & (b) \\
\hline $2.0 \cdot 10^{-11}$ & 450 & $6.4 \cdot 10^{16}(\mathrm{He})$ & Van den Berg, $1976^{3}$ & (c) \\
\hline $4.0 \cdot 10^{-11}$ & & $6.4 \cdot 10^{17}$ & & \\
\hline $3.2 \cdot 10^{-12}$ & 1350 & $1.2 \cdot 10^{18}(\Lambda r)$ & Glänzer ct al., 1976, $1977^{4}$ & (d) \\
\hline $1.3 \cdot 10^{-11}$ & & $1.5 \cdot 10^{19}$ & & \\
\hline $1.8 \cdot 10^{-11}$ & & $6.0 \cdot 10^{19}$ & & \\
\hline $1.6 \cdot 10^{-11}$ & & $1.2 \cdot 10^{20}$ & & \\
\hline $5.2 \cdot 10^{-11}$ & 295 & $2.5 \cdot 10^{19}\left(\mathrm{~N}_{2}\right)$ & Hochanadel et al., $1977^{5}$ & (e) \\
\hline $7.0 \cdot 10^{-12}$ & $640-818$ & $1: 0 \cdot 10^{17}(\mathrm{Ar})$ & Sepehrad et al., $1979^{6}$ & (f) \\
\hline $8.0 \cdot 10^{-12}$ & & $1.9 \cdot 10^{17}$ & & \\
\hline $2.4 \cdot 10^{-12}$ & $1700-1800$ & $1.4 \cdot 10^{18}(\mathrm{Ar})$ & Zaslonko and Smimov, $1979^{7}$ & (g) \\
\hline $5.3 \cdot 10^{-11}$ & 295 & $1.6 \cdot 10^{18}(n$-pentane $)$ & Adachi et al., $1980^{8}$ & (h) \\
\hline $1.1 \cdot 10^{-11}$ & 823 & $4.7 \cdot 10^{16}(n$-pentane $)$ & Pacey and Wimalasena, $1980^{\circ}$ & (i) \\
\hline $2.6 \cdot 10^{-11}$ & & $5.4 \cdot 10^{17}$ & & \\
\hline $6.0 \cdot 10^{-11}$ & & $3.9 \cdot 10^{18}$ & & \\
\hline $5.5 \cdot 10^{-11}$ & 296 & $2.5 \cdot 10^{19}(\mathrm{Ar})$ & Hippler et al., $1984^{10}$ & (j) \\
\hline $6.3 \cdot 10^{-11}$ & & $2.5 \cdot 10^{20}$ & & \\
\hline $5.0 \cdot 10^{-11}$ & & $5.2 \cdot 10^{21}$ & & \\
\hline $5.0 \cdot 10^{-11}$ & & $2.8 \cdot 10^{19}\left(\mathrm{~N}_{2}\right)$ & & \\
\hline $4.6 \cdot 10^{-11}$ & & $2.5 \cdot 10^{20}$ & & \\
\hline $2.6 \cdot 10^{-11}$ & & $2.5 \cdot 10^{21}$ & & \\
\hline $1.8 \cdot 10^{-11}$ & & $5.0 \cdot 10^{21}$ & & \\
\hline $5.2 \cdot 10^{-11}$ & 296 & $1.6 \cdot 10^{17}(\mathrm{Ar})$ & Macpherson et al., $1985^{11}$ & (k) \\
\hline $5.7 \cdot 10^{-11}$ & & $1.3 \cdot 10^{18}$ & & \\
\hline $6.0 \cdot 10^{-11}$ & & $1.6 \cdot 10^{19}$ & & \\
\hline $1.9 \cdot 10^{-11}$ & 577 & $8.4 \cdot 10^{16}(\mathrm{Ar})$ & & \\
\hline $3.5 \cdot 10^{-11}$ & & $1.1 \cdot 10^{18}$ & & \\
\hline $4.1 \cdot 10^{-11}$ & & $6.6 \cdot 10^{18}$ & & \\
\hline $3.8 \cdot 10^{-11}$ & 302 & $1.3 \cdot 10^{17}\left(\mathrm{~N}_{2}\right)$ & Arthur, $1986^{12}$ & (l) \\
\hline $4.0 \cdot 10^{-11}$ & & $2.7 \cdot 10^{18}$ & & \\
\hline $4.0 \cdot 10^{-11}$ & & $1.8 \cdot 10^{19}$ & & \\
\hline $4.7 \cdot 10^{11}$ & $373-463$ & $6.3 \cdot 10^{17}\left(\mathrm{~N}_{2}\right)$ & Arthur and Biordi, $1986^{13}$ & (m) \\
\hline $4.4 \cdot 10^{-11}$ & 296 & $3.8 \cdot 10^{16}(\mathrm{Ar})$ & Slagle et al., $1988^{14}$ & (n) \\
\hline $5.2 \cdot 10^{-11}$ & & $3.4 \cdot 10^{17}$ & & \\
\hline $3.4 \cdot 10^{-12}$ & 906 & $4.0 \cdot 10^{16}(\mathrm{Ar})$ & & \\
\hline $1.5 \cdot 10^{-12}$ & & $7.9 \cdot 10^{17}$ & & \\
\hline $2.9 \cdot 10^{-11}$ & & $6.4 \cdot 10^{18}$ & & \\
\hline $6.65 \cdot 10^{-11}$ & 200 & $4.15 \cdot 10^{17}(\mathrm{Ar})$ & Walter et al., $1990^{15}$ & (o) \\
\hline $6.86 \cdot 10^{-11}$ & & $4.79 \cdot 10^{18}$ & & \\
\hline $7.30 \cdot 10^{-11}$ & & $1.94 \cdot 10^{29}$ & & \\
\hline $1.70 \cdot 10^{-11}$ & 300 & $4.7 \cdot 10^{15}(\mathrm{Ar})$ & & \\
\hline $3.3 \cdot 10^{-11}$ & & $2.4 \cdot 10^{16}$ & & \\
\hline $4.1 \cdot 10^{-11}$ & & $6.95 \cdot 10^{16}$ & & \\
\hline $1.1 \cdot 10^{-11}$ & 408 & $6.9 \cdot 10^{15}(\mathrm{Ar})$ & & \\
\hline $2.1 \cdot 10^{-11}$ & & $3.69 \cdot 10^{16}$ & & \\
\hline $2.9 \cdot 10^{-11}$ & & $7.46 \cdot 10^{16}$ & & \\
\hline $1.3 \cdot 10^{-11}$ & 1200 & $6.2 \cdot 10^{19}(\mathrm{Ar})$ & Hwang et al., $1990^{16}$ & (p) \\
\hline $1.3 \cdot 10^{-11}$ & 1400 & $2.0 \cdot 10^{20}(\mathrm{Ar})$ & & \\
\hline $1.2 \cdot 10^{-11}$ & & $3.3 \cdot 10^{20}$ & & \\
\hline $1.4 \cdot 10^{-11}$ & & $6.4 \cdot 10^{20}$ & & \\
\hline $6.1 \cdot 10^{-12}$ & 1500 & $5.0 \cdot 10^{19}(\mathrm{Ar})$ & & \\
\hline $8.6 \cdot 10^{-12}$ & & $4.1 \cdot 10^{20}$ & & \\
\hline $9.3 \cdot 10^{-12}$ & & $6.5 \cdot 10^{20}$ & & \\
\hline $6.0 \cdot 10^{-12}$ & 1600 & $2.0 \cdot 10^{20}(\mathrm{Ar})$ & & \\
\hline $1.2 \cdot 10^{-11}$ & & $1.0 \cdot 10^{21}$ & & \\
\hline
\end{tabular}




$$
\mathrm{CH}_{3}+\mathrm{CH}_{3}(+\mathrm{M}) \rightarrow \mathrm{C}_{2} \mathrm{H}_{6}(+\mathrm{M})-\text { Continued }
$$

Rate Coefficient Data

\begin{tabular}{|c|c|c|c|c|}
\hline$k / \mathrm{cm}^{3}$ molecule $^{-1} \mathrm{~s}^{-1}$ & $T / \mathrm{K}$ & {$[\mathrm{M}] /$ molecule $\mathrm{cm}^{-3}$} & Reference & Comments \\
\hline \multicolumn{5}{|l|}{ High Pressure Range } \\
\hline $5.8 \cdot 10^{-11}$ & 296 & $(2.5-523) \cdot 10^{19}(\mathrm{Ar})$ & Hippler et al., $1984^{10}$ & (j) \\
\hline \multicolumn{5}{|l|}{ Reviews and Evaluations } \\
\hline$k_{\infty}=5.1 \cdot 10^{-11}$ & 300 & & Quack and Troe, $1977^{17}$ & (q) \\
\hline$k_{\infty}=4.8 \cdot 10^{-11}$ & 1300 & & & \\
\hline$k_{\infty}=4 \cdot 10^{-11}$ & $250-420$ & & Baulch and Duxbury, $1980^{19}$ & (r) \\
\hline$k_{x x}=4 \cdot 10^{-10} T^{-0.4}$ & $300-1200$ & & Warnatz, $1984^{20}$ & (s) \\
\hline$k_{\infty}=1.7 \cdot 10^{-9} T^{-0.64}$ & $250-1400$ & & Tsang and Hampson, $1986^{21}$ & $(\mathrm{t})$ \\
\hline$k_{\infty}=1.5 \cdot 10^{-7} T^{-1.18} \exp (-329 / T)$ & $300-2000$ & & Wagner and Wardlaw, $1988^{22}$ & (u) \\
\hline$k_{0}=[$ Ar $] 8.8 \cdot 10^{-7} \mathrm{~T}^{-7} \exp (-1390 / T)$ & & & & \\
\hline \multicolumn{5}{|l|}{$F_{c}=0.38 \exp (-T / 73)$} \\
\hline \multicolumn{5}{|l|}{$+0.62 \exp (-T / 1180)$} \\
\hline$k_{\infty}=6 \cdot 10^{-11}$ & $300-1400$ & & Troe, $1989^{23}$ & (v) \\
\hline$k_{\infty}=1.7 \cdot 10^{-9} T^{-0.64}$ & $250-1400$ & & Tsang, $1989^{24}$ & (w) \\
\hline $\begin{aligned} k_{0} & =\left[\mathrm{A}_{1}\right] 0.313 \cdot 10^{-11} \mathrm{~T}^{-5.246} \\
& \exp (-858 / T)\end{aligned}$ & $200-2000$ & & Walter et al., $1990^{15}$ & (o) \\
\hline $\begin{aligned} k_{\infty} & =0.153 \cdot 10^{-6} \mathrm{~T}^{-1.174} \\
& \exp (-320 / T)\end{aligned}$ & $200-2000$ & & & \\
\hline \multirow{2}{*}{\multicolumn{5}{|c|}{$\begin{aligned} F_{\mathrm{c}} & =0.595 \exp (-T / 1120) 200-2000 \\
& +0.405 \exp (-T / 69.6)\end{aligned}$}} \\
\hline & & & & \\
\hline$k_{\infty}=1.91 \cdot 10^{-9} T^{-0.6}$ & $1200-1600$ & & Hwang et al., $1990^{16}$ & (p) \\
\hline$k_{\infty}=6.0 \cdot 10^{-11}$ & $300-2000$ & & CEC, $1992^{25}$ & $(\mathrm{x})$ \\
\hline$k_{0}=[\operatorname{Ar}] 3.5 \cdot 10^{-7} T^{-7}$ & $300-2000$ & & & \\
\hline \multicolumn{5}{|l|}{$\exp (-1390 / T)$} \\
\hline \multicolumn{5}{|l|}{$F_{\mathrm{c}}=0.38 \exp (-T / 73) \quad 300-2000$} \\
\hline$+0.62 \exp (-T / 1180)$ & & & & \\
\hline
\end{tabular}

\section{Comments}

(a) Molecular modulation spectroscopy, $\mathrm{CH}_{3}$ detection at $216 \mathrm{~nm}$.

(b) Flash photolysis of $\mathrm{HgMe}_{2}, k=4.9 \cdot 10^{-11} \mathrm{~cm}^{3}$ molecule $\mathrm{s}^{-1}$ for $2 \mathrm{CD}_{3}+\mathrm{M} \rightarrow \mathrm{C}_{2} \mathrm{D}_{6}+\mathrm{M} ; \mathrm{CH}_{3}$ detection at $216 \mathrm{~nm}$.

(c) Flash photolysis of $\mathrm{HgMe}_{2}, \mathrm{CH}_{3}$ detection at $216 \mathrm{~nm}$, pressure dependence between 3 and 30 Torr.

(d) Shock wave pyrolysis study of azomethane at 1200 $1500 \mathrm{~K}, \mathrm{CH}_{3}$ detection at $216 \mathrm{~nm}$, fall-off curve between 170 and 17000 Torr, rate coefticients for $2 \mathrm{CD}_{3}+\mathrm{Ar} \rightarrow$ $\mathrm{C}_{2} \mathrm{D}_{6}+\mathrm{Ar}$ identical to those for methyl recombination.

(e) Flash photolysis of azomethane, $\mathrm{CH}_{3}$ detection at $216 \mathrm{~nm}$.

(f) Dischargc-flow study of the reaction $\mathrm{II}+\mathrm{CII}_{4}$, modelling of the mechanism.

(g) Shock wave pyrolysis study of tetramethyl tin, $\mathrm{CH}_{3}$ detection at $216 \mathrm{~nm}$.

(h) Flash photolysis of azomethane, $\mathrm{CH}_{3}$ detection at $216 \mathrm{~nm}$.

(i) Flow pyrolysis of neo-pentane, study of the induction period.

(j) Excimer laser flash photolysis of azomethane at $193 \mathrm{~nm}$, $\mathrm{CH}_{3}$ detection at $216 \mathrm{~nm}$, onset of diffusion control seen in high pressure $\mathrm{N}_{2}$. Results for Ar shown in Fig. 1.

(k) Excimer laser flash photolysis of azomethane at $193 \mathrm{~nm}$, $\mathrm{CH}_{3}$ detection at $216 \mathrm{~nm}$, temperature dependence between 296 and $577 \mathrm{~K}$.

(1) Molecular modulation spectroscopy, $\mathrm{CH}_{3}$ detection at $216 \mathrm{~nm}$. (m) Rotating sector measurements based on acetone photolysis.

(n) Excimer laser flash photolysis of acetone at $193 \mathrm{~nm}$, analysis by photoionization mass spectrometry at low pressures and by absorption spectroscopy at higher pressures. Results shown in Fig. 1. Experiments also with $M$ $=$ He from 296 to $810 \mathrm{~K}$. Fall-off curves with $\mathrm{M}=\mathrm{Ar}$ for many temperatures between 296 and $906 \mathrm{~K}$.

(o) The $\mathrm{CH}_{3}$ radicals were generated by $193 \mathrm{~nm}$ laser photolysis of acetone at $200 \mathrm{~K}$ and by the reaction $\mathrm{F}+\mathrm{CH}_{4} \rightarrow$ $\mathrm{HF}+\mathrm{CH}_{3}$ at 300 and $408 \mathrm{~K}$. At lower temperatures the $\mathrm{CH}_{3}$ radicals were monitored by their $\mathrm{UV}$ absorption at $216.36 \mathrm{~nm}$, while at $300 \mathrm{~K}$ and $408 \mathrm{~K}$ they were detected via the reaction $\mathrm{CH}_{3}+\mathrm{NO}_{2} \rightarrow \mathrm{CH}_{3} \mathrm{O}+\mathrm{NO}$. NO concentrations were determined by measuring the $\mathrm{NO}$ signal at $\mathrm{m} / \mathrm{e}=30 \mathrm{amu}$. These and previous measurements from Ref. 14 were interpreted, between $200-2000 \mathrm{~K}$, using a variational RRKM theory.

(p) Reflected shock wave study. $\mathrm{CH}_{3}$ absorption coefficients calibrated via dissociation of azomethane and monitored at $216.5 \mathrm{~nm}$ by UV absorption spectroscopy. Computer simulation of a mechanism with seven reactions. The values given for the intermediate fall-off range are average values taken from Table 1 of this work.

(q) Statistical adiabatic channel modelling. Value for $300 \mathrm{~K}$ fitted to the experiments, value for $1300 \mathrm{~K}$ calculated on the basis of this fit. Evaluation of earlier work in Ref. 18.

(r) Systemic evaluation of earlier work. 
(s) Data evaluation and simplified fall-off construction.

(t) Construction of fall-off curves over the range 300 $2500 \mathrm{~K}$.

(u) Modelling with variational transition state theory, RRKM theory, and including weak collision effects. Based on experimental data from Refs. 4, 10, 11, and 14.

(v) Modelling of experimental data from Refs. 4, 10, 11, and 14 with constant $k_{\text {rec, } \infty}$ as suggested by the statistical adiabatic channel model from Rer. 15.

(w) See comment (t).

(x) See Comments on Preferred Values.

\section{Preferred Values}

$k_{\infty}=6.0 \cdot 10^{-11} \mathrm{~cm}^{3}$ molecule $\mathrm{s}^{-1} \mathrm{~s}^{-1}$ over range $300-2000 \mathrm{~K}$. $k_{\mathrm{o}}=[\mathrm{Ar}] 3.5 \cdot 10^{-7} \mathrm{~T}^{-7} \exp (-1390 / T) \mathrm{cm}^{3}$ molecule ${ }^{-1} \mathrm{~s}^{-1}$ over range $300-2000 \mathrm{~K}$.

$F_{\mathrm{c}}=0.38 \exp (-T / 73)+0.62 \exp (-T / 1180)$ over range $300-2000 \mathrm{~K}$.

\section{Reliability}

$\Delta \log k_{\infty}= \pm 0.3$ over range $300-2000 \mathrm{~K}$.

$\Delta \log k_{\mathrm{o}}= \pm 0.3$ for $\mathrm{M}=$ Ar over range $300-2000 \mathrm{~K}$.

$\Delta F_{\mathrm{c}}= \pm 0.1$ for $\mathrm{M}=$ Ar over range $300-2000 \mathrm{~K}$.

\section{Comments on Preferred Values}

The recommended values are based mainly in the extensive sets of data from Refs. 4, 10,11 and 14 up to $1000 \mathrm{~K}$ and the new experiments over the range $200-400 \mathrm{~K}$ from Ref. 15 which essentially agree with previous measurements. Recent experiments $^{16}$ over the range $1200-1400 \mathrm{~K}$ again suggest a negative temperature coefficient of $k_{\infty}$ which is of the order $k_{\infty} \propto T^{-0.6}$. However, these new data are inconsistent with the results from Ref. 4 although the same technique was applied. The difference of the rate coefficients (about a factor of 2) is due to different $\mathrm{CH}_{3}$ absorption coefficients. Because the uncertainty of the high pressure shock wave experiments is probably larger than that of the low pressure shock wave experiments, we prefer the data of Ref. 4 and retain the interpretation of Ref. 25 based on the analysis of Ref. 22 . Never- theless, the question of the temperature coefficient of $k_{\infty}$ at high temperatures remains open $\left(k_{\infty} \propto T^{n}\right.$ with about $0 \leqslant n \leqslant$ $0.6)$. Figure 1 shows fall-off curves between $200-1600 \mathrm{~K}$. The recommended values are consistent with those of the dissociation reaction via the equilibrium constant given above. For $M=N_{2}$ expressions identical with those for $M=$ Ar may be assumed.

\section{Reforences}

${ }^{2}$ D.A. Parkes, D.M. Paul, and C.P. Quinn, J. Chem. Soc., Faraday Trans. 1, 72, 1935 (1976).

${ }^{2}$ A.B. Calleal auld M.P. Metcalfe, Cliem. Pliys. 14, 275 (1976).

${ }^{3}$ H.E. Van den Bergh, Chem. Phys. Lett. 43, 201 (1976).

${ }^{4}$ K. Glänzer, M. Quack, and J. Troe, Chem. Phys. Lett. 39, 304 (1976); 16th Symp. (Int.) Combust., 949 (1977).

${ }^{5}$ C.J. Hochanadel, J.A. Ghormley, J.W. Boyle, and P.J. Ogren, J. Phys. Chem. 81, 3 (1977)

${ }^{6}$ A. Sepehrad, R.M. Marshall, and H. Purnell, J. Chem. Soc., Faraday Trans. $1,75,835$ (1979).

${ }^{7}$ I.S. Zaslonko and V.N. Smimov, Kinet. Katal. 20, 575 (1975).

${ }^{8} \mathrm{H}$. Adachi, N. Basco, and D.G.L. James, Int. J. Chem. Kin. 12, 949 (1980).

${ }^{9}$ P.D. Pacey and J.H. Wimalasena, J. Phys. Chem. 84, 2221 (1980).

${ }^{10}$ H. Hippler, K. Luther, A.R. Ravishankara, and J. Troe, Z. Phys. Chem. NF, 142, 1 (1984).

${ }^{11}$ M.T. Macpherson, M.J. Pilling, and M.J.C. Smith, J. Phys. Chem. 89, 2268 (1985).

${ }^{12}$ N.L. Arthur, J. Chem. Soc., Faraday Trans. 2, 82, 331 (1986).

${ }^{13}$ N.L. Arthur and J.C. Biordi, Aust. J. Chem. 39, 1257 (1986).

${ }^{14}$ I.R. Slagle, D. Gutman, J.W. Davies, and M.J. Pilling, J. Phys. Chem. 92, 2455 (1988).

${ }^{15}$ D. Walter, H.H. Grotheer, J.W. Davies, M.J. Pilling, and A.F. Wagner, 23rd Symp. (Int.) Combust., 107 (1990).

${ }^{16}$ S.M. Hwang, H.Gg. Wagner, and Th. Wolff, 23rd Symp. (Int.) Combust., 99 (1990).

${ }^{17}$ M. Quack and J. Troe, Ber. Bunsenges. Phys. Chem. 81, 329 (1977).

${ }^{18} \mathrm{M}$. Quack and J. Troe, in "Gas Kinetics and Energy Transfer", Vol. 2 (The Chemical Society, London, 1977), 175.

${ }^{19}$ D.L. Baulch and J. Duxbury, Comb. Flame 37, 313 (1980).

${ }^{20} \mathrm{~J}$. Warnatz, in "Combustion Chemistry", ed. W.C. Gardiner, Springer-Verlag, New York (1984).

${ }^{21}$ W. Tsang and R.F. Hampson, J. Phys. Chem. Ref. Data 15, 1087 (1986).

${ }^{22}$ A.F. Wagner and D.M. Wardlaw, J. Phys. Chem. 92, 2462 (1988).

${ }^{23} \mathrm{~J}$. Troe, Comb. Flame 78, 59 (1989).

${ }^{21} \mathrm{~W}$. Tsang, Comb. Flame 78, 71 (1989).

${ }^{25} \mathrm{CEC}, 1992$ (see references in Introduction). 


$$
\mathrm{CH}_{3}+\mathrm{CH}_{3}+\mathrm{M} \rightarrow \mathrm{C}_{2} \mathrm{H}_{6}+\mathrm{M}
$$

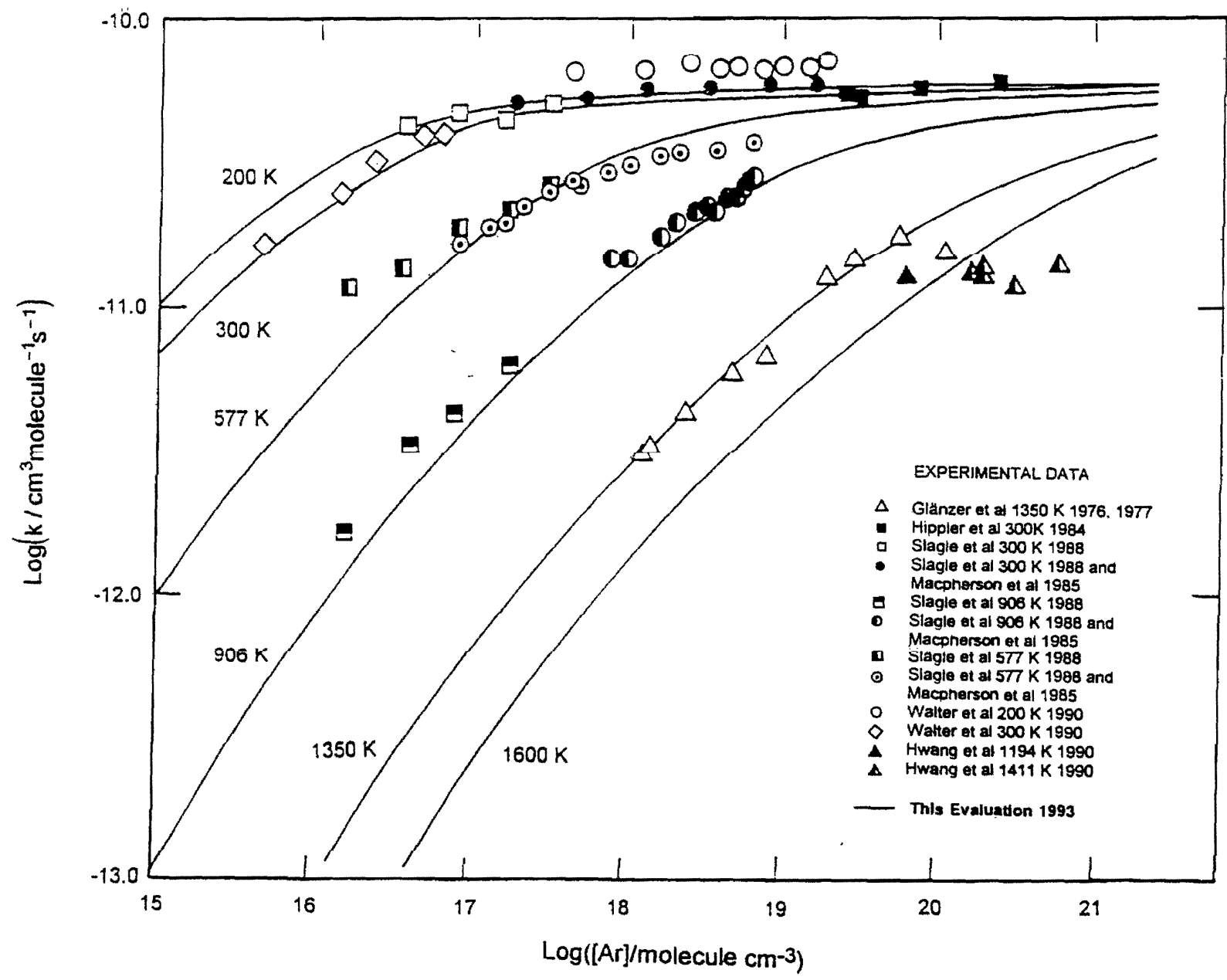


BAULCH ET AL.

\section{$\mathrm{C}_{2} \mathrm{H}_{6}(+\mathrm{M}) \rightarrow \mathrm{CH}_{3}+\mathrm{CH}_{3}(+\mathrm{M})$}

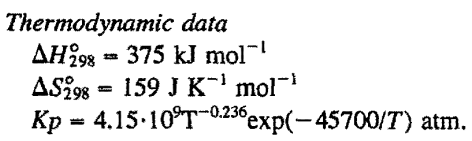

Rate Coefficient Data

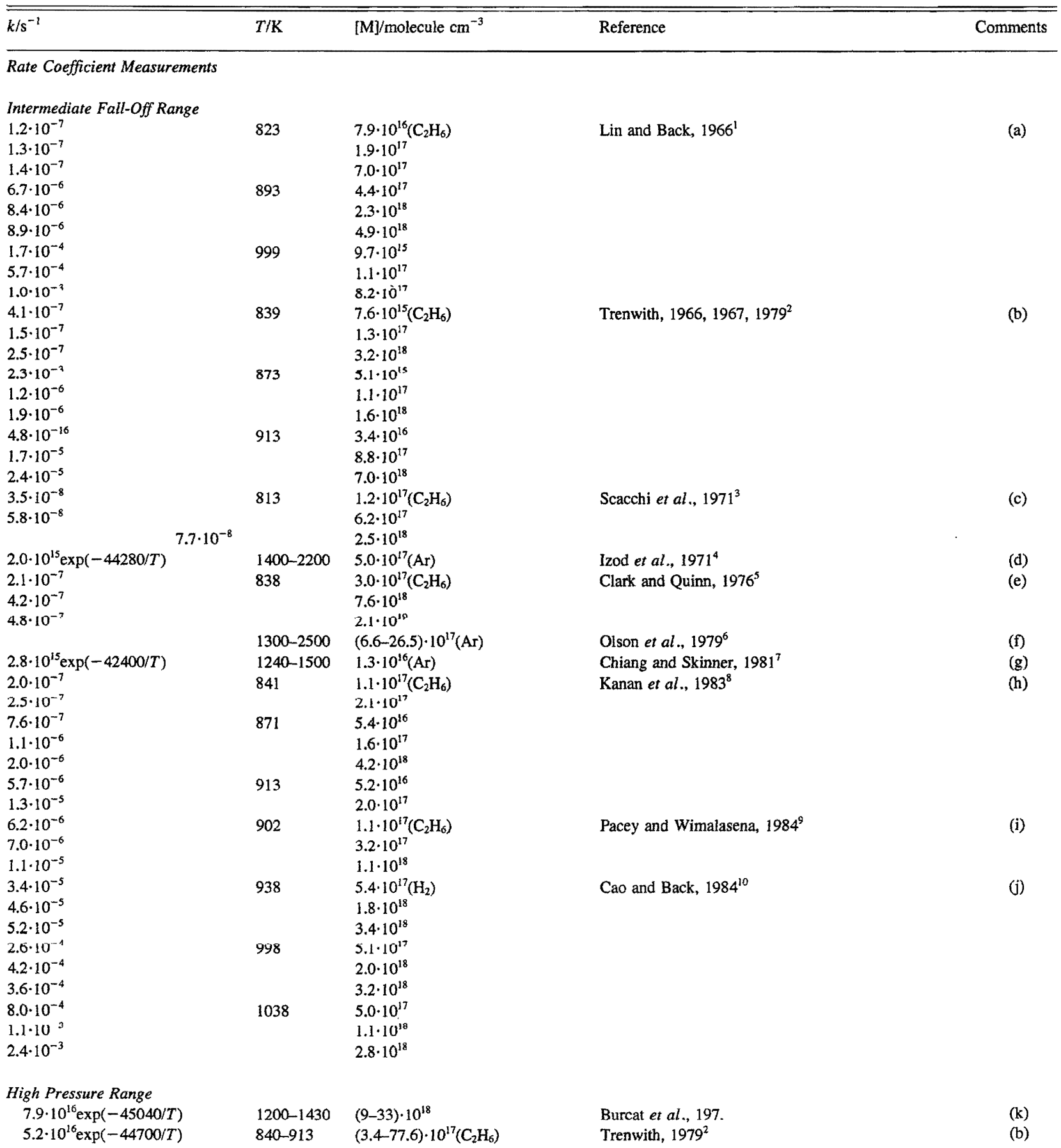




$$
\mathrm{C}_{2} \mathrm{H}_{6}(+\mathrm{M}) \rightarrow \mathrm{CH}_{3}+\mathrm{CH}_{3}(+\mathrm{M})
$$

Rate Coefficient Data

\begin{tabular}{|c|c|c|c|}
\hline$k / \mathrm{s}^{-1}$ & {$[\mathrm{M}] /$ molecule $\mathrm{cm}^{-3}$} & Reference & Comments \\
\hline \multicolumn{4}{|l|}{ Reviews and Evaluations } \\
\hline$k_{\infty}=2.4 \cdot 10^{16} \exp (-44010 / T)$ & $750-1500$ & Baulch and Duxbury, $1980^{12}$ & (l) \\
\hline$k_{0}=[\mathrm{Ar}] 1.7 \cdot 10^{-5} \exp (-34280 / T)$ & $800-2500$ & Warnatz, $1984^{13}$ & (m) \\
\hline$k_{\infty}=2.4 \cdot 10^{16} \exp (-44020 / T)$ & $750-2000$ & & \\
\hline$k_{\infty}=3.2 \cdot 10^{22} \mathrm{~T}^{-1.79} \exp (-45834 / \mathrm{T})$ & $300-1400$ & Tsang and Hampson, $1986^{14}$ & (n) \\
\hline$k_{\infty}=3.0 \cdot 10^{22} \mathrm{~T}^{-1.79} \exp (-45834 / T)$ & $300-1400$ & Tsang, $1989^{15}$ & (o) \\
\hline $\begin{aligned} k_{0}= & {[\mathrm{Ar}] 1.1 \cdot 10^{25} \mathrm{~T}^{-8.24} } \\
& \exp (-47090 / T)\end{aligned}$ & $300-2000$ & & \\
\hline$k_{0}=\left[\mathrm{C}_{2} \mathrm{H}_{6}\right] 4.5 \cdot 10^{-2} \exp (-41930 / T)$ & $800-1000$ & & \\
\hline $\begin{array}{c}F_{\mathrm{c}}(\mathrm{Ar})=0.38 \exp (-T / 73) \\
\quad 0.62 \exp (-T / 1180)\end{array}$ & $300-2000$ & & \\
\hline$F_{\mathrm{c}}\left(\mathrm{C}_{2} \mathrm{H}_{6}\right)=0.54 \exp (-T / 1250)$ & $800-1000$ & & \\
\hline
\end{tabular}

\section{Comments}

(a) Static reactor, dissociation of pure ethane with measurement of the rate of production of methane and butane. Extrapolation to the high pressure limit and comparison with earlier work.

(b) Ethane dissociation studied in static reactor. Product analysis by gas chromatography. Extrapolation to the high pressure limit. Relative efficiencies of different bath gases: $k_{0}(\mathrm{M}) / k_{0}\left(\mathrm{C}_{2} \mathrm{H}_{6}\right)=0.25\left(\mathrm{~N}_{2}\right), 0.33\left(\mathrm{O}_{2}\right), 0.17(\mathrm{He})$, $0.18(\mathrm{Ne}), 0.26(\mathrm{Ar}), 0.30(\mathrm{Kr}), 0.88\left(\mathrm{H}_{2} \mathrm{O}\right)$.

(c) Pyrolysis of ethane in static reactor. Analysis of initiation of the reaction using manometric and gas chromatographic measurements.

(d) Pyrolysis of $\mathrm{CO} / \mathrm{O}_{2} /$ ethane/azomethane/Ar mixtures in a shock tube. The reaction was followed by measuring emission from $\mathrm{CO}$ and $\mathrm{CO}_{2}$. Modelling with 8 reactions.

(e) Static reactor study of dissociation in pure ethane. Gas chromatographic analysis of reaction products.

(f) Shock tube study of ethane dissociation in Ar using laserabsorption and laser-schlieren measurements. Modelling mechanism. Data near $1300 \mathrm{~K}$ are markedly lower than recombination results and shock wave results from Ref. 7 . Better agreement with Kef. 7 at higher temperatures. Extrapolation to the high pressure limit uncertain due to fall-off effects.

(g) Shock tube study of ethanc dccomposition in $\mathrm{Ar}$ mcasuring $\mathrm{H}$ atom concentrations from $\mathrm{CH}_{3}+\mathrm{C}_{2} \mathrm{H}_{6} \rightarrow \mathrm{CH}_{4}+$ $\mathrm{C}_{2} \mathrm{H}_{5}, \mathrm{C}_{2} \mathrm{H}_{5} \rightarrow \mathrm{C}_{2} \mathrm{H}_{4}+\mathrm{H}$ sequence.

(h) Ethane pyrolysis in static reactor with gas chromatographic analysis. Enhanced hydrogen recombination at activated vessel surface. Results in good agreement with Ref. 2.

(i) Ethane pyrolysis in a flow system with gas chromatographic product analysis. Evaluation of induction periods.

(j) Pyrolysis of ethane in static reactor. Product analysis by gas chromatography. Collision efficiencies of Xe and $\mathrm{H}_{2}$ relative to $\mathrm{C}_{2} \mathrm{H}_{6}$ have been measured.

(k) Single-pulse shock tube study of ethane dissociation in $\mathrm{Ar}$, measurement of methane production rate. Analysis of earlier shock tube work, extrapolation to the high pres- sure limit. Data neglected in later work by one of the authors?

(l) Complete review of earlier literature.

(m) Dara evaluation and simplified fall-off construction.

(n) Data evaluation and construction of RRKM fall-off curves.

(o) See comment (n).

(p) Critical evaluation of gas phase chemical reactions for use in modelling combustion processes.

\section{Preferred Values}

$k_{\infty}=1.8 \cdot 10^{21} T^{-1.24} \exp (-45700 / T) \mathrm{s}^{-1}$ over range 300 $2000 \mathrm{~K}$.

$k_{\mathrm{o}}=[\mathrm{Ar}] 1.1 \cdot 10^{25} T^{-8.24} \exp (-47090 / T) \mathrm{s}^{-1}$ over range $300-$ $2000 \mathrm{~K}$.

$k_{\mathrm{o}}=\left[\mathrm{N}_{2}\right] 1.1 \cdot 10^{25} \mathrm{~T}^{-8.24} \exp (-47090 / T) \mathrm{s}^{-1}$ over range $300-$ $2000 \mathrm{~K}$.

$k_{\mathrm{o}}=\left[\mathrm{C}_{2} \mathrm{H}_{6}\right] 4.5 \cdot 10^{-2} \exp (-41930 / T) \mathrm{s}^{-1}$ over range 800$1000 \mathrm{~K}$.

$F_{\mathrm{c}}=0.38 \exp (-T / 73)+0.62 \exp (-T / 1180)$ for $M=\mathrm{Ar}$ and for $\mathrm{M}=\mathrm{N}_{2}$ over range $300-2000 \mathrm{~K}$.

$F_{\mathrm{c}}=0.54 \exp (-T / 1250)$ for $M=\mathrm{C}_{2} \mathrm{H}_{6}$ over range 800 $1000 \mathrm{~K}$.

\section{Reliability}

$\Delta \log k_{\infty}= \pm 0.3$ over range $300-2000 \mathrm{~K}$.

$\Delta \log k_{0}= \pm 0.5$ for $M=\mathrm{Ar}$ and $M=\mathrm{N}_{2}$ over range $300-$ $2000 \mathrm{~K}$.

$\Delta \log k_{\mathrm{o}}= \pm 0.5$ for $M=\mathrm{C}_{2} \mathrm{H}_{6}$ over range $800-1000 \mathrm{~K}$.

$\Delta F_{\mathrm{c}}= \pm 0.1$ for $M=$ Ar over range $300-2000 \mathrm{~K}$.

$\Delta F_{\mathrm{c}}= \pm 0.1$ for $M=\mathrm{C}_{2} \mathrm{H}_{6}$ over range $800-1000 \mathrm{~K}$.

\section{Comments on Preferred Values}

The preferred values for $k_{\infty}$ and $k_{\mathrm{o}}$ (for $\mathrm{M}=\mathrm{Ar}$ ) have been derived from the recommended rate coefficients of the reverse reaction $2 \mathrm{CH}_{3}+\mathrm{M} \rightarrow \mathrm{C}_{2} \mathrm{H}_{6}+\mathrm{M}$ from this evaluation and the expression given for the equilibrium constant. They are based on the combined evaluation of dissociation and recombination data given in the review of Ref. 17 which assumes a nearly temperature independent rate coefficient $k_{\infty}$ for the reverse 
recombination over the range $300-2000 \mathrm{~K}$. For $\mathrm{M}=\mathrm{N}_{2}$ an expression for $k_{\mathrm{o}}$ identical with that for $\mathrm{M}=\mathrm{Ar}$ is assumed. In Figs. 1 and 2 the dependence on temperature of the recommended $k_{0}$ and $k_{\infty}$ is shown together with the values recommended in previous compilations. Figure 3 shows fall-off curves for experiments performed near $1000 \mathrm{~K}$. Theoretical fall-off curves based on the preferred values are depicted in Fig. 4. The expressions for $k_{\mathrm{o}}$ and $F_{\mathrm{c}}$ also follow from the combination of experimental and theoretical data analysed in Ref. 17. The preferred values obtained in this way are in good agreement with the available dissociation experiments and measurements performed at lower temperatures for the reverse association of $\mathrm{CH}_{3}$ radicals. They are not influenced by the numerous mechanistic complications of the high temperature shock tube studies of this dissociation.

\section{References}

${ }^{1}$ M.C. Lin and M.H. Back, Can. J. Chem. 44, 5052357 (1966).

${ }^{2}$ A.B. Trenwith, J. Chem. Soc. Faraday I rans. 1, 62, 1578 (1966), 63, 2452 (1967), 75, 614 (1979).
${ }^{3}$ G. Scacchi, R. Martin, and M. Niclause, Bull. Soc. Chim. France, 731 (1971).

${ }^{4}$ T.P. Izod, G.B. Kistiakowsky, and S. Matsuda, J. Chem. Phys. 55, 4425 (1971).

${ }^{5}$ J.A. Clark and C.P. Quinn, J. Chem. Soc. Faraday Trans. 1, 72, 706 (1976). ${ }^{6}$ D.B. Olson, T. Tanzawa, and W.C. Gardiner, Int. J. Chem. Kin. 11, 23 (1979); D.B. Olson and W.C. Gardiner, J. Phys. Chem. 83, 922 (1979). ${ }^{7}$ C.C. Chiang and G.B. Skinner, J. Phys. Chem. 85, 3126 (1981).

${ }^{8}$ K. Kanan, H. Purnell, and A. Sepehrad, Int. J. Chem. Kin. 15, 845 (1983). ${ }^{9}$ P.D. Pacey and J.H. Wimalasena, J. Phys. Chem. 88, 5657 (1984).

${ }^{10}$ J.R. Cao and M.H. Back, J. Phys. Chem. 88, 3074 (1984).

${ }^{11}$ A. Burcat, G.B. Skinner, R.W. Crossley, and K. Scheller, Int. J. Chem. Kin. 5, 345 (1973).

${ }^{12}$ D.L. Baulch and J. Duxbury, Comb. Flame 37, 313 (1980).

${ }^{13} \mathrm{~J}$. Warnatz, in "Combustion Chemistry", ed. W.C. Gardiner, Springer-Verlag, New York (1984).

${ }^{14}$ W. Tsang and R.F. Hampson, J. Phys. Chem. Ref. Data 15, 1087 (1986). ${ }^{15}$ W. Tsang, Comb. Flame 78, 71 (1989).

${ }^{16} \mathrm{CEC}, 1992$ (see references in Introduction).

${ }^{17} \mathrm{~J}$. Troe, Comb. Flame 78, 59 (1989).

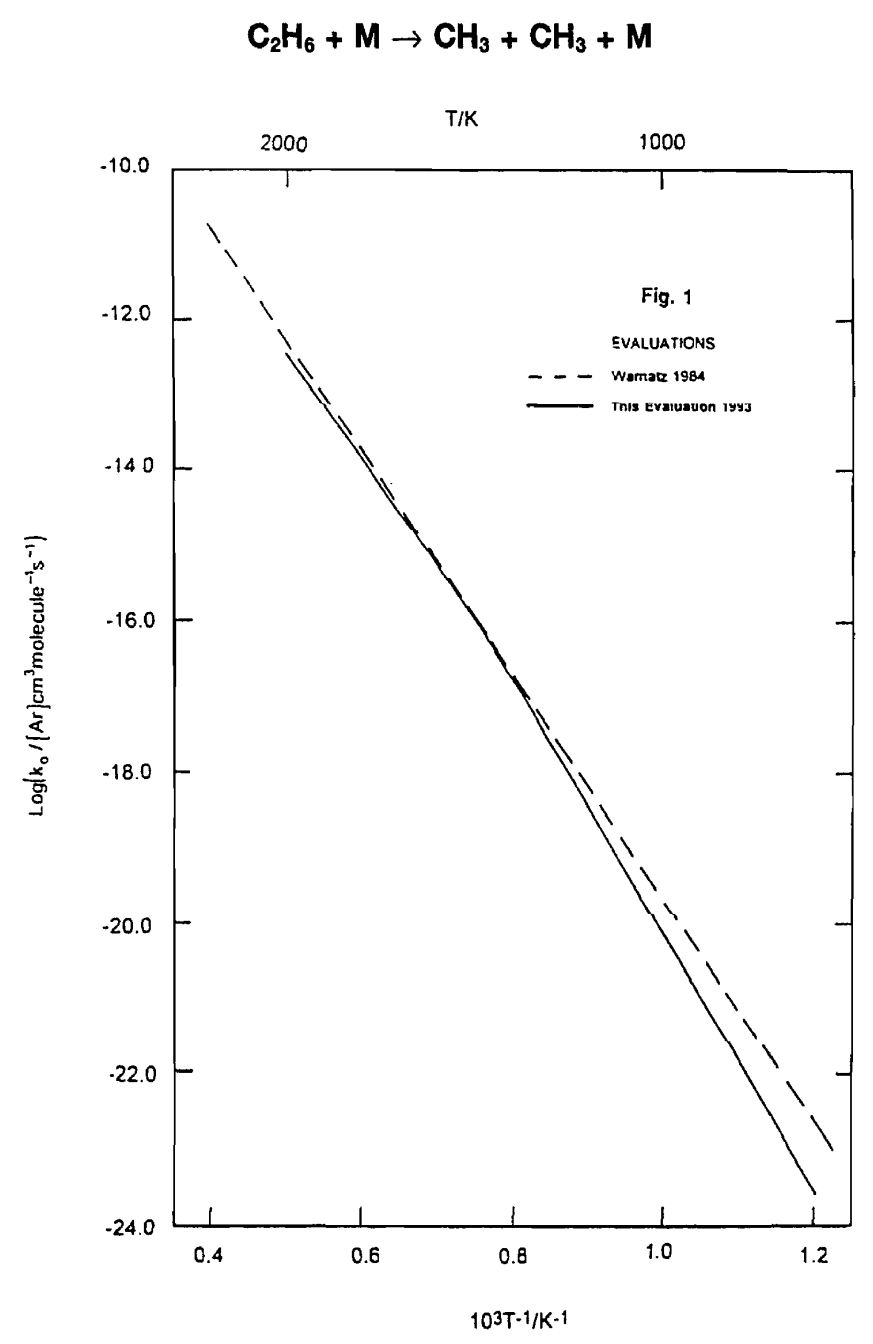




$$
\mathrm{C}_{2} \mathrm{H}_{6}+\mathrm{M} \rightarrow \mathrm{CH}_{3}+\mathrm{CH}_{3}+\mathrm{M}
$$
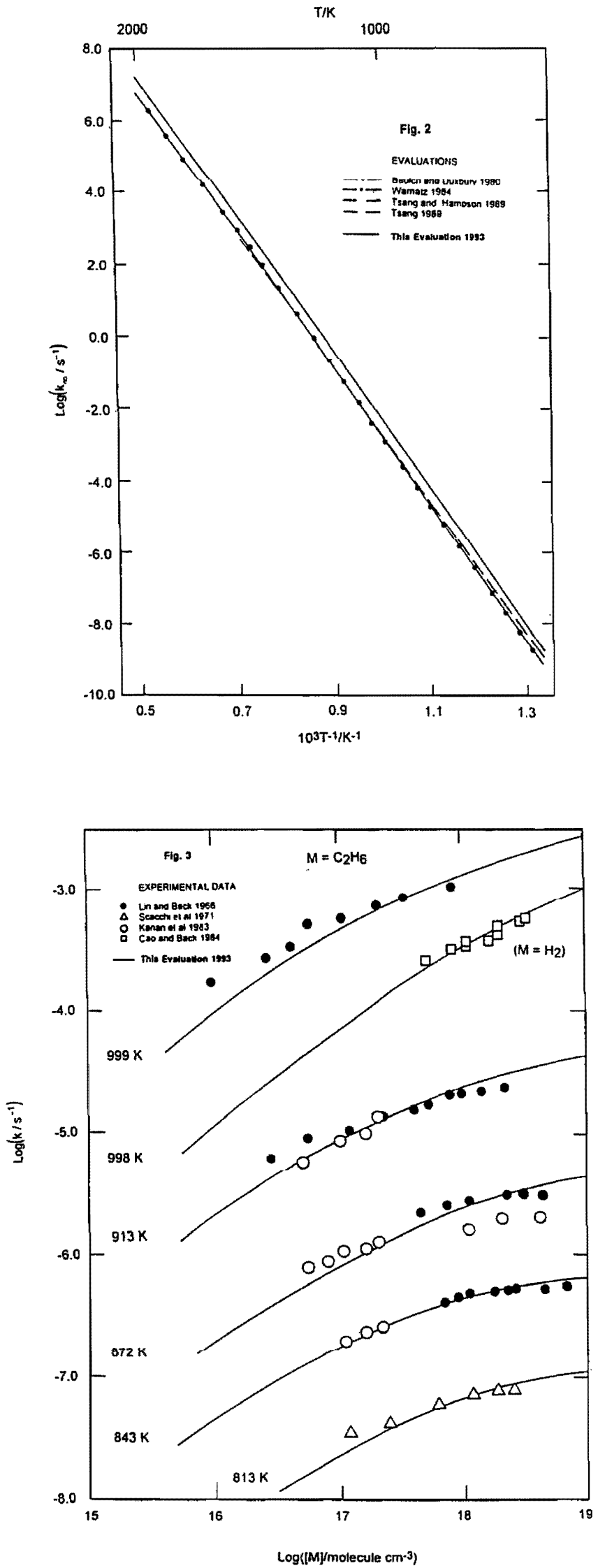


\section{$\mathrm{C}_{2} \mathrm{H}_{6}+\mathrm{M} \rightarrow \mathrm{CH}_{3}+\mathrm{CH}_{3}+\mathrm{M}$}

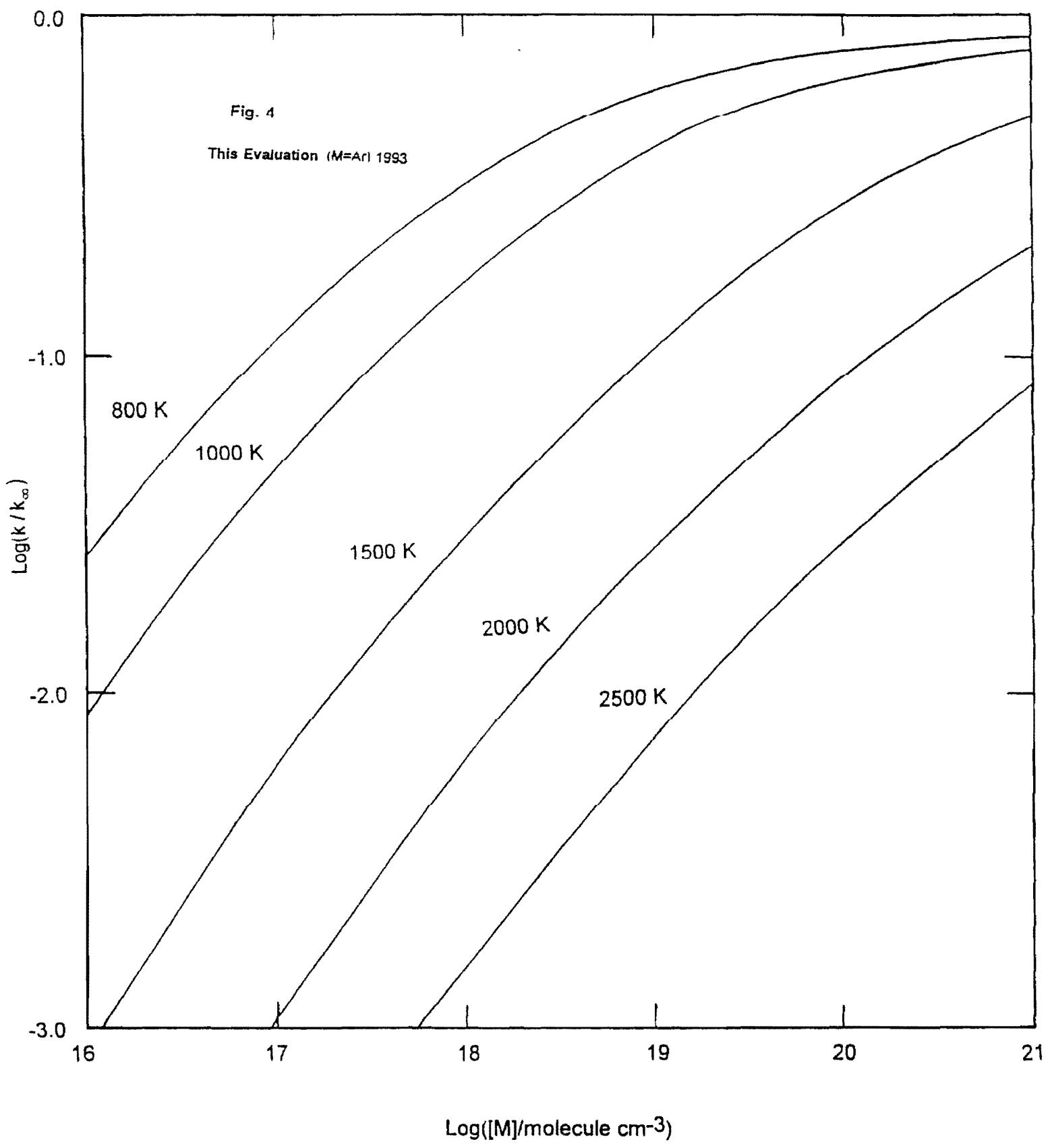




$$
\mathrm{CH}_{3}+\mathrm{HCHO} \rightarrow \mathrm{CH}_{4}+\mathrm{HCO}
$$

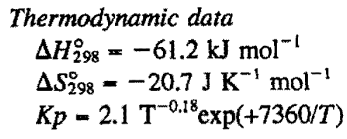

Rate Coefficient Data

\begin{tabular}{|c|c|c|c|}
\hline $\mathrm{k} / \mathrm{cm}^{3}$ molecule $\mathrm{e}^{-1} \mathrm{~s}^{-1}$ & $T / \mathrm{K}$ & Reference & Comments \\
\hline \multicolumn{4}{|l|}{ Rate Coefficient Measurements } \\
\hline $4.2 \cdot 10^{-9} \exp (-11600 / T)$ & $1170-1630$ & Choudhury, Sanders, and Lin, $1989^{1}$ & (a) \\
\hline \multicolumn{4}{|l|}{ Reviews and Evaluations } \\
\hline $9.2 \cdot 10^{-21} T^{2.81} \exp (-2950 / T)$ & $300-2500$ & Tsang and Hampson, $1986^{2}$ & (b) \\
\hline $3.0 \cdot 10^{-12} \exp (-3610 / T)$ & $300-1000$ & CEC, $1992^{3}$ & (c) \\
\hline
\end{tabular}

\section{Comments}

(a) Shock tube study of decomposition of $t$-butyl hydroperoxide/trioxane mixtures to generate $\mathrm{CH}_{3}$ and $\mathrm{HCHO}$, with kinetic modelling of observed $\mathrm{CO}$ formation. The expression: $1.48 \cdot 10^{-36} T^{7.4} \exp (-483 / T) \mathrm{cm}^{3}$ molecule ${ }^{-1} \mathrm{~s}^{-1}$ was calculated using transition state theory with quantum mechanical tunnelling correction, which gave a good description of all reliable data in the temperature range $300-2000 \mathrm{~K}$.

(b) Based on data of Held et $a l .^{4}$, Manthorne and Pacey, Anastasi ${ }^{6}$ and the low temperature data evaluation of Kerr and Parsonage?

(c) Based on data in Refs. 4,5,6,7 and in Selby ${ }^{8}$.

\section{Preferred Values}

$k=1.29 \cdot 10^{-31} T^{6.1} \exp (-990 / T) \mathrm{cm}^{3}$ molecule $\mathrm{s}^{-1} \mathrm{~s}^{-1}$ over range $300-2000 \mathrm{~K}$

\section{Reliability}

$\Delta \log k= \pm 0.2$ over range.

\section{Comments on Preferred Values}

The new results provide a significant extension in the temerature range and confirm earlier indications that this reaction exhibits non-Arrhenius behaviour. Curvature in the Arrhenius plot is not so dramatic as suggested by the high temperature data of Aronowitz and Naegeli ${ }^{9}$ and $\mathrm{Hsu}$ and
$\mathrm{Lin}^{10}$, which was not included in previous evaluations due to the uncertainty arising from the complex chemistry of the reaction systems employed. Reference to the Arrhenius plot shows that the new data are consistent with the lower temperature data of Held et al. ${ }^{4}$, Manthorne and Pacey ${ }^{5}$ and the evaluation of Kerr and Parsonage ${ }^{7}$, but not the data reported by Anastasi ${ }^{6}$. Choudhury et al ${ }^{11}$ have re-analysed the data of Anastasi, which was obtained using the direct molecular modulation technique, taking account of additional $\mathrm{CH}_{3}$ radical loss processes. The reworked rate constants are much more consistent with the data at higher and lower temperatures. The recommended expression is a best fit to the data of Choudhury et al. ${ }^{1}$, the reworked data from Anastasi, together with those at lower temperatures from Refs. 4, 5, and 7 .

\section{References}

${ }^{1}$ T.K. Choudhury, W.A. Sanders, and M.C. Lin, J. Phys. Chem. 93, 5143 (1989).

${ }^{2}$ W. Tsang and R.F. Hampson, J. Phys. Chem. Ref. Data 15, 1087 (1986). ${ }^{3} \mathrm{CEC}, 1992$ (see references in Introduction).

${ }^{4}$ A.M. Held, K.C. Manthorne, P.D. Pacey, and H.P. Reinholt, Can J. Chem. 55, 4128 (1977).

${ }^{5}$ K.C. Manthorne and P.D. Pacey, Can. J. Chem. 56, 1307 (1978),

${ }^{6}$ C. Anastasi, J. Chem. Soc., Faraday Trans. 1 79, 749 (1983).

7J.A. Kerr and M.J. Parsonage, "Evaluated Kinetic Data on Hydrogen Transfer Reactions of the Methyl Radical', p. 166, Butterworths, London, 1976.

${ }^{8}$ K.R. Selby, Ph.D. Thesis (University of York, 1978).

${ }^{9}$ D. Aronowitz and D. Naegeli, Int. J. Chem. Kinet. 9, 471 (1977).

${ }^{10}$ D.S.Y. Hsu and M.C. Lin, J. Energ. Mater. 3, 95 (1985).

"T.K. Choudhury, W.A. Sanders, and M.C. Lin, J. Chem. Soc., Faraday Trans. 2 85, 801 (1989). 


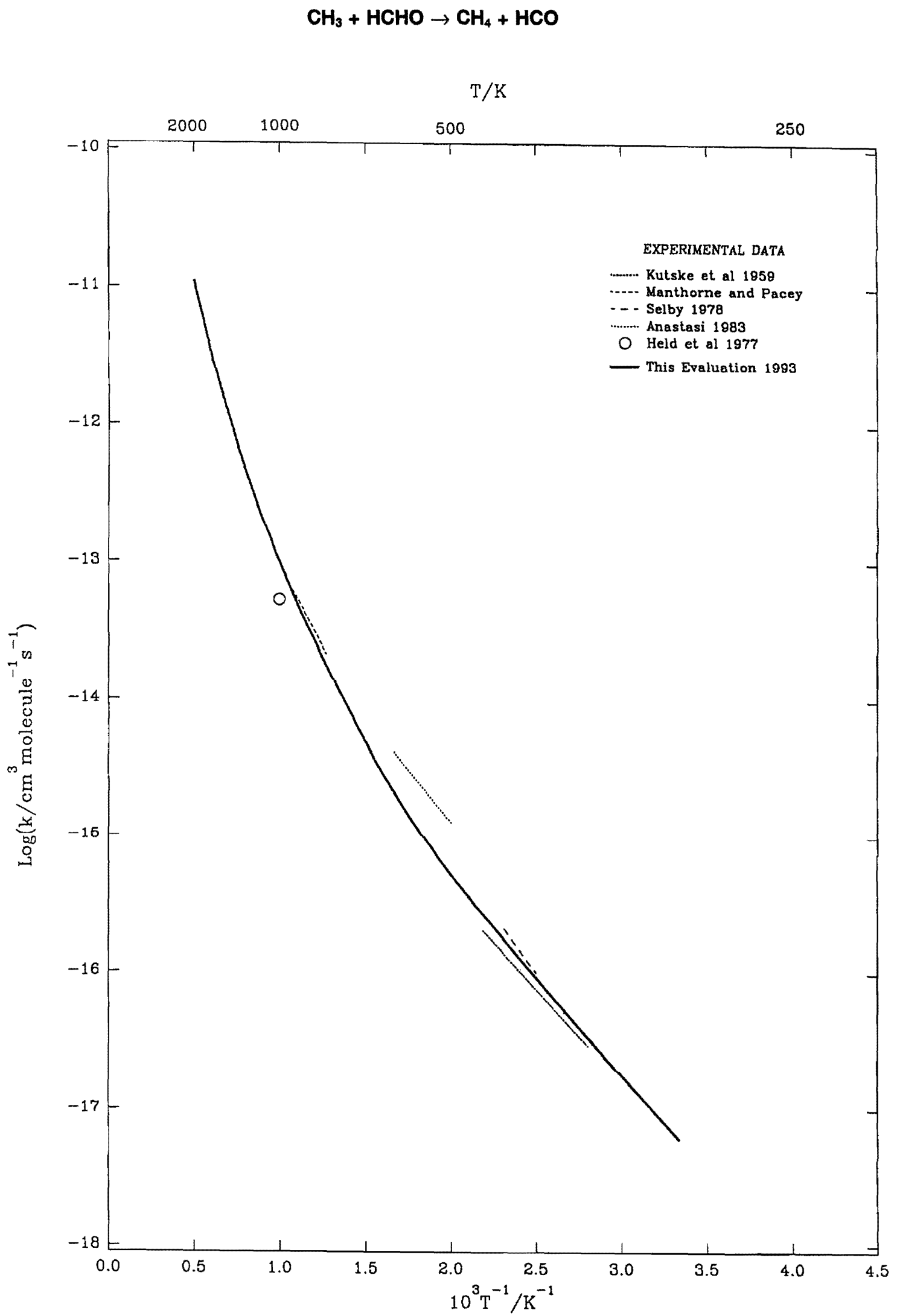




$$
\begin{aligned}
\mathrm{CH}_{3}+\mathrm{C}_{2} \mathrm{H}_{5}(+\mathrm{M}) & \rightarrow \mathrm{C}_{3} \mathrm{H}_{8}(+\mathrm{M}) \\
\mathrm{CH}_{3}+\mathrm{C}_{2} \mathrm{H}_{5} & \rightarrow \mathrm{CH}_{4}+\mathrm{C}_{2} \mathrm{H}_{4}
\end{aligned}
$$

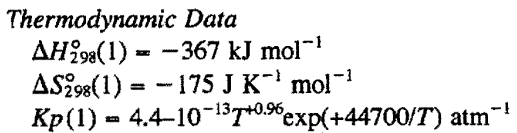

$\Delta H_{298}^{\circ}(2)=-285 \mathrm{~kJ} \mathrm{~mol}^{-1}$
$\Delta S_{298}^{\circ}(2)=-40.5 \mathrm{~J} \mathrm{~K}^{-1} \mathrm{~mol}^{-1}$
$K p(2)=3.0 \cdot 10^{-3} T^{0.078} \exp (+34500 / T) \mathrm{atm}^{-1}$

\begin{tabular}{|c|c|c|c|c|}
\hline$k / \mathrm{cm}^{3}$ molecule $\mathrm{l}^{-1 \mathrm{~s}-1}$ & $T / \mathrm{K}$ & {$[\mathrm{M}] /$ molecule $\mathrm{cm}^{-3}$} & Reference & Comments \\
\hline \multicolumn{5}{|l|}{ Rate Coefficient Measurements } \\
\hline \multicolumn{5}{|l|}{ Intermediate Fall-off Range } \\
\hline $3.3 \cdot 10^{-10}$ & 298 & $4.3 \cdot 10^{18}\left(\mathrm{H}_{2}\right)$ & Pagsberg, Ratajczak, and Sillesen, $1992^{1}$ & (a) \\
\hline \multicolumn{5}{|l|}{ Iligh Pressure Range } \\
\hline$(9.3 \pm 4.2) \cdot 10^{-11}$ & 300 & $1.2 \cdot 10^{17}(\mathrm{Ar})$ & Garland and Bayes, $1990^{2}$ & (b) \\
\hline \multicolumn{5}{|l|}{ Reviews and Evaluations } \\
\hline$k_{\infty}=1.2 \cdot 10^{-11}$ & $300-2000$ & & Warnali, $1984^{7}$ & (c) \\
\hline$k_{\infty}=4.7 \cdot 10^{-11}(T / 300)^{-0.5}$ & $300-2500$ & & Tsang and Hampson, $1986^{5}$ & (d) \\
\hline$k_{\infty}=3.2 \cdot 10^{-10} T^{-0.32}$ & $300-2500$ & & Tsang, $1989^{6}$ & (e) \\
\hline$k_{\infty}=4.7 \cdot 10^{-11}$ & $300-800$ & & CEC, $1992^{8}$ & (f) \\
\hline$k_{2} / k_{1}=0.04$ & & & & \\
\hline
\end{tabular}

Rate Coefficient Data

\section{Comments}

(a) Pulse radiolysis of $\mathrm{H}_{2} / \mathrm{C}_{2} \mathrm{H}_{4}$ mixtures. $\mathrm{CH}_{3}$ monitored by IR absorption at the $Q(3,3)$ line of the $v_{2}=0 \rightarrow 1$ vibrational transition at $606.12 \mathrm{~cm}^{-1}$. A value $k_{2} /\left(k_{1}+k_{2}\right)=0.5$ was estimated by gas chromatographic analysis.

(b) Co-photolysis of acetone (1-35 mTorr.) and 3-pentanone (5 mTorr.). $\left[\mathrm{CH}_{3}\right]$ and $\left[\mathrm{C}_{2} \mathrm{H}_{5}\right]$ decays monitored by photoionization mass spectrometry using the resonance lines of $121.6 \mathrm{~nm}$ and $147 \mathrm{~nm}$. Computer modelling of the concentration profiles of the two radicals. Rate coefficient assumed in the high pressure limit.

(c) Review of literature data. Recommended value based on results of Ref. 4.

(d) Evaluated from the rate coefficients of $\mathrm{CH}_{3}$ and $\mathrm{C}_{2} \mathrm{H}_{5}$ self-recombination reactions and the cross combination ratio.

(e) Derived from results of Parkes and Quinn ${ }^{7}$ for $\mathrm{C}_{2} \mathrm{H}_{5}$ selfrecombination over the range $300-800 \mathrm{~K}$ and the geometrical mean rule of cross combination ratios.

(f) Accepts the recent value of $k_{\infty}$ of Anastasi and Arthur ${ }^{9}$ at $308 \mathrm{~K}$.

\section{Preferred Values}

$k_{\infty}(1)=5.6 \cdot 10^{-11} \mathrm{~cm}^{3}$ molecule ${ }^{-1} \mathrm{~s}^{-1}$ over range $300-$ $2000 \mathrm{~K}$.

Reliability

$\Delta \log k_{\infty}(1)= \pm 0.3$ over the range $300-2000 \mathrm{~K}$.

\section{Comments on Preferred Values}

The recommended value for $k_{\infty}(1)$ is a weighted average of earlier experiments ${ }^{2,5,6,9}$ in agreement with SACM calculations following Ref. 10. A temperature independent value of $k_{\infty}(1)$ is assumed until more definitive experimental information is available.

Reduced fall-off curves of this recombination are identical to those for the dissociation $\mathrm{C}_{3} \mathrm{H}_{8}+\mathrm{M} \rightarrow \mathrm{CH}_{3}+\mathrm{C}_{2} \mathrm{H}_{5}+\mathrm{M}$ and are represented on the corresponding data sheet. $\mathrm{A}$ branching ratio $k_{2} /\left(k_{1}+k_{2}\right)=0.04$ for $300 \mathrm{~K}$ follows from Refs. 5 and 8 . Nevertheless, a value of 0.5 has been recently estimated in Ref. 1 . A confirmation of this last value is necessary.

\section{References}

${ }^{1}$ P. Pagsberg, E. Ratajczak, and A. Sillesen, 12th International Symposium onGas Kinetics, Reading, England, 1992.

${ }^{2}$ L.J. Garland and K.D. Bayes, J. Phys. Chem. 94, 4941 (1990)

${ }^{3}$ J. Warnatz, in "Combustion Chemistry", ed. W.C. Gardiner, SpringerVerlag, New York, p.196 (1984)

${ }^{4} T$. Koike and W.C. Gardiner, J. Phys. Chem. 84, 2005 (1980).

${ }^{5}$ W. Tsang and R.F. Hampson, J. Phys. Chem. Ref. Data 15, 1087 (1986). ${ }^{6} \mathrm{~W}$. Tsang, Comb. Flame 78, 71 (1989).

${ }^{7}$ D. Parkes and C.P. Quinn, J. Chem. Soc., Faraday Trans. I 72, 1953 (1976).

${ }^{8} \mathrm{CEC}, 1992$ (see references in Introduction).

${ }^{9}$ C. Anastasi and N.L. Arthur, J. Chem. Soc., Faraday Trans. II 83, 277 (1987).

${ }^{10}$ J. Troe, Z. Phys. Chem. NF 161, 209 (1989). 


\section{$\mathrm{C}_{3} \mathrm{H}_{8}(+\mathrm{M}) \rightarrow \mathrm{CH}_{3}+\mathrm{C}_{2} \mathrm{H}_{5}(+\mathrm{M})$}

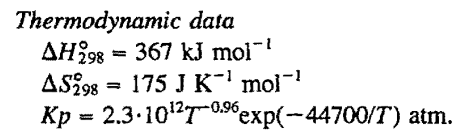

Rate Coefficient Data

\begin{tabular}{|c|c|c|c|c|}
\hline$k / \mathrm{s}^{-1}$ & $T / \mathrm{K}$ & {$[\mathrm{M}] /$ molecule $\mathrm{cm}^{-3}$} & Reference & Comments \\
\hline \multicolumn{5}{|l|}{ Rate Coefficient Measurements } \\
\hline \multicolumn{5}{|l|}{ Intermediate Fall-Off Range } \\
\hline $1.3 \cdot 10^{16} \exp (-41800 / T)$ & $1050-1250$ & $1 \cdot 10^{19}(\mathrm{Ar})$ & Lifshitz and Frenklach, $1975^{1}$ & (a) \\
\hline $4.0 \cdot 10^{16} \exp (-42520 / T)$ & 817 & $1.2 \cdot 10^{18}\left(\mathrm{C}_{3} \mathrm{H}_{8}\right)$ & Allara and Edelson, $1975^{2}$ & (b) \\
\hline $5.0 \cdot 10^{16} \exp (-42723 / T)$ & $748-793$ & & Jezequel, Baronnet, and Niclause, $1978^{4}$ & (c) \\
\hline 12.5 & 1250 & $(2.6-6.0) \cdot 10^{18}(\mathrm{Ar})$ & Bradley, $1979^{5}$ & (d) \\
\hline 37.6 & 1350 & & & \\
\hline 82.6 & 1450 & & & \\
\hline 153 & 1550 & & & \\
\hline $3 \cdot 10^{-3}$ & 1008 & $5.7 \cdot 10^{18}(\mathrm{Ar})$ & Pratt and Rogers, $1979^{6}$ & (e) \\
\hline $2.5 \cdot 10^{16} \exp (-41400 / T)$ & $1300-1700$ & $-5 \cdot 10^{18}(\mathrm{Ar})$ & Koike and Gardiner, $1980^{7}$ & (f) \\
\hline $6.7 \cdot 10^{16} \exp (-45390 / T)$ & $1200-1450$ & $1.5 \cdot 10^{19}(\mathrm{Ar})$ & Chiang and Skinner, $1981^{8}$ & (g) \\
\hline $4.5 \cdot 10^{16} \exp (-42623 / T)$ & $873-1053$ & $2.0 \cdot 10^{18}\left(\mathrm{~N}_{2}\right)$ & Juste, Scacchi and Niclause, $1981^{\circ}$ & (h) \\
\hline $4.0 \cdot 10^{16} \exp (-42800 / T)$ & $1110-1235$ & $6.0 \cdot 10^{18}\left(\mathrm{~N}_{2}\right)$ & Hautman et al., $1981^{10}$ & (i) \\
\hline $3.6 \cdot 10^{14} \mathrm{exp}(-37600 / T)$ & $1300-1700$ & $9.0 \cdot 10^{18}\left(\mathrm{Ar}, \mathrm{N}_{2}\right)$ & Simmie, Gardiner, and Eubank, $1982^{11}$ & (j) \\
\hline $5.1 \cdot 10^{16} \exp (-41969 / T)$ & $773-793$ & $2.5 \cdot 10^{18}\left(\mathrm{C}_{3} \mathrm{H}_{8}\right)$ & Kanan, Purnell, and Smith, $1983^{12}$ & (k) \\
\hline $7.74 \cdot 10^{11} \exp (-28030 / T)$ & $1400-1800$ & $(0.9-3.6) \cdot 10^{18}(\mathrm{Kr})$ & Al-Alami and Kiefer, $1983^{13}$ & (1) \\
\hline $4.2 \cdot 10^{7} \exp (-2803 \mathrm{U} / \mathrm{L})[\mathrm{Kr}]$ & $1800-2300$ & $(0.3-1.0) \cdot 10^{18}(\mathrm{Kr})$ & & \\
\hline $1.1 \cdot 10^{16} \exp (-42270 / T)$ & $1100-1450$ & $1 \cdot 10^{19}(\mathrm{Ar})$ & Hidaha, Oki, and Kawano, $1989^{14}$ & (m) \\
\hline \multicolumn{5}{|l|}{ Reviews and Evaluations } \\
\hline$k_{\infty}=1.5 \cdot 10^{16} \exp (-41300 / T)$ & 1100 & & Tsang, $1969^{15}$ & (n) \\
\hline$k_{\infty}=5.6 \cdot 10^{16} \exp (-42600 / T)$ & 1100 & & Tsang, $1981^{16}$ & (o) \\
\hline$k_{\infty}=5.0 \cdot 10^{15} \exp (-42095 / T)$ & $800-2000$ & & Warnatz, $1984^{17}$ & (p) \\
\hline$k_{\infty}=7.9 \cdot 10^{22} \mathrm{~T}^{-1.8} \exp (-44637 / T)$ & $300-1200$ & & Tsang, $1988^{18}$ & (q) \\
\hline$k_{\infty}=6.9 \cdot 10^{22} \mathrm{~T}^{-1.79} \exp (-44637 / T)$ & $300-1200$ & & Tsang, $1989^{\circ}$ & (r) \\
\hline
\end{tabular}

\section{Comments}

(a) Shock wave study using mixtures of $0.4-1.6 \% \mathrm{C}_{3} \mathrm{H}_{8}$ in Ar. Mechanism with reactions discussed.

(b) Modelling of the $\mathrm{C}_{3} \mathrm{H}_{8}$ pyrolysis based on results of Leathard and Purnell ${ }^{3}$.

(c) Pyrolysis of $\mathrm{C}_{3} \mathrm{H}_{8}$ with chromatographic analysis of products. The major primary products are methane, ethylene, hydrogen and propene. Modelling of reaction.

(d) Pyrolysis of $\mathrm{C}_{3} \mathrm{H}_{8}$ in $\mathrm{Ar}$ studied in a single-pulse shock twhe. Analysis of products by gas chromatography.

(e) Early stages of the pyrolysis of $\mathrm{C}_{3} \mathrm{H}_{8}$ studied by a wallless reactor technique. Measurements of the rates of formation of methane, ethene and propene.

(f) Thermal decomposition of $\mathrm{C}_{3} \mathrm{H}_{8}$ in a shock tube coupled to IR laser absorption spectroscopy. Modelling with a 44-reaction mechanism.

(g) Pyrolysis of $\mathrm{C}_{3} \mathrm{H}_{8}$ - $\mathrm{Ar}$ mixtures behind reflected shock waves. $\mathrm{H}$ atoms monitoring by atomic resonance absorption spectroscopy.

(h) Thermal decomposition of $\mathrm{C}_{3} \mathrm{H}_{8}$ in a continuous jetstirred reactor. Reaction products measured by gas chromatography.

(i) Turbulent flow reactor study of $\mathrm{C}_{3} \mathrm{H}_{8}$ pyrolysis. The kinetics are described by a 34-reaction mechanism. (j) Shock wave study using mixtures of $5 \% \mathrm{C}_{3} \mathrm{H}_{8}$ in $\mathrm{Ar}$ and $\mathrm{N}_{2}$. Analysis by IR laser absorption kinetic spectroscopy.

(k) Pyrolysis of $\mathrm{C}_{3} \mathrm{H}_{8}$ in a static reactor. Products analysed by GC.

(1) Pyrolysis of $\mathrm{C}_{3} \mathrm{H}_{8}$ studied in incident shock waves with the laser-schlieren technique. Mechanism with 30 reactions.

(m) Thermal decomposition of $\mathrm{C}_{3} \mathrm{H}_{8}$ studied in reflected shock waves monitoring absorption-time profiles at 3.39 $\mu \mathrm{m}$ due to $\mathrm{C}_{3} \mathrm{H}_{8}, \mathrm{C}_{2} \mathrm{H}_{4}, \mathrm{C}_{2} \mathrm{H}_{2}$ and $\mathrm{CH}_{4}$.

(n) Fstimation hased on the geometrical mean rule and thermochemical parameters.

(o) Review of literature.

(p) Review of literature data.

(q) Review of literature data. The recommended value is based on the high pressure limiting rate coefficient for the recombination $\mathrm{CH}_{3}+\mathrm{C}_{2} \mathrm{H}_{5} \rightarrow \mathrm{C}_{3} \mathrm{H}_{8}\left(4.7 \cdot 10^{-44}(T / 300)^{-0.5}\right.$ $\mathrm{cm}^{3}$ molecule $\left.\mathrm{s}^{-1} \mathrm{~s}^{-119}\right)$ and the equilibrium constant tabulated here.

(r) Based on the results of Parkes and Quinn ${ }^{21}$ for the reaction $\mathrm{C}_{2} \mathrm{H}_{5}+\mathrm{C}_{2} \mathrm{H}_{5} \rightarrow n-\mathrm{C}_{4} \mathrm{H}_{30}$ and the geometrical mean rule. 


\section{Preferred Values}

$k_{\infty}=1.1 \cdot 10^{17} \exp (-42470 / T) \mathrm{s}^{-1}$ over range $700-2000 \mathrm{~K}$. $k_{\mathrm{o}}=[\mathrm{Ar}] 1.3 \cdot 10^{-5} \exp (-32700 / T) \mathrm{s}^{-1}$ over range $700-$ $2000 \mathrm{~K}$.

$F_{\mathrm{c}}=0.24 \exp (-T / 1946)+0.76 \mathrm{exp}(-T / 38)$ for $\mathrm{M}=$ Ar over range $700-2000 \mathrm{~K}$.

\section{Reliability}

$\Delta \log k_{\infty}= \pm 0.3$ over range $700-2000 \mathrm{~K}$.

$\Delta \log k_{0}= \pm 0.5$ for $\mathrm{M}=\mathrm{Ar}$ over range $700-2000 \mathrm{~K}$.

$\Delta F_{\mathrm{c}}= \pm 0.2$ over range $700-2000 \mathrm{~K}$.

\section{Comments on Preferred Values}

The preferred values are based on theorctical modelling ${ }^{22-24}$ which is required to reconcile the largely scattered data. These calculations predict for the high pressure rate coefficient of the reverse recombination process a value $5.6 \cdot 10^{-11} \mathrm{~cm}^{3}$ molecule ${ }^{-1} \mathrm{~s}^{-1}$ over the range $300-2000 \mathrm{~K}$. The value at $300 \mathrm{~K}$ is in good agreement with recent direct determinations ${ }^{25.26}$. The preferred dissociation rate coefficient $k_{\infty}$ is obtained via detailed balance. The recommended $k_{\circ}$ was estimated using an average energy transferred per collision of 120 $\mathrm{cm}^{-1}$ which leads to collisional efficiencies of $0.12-0.18$ between $700-2000 \mathrm{~K}$. In Figs. 1 and 2 the temperature dependence of $k_{0}$ and $k_{\infty}$ is shown. Figure 3 shows theoretical falloff curves and selected experimental rate coefficients. At $1250 \mathrm{~K}$ there is considerable scatter in the results.

\section{References}

'A. Lifshitz and M. Frenklach, J. Phys. Chem. 79, 686 (1975).

${ }^{2}$ D.L. Allara and D. Edelson, Int. J. Chem. Kinet. 7, 479 (1975).

${ }^{3}$ J.Y. Jezequel, F. Baronnet, and M. Niclause, J. Chim. Phys. 75, 773, 991 (1978).

${ }^{4}$ D.A. Leathard and J.H. Pumell, Proc. Roy. Soc. (London), A305, 517 (1968).

${ }^{5}$ J.N. Bradley, J. Chem. Soc., Faraday Trans. 1 75, 2819 (1979).

${ }^{6} \mathrm{G}$. Pratt and D. Rogers, J. Chem. Soc., Faraday Trans. 1 75, 1101 (1979).

${ }^{7}$ T. Koike and W.C. Gardiner, J. Phys. Chem. 84, 2005 (1980).

${ }^{8}$ C.C. Chiang and G.B. Skinner, 18th Symp. (Int.) Combust. 915 (1981).

${ }^{9}$ C. Juste, G. Scacchi, and M. Niclause, Int. J. Chem. Kinet. 13, 855 (1981).

${ }^{10}$ D.J. Hautman, R.J. Santoro, F.L. Dryer, and 1. Glassman, Int. J. Chem. Kinet. 13, 149 (1981).

${ }^{11}$ J.M. Simmie, W.C. Gardiner, and C.S. Eubank, J. Phys. Chem. 86, 799 (1982).

${ }^{12} \mathrm{~K}$. Kanan, H. Purnell, and E. Smith, Int. J. Chem. Kinet. 15, 63 (1983).

${ }^{13}$ M.Z. Al-Alami and J.H. Kiefer, J. Phys. Chem. 87, 499 (1983).

${ }^{14}$ Y. Hidaka, T. Oki, and H. Kawano, Int. J. Chem. Kinet. 21, 689 (1989).

${ }^{15}$ W. Tsang, Int. J. Chem. Kinet. 1, 245 (1969).

${ }^{16} \mathrm{~W}$. Tsang, in "Shock Waves in Chemistry", ed. A. Lifshitz, Marcel Dekker, Inc., New York, p. 59 (1981).

${ }^{17}$ J.W. Warnatz, in "Combustion Chemistry", ed. W.C. Gardiner, SpringerVerlag, New York, p. 196 (1984).

${ }^{18}$ W. Tsang, J. Phys. Chem. Ref, Data, 17, 887 (1988).

${ }^{19}$ W. Tsang and R.F. Hampson, J. Phys. Chem. Ref. Data 15, 1087 (1986).

${ }^{20} \mathrm{~W}$. Tsang, Comb. Flame 78, 71 (1989).

${ }^{21}$ D. Parkes and C.P. Quinn, J. Chem. Soc., Faraday Trans. 1, 72, 1953 (1976).

${ }^{22}$ J. Troe, J. Chem. Phys. 66, 4758 (1977).

${ }^{23}$ J. Troe, J. Phys. Chem. 83, 114 (1979).

${ }^{24}$ J. Troe, Z. Phys. Chem. NF, 161, 209 (1989).

${ }^{25}$ C. Anastasi and N.L. Arthur, J. Chem. Soc., Faraday Trans. II 83, 27 (1987).

${ }^{26}$ L.J. Garland and K.D. Bayes, J. Phys. Chem. 94, 4941 (1990).

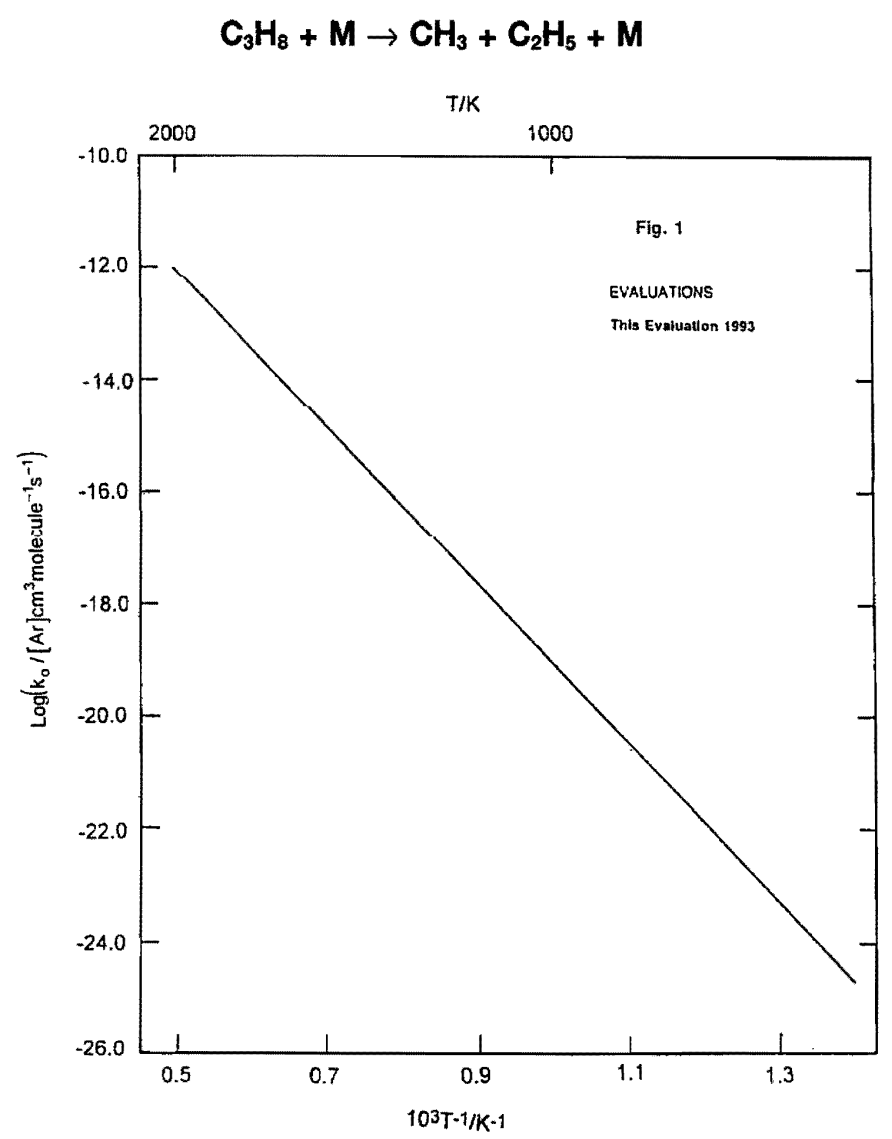



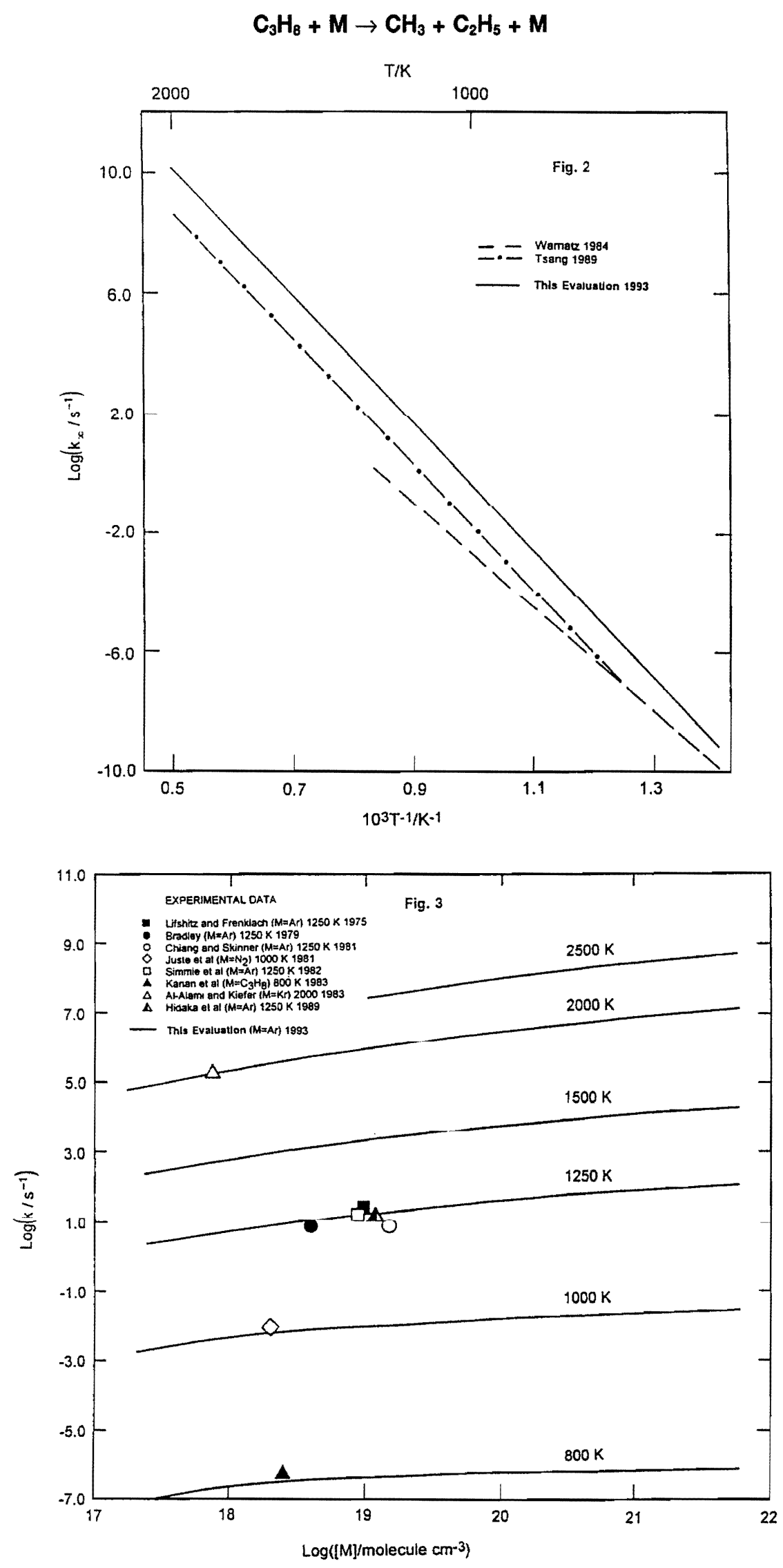


$$
\begin{aligned}
\mathrm{HCHO}(+\mathrm{M}) & \rightarrow \mathrm{CHO}+\mathrm{H}(+\mathrm{M}) \\
& \rightarrow \mathrm{CO}+\mathrm{H}_{2}(+\mathrm{M})
\end{aligned}
$$
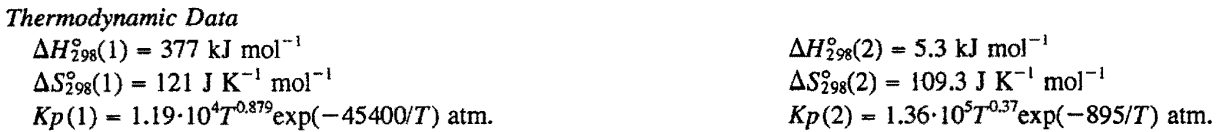

\begin{tabular}{|c|c|c|c|}
\hline $\mathrm{k} / \mathrm{cm}^{3}$ molecule ${ }^{-1} \mathrm{~s}^{-1}$ & $T / \mathrm{K}$ & Reference & Comments \\
\hline \multicolumn{4}{|l|}{ Rate Coefficient Measurements } \\
\hline \multicolumn{4}{|l|}{ Low Pressure Range } \\
\hline$[\mathrm{M}] 8.0 \cdot 10^{-8} \exp (-36300 / T)$ & $1400-2200$ & Schecker and Jost, $1969^{1}$ & (a) \\
\hline$[\mathrm{M}] 3.5 \cdot 10^{-8} \exp (-17700 / T)$ & $1350-2900$ & Peeters and Mahnen, $1973^{2}$ & (b) \\
\hline$[\mathrm{M}] 1.7 \cdot 10^{-10} \exp (-43800 / T)$ & $1070-1225$ & Aronowitz et al., $1977^{3}$ & (c) \\
\hline$[\mathrm{M}] 6.0 \cdot 10^{-7} \exp (-43800 / T)$ & $1800-2500$ & Dean et al., $1979^{5}$ & (e) \\
\hline$[\mathrm{M}] 5.5 \cdot 10^{-8} \exp (-40800 / T)$ & $1600-3000$ & Dean et al., $1980^{6}$ & (f) \\
\hline$[\mathrm{M}] 4.2 \cdot 10^{-10} \exp (-14600 / T)$ & $1400-2000$ & Vandooren and Van Tiggelen, $1981^{\top}$ & (g) \\
\hline$[\mathrm{M}] 5.25 \cdot 10^{-9} \exp (-37700 / T)$ & $2200-2650$ & Saito et al., $1985^{8}$ & (h) \\
\hline$[\mathrm{M}] k_{\mathrm{o}}(2)=[\mathrm{Ar}] 3.89 \cdot 10^{-15}$ & 1915 & Buxton and Simpson, $1986^{9}$ & (i) \\
\hline$-[A r] 1.74 \cdot 10^{-14}$ & 2107 & & \\
\hline$=[\operatorname{Ar}] 2.34 \cdot 10^{-14}$ & 2218 & & \\
\hline$k_{0}(1)=[\mathrm{Ar}] 2.7 \cdot 10^{12} \mathrm{~T}^{-5.54} \exp (-48660 / T)$ & $1700-3200$ & Irdam et al., $1992^{11}$ & $(\mathrm{k})$ \\
\hline \multicolumn{4}{|l|}{ Reviews and Evaluations } \\
\hline$[\mathrm{M}] k_{0}(1)=8.3 \cdot 10^{-8} \exp (-38500 / T)$ & $1000-3000$ & Warnatz, $1984^{12}$ & (l) \\
\hline$[\mathrm{M}] k_{0}(1)=2.0 \cdot 10^{17} \mathrm{~T}^{-6.9} \exp (-48590 / T)$ & $1000-3000$ & Tsang and Hampson, $1986^{13}$ & $(\mathrm{~m})$ \\
\hline$[\mathrm{M}] k_{0}(1)=[\mathrm{Ar}] 2.1 \cdot 10^{-8} \exp (-39200 / T)$ & $1500-2500$ & CEC, $1992^{14}$ & (n) \\
\hline
\end{tabular}

Rate Coefficient Data $\left(k=k_{1}+k_{2}\right)$

\section{Comments}

(a) Shock tube study of thermal decomposition of HCHO. Analysis by UV and IR absorption.

(b) Thermal decomposition of $\mathrm{HCHO}$ in a flame. Mass spectrometric analysis.

(c) Thermal decomposition of $\mathrm{HCHO}$ in a flow reactor. Gas chromatographic analysis.

(d) Shock tube study of HCHO decomposition. Analysis by resonance absorption.

(e) HCHO decay behind reflected shock wave monitored by IR emission.

(f) $\mathrm{HCHO} / \mathrm{O}_{2} / \mathrm{Ar}$ and $\mathrm{HCHO} / \mathrm{N}_{2} / \mathrm{Ar}$ mixtures investigated behind reflected shock waves; HCHO detected by IR emission. $\mathrm{M}=\mathrm{Ar}$.

(g) Thermal decomposition of HCHO in a flame. Mass spectrometric analysis.

(h) Thermal decomposition of $\mathrm{HCHO}$ behind reflected shock waves. $\mathrm{HCHO}$ decay and $\mathrm{CO}$ production determined by IR emission. $H$ atom production measured by ARAS. $M$ = Ar. Channel (2) appeared to have a smaller rate under the experimental conditions.

(i) Shock tube study of thermal decomposition of HCHO. Analysis by cwCO laser absorption to follow HCHO decay and $\mathrm{CO}$ production. Measurements performed between $1750-2220 \mathrm{~K}$ and total gas density from $1.28 \cdot 10^{18}$ to $1.32 \cdot 10^{19}$ molecule $\mathrm{cm}^{-3}\left(0.05-2 \%\right.$ of $\left.\mathrm{H}_{2} \mathrm{CO}\right)$. (j) Thermal decomposition of HCHO behind reflected shock wave. $\mathrm{H}$ atom production measured by ARAS. $\mathrm{M}=\mathrm{Ar}$.

(k) Shock tube study of the pyrolysis of HCHO. The HCHO was generated by the thermal dissociation of its cyclic trimer, 1,3,5-trioxane. RRKM analysis based on ab initio potential energy surface. The simulations shows that reaction (2) is 2-3 times faster than reaction (1) between $2000-3000 \mathrm{~K}$.

(1) Based on the shock tube data of Schecker and Jost ${ }^{1}$, Bhaskaran et al. ${ }^{4}$, and Dean et al. ${ }^{5.6}$.

(m) Theoretical calculation of $k_{1}$ in Ar using RRKM theory.

(n) Critical evaluation of gas phase chemical reactions for use in modelling combustion processes.

\section{Preferred Values}

$k_{\mathrm{o}}(1)=[\mathrm{Ar}] 2.7 \cdot 10^{12} T^{-5.54} \exp (-48660 / T) \mathrm{s}^{-1}$ over range $1700-3200 \mathrm{~K}$.

$k_{\mathrm{o}}(2) / k_{\mathrm{o}}(1) \approx 2.5$ over range $2000-3000 \mathrm{~K}$.

\section{Reliability}

$$
\Delta\left[k_{\circ}(2) / k_{\mathrm{o}}(1)\right]= \pm 0.5 \text { over range } 2000-3000 \mathrm{~K} .
$$

\section{Comments on Preferred Values}

The reaction in second order under all conditions relevant to combustion. Recent shock waves studies are in conflict. the results of Buxton and Simpson ${ }^{9}$ are in good agreement with 
those of Dean et al.$^{6}$ and Saito et al.$^{8}$ indicating that channel (2) is unimportant near $2000 \mathrm{~K}$. However, Rimpel and Just ${ }^{10}$ and more recently Irdam et al. ${ }^{11}$ suggest that reaction (2) predominates over reaction (1). In fact, from Ref. 11 a $k_{\circ}(2)$ $\approx(2-3) k_{0}(1)$ has been found. We have revised the preferred values for $k_{0}(1)$, and the recommended value corresponds to Ref. 11. On the other hand, even though the value of the branching ratio is unclear, we have selected a $k_{0}(2) / k_{0}(1)$ value similar to that given in Ref. 11.

\section{References}

${ }^{1}$ H.G. Schecker and W. Jost, Ber. Bunsenges. Phys. Chem. 73, 521 (1969). ${ }^{2} J$. Peeters and G. Mahnen, 14th Symp. (Int.) Combust. 133 (1973).

${ }^{3}$ D. Aronowitz, D.W. Naegeli, and I. Glassman, J. Phys. Chem. 81, 2555 (1977).
${ }^{4}$ K.A. Bhaskaran, P. Frank, and Th. Just, 12th Shock Tube Symp., Jerusalem, 1979.

${ }^{5}$ A.M. Dean, B.L. Craig, R.L. Johnson, M.C. Schultz, and E.E. Wang, 17th Symp. (Int.) Combust., 577 (1979).

${ }_{6}^{6}$ A.M. Dean, R.L. Johnson, and D.C. Steiner, Comb. Flame 37, 41 (1980).

'J. Vandooren and P.J. Van Tiggelen, 18th Symp. (Int.) Combust., 473 (1981).

${ }^{8}$ K. Saito, T. Kakumoto, Y. Nakanishi, and A. Imamura, J. Phys. Chem. 89, 3109 (1985).

9J.P. Buxton and C.J.S.M. Simpson, Chem. Phys. Lett., 128, 577 (1986).

${ }^{10} \mathrm{G}$. Rimpel and Th. Just, manuscript in preparation (1989).

"E.A. Irdam, J.H. Kiefer, L.B. Harding, and A.F. Wagner, Int. J. Chem. Kinet., submitted, 1992.

${ }^{12} \mathrm{~J}$. Warnatz, in "Combustion Chemistry", ed. W.C. Gardiner, Springer-Verlag, New York (1984).

${ }^{13}$ W. Tsang and R.F. Hampson, J. Phys. Chem. Ref. Data 15, 1087 (1986). ${ }^{14} \mathrm{CEC}, 1992$ (see references in Introduction).

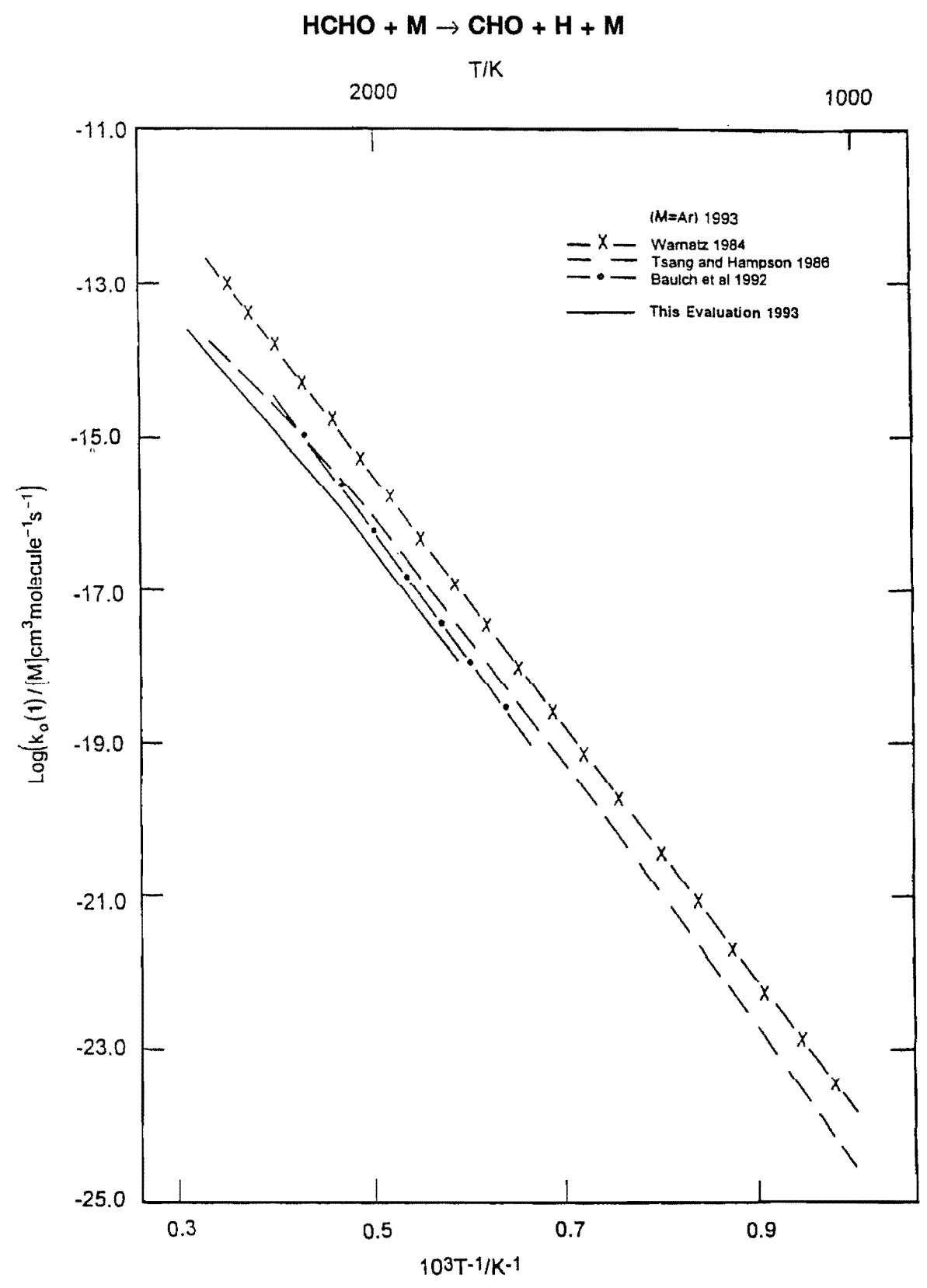


$\mathrm{CH}_{3} \mathrm{O}(+\mathrm{M}) \rightarrow \mathrm{HCHO}+\mathrm{H}(+\mathrm{M})$

Thermodynamic Data

$\Delta H_{298}^{\circ}=85.8 \mathrm{~kJ} \mathrm{~mol}^{-1}$

$\Delta S_{298}^{\circ}=105 \mathrm{~J} \mathrm{~K}^{-1} \mathrm{~mol}^{-1}$

$K p=6.67 \cdot 10^{4} T^{0.67} \exp (-10300 / T)$ atm.

Rate Coefficient Data

\begin{tabular}{|c|c|c|c|}
\hline $\mathrm{k} / \mathrm{cm}^{3}$ molecule $^{-1} \mathrm{~s}^{-1}$ & $T / \mathrm{K}$ & Reference & Comments \\
\hline $\begin{array}{l}\text { Rate Coefficient Measurements } \\
9.05 \cdot 10^{-11} \exp (-6794 / T) \\
(\mathrm{M}=\mathrm{Ar} \text { or } \mathrm{He})\end{array}$ & $550-1660$ & Choudhury et al., $1990^{2}$ & (a) \\
\hline $\begin{array}{l}\text { Reviews and Evaluations } \\
\quad 3.16 \cdot 10^{2} T^{-2.7} \exp (-15400 / T)\end{array}$ & $300-1000$ & CEC, $1992^{2}$ & (b) \\
\hline
\end{tabular}

\section{Comments}

(a) Pyrolysis of $\mathrm{CH}_{3} \mathrm{ONO}$ in static system (550-770 K) with product analysis $\left(\mathrm{CO}, \mathrm{HCHO}\right.$ and $\left.\mathrm{CH}_{3} \mathrm{OH}\right)$ by FTIR spectroscopy, and in shock tube $(1000-1660 \mathrm{~K})$ with product analysis (CO and NO) by laser absorption spectroscopy. Rate constants obtained from kinetic modelling of the product yields, and compared with theoretical RRKM calculations.

(b) Based on $k_{\infty}$ from Batt ${ }^{3}$ and RRKM calculations carried out by Tsang and Hampson ${ }^{4}$.

\section{Preferred Value}

$k_{\mathrm{o}}=9.0 \cdot 10^{-11} \exp (-6790 / T) \mathrm{cm}^{3}$ molecule $\mathrm{e}^{-1} \mathrm{~s}^{-1}$ over the range $300-1700 \mathrm{~K}$.

Reliability

$\Delta \log k_{\mathrm{o}}= \pm 0.3$ over the range $300-1700 \mathrm{~K}$.

\section{Comments on Preferred Values}

Under practically all conditions in combustion systems, the reaction is in the second-order region. The recent experimental measurements of $k_{\mathrm{o}}$ are the first reported for this reaction. The values are substantially higher than the previous theoretical estimates of Greenhill et al. ${ }^{5}$ and Tsang and Hampson ${ }^{4}$ (e.g. a factor of 150 at $555 \mathrm{~K}$ and a factor of 2 at $1250 \mathrm{~K}$ ). The experimental data provide the basis for the recommended values.

\section{References}

'T.K. Choudhury, Y. He, W.A. Sanders, and M.C. Lin, J. Phys. Chem. 94, 2394 (1990)

${ }^{2} \mathrm{CEC}, 1992$ (see references in Introduction).

${ }^{3}$ L. Batt, Int. Rev. Phys. Chem. 6, 53 (1987).

${ }^{4}$ W. Tsang and R.F. Hampson, J. Phys. Chem. Ref. Data 15, 1087 (1986). ${ }^{5}$ P.G. Greenhill, B.V. O'Grady, and R.G. Gilbert, Aust. J. Chem. 39, 1929 (1986).

$$
\begin{aligned}
\mathrm{CH}_{3} \mathrm{O}+\mathrm{O}_{2} & \rightarrow \mathrm{HCHO}+\mathrm{HO}_{2} \\
& \rightarrow \mathrm{CH}_{2} \mathrm{OH}+\mathrm{O}_{2} \\
& \rightarrow \mathrm{HCHO}+\mathrm{H}+\mathrm{O}_{2}
\end{aligned}
$$

Thermodynamic data

$\Delta H_{298}^{\circ}(1)=-122.0 \mathrm{~kJ} \mathrm{~mol}^{-1}$

$\Delta S_{298}^{\circ}(1)=14.1 \mathrm{~J} \mathrm{~K}^{-1} \mathrm{~mol}^{-1}$

$K p(1)=4.63 \mathrm{~T}^{-0.28} \exp (+14500 / T)$

$\Delta H_{298}^{\circ}(3)=85.8 \mathrm{~kJ} \mathrm{~mol}^{-1}$

$\Delta S_{298}^{\circ}(3)=104.7 \mathrm{~J} \mathrm{~K}^{-1} \mathrm{~mol}^{-1}$

$K p(3)=6.67 \cdot 10^{4} T^{0.67} \exp (-10300 / T)$ atm.

\begin{tabular}{|c|c|c|c|}
\hline$k / \mathrm{cm}^{3}$ molecule $\mathrm{l}^{-1} \mathrm{~s}^{-1}$ & $T / \mathrm{K}$ & Reference & Comments \\
\hline $\begin{array}{l}\text { Pate Coefficient Measurements } \\
7.28 \cdot 10^{-43} T^{9.5} \exp (2768 / T)\end{array}$ & $298-973$ & Wantuck et al., $1987^{1}$ & (a) \\
\hline $\begin{array}{c}\text { Reviews and Evaluations } \\
7.2 \cdot 10^{-14} \exp (-1080 / T) \\
3.9 \cdot 10^{-14} \exp (-900 / T) \\
6.7 \cdot 10^{-14} \exp (-1070 / T)\end{array}$ & $\begin{array}{l}298-610 \\
200-300 \\
300-1000\end{array}$ & $\begin{array}{l}\text { IUPAC, } 1992^{2} \\
\text { NASA, } 1992^{3} \\
\text { CEC, } 1992^{4}\end{array}$ & $\begin{array}{l}\text { (b) } \\
\text { (c) } \\
\text { (d) }\end{array}$ \\
\hline
\end{tabular}

$$
\begin{aligned}
& \Delta H_{298}^{\circ}(2)=-33.4 \mathrm{~kJ} \mathrm{~mol}^{-1} \\
& \Delta S_{298}^{\circ}(2)=17.9 \mathrm{~J} \mathrm{~K}^{-1} \mathrm{~mol}^{-1} \\
& K p(2)=4.02 T^{0.19} \exp (+3900 / T)
\end{aligned}
$$

Rate Coefficient Data $\left(k=k_{1}+k_{2}+k_{3}\right)$ 


\section{Comments}

(a) Laser photolysis of $\mathrm{CN}_{3} \mathrm{ONO}$ or $\mathrm{CH}_{3} \mathrm{OH}$ at $193 \mathrm{~nm}$; $\mathrm{CH}_{3} \mathrm{O}$ monitored by LIF. Pseudo first order conditions with excess $\mathrm{O}_{2}$. Non Arrhenius behaviour observed over the whole temperature range. Their own data together with those of Gutman et al. ${ }^{5}$ and Lorenz et al ${ }^{6}$ were well described by a bi-exponential expression:

$k=1.5 \cdot 10^{-10} \exp (-6028 / T)+3.6 \cdot 10^{-14} \exp (-880 / T) \mathrm{cm}^{3}$ molecule ${ }^{-1} \mathrm{~s}^{-1}$.

(b) Based on data of Gutman et al. ${ }^{5}$, Lorenz et al. ${ }^{6}$ and Wantuck et al.'.

(c) Based on data of Lorenz et al. ${ }^{6}$.

(d) Based on data of Gutman et al. ${ }^{5}$, Lorenz et al. ${ }^{6}$.

\section{Preferred Values}

$k_{1}=3.6 \cdot 10^{-14} \exp (-880 / T) \mathrm{cm}^{3}$ molecule $\mathrm{e}^{-1} \mathrm{~s}^{-1}$ over range $300-1000 \mathrm{~K}$

Reliability

$\Delta \log k_{1}- \pm 0.1$ at $500 \mathrm{~K}$ rising to \pm 0.3 at $300 \mathrm{~K}$ and $1000 \mathrm{~K}$.

\section{Comments on Preferred Values}

The new data from Wantuck et al. ${ }^{1}$ extend the temperature range for which direct measurements of $k$ are available up to $1000 \mathrm{~K}$. The agreement with earlier direct rate measurements in the overlapping temperature range is good. The temperature dependence in the new study is non-Arrhenius over the whole range covered and suggests an increasing contribution, at the higher temperatures, of additional channels: $\mathrm{CH}_{3} \mathrm{O}+\mathrm{O}_{2}$ $\rightarrow \mathrm{CH}_{2} \mathrm{OH}+\mathrm{O}_{2}$ (2) and $\mathrm{CH}_{3} \mathrm{O}+\mathrm{O}_{2} \rightarrow \mathrm{HCHO}+\mathrm{H}+\mathrm{O}_{2}$ (3) for methoxy radical removal by $\mathrm{O}_{2}$. The double exponential expression given by Wantuck et al ${ }^{1}$, was obtained by fitting the data from the three direct studies ${ }^{1,5.6}$, and is applicable for the overall reaction up to $1000 \mathrm{~K}$. The component with the larger $E / R$ of $6028 \mathrm{~K}$ is remarkably similar to the expression recommended in this evaluation for the decomposition reaction: $\mathrm{CH}_{3} \mathrm{O}+\mathrm{M} \rightarrow \mathrm{HCHO}+\mathrm{H}+\mathrm{M}(\mathrm{M}=\mathrm{Ar}$ or He, $k=$ $9.0 \cdot 10^{-11} \exp (-6790 / T) \mathrm{cm}^{3}$ molecule $\left.\mathrm{c}^{-1} \mathrm{~s}^{-1}\right)$, and therefore may be provisionally assigned to channel (3).

The recommendation for channel (1) is the low $E / R$ component of the bi-exponential expression of Wantuck et al .'; it is not significantly different from that recommended by $\mathrm{NASA}^{3}$ for this reaction in the low temperature range.

\section{References}

'P.J. Wantuck, R.C. Oldenborg, S.L. Baughcum, and K.R. Winn, J. Phys. Chem. 91, 4653 (1987).

${ }^{2}$ IUPAC Evaluation, Supplement IV, 1992 (see references in Introduction).

${ }^{3}$ NASA Evaluation No. 10, 1992 (see references in Introduction).

${ }^{4} \mathrm{CEC}, 1992$ (see references in Introduction).

${ }^{5}$ D. Gutman, N. Sanders, and J.E. Butler, J. Phys. Chem. 86, 66 (1982).

${ }^{6} \mathrm{~K}$. Lorenz, D. Rhasa, R. Zellner, and B. Fritz, Ber. Bunsenges. Phys. Chem. 89, 341 (1985).

\section{$\mathrm{CH}_{2} \mathrm{OH}+\mathrm{O}_{2} \rightarrow \mathrm{CH}_{2} \mathrm{O}+\mathrm{HO}_{2}$}

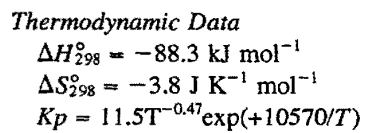

Rate Coefficient Data

\begin{tabular}{llll}
\hline \hline$k / \mathrm{cm}^{3}$ molecule & Reference & Comments \\
\hline $\begin{array}{l}\text { Rate Coefficient Measurements } \\
1.7 \cdot 10^{-13}\end{array}$ & $T / \mathrm{K}$ & Miyoshi, Matsui, and Washida, 1990 & \\
& 296 & & \\
Reviews and Evaluations & & (a) \\
$1.7 \cdot 10^{-11}$ exp $(-3600 / T)$ & $300-2000$ & Warnatz, $1984^{2}$ & NASA, $1992^{3}$ \\
$9.1 \cdot 10^{-12}$ & 298 & CEC, $1992^{4}$ & $(\mathrm{~b})$ \\
$2.6 \cdot 10^{-9} \mathrm{~T}^{-1}+1.2 \cdot 10^{-10} \exp (-1800 / \mathrm{T})$ & $300-1200$ & IUPAC, $1992^{5}$ & $(\mathrm{c})$ \\
$9.4 \cdot 10^{-12}$ & 298 & $(\mathrm{~d})$ \\
& & & $(\mathrm{e})$ \\
\hline
\end{tabular}




\section{Comments}

(a) Laser flash photolysis of $\mathrm{CH}_{3} \mathrm{COCH}_{2} \mathrm{OH}$ with decay of $\mathrm{CH}_{2} \mathrm{OH}$ monitored by photoionization MS.

(b) Based on high-temperature data from shock-tube and other studies.

(c) Average of dàta of Grotheer et al ${ }^{6}$, Dōbē et al. ${ }^{7}$, and Payne et al. ${ }^{8}$.

(d) See Comments on Preferred Values.

(e) Average of room temperature data of Grotheer et al. ${ }^{6}$, Nesbitt et al.$^{9}$, Pagsberg et al..$^{10}$, Miyoshi et al.$^{1}$, Grotheer et al..$^{11}$, Dōbē et al. ${ }^{7}$, and Payne et al.$^{8}$.

\section{Preferred Value}

$k=2.6 \cdot 10^{-9} T^{-1}+1.2 \cdot 10^{-10} \exp (-1800 / T) \mathrm{cm}^{3}$ molecule $^{-1}$ $\mathrm{s}^{-1}$ over range $300-1200 \mathrm{~K}$.

\section{Reliability}

$\Delta \log k= \pm 0.1$ at $300 \mathrm{~K}$ increasing to \pm 0.3 at $1200 \mathrm{~K}$.

\section{Comments on Preferred Values}

The results of Miyoshi et al. ${ }^{1}$ have become available since our previous evaluation ${ }^{4}$, and are in good agreement with the ther most recent room temperature measurements ${ }^{6-11}$. Our previous recommendation ${ }^{4}$, based on an average room temperature rate coefficient $t^{6-11}$, and the temperature dependences observed by Vandooren and van Tiggelen ${ }^{12}$ and by Grotheer et al.$^{6}$, remains unaltered.

As previously pointed out ${ }^{4}$, it is difficult to reconcile the data of Nesbitt et al.$^{9}$, over the temperature range $215-250 \mathrm{~K}$, with the recommended high temperature data. More work is needed to confirm the temperature dependence of this reaction.

\section{References}

'A. Miyoshi, H. Matsui, and N. Washida, J. Phys. Chem. 94, 3016 (1990). ${ }^{2}$ J. Warnatz, in "Combustion Chemistry", ed. W.C. Gardiner, Springer-Verlag, New York (1984).

${ }^{3}$ NASA Evaluation No. 10, 1992 (see references in Introduction).

${ }^{4} \mathrm{CEC}, 1992$ (see references in Introduction).

${ }^{5}$ IUPAC, 1992 (see references in Introduction)

${ }^{6}$ H.H. Grotheer, G. Riekert, D. Walter, and Th. Just, J. Phys. Chem. 92, 4028 (1988); H.H. Grotheer, G. Riekert, D. Walter, and Th. Just, 22nd Symp. (Int.) Combust., 963 (1988).

${ }^{7} \mathrm{~S}$. DJbe, F. Temps, T. Böhland, and H.Gg. Wagner, Z. Naturforsch. 40a, 1289 (1985).

${ }^{8}$ W.A. Payne, J. Brunning, M.B. Mitchell, L.J. Stief, Int. J. Chem. Kinet. 20, 63 (1988).

${ }^{9}$ F.L. Nesbitt, W.A. Payne, and L.J. Stief, I. Phys Chem. 92, 4030 (1988) ${ }^{10}$ P. Pagsberg, J. Munk, C. Anastasi, and V.J. Simpson, J. Phys. Chem. 93, 5162 (1989).

${ }^{11}$ H.H. Grotheer, G. Riekert, U. Meier, and Th. Just, Ber. Bunsenges. Phys. Chem. 89, 187 (1985).

${ }^{12}$ J. Vandooren and P.J. van Tiggelen, 18th Symp. (Int.) Combust., 437 (1980). 


$$
\begin{aligned}
\mathrm{CH}_{3} \mathrm{O}_{2}+\mathrm{CH}_{3} \mathrm{O}_{2} & \rightarrow \mathrm{CH}_{3} \mathrm{O}+\mathrm{CH}_{3} \mathrm{O}+\mathrm{O}_{2} \\
& \rightarrow \mathrm{CH}_{3} \mathrm{OH}+\mathrm{HCHO}+\mathrm{O}_{2} \\
& \rightarrow \mathrm{CH}_{3} \mathrm{OOCH}+\mathrm{O}_{2}
\end{aligned}
$$

Thermodynamic Data $\Delta H_{298}^{\circ}(1)=19.8 \mathrm{~kJ} \mathrm{~mol}^{-1}$ $\Delta S_{298}^{\circ}(1)=124.8 \mathrm{~J} \mathrm{~K}^{-1} \mathrm{~mol}^{-1}$

$K p(1)=8.0 \cdot 10^{11} T^{-1.65} \exp (-2080 / T) \mathrm{atm}$
$\Delta H_{298}^{\circ}(2)=-337.7 \mathrm{~kJ} \mathrm{~mol}^{-1}$ $\Delta S_{298}^{\circ}(2)=126.0 \mathrm{~J} \mathrm{~K}^{-1} \mathrm{~mol}^{-1}$

\begin{tabular}{|c|c|c|c|}
\hline$k / \mathrm{cm}^{3}$ molecule $\mathrm{e}^{-1} \mathrm{~s}^{-1}$ & $T / \mathrm{K}$ & Reference & Comments \\
\hline \multicolumn{3}{|l|}{ Rate Coefficient Measurements } & (a) \\
\hline$k=3.6 \cdot 10^{-13}$ & 298 & Simon, Schneider, and Moortgat, $1990^{1}$ & (b) \\
\hline$k=1.3 \cdot 10^{-13} \exp (365 / T)$ & $248-573$ & Lightfoot, Veyret, and Lesclaux, $1990^{2}$ & (c) \\
\hline $\begin{array}{l}k=1.3 \cdot 10^{-13} \exp (297 / T) \text { at } 11 \text { Torr } \\
k=8.9 \cdot 10^{-14} \exp (424 / T) \text { at } 760 \text { Torr }\end{array}$ & $268-350$ & Jenkin and Cox, $1991^{3}$ & (d) \\
\hline$k=1.0 \cdot 10^{-13} \exp (416 / T)$ & $248-650$ & Lightfoot et al., $1991^{4}$ & (e) \\
\hline \multicolumn{3}{|l|}{ Branching Ratio Measurements } & (a) \\
\hline$k_{1} / k_{2}=7.5 \exp (-760 / T)$ & $376-430$ & Ballod et al., 1989.5 & (f) \\
\hline$k_{1} /\left(k_{2}+k_{3}\right)=45 \exp (-1470 / T)$ & $388-573$ & Lightfoot, Veyret, and Lesclaux, $1990^{2}$ & (c) \\
\hline$k_{1} /\left(k_{2}+k_{3}\right)=19 \exp (-1131 / T)$ & $223-333$ & Horie, Crowley, and Moortgat, $1990^{6}$ & (g) \\
\hline \multicolumn{4}{|l|}{ Reviews and Evaluations } \\
\hline$k=2.5 \cdot 10^{-13} \exp (190 / T)$ & $200-400$ & NASA, $1992^{7}$ & (h) \\
\hline$k_{1} / k=0.35 ; k_{2} / k=0.55 ; k_{3} / k=0.10$ & 298 & & \\
\hline$k=1.1 \cdot 10^{-13} \exp (365 / T)$ & $200-400$ & IUPAC, $1992^{8}$ & (i) \\
\hline$k=9.2 \cdot 10^{-14} \exp (390 / T)$ & $250-600$ & Wallington, Dagaut, and Kurylo, $1992^{9}$ & (j) \\
\hline \multicolumn{4}{|l|}{$k_{1} /\left(k_{2}+k_{3}\right)=37,3 \exp (-1350 / T)$} \\
\hline$k=9.1 \cdot 10^{-14} \exp (416 / T)$ & $248-650$ & Lightfoot et al., $1992^{10}$ & (k) \\
\hline$k_{1} /\left(k_{2}+k_{3}\right)=25 \exp (-1165 / T)$ & $228-573$ & & \\
\hline
\end{tabular}

$K p(2)=1.2 \cdot 10^{18} T^{-3.38} \exp (+38800 / T)$ atm.

Rate Coefficient Data $\left(k=k_{1}+k_{2}+k_{3}\right)$

\section{Comments}

(a) Studies on this reaction undertaken prior to 1989 (references 11-26) are not listed explicitly but have been discussed previously in the NASA ${ }^{7}$ and IUPAC ${ }^{8}$ evaluations and in the recent reviews of peroxy radical chemistry $y^{9,10}$.

(b) Molecular modulation study of the broad-band photolysis (280-370 nm) of $\mathrm{Cl}_{2} / \mathrm{CH}_{4} / \mathrm{O}_{2}$ mixtures. The UV absorption spectrum of $\mathrm{CH}_{3} \mathrm{O}_{2}$ was recorded between 220 and $270 \mathrm{~nm}$ and calibrated by determining the rate of loss of $\mathrm{Cl}_{2}$. Numerical analysis of individual waveforms between 230 and $260 \mathrm{~nm}$ was undertaken with an assumed mechanism, and the branching ratios taken from the study of Niki et al. ${ }^{19}$.

(c) Flash photolysis of $\mathrm{Cl}_{2} / \mathrm{CH}_{4} / \mathrm{O}_{2} / \mathrm{N}_{2}$ mixtures with UV absorption detection between 210 and $260 \mathrm{~nm}$. Composite transient absorption profiles due to $\mathrm{CH}_{3} \mathrm{O}_{2}$ and $\mathrm{HO}_{2}$ analysed using UV absorption cross-sections taken from McAdam et al.$^{23}$. Absorption cross-sections used (in units of $10^{-18} \mathrm{~cm}^{2}$ molecule $\left.{ }^{-1}\right)-\mathrm{CH}_{3} \mathrm{O}_{2}, \sigma_{210}=2.5, \sigma_{240}=$ 4.8, $\sigma_{260}=3.6 ; \mathrm{HO}_{2}, \sigma_{210}=5.3, \sigma_{240}=1.8 ; \sigma_{260}=0.3$. At higher temperatures, pairs of composite waveforms were analysed simultaneously.

(d) Molecular modulation study of the $254 \mathrm{~nm}$ photolysis of $\mathrm{CH}_{3} \mathrm{I} / \mathrm{O}_{2} / \mathrm{N}_{2}$ mixture with UV absorption detection. UV absorption spectrum of $\mathrm{CH}_{3} \mathrm{O}_{2}$ recorded between 210 and $320 \mathrm{~nm}$ but presence of a second absorber, tentatively assigned to $\mathrm{CH}_{3} \mathrm{OOI}$, observed at longer wavelengths. MM waveforms recorded between 210 and 240 were consistent with those obtained from $\mathrm{Cl}_{2} / \mathrm{CH}_{4} / \mathrm{O}_{2}$ system. Difficulties were apparent in using photolysis rate of $\mathrm{CH}_{3} \mathrm{I}$ to calibrate absorption spectrum of $\mathrm{CH}_{3} \mathrm{O}_{2}$. Only the ratio $k / \sigma$ given but rate parameters have been derived using the UV absorption spectrum and temperature branching ratios recommended by Lightfoot $e t$ al.$^{10}$.

(e) Flash photolysis of $\mathrm{O}_{2} / \mathrm{CH}_{4} / \mathrm{CH}_{3} \mathrm{OH}$ mixtures between 600 and $719 \mathrm{~K}$ with UV absorption detection. The earlier data of Lightfoot et al..$^{2}$ were reanalysed using temperature dependent absorption cross-sections ${ }^{28}$ and combined with the results of this study.

(f) Thermal decomposition of static mixtures of di-tbutylperoxide and $\mathrm{O}_{2}$ used to study branching ratios of $\mathrm{CH}_{3} \mathrm{O}_{2}$ over the temperature range $376-430 \mathrm{~K}$. Chromatographic analysis used for acetone and methanol. HCHO converted into a complex with chromotropic acid and detected spectrophotometrically. Iodometric analysis used for $\mathrm{CH}_{3} \mathrm{OOH}$. Arrhenius fit to experimental data undertaken with their preferred value of the branching ratio, $\left(k_{1} / k_{2}=0.6\right)$ at $298 \mathrm{~K}$.

(g) Continuous photolysis of $\mathrm{Cl}_{2} / \mathrm{CH}_{4} / \mathrm{O}_{2}$ mixtures with molecular beam sampling. Molecular beam deposited onto a cold finger at $50 \mathrm{~K}$ before cooling to $5 \mathrm{~K}$. FTIR spectroscopy used to identify products and quantify yields.

(h) The NASA evaluation used an averaged value of the cross-section at $250 \mathrm{~nm}$ of $4.0 \cdot 10^{-18} \mathrm{~cm}^{2}$ molecule ${ }^{-1}$. This cross-section was used to obtain $k$ from a weighted average of values of $k / \sigma$ from the studies of Cox and Tyn- 
dall ${ }^{16}$, Jenkin et $a l .^{24}$, Sander and Watson ${ }^{20}$, McAdams et al..$^{23}$, Kurylo and Wallington ${ }^{22}$ and Lightfoot et al. ${ }^{2}$, The temperature dependence was based on the studies of Sander and Watson ${ }^{20}$, Kurylo and Wallington ${ }^{22}$, Lightfoot et $a l .{ }^{2}$, and Jenkin and $\mathrm{Cox}^{3}$. Branching ratios $k_{1} / k=0.35$; $k_{2} / k=0.55$; and, $k_{3} / k=0.1$, are recommended at $298 \mathrm{~K}$ based on the FT-IR studies of Kan et al ${ }^{15}$, Niki et al.$^{19}$, and the study of Lightfoot et al. ${ }^{2}$. No evidence is found for the occurrence of a channel leading to the products $\mathrm{CH}_{3} \mathrm{OOH}+\mathrm{CH}_{2} \mathrm{O}_{2}$.

(i) The IUPAC evaluation noted that the studies of Simon et al. ${ }^{1}$, Lightfoot et al ${ }^{2}$ and Jenkin and $\mathrm{Cox}^{3}$ gave values of $k / \sigma(250 \mathrm{~nm})$ which were in excellent agreement. The branching ratio was taken from the low temperature study of Hurie et al. ${ }^{6}$ as the experimental conditions were the most relevant for atmospheric modelling purposes. This branching ratio was used to give the overall elementary rate constant. The $E / R$ value was taken from the study of Lightfoot et $a l .^{2}$ because of the wide temperature range covered in that work.

(j) Wallington et al.$^{9}$ have used their recommended spectrum for $\mathrm{CH}_{3} \mathrm{O}_{2}\left(\sigma_{240}=4.42 \cdot 10^{-18} \mathrm{~cm}^{2}\right.$ molecule $\left.{ }^{-1}\right)$ to deduce rate parameters from the observed $k / \sigma$ values. They derived $k_{\mathrm{obs}}=4.6 \cdot 10^{-13} \mathrm{~cm}^{3}$ molecule ${ }^{-1} \mathrm{~s}^{-1}$ (omitting the Sander and Watson kinetic data obtained at $270 \mathrm{~nm}^{18}$ ). A single unweighted Arrhenius fit of the kinetic data obtained by Sander and Watson ${ }^{20}$, Kurylo and Wallington ${ }^{22}$, Jenkin and $\mathrm{Cox}^{3}$, Tightfont et al. ${ }^{2}$ and the unpublished work of Anastasi et al. ${ }^{25}$ gave $k_{\mathrm{obs}}=2.5 \cdot 10^{-13} \exp (180 / T)$.

Wallington et al. ${ }^{9}$ noted the good agreement between the different studies of the branching ratios at room temperature and recommend $k_{1} / k=0.35, k_{2} / k=0.58$ and $k_{3} / k$ $=0.07$ which is based on an average of the studies of Parkes ${ }^{12}$, Weaver et al. ${ }^{11}$, Kan et al.$^{18}$, Niki et al. ${ }^{19}$ and Horie et al. ${ }^{6}$. A linear regression analysis of all the data except the $388 \mathrm{~K}$ data point of Lightfoot et al. ${ }^{2}$ was undertaken in which either $\alpha\left(=k_{1} / k\right)$ or $\log _{\mathrm{e}} \beta[\beta=$ $k_{1} /\left(k_{2}+k_{3}\right)$ ] was plotted against the inverse of the absolute temperature. The expressions derived were

$$
\alpha=1.24-\frac{280}{T} \text { and } \beta=37.3 \exp (-1350 / T)
$$

(k) Lightfoot et al..$^{10}$ have recommended a UV absorption spectrum for $\mathrm{CH}_{3} \mathrm{O}_{2}$ based on an average of the measurements of Jenkin et al.$^{24}$, Moortgat et al ${ }^{26}$, Simon et al. ${ }^{1}$, Jenkin and $\mathrm{Cox}^{3}$, Dagaut and Kurylo ${ }^{27}$, and Lightfoot and Jemi-Alade ${ }^{28}$. The spectrum was normalised to a value of $4.58 \cdot 10^{-18} \mathrm{~cm}^{2}$ molecule $\mathrm{e}^{-1}$ at $240 \mathrm{~nm}$ based on the above studies but excluding the relative spectra reported by Jenkin and $\mathrm{Cox}^{3}$, and Lightfoot and Jemi-Alade ${ }^{28}$. The spectrum was used to scale the $k / \sigma$ values reported in the different kinetics studies to give $k_{\mathrm{obs}}=4.9 \cdot 10^{-13} \mathrm{~cm}^{3}$ molecule $\mathrm{s}^{-1} \mathrm{~s}^{-1}$. The branching ratio data were analysed simultaneously to give the temperature dependent expression $\beta=25 \exp (-1165 / T)$ which was used to derive $k_{298}$ as $3.7 \cdot 10^{-13} \mathrm{~cm}^{3}$ molecule $\mathrm{s}^{-1}$. The temperature dependent branching ratio was used to convert the obscrved rate constant into the elementary rate constant. The studies of
Sander and Watson ${ }^{20}$, Kurylo and Wallington ${ }^{22}$, Lightfoot et $a l .{ }^{2}$, Jenkin and $\mathrm{Cox}^{3}$, all gave $\mathrm{E} / \mathrm{R}$ values which lay between -365 and $-481 \mathrm{~K}$. The low pressure study of Jenkin and $\operatorname{Cox}^{3}$ gave a slightly lower value of -297 for $E / R$ which was significant at the $1 \sigma$ level. Lightfoot et $a l .{ }^{10}$ took the $E / R$ value derived by Lightfoot et al.$^{4}$ and combined this with the value $k_{298}=3.7 \cdot 10^{-13} \mathrm{~cm}^{3}$ molecules ${ }^{-1} \mathrm{~s}^{-1}$ to give their recommended expression.

\section{Preferred Values}

$k=9.1 \cdot 10^{-14} \exp (420 / T)$ over the range $298-700 \mathrm{~K}$. $k_{1} / k_{2}=25 \exp (-1170 / T) ; k_{3}=0$ over the range $298-700 \mathrm{~K}$.

\section{Reliability}

$\Delta \log k= \pm 0.1$ at $298 \mathrm{~K}$ increasing to \pm 0.3 at $700 \mathrm{~K}$.

\section{Comments on Preferred Values}

Experimental determinations of the rate constants for the $\mathrm{CH}_{3} \mathrm{O}_{2}+\mathrm{CH}_{3} \mathrm{O}_{2}$ reaction are usually carried out by monitoring the decrease in concentration of $\mathrm{CH}_{3} \mathrm{O}_{2}$, leading to the rate law

$$
\frac{d\left[\mathrm{CH}_{3} \mathrm{O}_{2}\right]}{d t}=-2 k_{\mathrm{obs}}\left[\mathrm{CH}_{3} \mathrm{O}_{2}\right]^{2}
$$

The rate constant, $k_{\mathrm{obs}}$, defined by this equation is only identical with $k\left(=k_{1}+k_{2}+k_{3}\right)$ when the experiments are carried out in the absence of $\mathrm{O}_{2}$. For experiments performed in the presence of $\mathrm{O}_{2}, k_{\mathrm{obs}}$ is related to $k$ by $k_{\mathrm{obs}}=k(1+\alpha)$ where $\alpha$ is the branching ratio for channel 1 i.e. $\alpha=k_{1} / k$. This arises because the $\mathrm{CH}_{3} \mathrm{O}$ formed via channel 1 reacts rapidly with $\mathrm{O}_{2}$ to form $\mathrm{HO}_{2}$. The reaction of $\mathrm{HO}_{2}$ with $\mathrm{CH}_{3} \mathrm{O}_{2}$ is about 20 times faster at room temperature than the self-reaction of $\mathrm{CH}_{3} \mathrm{O}_{2}$ so that a second $\mathrm{CH}_{3} \mathrm{O}_{2}$ is rapidly lost on the time scale of the $\mathrm{CH}_{3} \mathrm{O}_{2}$ decay. Under such experimental conditions it is therefore necessary to have values of $\alpha$ to derive values of $k$.

Most studies have monitored $\mathrm{CH}_{3} \mathrm{O}_{2}$ by UV absorption and the derivation of accurate values of $k$ is critically dependent on the quality of the data on the UV absorption cross-sections.

Wallington et al. ${ }^{9}$ and Lightfoot et al.$^{10}$ have independently undertaken a critical appraisal of the available literature on the UV absorption spectrum of $\mathrm{CH}_{3} \mathrm{O}_{2}$ and the kinetic and mechanistic data on the self-reaction of $\mathrm{CH}_{3} \mathrm{O}_{2}$. The kinetic parameters are very dependent on the absorption cross-sections chosen for $\mathrm{CH}_{3} \mathrm{O}_{2}$ and differences in rate parameters between studies reflect, in part, the different values used for the absorption cross-sections. The two reviews recommend cross-sections at $240 \mathrm{~nm}$ of $4.42 \cdot 10^{-18} \mathrm{~cm}^{2}$ molecule $^{-1}$ (Wallington et al.$^{9}$ ) and $4.58 \cdot 10^{-18} \mathrm{~cm}^{2}$ molecule ${ }^{-1}$ (Lightfoot et $\left.a l .{ }^{10}\right)$. The recommended rate expressions in the two reviews give similar values over the temperature range of the experimental data. The expression of Lightfoot et al.${ }^{10}$ utilizes new data generated by the Bordeaux group ${ }^{4}$ which extends the temperature range of the kinetic measurements to higher temperatures (up to $650 \mathrm{~K}$ ). The expressions derived by Lightfoot et $a l .{ }^{10}$ for the overall rate constant and for the branching ratios are the preferred choice of this recommendation due to the inclusion of rate parametcrs measurcd at the highor temperatures. The most recent IUPAC evaluation does not in- 
clude the new measurements of Lightfoot et al.$^{4}$ and, for that reason, differs slightly from the present evaluation.

There is some disagreement over the exact magnitude of the value for the branching ratio for channel (3). The latest studies suggest that the channel is minor $\left(k_{3} / k=<0.05\right)$ and for practical applications can be set to zero.

\section{References}

${ }^{1}$ F.G. Simon, W. Schneider, and G. Moortgat, Int. J. Chem. Kinet. 22, 791 (1990).

${ }^{2}$ P.D. Lightfoot, R. Lesclaux and B. Veyret, J. Phys. Chem. 94, 700 (1990).

${ }^{3}$ M.E. Jenkin and R.A. Cox, J. Phys. Chem. 95, 3229 (1991).

${ }^{4}$ P.D. Lightfoot, P. Roussel, F. Caralp, and R. Lesclaux, J. Chem. Soc., Faraday Trans. 87, 3213 (1991).

${ }^{5}$ A.P. Ballod, A.I. Poroikova, T.A. Titarchuk, and V.N. Khabarov, Kinet. and Catalysis 30, 476 (1989).

${ }^{6}$ O. Horie, J.N. Crowley, and G.K. Moortgat, J. Phys. Chem. 94, 8198 (1990).

${ }^{7}$ NASA Evaluation No. 10, 1992 (see references in Introduction).

${ }^{8}$ IUPAC, 1992 (see references in Introduction).

${ }^{9}$ T.J. Wallington, P. Dagaut, and M.J. Kurylo, Chem. Rev. 92, 667 (1992).

${ }^{10}$ P.D. Lightfoot, R.A. Cox, J.N. Crowley, M. Destriau, G.D. Hayman, M.E. Jenkin, G.K. Moortgat, and F. Zabel, Atmos. Environ. 26A, 1805 (1992).

${ }^{11} \mathrm{~J}$. Weaver, R. Shortridge, J. Meagher, and J. Heicklen, J. Photochem. 4, 109 (1975).
${ }^{12}$ D.A. Parkes, Int. J. Chem. Kinet. 9, 451 (1977).

${ }^{13}$ C.J. Hochanadel, J.A. Ghormley, J.W. Boyle, and P.J. Ogren, J. Phys. Chem. 81, 3 (1977).

${ }^{14}$ C. Anastasi, I.W.M. Smith, and D.A. Parkes, J. Chem. Soc., Faraday Trans. 274,1693 (1978).

${ }^{15}$ C.S. Kan, R.D. McQuigg, M.R. Whitbeck, and J.G. Calvert, Int. J. Chem. Kinet. 11, 921 (1979).

${ }^{16}$ R.A. Cox and G.S. Tyndall, Chem. Phys. Lett. 65, 357 (1979).

${ }^{17}$ H. Adachi, N. Basco, and D.G.L. James, Int. J. Chem. Kinet. 12, 949 (1980).

${ }^{18}$ C.S. Kan, J.G. Calvert, and J.H. Shaw, J. Phys. Chem. 84, 3411 (1980),

${ }^{19}$ H. Niki, P.D. Maker, C.M. Savage, and L.P. Breitenbach, J. Phys. Chem. 85, 877 (1981).

${ }^{20}$ S.P. Sander and R.T. Watson, J. Phys. Chem. 85, 2960 (1981).

${ }^{21}$ M.J. Pilling and M.J.C. Smith, J. Phys. Chem. 89, 4713 (1985).

${ }^{22}$ M.J. Kurylo and T.J. Wallington, Chem. Phys. Lett. 138, 543 (1987).

${ }^{23}$ K. McAdam, B. Veyret, and R. Lesclaux, Chem. Phys. Lett. 133, 39 (1987)

${ }^{24}$ M.E. Jenkin, R.A. Cox, G.D. Hayman, and L.J. Whyte, J. Chem. Soc., Faraday Trans. 2 84, 913 (1988).

${ }^{25}$ C. Anastasi, P.J. Couzens, D.J. Waddington, J.M. Brown, and D.B. Smith, poster presentation made at the 10th International Symposium on Gas Kinetics, Swansea (1988).

${ }^{\llcorner 0}$ G.K. Moortgat, B. Veyret, and R. Lesclaux, J. Phys. Chem. 93, 2362 (1989).

${ }^{27}$ P. Dagaut and M.J. Kurylo, J. Photochem. 51, 133 (1990).

${ }^{28}$ P.D. Lightfoot and A.A. Jemi-Alade, J. Photochem. 59, 1 (1991). 


$$
\begin{aligned}
\mathrm{CH}_{3} \mathrm{O}_{2}+\mathrm{CH}_{3} \mathrm{O}_{2} & \rightarrow \mathrm{CH}_{3} \mathrm{O}+\mathrm{CH}_{3} \mathrm{O}+\mathrm{O}_{2} \\
& \rightarrow \mathrm{CH}_{3} \mathrm{OH}+\mathrm{HCHO}_{2}+\mathrm{O}_{2} \\
& \rightarrow \mathrm{CH}_{3} \mathrm{OOCH}+\mathrm{O}_{2}
\end{aligned}
$$

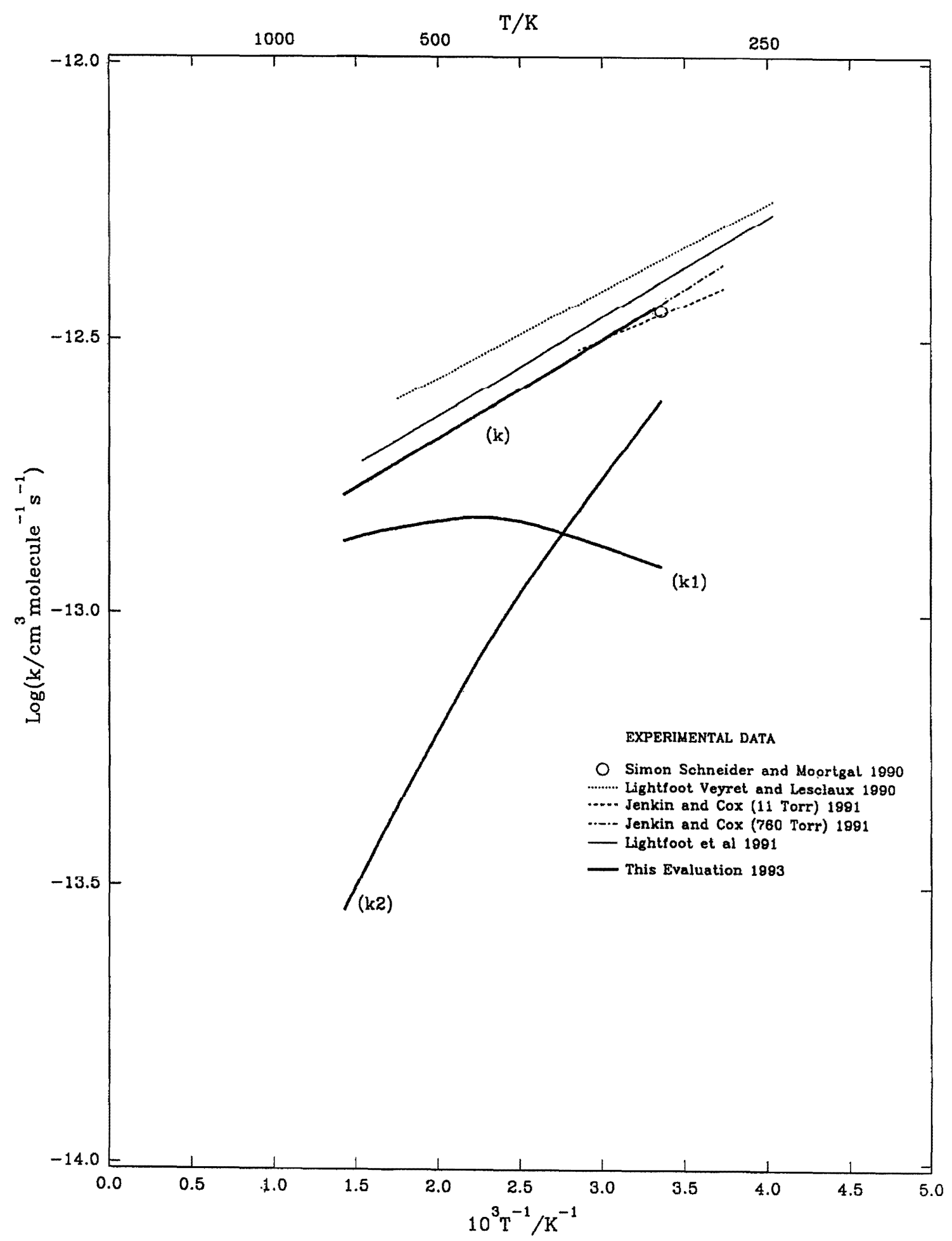


BAULCH ET AL.

\section{$\mathrm{CH}_{3} \mathrm{OOH}(+\mathrm{M}) \rightarrow \mathrm{CH}_{3} \mathrm{O}+\mathrm{OH}(+\mathrm{M})$}

Thermodynamic data $\Delta H_{298}^{\circ}=195 \mathrm{k} \mathrm{J} \mathrm{mol}^{-1}$

Rate Coefficient Data

\begin{tabular}{|c|c|c|c|}
\hline$k / s^{-1}$ & $T / \mathrm{K}$ & Reference & Comments \\
\hline \multicolumn{4}{|l|}{ Rate Coefficient Measurements } \\
\hline $6.3 \cdot 10^{14} \exp (-21300 / T)$ & $600-719$ & Lightfoot, Roussel, and Lesciaux, $1991^{1}$ & (a) \\
\hline \multicolumn{4}{|l|}{ Reviews and Evaluations } \\
\hline$k_{\infty}=4.0 \cdot 10^{15} \exp (-21600 / T)$ & $450-1000$ & $\mathrm{CEC}, 1992^{2}$ & (b) \\
\hline
\end{tabular}

\section{Comments}

(a) UV absorption measurements of the kinetics of $\mathrm{CH}_{3} \mathrm{O}_{2}$ and $\mathrm{HO}_{2}$ in the flash photolysis of $\mathrm{O}_{2}-\mathrm{CH}_{4}-\mathrm{CH}_{3} \mathrm{OH}$ mixtures. $\mathrm{CH}_{3} \mathrm{OOH}$ formed in situ by reaction of $\mathrm{CH}_{3} \mathrm{O}_{2}$ and $\mathrm{HO}_{2}$ with decay by thermal decomposition, reforming the precursor radicals by subsequent reactions of $\mathrm{CH}_{3} \mathrm{O}$ and $\mathrm{OH}$. $k_{3}$ obtained by fitting time dependent absorption at $210 \mathrm{~nm}$ and $240 \mathrm{~nm}$ up to $1000 \mathrm{~ms}$. Pressure $-1 \mathrm{~atm}$.

(b) Based on thermochemistry together with an assumed temperature independent value for the rate constant of the reverse reaction.

\section{Preferred Values}

$k=6 \cdot 10^{14} \exp (-21300 / T) \mathrm{s}^{-1}$ over range $500-800 \mathrm{~K}$ and 1 atm. pressure.

Reliability

$\Delta \log k= \pm 0.2$ at $600 \mathrm{~K}$ increasing to \pm 0.5 at ends of range.

\section{Comments on Preferred Values}

The new measurements of the kinetics of this reaction overcome the main difficulties encountered in all the previous experimental measurements of the rate constants, i.e. interference by heterogeneous decomposition on the reactor walls. Thus both Kirk ${ }^{3}$ and Kaiser et al. ${ }^{4}$ measured much higher values, particularly at low temperatures, which gave unrea- sonably low Arrhenius parameters, incompatible with the thermochemistry.

The most recent thermochemical data ${ }^{5}$ for $\mathrm{D}\left(\mathrm{CH}_{3}-\mathrm{OOH}\right)$ gives $\Delta H^{\circ}=195 \mathrm{~kJ} \mathrm{~mol}^{-1}$, which is approximately $12 \mathrm{~kJ}$ $\mathrm{mol}^{-1}$ greater than the value obtained by group methods. The new values are consistent with the new experimental values only if the reaction was in the fall-off region. A good fit to the experimental data was obtained by Lightfoot et al ${ }^{1}$ by RRKM analysis using $k_{\infty}=3 \cdot 10^{16} \exp (-22900 / T) \mathrm{s}^{-1}$, and a collision efficiency of 0.35 . However, the derived $A$ factor corresponds to an unreasonably high rate for the reverse association reaction. Alternatively, if the measured values are at the high pressure limit at $1 \mathrm{~atm}$., they can be modelled with a reasonable $A$ factor, but only with a lower $\Delta H^{\circ}$. Until the degree of fall-off is established, this problem cannot be resolved and a recommendation cannot be given for $k_{\infty}$. The preferred expression for $k$ is that given by Lightfoot et al.$^{1}$, and applies to 1 atm pressure and a limited temperature range.

\section{References}

'P.D. Lightfoot, P. Rousscl, and R. Lesclaux, J. Chem. Soc., Faraday Trans. 87, 3215 (1990).

${ }^{2} \mathrm{CEC}, 1992$ (see references in Introduction).

${ }^{3}$ A.D. Kirk, Can. J. Chem. 43, 2236 (1965).

${ }^{4}$ E.W. Kaiser, C.K. Westbrook, and W.J. Pitz, Int. J. Chem. Kinet. 18, 655 (1986).

${ }^{5}$ O. Kondo and S.W. Benson, J. Phys. Chem. 88, 6675 (1988). 


$$
\mathrm{CN}+\mathrm{O}_{2} \rightarrow \mathrm{NCO}+\mathrm{O}
$$

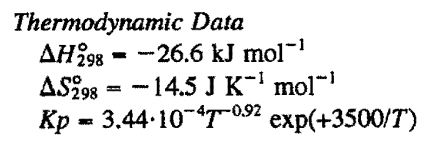

Rate Coefficient Data

\begin{tabular}{|c|c|c|c|}
\hline $\mathrm{k} / \mathrm{cm}^{3}$ molecule $\mathrm{e}^{-1} \mathrm{~s}^{-1}$ & $T / \mathrm{K}$ & Reference & Comments \\
\hline \multicolumn{4}{|c|}{ Rate Coefficient Measurements } \\
\hline $1.16 \cdot 10^{-11}$ & $1928-3100$ & Burmeister et al., $1988^{1}$ & (a) \\
\hline $1.24 \cdot 10^{-11} \exp (200 / T)$ & $295-775$ & Durant and Tully, $1989^{2}$ & (b) \\
\hline $1.4 \cdot 10^{-11} \exp (220 / T)$ & $294-1000$ & Atakan et al., $1989^{3}$ & (c) \\
\hline $2.2 \cdot 10^{-11}$ & 298 & Jensen et al., $1990^{4}$ & (d) \\
\hline $1.0 \cdot 10^{11} \exp (220 / T)$ & $292-1565$ & Balla and Casleton, $1991^{\circ}$ & (e) \\
\hline $1.66 \cdot 10^{-11}$ & $1550-4500$ & Davidson et al., $1991^{6}$ & (f) \\
\hline \multicolumn{4}{|l|}{ Reviews and Evaluations } \\
\hline $1.1 \cdot 10^{11} \exp (205 / T)$ & $290-760$ & IUPAC, 1992 & (g) \\
\hline $1.1 \cdot 10^{-11} \exp (205 / T)$ & $298-2500$ & CEC, $1992^{8}$ & (h) \\
\hline
\end{tabular}

\section{Comments}

(a) Shock tube study. $\mathrm{CN}$ generated from $\mathrm{C}_{2} \mathrm{~N}_{2} / \mathrm{O}_{2} / \mathrm{Ar}$ and $\mathrm{BrCN} / \mathrm{O}_{2} / \mathrm{Ar}$ mixtures. [N] and $[\mathrm{O}]$ in post shock zone monitored by ARAS. [N] and [O] temporal profiles fitted to complex reaction mechanism; fit shown to be sensitive to $k$.

b) Pulsed laser photolysis at $193 \mathrm{~nm}$ of flowing $\mathrm{C}_{2} \mathrm{~N}_{2} / \mathrm{O}_{2} / \mathrm{He}$ or $\mathrm{ClCN} / \mathrm{O}_{2} / \mathrm{He}$ mixtures. Pressures $100-400$ Torr. [CN] and [NCO] monitored by LIF.

(c) Pulsed laser photolysis at $193 \mathrm{~nm}$ of flowing $\mathrm{C}_{2} \mathrm{~N}_{2} / \mathrm{O}_{2} / \mathrm{N}_{2}$ mixtures. Pressures 3-50 Torr. [CN] monitored by LIF. $\mathrm{CN}(v=1)$ also studied.

(d) Pulsed laser photolysis at $193 \mathrm{~nm}$ of flowing $\mathrm{C}_{2} \mathrm{~N}_{2} / \mathrm{O}_{2} / \mathrm{Ar}$ mixtures at $p=3$ Torr. [CN] monitored by LIF.

(e) As in (d). Pressures 5-50 Torr.

(f) Shock tube study. In one series of experiments $\mathrm{C}_{2} \mathrm{~N}_{2} / \mathrm{O}_{2} /$ Ar mixture were shock heated in temperature range $2700-3800 \mathrm{~K}$ at pressures $0.62-1.05 \mathrm{~atm}$. In other experiments $\mathrm{C}_{2} \mathrm{~N}_{2} / \mathrm{O}_{2} / \mathrm{Ar}$ mixtures were shock heated in range $1550-1950 \mathrm{~K}$ and pressures $1.19-1.57 \mathrm{~atm}$. with $\mathrm{CN}$ generated by $193 \mathrm{~nm}$ photolysis pulse. In all cases [CN] monitored by laser absorption spectroscopy.

(g) Based on the temperature coefficient of Sims and Smith ${ }^{9}$ and data close to $298 \mathrm{~K}$.

(h) See Comments on Preferred Value.

\section{Preferred Value}

$k=1.2 \cdot 10^{-11} \exp (210 / T) \mathrm{cm}^{3}$ molecule ${ }^{-1} \mathrm{~s}^{-1}$ over range $290-4500 \mathrm{~K}$.

\section{Reliability}

$\Delta \log k= \pm 0.15$ over range $290-4500 \mathrm{~K}$.

\section{Comments on Preferred Values}

The recent measurements are all in excellent agreement with the recommendations in our previous evaluation ${ }^{8}$ which are changed only slightly. Only measurements since 1988 are tabulated. Earlier results ${ }^{9-13}$ are in good agreement on the temperature coefficient of $k$ over a wide temperature range. Our recommended value of $E / R$ is the mean of the values of Sims and Smith', Durant and Tully ${ }^{2}$, Atakan et al. ${ }^{3}$, Balla and Casleton ${ }^{5}$ and Davidson et al ${ }^{6}$. The pre-exponential factor is based on this value of $E / R$ and the mean value of $k$ at $700 \mathrm{~K}$ from these five studies.

The graph shows only the results of the recent studies listed in the Table. For earlier studies see Ref. 8.

The reaction has an alternative, highly exothermic channel, giving $\mathrm{CO}+\mathrm{NO}\left(\Delta H_{298}^{\circ}=-455 \mathrm{~kJ} \mathrm{~mol}^{-1}\right)$. There is experimental evidence to suggest that it is unimportant both at high and low temperatures ${ }^{14,15}$.

\section{References}

${ }^{1}$ M. Burmeister, S.K. Gulati, K. Natarajan, K. Thielen, E. Mozzhukin, and P. Roth, 22nd Symp. (Int.) Combust., 1083 (1988).

${ }^{2}$ J.L. Durant and F.P. Tully, Chem. Phys. I ett. 154, 568 (1989)

${ }^{3}$ B. Atakan, A. Jacobs, M. Wahl, R. Weller, and J. Wolfrum, Chem. Phys. Lett. 154, 449 (1989).

${ }^{4}$ R.C. Jensen, D.B. Walton, and R.D. Coombe, Chem. Phys. Lett. 169, 441 (1990).

${ }^{5}$ R.J. Balla and K.H. Casieton, J. Phys. Chem. 95, 2344 (1991).

${ }^{6}$ D.F. Davidson, A.J. Dean, M.D. DiRosa, R.K. Hanson, Int. J. Chem. Kinet. 23, 1035 (1991).

${ }^{7}$ IUPAC Evaluation, Supplement III, 1989 (see references in Introduction). ${ }^{8} \mathrm{CEC}, 1992$ (see references in Introduction).

${ }^{9}$ I.R. Sims and I.W.M. Smith, J. Chem. Soc., Faraday Trans. 2 84, 527 (1988).

${ }^{10}$ Y.Li, N. Sayah, and W.M. Jackson, J. Chem. Phys. 81, 833 (1984).

"D.A. Lichtin and M.C. Lin, Chem. Phys. 96, 473 (1985).

${ }^{12}$ J. deJuan, I.W.M. Smith, and B. Veyret, J. Phys. Chem. 91, 69 (1987).

${ }^{13}$ C. Anastasi and D.U. Hancock, J. Chem. Soc. Faraday Trans. 2 84, 9 (1988).

${ }^{14}$ M.Y. Louge and R.H. Hanson, Int. J. Chem. Kinet. 16, 231 (1984).

${ }^{15}$ K.J. Schmatjko and J. Wolfrum, Ber. Bunsenges. Phys. Chem. 82, 419 (1978). 


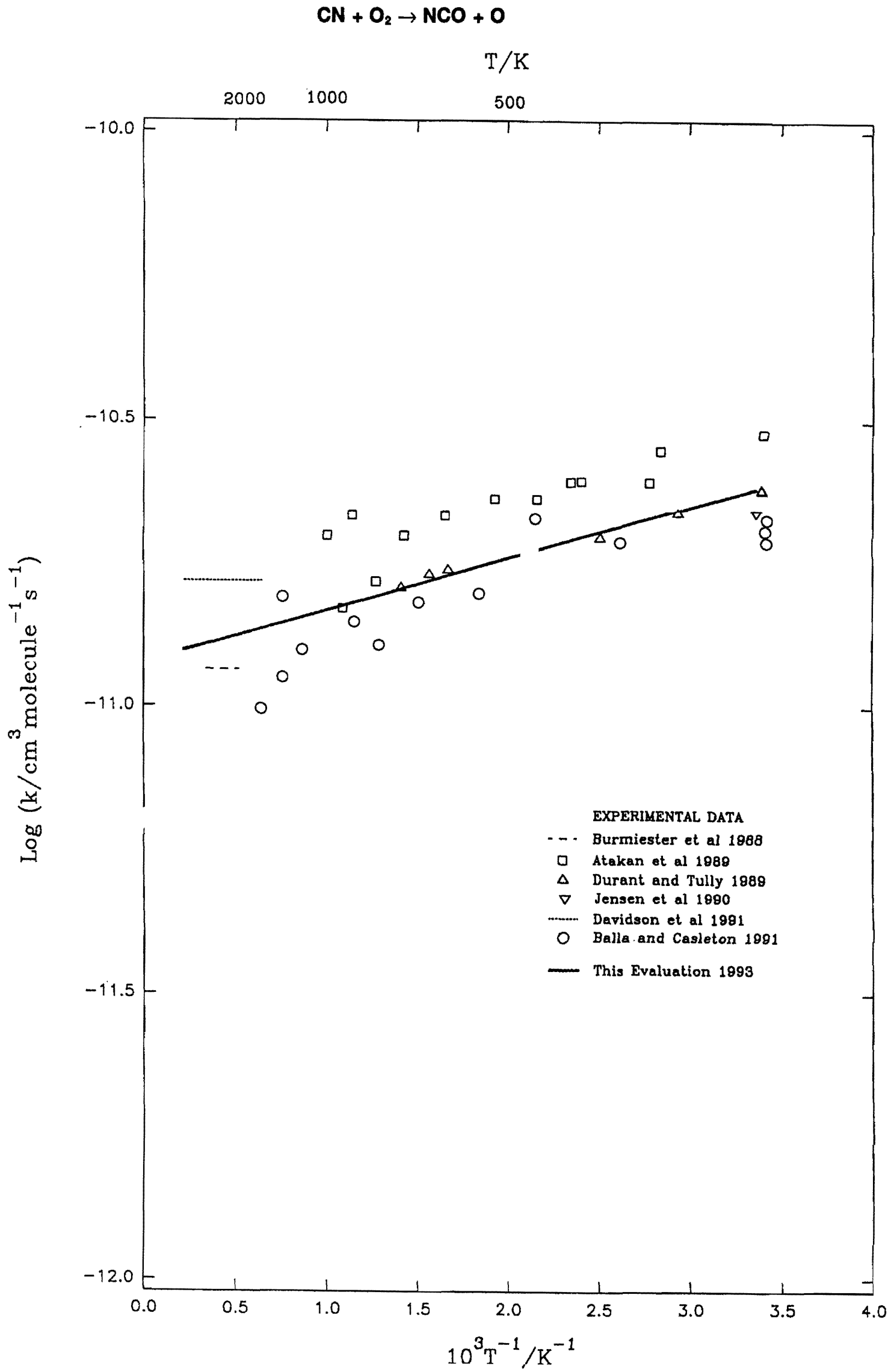




$$
\mathrm{CN}+\mathrm{H}_{2} \rightarrow \mathrm{HCN}+\mathrm{H}
$$

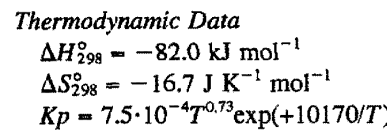

Rate Coefficient Data

\begin{tabular}{|c|c|c|c|}
\hline $\mathrm{k} / \mathrm{cm}^{3}$ molecule $\mathrm{e}^{-1} \mathrm{~s}^{-1}$ & $T / \mathrm{K}$ & Reference & Comments \\
\hline \multicolumn{4}{|l|}{ Rate Coefficient Measurements } \\
\hline$<3.3 \cdot 10^{-13}$ & 687 & Boden and Thrush, $1967^{1}$ & (a) \\
\hline $1.0 \cdot 10^{-10} \exp (-2670 / T)$ & $275-398$ & Albers et al., $1974^{2}$ & (b) \\
\hline $1.0 \cdot 10^{-10} \exp (-2670 / T)$ & $259-396$ & Schacke, Wagner, and Wolfrum, $1977^{3}$ & (c) \\
\hline $1.4 \cdot 10^{-14}$ & 300 & $\mathrm{Li}$, Sayah, and Jackson, $1984^{4}$ & (d) \\
\hline $4.9 \cdot 10^{-14}$ & 294 & Lichtin and Lin, $1985^{5}$ & (e) \\
\hline $1.25 \cdot 10^{-10}$ & $2700-3500$ & Szekely, Hanson, and Bowman, $1983^{\circ}$ & (f) \\
\hline $3,0 \cdot 10^{-10} \exp (-4000 / T)$ & $2050-3160$ & Natarajan and Roth, $1986^{7}$ & (g) \\
\hline $2.45 \cdot 10^{-14}$ & 298 & de Juan et al., $1987^{8}$ & (h) \\
\hline $2.6 \cdot 10^{-14}$ & 298 & Balla and Pasternack, $1987^{\circ}$ & (i) \\
\hline $2.4 \cdot 10^{-12}(T / 298)^{1.6} \exp (-1340 / T)$ & $295-768$ & Sims and Smith, $1988^{10}$ & (j) \\
\hline $5.1 \cdot 10^{-19} T^{2.45} \exp (-1119 / T)$ & $294-1000$ & Atakan et al., $1989^{11}$ & (k) \\
\hline $2.23 \cdot 10^{-21} T^{3.31} \exp (-756 / T)$ & $209-740$ & Sun et al., $1990^{12}$ & (1) \\
\hline \multicolumn{4}{|l|}{ Reviews and Evaluations } \\
\hline $1.1 \cdot 10^{-10} \exp (-2700 / T)$ & $300-1000$ & Baulch et al., $1981^{13}$ & $(\mathrm{~m})$ \\
\hline
\end{tabular}

\section{Comments}

(a) Discharge flow study. $\mathrm{CN}$ produced by reaction of $\mathrm{O}$ atoms with cyanogen. $[\mathrm{CN}]$ monitored by absorption between 387.6 and $388.6 \mathrm{~nm}$.

(b) Flash photolysis, discharge flow study with photolysis of $\mathrm{C}_{2} \mathrm{~N}_{2}(\geqslant 165 \mathrm{~nm}) . \mathrm{CN}$ detected in absorption at $388.3 \mathrm{~nm}$.

(c) Flash photolysis of $\mathrm{C}_{2} \mathrm{~N}_{2} / \mathrm{H}_{2}$ mixtures. [CN] monitored by kinetic absorption spectroscopy.

'd) Pulsed laser photolysis of $\mathrm{C}_{2} \mathrm{~N}_{2} / \mathrm{Ar} / \mathrm{H}_{2}$ mixtures at 193 $\mathrm{nm}$. [CN] monitored by LIF.

(e) $\mathrm{CN}$ generated by pulsed laser photolysis of ICN at 266 nm. [CN] monitored by LIF of $\mathrm{CN}(A \leftarrow X)$ and $\mathrm{CN}(B$ $\leftarrow X$ ) transitions.

(f) Shock tube study on mixtures of $\mathrm{C}_{2} \mathrm{~N}_{2} / \mathrm{H}_{2} / \mathrm{Ar}$. [CN] monitored by broad-band absorption spectroscopy.

(g) Shock tube study of $\mathrm{C}_{2} \mathrm{~N}_{2} / \mathrm{H}_{2} / \mathrm{Ar}$ mixtures, with ARAS monitoring of $\mathrm{H}$ atom concentrations.

(h) Pulsed laser photolysis of NCNO at $572 \mathrm{~nm}$. [CN] monitored by LIF at $388 \mathrm{~nm}$.

(i) Pulsed laser photolysis of $\mathrm{C}_{2} \mathrm{~N}_{2}$ at $193 \mathrm{~nm}$. [CN] and [HCN] monitored by diode laser absorption.

(j) Pulsed laser photolysis of NCNO at $532 \mathrm{~nm}$; LIF monitoring of [CN].

(k) Pulsed laser photolysis of $\mathrm{C}_{2} \mathrm{~N}_{2}$ at $193 \mathrm{~nm}$. LIF monitoring of [CN] at $386.871 \mathrm{~nm}$ and $386.887 \mathrm{~nm}$.

(l) Pulsed laser photolysis of ICN at $248 \mathrm{~nm}$; LIF monitoring of $[\mathrm{CN}]$ at $388 \mathrm{~nm}$.

(m) Evaluation of data to 1980

\section{Preferred Value}

$k=3.2 \cdot 10^{-20} T^{2.8 /} \exp (-820 / T)$ over the range $200-3500 \mathrm{~K}$.

\section{Reliability}

$\Delta \log k= \pm 0.2$ at $300 \mathrm{~K}$ rising to \pm 0.5 at $3500 \mathrm{~K}$.

\section{Comments on Preferred Values}

There is very good agreement among the most recent studies of this reaction over a wide temperature range. The older, discharge flow studies ${ }^{1,2}$, in general give low values for $k$ and are not used in deriving the recommended expression, which is based on the data of Refs. 3-12.

\section{References}

'J.C. Boden and B.A. Thrush, Proc. Roy. Soc. A 305, 107 (1968). ${ }^{2}$ E.A. Albers, K. Hoyermann, H. Schacke, K.J. Schmatjko, H.Gg. Wagner, and J. Wolfrum, 15th Symp. Int. Comb. 765 (1974).

${ }^{3} \mathrm{H}$ Schacke, H.Gg. Wagner, and I Wolfrum, Rer. Bunsenges. Phys. Chem. 81, $670(1977)$.

${ }^{4}$ X. Li, N. Sayah, and W.M. Jackson, J. Chem. Phys. 81, 833 (1984).

${ }^{5}$ D.A. Lichtin and M.C. Lin, Chem. Phys. 96, 473 (1985).

${ }^{6}$ A. Szekely, R.K. Hanson, and C.T. Bowman, Int. J. Chem. Kinet. 15, 915 (1983).

${ }^{7}$ K. Natarajan and P. Roth, 21 st Symp. Int. Comb. 729 (1986).

${ }^{8}$ J. de Juan, I.W.M. Smith, B. Veyret, J. Phys. Chem. 91, 69 (1987).

${ }^{9}$ R.J. Balla and L. Pasternack, J. Phys. Chem. 91, 73 (1987).

${ }^{10}$ I.R. Sims and I.W.M. Smith, Chem. Phys. Lett. 149, 565 (1988).

${ }^{11}$ B. Atakan, A. Jacobs, M. Wahl, R. Weller, and J. Wolfrum. Chem. Phys. Lett. 154, 449 (1989)

${ }^{12}$ Q. Sun, D.L. Yan, N.S. Yang, J.M. Bowman, and M.C. Lin, J. Chem. Phys. 93, 4730 (1990).

${ }^{13}$ D.L. Baulch, J. Duxbury, S.J. Grant, and D.C. Montague, 'Evaluated Kinetic Data for High Temperature Reactions', Vol. 4, J. Phys. Chem. Ref. Data 10, Supplement 1 (1981) 


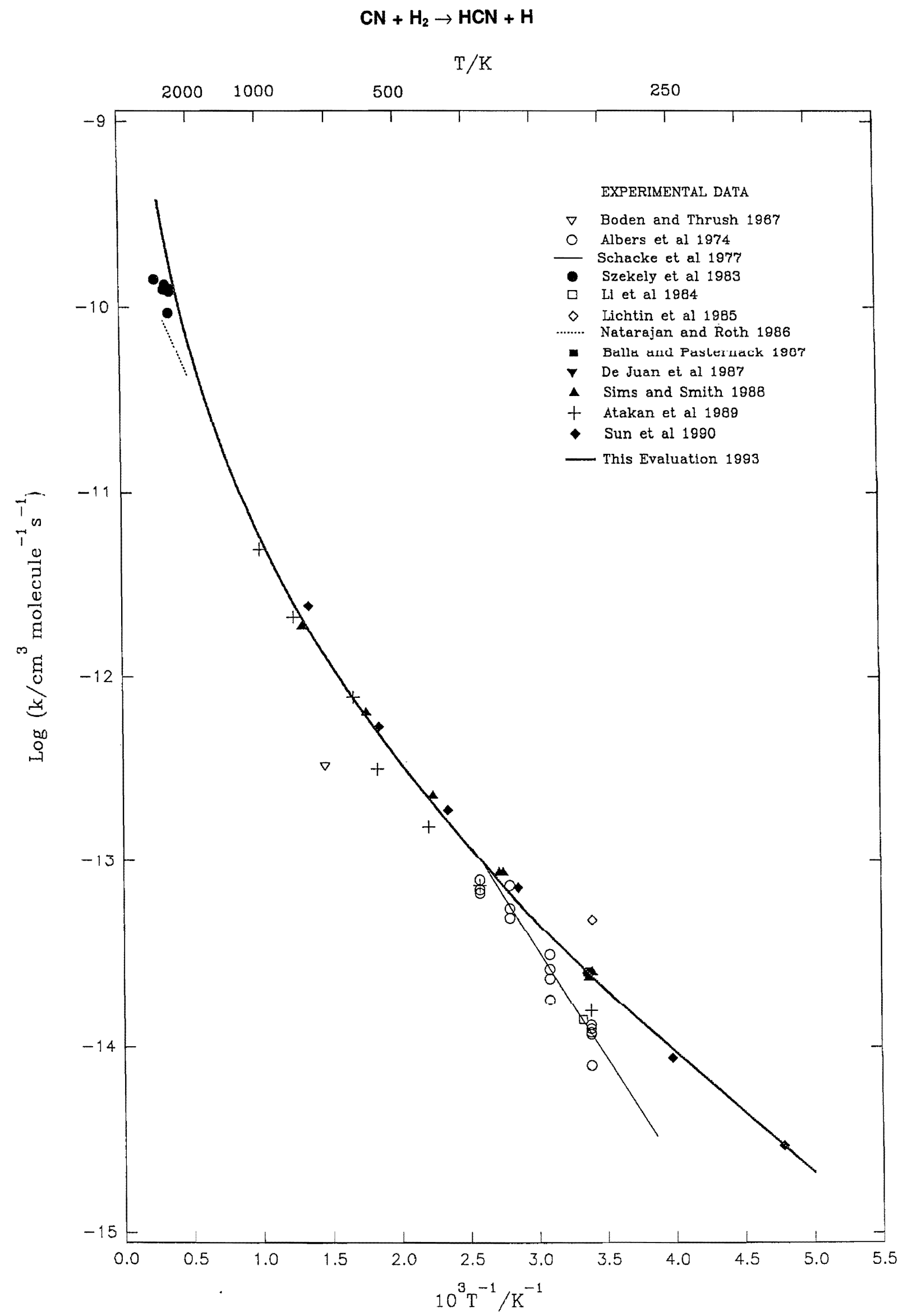




$$
\mathrm{CN}+\mathrm{CH}_{4} \rightarrow \mathrm{HCN}+\mathrm{CH}_{3}
$$

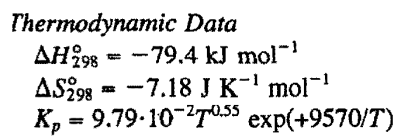

Rate Coefficient Data

\begin{tabular}{|c|c|c|c|}
\hline$k / \mathrm{cm}^{3}$ molecule $\mathrm{e}^{-1} \mathrm{~s}^{-1}$ & $T / \mathrm{K}$ & Reference & Comments \\
\hline \multicolumn{4}{|l|}{ Coefficient Measurements } \\
\hline $5.0 \cdot 10^{-13}$ & 293 & Schacke, Wagner, and Wolfrum, $1977^{1}$ & (a) \\
\hline \multicolumn{4}{|l|}{$1.1 \cdot 10^{-12}, \mathrm{CN}(v=1)$} \\
\hline $5.6 \cdot 10^{-13}$ & 300 & Li, Sayah, and Jackson, $1984^{2}$ & (b) \\
\hline \multicolumn{4}{|l|}{$8.3 \cdot 10^{-13}, \mathrm{CN}(\nu=1)$} \\
\hline $1.1 \cdot 10^{-12}$ & 294 & Lichtin and Lin, $1985^{3}$ & (c) \\
\hline $7.8 \cdot 10^{-13}$ & 298 & Balla and Pasternack, $1987^{4}$ & (d) \\
\hline $1.14 \cdot 10^{-12}$ & 300 & Anastasi and Hancock, $1988^{5}$ & (e) \\
\hline $5.6 \cdot 10^{-13}$ & 294 & Sayah et al., $1988^{6}$ & (f) \\
\hline \multicolumn{4}{|l|}{$8.4 \cdot 10^{-13}, \mathrm{CN}(v=1)$} \\
\hline $2.07 \cdot 10^{-19} T^{2.64} \exp (78 / T)$ & $294-1260$ & Atakan and Wolfrum, $1991^{7}$ & (g) \\
\hline $1.0 \cdot 10^{-19} T^{2.64} \exp (220 / T)$ & $292-1500$ & Balla et al., $1991^{8}$ & (h) \\
\hline \multicolumn{4}{|l|}{ Reviews and Evaluations } \\
\hline $1.5 \cdot 10^{-11} \exp (-940 / T)$ & $260-400$ & CEC, $1992^{9}$ & (i) \\
\hline
\end{tabular}

\section{Comments}

(a) Flash photolysis of $\mathrm{CH}_{4}(0.037-0.4$ Torr $) / \mathrm{C}_{2} \mathrm{~N}_{2}(0.05-0.2$ Torr)/He mixtures. Total pressure $4-5$ Torr, in a flowing system. [CN] monitored by kinetic absorption spectroscopy at $388 \mathrm{~nm}$.

(b) Pulsed laser photolysis of $\mathrm{C}_{2} \mathrm{~N}_{2} / \mathrm{Ar} / \mathrm{CH}_{4}$ mixtures. [CN, $v=0, v=1]$ monitored as a function of time by laser induced fluorescence.

(c) Pulsed laser photolysis of $\mathrm{ICN} / \mathrm{CH}_{4} / \mathrm{Ar}$ mixtures in flowing system. $[\mathrm{CN}]$ monitored as a function of time at 388 $\mathrm{nm}$ by laser induced fluorescence.

(d) Laser photolysis of $\mathrm{C}_{2} \mathrm{~N}_{2}(0.05-0.3$ Torr $) / \mathrm{CH}_{4}(0-0.15$ Torr) mixtures with $\mathrm{He}, \mathrm{N}_{2}$ or Ar bath gas. Total pressures 1-200 Torr. [CN] decay and $\mathrm{HCN}$ formation, monitored by diode laser absorption spectroscopy at $2015.22 \mathrm{~cm}^{-1}$ and $3280.987 \mathrm{~cm}^{-1}$ respectively.

(e) Flash photolysis of flowing mixtures of $\mathrm{C}_{2} \mathrm{~N}_{2} / \mathrm{Ar} / \mathrm{CH}_{4}$. [CN] monitored by LIF. Total pressure, 20 Torr.

(f) Pulsed laser photolysis at $193 \mathrm{~nm}$ of flowing mixtures of $\mathrm{C}_{2} \mathrm{~N}_{2} / \mathrm{Ar} / \mathrm{CH}_{4}$. [CN] monitored by LIF. Total pressure, 5-30 Torr.

(g) Method as in (f). No pressure dependence of rate constant in range 2-38 Torr.

(h) Method as in (f). Pressure range 5-60 Torr.

\section{Preferred Value}

$k=1.5 \cdot 10^{-19} T^{2.64} \exp (150 / T) \mathrm{cm}^{3}$ molecule ${ }^{-1} \mathrm{~s}^{-1}$ over range $290-1500 \mathrm{~K}$.

\section{Reliability}

$\Delta \log k= \pm 0.3$ over range 290 to $1500 \mathrm{~K}$.

\section{Comments on Preferred Values}

Until the two recent studies of Balla et al..$^{8}$ and Atakan and Wolfrum ${ }^{7}$ the available data had been restricted to low temperatures $(<400 \mathrm{~K})$. These studies have extended the data to $1500 \mathrm{~K}$ and are in good agreement over the whole temperature range. The preferred values are based on the two expressions for $k$ derived by Balla et al. ${ }^{8}$ and Atakan and Wolfrum ${ }^{7}$.

Other exothermic reaction channels are possible but a search by Balla et al ${ }^{8}$ for alternative products found none; the formation of $\mathrm{HCN}+\mathrm{CH}_{3}$ appears to be the only pathway. The reaction is believed to occur by initial addition rather than by direct abstraction but no evidence has been found for any pressure dependence of $k$.

The rate of the reaction is increased by vibrational excitation of the $\mathrm{CN}$ and there have been a number of measurements of $k(v=1)$ which are in good agreement ${ }^{1,2,6}$.

\section{References}

'H. von Schacke, H.Gg. Wagner, and J. Wolfrum, Ber. Bunsenges. Phys. Chem. 81, 670 (1977).

${ }^{2}$ X. Li, N. Sayah, and W.M. Jackson, J. Chem. Phys. 81, 833 (1984).

${ }^{3}$ D.A. Lichtin and M.C. Lin, Chem. Phys. 96, 473 (1985).

${ }^{4}$ R.J. Balla and L. Pasternack, J. Phys. Chem. 91, 73 (1987).

${ }^{5}$ C. Anastasi and D.U. Hancock, J. Chem. Soc., Faraday Trans. 284,8 (1988).

${ }^{6}$ N. Sayah, X. Li, JK.F. Caballero, and W.M. Jackson, J. Photochem. Photobiol. A-Chem. 45, 177 (1988).

${ }^{7}$ B. Atakan and J. Wolfrum, Chem. Phys. Lett. 186, 547 (1991).

${ }^{8}$ R.J. Balla, K.H. Casleton, J.S. Adams, and L. Pasternack, J. Phys. Chem. 95 , 8694 (1991).

${ }^{9}$ J.C. Boden and B.A. Thrush, Proc. Roy. Soc. A 305, 107 (1971),

${ }^{10}$ G.E. Bullock and R. Cooper, Trans. Faraday Soc. 67, 3258 (1971).

"G.E. Bullock and R. Cooper, J. Chem. Soc., Faraday Trans. 1 68, 2185 (1972). 


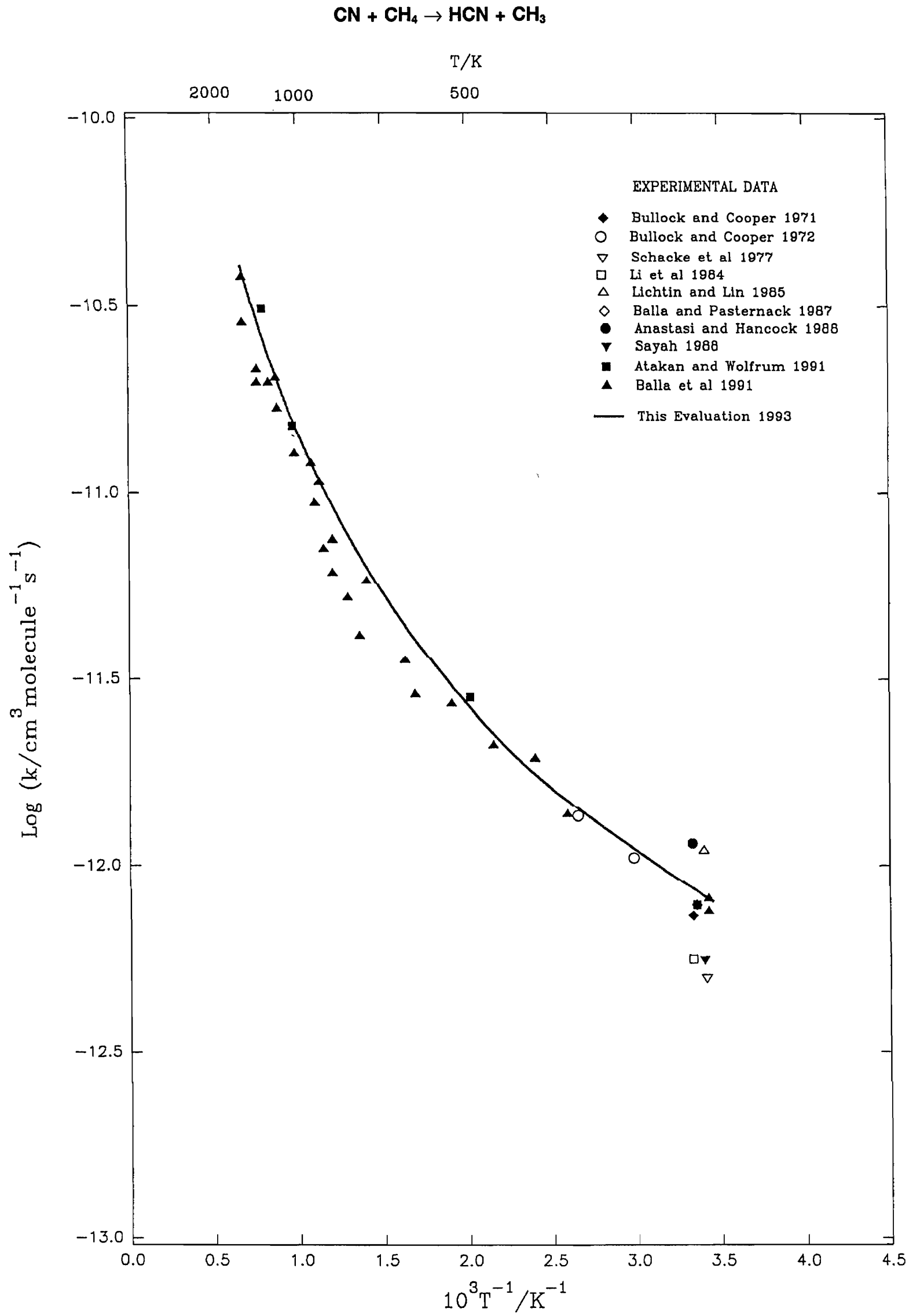




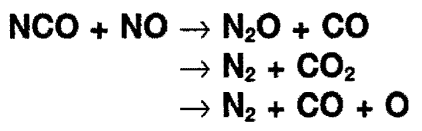

(1)

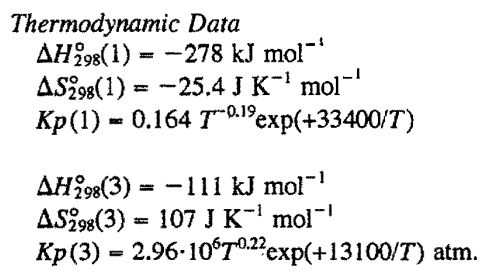

$\Delta H_{298}^{\circ}(2)=-643 \mathrm{~kJ} \mathrm{~mol}^{-1}$ $\Delta S_{298}^{\circ}(2)=-37.5 \mathrm{~J} \mathrm{~K}^{-1} \mathrm{~mol}^{-1}$ $K p(2)=7.22 \cdot 10^{-2} T^{0.30} \exp (+77300 / T)$

Rate Coefficient Data $\left(k=k_{1}+k_{2}+k_{3}\right)$

\begin{tabular}{llll}
\hline \hline$k / \mathrm{cm}^{3}$ molecule & & Comments \\
\hline Rate Coefficient Measurements & $T / \mathrm{K}$ & Reference & (a) \\
$1.66 \cdot 10^{-12}$ & $1329-1846$ & Fifer and Holmes, $1982^{1}$ & $(\mathrm{~b})$ \\
$1.69 \cdot 10^{-11} \exp (197 / T)$ & $294-538$ & Perry, 1985 & $(\mathrm{c})$ \\
$3.4 \cdot 10^{-11}$ & 295 & Hancook and McKendrick, $1986^{3}$ & $(\mathrm{~d})$ \\
$5.0 \cdot 10^{-7} \mathrm{~T}^{-1.53} \exp (-260 / T)$ & $294-1260$ & Atakan and Wolfrum, $1991^{4}$ & $(\mathrm{e})$ \\
$2.9 \cdot 10^{-12}$ & $2380-2660$ & Mertens et al., $1992^{5}$ & \\
& & & \\
Reviews and Evaluations & $300-600$ & CEC, $1992^{6}$ & $(\mathrm{f})$ \\
$1.7 \cdot 10^{-11} \exp (200 / T)$ & & & \\
\hline
\end{tabular}

\section{Comments}

(a) Shock tube study of $\mathrm{HCN} / \mathrm{NO}_{2} / \mathrm{Ar}$ mixtures. $\left[\mathrm{NO}_{2}\right]$ monitored by absorption at $450 \mathrm{~nm}$. [NO*]. [OH*], and $\left[\mathrm{NO}_{2}{ }_{2}\right]$ monitored by emission at 237,307 , and $427.5 \mathrm{~nm}$ respectively. Value of $k$ obtained is only an estimate from computer modelling of a 23 reaction mechanism.

(b) Flowing system. NCO produced by pulsed laser photolysis of $\mathrm{HCNO} / \mathrm{Ar} / \mathrm{NO}$ mixtures. Decay of [NCO] monitored using laser induced fluorescence at $416.8 \mathrm{~nm}$.

(c) NCO produced by infra-red multiphoton dissociation of phenyl isocyanate. Decay of [NCO] in large excess of NO monitored by laser induced fluorescence at $438.48 \mathrm{~nm}$. This work supersedes earlier similar studies in which vibrational excitation of NCO may have influenced results.

(d) Pulsed laser photolysis of $(\mathrm{CN})_{2} / \mathrm{O}_{2} / \mathrm{NO}$ mixtures at 193 nm. NCO produced by rapid reaction of photolytically generated $\mathrm{CN}$ with $\mathrm{O}_{2}$. [NCO] monitored by LIF.

(e) Shock tube study of $\mathrm{HNCO} / \mathrm{N}_{2} \mathrm{O} / \mathrm{Ar}$ mixtures. [NCO] monitored by absorption at $440.79 \mathrm{~nm}$. $k$ derived by fitting [NCO] profile to reaction scheme. Profile shown to be sensitive to value of $k$.

(f) Based on data of Perry ${ }^{2}$ and of Hancock and McK endrick $k^{3}$.

\section{Preferred Values}

$k=2.3 \cdot 10^{-6} \mathrm{~T}^{-1.73} \exp (-380 / T)$ over the range 290 $3000 \mathrm{~K}$.

\section{Reliability}

$\Delta \log k= \pm 0.25$ over the range $290-3000 \mathrm{~K}$.

\section{Cumments un Preferred Values}

The studies of Atakan and Wolfrum ${ }^{4}$ and Mertens et al..$^{5}$ considerably extend the temperature range over which data are available. At low temperatures Atakan and Wolfrum ${ }^{4}$ obtain values in good agreement with those of Perry ${ }^{2}$ and Hancock and McKendrick ${ }^{3}$. An extrapolation of the expression for $k$ given by Atakan and Wolfrum ${ }^{4}$ to higher temperatures allows comparison with the high temperature data of Fifer and Homes $^{1}$ and of Mertens et al. ${ }^{4}$. The agreement with the results of Mertens et al.$^{4}$ is excellent. Fifer and Homes ${ }^{1}$ obtained only an approxinnate value of $k$ from their shock tube study; their data are a factor of 3-4 lower than obtained from Atakan and Wolfrum's expression.

Mertens et al. ${ }^{5}$ have combined the results in Refs. $2-5$ to derive the expression which is recommended in the present evaluation.

The only information about branching ratios is indirect and limited to low temperatures. Hancock and McKendrick ${ }^{3}$ observe no $\mathrm{NO}+\mathrm{O}$ chemiluminescence in their experiments suggesting an absence of channel (3). Atakan and Wolfrum ${ }^{4}$ quote unpublished work of Hancock $e t$ al . in which infra-red chemiluminescence from the reaction products were studied. Vibrationally excited $\mathrm{CO}$ and $\mathrm{N}_{2} \mathrm{O}$ were observed but not $\mathrm{CO}_{2}$. Mertens et al..$^{5}$ report results of Cooper and Her schberger, in press, which indicate that at room temperatures both channels (1) and (2) are important. The substantial curvature in the Arrhenius plot may indicate a change in mechanism as the temperature is increased and further studies at high temperature to investigate this possibility are clearly desirable. 


\section{References}

${ }^{1}$ R.A. Fifer and H.E. Holmes, J. Phys. Chem. 88, 2935 (1982).

${ }^{2}$ R.A. Perry, J. Chem. Phys. 82, 5485 (1985).

${ }^{3}$ G. Hancock and K.G. McKendrick, Chem. Phys. Lett. 127, 125 (1986).
${ }^{4}$ B. Atakan and J. Wolfrum, Chem. Phys. Lett. 178, 157 (1991).

${ }_{\text {J.D. Mertens, A.J. Dean, R.K. Hanson, and C.T. Bowman, 24th Symp. (Int.) }}$ Combust. 701 (1992).

${ }^{6} \mathrm{CEC}, 1992$ (see references in Introduction).

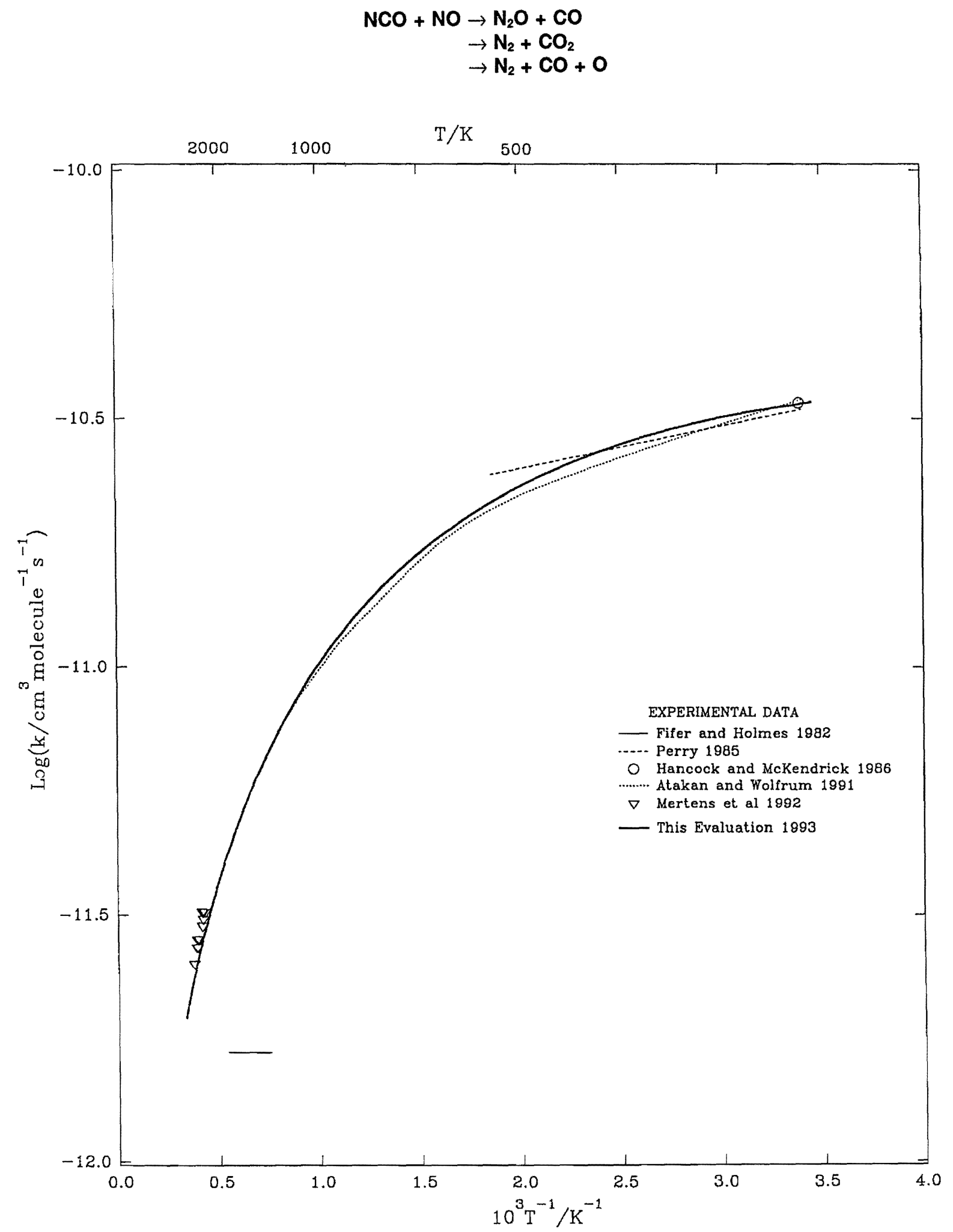




$$
\mathrm{C}_{2} \mathrm{H}+\mathrm{H}_{2} \rightarrow \mathrm{C}_{2} \mathrm{H}_{2}+\mathrm{H}
$$

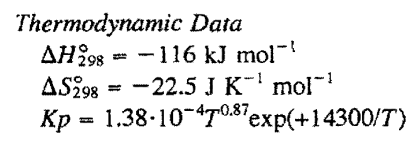

Rate Coefficient Data

\begin{tabular}{|c|c|c|c|}
\hline$k / \mathrm{cm}^{3}$ molecule $^{-1} \mathrm{~s}^{-3}$ & $T / \mathrm{K}$ & Reference & Comments \\
\hline \multicolumn{4}{|c|}{ Rate Coefficient Measurements } \\
\hline $4.4 \cdot 10^{-13}$ & 298 & Lander et al., $1990^{1}$ & (a) \\
\hline $1.8 \cdot 10^{-11} \exp (-1090 / T)$ & $298-438$ & Koshi et al, $1992^{2}$ & (b) \\
\hline $7.1 \cdot 10^{-1.3}$ & 293 & Koshi, Nishida, and Matsui, $1992^{3}$ & (c) \\
\hline $5.1 \cdot 10^{-13}$ & & & \\
\hline \multicolumn{4}{|l|}{ Reviews and Evaluations } \\
\hline $2.5 \cdot 10^{-11} \exp (-1564 / T)$ & $300-3000$ & Warnatz, $1984^{4}$ & (d) \\
\hline $1.9 \cdot 10^{-11} \exp (-1443 / T)$ & $300-2800$ & Gardiner et al., $1985^{5}$ & (e) \\
\hline $1.8 \cdot 10^{-11} \exp (-1455 / T)$ & $300-2500$ & Tsang and Hampson, $1986^{6}$ & (f) \\
\hline $2.5 \cdot 10^{-11} \exp (-1564 / T)$ & $300-2500$ & CEC, $1992^{7}$ & (g) \\
\hline
\end{tabular}

\section{Comments}

(a) Pulsed laser photolysis of $\mathrm{CF}_{3} \mathrm{C}_{2} \mathrm{H}$ at $193 \mathrm{~nm}$. Transient $\left[\mathrm{C}_{2} \mathrm{H}\right]$ monitored by diode IR laser absorption in presence of a large excess of $\mathrm{H}_{2}$. No pressure dependence of the decay rate found.

(b) Relative rate measurement. Pulsed $\mathrm{ArF}$ laser photolysis of $\mathrm{C}_{2} \mathrm{H}_{2} / \mathrm{H}_{2}$ mixtures to generate $\mathrm{C}_{2} \mathrm{H}$ and $\mathrm{H}$. Formation of $\mathrm{C}_{4} \mathrm{H}_{2}$ by the reaction $\mathrm{C}_{2} \mathrm{H}+\mathrm{C}_{2} \mathrm{H}_{2} \rightarrow \mathrm{C}_{4} \mathrm{H}_{2}+\mathrm{H}$ monitored by timc-rcsolvcd mass spcctrometry. Yield of $\mathrm{C}_{4} \mathrm{H}_{2}$ as a function of $\left[\mathrm{H}_{2}\right]$ gives $k / k_{1}$ where $k_{1}$ refers to the reaction of $\mathrm{C}_{2} \mathrm{H}$ with $\mathrm{C}_{2} \mathrm{H}_{2}$ to give $\mathrm{C}_{4} \mathrm{H}_{2}$. Value of $k_{1}=1.5 \cdot 10^{-10}$ $\mathrm{cm}^{3}$ molecule ${ }^{-1} \mathrm{~s}^{-1}$ used. obtained from a shock tube study in the same laboratory ${ }^{2}$.

(c) Pulsed ArF laser photolysis of $\mathrm{C}_{2} \mathrm{H}_{2} / \mathrm{H}_{2}$ mixtures. Reaction monitored by LIF detection of $\mathrm{H}$ and by time-resolved mass spectrometric detection of $\mathrm{C}_{4} \mathrm{H}_{2}$ in separate experiments. The former gives $k=(7.1 \pm 1.1) \cdot 10^{-13} \mathrm{~cm}^{3}$ molecule ${ }^{-1} \mathrm{~s}^{-1}$.

(d) Review of litcraturc to 1986.

(e) Re-analysis of data from shock tube studies of Koike and Morinaga ${ }^{8}$ and of Tanzawa and Gardiner.

(f) Accepts expression of Brown and Lanfer ${ }^{10}$ derived from value of $k$ at $300 \mathrm{~K}$ from Laufer and Bass ${ }^{11}$ together with BEBO calculation of temperature coefficient.

(g) Expression derived by Warnatz ${ }^{4}$ accepted.

\section{Preferred Values}

$k=1.8 \cdot 10^{-11} \exp (-1090 / T) \mathrm{cm}^{3}$ molecule ${ }^{-1} \mathrm{~s}^{-1}$ over range $300-2500 \mathrm{~K}$.
Reliability

$\Delta \log k= \pm 0.3$ at $300 \mathrm{~K}$ rising to \pm 0.5 at $2500 \mathrm{~K}$.

\section{Comments on Preferred Values}

The expression obtained by Koshi et al ., ${ }^{2}$ is adopted. This is significantly different from our previously recommended expression at low temperatures. Although the expression is based on low temperature results, when extrapolated it agrees well with the existing high temperature studies.

\section{References}

'D.R. Lander, K.G. Unfried, G.P. Glass, and R.F. Curl, J. Phys. Chem. 94, 7759 (1990).

${ }^{2}$ M. Koshi, F. Fukuda, K. Kamiya, H. Matsui, J. Phys. Chem. 96, 9839 (1992).

${ }^{3} M$. Kosh1, N. Nishida, H. Marsui, J. Phys. Chem. 96, 5875 (1992).

4J. Warnatz, in "Combustion Chemistry", Ed. W.C. Gardiner, Springer-Verlag, New York (1984).

${ }^{5}$ W.C. Gardiner, T. Tanzawa, T. Koike, and K. Morinaga, Bull. Chem. Soc. Jpn. 58, 1851 (1985).

${ }^{6}$ W. Tsang and R.F. Hampson, J. Phys. Chem. Ref. Data 15, 1087 (1986). ${ }^{7} \mathrm{CEC}, 1992$ (see references in Introduction).

${ }^{8}$ T. Koike and K. Morinaga, Bull. Chem. Soc. Jpn. 54, 530 (1981).

${ }^{\circ} T$. Tanzawa and W.C. Gardiner, Jr., 1/th Symp. (Int.) Combust., 563 (19/9).

${ }^{10}$ R.L. Brown and A.H. Laufer, J. Phys. Chem. 85, 3826 (1981).

"A.H. Laufer and A.M. Bass, J. Phys. Chem. 83, 310 (1979). 
BAULCH ET AL.

$\mathrm{C}_{2} \mathrm{H}+\mathrm{H}_{2} \rightarrow \mathrm{C}_{2} \mathrm{H}_{2}+\mathrm{H}$

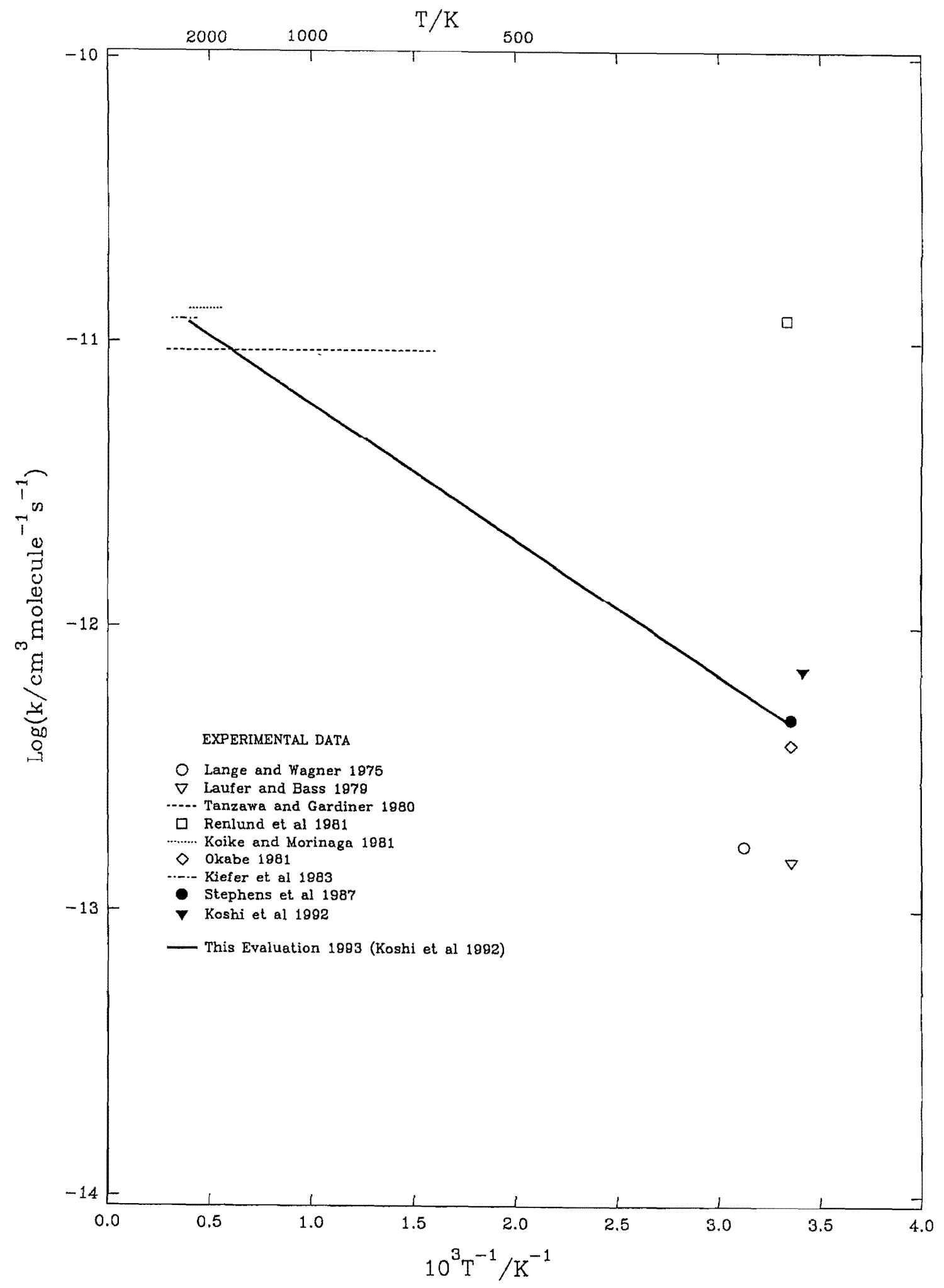


$\mathrm{C}_{2} \mathrm{H}+\mathrm{CH}_{4} \rightarrow$ Products

Rate Coefficient Data

\begin{tabular}{llll}
\hline \hline$k / \mathrm{cm}^{3}$ molecule $\mathrm{s}^{-1} \mathrm{~s}^{-1}$ & $T / \mathrm{K}$ & Reference & Comments \\
\hline Rate Coefficient Measurements & & Renlund et al., $1981^{1}$ & (a) \\
$4.8 \cdot 10^{-12}$ & 298 & Laufer, $1981^{2}$ & $(\mathrm{~b})$ \\
$1.2 \cdot 10^{-12}$ & 297 & Okabe, $1981^{3}$ & $(\mathrm{c})$ \\
$3.2 \cdot 10^{-12}$ & 298 & Lander et al., $1990^{4}$ & $(\mathrm{~d})$ \\
$3.0 \cdot 10^{-12}$ & 298 & & \\
& & & \\
Reviews and Evaluations & $300-2500$ & Tsang and Hampson, $1986^{5}$ & $(\mathrm{e})$ \\
$3.0 \cdot 10^{-12} \exp (-250 / T)$ & 298 & CEC, $1992^{6}$ & $(\mathrm{f})$ \\
$2.0 \cdot 10^{-12}$ & & & \\
\hline
\end{tabular}

\section{Comments}

(a) Flash photolysis of $\mathrm{C}_{2} \mathrm{H}_{2}, \mathrm{C}_{2} \mathrm{HBr}$, or $\mathrm{C}_{2} \mathrm{HCO}$ at $193 \mathrm{~nm}$, or of $\mathrm{C}_{2} \mathrm{HCO}$ at $953 \mathrm{~cm}^{-1} . \mathrm{CH}\left(A^{2} \Delta\right)$ from $\mathrm{C}_{2} \mathrm{H}+\mathrm{O}_{2}$ reaction monitored by chemiluminescence at $432.6 \mathrm{~nm}$, with and without added $\mathrm{CH}_{\Delta_{*}}\left[\mathrm{CO}_{2}\right]$ monitored by chemiluminescence at $2300 \mathrm{~cm}^{-1}$. Total pressures $200-800 \mathrm{~m}$ Torr Ar or He.

(b) VUV flash photolysis of $\mathrm{C}_{2} \mathrm{HCF}_{3}$. Gas chromatographic sampling of products $\left[\mathrm{C}_{2} \mathrm{H}_{2}\right]$ monitored by absorption spectroscopy at $152 \mathrm{~nm}$. $k$ independent of pressure between 20 and 700 Torr.

(c) Relativc ratc study photolysis of $\mathrm{C}_{2} \mathrm{H}_{2} / \mathrm{CH}_{4}$ mixturcs at $147 \mathrm{~nm}$. $\left[\mathrm{C}_{4} \mathrm{H}_{2}\right],\left[\mathrm{C}_{2} \mathrm{H}_{4}\right]$, and $\left[\mathrm{C}_{2} \mathrm{H}_{2}\right]$ measured by absorption spectroscopy at $\approx 165 \mathrm{~nm}, 174.4 \mathrm{~nm}$, and $151.9 \mathrm{~nm}$, respectively. Relative rates $k_{\mathrm{C}_{2} \mathrm{H}}+\mathrm{CH}_{4} / k_{\mathrm{C}_{2} \mathrm{H}_{+}} \mathrm{C}_{2} \mathrm{H}_{2}=0.032 . k$ given in Table based on $k_{\mathrm{C}_{2} \mathrm{H}}+\mathrm{C}_{2} \mathrm{H}_{2}=1.0 \cdot 10^{-10} \mathrm{~cm}^{3}$ molecule ${ }^{-1} \mathrm{~s}^{-1}$ (this review).

(d) Pulsed laser photolysis at $193 \mathrm{~nm}$ of $\mathrm{CF}_{3} \mathrm{C}_{2} \mathrm{H}$ to produce $\mathrm{C}_{2} \mathrm{H} .\left[\mathrm{C}_{2} \mathrm{H}\right]$ monitored by IR diode laser absorption in presence of large excess of $\mathrm{CH}_{4}$. No pressure dependence of $k$ found (8-70 Torr He).

(e) Accepts expression of Brown and Laufer' derived from value of $k$ at $300 \mathrm{~K}$ from Laufer ${ }^{8}$ together with BEBO calculation of temperature coefficient.

(f) Based on Refs. 1-3.

\section{Preferred Values}

$k=3.0 \cdot 10^{-12} \mathrm{~cm}^{3}$ molecule ${ }^{-1} \mathrm{~s}^{-1}$ at $298 \mathrm{~K}$.

\section{Reliability}

$\Delta \log k= \pm 0.5$ at $298 \mathrm{~K}$.

\section{Comments on Preferred Values}

The recent measurements of Lander et al ${ }^{4}$ are the most direct to date and given a value of $k$ in good agreement with the relative rate measurement of $\mathrm{Okabe}^{3}$. Our recommendations are based on these results but with fairly wide error limits.

\section{References}

'A.M. Renlund, F. Shokoohi, H. Reisler, and C. Wittig, Chem. Phys. Lett, 84, 293 (1981).

${ }^{2}$ A.H. Laufer, J. Phys. Chem. 85, 3828 (1981).

${ }^{3}$ H. Okabe, J. Chem. Phys. 75, 2772 (1981).

${ }^{\dagger}$ D.R. Lander, K.G. Unfried, G. Glass, P. Graham, R.F, Curl, J. Phys. Chem. 94, 7759 (1990).

${ }^{5}$ W. Tsang and R.F. Hampson, J. Phys. Chem. Ref. Data 15, 1087 (1986). ${ }^{6} \mathrm{CEC}, 1992$ (see references in Introduction).

${ }^{7}$ R.L. Brown and A.H. Laufer, J. Phys. Chem. 85, 3826 (1981).

${ }^{8}$ A.H. Laufer, J. Phys. Chem. 85, 3828 (1981). 
Thermodynamic Data

$\Delta H_{298}^{\circ}=-99.1 \mathrm{~kJ} \mathrm{~mol}^{-1}$

$\Delta S_{298}^{\circ}=-61.1 \mathrm{~J} \mathrm{~K}^{-1} \mathrm{~mol}^{-1}$

$K p=4.73 \cdot 10^{-9} T^{1.64} \exp (+12640 / T)$

Rate Coefficient Data

\begin{tabular}{|c|c|c|c|}
\hline$k / \mathrm{cm}^{3}$ molecule $\mathrm{e}^{-1} \mathrm{~s}^{-1}$ & $T / \mathrm{K}$ & Reference & Comments \\
\hline \multicolumn{4}{|c|}{ Rate Coefficient Measurements } \\
\hline $6.5 \cdot 10^{-12}$ & 297 & Laufer, $1981^{1}$ & (a) \\
\hline $2.4 \cdot 10^{-11}$ & 298 & Okabe, $1983^{2}$ & (b) \\
\hline $3.6 \cdot 10^{-11}$ & 298 & Lander et al., $1990^{3}$ & (c) \\
\hline \multicolumn{4}{|c|}{ Reviews and Evaluations } \\
\hline $6.5 \cdot 10^{-12}$ & $300-2500$ & Tsang and Hampson, $1986^{4}$ & (d) \\
\hline- & - & CEC, $1992^{5}$ & (e) \\
\hline
\end{tabular}

\section{Comments}

(a) VUV flash photolysis of $\mathrm{CF}_{3} \mathrm{C}_{2} \mathrm{H}$. Gas chromatographic sampling of products. $\left[\mathrm{C}_{2} \mathrm{H}_{2}\right]$ monitored by absorption spectroscopy at $152 \mathrm{~nm}$. No pressure dependence of $k$ found (20-700 Torr He).

(b) Relative rate study. Photolysis of $\mathrm{C}_{2} \mathrm{H}_{2} / \mathrm{C}_{2} \mathrm{H}_{6}$ mixtures at $147 \mathrm{~nm} .\left[\mathrm{C}_{4} \mathrm{H}_{2}\right],\left[\mathrm{C}_{2} \mathrm{H}_{4}\right]$ and $\left[\mathrm{C}_{2} \mathrm{H}_{2}\right]$ measured by sampling and absorption spectroscopy at $165 \mathrm{~nm}, 174.4 \mathrm{~nm}$, and $151.9 \mathrm{~nm}$ respectively. $k\left(\mathrm{C}_{2} \mathrm{H}+\mathrm{C}_{2} \mathrm{H}_{6}\right) / k\left(\mathrm{C}_{2} \mathrm{H}+\mathrm{C}_{2} \mathrm{H}_{2}\right)=$ 0.240 obtained. $k\left(\mathrm{C}_{2} \mathrm{H}+\mathrm{C}_{2} \mathrm{H}_{2}\right)=1.0 \cdot 10^{-10} \mathrm{~cm}^{3}$ molecule ${ }^{-1} \mathrm{~s}^{-1}$ (this review) used to obtain tabulated value of $k$.

(c) Pulsed laser photolysis at $193 \mathrm{~nm}$ of $\mathrm{CF}_{3} \mathrm{C}_{2} \mathrm{H}$ to produce $\mathrm{C}_{2} \mathrm{H}$. $\left[\mathrm{C}_{2} \mathrm{H}\right]$ monitored by IR diode laser absorption in presence of large excess of $\mathrm{C}_{2} \mathrm{H}_{6}$. Small pressure dependence of $k$ observed over range 8-70 Torr He.

(d) Accepts analysis of Brown and Laufer ${ }^{6}$ who derived their result from the value of $k$ at $300 \mathrm{~K}$ from Laufer together with a BEBO calculation indicating a negligible temperature coefficient for $k$.

(e) No recommendation made.

\section{Preferred Values}

No recommendation.

Comments on Preferred Values

The recent measurements of Lander et al. ${ }^{3}$ are the most direct study of this reaction but, although a value of $k$ in reasonable agreement with the relative rate values of $\mathrm{Okabe}^{2}$, is obtained, Lander $e t a l .^{3}$ also observed a significant pressure effect which could indicate complexities in the mechanism. The reaction requires more detailed study before recommendations for $k$ can be made.

\section{References}

${ }^{1}$ A.H. Laufer, J. Phys. Chem. 85, 3828 (1981).

'H. Okabe, J. Chem. Phys. 78, 1312 (1983).

${ }^{3}$ D.R. Lander, K.G. Unfried, P. Graham, R.F. Curl, J. Phys. Chem. 94, 7759 (1990).

${ }^{4}$ W. Tsang and R.F. Hampson, J. Phys. Chem. Ref. Data 15, 1087 (1986) ${ }^{s} \mathrm{CEC}, 1992$ (see references in Introduction).

${ }^{6}$ R.L. Brown and A.H. Laufer, J. Phys. Chem. 85, 3826 (1981). 


$$
\mathrm{C}_{2} \mathrm{H}+\mathrm{C}_{2} \mathrm{H}_{2} \rightarrow \mathrm{C}_{4} \mathrm{H}_{2}+\mathrm{H}
$$

Thermodynamic Data

$\Delta H_{298}^{\circ}=-102 \mathrm{~kJ} \mathrm{~mol}^{-1}$

$\Delta S_{298}^{\circ}=-43.5 \mathrm{~J} \mathrm{~K}^{-1} \mathrm{~mol}^{-1}$

$K p=4.46 \cdot 10^{-7} T^{\mathrm{t} .43} \exp (+12600 / T)$

Rate Coefflcient Data

\begin{tabular}{|c|c|c|c|}
\hline$k / \mathrm{cm}^{3}$ molecule $\mathrm{e}^{-1} \mathrm{~s}^{-1}$ & $T / \mathrm{K}$ & Reference & Comments \\
\hline \multicolumn{4}{|c|}{ Rate Coefficient Measurements } \\
\hline $1.3 \cdot 10^{-10}$ & 298 & Shin and Michael, $1991^{k}$ & (a) \\
\hline $2.5 \cdot 10^{-10}$ & $1236-1475$ & & \\
\hline $1.6 \cdot 10^{-10}$ & 293 & Koshi, Nishida and Matsui, $1992^{2}$ & (b) \\
\hline \multicolumn{4}{|l|}{$1.4 \cdot 10^{-10}$} \\
\hline $1.4 \cdot 10^{-10}$ & 298 & Koshi et al., $1992^{3}$ & (c) \\
\hline $1.4 \cdot 10^{-10}$ & 409 & & \\
\hline $1.3 \cdot 10^{-10}$ & 438 & & \\
\hline $1.5 \cdot 10^{-10}$ & 1600 & & \\
\hline $1.8 \cdot 10^{-10}$ & 1613 & & \\
\hline $1.5 \cdot 10^{-10}$ & 1638 & & \\
\hline $1.5 \cdot 10^{-10}$ & 2010 & & \\
\hline $1.9 \cdot 10^{-10}$ & 2177 & & \\
\hline \multicolumn{4}{|c|}{ Reviews and Evaluations } \\
\hline $4.0 \cdot 10^{-11}$ & $300-2500$ & Tsang and Hampson, $1986^{4}$ & (d) \\
\hline $5 \cdot 10^{-11}$ & $300-2700$ & CEC, $1992^{5}$ & (e) \\
\hline
\end{tabular}

\section{Comments}

(a) Pulsed laser $(193 \mathrm{~nm})$ photolysis of $\mathrm{C}_{2} \mathrm{H}_{2} / \mathrm{He}$ mixtures. $[\mathrm{H}]$ monitored by atomic resonance absorption. High temperature experiments carried out by pulsed photolysis of shock heated $\mathrm{C}_{2} \mathrm{H}_{2} / \mathrm{He}$ mixtures. Scatter on results is such that they can be interpreted as $k$ temperature independent over temperature range or represented by the expression

$k=3.02 \cdot 10^{-10} \exp (-235 / T) \mathrm{cm}^{3}$ molecule ${ }^{-1} \mathrm{~s}^{-1}$.

(b) Pulsed ArF laser photolysis of $\mathrm{C}_{2} \mathrm{H}_{2}$. Reaction monitored by LIF detection of $\mathrm{H}$ and by time-resolved mass spectrometric detection of $\mathrm{C}_{4} \mathrm{H}_{2}$ in separate experiments. The former gives $k=(1.6 \pm 0.1) \cdot 10^{-10} \mathrm{~cm}^{3}$ molecule $^{-1} \mathrm{~s}^{-1}$ and the latter, $k=(1.4 \pm 0.1) \cdot 10^{-10} \mathrm{~cm}^{3}$ molecule $\mathrm{e}^{-1} \mathrm{~s}^{-1}$.

(c) Measurements in the range 298-438 were carried out by pulsed laser photolysis with time-resolved mass spectrometric detection of $\mathrm{C}_{4} \mathrm{H}_{2}$ (see comment (b)). For experiments at higher temperatures shock heating of $\mathrm{C}_{2} \mathrm{H}_{2} / \mathrm{Ar}$ mixtures was employed with pulsed ArF laser photolysis of the heated mixture behind the reflected shock wave. $[\mathrm{H}]$ was monitored by ARAS.

(d) Mean of the values of Refs. 8 and 9.

(e) Based on Refs. 6-9.

\section{Preferred Values}

$k=1.5 \cdot 10^{-10} \mathrm{~cm}^{3}$ molecule $\mathrm{s}^{-1} \mathrm{~s}^{-1}$ over the range 300 $2700 \mathrm{~K}$.
Reliability

$$
\Delta \log k= \pm 0.2 \text { at } 298 \mathrm{~K} \text { rising to } \pm 0.5 \text { at } 2700 \mathrm{~K} \text {. }
$$

\section{Comments on Preferred Values}

There are now several low temperature studies of this reaction which are in very good agreement ${ }^{1,2,3,6}$. The measurements at high temperature are more scattered ${ }^{1,3,7}$ but together with the low temperature data they indicate a very small temperature coefficient for the rate constant, as would be expected for such a fast reaction. The recommendations are based on the low temperature results of Stephens et al.$^{6}$, Shin and Michael', and Koshi et al.$^{2.3}$ and the rate constant is taken to be temperature independent but substantial error limits are assigned at high temperatures.

\section{References}

${ }^{1}$ K.S. Shin, J.V. Michael, J. Phys. Chem. 95, 5864 (1991).

${ }^{2}$ M. Koshi, N. Nishida, and H. Matsui, J. Phys. Chem. 96, 5875 (1992).

${ }^{3}$ M. Koshi, K. Fukuda, K. Kamiya, H. Matsui, J. Phys. Chem. 96, 9839 (1992).

${ }^{4}$ W. Tsang and R.F. Hampson, J. Phys. Chem. Ref. Data 15, 1087 (1986). ${ }^{5} \mathrm{CEC}, 1992$ (see references in Introduction).

${ }^{6}$ J.W. Stephens, J.L. Hall, H. Solka, W.-B. Yan, R.F. Curl, and G.P. Glass, J. Phys. Chem. 91, 5740 (1987).

${ }^{7}$ P. Frank and Th. Just, Comb. Flame 38, 231 (1980).

${ }^{8}$ A.H. Laufer and A.M. Bass, J. Phys. Chem. 83, 310 (1979).

${ }^{9}$ W. Lange and H.Gg. Wagner, Ber. Bunsenges. Phys. Chem. 79, 165 (1975). 


\section{$\mathrm{C}_{2} \mathrm{H}+\mathrm{C}_{2} \mathrm{H}_{2} \rightarrow \mathrm{C}_{4} \mathrm{H}_{2}+\mathrm{H}$}

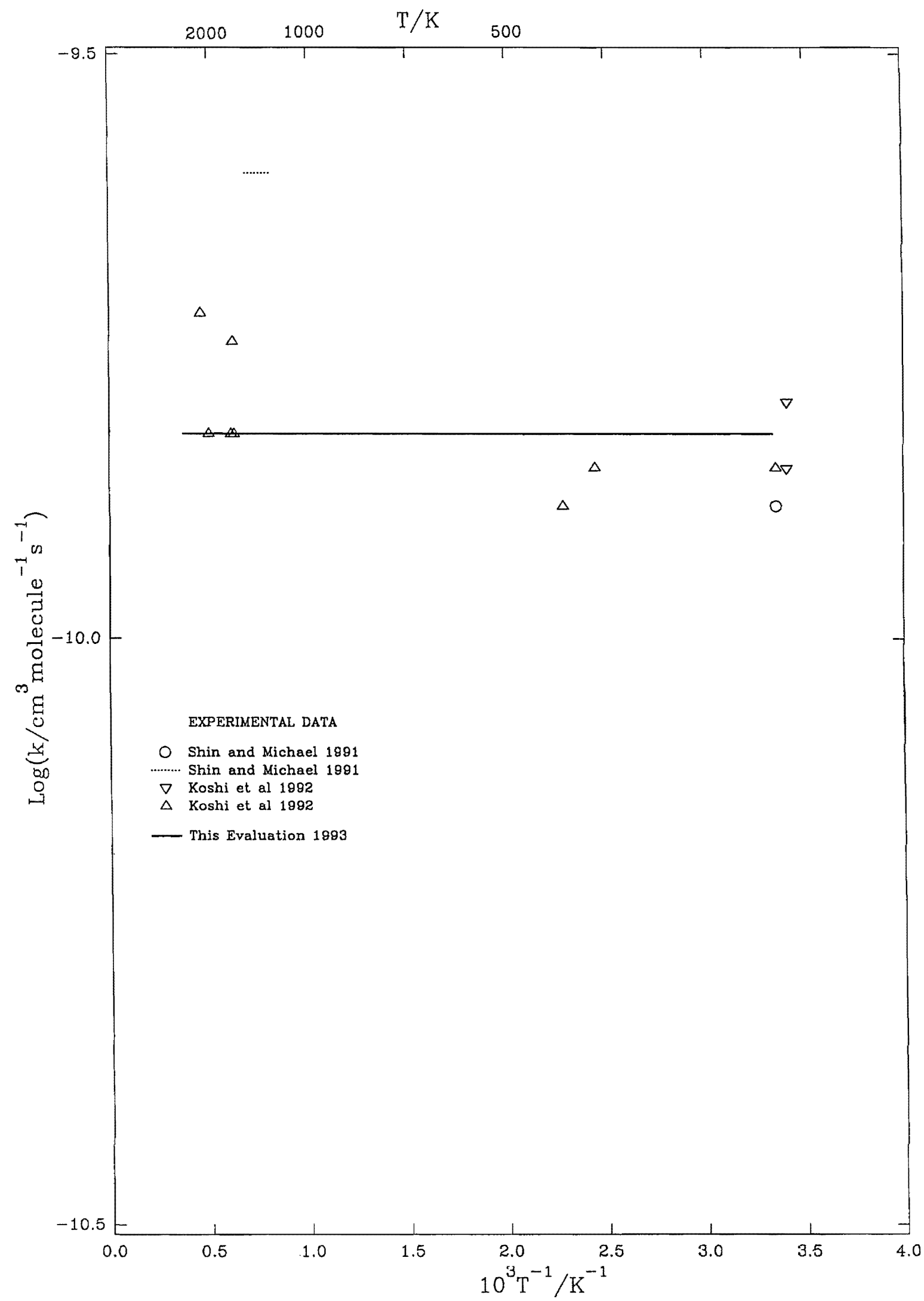




$$
\begin{aligned}
\mathrm{C}_{2} \mathrm{H}_{3}+\mathrm{O}_{2} & \rightarrow \mathrm{C}_{2} \mathrm{H}_{2}+\mathrm{HO}_{2} \\
& \rightarrow \mathrm{H}_{2} \mathrm{CO}+\mathrm{CHO} \\
& \rightarrow \mathrm{C}_{2} \mathrm{H}_{3} \mathrm{O}+\mathrm{O} \\
& \rightarrow \mathrm{C}_{2} \mathrm{H}_{3} \mathrm{O}_{2}
\end{aligned}
$$

Thermodynamic Data $\Delta H_{298}^{\circ}(1)=-49.0 \mathrm{~kJ} \mathrm{~mol}^{-1}$ $\Delta S_{298}^{\circ}(1)=-6.9 \mathrm{~J} \mathrm{~K}^{-1} \mathrm{~mol}^{-1}$ $K p(1)=1.69 \cdot 10^{-2} T^{0.55} \exp (+5940 / T)$
$\Delta H_{298}^{\circ}(2)=-358.6 \mathrm{~kJ} \mathrm{~mol}^{-1}$

\begin{tabular}{|c|c|c|c|}
\hline$k / \mathrm{cm}^{3}$ molecule $\mathrm{e}^{-1} \mathrm{~s}^{-1}$ & $T / \mathbf{K}$ & Reference & Comments \\
\hline \multicolumn{4}{|c|}{ Rate Coefficient Measurements } \\
\hline$k_{1}=1.7 \cdot 10^{-12}$ & 1726 & Cooke and Williams, $1971^{1}$ & (a) \\
\hline$k_{2}=6.6 \cdot 10^{-12} \exp (125 / T)$ & $291-602$ & Slagle et al., $1984^{2}$ & (b) \\
\hline$k_{2}=1.0 \cdot 10^{-11}$ & 296 & Park, Heaven, and Gutman, $1984^{3}$ & (c) \\
\hline$k_{2}=1.0 \cdot 10^{-11}$ & 298 & Krueger and Weitz, $1988^{4}$ & (d) \\
\hline$k_{3}=2.5 \cdot 10^{-12}$ & 298 & Munk et al., $1987^{5}$ & (e) \\
\hline$k=6.7 \cdot 10^{-12}$ & 298 & Fahr and Laufer. $1988^{6}$ & (f) \\
\hline \multicolumn{4}{|l|}{ Reviews and Evaluations } \\
\hline $9.0 \cdot 10^{-12}$ & $300-2000$ & CEC, $1992^{7}$ & (g) \\
\hline
\end{tabular}
$\Delta S_{298}^{\circ}(2)=6.6 \mathrm{~J} \mathrm{~K}^{-1} \mathrm{~mol}^{-1}$ $K p(2)=23.1 T^{-0.33} \exp (+43000 / T)$

Rate Coefficient Data $\left(k=k_{1}+k_{2}+k_{3}+k_{1}\right)$

\section{Comments}

(a) Shock tube study of $\mathrm{C}_{2} \mathrm{H}_{4}, \mathrm{CH}_{4}+\mathrm{O}_{2}$ mixtures. Based on simulation of reaction mechanism.

(b) Excimer laser flash photolysis (193 nm)-photoionization mass spectrometry at 0.76-3.60 Torr. Monitored $\mathrm{C}_{2} \mathrm{H}_{3}$, $\mathrm{CHO}, \mathrm{H}_{2} \mathrm{CO}$. No signals corresponding to products of channel (1), therefore, $k_{1} \ll k_{2}$. Similar conclusion by Baldwin and Walker ${ }^{8}$.

(c) Excimer laser flash photolysis (193 nm)-photoionization mass spectrometry at $0.4-4.0$ Torr.

(d) Excimer laser flash photolysis ( $248 \mathrm{~nm}$ ), diode laser spectroscopy on $\mathrm{C}_{2} \mathrm{H}_{4}$ in $\mathrm{C}_{2} \mathrm{H}_{3} \mathrm{I} / \mathrm{HCl} / \mathrm{O}_{2}$ mixtures at $\approx 7$ Torr. The effect of $\mathrm{O}_{2}$ on the rate of growth of $\mathrm{C}_{2} \mathrm{H}_{4}$, generated in the $\mathrm{C}_{2} \mathrm{H}_{3}+\mathrm{HCl}$ reaction, was used to determine $k$.

(e) Pulse radiolysis with a variety of $\mathrm{C}_{2} \mathrm{H}_{3}$ precursors, pressure $\approx 1 \mathrm{~atm}$. Monitored disappearance of $\mathrm{C}_{2} \mathrm{H}_{3}$ and the build-up of a long lived product at 230 and $270 \mathrm{~nm}$. Latter ascribed to a product $X$ of $\mathrm{C}_{2} \mathrm{H}_{3}+\mathrm{O}_{2}$, presumed to be $\mathrm{C}_{2} \mathrm{H}_{3} \mathrm{O}_{2}$; the rate coefficient was deduced from the product build up.

(f) Spectroscopic study with vacuum UV photolysis of $\mathrm{Sn}\left(\mathrm{C}_{2} \mathrm{H}_{3}\right)_{4}$ or $\mathrm{Hg}\left(\mathrm{C}_{2} \mathrm{H}_{3}\right)_{2}$, monitoring the decay of $\mathrm{C}_{2} \mathrm{H}_{3}$ at 164.7 and $168.3 \mathrm{~nm}$ by absorption spectroscopy. Total pressure 400 Torr.

(g) Based on Park et al. ${ }^{3}$.

\section{Preferred Values}

$k=9.0-10^{-12} \mathrm{~cm}^{3}$ molecule ${ }^{-1} \mathrm{~s}^{-1}$ over range $300-2000 \mathrm{~K}$.

\section{Reliability}

$\Delta \log k= \pm 0.3$ over range $300-600 \mathrm{~K} ; \pm 0.5$ over range $600-2000 \mathrm{~K}$.

\section{Comments on Preferred Values}

There is excellent agreement between the low pressure studies of Slagle et al. ${ }^{2}$ and Krueger and Weitz ${ }^{4}$. The higher pressure measurements of Fahr and Laufer ${ }^{6}$ are in reasonable agreement and clearly do not confirm the significant decrease in $k$ with pressure suggested by the measurements of Munk et al..$^{5}$ who obtained their data by observing the rate of growth of an absorption feature attributed to $\mathrm{C}_{2} \mathrm{H}_{3} \mathrm{O}_{2}$.

The available experimental data are in agreement that channel (2) dominates, at $T<1000 \mathrm{~K}$. Flame modelling, however, suggests that channel (1) becomes more significant at higher temperatures'.

\section{References}

'D.F. Cooke and A. Williams, 13th Symp. (Int.) Combust. 757 (1971).

${ }^{2}$ I.R. Slagle, J.Y. Park, M.C. Heaven, and D. Gutman, J. Am. Chem. Soc., 106, 4356 (1984).

${ }^{3}$ J.Y. Park, M.C. Heaven, and D. Gutman, Chem. Phys. Lett 104, 469 (1984).

${ }^{4}$ H. Krueger and E. Weitz, J. Chem. Phys. 88, 1608 (1988).

${ }^{5}$ J. Munk, P. Pagsberg, E. Ratajczak, and A. Sillesen, Periodic Report (2), Contract No. EN3E-0095-D $k$ (B).

${ }^{6}$ A. Fahr and A.H. Laufer, J. Phys. Chem. 92, 7229 (1988).

${ }^{7} \mathrm{CEC}, 1992$ (see references in Introduction).

${ }^{8}$ R. Baldwin and R.W. Walker, 18th Symp. (Int.) Combust. 819 (1981).

${ }^{9} J$. Warnatz, 24th Symp. (Int.) Combust., 553 (1992). 


$$
\begin{aligned}
\mathrm{C}_{2} \mathrm{H}_{4}(+\mathrm{M}) & \rightarrow \mathrm{C}_{2} \mathrm{H}_{2}+\mathrm{H}_{2}(+\mathrm{M}) \\
& \rightarrow \mathrm{C}_{2} \mathrm{H}_{3}+\mathrm{H}(+\mathrm{M})
\end{aligned}
$$

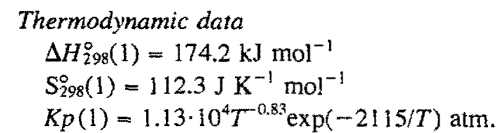

$\Delta H_{298}^{\circ}(2)=451.5 \mathrm{~kJ} \mathrm{~mol}^{-1}$ $\Delta S_{298}^{\circ}(2)=126,9 \mathrm{~J} \mathrm{~K}^{-1} \mathrm{~mol}^{-1}$

$K p(2)=1.46 \cdot 10^{5} T^{0.608} \exp (-54400 / T)$ atm.

\begin{tabular}{|c|c|c|c|c|}
\hline$k / s^{-1}$ & $T / \mathrm{K}$ & {$[\mathrm{M}] /$ molecule $\mathrm{cm}^{-3}$} & Reference & Comments \\
\hline \multicolumn{5}{|l|}{ Rate Coefficient Measurements } \\
\hline \multicolumn{5}{|l|}{ Low Pressure Range } \\
\hline$[\mathrm{Ar}] 2.95 \cdot 10^{-7} \exp (-39000 / T)$ & $1675-2210$ & $(2.5-32) \cdot 10^{18}$ & Roth and Just, $1973^{1}$ & (a) \\
\hline$\left[\right.$ Ar] $4.3 \cdot 10^{-7} \exp (-39900 / T)$ & $1700-2200$ & $(6-16) \cdot 10^{18}$ & Just, Roth and Damm, $1976^{2}$ & (b) \\
\hline$\left[\mathrm{Arj} 4.9 \cdot 10^{7} \exp (-40887 / T)\right.$ & $2000-2540$ & $(1.1-3.3) \cdot 10^{18}$ & Tanzawa and Gardiner, $1980^{3}$ & (c) \\
\hline$[\mathrm{Kr}] 2.5 \cdot 10^{-9} \exp (-27900 / T)$ & $2300-3200$ & $(7-32) \cdot 10^{18}$ & Kiefer et al., $1983^{4}$ & (d) \\
\hline \multicolumn{5}{|l|}{ Intermediate Fall-Off Range } \\
\hline 0.44 & 1168 & $1.2 \cdot 10^{20}(\mathrm{Ar})$ & Skinner and Sokoloski, $1960^{6}$ & (e) \\
\hline $8.2 \cdot 10^{3}$ & 1423 & & & \\
\hline $1.52 \cdot 10^{3}$ & 1788 & & & \\
\hline $8.6 \cdot 10^{-1}$ & 2100 & $2.5 \cdot 10^{19}(\mathrm{M})$ & Leroux and Mathieu, $1961^{7}$ & (f) \\
\hline 4.2 & 2450 & & & \\
\hline $6.4 \cdot 10^{-2}$ & 1176 & $2.5 \cdot 10^{19}\left(\mathrm{C}_{2} \mathrm{H}_{4}\right)$ & Towell and Martin, $1961^{8}$ & (g) \\
\hline $1.5 \cdot 10^{1}$ & 1374 & & & \\
\hline $6.5 \cdot 10^{1}$ & 1470 & & & \\
\hline $1.0 \cdot 10^{2}$ & 1330 & $(1.6-2.3) \cdot 10^{19}(\mathrm{Ar})$ & Kozlov and Knorre, 1962, $1963^{\circ}$ & (h) \\
\hline $3.1 \cdot 10^{2}$ & 1460 & & & \\
\hline $2.9 \cdot 10^{3}$ & 1830 & & & \\
\hline $1.4 \cdot 10^{3}$ & 1712 & $(7.3-52) \cdot 10^{18}(\mathrm{Ne})$ & Gay et al., $1966^{10}$ & (i) \\
\hline $6.9 \cdot 10^{4}$ & 2020 & & & \\
\hline $1.1 \cdot 10^{4}$ & 2170 & & & \\
\hline $3.3 \cdot 10^{3}$ & 1950 & $8.3 \cdot 10^{17}(\mathrm{Ar})$ & Homer and Kistiakowsky, $1967^{11}$ & (j) \\
\hline $4.8 \cdot 10^{3}$ & 2060 & & & \\
\hline $2.0 \cdot 10^{4}$ & 2260 & & & \\
\hline \multicolumn{5}{|l|}{ Reviews and Evaluations } \\
\hline $\begin{array}{l}k_{0}(1)=[\mathrm{Ar}] 4.3 \cdot 10^{-7} \exp (-39930 / T) \\
k_{0}(2)=[\mathrm{Ar}] 4.3 \cdot 10^{-1} \exp (-48590 / T)\end{array}$ & $1500-2500$ & & Warnatz, $1989^{12}$ & (k) \\
\hline$k_{\infty}(1)=7.9 \cdot 10^{12} T^{0.44} \exp (-44670 / T)$ & $1100-2500$ & & Tsang and Hampson, $1986^{13}$ & (l) \\
\hline
\end{tabular}

Rate Coefficient Data $\left(k=k_{1}+k_{2}\right)$

\section{Comments}

(a) Shock tube study of $\mathrm{C}_{2} \mathrm{H}_{4}(0.1-1 \%) / \mathrm{Ar}$ mixtures in reflected shocks. $\left[\mathrm{C}_{2} \mathrm{H}_{4}\right]$ and $\left[\mathrm{C}_{2} \mathrm{H}_{2}\right]$ followed simultaneously by IR emissions at 3.0 and $3.35 \mu \mathrm{m}$ respectively. Emission profiles corrected for interference between emission bands. $\mathrm{C}_{2} \mathrm{H}_{4}$ decay found to proceed in two distinct phases: an initial phase of second order for which the rate coefficient was given as indicated above, and a later phase for which the best interpretation was given by an order of 0.6 in [Ar] with rate coefficient $k=$ $2.85 \cdot 10^{-2} \exp (-26570 / T) \mathrm{cm}^{1.8}$ molecule $\mathrm{e}^{-0.6} \mathrm{~s}^{-1}$.

(b) Shock tube study $\mathrm{C}_{2} \mathrm{H}_{4}(20-800 \mathrm{ppm}) / \mathrm{Ar}$ mixtures in reflected shocks. $[\mathrm{H}]$ followed by atomic resonance absorption at $121.5 \mathrm{~nm}$ calibrated by $\mathrm{H}_{2}$ dissociation in $\mathrm{H}_{2} / \mathrm{Ar}$ mixtures. $\left[\mathrm{C}_{2} \mathrm{H}_{4}\right]$ followed by absorption at $100.8 \mathrm{~nm} . \mathrm{H}$ absorption corrected for $\mathrm{C}_{2} \mathrm{H}_{4}$ and $\mathrm{C}_{2} \mathrm{H}_{2}$ contribution. The results of this work and those of Ref. 1 led the authors to conclude that there were two pathways for $\mathrm{C}_{2} \mathrm{H}_{4}$ dissociation. Both sets of data were analysed to give $k_{1}$ (which was used in the analysis to obtain $k_{2}$ ). The analysis of $\mathrm{C}_{2} \mathrm{H}_{4}$ decomposition showed a strong influence of diluent on channel (2) but only weak effects on channel (1). The expression $k_{2}=6.3 \cdot 10^{-7} \mathrm{exp}(-49400 / T) \mathrm{cm}^{3}$ molecule $^{-1}$ $\mathrm{s}^{-1}$ was obtained for reaction 2 .

(c) Shock tube study of incident shock waves in $\mathrm{C}_{2} \mathrm{H}_{4}(2.5,5$ and 10\%)/Ar mixtures. Analysis by lasen schlieren technique. Data analysis by computer modelling of a 14 reaction mechanism. $k_{1}$ was obtained by optimization of the model to fit initial deflection of laser beam. $k_{2}$ taken from Ref. 2 multiplied by 1.2 to improve fit to laser schlieren data.

(d) Shock tube study of $3 \% \quad \mathrm{C}_{2} \mathrm{H}_{4} / \mathrm{Kr}$ mixtures. Laser schlieren technique. Initial dissociation of $\mathrm{C}_{2} \mathrm{H}_{4}$ was clearly resolved over the range $2300-3200 \mathrm{~K}$. Rate coefficients for both dissociation channels were derived from the initial gradients and the location of the $\mathrm{C}_{2} \mathrm{H}_{2}$ gradient maximum. For reaction 2 the following value was obtained: $k_{2}=2.3 \cdot 10^{-9} \exp (-41180 / T) \mathrm{cm}^{3}$ molecule $\mathrm{e}^{-1} \mathrm{~s}^{-1}$. $\Lambda$ nRRKM calculation using $E_{0}-\Delta H_{0}^{\circ}-355.6 \pm 8.4 \mathrm{~kJ}$ 
mol $^{-1}$ for channel (1) give a good fit to the data of Refs. 1,3 and 4.

(e) Shock tube study of $\mathrm{C}_{2} \mathrm{H}_{4}(0.466-6 \%)$ in Ar. Analysis for $\mathrm{H}_{2}, \mathrm{C}_{2} \mathrm{H}_{6}, \mathrm{C}_{2} \mathrm{H}_{4}$ and $\mathrm{C}_{2} \mathrm{H}_{2}$ by gas chromatography.

(f) Flame study, $\mathrm{C}_{2} \mathrm{H}_{4} / \mathrm{O}_{2}$ flames at 1 atm with $\left[\mathrm{CH}_{4}\right] /\left[\mathrm{O}_{2}\right]$ ratios from 1.75 to 2.07. Products quenched and analyzed for $\mathrm{CH}_{4}, \mathrm{C}_{2} \mathrm{H}_{2}, \mathrm{C}_{2} \mathrm{H}_{4}, \mathrm{C}, \mathrm{CO}$ and higher hydrocarbons.

(g) Flow system, $\mathrm{C}_{2} \mathrm{H}_{4}$ passed through ceramic reactor tube; products analyzed by mass spectrometry. Production of $\mathrm{C}_{2} \mathrm{H}_{2}$ and $\mathrm{C}_{4}$ hydrocarbons found to be first and second order respectively.

(h) Shock tube study of $\mathrm{C}_{2} \mathrm{H}_{4}(0.2 \%$ and $5 \%) / \mathrm{Ar}$ mixtures in reflected shocks. Reaction products sampled and analyzed for $\mathrm{H}_{2}, \mathrm{CH}_{4}, \mathrm{C}_{2} \mathrm{H}_{6}, \mathrm{C}_{2} \mathrm{H}_{4}$ and $\mathrm{C}_{2} \mathrm{H}_{2}$ by gas chromatography. $\mathrm{C}_{2} \mathrm{H}_{4}$ decomposition rate found to be independent of pressure. Conversion to $\mathrm{C}_{2} \mathrm{H}_{2}$ increases with increasing temperature.

(i) Shock tube study of $\mathrm{C}_{2} \mathrm{H}_{4}(0.5-3 \%) / \mathrm{Ne}$ mixtures in reflected shocks, products sampled by mass spectronetry of $\mathrm{C}_{2} \mathrm{H}_{2}$ and $\mathrm{H}_{2}$ which were the only products-observed. $\mathrm{C}_{2} \mathrm{H}_{4}$ decay is first order in $\left[\mathrm{C}_{2} \mathrm{H}_{4}\right]$ and of order $1 / 2$ in [Ne].

(j) Flow system study of $\mathrm{C}_{2} \mathrm{H}_{4}(8.13-14.9 \%) / \mathrm{H}_{2}$ mixtures. Products $\mathrm{CH}_{4}, \mathrm{C}_{2} \mathrm{H}_{6}, \mathrm{C}_{2} \mathrm{H}_{2}, \mathrm{C}_{3} \mathrm{H}_{6}$ monitored by gas chromatography.

(k) Data evaluation.

(l) Data evaluation and construction of RRKM fall-off curves.

\section{Preferred Values}

$k_{\mathrm{o}}(1)=[\mathrm{Ar}, \mathrm{Kr}] 5.8 \cdot 10^{-8} \exp (-36000 / T) \mathrm{s}^{-1}$ over range $1500-3200 \mathrm{~K}$.

$k_{\mathrm{o}}(2)=[\mathrm{Ar}] 4.3 \cdot 10^{-7} \exp (-48600 / T) \mathrm{s}^{-1}$ over range 1500 $3200 \mathrm{~K}$.

\section{Reliability}

$\Delta \log k_{\circ}(1)= \pm 0.3$ over range $1500-3200 \mathrm{~K}$.

$\Delta \log k_{\circ}(2)= \pm 0.5$ over range $1500-3200 \mathrm{~K}$.
Comments on Preferred Values

The thermal decomposition of $\mathrm{C}_{2} \mathrm{H}_{4}$ apparently is dominated by the 1,1 elimination channel to form singlet vinylidene $\left(: \mathrm{C}=\mathrm{CH}_{2}\right)$ which immediately isomerizes to acetylene. All experiments reported are in the fall-off region close to the low pressure limit. Figure 1 gives Arrhenius plots of $k_{0}$ from Refs. $1-4$. The agreement among the rate coefficients is quite satisfactory, thus, we have chosen an average $k_{0}$ as the preferred value. A theoretical analysis ${ }^{14}$ of these rate coefficients using a recent determination of the reaction barrier by Kiefer et al. $.^{15}, 355.6 \mathrm{~kJ} \mathrm{~mol}^{-1}$, leads to collisional efficiencies $\beta_{\mathrm{c}}$ ranging from 0.002 to 0.004 between 1700 to $3200 \mathrm{~K}$. However, employing a value of $\Delta H_{\circ}^{\circ}=368.2 \mathrm{~kJ} \mathrm{~mol}^{-1}$ an almost constant $\beta_{c} \approx 0.006$ is obtained over the same temperature range. The experiments provide no information about the high pressure rate coefficient. The second channel (2) is expected to depend strongly on the bath gas ${ }^{16}$.

\section{References}

'P. Roth and T. Just, Ber. Bunsenges. Phys. Chem. 77, 1114 (1973).

${ }^{2}$ T. Just, P. Roth, and R. Damm, 16th Symp. (Int.) Combust., 961 (1976).

${ }^{3}$ T. Tanzawa and W.C. Gardiner, Comb. Flame 39, 241 (1980).

${ }^{4} J . H$. Kiefer, S.A. Kapsalis, M.P. Al-Alami, and K.A. Budach, Comb. Flame 51, 79 (1983).

${ }^{5}$ J.II. Kicfcr, S.S. Sidhu, S.S. Kumaran, and E.A. Irdam, Chcm. Thys. Lctt. 159, 32 (1989)

${ }^{6}$ G.B. Skinner and E.M. Sokoloski, J. Phys. Chem. 64, 1028 (1960).

${ }^{7}$ P.J. Leroux and P.M. Mathieu, Comb. Flame 6, 253 (1962).

${ }^{8}$ G.D. Towcll and J.J. Martin, A.I.Ch.E.J. 7, 693 (1961).

${ }^{9}$ G.I. Kozlov and V.G. Kuorre, Comb. Flame 6, 253 (1962), Kin. i Kat. 4, 189 (1963).

${ }^{10}$ I.D. Gay, R.D. Kem, G.B. Kistiakowsky, and H. Niki, J. Chem. Phys. 45, 2371 (1966).

${ }^{11}$ J.B. Homer and G.B. Kistiakowsky, J. Chem. Phys. 47, 5290 (1967).

${ }^{12}$ J. Warnatz, in "Combustion Chemistry", W.C. Gardiner, Jr., (Ed.), Springer-Verlag, p.197 (1984).

${ }^{13}$ W. Tsang and R.F. Hampson, J. Pliys. Chem. Ref. Data, 15, 1087 (1986). ${ }^{14}$ J. Troe, J. Chem. Phys. 66, 4758 (1977).

${ }^{15}$ J.H. Kiefer, S.S. Sidhu, S.S. Kumaran, and G.A. Irdam, Chem. Phys. Lett. 159, 32 (1989).

'Th. Just and J. Troe, J. Phys. Chem. 84, 3068 (1980). 


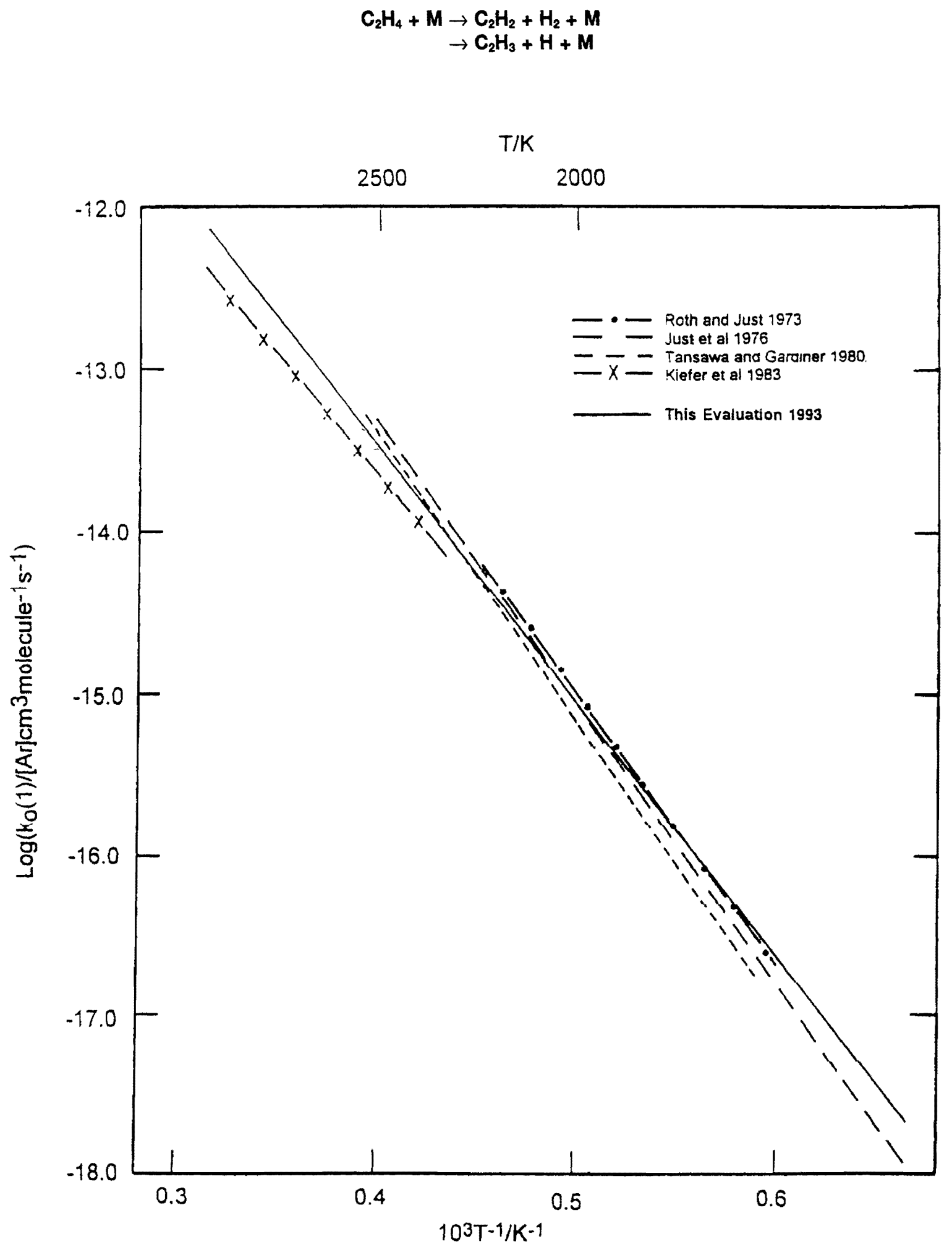




\section{$\mathrm{C}_{2} \mathrm{H}_{5} \mathrm{OOH}(+\mathrm{M}) \rightarrow \mathrm{C}_{2} \mathrm{H}_{5} \mathrm{O}+\mathrm{OH}(+\mathrm{M})$}

Thermodynamic data $\Delta H_{298}^{\circ}=180 \mathrm{~kJ} \mathrm{~mol}^{-1}$

Rate Coefficient Data

\begin{tabular}{|c|c|c|c|}
\hline$k / \mathrm{s}^{-1}$ & $T / \mathrm{K}$ & Reference & Comments \\
\hline \multicolumn{4}{|l|}{ Rate Coefficient Measurements } \\
\hline $2.5 \cdot 10^{13} \exp (-19000 / T)\left(M=\mathrm{C}_{6} \mathrm{H}_{6}\right)$ & $553-653$ & Kirk and Knox, $1960^{1}$ & (a) \\
\hline \multicolumn{4}{|l|}{ Reviews and Evaluations } \\
\hline $2.2 \cdot 10^{15} \exp (-21600 / T)$ & - & Benson and O'Neal, $1970^{2}$ & (b) \\
\hline $4.0 \cdot 10^{15} \exp (-21600 / T)$ & $400-1000$ & $\mathrm{CEC}, 1992^{3}$ & (c) \\
\hline
\end{tabular}

\section{Comments}

(a) Pyrolysis of $\mathrm{C}_{2} \mathrm{H}_{5} \mathrm{OOH}$ in benzene carrier gas flow system (553-653 K) at total pressure of 10-20 Torr. Analysis of the amount of peroxide consumed and phenyl product allowed distinction between homogeneous and heterogeneuus components; expression given is for homogeneous reaction.

(b) Based on data of Kirk and $\mathrm{Knox}^{1}$ and transition state calculation.

(c) Based on analogy with the estimated high pressure limit for decomposition of methyl hydroperoxide.

\section{Preferred Values}

$k_{\infty}=4.0 \cdot 10^{15} \exp (-21600 / T) \mathrm{s}^{-1}$ over range $400-800 \mathrm{~K}$

\section{Reliability}

$\Delta \log k= \pm 0.3$

\section{Comments on Preferred Values}

The cited experimental measurements are the only reported for this reaction, and were overlooked in the previous CEC evaluation ${ }^{3}$. The Arrhenius parameters are substantially lower than measured recently for $\mathrm{CH}_{3} \mathrm{OOH}$ decomposition, although the rate coefficient values at $650 \mathrm{~K}$ are comparable. There is a strong possibility that the reaction is in the fall-off region at the low pressures used which would account for the low $A$ factor. The uncertainties do not allow a firm recommendation but the expression recommended previously for $k_{\infty}$ is consistent with the data.

\section{References}

'A.D. Kirk and J.H. Knox, Trans. Faraday Soc. 56, 1296 (1960).

${ }^{2}$ S.W. Benson and H.E. O'Neal, 'Kinetic Data on Gas Phase Unimolecular Reactions', NSRDS-NBS21, p. 436 (1970).

${ }^{3} \mathrm{CEC}, 1992$ (see references in Introduction).

${ }^{4}$ P.D. Lightfoot, P. Roussel and R. Lesclaux, J. Chem. Soc., Faraday Trans. 87, 3215 (1991). 


$$
\begin{aligned}
\mathrm{C}_{6} \mathrm{H}_{5} \mathrm{CH}_{3}(+\mathrm{M}) & \rightarrow \mathrm{H}+\mathrm{C}_{6} \mathrm{H}_{5} \mathrm{CH}_{2}(+\mathrm{M}) \\
& \rightarrow \mathrm{CH}_{3}+\mathrm{C}_{6} \mathrm{H}_{5}(+\mathrm{M})
\end{aligned}
$$

Thermodynamic Data
$\Delta H_{298}^{\circ}(1)=367.9 \mathrm{~kJ} \mathrm{~mol}^{-1}$
$\Delta S_{298}^{\circ}(1)=110.9 \mathrm{~J} \mathrm{~K}^{-1} \mathrm{~mol}^{-1}$
$K p(1)=5.6-10^{1} T^{1.49} \exp (-44030 / T)$ atm
$\Delta H_{298}^{\circ}(2)=424.1 \mathrm{~kJ} \mathrm{~mol}^{1}$
$\Delta S_{298}^{\circ}(2)=162.5 \mathrm{~J} \mathrm{~K}^{-1} \mathrm{~mol}^{-1}$
$K p(2)=2.1-10^{10} \mathrm{~T}^{-0.50} \exp (-51450 / T) \mathrm{atm}$

\begin{tabular}{|c|c|c|c|}
\hline$k / s^{-1}$ & $T / \mathrm{K}$ & Reference & Comments \\
\hline \multicolumn{4}{|l|}{ Rate Coefficient Measurements } \\
\hline$k_{1}=2.0-10^{13} \exp (-38900 / T)$ & $1011-1138$ & Swarc, $1948^{1}$ & (a) \\
\hline$k_{1}=2.5-10^{12} \exp (-37091 / T)$ & $1011-1122$ & Takahashi, $1960^{2}$ & (b) \\
\hline$k_{1}=1.3-10^{18} \exp (-52340 / T)$ & $1185-1206$ & & \\
\hline$k_{1}=6.3-10^{14} \exp (-42778 / T)$ & $913-1143$ & Price, $1962^{3}$ & (c) \\
\hline$k_{2}=3.4-10^{24} \exp (-40262 / T)$ & $1073-1373$ & Errede and DeMaria, $1964^{4}$ & (d) \\
\hline$k_{1}=9.2-10^{15} \exp (-44737 / T)$ & $920-970$ & Brooks, Cummings, and Peacock, $1971^{5}$ & (e) \\
\hline$k_{1}=1.7-10^{14} \exp (-41268 / T)$ & $1410-1730$ & Rao and Skinner, $1984^{6}$ & (f) \\
\hline$k_{1}=2.0-10^{15} \exp (-44393 / T)$ & $1500-1900$ & Mueller-Markgraf and Troe, $1986^{7}$ & (g) \\
\hline$k_{1}=8.1-10^{12} \exp (-36534 / T)$ & $1300-1800$ & Mizerka and Kiefer, $1986^{8}$ & (h) \\
\hline$k_{2}=4.0-10^{11} \exp (-45291 / T)$ & $1300-1800$ & & \\
\hline$k_{2}=8.9-10^{12} \exp (-36534 / T)$ & $1600-2100$ & Pamidimukkala et al., $1987^{\circ}$ & (i) \\
\hline$k_{1}=2.8-10^{15} \exp (-44730 / T)$ & $1450-1900$ & Brouwer, Mueller-Markgraf, and Troe, $1988^{10}$ & (j) \\
\hline$k_{1}=3.6-10^{15} \exp (-45000 / T)$ & $1380-1700$ & Braun-Unkhoff, Frank, and Just, $1989^{13}$ & (k) \\
\hline$k^{\infty}=1-10^{15} \exp (-43300 / T)$ & $1250-1500$ & Hippler, Reihs, and Troe, $1990^{14}$ & (1) \\
\hline \multicolumn{4}{|l|}{$k_{1}^{\infty}=6.3-10^{15} \exp (-45465 / T)$} \\
\hline \multicolumn{4}{|l|}{ Reviews and Evaluations } \\
\hline$k_{1}=3.2-10^{15} \exp (-44439 / T)$ & . $920-1140$ & Benson and O'Neal, $1970^{11}$ & $(\mathrm{~m})$ \\
\hline$k_{1}=2.7-10^{14} \exp (-41722 / T)$ & $1050-1600$ & Rao and Skinner, $1984^{6}$ & (n) \\
\hline$k_{1}=3.1-10^{10} \exp (-44890 / T)$ & $920-2200$ & $\mathrm{CEC}, 1992^{13}$ & (o) \\
\hline
\end{tabular}

Rate Coefflclent Data $\left(k=k_{1}+k_{2}\right)$

\section{Comments}

(a) Pyrolysis of toluene and xylene in a flow system at pressure between 3 and 20 mbar.

(b) Flow system with mass spectrometric analysis. It was concluded that the curvature of the Arrhenius plot for channel (1) was caused mainly by competitive reactions.

(c) The flow system study (pressure 8-28 mbar) revealed that the toluene decay was strongly surface controlled at temperatures below $1000 \mathrm{~K}$. The reported Arrhenius parameters for reaction (1) were derived from the isolated homogeneous reaction.

(d) Flow system study. Rate coefficient parameters for reaction pathway (2) were deduced from the rate of benzene formation during the decomposition of xylene between 1070 and $1370 \mathrm{~K}$. Due to the indirect method which was used in this study, the results were criticized by Benson and $\mathrm{O}^{\prime} \mathrm{Neal}^{11}$ who suggested that the pre-exponential factor and the activation energy obtained seem unlikely for this reaction.

(c) Pyrolysis of tolucne/nitrogen mixtures in a static system at total pressures below $300 \mathrm{mbar}$ ( $P_{\text {toluene }} \leqslant 30 \mathrm{mbar}$ ). Stable compounds analysed by gas chromatography.

(f) Shock tube study with initial mixtures of toluene- $d_{8} / \mathrm{Ar}$ and neopentane/toluene- $d_{8} / \mathrm{Ar}$ mixtures. $\mathrm{D}$ and $\mathrm{H}$ atoms are monitored as function of time by ARAS. Investigation covered a temperature range from $1200-1460 \mathrm{~K}$ for neopentane/toluene, and from $1410-1730 \mathrm{~K}$ for toluene experiments at total pressures of about 3 bar. The authors recommend an isotope correction factor of 1.5 for the evaluation of $k_{\mathrm{H}}$ of channel (1). The estimated uncertainty for $k_{\mathrm{H}}, k_{\mathrm{D}}$ is about $\log k= \pm 0.2$.

(g) In an earlier shock tube study on toluene decomposition using light absorption by toluene and benzyl in the 200$350 \mathrm{~nm}$ range $^{12}$ rate constants were derived on the assumption that the benzyl radical exhibits sufficient thermal stability. The measurements were reinterpreted and superseded by experimental results on benzyl decomposition ${ }^{7}$. These experiments indicate an unexpectedly low thermal stability of the benzyl radical. With these results, from a reinterpretation of the experiments of Ref. 12 rate coefficients for channel (1) were derived for the density range (1-3)-10 $0^{-5} \mathrm{~mol} \mathrm{~cm}^{-3}$. The given Arrhenius expression in the present table corresponds to $1.05-10^{-5} \mathrm{~mol}$ $\mathrm{cm}^{-3}$.

(h) Shock tube study on high temperature pyrolysis of ethylbenzene with the laser schlieren technique. Rate expressions for channels (1) and (2) have been included in the reaction system by the authors and originate from their unpublished LS measurements of toluene pyrolysis.

(i) Two independent shock tube techniques (time-of-flight mass spectroscopy and laser schlieren densitometry) were used to investigate the high temperature pyrolysis of toluene in mixtures with $\mathrm{Kr}$ and $\mathrm{Ne}$, respectively. A rate coefficient for the formation of methyl and phenyl (channel (2)) was deduced at total pressures around 0.5 bar. A 
high pressure limiting rate coefficient of $1.2-10^{16} \exp$ $(-47505 / T) \mathrm{s}^{-1}$ has also been calculated for reaction pathway (2).

(j) The thermal decomposition of toluene has been reinvestigated in shock waves detecting toluene, benzyl, and benzyl fragment concentrations by UV absorption spectrometry. The results give evidence for toluene dissociation predominantly to benzyl radicals and $\mathrm{H}$ atoms (channel (1)). The derived thermally averaged rate coefficient for channel (1) is consistent with specific rate constants $k(E, J)$ from laser excitation experiments.

(k) Decomposition of toluene and nitrosobenzene highly diluted in argon behind reflected shock waves. The hydrogen atom formation was followed by ARAS. Nitrosobenzene served as thermal source of phenyl radicals in the separate study of the phenyl decomposition mechanism. The results for phenyl dissociation indicated that the main product channel is the $\mathrm{H}$ atom abstraction channel (1) and that the rate coefficient for channel (2) should not exceed $0.2-k_{1}$. The rate expression for channel (1) is in excellent agreement with the results of Brouwer et al..$^{10}$

(1) Thermal dissociation of high concentrations of toluene studied in reflected shock waves. Absorption signals mostly at $260 \mathrm{~nm}$, were recorded (see also Ref. 10). At this wavelength the absorption coefficient of the benzyl radical exceeds that of toluene by a factor of 100 , and very small conversions of toluene to benzyl can be detected. Density range $3-10^{-6}-2-10^{-4} \mathrm{~mol} \mathrm{~cm}^{-3}$. No dependence of the measured rate constant on total pressure observed. Allowing for the presence of some fall off in the data of Ref. 13, the authors evaluate from the present work and that of Ref. 13 a high pressure limiting rate constant for channel (1).

(m) Re-evaluation of earlier flow system results in the pressure range 2-22 Torr. The preferred parameters for reaction pathway (1) are obtained by accepting the rate constant of Ref. 6 and scaling the parameters to fit the thermodynamic enthalpy.

(n) See comment (f). The limiting high pressure rate constant for toluene decomposition (channel (1)) is derived from RRKM calculations and $k_{\mathrm{H}}=1.5-k_{\mathrm{D}}$

(o) See Comments on Preferred Values.

\section{Preferred Values}

$k_{1}=3.1-10^{15} \exp (-44890 / T) \mathrm{s}^{-1}$ over range $920-2200 \mathrm{~K}$.
Reliability

$\Delta \log k_{1}= \pm 0.5$ at $2200 \mathrm{~K}$ reducing to \pm 0.3 at $900 \mathrm{~K}$.

\section{Comments on Preferred Values}

The recommendations are unchanged from our previous evaluation. ${ }^{15}$ A large variety of studies on toluene pyrolysis exist in the lower temperature range, up to approximately $1000 \mathrm{~K}$, but most of these studies were conducted under experimental conditions in which bimolecular reactions of toluene leading to dibenzyl and other compounds dominate. The investigation of unimolecular decomposition of toluene becomes less difficult at temperatures above $900 \mathrm{~K}$. Most of the available data give evidence for the product channel (1) leading to benzyl radicals and hydrogen atoms. From some of the experiments, in conjunction with the calculated limiting high pressure rate coefficient, it can be deduced that the recommended Arrhenius expression, covering a density range of about $(1-3)-10^{-5} \mathrm{~mol} \mathrm{~cm}^{-3}$, is very close to the high pressure limit.

The experimental data for the second decomposition channel leading to phenyl and methyl radicals (channel (2)) are insufficient to permit recommendation of a rate expression. Thermochemical arguments together with the findings of some of the authors give evidence that the rate for this channel should not exceed 10 to $20 \%$ of the rate for channel (1) for $T$ $\leqslant 2000 \mathrm{~K}$.

\section{References}

'M. Swarc, J. Phys. Chem. 16, 128 (1948).

${ }^{2}$ M. Takahashi, Bull. Chem. Soc. Jpn. 33, 801 (1960).

${ }^{3}$ S.J. Price, Can J. Chem. 40, 1310 (1962).

${ }^{4}$ L.A. Errede and F. DeMaria, J. Phys. Chem. 66, 2664 (1964).

${ }^{5}$ C.T. Brooks, C.P.R. Cummings, and S.J. Peacock, Trans. Faraday Soc. 67, 3265 (1971).

${ }^{6}$ V.S. Rao and G.B. Skinner, J. Phys. Chem. 88, 4362 (1984).

'M. Mueller-Markgraf and J. Troe, 21 st Symp. (Int.) Combust., 875 (1986).

${ }^{8}$ L.J. Mizerka and J.H. Kiefer, Int. J. Chem. Kinet. 18, 363 (1986).

${ }^{9}$ K. Pamidimukkala, R.D. Kem, M.R. Patel, H.C. Wei, and J.H. Kiefer, J. Phys. Chem. 91, 2148 (1987).

${ }^{10} \mathrm{~L}$.D. Brouwer, M. Mueller-Markgraf, and J. Troe, J. Phys. Chem. 92, 4905 (1988).

"S.W. Benson and H.E. O'Neal, "Kinetic Data on Gas Phase Unimolecular Reactions", NSRDS-NBS, Washington (1970).

${ }^{12}$ D.C. Astholz, J. Durant, and J. Troe, 18th Symp. (Int.) Combust., 885 (1981).

${ }^{13}$ M. Braun-Unkhoff, P. Frank, and Th. Just, 22nd Symp. (Int.) Combust., 1053 (1989).

${ }^{14} \mathrm{H}$. Hippler, C. Keins, and J. I roe, Zeits. t. Phys. Chemie N.F. 167, I (1990).

${ }^{15} \mathrm{CEC}, 1992$ (see references in Introduction). 
TABLE 1. Evaluated rate data for some reactions of ethyl, i-propyl, and t-butyl radicals

\begin{tabular}{|c|c|c|c|c|}
\hline Reaction & $k / \mathrm{cm}^{3}$ molecule $\mathrm{e}^{-1} \mathrm{~s}^{-1}$ & $T / \mathrm{K}$ & $\pm \Delta \log k$ & Note \\
\hline \multicolumn{5}{|c|}{ Ethyl Radicals } \\
\hline $\mathrm{C}_{2} \mathrm{H}_{5}+\mathrm{M} \rightarrow \mathrm{C}_{2} \mathrm{H}_{4}+\mathrm{H}+\mathrm{M}$ & $k^{\infty}=8.2 \cdot 10^{13} \exp (-20070 / T) \mathrm{s}^{-1}$ & $700-1100$ & 0.3 & Al \\
\hline & $k^{0}=\left[\mathrm{C}_{2} \mathrm{H}_{5}\right] 1.71 \cdot 10^{-6} \exp (-16800 / T) \mathrm{s}^{-1}$ & $700-900$ & 0.3 & Al \\
\hline & $F_{\mathrm{c}}\left(\mathrm{C}_{2} \mathrm{H}_{6}\right)=0.25 \exp (-T / 97)+0.75 \exp (-T / 1379)$ & $700-1000$ & $\Delta F_{\mathrm{c}}= \pm 0.1$ & Al \\
\hline $\mathrm{C}_{2} \mathrm{H}_{5}+\mathrm{O}_{2} \rightarrow \mathrm{C}_{2} \mathrm{H}_{4}+\mathrm{HO}_{2}$ & $1.7 \cdot 10^{-14} \exp (+1100 / T)$ & $600-1200$ & 03 & A2 \\
\hline $\mathrm{C}_{2} \mathrm{H}_{5}+\mathrm{H}_{2} \rightarrow \mathrm{C}_{2} \mathrm{H}_{6}+\mathrm{H}$ & $5.1 \cdot 10^{-24} T^{3.6} \exp (-4250 / T)$ & $700-1200$ & $\begin{array}{l}0.2 \text { at } 700 \mathrm{~K} \text { rising to } \\
0.6 \text { at } 1200 \mathrm{~K}\end{array}$ & $\mathrm{~A} 3$ \\
\hline $\mathrm{C}_{2} \mathrm{H}_{5}+\mathrm{CH}_{3} \rightarrow \mathrm{C}_{2} \mathrm{H}_{4}+\mathrm{CH}_{4}$ & $1.9 \cdot 10^{-12}$ & $300-300$ & 0.4 & A4 \\
\hline$\rightarrow \mathrm{C}_{3} \mathrm{H}_{8}$ & $k^{\infty}=5.6 \cdot 10^{-11}$ & $300-800$ & 03 & A4 \\
\hline $\mathrm{C}_{2} \mathrm{H}_{5}+\mathrm{C}_{2} \mathrm{H}_{2} \rightarrow \mathrm{C}_{2} \mathrm{H}_{5} \mathrm{CH}=\mathrm{CH}$ & $5.6 \cdot 10^{-14} \exp (-3520 / 7)$ & $300-600$ & 0.5 & A5 \\
\hline $\mathrm{C}_{2} \mathrm{H}_{5}+\mathrm{C}_{2} \mathrm{H}_{4} \rightarrow n-\mathrm{C}_{4} \mathrm{H}_{9}$ & $1.8 \cdot 10^{-13} \exp (-3670 / T)$ & $300-600$ & 0.5 & A6 \\
\hline $\mathrm{C}_{2} \mathrm{H}_{5}+\mathrm{C}_{2} \mathrm{H}_{5} \rightarrow n-\mathrm{C}_{4} \mathrm{H}_{10}$ & $k^{\infty}=1.9 \cdot 10^{-11}$ & $300-1200$ & 0.3 & A7 \\
\hline$\rightarrow \mathrm{C}_{2} \mathrm{H}_{6}+\mathrm{C}_{2} \mathrm{H}_{4}$ & $2.4 \cdot 10^{-12}$ & $300-1200$ & 0.4 & A7 \\
\hline $\mathrm{C}_{2} \mathrm{H}_{5}+\mathrm{C}_{2} \mathrm{H}_{5} \mathrm{CHO} \rightarrow \mathrm{C}_{2} \mathrm{H}_{6}+\mathrm{C}_{2} \mathrm{H}_{5} \mathrm{CO}$ & $2.9 \cdot 10^{-13} \exp (-3660 / T)$ & $300-700$ & 0.3 & A8 \\
\hline $\mathrm{C}_{2} \mathrm{H}_{5}+\mathrm{C}_{3} \mathrm{H}_{5} \rightarrow \mathrm{CH}_{2}=\mathrm{C}=\mathrm{H}_{4}+\mathrm{C}_{2} \mathrm{H}_{6}$ & $1.6 \cdot 10^{-12} \exp (66 / T)$ & $500-1200$ & 0.3 & A9 \\
\hline$\rightarrow \mathrm{C}_{3} \mathrm{H}_{6}+\mathrm{C}_{2} \mathrm{H}_{4}$ & $4.3 \cdot 10^{-12} \exp (66 / T)$ & $500-1200$ & 0.4 & \\
\hline$\rightarrow \mathrm{CH}_{3} \mathrm{CH}_{2} \mathrm{CH}_{2} \mathrm{CHCH}_{2}$ & $k^{\infty}=3.3 \cdot 10^{-10} \exp (66 / T)$ & $500-1200$ & 0.4 & \\
\hline \multicolumn{5}{|c|}{ i-Propyl Radicals } \\
\hline $\mathrm{i}-\mathrm{C}_{3} \mathrm{H}_{7}+\mathrm{M} \rightarrow \mathrm{C}_{3} \mathrm{H}_{6}+\mathrm{H}+\mathrm{M}$ & $k^{\infty}=8.76 \cdot 10^{7} T^{1.76} \exp (-17870 / T) \mathrm{s}^{-1}$ & $170-1000$ & 0.3 & B1 \\
\hline & $k^{o}=[\mathrm{He}] 3.56 \cdot 10^{-7} \exp (-14200 / T) \mathrm{s}^{-1}$ & $750-830$ & 0.3 & B1 \\
\hline & $F_{\mathrm{c}}(\mathrm{He})=0.35$ & $750-830$ & $\Delta F_{\mathrm{c}}= \pm 0.1$ & B1 \\
\hline$i-\mathrm{C}_{3} \mathrm{H}_{7}+\mathrm{O}_{2} \rightarrow \mathrm{C}_{3} \mathrm{H}_{6}+\mathrm{HO}_{2}$ & $3.3 \cdot 10^{-14} \exp (+1290 / T)$ & $600-800$ & 0.5 & B2 \\
\hline$i-\mathrm{C}_{3} \mathrm{H}_{7}+\mathrm{H}_{2} \rightarrow \mathrm{C}_{3} \mathrm{H}_{8}+\mathrm{H}$ & $1.3 \cdot 10^{-23} T^{3.28} \exp (-4350 / T)$ & $300-1200$ & 05 & B3 \\
\hline$i-\mathrm{C}_{3} \mathrm{H}_{7}+\mathrm{C}_{2} \mathrm{H}_{2} \rightarrow\left(\mathrm{CH}_{3}\right)_{2} \mathrm{CHCH}=\mathrm{CH}$ & $5.3 \cdot 10^{-14} \exp (-3470 / T)$ & $300-600$ & 0.5 & B4 \\
\hline$i-\mathrm{C}_{3} \mathrm{H}_{7}+\mathrm{C}_{2} \mathrm{H}_{4} \rightarrow\left(\mathrm{CH}_{3}\right)_{2} \mathrm{CHCH}_{2} \mathrm{CH}_{2}$ & $7.5 \cdot 10^{-14} \exp (-3470 / T)$ & $300-600$ & 0.5 & B5 \\
\hline$i-\mathrm{C}_{3} \mathrm{H}_{7}+i-\mathrm{C}_{3} \mathrm{H}_{7} \rightarrow \mathrm{C}_{6} \mathrm{H}_{14}$ & $k^{\infty}=6.8 \cdot 10^{-12}$ & $300-1000$ & $\begin{array}{l}01 \text { at } 300 \mathrm{~K} \text { rising to } \\
0.3 \text { at } 1000 \mathrm{~K}\end{array}$ & B6 \\
\hline$\rightarrow \mathrm{C}_{3} \mathrm{H}_{8}+\mathrm{C}_{3} \mathrm{H}_{6}$ & $4.2 \cdot 10^{-12}$ & $300-1000$ & $\begin{array}{l}01 \text { at } 300 \mathrm{~K} \text { rising to } \\
0.5 \text { at } 1000 \mathrm{~K}\end{array}$ & B6 \\
\hline$\left.i-\mathrm{C}_{3} \mathrm{H}_{7}+i-\mathrm{C}_{3} \mathrm{H}_{7} \mathrm{CHO} \rightarrow \mathrm{C}_{3} \mathrm{H}_{8}+\left(\mathrm{CH}_{3}\right)_{2} \mathrm{CHCO}\right]$ & $6.6 \cdot 10^{-14} \exp (-3170 / T)$ & $300-650$ & 0.5 & $\mathrm{~B} 7$ \\
\hline \multicolumn{5}{|l|}{$\left.\rightarrow \mathrm{C}_{3} \mathrm{H}_{8}+\left(\mathrm{CH}_{3}\right)_{2} \mathrm{CCHO}\right\rfloor$} \\
\hline$\rightarrow \mathrm{C}_{3} \mathrm{H}_{8}+\mathrm{CH}_{2} \mathrm{CH}\left(\mathrm{CH}_{3}\right) \mathrm{CHO}$ & $5.3 \cdot 10^{-14} \exp (-4780 / T)$ & $500-550$ & 0.5 & B7 \\
\hline \multicolumn{5}{|c|}{ t-Butyl Radicals } \\
\hline$t-\mathrm{C}_{4} \mathrm{H}_{9}+\mathrm{M} \rightarrow i-\mathrm{C}_{4} \mathrm{H}_{8}+\mathrm{H}+\mathrm{M}$ & $k^{\alpha}=8.3 \cdot 10^{13} \exp (-19200 / T) \mathrm{s}^{-1}$ & $300-800$ & 0.5 & $\mathrm{Cl}$ \\
\hline$t-\mathrm{C}_{4} \mathrm{H}_{9}+\mathrm{O}_{2} \rightarrow i-\mathrm{C}_{4} \mathrm{H}_{8}+\mathrm{HO}_{2}$ & $5 \cdot 10^{-14} \exp (+2115 / T)$ & $600-300$ & 0.5 & $\mathrm{C} 2$ \\
\hline$t-\mathrm{C}_{4} \mathrm{H}_{9}+\mathrm{H}_{2} \rightarrow i-\mathrm{C}_{4} \mathrm{H}_{10}+\mathrm{H}$ & $3.1 \cdot 10^{-26} T^{4.24} \exp (-4510 / T)$ & $300-1200$ & 0.5 & $\mathrm{C3}$ \\
\hline$t-\mathrm{C}_{4} \mathrm{H}_{9}+\mathrm{C}_{2} \mathrm{H}_{2} \rightarrow\left(\mathrm{CH}_{3}\right)_{3} \mathrm{CCH}=\mathrm{CH}$ & $1.2 \cdot 10^{-13} \exp (-4320 / T)$ & $300-600$ & 0.5 & $\mathrm{C} 4$ \\
\hline$t-\mathrm{C}_{4} \mathrm{H}_{9}+\mathrm{C}_{2} \mathrm{H}_{4} \rightarrow\left(\mathrm{CH}_{3}\right)_{3} \mathrm{CCH}_{2} \mathrm{CH}_{2}$ & $3.3 \cdot 10^{-14} \exp (-4020 / T)$ & $300-650$ & 0.5 & $\mathrm{C} 5$ \\
\hline$t-\mathrm{C}_{4} \mathrm{H}_{9}+t-\mathrm{C}_{4} \mathrm{H}_{9} \rightarrow \mathrm{C}_{8} \mathrm{H}_{38}$ & $k^{\infty}=5.2 \cdot 10^{-8} \mathrm{~T}^{-1.73}$ & $300-1000$ & $\begin{array}{l}0.15 \text { at } 300 \mathrm{~K} \text { rising to } \\
0.3 \text { at } 1000 \mathrm{~K}\end{array}$ & $\mathrm{C} 6$ \\
\hline$\rightarrow i-\mathrm{C}_{4} \mathrm{H}_{10}+i-\mathrm{C}_{4} \mathrm{H}_{8}$ & $1.2 \cdot 10^{-7} \mathrm{~T}^{-1.73}$ & $300-1000$ & $\begin{array}{l}0.15 \text { at } 300 \mathrm{~K} \text { rising to } \\
0.5 \text { at } 1000 \mathrm{~K}\end{array}$ & $\mathrm{C} 6$ \\
\hline
\end{tabular}


TABLE :. Evaluated rate data for some reactions of ethyl, i-propyl, and t-butyl adicals - Continued

\begin{tabular}{|c|c|c|c|c|}
\hline Reaction & $k / \mathrm{cm}^{3}$ molecule $^{-1} \mathrm{~s}^{-1}$ & $T / \mathrm{K}$ & $\pm \Delta \log k$ & Note \\
\hline \multicolumn{5}{|c|}{$t$-Butyl Radicals - Continued } \\
\hline $\begin{aligned} t-\mathrm{C}_{4} \mathrm{H}_{9}+t-\mathrm{C}_{4} \mathrm{H}_{9} \mathrm{CHO} & \rightarrow i-\mathrm{C}_{4} \mathrm{H}_{10}+t-\mathrm{C}_{4} \mathrm{H}_{9} \mathrm{CO} \\
& \rightarrow i-\mathrm{C}_{4} \mathrm{H}_{10}+\mathrm{CH}_{2} \mathrm{C}\left(\mathrm{CH}_{3}\right)_{2} \mathrm{CHO}\end{aligned}$ & $\begin{array}{l}1.0 \cdot 10^{-14} \exp (-3200 / T) \\
3.9 \cdot 10^{-14} \exp (-5540 / T)\end{array}$ & $\begin{array}{l}300-700 \\
500-700\end{array}$ & $\begin{array}{l}0.5 \\
0.5\end{array}$ & $\begin{array}{l}\mathrm{C} 7 \\
\mathrm{C} 7\end{array}$ \\
\hline
\end{tabular}


A1. $\mathrm{C}_{2} \mathrm{H}_{5}+\mathrm{M}$. See separate data sheet for a discussion of this reaction.

A2. $\mathrm{C}_{2} \mathrm{H}_{5}+\mathrm{O}_{2}$. See separate data sheet for a discussion of this reaction.

A3. $\mathrm{C}_{7} \mathrm{H}_{5}+\mathrm{H}_{3}$. The available literature data have recently been reviewed by Tsang $^{1}$, and we have adopted his recommendation here.

A4. $\mathrm{C}_{2} \mathrm{H}_{5}+\mathrm{CH}_{3}$. See separate data for the reaction $\mathrm{CH}_{3}$ $+\mathrm{C}_{2} \mathrm{H}_{5}$.

A5. $\mathrm{C}_{2} \mathrm{H}_{5}+\mathrm{C}_{2} \mathrm{H}_{2}$. For the addition reaction we have recommended the rate expression given by Kerr and Parsonage ${ }^{4}$, with adjustment to allow for the change in $k$ of the reference reaction, $k\left(\mathrm{C}_{2} \mathrm{H}_{5}+\mathrm{C}_{2} \mathrm{H}_{5} \rightarrow\right.$ $n-\mathrm{C}_{4} \mathrm{H}_{10}$ ) $=1.9 \cdot 10^{-11} \mathrm{~cm}^{3}$ molecule ${ }^{-1} \mathrm{~s}^{-1}$ (see Note A7).

A6. $\mathrm{C}_{2} \mathrm{H}_{5}+\mathrm{C}_{2} \mathrm{H}_{4}$. For the addition reaction we have recommended the rate expression given by Kerr and Parsonage ${ }^{4}$, with adjustment to allow for the change in $k$ of the reference reaction, $k\left(\mathrm{C}_{2} \mathrm{H}_{5}+\mathrm{C}_{2} \mathrm{H}_{5} \rightarrow\right.$ $\left.n-\mathrm{C}_{4} \mathrm{H}_{10}\right)=1.9 \cdot 10^{-11} \mathrm{~cm}^{3}$ molecule ${ }^{-1} \mathrm{~s}^{-1}$ (see Note A7).

A7. $\mathrm{C}_{2} \mathrm{H}_{5}+\mathrm{C}_{2} \mathrm{H}_{5}$. See separate data sheet for a discussion of this reaction.

A8. $\mathrm{C}_{2} \mathrm{H}_{5}+\mathrm{C}_{2} \mathrm{H}_{5} \mathrm{CHO}$. The available literature data have been evaluated by McAdam and Walker ${ }^{5}$ and we have adopted their recommendation, with adjustment to allow for the change in $k$ of the reference reaction, $k\left(\mathrm{C}_{2} \mathrm{H}_{5}+\mathrm{C}_{2} \mathrm{H}_{5} \rightarrow \mathrm{n}-\mathrm{C}_{4} \mathrm{H}_{10}\right)=1.9 \cdot 10^{-11} \mathrm{~cm}^{3}$ molecule ${ }^{-1} \mathrm{~s}^{-1}$ (see Note A7).

A9. Only disproportion/combination ratios are available $^{22}$ for this reaction. We accept Tsang's ${ }^{23}$ recommendations for the various paths and the RRKM calculations for fall-off.

B1. $\quad i-\mathrm{C}_{3} \mathrm{H}_{7}+\mathrm{M}$. Taken from the recent direct study of Seakins et al..$^{6}$ using laser flash photolysis coupled with photoionisation mass spectrometry; rate expressions derived from a transition state model including literature data ${ }^{7-11}$ for the forward and reverse reactions.

B2. $i-\mathrm{C}_{3} \mathrm{H}_{7}+\mathrm{O}_{2}$. Calculated from the ratio $k\left(i-\mathrm{C}_{3} \mathrm{H}_{7}+\right.$ $\left.i-\mathrm{C}_{3} \mathrm{H}_{7} \mathrm{CHO} \rightarrow \mathrm{C}_{3} \mathrm{H}_{8}+\mathrm{C}_{4} \mathrm{H}_{7} \mathrm{O}\right) / k\left(\mathrm{i}-\mathrm{C}_{3} \mathrm{H}_{7}+\mathrm{O}_{2} \rightarrow\right.$ $\left.\mathrm{C}_{3} \mathrm{H}_{6}+\mathrm{HO}_{2}\right)=2.57 \exp (-4580 / T)$, as determined by Gulati and Walker ${ }^{12}$ over the temperature range $653-773 \mathrm{~K}$, from measurements of the yields of $\mathrm{C}_{3} \mathrm{H}_{8}$ and $\mathrm{C}_{3} \mathrm{H}_{6}$ in the oxidation of $\mathrm{i}-\mathrm{C}_{3} \mathrm{H}_{7} \mathrm{CHO}$. Recommended $k$ based on $k\left(i-\mathrm{C}_{3} \mathrm{H}_{7}+i-\mathrm{C}_{3} \mathrm{H}_{7} \mathrm{CHO} \rightarrow\right.$ $\left.\mathrm{C}_{3} \mathrm{H}_{8}+\mathrm{C}_{4} \mathrm{H}_{7} \mathrm{O}\right)=8.47 \cdot 10^{-14} \exp (-3290 / \mathrm{T}) \mathrm{cm}^{3}$ molecule ${ }^{-1} \mathrm{~s}^{-1}$, as calculated for the temperature range $653-773 \mathrm{~K}$ from the data of Kerr and TrotmanDickenson $^{18}$ (see Note B7).

B3. $i-\mathrm{C}_{3} \mathrm{H}_{7}+\mathrm{H}_{2}$. The only experimental data for this reaction were measured at $713 \mathrm{~K}$, where the ratio $k\left(i-\mathrm{C}_{3} \mathrm{H}_{7}+\mathrm{O}_{2} \rightarrow \mathrm{C}_{3} \mathrm{H}_{6}+\mathrm{HO}_{2}\right) / k\left(i-\mathrm{C}_{3} \mathrm{H}_{7}+\mathrm{H}_{2} \rightarrow\right.$ $\left.\mathrm{C}_{3} \mathrm{H}_{8}+\mathrm{H}\right)=3.06 \cdot 10^{3}$ has been determined by Baldwin et al ${ }^{13}$ from measurements of the yields of $\mathrm{C}_{3} \mathrm{H}_{8}$ and $\mathrm{C}_{3} \mathrm{H}_{6}$ in the oxidation of $i-\mathrm{C}_{3} \mathrm{H}_{7} \mathrm{CHO}$ in the presence of added $\mathrm{H}_{2}$. This yields $k=6.5 \cdot 10^{-17} \mathrm{~cm}^{3}$ molecule $\mathrm{s}^{-1}$ based on $k\left(i-\mathrm{C}_{3} \mathrm{H}_{7}+\mathrm{O}_{2} \rightarrow \mathrm{C}_{3} \mathrm{H}_{6}+\right.$ $\mathrm{HO}_{2}$ ) $=2.0 \cdot 10^{-13} \mathrm{~cm}^{3}$ molecule ${ }^{-1} \mathrm{~s}^{-1}$ at $713 \mathrm{~K}$ (see Note B2). To obtain a temperature dependence of $k$, we have taken the recommendation of $\mathrm{Tsang}^{2}, k=$ $5.8 \cdot 10^{-23} T^{3.28} \exp (-4363 / T) \quad \mathrm{cm}^{3}$ molecule ${ }^{-1} \mathrm{~s}^{-1}$ (based on his evaluated data for the reverse reaction and the equilibrium constant) and adjusted the preexponential factor to fit the above value of $k$ at $713 \mathrm{~K}$.

B4. $i-\mathrm{C}_{3} \mathrm{H}_{7}+\mathrm{C}_{2} \mathrm{H}_{2}$. For the addition reaction we have recommended the rate expression given by Kerr and Parsonage ${ }^{4}$, with adjustment to allow for the change in $k$ of the reference reaction, $k\left(i-\mathrm{C}_{3} \mathrm{H}_{7}+i-\mathrm{C}_{3} \mathrm{H}_{7} \rightarrow\right.$ $\left.\mathrm{C}_{6} \mathrm{H}_{14}\right)=6.8 \cdot 10^{-12} \mathrm{~cm}^{3}$ molecule ${ }^{-1} \mathrm{~s}^{-1}$ (see Note B6).

B5. $i-\mathrm{C}_{3} \mathrm{H}_{7}+\mathrm{C}_{3} \mathrm{H}_{4}$. For the addition reaction we have recommended the rate expression as evaluated by Kerr and Parsonage ${ }^{4}$, with allowance for the change in $k$ of the reference reaction, $k\left(i-\mathrm{C}_{3} \mathrm{H}_{7}+i-\mathrm{C}_{3} \mathrm{H}_{7} \rightarrow\right.$ $\left.\mathrm{C}_{6} \mathrm{H}_{14}\right)=6.8 \cdot 10^{-12} \mathrm{~cm}^{3}$ molecule ${ }^{-1} \mathrm{~s}^{-1}$ (see Note B6).

B6. $i-\mathrm{C}_{3} \mathrm{H}_{7}+i-\mathrm{C}_{3} \mathrm{H}_{7}$. There is good agreement on the room temperature total rate coefficient of the combination reaction $\left(k_{\mathrm{c}}\right)$ plus the disproportionation reaction $\left(k_{\mathrm{d}}\right)$ as measured by molecular modulation studies $^{14}$. The preferred value is the mean of the results of Anastasi and Arthur ${ }^{14}$, Parkes and Quinn ${ }^{15}$, and Arrowsmith and Kirsch ${ }^{16}$, i.e. $k_{\mathrm{c}}+k_{\mathrm{d}}=1.1 \cdot 10^{-11} \mathrm{~cm}^{3}$ molecule ${ }^{-1} \mathrm{~s}^{-1}$. The recommended values of $k_{\mathrm{c}}$ and $k_{\mathrm{d}}$ were then derived from the ratio $k_{\mathrm{d}} / k_{\mathrm{c}}=0.62$ at room temperature ${ }^{14}$. The value of $k_{c}=5 \cdot 10^{-12} \mathrm{~cm}^{3}$ molecule $\mathrm{e}^{-1} \mathrm{~s}^{-1}$, over the temperature range 683 $808 \mathrm{~K}$ from very-low-pressure-pyrolysis studies ${ }^{17}$, is in good agreement with the molecular modulation studies.

B7. $i-\mathrm{C}_{3} \mathrm{H}_{7}+i-\mathrm{C}_{3} \mathrm{H}_{7} \mathrm{CHO}$. The preferred data are from the study of Kerr and Trotman-Dickenson ${ }^{18}$, with allowance for the change in the $k$ of the reference reaction, $k\left(i-\mathrm{C}_{3} \mathrm{H}_{7}+i-\mathrm{C}_{3} \mathrm{H}_{7} \rightarrow \mathrm{C}_{6} \mathrm{H}_{14}\right)=6.8 \cdot 10^{-12}$ $\mathrm{cm}^{3}$ molecule $\mathrm{s}^{-1}$ (see Note $\mathrm{B} 6$ ).

C1. $t-\mathrm{C}_{4} \mathrm{H}_{9}+\mathrm{M}$. The available literature data have recently been reviewed by Tsang $^{3}$ and we have adopted his recommendations here.

C2. $t-\mathrm{C}_{4} \mathrm{H}_{9}+\mathrm{O}_{2}$. The rate coefficient at $753 \mathrm{~K}, k=$ $8.3 \cdot 10^{-13} \mathrm{~cm}^{3}$ molecule ${ }^{-1} \mathrm{~s}^{-1}$ was calculated from the ratio $k\left(t-\mathrm{C}_{4} \mathrm{H}_{9}+\mathrm{O}_{2} \rightarrow i-\mathrm{C}_{4} \mathrm{H}_{8}+\mathrm{HO}_{2}\right) / k\left(\mathrm{t}-\mathrm{C}_{4} \mathrm{H}_{9}+\mathrm{H}_{2}\right.$ $\left.\rightarrow i-\mathrm{C}_{4} \mathrm{H}_{10}+\mathrm{H}\right)=6.89 \cdot 10^{3}$ at $753 \mathrm{~K}$, as determined by Evans and Walker ${ }^{19}$, from measurements of yields of $i-\mathrm{C}_{4} \mathrm{H}_{8}$ and $i-\mathrm{C}_{4} \mathrm{H}_{10}$ in the decomposition of $2,2,3,3$,-tetramethylbutane in the presence of $\mathrm{O}_{2}$ and $\mathrm{H}_{2}$, by taking $k\left(t-\mathrm{C}_{4} \mathrm{H}_{9}+\mathrm{H}_{2} \rightarrow i-\mathrm{C}_{4} \mathrm{H}_{10}+\mathrm{H}\right)=$ $1.1 \cdot 10^{-16} \mathrm{~cm}^{3}$ molecule $\mathrm{s}^{-1} \mathrm{~s}^{-1}$ at $753 \mathrm{~K}$ (see Note $\mathrm{C} 3$ ). The temperature coefficient of $k$ was then obtained by assuming the recommended value of $\mathrm{A}=5 \cdot 10^{-14}$ $\mathrm{cm}^{3}$ molecule ${ }^{-1} \mathrm{~s}^{-1}$, based on the analogous reactions of $\mathrm{C}_{2} \mathrm{H}_{5}$ and $i-\mathrm{C}_{3} \mathrm{H}_{7}$.

C3. $t-\mathrm{C}_{4} \mathrm{H}_{9}+\mathrm{H}_{2}$. There are no experimental data on the rate coefficient of this reaction, but we have accepted the recommendation of $\mathrm{Tsang}^{3}$, which is based on 
reliable data for the reverse reaction $k\left(\mathrm{H}+i-\mathrm{C}_{4} \mathrm{H}_{10}\right)$ together with thermochemical data which now appears to be established.

C4. $t-\mathrm{C}_{4} \mathrm{H}_{9}+\mathrm{C}_{2} \mathrm{H}_{2}$. We have accepted the evaluation of Kerr and Parsonage ${ }^{4}$ on the addition reaction, with adjustment of the ratc cocfficient of the reference reaction, $k\left(t-\mathrm{C}_{4} \mathrm{H}_{9}+t-\mathrm{C}_{4} \mathrm{H}_{9} \rightarrow \mathrm{C}_{8} \mathrm{H}_{18}\right)=2.7 \cdot 10^{-12}$ $(T / 300)^{-1.73} \mathrm{~cm}^{3}$ molecule ${ }^{-1} \mathrm{~s}^{-1}$ (see Note C6).

C5. $t-\mathrm{C}_{4} \mathrm{H}_{9}+\mathrm{C}_{2} \mathrm{H}_{4}$. We have accepted the evaluation of Kerr and Parsonage ${ }^{4}$ on the addition reaction, with adjustment of the rate coefficient of the reference reaction, $k\left(\mathrm{t}-\mathrm{C}_{4} \mathrm{H}_{9}+\mathrm{t}-\mathrm{C}_{4} \mathrm{H}_{9} \rightarrow \mathrm{C}_{8} \mathrm{H}_{18}\right)=2.7 \cdot 10^{-12}$ $(T / 300)^{-1.73} \mathrm{~cm}^{3}$ molecule $\mathrm{s}^{-1}$ (see Note $\mathrm{C} 6$ ).

C6. $t-\mathrm{C}_{4} \mathrm{H}_{9}+t-\mathrm{C}_{4} \mathrm{H}_{9}$. There is good agreement on the room temperature rate coefficient of the combination reaction $\left(k_{c}\right)$, as measured by molecular modulation studies. The preferred data are from the evaluation of all the experimental data by Arthur ${ }^{20}$, which differs slightly from the recommendation of $\mathrm{Ts}_{\text {sang }}{ }^{3}$, based on the earlier data of Parkes and Quinn ${ }^{15}$. The rate coefficient of the disproportionation reaction $\left(k_{\mathrm{d}}\right)$ has been calculated from the ratio $k_{\mathrm{d}} / k_{\mathrm{c}}=2.3$ at room temperature ${ }^{20}$.

C7. $t-\mathrm{C}_{4} \mathrm{H}_{9}+\mathrm{t}-\mathrm{C}_{4} \mathrm{H}_{9} \mathrm{CHO}$. The preferred data are from the study of Birrell and Trotman-Dickenson ${ }^{21}$, with allowance for the change in the $k$ of the reference reaction, $k\left(\mathrm{t}-\mathrm{C}_{4} \mathrm{H}_{9}+\mathrm{t}-\mathrm{C}_{4} \mathrm{H}_{9} \rightarrow \mathrm{C}_{8} \mathrm{H}_{18}\right)=2.7 \cdot 10^{-12}$ $(T / 300)^{-1.73} \mathrm{~cm}^{3}$ molecule ${ }^{-1} \mathrm{~s}^{-1}$ (see Note C6). For the reaction $t-\mathrm{C}_{4} \mathrm{H}_{9}+t-\mathrm{C}_{4} \mathrm{H}_{9} \mathrm{CHO} \rightarrow i-\mathrm{C}_{4} \mathrm{H}_{10}+t$ $\mathrm{C}_{4} \mathrm{H}_{9} \mathrm{CO}$, the data of Birrell and Trotman-Dickenson $^{21}$ yield the value $k=1.9 \cdot 10^{-15} \exp (-2540 / T) \mathrm{cm}^{3}$ molecule ${ }^{-1} \mathrm{~s}^{-1}$, which would appear to be a serious underestimation of the Arrhenius parameters, in relation to data for analogous reactions, $\mathrm{R}+\mathrm{RCHO} \rightarrow$ $\mathrm{RH}+\mathrm{RCO}$. Accordingly, we have calculated the preferred rate equation from the experimental value of $k$ at $550 \mathrm{~K}$ and an assumed value of $A=1.0 \cdot 10^{-14}$ $\mathrm{cm}^{3}$ molecule $\mathrm{s}^{-1}$.

\section{References}

${ }^{I}$ W. Tsang, J. Phys. Chem. Ref. Data, 15, 1087 (1986).

${ }^{2}$ W. Tsang, J. Phys. Chem. Ref. Data 17, 887 (1988).

${ }^{3}$ W. Tsang, J. Phys. Chem. Ref. Data 19, 1 (1990).

${ }^{4} J . A$. Kerr and M.J. Parsonage, "Evaluated Kinetic Data on Gas Phase Addition Reactions", Butterworths, London (1972).

${ }^{5}$ K.G. McAdam and R.W. Walker, J. Chem. Soc., Faraday Trans. 2, 83, 1509 (1987).

${ }^{6}$ P.W. Seakins, S.H. Robertson, M.J. Pilling, I.R. Slagle, G.W. Gmutczyk, -Bencsura, D. Gutman, and W. Tsang, J. Phys. Chem. (in press).

${ }^{7}$ R.A. Back and S. Takamuku, J. Am. Chem. Soc. 86, 2558 (1964).

${ }^{8}$ M.M. Papic and K.J. Laidler, Can. J. Chem. 49, 549 (1971).

${ }^{9}$ M. Kurylo, N.C. Peterson, and W. Braun. J. Chem. Phys. 54. 4662 (1971).

${ }^{10}$ G.W. Harris and J.N. Pitts, Jr., J. Chem. Phys. 77, 3994 (1982).

${ }^{11}$ T. Watanabe, T. Kyogoku, S. Tsunashima, S. Sato, and S. Nagase, Bull. Chem. Soc. Jpn. 55, 3720 (1982).

${ }^{12}$ S.K. Gulati and R.W. Walker. J. Chem. Soc., Faraday Trans. 2, 84, 401 (1988).

${ }^{13}$ R.R. Baldwin, C.J. Cleugh, and R.W. Walker, J. Chem. Soc., Faraday Trans. 172,175 (1976).

${ }^{14}$ C. Anastasi and N.L. Arthur, J. Chem. Soc., Faraday Trans. 2 83, 277 (1987).

${ }^{15}$ D.A. Parkes and C.P. Quinn, J. Chem. Soc., Faraday Trans. 1 72, 1952 (1976).

${ }^{16}$ P. Arrowsmith and L.J. Kirsch, J. Chem. Soc., Faraday Trans. 1 74, 3016 (1978).

${ }^{17}$ D.M. Golden, L.W. Pisciewicz, M.J. Perona, and P.C. Beadle, J. Am. Chem. Soc. 96, 1645 (1974).

${ }^{18}$ J.A. Kerr and A.F. Trotman-Dickenson, Trans. Faraday Soc. 55, 921 (1959).

${ }^{19}$ G.A. Evans and R.W. Walker, J. Chem. Soc., Faraday Trans. 1 79, 1458 (1979).

${ }^{20}$ N.L. Arthur, J. Chem. Soc., Faraday Trans. 2 83, 1057 (1986).

${ }^{21}$ R.N. Birrell and A.F. Trotman-Dickenson, J. Chem. Soc. 4218 (1960).

${ }^{22}$ D.G.L. James and G.E. Troughton, Trans. Faraday Soc. 62, 145 (1966).

${ }^{23}$ W. Tsang, J. Phys. Chem. Ref. Data 20, 221 (1991). 
TARLE 2. Evaluated rate data for some reactions of allyl radicals

\begin{tabular}{|c|c|c|c|c|}
\hline Reaction & $\mathrm{k} / \mathrm{cm}^{3}$ molecule $\mathrm{e}^{-1} \mathrm{~s}^{-1}$ & $T / \mathrm{K}$ & $\pm \Delta \log k$ & Note \\
\hline $\mathrm{C}_{3} \mathrm{H}_{5}+\mathrm{M} \rightarrow \mathrm{CH}_{2}=\mathrm{C}=\mathrm{CH}_{2}+\mathrm{H}+\mathrm{M}$ & $k^{\infty}=1.5 \cdot 10^{11} T^{0.84} \exp (-30050 / T) \mathrm{s}^{-1}$ & $800-1500$ & 0.3 & Al \\
\hline $\mathrm{C}_{3} \mathrm{H}_{5}+\mathrm{O}_{2} \rightarrow \mathrm{CH}_{2}=\mathrm{C}=\mathrm{CH}_{2}+\mathrm{HO}_{2}$ & $1.7 \cdot 10^{-12} \exp (-11400 T)$ & $600-1200$ & $\begin{array}{l}0.3 \text { at } 600 \text { rising to } \\
0.5 \text { at } 1200 \mathrm{~K}\end{array}$ & $\mathrm{~A} 2$ \\
\hline$\rightarrow \mathrm{CO}+$ products & $7.6 \cdot 10^{-12} \exp (-9450 / T)$ & $600-1200$ & 0.3 & \\
\hline $\mathrm{C}_{3} \mathrm{H}_{5}+\mathrm{H}_{2} \rightarrow \mathrm{C}_{3} \mathrm{H}_{6}+\mathrm{H}$ & $1.8 \cdot 10^{-19} T^{2.4} \exp (-9550 / T)$ & $300-1100$ & $\begin{array}{l}0.7 \text { at } 300 \mathrm{~K} \text { reducing to } \\
0.3 \text { at } 1100 \mathrm{~K}\end{array}$ & $\mathrm{~A} 3$ \\
\hline $\mathrm{C}_{3} \mathrm{H}_{5}+\mathrm{CH}_{4} \rightarrow \mathrm{C}_{3} \mathrm{H}_{6}+\mathrm{CH}_{3}$ & $6.6 \cdot 10^{-23} T^{3.4} \exp (-11670 / T)$ & $300-1200$ & 0.4 & A4 \\
\hline $\mathrm{C}_{3} \mathrm{H}_{5}+\mathrm{C}_{2} \mathrm{H}_{6} \rightarrow \mathrm{C}_{3} \mathrm{H}_{6}+\mathrm{C}_{2} \mathrm{H}_{5}$ & $3.9 \cdot 10^{-22} T^{3.3} \exp (-9990 / T)$ & $300-1200$ & 0.4 & A5 \\
\hline $\mathrm{C}_{3} \mathrm{H}_{5}+\mathrm{C}_{3} \mathrm{H}_{8} \rightarrow \mathrm{C}_{3} \mathrm{H}_{6}+\mathrm{CH}_{3} \mathrm{CH}_{2} \mathrm{CH}_{2}$ (a) & $3.9 \cdot 10^{-22} T^{3.3} \exp (-9990 / T)$ & $300-1200$ & 0.4 over the range 600 to & A6 \\
\hline$\rightarrow \mathrm{C}_{3} \mathrm{H}_{6}+\mathrm{CH}_{3} \mathrm{CHCH}_{3}$ (b) & $1.3 \cdot 10^{-22} T^{3.3} \exp (-8660 / T)$ & $300-1200$ & $\begin{array}{l}1000 \mathrm{~K} \text { rising to } 0.7 \text { at other } \\
\text { temperatures. }\end{array}$ & \\
\hline $\mathrm{C}_{3} \mathrm{H}_{5}+i-\mathrm{C}_{4} \mathrm{H}_{1 \mathrm{C}} \rightarrow \mathrm{C}_{3} \mathrm{H}_{6}+\left(\mathrm{CH}_{3}\right)_{2} \mathrm{CHCH}_{2}$ (a) & $5.9 \cdot 10^{-22} T^{3.3} \exp (-9990 / T)$ & $300-1200$ & 0.4 over the range 600 to & A7 \\
\hline$\rightarrow \mathrm{C}_{3} \mathrm{H}_{6}+\left(\mathrm{CH}_{3}\right)_{3} \mathrm{C}(\mathrm{b})$ & $0.7 \cdot 10^{-22} T^{3.3 .3} \exp (-7800 / T)$ & $300-1200$ & $\begin{array}{l}1000 \mathrm{~K} \text { rising to } 0.7 \text { at other } \\
\text { temperatures. }\end{array}$ & \\
\hline $\mathrm{C}_{3} \mathrm{H}_{5}+\mathrm{HCHO} \rightarrow \mathrm{C}_{3} \mathrm{H}_{6}+\mathrm{HCO}$ & $1.2 \cdot 10^{-16} T^{1.8} \exp (-9155 / T)$ & $300-1000$ & 0.4 & A8 \\
\hline $\mathrm{C}_{3} \mathrm{H}_{5}+\mathrm{C}_{6} \mathrm{H}_{5} \mathrm{CH}_{3} \rightarrow \mathrm{C}_{3} \mathrm{H}_{6}+\mathrm{C}_{6} \mathrm{H}_{5} \mathrm{CH}_{2}$ & $3.3 \cdot 10^{-12} \exp (-8660 / 7)$ & $600-1000$ & 0.4 & A9 \\
\hline $\mathrm{C}_{3} \mathrm{H}_{5}+\mathrm{C}_{2} \mathrm{H}_{4} \rightarrow \mathrm{C}_{3} \mathrm{H}_{6}+\mathrm{C}_{2} \mathrm{H}_{3}$ (a) & $6.6 \cdot 10^{-23} T^{3.4} \exp (-13120 / T)$ & $600-1200$ & 0.5 & A 10 \\
\hline$\rightarrow c-\mathrm{C}_{5} \mathrm{H}_{8}+\mathrm{H}(\mathrm{b})$ & $1.0 \cdot 10^{-13} \exp (-9620 / 7)$ & $600-1200$ & 0.7 & \\
\hline $\mathrm{C}_{3} \mathrm{H}_{5}+2-\mathrm{C}_{4} \mathrm{H}_{8} \rightarrow \mathrm{C}_{3} \mathrm{H}_{6}+\mathrm{CH}_{2} \mathrm{CHCHCH}_{3}$ (a) & $6.6 \cdot 10^{-12} \exp (-8180 / T)$ & $600-1000$ & 0.5 & All \\
\hline $\begin{aligned} \rightarrow \mathrm{C}_{3} \mathrm{H}_{6}+\mathrm{CH}_{3} \mathrm{C}=\mathrm{CHCH}_{3} \text { (b) }\end{aligned}$ & $3.3 \cdot 10^{-23} T^{3.4} \exp (-12160 / T)$ & $600-1000$ & 0.5 & \\
\hline$\rightarrow \mathrm{CH}_{2}=\mathrm{CHCH}_{2} \mathrm{CH}\left(\mathrm{CH}_{3}\right) \mathrm{CHCH}_{3}(\mathrm{ci}$ & $k_{c}^{\infty}=1.0 \cdot 10^{-13} \exp (-9620 / T)$ & $600-1200$ & 0.7 & \\
\hline $\mathrm{C}_{3} \mathrm{H}_{5}+\mathrm{H} \rightarrow \mathrm{C}_{3} \mathrm{H}_{6}$ (a) & $\left(k_{\mathrm{a}}^{\infty}+k_{b}\right)=2.8 \cdot 10^{-10}$ & $300-1000$ & 0.2 at $300 \mathrm{~K}$ rising to & $\mathrm{A} 12$ \\
\hline$\rightarrow \mathrm{C}_{2} \mathrm{H}_{3}+\mathrm{CH}_{3}(b)$ & & & 0.5 at $1000 \mathrm{~K}$ & \\
\hline$\rightarrow \mathrm{C}_{3} \mathrm{H}_{4}+\mathrm{H}_{2}(\mathrm{c})$ & $k_{\mathrm{c}}=3 \cdot 10^{-11}$ & $300-1000$ & 0.5 & \\
\hline $\mathrm{C}_{3} \mathrm{H}_{5}+\mathrm{O} \rightarrow \mathrm{H}+\mathrm{CH}_{2}=\mathrm{CHCHO}$ (a) & $3.0 \cdot 10^{-10}$ & $300-1000$ & 0.2 over the range 300 to & A13 \\
\hline$\rightarrow \mathrm{C}_{2} \mathrm{H}_{3}+\mathrm{HCHO}(b)$ & $<3 \cdot 10^{-11}$ & & $\begin{array}{l}600 \mathrm{~K} \text { and } 0.4 \text { over the range } \\
600 \text { to } 1000 \mathrm{~K} \text {. }\end{array}$ & \\
\hline $\mathrm{C}_{3} \mathrm{H}_{5}+\mathrm{OH} \rightarrow \mathrm{C}_{3} \mathrm{H}_{4}+\mathrm{H}_{2} \mathrm{O}$ (a) & $k_{\mathrm{a}}=1.0 \cdot 10^{-11}$ & $300-1000$ & 0.5 & A14 \\
\hline$\rightarrow \mathrm{CH}_{2}=\mathrm{CHCH}_{2} \mathrm{OH}(\mathrm{b})$ & $\left(k_{\mathrm{b}}^{\infty}+k_{\mathrm{c}}\right)=2.5 \cdot 10^{-11}$ & $300-1000$ & 0.3 & \\
\hline$\rightarrow \mathrm{CH}_{2}=\mathrm{CHCHO}+2 \mathrm{H}(\mathrm{c})$ & & & & \\
\hline $\mathrm{C}_{3} \mathrm{H}_{5}+\mathrm{HO}_{2} \rightarrow \mathrm{C}_{3} \mathrm{H}_{6}+\mathrm{O}_{2}(\mathrm{a})$ & $4.4 \cdot 10^{-12}$ & $300-1000$ & $\begin{array}{l}0.3 \text { over the range } 600 \text { to } \\
800 \mathrm{~K} \text { rising to } 0.5 \text { at other } \\
\text { temperatures. }\end{array}$ & A.15 \\
\hline$\rightarrow \mathrm{CO}+$ products $(\mathrm{b})$ & $1.1 \cdot 10^{-31}$ & $500-900$ & 0.3 & \\
\hline $\mathrm{C}_{3} \mathrm{H}_{5}+\mathrm{CH}_{3} \rightarrow \mathrm{CH}_{4}+\mathrm{CH}_{2}=\mathrm{C}=\mathrm{CH}_{2}$ (a) & $3.5 \cdot 10^{-13}$ & $500-1200$ & 0.5 & Al6 \\
\hline$\rightarrow \mathrm{C}_{2} \mathrm{H}_{5} \mathrm{CH}=\mathrm{CH}_{2}$ (b) & $k_{\mathrm{b}}^{\infty}=1.7 \cdot 10^{-10} \mathrm{~T}^{-0.32} \exp (66 / T)$ & $500-1200$ & 0.2 & \\
\hline $\mathrm{C}_{3} \mathrm{H}_{5}+\mathrm{CH}_{3} \mathrm{O}_{2} \rightarrow \mathrm{CH}_{2}=\mathrm{CHCH}_{2} \mathrm{O}+\mathrm{CH}_{3} \mathrm{O}$ & $2.0 \cdot 10^{-11}$ & $500-1200$ & 0.5 & A17 \\
\hline $\mathrm{C}_{3} \mathrm{H}_{5}+\mathrm{C}_{2} \mathrm{H}_{5} \rightarrow \mathrm{CH}_{2}=\mathrm{C}=\mathrm{CH}_{2}+\mathrm{C}_{2} \mathrm{H}_{6}$ (a) & $1.6 \cdot 10^{-12} \exp (66 / T)$ & $500-1200$ & 0.3 & A18 \\
\hline$\rightarrow \mathrm{C}_{3} \mathrm{H}_{6}+\mathrm{C}_{2} \mathrm{H}_{4}$ (b) & $4.3 \cdot 10^{-12} \exp (66 / T)$ & $500-1200$ & 0.4 & \\
\hline$\rightarrow \mathrm{CH}_{3} \mathrm{CH}_{2} \mathrm{CH}_{2} \mathrm{CH}=\mathrm{CH}_{2}$ (c) & $k_{c}^{\infty}=3.3 \cdot 10^{-11} \exp (66 / T)$ & $500-1200$ & 0.4 & \\
\hline $\mathrm{C}_{3} \mathrm{H}_{5}+\mathrm{C}_{3} \mathrm{H}_{5} \rightarrow \mathrm{CH}_{2}=\mathrm{CHCH}_{2} \mathrm{CH}_{2} \mathrm{CH}=\mathrm{CH}_{2}$ (a) & $k_{a}^{\infty}=1.7 \cdot 10^{-11} \exp (132 / T)$ & $300-600$ & 0.2 & A.19 \\
\hline & $k_{\mathrm{a}}^{\infty}=2.0 \cdot 10^{-11}$ & $600-1000$ & 0.4 & \\
\hline$\rightarrow \mathrm{C}_{2} \mathrm{H}_{6}+\mathrm{CH}_{2}=\mathrm{C}=\mathrm{CH}_{2}$ (b) & $k_{\mathrm{p}}=1.0 \cdot 10^{-13} \exp (132 / T)$ & $300-1000$ & 0.7 & \\
\hline
\end{tabular}


A1. $\mathrm{C}_{3} \mathrm{H}_{5}+\mathrm{M}$. Tsang and Walker ${ }^{1}$ obtained the high pressure value $k^{\infty}=40 \pm 10 \mathrm{~s}^{-1}$ at $1080 \mathrm{~K}$ from single pulse shock tube studies of 1,7-octadiene decomposition. Combination with low-temperature data on $\mathrm{H}$ atom addition to allene to form allyl gave the recommended expression for $k^{\infty}$. No other high temperature data are available, but Walker ${ }^{2}$ recommended $k^{\infty}=10^{14.0} \exp (-31270 / T) \mathrm{s}^{-1}$, based on thermochemical estimates, which gives $k^{\infty}=27 \mathrm{~s}^{-1}$ at $1080 \mathrm{~K}$ in excellent agreement with Tsang's experimental value. Tsang ${ }^{3}$ gives data for fall-off effects in his review.

A2. $\mathrm{C}_{3} \mathrm{H}_{5}+\mathrm{O}_{2}$. Walker et al. ${ }^{4-6}$ used the decomposition of 4,4-dimethylpent-1-ene in the presence of $\mathrm{O}_{2}$ and the direct oxidation of $\mathrm{C}_{3} \mathrm{H}_{6}$ to study the reactions of allyl radicals with $\mathrm{O}_{2}$ between 673 and $773 \mathrm{~K}$. Analysis of allene and $\mathrm{CO}$ was used to monitor the reactions. All the reactions have a high energy barrier. Rate constants determined as $k / k_{\mathrm{r}}^{1 / 2}$ where $k_{\mathrm{r}}=$ $1.69 \cdot 10^{-11} \exp (132 / T) \mathrm{cm}^{3}$ molecule ${ }^{-1} \mathrm{~s}^{-1}$ for the recombination of allyl radicals. Reactions to give $\mathrm{CO}$ probably involve the formation of a cyclic peroxy intermediate, so that aiternative pathways may occur outside the temperature range studied. Walker and Stothard ${ }^{7}$ found evidence for a radical branching reaction $\left(\mathrm{C}_{3} \mathrm{H}_{5}+\mathrm{O}_{2} \rightarrow 2\right.$ radicals + products $)$ and give $k=2.7 \cdot 10^{-13} \exp (-8720 / T) \mathrm{cm}^{3}$ molecule ${ }^{-1} \mathrm{~s}^{-1}$. Formation of allylperoxy radicals will not be important under combustion conditions.

A3. $\mathrm{C}_{3} \mathrm{H}_{5}+\mathrm{H}_{2}$. This rate constant has not been measured experimentally. We accept Tsang's ${ }^{3}$ recommendation which is based on a thermochemical calculation involving

$$
\mathrm{s}^{-1} \quad k=2.87 \cdot 10^{-19} \mathrm{~T}^{2.5} \exp (-1255 / T) \mathrm{cm}^{3} \text { molecule }{ }^{-1}
$$

for the reverse reaction, which is itself based on the experimental value for $k\left(\mathrm{H}+2-\mathrm{C}_{4} \mathrm{H}_{8} \rightarrow \mathrm{H}_{2}+\right.$ $\left.\mathrm{CH}_{3} \mathrm{CHCHCH}_{2}\right)^{3}$.

A4. $\mathrm{C}_{3} \mathrm{H}_{5}+\mathrm{CH}_{4}$. No experimental data are available. We accept Tsang' ${ }^{3}$ recommendation which is based on a thermochemical calculation with $k\left(\mathrm{CH}_{3}+\mathrm{C}_{3} \mathrm{H}_{6} \rightarrow\right.$ $\left.\mathrm{CH}_{4}+\mathrm{CH}_{2} \mathrm{CHCH}_{2}\right)=3.7 \cdot 10^{-24} T^{3.5} \exp (-2860 / T)$ $\mathrm{cm}^{3}$ molecule $\mathrm{e}^{-1} \mathrm{~s}^{-1}$.

A5. $\quad \mathrm{C}_{3} \mathrm{H}_{5}+\mathrm{C}_{2} \mathrm{H}_{6}$. No experimental data are available. We accept Tsang's ${ }^{3}$ recommendation which is based on a thermochemical calculation with $k\left(\mathrm{C}_{2} \mathrm{H}_{5}+\mathrm{C}_{3} \mathrm{H}_{6} \rightarrow\right.$ $\left.\mathrm{C}_{2} \mathrm{H}_{6}+\mathrm{CH}_{2} \mathrm{CHCH}_{2}\right)=3.7 \cdot 10^{-24} T^{3.5} \exp (-3340 / T)$ $\mathrm{cm}^{3}$ molecule ${ }^{-1} \mathrm{~s}^{-1}$ which itself is based on Tsang' $\mathrm{s}^{3}$ recommendation for $k\left(\mathrm{CH}_{3}+\mathrm{C}_{3} \mathrm{H}_{6}\right)$ (see above). A simple check supports the validity of the data on allyl $+\mathrm{CH}_{4}$ and allyl $+\mathrm{C}_{2} \mathrm{H}_{6}$. At $750 \mathrm{~K}, k\left(\mathrm{C}_{3} \mathrm{H}_{5}+\right.$ $\left.\mathrm{C}_{2} \mathrm{H}_{6}\right) / k\left(\mathrm{C}_{3} \mathrm{H}_{5}+\mathrm{CH}_{4}\right)=29$ compared with $k\left(\mathrm{HO}_{2}+\right.$ $\left.\mathrm{C}_{2} \mathrm{H}_{6}\right) / k\left(\mathrm{HO}_{2}+\mathrm{CH}_{4}\right)=23$ from Walker's ${ }^{9.10}$ experimental $\mathrm{HO}_{2}$ data. As the allyl reactions are only about $10 \mathrm{~kJ} \mathrm{~mol}^{-1}$ morc endothermic than the $\mathrm{IIO}_{2}$ reactions, the allyl ratio should be marginally higher than the $\mathrm{HO}_{2}$ value as observed.

A6. $\quad \mathrm{C}_{3} \mathrm{H}_{5}+\mathrm{C}_{3} \mathrm{H}_{8}$. No experimental data are availahle. We accept Tsang' ${ }^{3}$ recommendation for abstraction at a primary position (equal to $k\left(\mathrm{C}_{3} \mathrm{H}_{5}+\mathrm{C}_{2} \mathrm{H}_{6}\right)$, see A5). For abstraction at the secondary position, Tsang recommends the same $A$ factor (per $\mathrm{C}-\mathrm{H}$ bond) and a reduction in activation energy of $7 \mathrm{~kJ} \mathrm{~mol}^{-1}$. However, at $750 \mathrm{~K}, k\left(\mathrm{C}_{3} \mathrm{H}_{5}+\mathrm{CH}_{3} \mathrm{CH}_{2} \mathrm{CH}_{3} \rightarrow\right.$ $\left.\mathrm{CH}_{3} \mathrm{CHCH}_{3}\right) / k\left(\mathrm{C}_{3} \mathrm{H}_{5}+\mathrm{C}_{2} \mathrm{H}_{6}\right)=1.0$ compared with the analogous $\mathrm{HO}_{2}$ reaction ratio $=1.7$ which arises ${ }^{9.10}$ from the fact that the allyl reactions are about $10 \mathrm{~kJ} \mathrm{~mol}^{-1}$ more endothermic than the equivalent $\mathrm{HO}_{2}$ reactions. A difference of $11 \mathrm{~kJ} \mathrm{~mol}^{-1}$ in the allyl activation energies is therefore recommended giving $k_{b}=1.3 \cdot 10^{-22} T^{3.3} \exp (-8660 / T) \mathrm{cm}^{3}$ molecule $\mathrm{e}^{-1} \mathrm{~s}^{-1}$ for abstraction by allyl at the secondary $\mathrm{C}-\mathrm{H}$ positions.

A7. $\mathrm{C}_{3} \mathrm{H}_{5}+i-\mathrm{C}_{4} \mathrm{H}_{10}$. No experimental data are available. The expression for primary abstraction is the same as for allyl $+\mathrm{C}_{2} \mathrm{H}_{6}$ with allowance for path degeneracy (i.e. $3 / 2\left(k\right.$ for allyl $\left.\left.+\mathrm{C}_{2} \mathrm{H}_{6}\right)\right)$. The expression for attack at the tertiary position is derived by comparison with $\mathrm{HO}_{2}$ data ${ }^{9,10}$ (see $\mathrm{A} 6$ ) and we recommend $k$ $=0.7 \cdot 10^{-22} T^{3.3} \exp (-7800 / T) \mathrm{cm}^{3}$ molecule ${ }^{-1} \mathrm{~s}^{-1}$.

A8. $\mathrm{C}_{3} \mathrm{H}_{5}+\mathrm{HCHO}$. No experimental data are available. Tsang ${ }^{3}$ gives $k=2.4 \cdot 10^{-16} T^{1.8} \exp (-9154 / T)$, calculated thermochemically from an estimate of the reverse reaction. In combination with the recommended value for $k$ (allyl $+\mathrm{C}_{2} \mathrm{H}_{6}$ ), then $k / k$ (allyl + $\left.\mathrm{C}_{2} \mathrm{H}_{6}\right)=84$ at $770 \mathrm{~K}$ compared with $k\left(\mathrm{HO}_{2}+\right.$ $\mathrm{HCHO}) /\left(\mathrm{HO}_{2}+\mathrm{C}_{2} \mathrm{H}_{6}\right)=29$ from Walker's $\mathrm{HO}_{2}$ data $^{9-11}$. The difference in the ratios is a little larger than expected (see A6) and we recommend a reduction in Tsang's A factor for allyl $+\mathrm{HCHO}$ by a factor of 2 .

A9. $\mathrm{C}_{3} \mathrm{H}_{5}+\mathrm{C}_{6} \mathrm{H}_{5} \mathrm{CH}_{3} . \log \left(k / k_{1}\right)=-0.55-3760 / T$ was obtained by Throssell ${ }^{12}$ from the measurement of propene and but-1-ene in the decomposition of 4-phenylbut-1-ene and hexa-1,5-diene between 850 and $950 \mathrm{~K}$, where reaction (1) is $\mathrm{CH}_{3}+\mathrm{C}_{3} \mathrm{H}_{5} \rightarrow$ $\mathrm{C}_{4} \mathrm{H}_{8}-1$. A value of $k_{1}=2.3 \cdot 10^{-11} \mathrm{~cm}^{3}$ molecule ${ }^{-1} \mathrm{~s}^{-1}$ is used to calculate $k$, which at $725 \mathrm{~K}$ is a factor of 10 higher than the only other experimental value of $6.6 \cdot 10^{-18} \mathrm{~cm}^{3}$ molecule ${ }^{-1} \mathrm{~s}^{-1}$ obtained by Louw ${ }^{13}$ from studies of the decomposition of diallyloxalate, as a source of allyl radicals, in the presence of toluene. We consider the value used for $k_{1}$ to be slightly high and reduce Throssell's $\Lambda$ factor by a factor of 2, leading to the recommended value of $k$. Use of this and the recommended data for allyl + HCHO (see A8) gives $k\left(\mathrm{C}_{3} \mathrm{H}_{5}+\mathrm{HCHO}\right) / k\left(\mathrm{C}_{3} \mathrm{H}_{5}+\right.$ $\left.\mathrm{C}_{6} \mathrm{H}_{5} \mathrm{CH}_{3}\right)=6$ at $770 \mathrm{~K}$ compared with the analogous $\mathrm{HO}_{2}$ ratio from Walker's data ${ }^{9,10}$ equal to 10 , comparable values being expected from the similar thermochemistry involved (see A5 and A6 above).

A10. $\mathrm{C}_{3} \mathrm{H}_{5}+\mathrm{C}_{2} \mathrm{H}_{4}$. There are no experimental data for the addition and abstraction paths. The recommended expression for abstraction is based on $k\left(\mathrm{C}_{3} \mathrm{II}_{5}+\mathrm{CII}_{4}\right)$ with an increase of $12 \mathrm{~kJ} \mathrm{~mol}^{-1}$ in the activation energy on thermochemical grounds. For the addition path which will be reversed at combustion temperatures, the recommendation is based ${ }^{14}$ on the $A$ factors 
for addition of $\mathrm{C}_{2} \mathrm{H}_{5}, n-\mathrm{C}_{3} \mathrm{H}_{7}$ and $i-\mathrm{C}_{3} \mathrm{H}_{7}$ to $\mathrm{C}_{2} \mathrm{H}_{4}$ (A $=1 \cdot 10^{-13} \mathrm{~cm}^{3}$ molecule $\left.\mathrm{e}^{-1} \mathrm{~s}^{-1}\right)$ and an increase in the activation energy $\left(\mathrm{E}=30 \mathrm{~kJ} \mathrm{~mol}^{-1}\right)$ by $50 \mathrm{~kJ} \mathrm{~mol}^{-1}$, the delocalization energy of allyl radicals ${ }^{1}$. Tsang ${ }^{3}$ reports evidence at $1100 \mathrm{~K}$ that the decomposition of 4-pentenyl radicals leads to $2.5 \%$ conversion to cyclopentene. It is possible, therefore, that addition of allyl to $\mathrm{C}_{2} \mathrm{H}_{4}$ may lead to cyclopentane through the sequence $\mathrm{C}_{3} \mathrm{H}_{5}+\mathrm{C}_{2} \mathrm{H}_{4} \rightarrow$ 4-pentenyl $\rightarrow$ cyclopentyl $\rightarrow$ cyclopentane $+\mathrm{H}$.

A11. $\mathrm{C}_{3} \mathrm{H}_{5}+2-\mathrm{C}_{4} \mathrm{H}_{8}$. No experimental data are available for any path. The recommended value for abstraction at the allyl position is based on $k\left(\mathrm{C}_{3} \mathrm{H}_{5}+\mathrm{C}_{6} \mathrm{H}_{5} \mathrm{CH}_{3}\right)$ with adjustments due to path degeneracy ( 3 to 6 ) and to a slight weakening of the $\mathrm{C}-\mathrm{H}$ bond in 2$\mathrm{C}_{4} \mathrm{H}_{8}\left(\mathrm{ca} .6 \mathrm{~kJ} \mathrm{~mol}^{-1}\right)$. For the alternative abstraction, the recommendation is based on $k\left(\mathrm{C}_{3} \mathrm{H}_{5}+\mathrm{C}_{2} \mathrm{H}_{4}\right)$ with adjustments for path degeneracy ( 4 to 2 ) and for the weaker $\mathrm{C}-\mathrm{H}$ bond ( $\mathrm{E}$ lower by $12 \mathrm{~kJ} \mathrm{~mol}^{-1}$ ). The recommended expression for addition is based on kinetic data for alkyl + alkene ${ }^{14}$ with $\mathrm{E}$ increased by $50 \mathrm{~kJ} \mathrm{~mol}^{-1}$ delocalization energy.

A12. $\quad \mathrm{C}_{3} \mathrm{H}_{5}+\mathrm{H}$. The only experimental data were obtained by Hanning-Lee and Pilling ${ }^{15}$ who used laser flash photolysis of hexa-1,5-diene at $291 \mathrm{~K}$, measuring $[\mathrm{H}]$ and $\left[\mathrm{C}_{3} \mathrm{H}_{5}\right]$ by resonance fluorescence and absorption spectroscopy, respectively. The rate coefficient showed no significant variation between 100 and 400 Torr. The value is consistent with an estimate by Tsang ${ }^{3}$, who has calculated fall-off values for $k_{\mathrm{a}} /\left(k_{\mathrm{a}}+k_{\mathrm{b}}\right)$. Allera and Shaw ${ }^{16}$ estimate $k_{\mathrm{c}} /\left(k_{\mathrm{a}}^{\infty}+\right.$ $\left.k_{\mathrm{b}}+k_{\mathrm{c}}\right) \approx 0.1$, used as the basis of the recommended value of $k_{c}$. Negligible temperature coefficient is expected between 300 and $1000 \mathrm{~K}$.

A 13. $\quad \mathrm{C}_{3} \mathrm{H}_{5}+\mathrm{O}$. Stidied directly by Pilling et $a l .{ }^{17}$ between 300 and $600 \mathrm{~K}$ using laser flash photolysis and detection firstly by photo-ionization mass spectrometry and secondly by absorption spectroscopy and resonance fluorescence for $\mathrm{C}_{3} \mathrm{H}_{5}$ and $\mathrm{O}$, respectively. The mass spectrometry results suggest a slight decrease in $k$ with temperature $\left(2.3 \cdot 10^{-10} \exp (120 / T)\right.$ $\mathrm{cm}^{3}$ molecule $\left.{ }^{-1} \mathrm{~s}^{-1}\right)$, but no such trend is observed from absorption spectroscopy. The only detectable product by mass spectrometry was acrolein suggesting that the major channel is $\mathrm{O}+\mathrm{C}_{3} \mathrm{H}_{5} \rightarrow \mathrm{C}_{3} \mathrm{H}_{4} \mathrm{O}+$ $\mathrm{H}$. In particular, no $\mathrm{C}_{2} \mathrm{H}_{3}$ or $\mathrm{HCHO}$ was observed and $k_{\mathrm{b}}<3 \cdot 10^{-11}$ is recommended.

A14. $\mathrm{C}_{3} \mathrm{H}_{5}+\mathrm{OH}$. There are no experimental data. Tsang ${ }^{3}$ recommends $k_{\mathrm{a}}=1 \cdot 10^{-11}$ for the abstraction process (based on comparable reactions) and $\left(k_{\mathrm{b}}^{\infty}+k_{\mathrm{c}}\right)=$ $2.5 \cdot 10^{-11} \mathrm{~cm}^{3}$ molecule ${ }^{-1} \mathrm{~s}^{-1}$ for the high pressure limit for the addition channel. Tsang ${ }^{3}$ has carried out RRKM calculations for the fall-off effects which are unimportant below about $1200 \mathrm{~K}$.

A15. $\mathrm{C}_{3} \mathrm{H}_{5}+\mathrm{HO}_{2}$. There is only one, indirect, study ${ }^{4}$. Measurement of propene and $\mathrm{CO}$ yields in the decomposition of 4,4-dimethylpent-1-ene in the presence of $\mathrm{O}_{2}$ gives $k_{\mathrm{a}} / k_{\mathrm{b}}=0.38 \pm 0.10$ between $670+$ $750 \mathrm{~K}$, and further studies ${ }^{5}$ with added propene give $k_{\mathrm{b}}$. $\left[\mathrm{C}_{3} \mathrm{H}_{5}\right]$ is determined from the rate of formation of hexa-1,5-diene and $\left[\mathrm{HO}_{2}\right]$ from the rate of formation of propene oxide in the reaction $\mathrm{HO}_{2}+\mathrm{C}_{3} \mathrm{H}_{6} \rightarrow$ $\mathrm{C}_{3} \mathrm{H}_{6} \mathrm{O}+\mathrm{OH}$ ( $k$ is accurately known). Small corrections are made for the formation of propene in the molecular decomposition of 4,4-dimethylpent-1ene $^{4}$. Original values modified first by use of the value of $k$ for allyl recombination recommended in this table and, secondly, (5\%) for the formation of $\mathrm{CO}$ in the reaction $\mathrm{C}_{3} \mathrm{H}_{5}+\mathrm{O}_{2}$. The mechanism of (b) almost certainly involves addition followed by rapid loss of $\mathrm{OH}$ and further decomposition to form $\mathrm{HCHO}+\mathrm{C}_{2} \mathrm{H}_{3}$ radicals which react uniquely with $\mathrm{O}_{2}$ under the conditions used to form $\mathrm{CO}$. Other paths including formation of acrolein may be possible.

A16. $\mathrm{C}_{3} \mathrm{H}_{5}+\mathrm{CH}_{3}$. There are no experimental data. Tsang ${ }^{3}$ recommends $k_{\mathrm{b}}^{\infty}=1.69 \cdot 10^{-10} T^{-0.32} \exp (66 / T) \mathrm{cm}^{3}$ molecule ${ }^{-1} \mathrm{~s}^{-1}$ based on use of the cross-combination rule with data for $\mathrm{CH}_{3}$ radical combination and $\mathrm{C}_{3} \mathrm{H}_{5}$ recombination (recommended value used). At $1000 \mathrm{~K}, k_{\mathrm{b}}^{\infty}=1.75 \cdot 10^{-11} \mathrm{~cm}^{3}$ molecule $\mathrm{s}^{-1} \mathrm{~s}^{-1}$ in satisfactory agreement with $2.3 \cdot 10^{-11} \mathrm{~cm}^{3}$ molecule ${ }^{-1} \mathrm{~s}^{-1}$ calculated thermochemically by Throssel $1^{12}$ from the kinetics of but-1-ene homolysis into $\mathrm{C}_{3} \mathrm{H}_{5}$ and $\mathrm{CH}_{3}$ radicals. Tsang ${ }^{3}$ has carried nut RRKM calculations for the fall-off in $k_{\mathrm{b}}$. Based on data ${ }^{18}$ for the disproportion/combination ratio of methylallyl $+\mathrm{CH}_{3}=$ $0.02), k_{\mathrm{a}}=3.5 \cdot 10^{-13} \mathrm{~cm}^{3}$ molecule $\mathrm{s}^{-1} \mathrm{~s}^{-1}$ is recommended for the disproportionation path.

A17. $\mathrm{C}_{3} \mathrm{H}_{5}+\mathrm{CH}_{3} \mathrm{O}_{2}$. There are no experimental data or suggested mechanisms for this reaction. The main path almost certainly involves combination followed by rapid loss of $\mathrm{CH}_{3} \mathrm{O}$ radicals to give $\mathrm{CH}_{2}=\mathrm{CHCH}_{2} \mathrm{O}$ radicals which will undergo homolysis and react with $\mathrm{O}_{2}$ to give a variety of products such as $\mathrm{CO}, \mathrm{HCHO}$ and acrolein. A value of $k=$ $2 \cdot 10^{-11} \mathrm{~cm}^{3}$ molecule $\mathrm{e}^{-1} \mathrm{~s}^{-1}$ is recommended for the overall reaction, based on the specific rate constant for $\mathrm{CO}$ formation in the reaction $\mathrm{C}_{3} \mathrm{H}_{5}+\mathrm{HO}_{2}$ (see recommendation).

A18. $\mathrm{C}_{3} \mathrm{H}_{5}+\mathrm{C}_{2} \mathrm{H}_{5}$. Only disproportionation/combination ratios are available ${ }^{19}$ for this reaction. We accept Tsang's ${ }^{3}$ recommendations for the various paths and the RRKM calculations for fall-off.

A19. $\mathrm{C}_{3} \mathrm{H}_{5}+\mathrm{C}_{3} \mathrm{H}_{5}$. The only direct high pressure study was carried out by Tulloch et al..$^{20}$ who used laser flash photolysis coupled with absorption spectroscopy to measure $\left[\mathrm{C}_{3} \mathrm{H}_{5}\right]$. The absorption coefficient was assumed independent of temperature. Mixtures of hexa-1,5-diene (1 Torr) and argon (up to 250 Torr) gave the high pressure limit $k_{\mathrm{a}}^{\infty}$. Other studies (see Tsang ${ }^{3}$ ) were either indirect or involved low pressure pyrolysis with extensive extrapolation to high pressure. The values obtained by Tulloch et al. show a slight negative temperature coefficient between 300 and $600 \mathrm{~K}$. Above $600 \mathrm{~K}$, there is some evidence of a slight increase in $k_{\mathrm{a}}^{\infty}$ and in consequence, between 600 and $1000 \mathrm{~K}$ in the absence of independent evidence, a temperature independent 
value is recommended. Fall-off becomes important in combustion above about $1200 \mathrm{~K}^{3}$. James and Kambanis ${ }^{21}$ give $k_{b} / k_{a}^{\infty}=0.008$ between 400 and $460 \mathrm{~K}$, but Tsang and Walker ${ }^{1}$ found a value below 0.005 above $1000 \mathrm{~K}$. A value of $k_{\mathrm{b}}=1.0 \cdot 10^{-13}$ $\exp (132 / T)$ is recommended.

\section{References}

${ }^{i} W$. Tsang and J.A. Walker, private communication.

${ }^{2}$ R.W. Walker, "Major Research Topics in Combustion", ICASE/NASA

LaRC Series, Springer-Verlag, New York, 277 (1992).

${ }^{3}$ W. Tsang, J. Phys. Chem. Ref. Data 20, 221 (1991).

${ }^{4}$ Z.H. Lodhi and R.W. Walker, J. Chem. Soc., Faraday Trans. 87, 681 (1991).

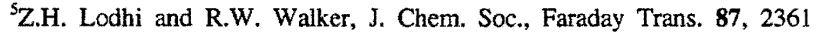
(1991).

${ }^{6}$ N.D. Stothard and R.W. Walker. J. Chem. Soc.. Faraday Trans. 88. 2621 (1992).

${ }^{7}$ N.D. Stothard and R.W. Walker, J. Chem. Soc., Faraday Trans. 87, 241 (1991).
${ }^{8}$ C.A. Morgan, M.J. Pilling, J.M. Tulloch, R.P. Ruiz, and K.D. Bayes, J. Chem. Soc., Faraday Trans. 2, 78, 1323 (1982).

${ }^{9}$ M. Scott and R.W. Walker, J. Chem. Soc., Faraday Trans. (1995) (submitted for publication).

${ }^{10}$ R.W. Walker, 22ne int. Symp. on Combustion, The Combustion Institute, p.883 (1988).

"R.R. Baldwin, A.R. Fuller, D. Longthorn, and R.W. Walker, J. Chem. Soc., Faraday Trans. 1, 68, 1362 (1972).

${ }^{12}$ J.J. Throssell, Int. J. Chem. Kin. 4, 273 (1972).

${ }^{13}$ R. Louw, Rec. Trav. Chim. Pays Bas. 90, 469 (1971).

${ }^{14}$ J.A. Kerr and S.J. Moss, "Handbook of Bimolecular and Termolecular Gas Reactions", Vol. II, CRC Press, Florida, 1981.

${ }^{15}$ M.A. Hanning-Lee and M.J. Pilling, Int. J. Chem. Kin. 24, 271 (1992).

${ }^{16}$ D.L. Allera and R. Shaw, J. Phys. Chem. Ref. Data 9, 523 (1980).

${ }^{17}$ I.R. Slagle, J.R. Bernhardt, D. Gutman, M.A. Hanning Lee, and M.J. Pilling, J. Phys. Chem. 94, 3652 (1990).

${ }^{18}$ D.C. Montague, Int. J. Chem. Kin. 5, 513 (1973).

${ }^{19}$ D.G.L. James and G.E. Troughton. Trans. Faraday Soc. 62. 145 (1966).

${ }^{20}$ J.M. Tulloch, M.T. MacPherson, C.A. Morgan, and M.J. Pilling, J. Phys. Chem. 86, 3812 (1982).

${ }^{21}$ D.G.L. James and S.M. Kambanis, Trans. Faraday Soc., 65, 1350 (1969). 